
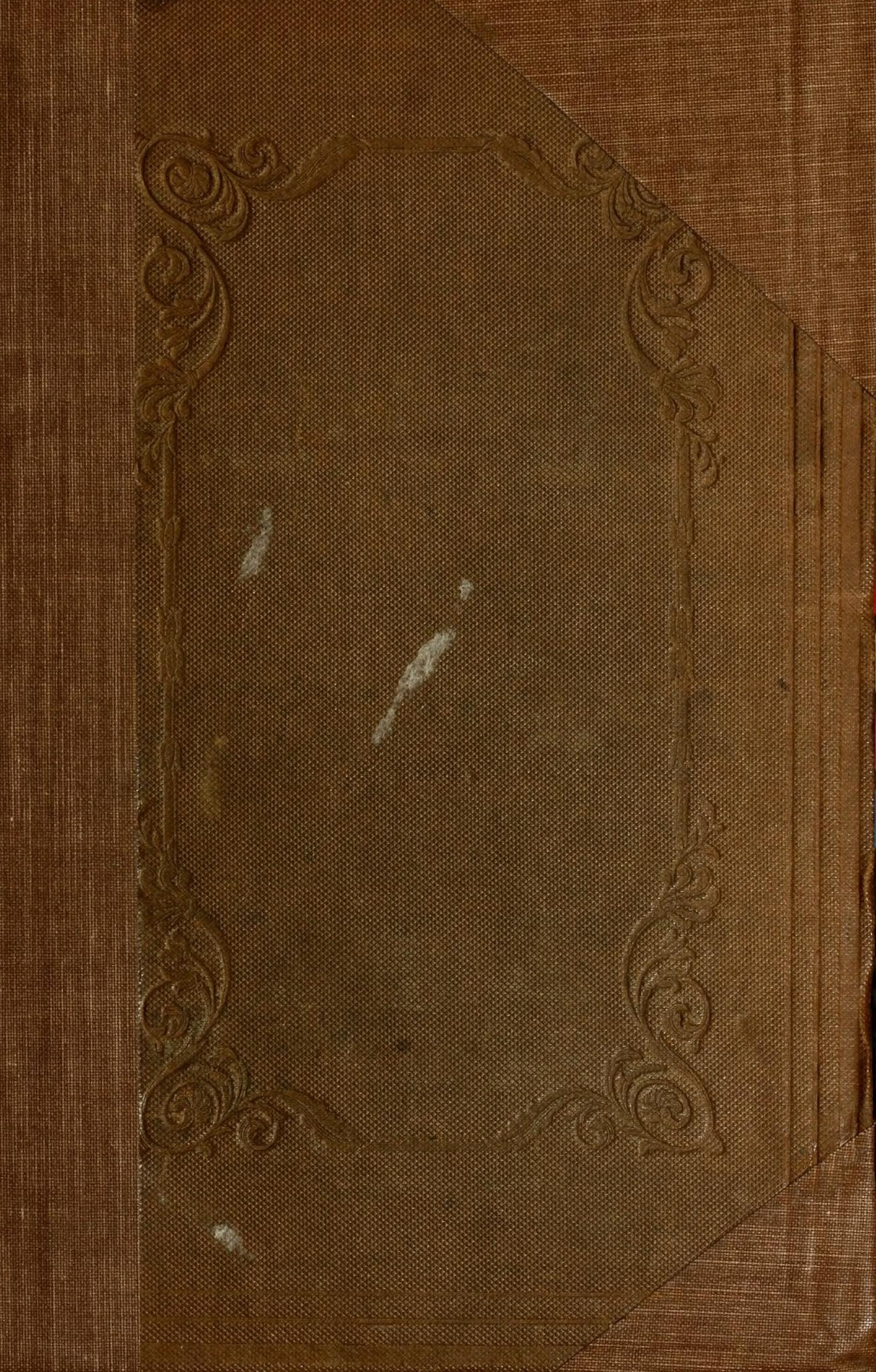

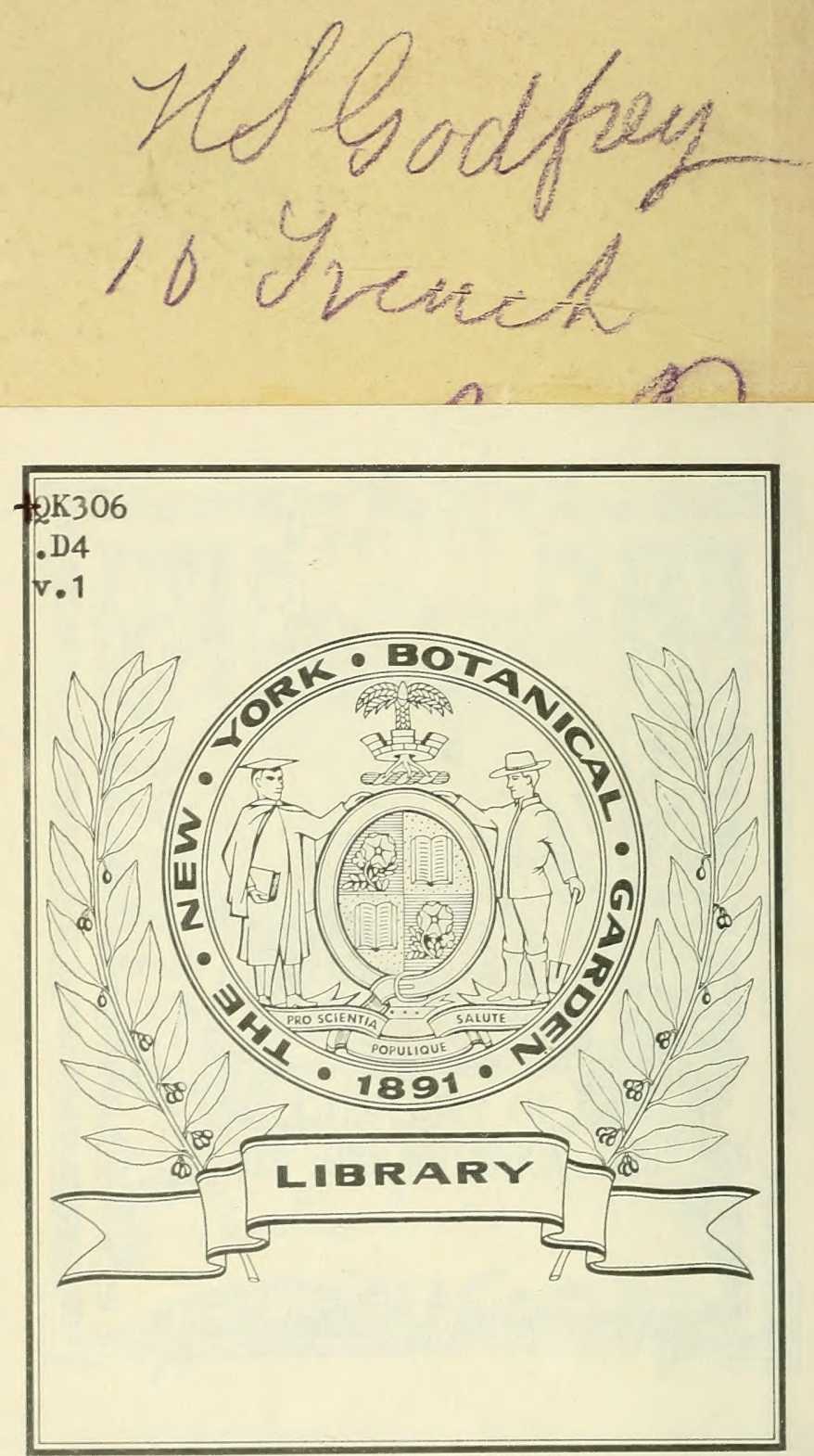
<smiles>CCC1CCC(C)C1</smiles> 



\title{
FLORIGRAPHIA BRITANNICA;
}

OR,

\author{
ENGRAVINGS AND DESCRIPTIONS
}

OF THE

\section{FLOWERING PLANTS \& FERNS}

\section{OF BRITAIN.}

BY RICHARD DEAKIN, M.D.

VOL. I.-Classes I. To V.

LONDON :

R. GROOMBRIDGE, PANYER-ALLEY, PATERNOSTER-ROW ;

RIDGE AND JACKSON, KING-STREET, SHEFRIELD,

MDCCCXLI. 


$$
\begin{gathered}
+Q K 306 \\
. D 4
\end{gathered}
$$

v. I 


\section{SYNOPSIS OF THE GENERA.}

\section{Class 1. Monandria.-1 Stamen.}

Order 1. Munogynia.-1 Pistil.

1. Saličor'nia, [Page 1.] Perianth single, swelling, fleshy, nearly equal. Style, short. Stigmas, two or three-cleft. Seed one, inclosed in a thin transparent skin, enveloped in the inflated perianth.

2. Hippu'rus, [Page 3.] Perianlh single, crowning the germen with a slight border. Sced one, inclosed in a small oval, hard, and shining pericarp.

(See Valeriana rubra, in Class III.; Alchemilla arvensis in Class $I V$. ; Zoslera and Callitriche, in Class XXI.; Chara, in Class XXIV.)

\section{Class 2. Diandria.-2 Slamens.}

\section{Order 1. Monograta.-1 Pistil.}

* Perianth double, inferior, monopotalous, regular.

1 Ligus'trom, [Page 4.] Caly $x$ of one leaf, with four bluntish projecting teeth. Corolla of one petal, regular, in four segments. Berry of two cells, with two seeds in each.

* Perianth double, inferior, monopetalous, irregular. Seeds inclosed in a pericarp.

2. VËron'ICA, [Page 5.] Calyx of one piece, inferior, persistent, divided into four deep segments. Corolla wheel-shaped deeply four-cleft, the lower segments smallest. Capsule two-celled.

3. Pinguio'via, [Page 17.] Calyx permanent, two-lipped, upper three-cleft, the lower bifid. Corolla ringent, spurred, and 
five-cleft. Germen globose. Style very short. Sligma of two unequal lobes. Capsule one-celled. Seeds numerous, and attached to a central receptacle.

4. Utricula'ria, [Page 20.] Calyx permanent, of two ovate equal leaves. Corolla personate, spurred. Germen globose. Style sbort. Stigma two-lipped. Capsule one-celled. Seeds numerous, small, attached to a central receptacle.

** Perianth double, inferior, monopelalous, irregular. Seeds four, apparenlly naked.

5. Lyco'pus, [Page 23.] Calyx tubular, permanent, divided into five na:row acute segments. Corolla tubular, nearly equal, four cleft, the upper segments broadest, and notched. Stamens simple.

6. SAL'via, [Page 23.] Calyx tubolar, permanent, nnequally twolipped, the lower bifid, the other three-toothed. Corolla labiate tube compressed and dilated upwards, lower lip of three lobes, the upper concave. Filaments with two divaricated branches, the one only bearing a perfect singlecelled anther.

\section{**** Perianlh double, superior.}

7. CrRca' A, [Page 25.] Caly $x$ tubular at the base, divided into two ovate obtuse deflexed segments. Corolla of two petals, alternate with the segments of the calyx, and inserted into it. Slamens alternate with the petals. Capsules two-celled, with one seed in each.

***** Perianth, single or none.

8. Frax'inds, [Page 27.] Calyx absent, or in ovate segments. Capsule flat and foliaceous, at the extremity, two-celled, with a seed in each cell. Seed solitary, flat, brown, and pendulons. Flowers sometimes without stamens, rarely

- with stamens only.

9. Lem'ns, [Page 29.] Perianth single, membranous, inflated. Fruit a thin transparent membraneous utricle, single. seeded.

10. Cin'dinm, [Page 32.] Perianth single, glumaceous، Glumes concave, of one piece, single-flowered, outer ones smaller, mostly barren. Fruit a nut, with three slight angles, covered with a loose coat, and destitute of bristles at the base.

(See Salicornia in Class I. Schenus in Class III. Lepidium and Coronopus in Class $X V$. Carex in Class XXI.) 
1. Snimoxan'тhum, [Page 33.] Glumes of two nnequal valves, containing one perfect and two imperfect florets; the middle floret perfect. Glumella of two small awnless valves; the lateral florets each reduced to a single awned valve.

\section{Class III. Triandria.-3 Stamens.}

\section{Order 1. Monogrnia.-1 Pistil.}

1. Valeria'na, [Page 24.] Caly $x$ a thick slightly crenated margiv, ultimately expanding into a feathery pappus. Corolla of one piece, tubular, the limb five-cleft, gibbous or spurred on one side at the base. Fruit single-seeded, surrounded at the top with the feathery pappus.

2. Fu'Dia, [Page 36.] Calyx three to five unequal teeth, first very smail, at length crowning the fruit. Corolla of one petal, gibbous at the base, the limbs of five unequal segments. Capsule indehiscent, of one fertile and two abortive cells.

3. Cno'cus, [Page 39.] Perianth divided into six equal coloured segments, its tube longer than the limb, and enveloped in two or more membranous sheaths. Stigma three-lobed, dilated, folded, and varionsly cut and jagged at the extremity,

4. Thichon'ema, [Page 42.] Perianth divided into six deep equal segments; its tube shorter than the limb, and enveloped in a sheath longer than the tube. Filaments short, hairy. Stigma very slender, deeply divided, its lobes bipartite, spreading. Capsule three-celled. Seeds globose and ntmerous.

5. Iris, [Page 43.] Perianth single, of six unequal segments, three alternate ones larger and reflexed. Stigmas three, resembling petals, and forming a covering to the oblong anthers.

** Flowers inferior, glumaceous. Seed single.

6. Cr'perus, [Page 44.] Flowers in spikes. Spikelets two-ranked, imbricated, many-flowered. Glumes of one keeled valve, generally fertile, equal. Bristles none. Style simple, deciduous. 
7. Sсне'Nus, [Page 46.] Spikelets one to three-flowered. Glumes two, rauked, the outer ones smaller, barren. Brislles very small, or none. Style jointed, or deciduous.

8. Rhynchos'rora, [Page 46.] Spikelelsfew-flowered. Glumes of one valve, imbricated on all sides, the outer ones smaller, barren. Bristles various in number, spiny, and shorter than the glumes. Style bifid, dilated at the base, more or less articulated, persistent, and crowning the fruit.

9. ScIR'Pus, [Page 48.] Glumes of one valve, imbricated on all sides, the onter ones sometimes barren. Bristles sometimes wanting. Style simple, deciduous. Fruit terminating in a point.

10. Eleo'Charis, [Page 52.] Spike terminal, solitary. Glumes of one valve, imbricated on all sides, mostly all fertile. Bristles four to twelve, finely toothed, rarely absent. Slyle dilated at the base, and jointed upon the germen. Stigmas two or three. Fruit lenticular or triangular, crowned by the indurated base of the style. Slem erect, simple, sheathed at the baso.

11. Elio'geton, [Page 54.] 'Spike terminal. Glumes nearly equal, of one valve, imbricated on all sides, all fertile. Bristles absent. Style deciduous. Fruit tipped with a short point.

12. Blys'mus, [Page 55.] Spike terminal, compressed. Spikelets bracteated, arranged in a distichous manner on a slightly zig-zag rachis. Glumes of one valve, imbricated on all sides, onter ones the largest, barren. Bristles often absent. Fruit compressed, terminated by the tapering persistent slyle.

13. Eriopho'rum, [Page 56.] Spikes terminal, solitary or nitmerous. Glumes of one valve, imbricated on all sides, nearly equal. Style deciduous. Stigmas three. Fruit with very long silky hairs springing from the base.

14. Nar'dus, [Page 61.] Glumes wanting. Glumelles two unequal lanceolate valves, the outer one the largest.

\section{Order II. Digynia -2 Pistils.}

* Flowers panicled; (compact, appearing like a spike, or spreading.) + Spikelels single-flowered.

15. Alopecu'rus, [Page 74.] Panicle spiked. Glumes of two 
simple nearly equal valves, mostly united at the base. Glunella of one valve, with an awn arising from the base.

16. Phal'inis, [Page 78.] Panicle contracted, or spreading. Glumes two, equal, keeled, longer than the Glumella. Glumelles of two equal awnless valves, at length forming an indurated covering to the seed, and accompanied at its base with one or two unequal imperfect florets.

17. Amo'punus, [Page 80.] Panicle spiked. Glumes nearly equal, keeled. Glumelles shorter than the glumes, hairy at the base, the outer valve awned bencath the bifid apex.

18. Gastridium, [Page 81.] Panicle contracted, spiked. Glumes two, unequal, awnless, unequally swelled at the base, inuch longer than the glumelles, which form a covering to the seed; the outer valve mostly with a dorsal awn.

19. MIn'rur, [Page 81.] Panicle spreading. Glumes two, equal, flattish, awnless, ribbed. Glumelles two, equal, shorter than the glumes, smooth, shining, ribless, without awns, forming a hard, permanent covering to the seed.

20. Pule'vi, [Page 82.] Panicle spiked, compact. Glumes nearly equal, acuminate, or the keel terminating in an awn: Glumelles two, smaller, awnless, membranons. Seed oblong, loose.

21. Lagu'revs, [Page 86.] Panicle spilied, ovatc. Glumes of two equal fringed walves, terminating in feathery awns. Glucmella of two unequal valves, external one the largest, with a dorsal awn, bifid at the apex ; the lobes, long, rough, awn-like.

22. Sirita, [Page 87.] Panicle erect, or branched. Glumes of two nearly equal valves, longer than the glumella. Glumella of two involute valves, the external one bearing from its apex a long twisted awn, jointed at the base, and finally separating at the joint.

23. Pulrpo'Gos, [Page S7.] Paniclecontracted, somewhat spiked. Glumes of two equal awned valves. Glumella of two unequal valves, smaller than the glumes, the outer largest, obtuse, awned at the extremity.

24. Cala'magrostis, [Page 89.] Panicle lonse. Glumes two, longer than the glumella. Glumella of two unequal valves, surrounded with hairs at the base, the outer valve awned beneath the bifid apex: 
26. Airas'ris, [Page 91.] Panicle loose. Glumes two, unequal, longer than the glumelles. Glumelles two, unequal, the shorter valve largest, with or without an awn, the inner one sometimes wanting.

\section{t† Spikelets two or three-flowered.}

26. Catabro's., [Page 96.] Panicle lonse or close. Spikelets two or three flowered, sometimes with a fourth imperfect floret. Glumes uneriual, membranous, obtuse, much shorter than the florets. Glumelles nearly equal, ribbed, awnless, the extremity truncated, erose.

27. A1'rs, [Page 96.] Panicle loose or close. Spinelels two flowered. Glumes unequal. Glumelles unequal, the outer valve mostly awned near the base. Fruil free.

2ส. HuL'cus, [Pagre 102.] Panicle loose. Spikelets two flowered. Glumes nearly equal, longer than the florets; lower floret perfect and awnless; upper with stimens only, aid awned. Fruit coated with the indurated glumelles.

20. Arrhexitn'zrum, [Page 104.] Punicle loose. Glumes two unequal, two flowered; lower floret with stamens only, and a lun: juinted awn, arising from near the base of the outer valve; the upper perfect, and the outer valve with a short straight bristle near the apex.

30. Pasi'cum, [Page 105.] Panicle erect, compound. G'lumes two, unequal, two-flowered; the lowest smallest, pointed or awned. Florets dissimilar. Glumelles of the fertile floret two, cartilaginous, the external one concenve, the interual plane; glumelles of the neuter or male floret, one or two; the external nembrawous, pointed, or awned; the inuer smaller, often absent.

31. Geta'sia, [P'ige 106.] Panicle spilich, cylindrical. Gihnes two, unequal, two-flowered, the spikelcls supported on short branched pedicles, two or three of which are supported by a bristly involucre. Florets dissimilar. Gilumelles of the perfect fluret two, unequal, cartalaginous; glumelles of the neuter or male floret, one or two ; membranous; the smaller one sometimes absent.

32. Suste'ru, [Page 107.] Panicle spilicrl. Glumes two, nearly equal, pointed or awned at the apex; glumelles nearly equal; the outer jagged, awned, at the anex; the inner bifinl.

33. IIrko'culoe, [Page 108.] Panicle spilicd. Gilumes two, 
nenily equal, thrce-flowered, the two lateral florets neuter, each contaiuing three stamens; the terminal one perfect, containing two stamens and pistils. Glumelles nearly cqual, with or without an awn.

34. Me'Lica, [Page 109.] Panicle loose. Spikelets one ormore flowered, with the rudiments of one or more imperfect ones. Glumes tivo, nearly equal, about as long as the florets. Glumelles two, unequal, awnless, becoming hard and investing the fruit.

35. Mor'inia, [Page 110.] Panicleloose. Spikelets two or more flowered, and sometimes with an imperfect floret. Glumes two, unequal, much shorter than the Rorets. Glumelles two, nearly equal, awnless.

\section{$1+\uparrow$ Spikelels three, or mostly many-flowered.}

36. Po's, [Page 111.] Panicle loose. Spikelels three or manyflowered. Glumes two, shorter than the florets. Glumelles two, nearly equal, awnless.

37. Trio'dia, [Puge 122.] Panicle racemed. Spikelets manyflowered. Glumes two, nearly equal. Glumelles two, unequal; extermal one with three nearly" equal teeth; the middle one stiff, straight.

38. Bri'za, [Page 123.] Panicle looge. Spikelels many-flowered. Glumes two, equal. Glumelles two, unequal, awnless; the outer convex, swelled at the base; the inner smaller, flat. Fruil closely invested with the glumelles.

39. Fes'tuca, [Page 124.] Panicle loose or contracted. Spikelets many-flowered. Glumes two, unequal. Glumelles two, the outer valve acuminated or awned at the apex.

40. Bru'sus, [Page 131.] Panicle loose. Spikelets manyflowered. Glumes two, unequal. Glumelles two, the outer awned below the bifit apex.

41. Ave'na, [Page 139.] Paniclo loose. Spikelets two or more flowered. Glumes two, nearly equal. Glumelles two, lanceolate, nearly equal; the outer bifid at the apex, and bearing a twisted dorsal awn.

42. Dactr'Lis, [Page 144.] Panicle loose or contracted; branches, solitary, the lower ones long, the upper very short. Spikelels clustered, three or four-flowered. Glumes two, unequal. Glumelles two, lanceolate, nearly equal, the outer with a short arrn. 
43. Crnosu'res, [Page 145.] Panicle spiked, Spikelets two or many-flowered, fixed upon pectinate bractex. Glumes iwo, equal. Glumelles two, nearly equal, the outer pointed or awned at the apex.

44. Arun'do, [Page 147.] Panicle loose. Spikelets many-flowered; the lower floret bearing stamens only, and naked; the upper perfect, and surrounded by a tuft of hairs. Glumes two, unequal, shorter than the florets. Glumelles two, unequal,

* Flowers spiked. Spikelets sessile, upon a common stalk or rachis.

$\uparrow$ Spikelets inserted on all sides.

45. Elr'mus, [149.] Inflorescence spiked. Spikelets two or three from the same point, two or three-flowered. Glumes two, both on one side of the spikelet. Glumelles two, nearly equal.

46. Hon'Deum, [Page 150.] Inflorescence spiked. Spikelels single-flowered, three together, the lateral ones mostly imperfect. Glumes two, lateral, Glumelles two, the outer valve awned, Fruit closely invested with the glumelles.

47. Trit'icur, [Pagc 154.] Inflorescence spiked, Spikelets many-flowered, all fertile. Glumes two, nearly equak, placed transversely, the sides directed to the rachis. Glumelles two, lanceolate; the external one mostly awned at the apex.

48. Brachy'ponium, [Page 160.] Inflorescence somewhat racemose. Spikelets alternate, somewhat compressed, manyflowered; footstalks short. Glumes unequal, transverse. Glumelles two, the outer valve mostly awned at the extremity.

49. Ló livm, [Page 162.] Inflorescence a two-sided spike. Spikelels alternate, compresserl, many-flowered. Gluma a single valve. Glumelles two, nearly equal; the outer valve awnless, or with an awn below the apex.

5(). Rotronoríta, [Page 165.] Inflorescence a two-sided spike. Spikelels altcrnate, one or two-flowered, Glumes of two valves, sometimes single, lateral, Glumelles two, awnless, imbedded in the notches of the rachis.

51. KNAP'PIA. [Page 166.] Inflorescence racemose, simple. Glumes two, truncated, nearly equal, awnless, Glumelles two, equal, obtuse, awnlesz, hairy. 


\section{t† Flowers on one-sided Spikes.}

52. Sparti'Na, [Page 167.] Inflorescence a one-sided spike. Spikelets one-sided, single-flowered, in two rows pressed close to the rachis. Glumes two, unequal, lanceolate, compressed, pointed or awned, Glumelles two, nearly equal, lanceolate, compressed. Styles partly united.

53. Crn'unon, [Page 168,] Inflorescence a compound spike, Spikelets one-sided, in two or more rows, Glumes two, nearly equal, keeled, spreading. Florets single-flowered, Glumelles shorter than the gluines, awnless, compressed, keeled; the outer valve broadest, enwrapping the shorter inner one, becoming hard, and forming a coat to the ovate seed.

54. Digita'ria, [Page 169.] Inflorescence a compound spike. Spikelets arranged on a zig zag rachis; Florets two: the outer sometimes wanting: the perfect one of two cartilaginous, nearly equal, valves; the imperfect one a single valve, Fruit coated with the harcened glumelles.

\section{Order III, Trigynia. -3 Pistils.}

55. Mon'tia, [Page 171.] Calyx inferior, of two ovate abrupt pieces, united at the base. Corolla of five unequal petals, united at the base. Capsule one-celled, with three valves and three seeds.

56. Holus'teum, [Page 172.] Calyx inferior, of five ovate pieces, Pelals five, jagged towards the extremity. Capsule one-celled, opening at the apex with six teeth, Seeds numerous, furrowed on one side, and dotted.

57. Polycar'pon, [Page 172.] Calyx inferior, of five ovate mucronate pieces, with membranous margins, and united at the base. Petals five, notched at the extremity. Slamens from three to five. Capsule three-valved, many-seeded.

\section{Class IV. Tetrandria.-4 Stamens (equal).}

\section{Order I. Monogrnia. $\rightarrow 1$ Pistil.}

* Perianth double. Corolla of one piece, superior. Seed single. 1. Dirsa'ous, [Page 173.] Flowers in heads, surrounded by a 
Hany-leaved involucrum, Involucellum with four sides and eight little excavations. Calyx cup-shaped, thickly clothed with short rigid hairs. Receptacle with spiny glumeceous bractece, shorter than the leaves of the involucrum.

2. KNat tia, [Page 176,] Flowers in heads, surrounded by a many. leaved involucrum. Involucellum compressed, with four little excavations. Calyx cup-shaped. Fruit placed upon a short stalk. Receptacle bristly,

3. Scsbioss, [Page 177.] Flowers in heads, surrounded by a many-leared involucrum. Involucellum nearly cylindrical, with eight little excarations and a membranous plaited limb. Calyx with a limb consisting of about five bristles.

* Perianth double. Corolla of one piece, superior. Seeds two, Leaves in Whorls.

4. Ga LIC3r, [Page 178.] Corolla wheel or bell-shaped, four or five cleft, Fruit a dry indehiscent pericarp, with two cells and two seeds, not crowned by the calyx,

5. Rr B1.2, [Page 188.] Corolla rotate or campanulate, with from three to five spreading segments. Fruit a succulent, smooth, two-lobed berry.

6. Sherar'dia, [Page 189.] Corolla funnel-shaped with four serments. Fruit crowned with the persistent teeth of the calyx.

7. Asper'tua, [Page 189.] Corolla funnel-shaped, with from three to four segments. Fruit not crowned with the calyx.

*** Perianth double. Corrolla of one piece inferior. Seeds two, or many.

y. Exacts, [Pagge 192.] C'alyx of one piece, with a four-cleft xtremity. Corolla four-cleft salver-shaped, with a globose ulse. Anther bursting longitudinally. Stigma capitate, entire. Capsule one-celled, two valved.

3. Pzanta'go, [Page 192.] Corolla with four reflexed segments. Stamens very long. Capsule of two or four-cells, mernbranous, two or many-seeded, bursting with a transverse incision.

10. Cestracenes, [I'agre 19f.] Corclla of one piece, the tube swelling, limb four-cleft. Stamens short. Capsule of one cell, many-seeded, bursting with a transverse incision. 
**** Perianth double. Corolla of four petals.

11. Eprmédur, [Page 196.] Calyx of four pieces, deciduous, petals four, inferior, with a large inflated nectary at the base. Pod oblong, two valred, one-celled, many seeded.

I2. Con'sus, [Page 189.] Calyx of four decidnous pieces. Corolla superior. Drupe with a two-celled, two-seeded, nut.

(See Euonymus in Class $V . ;$ Cardamine and Coronopus in Class $\left.\boldsymbol{X} V_{0}\right)$

***** Perianth double.

13. Parieta'ria, [Page 199.] Flowers polygamous, surrounded by a tro-leaved involucrum. Perianth single, inferior, four-cleft, persistent. Stamens at first incurved, at length expanded by the elastic force of the filaments. Fruit single seeded, enclosed by the enlarged perianth.

14. Alchemilla, [Page 201.] Perianth inferior, eight-cleft; the four outer alternate ones smallest. Fruit a solitary or double $n u t$, surrounded by the persistent perianth. Seed suspended.

15. Isxardia, [Page 202.] Calyx superior, the limb of four lobes, persistent. Petals four wanting. Stigma capitate. Capsule obovate, with four angles, four valves, four cells, and many seeded.

16. SAsguisor'BA, [Page 203.] Perianth superior, of four coloured lobes, with two or four scales at the base. Nuts one or two, surrounded by the dry persistent tube of the perianth. Seed suspended.

Order II. Digria, -2 Pistils.

17. Beffonia, [Page 204.] Calyx of four pieces. Corolla of four entire petals. Capsule compressed, one-celled, twovalved, two-seeded.

(See Alchemilla, in Order II. Gentiana and Cuscuta in Class V.)

Order III. Tetragria. -4 Pistils.

18. Thex, [Page 205.] Calyx persistent, of four or five teeth. Corolla of four or five petals, distinct or combined at the base. Stamens four, sometimes five. Fruit fleshy, containing four or five hard one-seeded nuts. Seeds inverted.

19. Pota O'Getox, [Page 207.] Flowers in spikes, arising from a sheathing bractea, or spatha. Perianth single of four 
pieces. Stamens with the anthers sessile, opposite the pieces of the perianth. Pistils four, alternating with the stamens, becoming compressed. Nuts, each containing a suspended, curved, more or less spiral seed.

20. RuP'Pia, [Page 217.] Flowers two, from the base of the leaves. Calyx and corolla wanting. Seeds four, convex at one side, slightly keeled on the other, and elevated on a short peduncle.

21. SAGI'NA, [Page 217.] Calyx inferior, of four permanent leaves. Petals four, shorter than the calyx, sometimes absent. Capsule of one-cell, and four equal valves. Seeds numerous, each attached to the receptacle by its own stalk.

22. MœN'CHIA, [Page 218.] Calyx inferior of four permanent equal pieces. Petals four, shorter than the calyx. Capsule of one-cell, opening at the summit, with eight or ten minute teeth. Seeds numerous, attached to the receptacle.

23. TILle' 'A, [Page 218.] Calyx of three or four segments. Capsules three or four oblong, recurved, bursting lengthwise, two-celled, two-valved, two-seeded.

24. Radiola, [Page 219.] Calyx or four pieces united together half way up each, mostly three-cleft. Petals four, undivided. Capsule of eight cells, and eight valves. Seeds ovate, solitary, compressed.

(See Cerastium tetrandum in Class $X$.) 


\section{Class V. Pentandria.—5 Stamens.}

\section{Order 1. Monogynia.-1 Pistil.}

* Perianth double, inferior. C'orolla monopetalous. Ovarium of four lobes. Style simple in the middle. Fruit four nuts, (apparently naked). Nat. Ord. Boragin'ex, Juss. (Assperifolia, Linn.)

\section{+ Corolla naked at the orifice.}

I. E'chiтm, [Page 220.] Corolla with a short tube, irregular, the limb campanulate, obliquely five lobed, the two upper largest, the lower acute and reflexed. Stigma deeply cloven. N Vuts covered with little tubercles.

2. Pulmona'ria, [Page 221.] Calyx campanulate, with five angles, five-cleft. Corolla funnel-shaped, five lobed. Stigma obtuse.

3. Lithosper'yum, [Page 223.] Calyx in five deep segments. Corolla funnel-shaped, five lobed. Sligma obtuse, bifid. Nuts smooth, or wrinkled.

$+\dagger$ Corolla with seales or valves at the orifice.

4. Srmpнт'тuм, [Page 226.] Calyx five-cleft. Corolla cylindrical, swollen upwards, limb with five short round lobes, its orifice closed with subulate connivent scales.

5. Bora'Go, [Page 228.] Calyx five-cleft. Corolla wheelshaped, the limb of five mostly spreading segments, the orifice of the tube closed with five obtuse emarginate scales.

6. Lrcop'sis, [Page 229.] Calyx five-cleft. Corolla funnelshaped, the limb of five lobes, the tube curved, its orifice clothed with five convex connivent scales.

7. Anchu'ss, [Page 230.] Calyx five-cleft. Corolla funnelshaped, the limb of five lobes, the tube straight, its orifice closed with five convex connivent scales.

8. Mroso'tis, [Page 231.] Calyx five-cleft. Corolla salvershaped, the limb of five flat obtuse lobes, tube short, its orifice nearly closed with smooth rounded scales. Nuts smooth. 
bell-shaped, with five equal lobes. Stamens distant. Berry within the calyx, globose, two celled.

26. Sols'num, [Page 281.] Calyx five or ten partite. Corolla wheel-shaped. Anthers connivent, oblong, opening with two pores at the extremity. Berry roundish, two or more celled.

\section{†十+十 Fruit in two follicles.}

27. VIN'CA, [Page 283.] Calyx five-partite. Corolla salvershaped, the segments oblique, spirally imbricated in the bud, the tube long, its orifice prominent, with five angles, Anthers closing over the pistil. Stigma crowned with a tuft of hairs. Follicles with naked seeds.

(See Gentiana in Ord. 2.)

** Perianth double, superior. Corolla monopetalous.

+ Fruit a capsule.

28. SA'molus, [Page 286.] Calyx half superior, five-cleft. Corolla somewhat bell-shaped, with a short tube, its mouth surrounded with five scales (sterile stamens), alternating with five stamens, and opposite the segments of the limb. Capsule half superior, two celled, opening with five valves. Seeds fixed to a large central placenta.

29. LoBe'Lia, [Page 287.] Calyx five-cleft. Corolla irregular, two lipped, five-cleft. Stamens united around the pistil. Stigma blunt, mostly two lobed and hairy. Capsule two or three celled, opening at the apex with two or three valves.

30. JAsi'one, [Puge 290.] Calyx five-cleft. Corolla wheelshaped, in five deep narrow segments. Anthers mited at their base. Stigma club-shaped, bifid. Capsule two celled, opening at the apex. (Flowers collected into a dense head, with a many leaved involucrum.)

31. Phytev'ma, [Page 291.] Calyx five-cleft. Corolla wheelshaped, in five deep narrow segments. Filaments dilated at the base. Anthers free. Stigma threc-cleft. Capsule of two or three cells, opening on the side. (Flowers collected into a dense bractealed head or spike.)

32. Campanu'ta, [Page 292.] Calyx five-cleft, Corolla bellshaped or wheel-shaped, with five larger or smaller segments, the month of the tube closed with the dilated base of the filaments. Anthers frce. Stigma two to five-cleft. 
Capsule from two to five celled, opening on the side, rarely at the extremity.

33. Prismato'carpes, [Page 304.] Calyx five-cleft. Corolla wheel-shaped, with a flat limb. Capsule oblong, prismatic, two or three celled, opening near the top.

\section{十† Fruit a berry.}

34. Lovice'rs, [Page 305.] Calyx of fire small teeth. Corolla tubular, with an irregular fire-cleft limb. Stigma capitate. Berry from one to three celled, one or many seeded.

**** Perianth double, inferior. Corolla of four or five petals.

\section{+ Flowers regular.}

35. Rham'sts, [Page 308.] Calyx urceolate, the limb four or five.cleft. Corolla of four or five petals, or wanting. Stamens opposite the petals, and with them inserted into the tube of the calyx. Slyles from two to four, united or distinct. Fruil fleshy, of two to four cells, each comtaining a single seed.

36. Euo'xrmus, [Page 311.] Calyx flat, four or five-cleft, with a peltate disk at the bottom. Pelals four or five, inserted into the margin of the disk. Stamens four or five, alternating with the petals, and inserted into the disk. Capsules with three to five angles, and as many cells. Seeds one in each cell, with a coloured fleshy arillus.

\section{t十 Flowers irregular.}

37. Impa'tiexs, [Page 313.] Calyx of two deciduons leaves. Petals four, very unequal, the lower one elongated at the base into a spur. Anthers united, three of which are two celled, and two one celled. Stigma fire, united. Capsule long, tapering, of five valves, bursting suddenly at the base, and rolling backwards.

38. Vro'La, [Page 314.] Calyx of five sepals, unequal, and appendiculated at the base. Petals unequal, the lower one spurred at the base. Stamens with dilated filaments, the anthers united around the pistil, the two lower ones with processes at the base. Capsule of one cell, opening with three elastic valves.

*\%*** Perianth double, superior. Corolla of five petals.

39. RI'BES, [Page 324.] ('alyx of four or five segments, regular, and bearing the petals and stamens. Style from tiro to four-cleft. Fruit a single celled many seeded berry. 
40. He'Dera, [Page 330.] Calyx of five teeth. Petals broadest at the base. Style simple or divided. Fruit a succulent berry, crowned by the calyx, of from three to five cells, and as many seeds.

****** Flowers incomplete, inferior.

41. Gla'UX, [Page 332.] Perianth single, inferior, bell-shaped, five-cleft, coloured. Stamens inserted at the bottom of the perianth. Stigma capitate. Capsule globose, of one cell, and five valves. Seeds about five, attached to a central placenta.

42. Ille'cebrum, [Page 332.] Calyx in five nearly separate segments, thickened and laterally compressed, cartilaginous, terminating in a slender arl-shaped point. Petals wanting, or reduced to five alternate awl-shaped scales. Style short. Stigmas two, obtuse. Capsule surrounded by the calyx, of one cell, marked with five longitudinal stria. Seed single, attached to the side of the cavity.

******* Flowers incomplete, superior.

43. The sidu, [Page 334.] Perianth four or five-cleft. Petals wanting. Stamens opposite the segments of the ealyx, surrounded with a small fascicle of hairs. Style long. Stigma obtuse. Fruit a single seeded dry or fleshy drupe, crowned by the persistent calyx.

\section{Order II. Digrnia.-2 Pistils.}

* Perianth double, inferior. Corolla monopetalous.

44. Gentiana, [Page 335.] Calyx four or five-cleft. Corolla funnel or salver-shaped, with a tubular base, the limb fivecleft. Stamens inserted into the tube of the corolla. Styles sometimes united into one. Stamens two. C'apsule of one cell, with two valves, and marginal placentas.

45. Cus'cuta, [Page 340.] Calyx four or five-cleft. Corolla roundish, bell-shaped, the limb of four or five lobes, with as many scales at the base below the stamens. Capsule two celled, two seeded, bursting at the base transversely.Parasitical twining leafless plants, with long thread-like stems.

P'rianth double, superior. Corolla of five petals. (Nat. Ord. UMBEJLIFERE. From Genus 46 to 88.)

† Flowers in heads or simple umbels. 
46. Hydroco'tyle, [Page 347.] C'alyx margin obsolete. Petals ovate, entire, acute, with a straight point. Fruit compressed at the sides, so as to form two flat nearly orbicular lobes. Carpels with five filiform ridges, those of the sides and back nearly obsolete, and the two intermediate ones arched. Seeds carinated, compressed.

47. SANI'CULA, [Page 347.] Calyx with a five toothed leafy margin. Petals erect, obovate, notched, with a slender inflexed point, as long as the petal. Fruit sub-globose, densely clothed with hooked prickles, without ridges, but with many vittc. General involucre lobed, partial of many lanceolate segments.

48. Eryn'Gium, [Page 350.] Calyx with a five toothed leafy margin. Petals erect, oblong, notched with a slender abruptly inflexed point the length of the petal. Frunt obovate, densely clothed with pointed scales, without ridges or vittæ. Involucre of several leaves. Flowers blue, upon a scaly receptacle, collected into an oblong compact head.

†† Flowers in compound umbels.

1. Fruit laterally compressed, with five primary filiform ridges. Albumen before plane or convex.

a. Petals entire.

49. Bupleu'rum, [Page 352.] Calyx limb obsolete. Pelals roundish, entire, broad, closely rolled inwards, the sides depressed. Fruit laterally compressed, crowned by the recurved styles and depressed disk. Carpels with five equal, winged, acute, filiform, or obsolete ridges, the lateral ones forming the margin. Channels with or without vittce. Albumen plane in front. Involucre various. Flowers yellow. Leaves undivided.

50. Apíum, [Page 355.] C'alyx limb obsolete. Petals roundish, entire, with an involute point. Fruit roundish, laterally contracted, double. Carpels with five filiform equal ridges, the two lateral ones forming the margin. Channels with single vitte, the outer ones sometimes having two or three. Albumen very convex at the back, plane in front. Involucre wanting. Flowers white.

a. Swent's, [Page 335.] Calyx four or five-partite. Corolla wheel-shaped, the limb of five segments, plane, with a fimbriated gland at the base of each. Capsule of one cell, and two valves, with marginal placentas. Seeds numerous.-Named after Emanual Swert, a Dutch Botanist, who published a Florilegium in 1612 . 
SYNODSIS OF THE GENERA.

Channels with three superficial ville. Albumen rounded at the back, flat in front. General involucre mostly of several linear segments, partial of numerous ones.

2. Fruit (on a transrerse section) roundish or compressed at the back with five primary fliform or winged ridges. Albumen before, plane or convex.

a. Seeds free in the pericarps.

69. Crith'sum, [Page 385.] Calyx margin obsolete. Petals roundish, entire, rolled inwards with an obovate point. Fruit on a transverse section, roundish. Carpels with five elevated sharp somewhat winged ridges, the lateral ones forming the margins a little wider than the others. Albumen free in the pericarp, with numerous villa. General and partial involucres of numerous segments.

70. Airchangerica, [Page 386.] Calyx margin of five teeth. Petals elliptical, eutire, with an incurved acuminated point. Fruil somewhat compressed at the back, with two wings on each side. Carpels with thick carinated ridges, the three dorsal ones elevated, the two lateral ones dilated into wings, twice as broad as the rest. Albumen free in the pericarp, with numerous viltce. General involucre of a few segments, or wanting, partial of numerous ones.

\section{b. Seeds adhering to the pericarp.}

\section{$\S$ Petals entire, acute, or acuminate.}

71. Axgel'ich, [Page 388.] Calyx margin obsolete. Pelals entire, lanceolate, acuminate, with a straight or incurved point. Fruit compressed at the back, with two wings on each side. Carpels with three dorsal filiform ridges, the two lateral ones dilated into broad membranous wings. Channels with single villa. Albumen roundish, adhering to the pericarp. General involucre scarcely any, partial of many segments.

68. ME'UM, [Page 384.] C'alyx margin obsolete. Pelals entire, elliptical, acute at each end. Fruit nearly round. Carpels with five equal somewhat winged ridges, the lateral ones forming the margins. Channels with many villa. Albumen about half round. General involucre of few segments, or wanting, parlial of numerous ones.

\section{$\S \S$ Petals erect.}

47. Sixicula, [Page 347.] Calyx with a five toothed leafy 
margin. Petals erect, obovate, notched with a slender inflexed point, as long as the petal. Fruit sub-globose, densely clothed with hooked prickles, without ridges, but with numerous villa. General involucre lobed, partial of many lanceolate segments.

$\S \S \S$ Pelals roundish, obovate or obcordate, entire, rolled inwards.

64. Fæni'culum, [Page 380.] Calyx margin obtuse, obsolete. Petals roundish, entire, rolled inwards, with a squarish incurved point. Fruit nearly round. Carpels with five obtuse prominent carinated ridges. Channels with single villce. Albumen half round. General and partial involucre wanting.

$\S \S \S$ Pelals roundish, obovate or obcordate, with an inflexed point.

a. a. Channels with single villc. Calyx with an obsolete margin. 63. Eтио'sa, [Page 378.] Calyx margin obsolete. Petals obcordate, notched with an inflexed point. Fruit roundish, ovate. Carpels with five elevated acutely carinated ridges, of which the lateral ones are rather wider than the uthers, and surrounded by a somewhat winged keel. Channels with single vilte. Albumen balf globose. General involucre wanting, partial of three unilateral drooping segments.

b. b. Channels with single viltce. Calyx with the margin toothed.

62. En'anthe, [Page 373.] Calyx margin of five teeth. Peta's obcordate, with an inflexed point. Fruit cylindrical, or oblong, crowned by the erect styles. Carpels with five somerwhat convex obtuse ridges, the lateral ones rather wider than the others, forming the margiv. Channels with single vitle. Albumen convex, or roundish. General involucre various, partial of numerous segments.

65. Se'seli, [Page 381.] Calyx margin of five teeth. Pelals obcordate, with an inflexed point, or nearly entire. Fruit ovate or oblong, roundish, on a transverse section, crowned with the reflexed styles. Carpels with five prominent or elevated filiform ridges, the lateral ones mostly rather wider than the others, and forming the margin. Channels with single vitla, rarely with two or three. Albumen half round. General involucre various, partial of numerous segments.

c. c. Channel swith many ville.

66. Ligus'ricum, [Page 382 ] Calyx margin of fire tecth, or 
obsolete. Petals obovate, notched with an inflexed point and very short claw. Fruit roundish, or the sides slightly compressed. Carpels with five sharp equal winged ridges, the lateral ones forming the margin. Channels with many vitte. Albumen half round. General involucre various, partial of many segments:

67. Sílads, [Page 383]. Calyx margin obsolete. Petals obovate oblong, entire, or somewhat notched, with an inflexed point, either sessile or with an appendage at the base. Fruit roundish. Carpels with five sharp equal somewhat winged ridges, the lateral ones forming the margin. Channels with many vitte. Albumen nearly round. General involucre of a few segments, or wanting, partial of many segments.

3. Fruit with five primary fliform ridges, flat at the back, with winged acute or thickened margins. Albumen before plane or convex.

a. Ridges very slender, three at the back at equal distances, the lateral ones remote, contiguous to the dilated border, or make part with it.

72. Pastrn'ACA, [Page 389.] Calyx margin obsolete, or minutely toothed. Petals roundish, entire, rolled inwards with a broad obtuse inflexed point. Fruit flattened at the back with a dilated flat margin. Carpels with five very slender filiform ridges, the three dorsal ones equi-distant, the lateral ones remote, near to the dilated margin. Channels with single vitte. Albumen flattened. General and partial involucre of few segments, or wanting.

73. Hera'cledr, [Page 390.] Calyx margin of five teeth. Petals obovate, emarginate, with an inflexed point, the outer ones often radiant, bifid. Fruit flattened at the back, with a broad plane margin. Carpels with very slender ridges, the three dorsal ones equi-distant, the two lateral ones remote, contiguous to the dilated margin. Channels with single clavate vittc. Albumen flattened. General involucre falling away, partial of numerous segments.

74. Tordy'Lium, [Page 392.] Calyx margin of five teeth. Petals obovate, emarginate, with an inflexed point, the outer ones radiant, bifid. Fruit flattened at the back, surrounded by a thickened often crenated accessory margin. Carpels with five very slender ridges, the dorsal 
ones equi-distant, the lateral ones remote, contiguous to the thickened margin, or sometimes covered over by it. Channels with one to three vitla. Albumen flattened. General and partial involucre of numerous segments.

b. Ridges slender, equi-dislant.

75. Peuce'danum, [Page 394.] Calyx margin of five teeth, sometimes obsolete. Petals obovate, emarginate, or entire, with an inflexed point. Fruit flattened at the back, with a broad thin margin. Carpels with five nearly equidistant ridges, the three dorsal ones filiform, the lateral ones more obsolete, contiguous to or confounded with the dilated margin. Channels with one to three vitte. Albumen flat in front. Pericarp double. General involucre various, partial of numerous segmeuts.

76. IMPE'Ratoria, [Page 396.] Calyx margin obsolete; (the rest as in Peucedanum.)

4. Fruit more or less compressed at the back, with five primary and four secondary ridges, prickly.

77. Dau'cus, [Page 397.] Calyx of five teeth. Petals obcordate, with an inflexed point, the outer ones radiant, bifid. Fruit compressed at the back, Carpels with five primary filiform bristly ridges, three at the back, the two lateral ones on the plane of the commissure, the four secondary ones more prominent than the rest, and with a single row of prickles. Channels under the secondary ridges, with single vitle. Albumen flat in front. General and partial involucre of numerous segments.

5. Fruit with the margins of the albumen rolled inwards, or deeply channeled in front.

a. Fruit prickly.

78. Cad'Caris, [Page 399.] Calyx of five teeth. Pelals obcordate, with an inflexed point, the outer ones radiant, and deeply bifid. Fruit slightly compressed on the sides. Carpels with five primury filiform, bristly or prickly ridges, three at the back, the two lateral ones on the plane of the commissure, and the four secondary ridges more prominent, with one or two rows of prickles. Channels under the secondary ridges, with single vilta. Albumen deeply channeled in front. General and partial involucre variable.

79. Toni'lis, [Page 401.] Calyx of five teeth. Petals obcor- 
date, with an inflexed point, the outer ones radiant, and deeply bifid. Fruit with the sides compressed. Carpels with five primary bristly ridges, three at the back, the two lateral ones on the plane of the commissure, the secondary ridges obliterated by the numerous prickles, which occupy the whole of the channels, under which are single villa. Albumen deeply channeled in front. General and partial involucre of numerous segments.

b. Fruit not prickly, ridges obtuse, sometimes wanting, except at the point.

80. Scdx'dix, [Page 404.] Calyx an obsolete margin. Petals obovate, with an inflexed point. Fruit with the sides compressed, and with a very long beak. Carpe's with five obtuse equal ridges, the lateral ones forming the margin. Channels without or with scarcely any vitlce. Albumen roundish, with a deep furrow in frout. General involucre wanting, or of few segments, partial of from five to seven segments.

81. Anthris'cos, [Page 405.] Calyx an obsolete margin. Petals obcordate, with an inflexed often very short point. Fruit contracted at the sides, beaked. Carpels nearly round, without ridges, except five on the beak. Albumen nearly round, deeply furrowed in front. General involucre wanting, partial of numerous segments.

82. Chдrophyl'ivi, [Page 407.] Calyx an obsolete margin. Pelals obcordate, with an inflexed point. Fruit contracted at the sides, beaked. Carpels with five very obtuse equal ridges, the lateral ones forming the margin, the commissure with a deep furrow. Channels with single villa. Albumen roundish, deeply furrowed in front. General involucre wanting, or of few segments, partial of numerous segments.

c. Fruit not prickly, ridges aculely winged, not crenated.

83. Mrrr'His, [Page 410.] Calyx an obsolete margin. Petals obcordate, with an inflexed point. Fruit laterally compressed. Carpels with a deep furrow between them, of five equal acutely winged hollow ridges. Channels deep, without vitta. Albumen closely invested with a second covering of the pericarp, the sides rolled inwards. General involucre wanting, partial of numerous segments.

84. Physusper'mum, [Page 411.] Calyx margin of five teeth. Petuls obcordate, with an inflexed point. Fruit laterally 


\section{SYNOPSIS OF THE GENERA.}

compressed. Carpels roundish, with fire equal ridges, of which the lateral ones are placed within the margin. Channels with single vitta. Albumen with the sides rolled inwards. General and partial involucre of numerous segments.

85. Surr'xium, [Page 413.] Calyx an obsolete margin. Petals lanceolate, or elliptical, entire, with a long inflexed point. Fruit laterally compressed, double. Carpels roundish, reniform, with three acute prominent ridges at the back, the two lateral ones nearly obliterated. Channels with numerous villce. Albumen with the sides rolled inwards. Involucres various.

\section{d. Fruit not prickly, ridges crenated or waved.}

87. Coxi'ur, [Page 415.] Calyx an obsolete margin. Petals obcordate, with a very small inflexed point. Fruit laterally compressed, orate. Carpels with fire equal prominent waved or crenated ridges, the lateral ones forming the margin. Channels with numerous streaks, but no vilte. Albumen with the sides rolled inwards. General involucre of fer segments, partial of three on one side.

86. Eснixn'phora, [Page 4[4.] Calyx margin of five teeth. Petals obcordate, with an inflexed point, the outer ones larger and bifid. Flowers of the ray on long stalks sterile, in the centre a solitary fertile one. Fruit ovate, roundish, inclosed in a hollow receptacle, with a short protruded beak. Carpels with five depressed equal waved striated ridges. Channels with single vitta, corered with an arachnoid membrane. Albumen with the sides rolled inwards. Involucre of numerous segments.

e. Fruit globose. Albumen concave in front.

88. Corian'drum, [Page 417.] Calyx margin of five teeth. Petals obcordate, with an inflexed point, the outer ones larger, bifid. Fruit globose. c'arpels with five primary depressed wared ridges, the lateral ones before an accessory margin, the four secoudary ones more prominent and carinated. Channels without vitla, the commissure with two vitla. Albumen hollow in tront, covered with a loose membrane. General involucre wanting, partial on one side.

*** Perianth double, inferior. Corolla of five petals.

(See Staphylea in ORD. III.) 
101. Li'vom, [Page 452.] Calyx of five persistent pieces. Corolla of fire petals. Stamens united at the base into a ring with intermediate teeth opposite the petals (abortive stamens). Capsule globose, pointed with the indurated base of the style, of ten valves, and ten cells. Seeds ovate, compressed.-Herbaceous plants, with entire leaves, and very fugitive petals.

102. Sibbatidia, [Page 456.] Calyx of ten segments, the alternate ones small. Corolla of five petals, inserted into the calyx. Fruit five small nuts, placed upon a dry receptacle. (Stamens and nuts vary from five to ten.) Small herbaceous plants, with compound leaves and yellow flowers.

(See Cerastrum and Spergula in Class 10.)

Order VI. HexagyNia.-6 Pistils.

103. Dro'sera, [Page 4557.] C'alyx deeply five-cleft. Corolla of five petals. Styles three to five, divided in two. Capsule one celled, three valved. Seeds numerous.Herbaceous plants, clothed with beautiful glandular hairs, flowers white.

Order VII. Polygrnia.-Many Pistils.

101. Mrosu'rus, [Page 459.] Calyx of fire pieces, elongated at the base. Corolla of five petals, with filiform tubular claws. Capsules indehescent, several, triquetrous, single seeded, inserted into a much elongated columnar receptacle, and terminated by the styles.-Small herbaceous plants, with linear radical leaves, yellowish flowers, and a remarkiably elongated receptacle.

(See Ranunculis Ficaria in Class 13.) 
FLORIGRAPHIA BRITANNICA. 




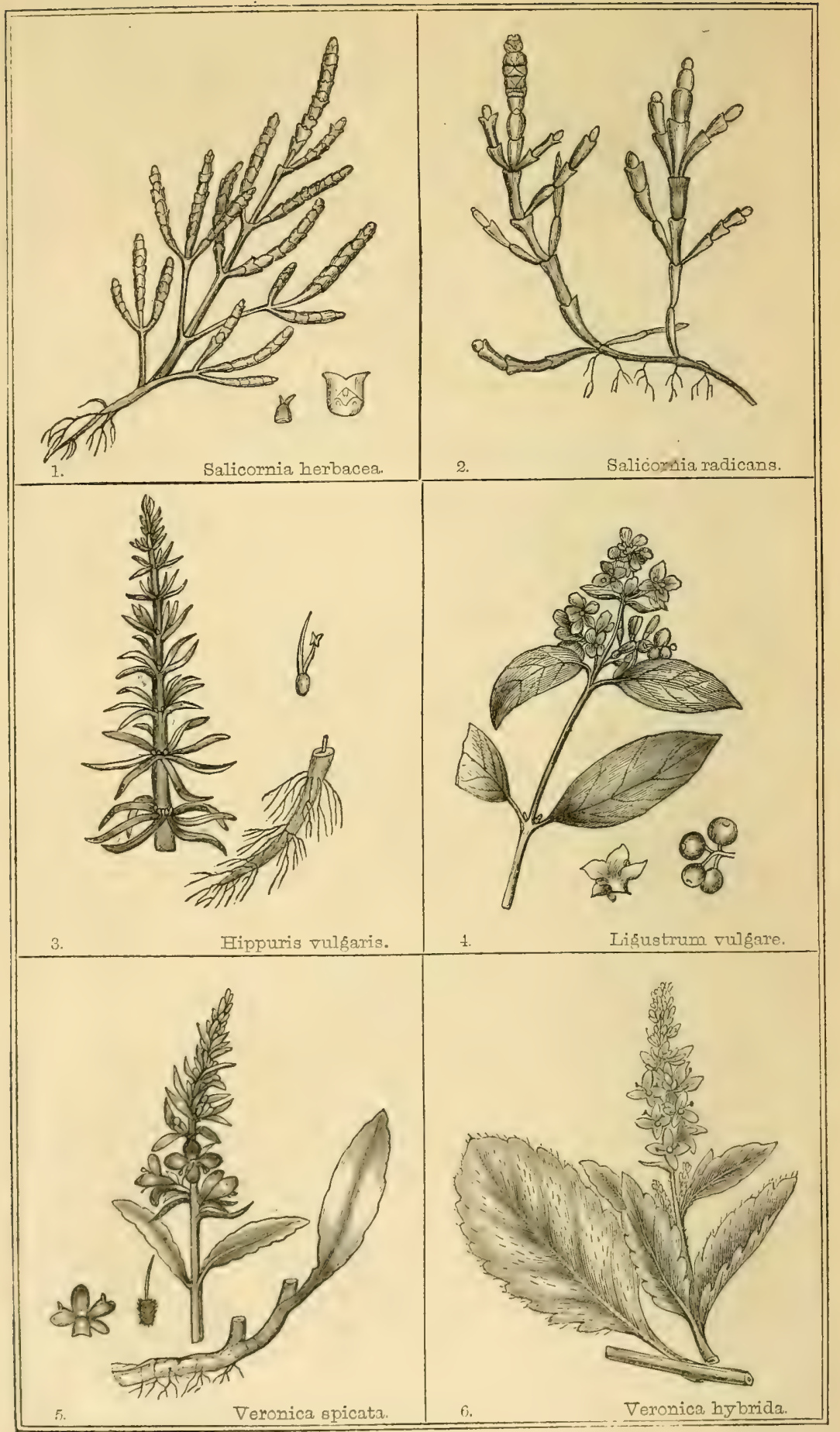




\title{
FLORIGRAPHIA BRITANNICA.
}

\author{
CLASS I. \\ MONAN'DRIA.† 1 STAMEN.
}

ORDER I.

MLNOGYN'TA. I PISTIL.

GENUS I. SALICOR'NIA. Glasswort.

Natural Order. Chenopo'nex.

Generic Character. Perianth single, swelling, fleshy, wearly equal. Style short. Stigmas two or three cleft. Seed one, inclosed in a thin transparent skin (Utricle) enveloped in the inflated Perianth. Named from sal, salt, and cornu, a hoon.

1. S. herba'cea, (Fig. 1.) jointed Glasswort. Stem herbaceons, joints compressed, notched and thickened upwards, lower hranches divided. Spikes tapering towards the extremity.

a. Stem erect. S. an'nua, English Botany, t. 415. S. herbacea, English Flora, vol. i. p. 2.

B. Stem procumbent. S. procum'bens, English Botany, t. 2475. English Flora, vol. i. p. 2.

Lindley, Synopsis of the British Flora, p. 214.-Hooker, British Flora, vol. i. p. 1.

Root small and annual. Plant six to twelve inches high, fleshy, jointed, brancherl and leafless, each joint surrounded by a short two.

+ The student may be somewhat perplexed with the anomalous plants of this class. A flower with one stamen is the character of the class; but Salicornia is not unfrequently found to contain two stamens, and the lower flowers of Hippuris frequently without any. Other anomalous species, such as Valeriana rubra, (which has only one stamen,) Valeriana dioica, Lychnis dioica, \&c., have the stamens and pistils in separate fiowers; they are, however, arranged with other species in their respective classes, and a reference will be inserted under the class to which they might he thought to belong. Zosterce and Callitriche are removed to the class Monceia, on account of the stamens and pistils generally heing found separated; and the genus Chara is now placed in the elass Cryptogamia.

VOL. I. 
lobed membraneous sheatl. Stem woody within. Flowers in close spikes, lateral, and terminal in short joints, bearing at the base of the articulations two clusters of three flowers each. Stigma two or three cleft. Stamen one or two.

Habitat.-Frequent in salt marshes.

Annual; flowering in August and September.

2. S. radicans, (Fig. 2.) creeping Glasswort. Stem woody, procumbent and taking root, joints compressed and notched at the top, interstices cylindrical, spikes oblong, obtuse.

English Botany, t. 1691 ; and 5. fruticosa, t. 2467.-Englis? Flora, vol. i. p. 3.-Lindley, Synopsis, p. 214.-Hooker, British Flora, vol. i. p. 2 .

Stem perennial and spreading. This varies but little from S. herbacea, except in its more spreading slender branches and perennial woody stem. The S.fruticosa of the English Botany, t. 2467, and the English Flora, p. 3, is only a variety or imperfect plant of the pre. sent species.

Habitat.-Muddy sea-shores; rare.

Perennial; flowering in August and September.

The various species of this genus of plants are found on the seacoasts of most parts of the world, and are of great importance from the soda which they produce. In the south of France, and on the Mediterramean shores of Spain, they are marle an object of extensire cultivation. Attempts have been made to cultivate them inland, but it was found that instead of producing soda, as when grown on the sea-coasts, they only contained potash: from which it appears that air impregnated with saline particles is necessary to the production of soda. When burned, their ashes form the barilla of commerce; dissolved in water, and crystallised, it obtains the name of soda; impregnated with car. bonic acid gas, it forms the carbonate of soda of the shops; and from soda being used in the manufactory of soap and glass, the genus has derived the English name, Glassurort. Sorla, called also fossil or mineral alkali, natron by the Germans and Swedes, and nitrum by the ancients, is now abundantly procured from common salt, which exists in rast quantities in the waters of the occan. It was demonstrated by Sir H. Dary, in a series of experiments with the galvanic battery, by which he made some of the most brilliant discoveries in the science of Chemistry, that soda is composed of a metal, to which he gave the name of sodium, and oxygen gas of the atmosphere. Salicomia is frequently gathered by the country people, and sold for Samplire (Crithmum maritimum); and is said not to be inferior to it when pickled with rinegar. 


\section{GENUS II. HIPPU'RIS. Mare's Tail.}

\section{Nat. Ord. Halorágez:}

Gev. Cuan. Perianth single, crowning the gemen with a very slight border. Seed one, inclosed in a small oval, hard, and shining pericarp (nut). Named from hippos, a mare, and oura, a tail. It was the opinion of the late Mr. Curtis, that the Hippuris of Linnæus was identical with a plant mentioned by Dioscorides under a different name, and arranged by his commentator Miathiolus with our Polygonum ariculare and Herniaria: "succeeding botanists," he says, "imagining from the growth of its leares, or from its producing seerl, that it had better pretensions to be ranked with the Equisctum, absurdly enough called it Canda equina famina, to which Mr. Hudson could not well aroid giving the English name of Mare's-tail."

1. H. vulya'ris, (Fig. 3.) common IIarc's Tail. Leaveslinear, six to ten in a whorl.

English Botany, t. 763.-English Flora, vol. i. p. 3.-Lindley, Synopsis, p. 110.-Hooker, British Flora, vol. i. p. 2.

Ront jointed, the fibres whorled at each artienlation. Stem undivider, crect, shining, with a tough wordy column passing through its centre. Leaves about eight in a whorl, narrow, smooth, with a callous point, spreading, ahout ais inch in length. Flmer small, attached to the stem at the base of the upper laves, never ilteruate; superior to the germen, and bearing within its slight horder a stemon and taperiring thead-like style: the former frequently abseut in the lower part of the stem. Filament at first short, afterwards nearly the length of the style. Anther when young of two large reddish lohes, with the style passing between them. Germen ovil, inferior. Seed single.

The short stems remaining under water are thickly set with longer and thinner leaves than those on the flowering stem, and generally ten in a whorl: the whorls frequently less than the eighth of an inch apart, forming dense brush-like tufts. Dr. Hooker finds this plant at Surlingham, Norfolk, two or three fect loug, with the leaves excessively crowded, three and cren four inches in length, pellueit, with an oparue nerve, their points not callous; the whole plant submerged, and consequently barren; and at Ben-y-gloe, in Scotland, at a considerable clevation abore tle se?, the opposite extreme of this, scarcely four inche: high.

Habitat.-Ditches, lakes, and slow streams; frequent in England, in gravelly soil; not so common in Scotland.

Perennial ; flowering June and July.

It possesses slightly astringent qualities, and is sometimes user by the country people as a tea in a relaxed state of the bowels, \&c:; but its rirtues are so slight as to render it unworthy attention. 


\title{
CLASS II.
}

\section{DIAN'DRIA. 2 S'IAMENS.}

\section{ORDER I.}

\author{
MONOGYN'IA. 1 Pistil.
}

\section{GENUS I. LIGUS'TRUM. Privel.}

Nat. Ord. OL'EACEE.

Gen. Char. Perianth double. Calyx inferior, of one leaf, with four bluntish projecting teeth. Corolla of one petal, regular, in four segments. Berry of two cells, with two seeds in each. Name from ligo, to bind; from its tough and pliant branches being used in making bands.

1. L. vulgar'e, (Fig. 4.) common Privet. Leaves elliptico-lanceolate, flowers in dense panicles.

English Botany, t. 764.-English Flora, vol. i. p. 13.-Lindley, Synopsis, p. 171.-Hooker, British Flora, vol. i. p. 4.

Shrub six or eight feet high, with terminal panicles of odoriferous white flowers. Bark smoothish, often sprinkled with numerous brown oval spots (Lenticular glands), which indicate the point from whence roots would appear, if placed in a fivourable situation for their production. Wood tough and flexible. Leaves on short footstalks (petioles) varying from long and narrow to nearly round, opposite and alternate. Calyx and pedicle somewhat hairy, with short deciduous bractea. Corolla white, incurved at the edges, longer than the calyx, turning brown before falling. Stamens opposite, alternate with the segments of the corolla. Style short. Berry blackish-purple or yellow, round and pulpy.

Habitat.-Hedges and thickets in shady situations; common.

Perennial ; flowering in July and $\Lambda$ ugust.

Priver.-Prim-privet is an ornamental and useful shrub. It is often planted with advantage in Beech (Fagus Sylvatica) and Hornbeam (Carpinus Betulus) hedges, in a stiff clay soil; in such situations it sometimes attairs the height of sixteen feet. In moist ground, when partially shader?, its long flexible branches form an impenetrable undergrowth, well adapted for covers in game preserves, \&e. The berries are harmless, and are fer on by pheasants, partridges, and other birds. It is remarkably patient of the shears, and is sometimes cut into singularly fantastic forms; and is one of the few plants that will grow under the shade and drip of trees, and confined smoky situations, for which reason it is common eren in the close parts of large 
towns. The catcrpillars of the Privet Hawkmoth, (Sphinx ligustris,) may fiequently be found fecding upon the leaves of this plant; and specimens of the moth are best obtiined by fecting the caterpillars in a cage made for the purpose, or in common garden-pots covered with glass, until they change into the chrysalis state; they may then be removed into a dry cool place until the following spring; during the months of $\Lambda$ pril or May, they shuuld be exposed to the influence of the sun, and in a short time the perfect moth will make its appearance.

\section{GENUS II. VERON'ICA. Speedwell.}

Nat. Ord. ScropheLARIN'E.E.

Gen. Chan. Perianth double. Calyx of one piece, inferior, persistent, divided into four deep segments. Corolla wheel-shaped (rotate), deeply four eleft, the lower segment smallest. Capsule two-celled. The derivation of the name of this beatiful genus has much puzzled botanists: Sir J. E. Smith says, "Its common etymology is of a mule kind between Greek and Latin, from verus, or rather vera, true, and हirov, a figure; and this, illiterate and barbarous as it is, has the sanction of the superstitious legend of St. Veroniea, whose handkerchief is recorded to have received the impression of our Saviour's face, as he used it in bearing his cross to the place of crucifixion. But we find nothing analogous in any of the herbs which have borne this name, nor any character, true or false, stamped upon them, except that of their own peculiar beauty." 'There exists to this day a difference of opinion as to the pronunciation of the name; and it was to the settling of this question that the controversial inquiry was mainly directed. "If," adds the learned authority above quoted, "there be any truth in its Greek origin, the $i$ must be long; but if otherwise, the analogy of Betonica may justify the usual practice of throwing the accent on the o."

\section{* Spikes or racemes terminal. (Root perennial.)}

1. V. spica'ta, (Fig. 5.) spiked Speeduell. Spike terminal, stem erect, undivided, branching at the base, lcaves opposite, oblong, tapering at the base, serrated, downy, lower or radical ones broader, ovate and stalked.

English Botany, t. 2.-English Flora, vol. i. p. 17.-Lindley, Synopsis, p. 188.-Hooker, British Flora, vol. i. p. 5.

Stem four to ten inches high, crect, downy. Lower Leares opposite, broader, serrated or crenated in the middle, entire towards the extremi. ties, upper ones long and narrow, serrater or entire, sometimes alternate. Spike terminal. Flowers numerous dark bluc. Bracteas linear. Caly $x$ remarkably downy twice as long as broad. Capsule in the immature state downy. 
Habitat.-Clalky fround about Bury St. Edmund's and Nowmarket Heath. Rare.

Perennial ; flowering July and August.

V. hyb'rida, (Fig. 6.†) Welsh Speeduell, of Engl. Botany, t. 673, and Engl. Flora, vol. i. p. 17, is now thought to be only a variety of the above; indeed, Dr. Hooker deems it scarce worthy of being commemorated as a variety, and to differ only in its more luxuriant growth. The whole plant is larger, with broader, more oval and distinctly veined Leares, stalked, often three in a whorl, unequally serrated, the lowermost ovate and broader. Stem erect and generally bearing three spikes. The whole plant is stouter, rougher, and much larger.

Habitat.-Humphrey Head, near Cartmel Wells, Lancashire,Ormeshead, and Gloddaeth, near Conway; Craig Wreiddim, in Montgomeryshire. Rare.

2.V. serpyl'lifolia, (Fig. 7.) thyme-leaved Speedwell. Raceme somewhat spiked, leaves ovate, obtuse, slightly crenate, three ribbed, smooth, capsules inversely reniform, about as long as the style.

English Botany, t. 1075. - English Flora, vol. i. p. 20.-Lindley, Synopsis, p. 188.-Hooker, British Flora, vol. i. p. 5.

B. V. alpi'na; stems prostrate. V. humifu'sa, Dicks. Linn. Tr. vol. ii. p. 288.

Root fibrous. Stem ascending, branching from the basc. Lcaves upposite, frequently entire, lower ones on footstalks, upper ones nearly sessile. Calyx segments, obovate, equal; blunt. Corolla light blue or flesh-coloured, with dark blue veins. Capsule in the immature state inversely heart-shaped (obcordate), when ripe inverscly kidneyshaped (reniform). The whole plant is more or less downy, depending upon the situation in which it has grown: if in a wet place, it is smooth and shining; in a dry one, it is clothed more or less with pubescence.

Habilat.-Gardens, pastures, \&c. Common: $\beta$. On the high mountains of Scotland; on Snowden; Cheviot Hills, Northumberland.

Perennial; flowering from May to July.

3. V. fruticulo'sa, (Fig. 8.) shrubby Speedwell. Raceme somewhat spiked, many flowered, leaves ovatc-lanceolate, thick, slightly serrated, stem ascending, woody and branching at the base, capsule ovate, slightly notched at the extremity.

English Botany, t. 1028.-English Flora, vol. i. p. 18.-Lindley, Synopsis, p. 188.-Hoolier, British Flora, vol. i. p. 6.

loot strong and woody. Stcm crect, round; wooly towards the root. I.cares opposite on short footstalks, palc green, leathery, frequently en-

+ It is intended to give firures, as in the present instance, of some of the more marked varieties of the different species of plants, which will be of considerable assistance to the young student in Botany. 


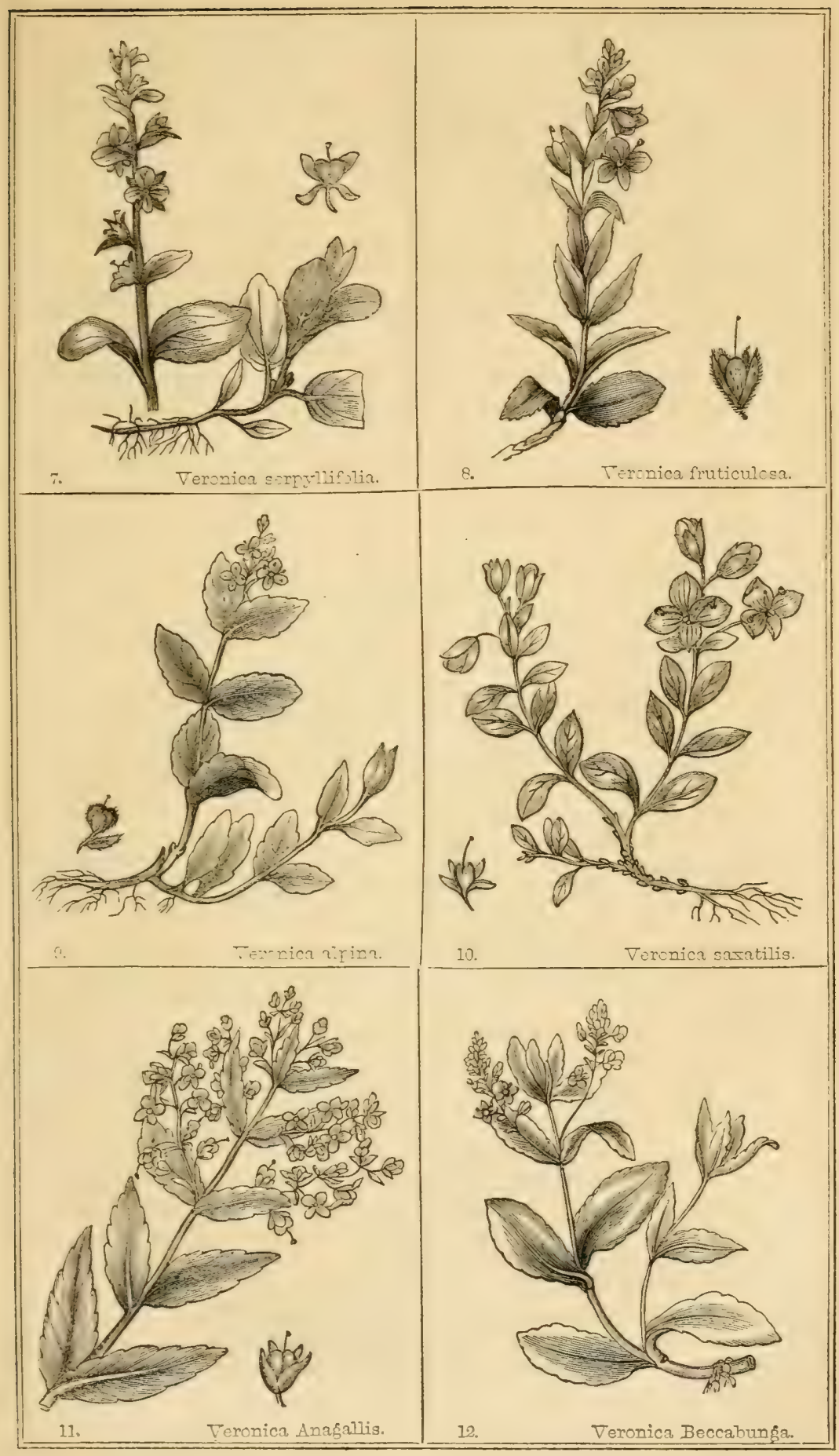



tire at the extremities and serrated in the middle. Racemes long, flower-stalks (pedicles) longer than the bractea. C'aly.r segments, olrovate, longer than the capsule. Corolla flesh-coloured and reined. Capsule ovate. Style longer than the capsule, its stigma capitate. Seed smooth and flat.

This species was long confounded with $V$. saxatilis, but appears to be quite distinct, and one of the rarest of our native plants. We have been unable to obtain other than cultivated specimens. It has only been found in Scotland, by Dr. Walker upon Ben Cruachan, and Mr. Brown upon Ben Lawers. Sir James Smith, in speaking of it, remarks, " Mr. Brown, whose accuraey is beyond all doubt or 'supposition,' told me he found this plant on Ben Lawers. I trust no further confirmation is requisite to establish it as a native." E. Bot.

In luxuriant cultivated specimens, the racemes or clusters are frequently lateral, the leares broaler at the hase and clasping the stem, and the whole plant downy.

Perennial; flowering in July.

1. V. alpina, (Fig. 9.) alpine Speedwell. Raceme corymbose, leaves ovate, slightly serrated, smoothish, calyx and bracteas fringerl with jointed hairs, capsule obovate, notched at the extremity, style short.

English Botany, t. 484.-English Flora, vol. i. p. 19.-Lindley, Synopsis, p. 188.-Hooker, British Flora, rol. i. p. 5.

Stem erect undirided from four to six inches high, branching at the base. Leares various in size, larger and more deeply serrated than those of V.serpyllifolia. Flowers deep blue, at first in a short compact corymb, afterwards elongated with the lower flower-stalks longer than the upper. Calyx in four unequal segments and as well as the bracteas hairy. Capsule obovate. Style rery short. Stigma capitate. The whole plant scattered with white jointed hairs.

Habitat.-Found only on the summit of the Highland mountains of Scotland, on the margin of rivulets and trickling rills; but rare.

Perennial; flowering in July and August.

5. V. saxat'itis, (Fig. 10.) blue rock Speedwell. Raceme of few flowers, corymbose, leaves oval, slightly serrated, stems spreading, capsules ovate, of four bifid ralves.

English Botany, t. 1027.-English Flora, vol. i. p. 19.-Lindley, Synopsis, p. 188.-Hooker, British Flora, vol. i.p. 5.

Root perennial long and fibrous. Sicms woody, slender, procumbent at the base and much branched. Leares smooth, veiny, serrated or entire, more or less stalked, turning black when dry. Floucers large, bright blue, richer in the brilliancy of its colour than any other of the genera.

Habitat.-On exposed rocks in Scotland; rare. Our specimenswere collected on Ben Lawers; it is also foumd on other mountains of the Breadalbane range.

Perennial; flowering in Suly. 
Deservedly esteemed as an ornament to the flower-garden; and patches of its rich hlue flowers, contrasted with the bright green leaves, are highly decorative to artificial rockery, \&c.

\section{* Racemes axillary. (Root perennial.)}

6. V. Anagal'lis, (Fig. 11.) Water Speedwell. Racemes arising from the base of the upper leaves (axillary), leaves opposite, lanceolate, serrated, stem erect.

English Botany, t. 781.-English Flora, vol. i. p. 21.-Lindley, Synopsis, p. 188.-Hooker, British Flora, vol. i. p. 6.

Root fibrous. Stem erect, succulent, smooth, from six inches to two feet high. Leaves tapering towards the end, without footstalks, various in wilth. Racemes lateral, slender, many flowered. Flower-stalks erect. Calyx of four equal ovate lanceolate segments, with three veins arising from the base of each, the centre one largest. Flowers light blue or flesh-coloured. Capsule nearly round, slightly notched, valves closely reticulated. Seed small and numerous. Style half the length of the capsule. The whole plant varying extremely in size, depending upon the situation in which it has grown: in the fens about Lincoln it grows two feet high, the lower part of the stem and axils of the leaves thickly clothed with close down. Racemes branched, and, as well as the pedicles, scattered with short pubescence.

Habitat.-Ditches and muddy places; not uncommon. Less fiequent in Scotland than in England.

Perennial; flowering in July and August.

7. V.Beccabun'ya, (Fig. 12.) Brooklime. Racemes arising from the base of the opposite leaves, leaves oval, blunt, slightly serrated, smooth, stem procumbent taking root at the joints.

English Botany, t. 655.-English Flora, vol. i. p. 20.-Lindley, Synopsis, p. 188.-Hooker, British Flora, vol. i. p. 6.

Stem creeping freely, taking root at the joints, when grown in water, whole plant very succulent, and bent in various forms. Leaves opposite with short footstalks, oval, serrated and spreading. Racemes long of numerous bright blue flowers. Flower-stalks erect. Calyx of four ovate acute equal segments, with three or five veins. Capsule roundish, tumid, scarcely reticulated. Seed small and numerous. Style about the length of the capsule.

Habitat.-Rivulets and ditches; very common.

Perennial; in flower during the summer months.

Brooklime was formerly greatly esteemer in the cure of numerous discases, particularly those of the skin, and had great reputation in the lealing of wounds and ulcers, but it is now entirely neglected; if any benefit is to be obtained from its use, it must be taken in large quantities, and as a common article of food; it is frequently gathered and eaten with water cresses (Nasturtium officinale).

Beccubunga is derived from the German Bach-pungen, bach meaning a rivulet; in Yorkshire and Norfolk a beck. (Smith.) 



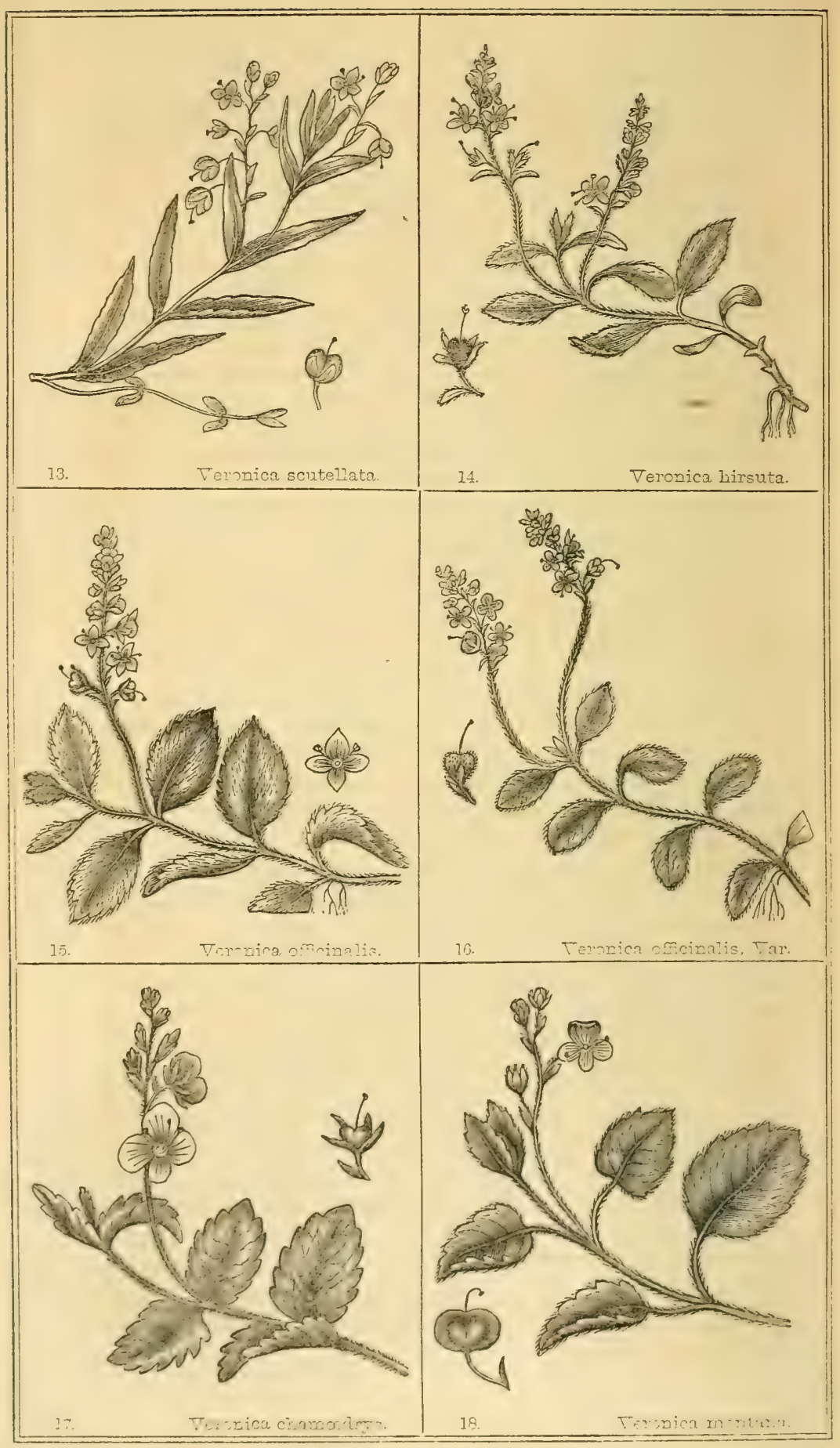


8. V. scutella'ta, (Fig. 13.) Narrow-leared Marish Speeduell. Racemes lateral, alternate, pedicles spreading, in fruit deflexed; leaves linear, slightly toothed.

English Botany, t. 782.-English Flora, vol. i. p. 21.- Lindley, Synopsis, 1. 188.-Hooker, British Flora, vol. i. p. 6.

Stem six to twelve inches long, weak, nearly erect. Leaves toothed or entire. Racemes lung, generally simple, sometimes divided, and the divisions, as well as the flower-stalks, spreading. Calyx ovato-lanceolate, half the length of the capsule. Corolla llesh-coloured, with dark blue veins. Capsule of two that orbicular membranous lobes. Style nearly as long as the capsule. Stigma capitate. Whole plant generally smooth, but sometimes it is found covered with more or less pubescence, depending, like $\boldsymbol{V}$. serpyllifolia, upon the situation iii which it has grown; the racemes also vary considerably in their length, which likewise depends upon the place of its growtl.

Habitat.-In marshy and boggy wet places not uncommon.

Perennial; flowering in July and August.

On a common near Esher, Surrey, we have gathered specimens of this plant remarkably slender, with racemes nearly twice the usual length, but differing in no other respect from the common appearance of the plant.

9. V. hirsu'ta, (Fig. I1.) small hairy Speeduell. Racemes lateral, slender, leaves ovato-lanceolite, somewhat serrated, scattered with hairs, stem procumbent, hairy, capsule obcordate, undivided.

Hopkirk, Flora Glottiana, p. 9.-English Flora, vol. i. p. 22.Hooker, in English Botany Supplement, t. 2673.

Y. setigera, D. Don's Deseription of Rare Plants of Scotland, p. 4. Lindley, Synopsis, p. 180.-Hooker, British Flora, vol. i. p. 7.

Stem procumbent, branching at the base, slender. Leaves narrow, acute, tapering into a footstalk. Racemes, slender, the lower flowers distant, the upper more compract. Flouer-stulks shorter than the bracteas. Corolla pale blue. Anthers purple. Stigma capitate. Capsule frequently abortive. A very small species, having the appearance of a starved specimen of $\mathrm{I}$. officinalis, and doubts are entertained as to its being any other. The abrupt undivided capsule, which Sir J. Smith considers as its most marked distinguishing character, we not unfrequently find in $V$. officinalis, but it retains its diminished size and the above characters after long cultivation.

Habitat.-In dry heathy places in Carrick, Ayrshire-Mr. James Simith.

Perennial; flowering in June.

10. V.officinalis, (Fig. 15.) common Speedwell. Racemes lateral, leaves opposite, ovate, serrated, petiolated, downy, stem procumbent, very downy.

yol. I. 
English Botany, t. 765.-English Flora, vol. i. p. 22.-Lindley, Synopsis, p. 188.-Hooker, British Flora; p. 6.

ß. Nearly smooth, English Flora, vol, i. p. 22. V. Allionii, D. Don, MSS. Hooker's Flora Scoticæ, vol. i. p. 7.

Stem three to twelve inches long, creeping, taking root from the axils of the leaves, branched at the base. Leaves obtuse or pointed, more or less serrated, petioles short. Racemes long, flower-stalks erect, shorter than their bracteas. Corolla light blue, with dark veins. Capsule obcordate, deeply notched, or entire. Style longer than the capsule, its stigma capitate. Seed pale, smooth. Whole plant more or less rough, with spreading hairs, which are apparently jointed, and are a beautiful example, when examined with a microscope, of the delicate transparent cellular structure of hairs. An exceedingly variable plant, sometimes very small, and thickly covered with close hair, leaves ovate, lanceolate, or rotundate, nearly entire or deeply serrated; at other times it is long and spreading, leaves broadly ovate, tapering into a footstalk, approaching spatulate, and much less downy.

The V. officinalis is sometimes found with flesl-coloured flowers; several plants of this description we have seen on the moors about five miles west of Sheffield, growing contiguous to and forming a pleasing contrast to the usual appearance of this species, from which, however, it differs in no material point, except in the colour of the flower, an occurrence by no means rare to plants even in a state of nature; it is nevertheless one of the most singulariy interesting changes of which plants are susceptible, and probably one of those over which human ingenuity possesses comparatively no control. Instances may indeed be mentioned-Hydrangea hortensis for example-when plants, by peculiar treatment, are sometimes made to change the colour of their flowers from white to blue; but even this transitory result cannot always be effected with certainty. Seedling plants of Pinks, Carnations, Picotees, \&c., but more especially Tulips, often defeat for years the diligent attention of the most skilful florist, until some cause, which by mere cultivation he can neither hasten nor retard, interposes, and causes his flowers to break, as it is technically termed, from the dingy self colour into perhaps a brilliant scarlet, purple, or yellow. Those floral changes of colour which affect plants in a state of nature, are mostly from blue to white, from red to blue, and from red to white-seldom from white to red or blue; whence it will appear that these changes tend to a loss rather than an accession of colour.

Habitat.-Woods, banks, heaths, and pastures; common. $\beta$. On mountains in Scotland and Ireland.

Perennial; flowering from May to August.

The student in Botany may find the varieties of this species somewhat perplexing, but with attention to the above characters, mistakes as to the itlentity of the species will not arise. We have frequently had specimens sent by individuals, with a doubt as to whether the ra- 
cenes were axillary or terminal, as seen in Fig. 16. The louger petioles, the nearly entire lcaves, and the whole plant smaller, have led them to indulge in the belief of its being a distinct species; but the removal of the plauts to better soil and a more farourable situation for their growth, has proved them to be only varieties, by assuming the more ordinary appearance of the plant; and, it will be observed, the small leaves between the racemes embrace the terminal bud which would have elongated and continued the stem.

This plant was formerly recommended medicinally, in the form of tea, as a pectoral against coughs and asthmatic affections. It entered into the materia of pharmacopxias under the names of Veronica mas; Thea germanica; Betonica pauli; and Chamadrys spuria. We have known cases of individuals labouring under affections of the chest, for the cure of which the greatest faith has been placed in the supposed virtues of this plant; the partics taking a strong infusion of it for a length of time, without experiencing the least benefit, or, happily, much injury, from the drink. Its efficacy, if any, is so slight as to be unworthy of attention, and is now justly forgotten. It is astriugent and hitter, and has been used extensively in Sweden and Germany as a substitute for China tea; but its bitter, disagreeable, sickly flavour, readily distinguishes its infusion from that of the real tea.

\section{V. chame'drys, (Figr. 17.) Germander Speedwell-Wild German-} der. Racemes lateral, clongated, many flowered, leares ovate, rugose, deeply serrated, sessile or on short footstalks, stem with two opposite longitudinal hairy lines, capsule inversely heartshaped, shorter than the calyx.

English Botany, t. 623.-English Flora, vol. i. p. 23.-Lindley, Synopsis, p. 189.-Hooker, British Flora, vol. i. p. 7.

Stem undivided, round, rooting at the base, ascending, marked with a hairy line on each side, changing their position at each pair of leaves. Leares deeply and unequally serrated, opposite, sessile or on short footstalks, with numerous veins sunk on the upper side, prominent and hairy bencath. Racemes latcral, sometimes opposite, long, slender, many flowerch, and gracefully curved in the upper part. Flouer-stalks also slender, more or less hent, about half an inch long, with lanceolate bracter. C'aly, segments, lanceolate, acute, ant hairy, shorter and much smaller than the corolla, the large petals of which are of a beautifu. blue, streaked with darker reins, sometimes purple, lilac, or whitish, downy at the base. Whole plant more or less hairy, and of a darker green than $V$. montana, which it most rescmbles, though essentially distinct, especially in the shorter leaf-stalks, the racemes longer and more abundantly flowered, the corolla larger, and the capsule much smaller.

IIabitat.-In groves, pastures, and hedges common.

Peremial; flowering May and June. 
When planted in rich soil, in a cool, 'sharly situation, this bcautiful little plant becomes a highly ornamental border flower, continuing to grow and produce blossoms long beyond its usual period of flowering; but in such situations it seldom survives more than one season: it thereforc becomes an annual, and is frequently cultivated as strch, excelling, in the brilliancy and profusion of its flowers, many of the rarer exotic species. It is a great favourite, not only from the beauty of its flowers, but as an early harbinger of Spring; and few plants present a morc pleasing appearance to the admirer of Nature, than its soft blue but transient flowers gaily decking its native banks, or gracefully drooping in the shady grove. It is frequently mistaken for the emblem of friendship, the Forget-Me-Not (Myosotis palustris), but a very slight botanical knowledge will correct a mistake in plants so different from each other. The petals close, and envelope the stamens and pistil, in cloudy or rainy weather, which was called by Linnæus the sleep of plants, and is a singular property observed in many other flowers, which expand only beneath the rays of the sun, and close when they are withdrawn. Others closely fold their petals during the day, and expand them at night, when they also become particularly fragrant. A striking illustration of this property is found in Evinus Lychnidea, a small but very beautiful half-shrubby plant, and one of the many splendid ornaments to the conservatories and greenhouses of this country, which from time to time have been introduced from the Cape of Good Hope: the pure white star-like flowers of this plant continue closely shut during sunshine, but in cloudy weather and twilight they become fully expanded. One of the most remarkable instances of nocturnal flowering plants is the Night-blowing Ccreus, or Cactus grandiflora, the flowers of which begin to open between eight and ten o'clock at night, and continue in bloom until about four the following morning, when they begin to close, hang down, and soon decay. These, and many similar phenomena, will be familiar to the observer of nature, the explanation of which, in several instances, has been long sought, but not satisfactorily accounted for. It is probable that light is a powerful agent in producing the change, for M. De Candolle has found that in many cases the petals would expand when remored from a dark situation to one in which there was light produced by candles.

Withering observes, that an infusion of the leaves of this plant forms a more preferable drink than those of $Y$. offeinalis, and perhaps cqually efficacious.

12. V. monta'na, (Fig. 18.) Mountain Germander Speedwell. Racemes lateral, short, few flowered, leaves cordato-ovate, petiolated, serrated, stem spreading, hairy all round, calyx smaller than the two-lobed orbicular capsule.

English Botany, t. 766.-English Flora, vol. i. 1. 23.-Lindley, Synopsis, p. 189.-Hooker, British Flora, vol. j. p. 7.

Root fibrous. Stem six to cighteen inches long, cqually hairy all 
round, ascending, weak. Ifares upposite, large, hairy, glossy, sometimes pointed at the extremity, equally serrated, with the footstalks about their own length. Rucemes lax, of few flowers. Calyx slightly Iniry, its scgments united in pairs on opposite sides of the large, compressed, membranaceous, and veiny capsule, the thin edges of which are fringed with fine jointerl white hairs. Corolla light blue, streaked with purple or reddish reins, lower segment lighter coloured, small and narrow.

Habitat.-Woods and moist situations; not very common.

Peremnial; flowering in May and June.

How this species, so distinct in its characters, should ever have been mistaken for $V$. chamedrys, is somewhat remarkable; its general appearance, as well as specific characters, are so obviously different.

\section{*** Flowers axillary, solitary. (Root annual.)}

13. V. agres'tis, (Fig. 19.) green proeumbent Field Speeduell-Germander Chickuced. Stem procumbent, leaves opposite, petiolated, cordato-ovate, deeply serrated, as long as the flower-stalks, segments of the calyx oblong obtuse, capsule of two tumid keeled lobes, each cell containing about six seeds.

Burrer, in English Botany Supplement, t. Sơ - English Flura, rol. i. p. 24.-Lindley, Sỵnopsis, p. 189.-Hooker, Britusu Fiuni, : : i. $\mathrm{p} .7$.

Stem from three to twelve inches long, branching at the basc. Leares ovate, decply scrrated, generally opposite, and on the lateral branches frequently shorter than the flower-stalks. Calyx segments, oblong, obtuse, longer than the capsule, dilating and becoming veiny as the fruit adranees to maturity. Flowers small, bright blue. Seed large, oval, wrinkled, and cupped. Whole plant seattered with hairs, varying considerably in size, and in the length of its flower-stalks. WC have specimens from Crab Marsh, Wisbech, nearly smooth, the leaves broad, their stalks dilated and channelled above, the two lower segments of the calyx much larger than the upper, and serrated.

Habitat.-In waste and cultivated places common.

Annual ; flowering during the summer months.

14. V. poli'ta, (Fig. 20.) grey procumbent Field Specduell. Stem procumbent, leares petiolated, cordato-orate, deeply serrated, shorter than the flower-stalks, segments of the calyx ovate, acute, capsule of two tumid lobes, cells containing many seeds.

Veronica agrestis, English Botany, t. 783.-V. polita of Fries ir English Botany Supplement, t. 2603,-Hooker, British Ilora, vol. i. p. 8.

Root small. Stem from threc to twelve inches long, branching at the hase. Leares on the lower part of the stem opposite, above alternate, 
inclining to heart-shape, more or less deeply serrated, shorter than the axillary flower-stalks. Calyx segments ovate, acute, dilating and becoming veiny in maturity, longer than the capsule, which is formed of two tumid round lobes, not keeled, and cach cell many-seeded. Corolla small, bright blue. The whole plant more or less hairy, and of a greyish-green colour. This varies but little from $V$. agrestis, and no doubt is frequently passed over as the same. The most permanent distinguishing characters are to be sought for in the calyx segments and tumid, not keeled capsule; the length of the flower-stalks we find to vary in both species, mainly depending upon the situations in which they have grown: the seeds too are more numerous than in the preceding.

Habitat.-In waste and cultivated ground frequently growing with V. agrestis.

Annual; flowering during the summer.

15. V. hederifo'lia, (Fig. 21.) Ivy-leaved Speeduell-small Henbil. Stem procumbent, leaves cordate, from five to seven, lobed, petiolated, calyx segments cordate and ciliated, capsule of two turgid lobes, its cells two-seeded.

Euglish Botany, t. 784.-English Flora, vol. i. p. 25.-Lindley, Synopsis, p. 189.-Hosker, British Flora, vol. i. p. 7.

Root long, fibrous. Stem from six to eighteen inches long, procumbent, hranching freely at the base, thinly scattered with slender hairs, sometimes in two opposite lines. Leaves somewhat fleshy, slightly bairy, more or less deeply divided into teeth or lobes, the terminal one the largest, upper ones alone nearly sessile, opposite or alternate, their petioles channelled above. Corolla small, sometimes shorter than the calyx, light blue, or whitish, with dark veins. Flover-stalks as long, or longer than the leaves, reflexed in fruit. The outer segments of the calyx frequently smallest. Capsule smooth. Seed large, mostly four, oval, cupped, and wrinkled.

Ilabitat.-In fields, hedge-banks, and cultivated ground frequont.

Annual; flowering during the summer months.

Farictics with decply divided leaves are sometimes mistaken for the more rare species, $V$. trijhyllos, but the tumid capsules at once distinguish them.

16. V.tripluyl'los, (Fig. 22.) trifid Spectwell-blunt-fingered Speedwell. Stem erect, with spreading branches, upper leaves sessile, deeply cut in obtuse segments, lower ones petiolated, flower-stalks longer than the bracteas or the calyx.

English Botany, t. 26.-English Flora, vol. i. 1. 25.-Lindley, Synopsis, p. 189.-Hooker, British Flora, vol. i. p. 9.

Stem from three to fise inches high, the branches mustly arising from the lower part. The uples leates alternate, of from three to five deep 


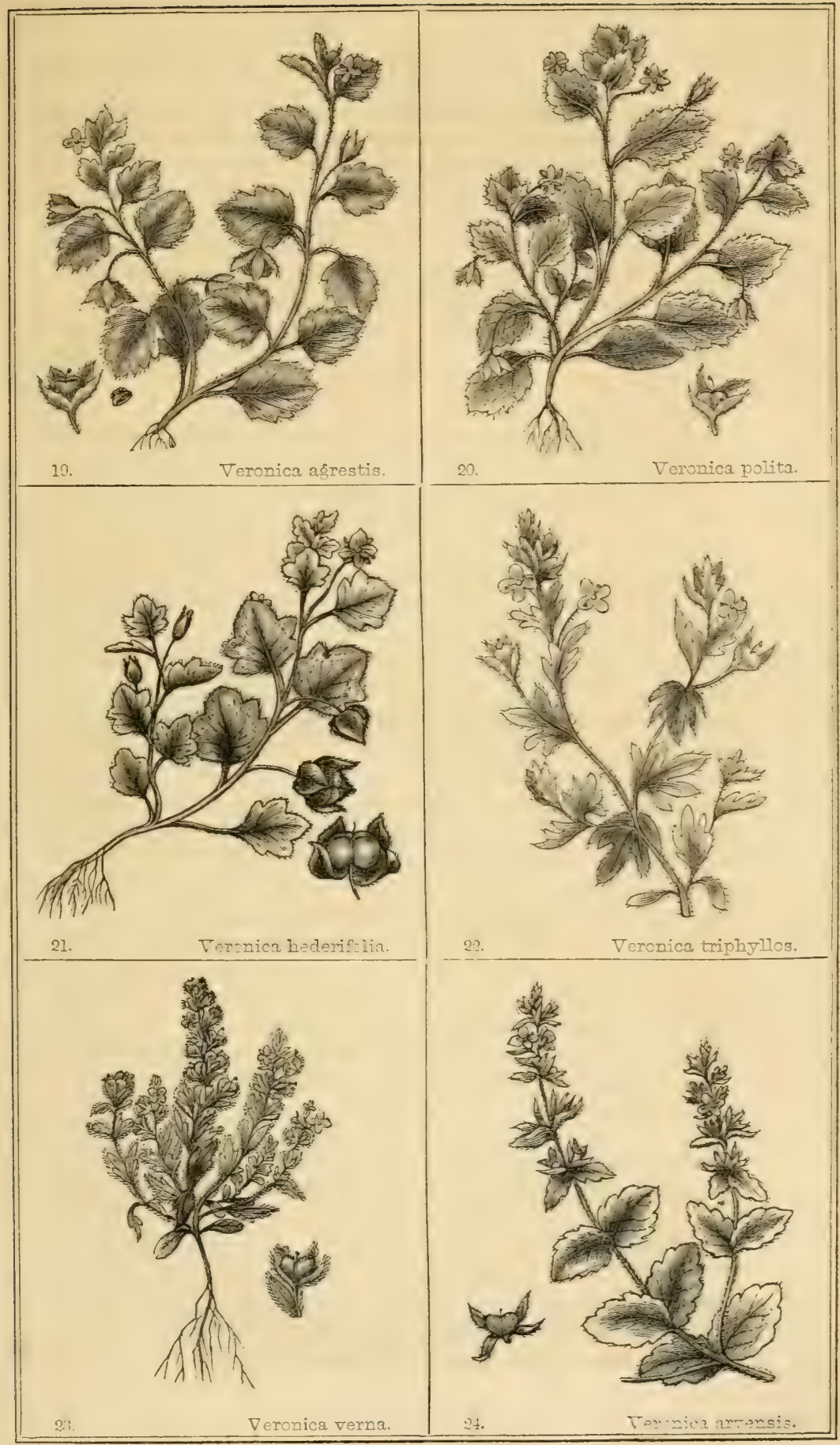



finger-like segments, the lower opposite, entire, or palmate. Corolla a dark rich blue, the lower llowers sometimes on long footstalks. Capsule inversely heart shaped, and hairy. Style short. Seed numerous, flat. The whole plant downy. It is distinguished from all the varieties of $V$. hederifolia by the flat, not tumid capsules, and each cell containing numerous flat seeds.

Habitat.-In sandy fields, but rare; chiefly on the confines of Norfolk and Suffolk, and said to have been found in Yorkshire, by Mr. Tofield. In the neighbourhood of Alcaster "not rare."-Purton's Midland Flora.

Annual; flowering in April.

17. V.ver'na, (Fig. 23.) vernal Speedwell. Stem erect, branching from the base, leaves pinnatifid, the upper ones or bracteas lanceolate, undivided, flower-stalks shorter than the calyx and bracteas.

English Botany, t. 25.-English Flora, vol. i. p. 26.-Lindley, Synopsis, p. 189.-Hooker, British Flora, vol. i. p.9.

A small erect plant, not more than one or two inches high, having the habit of $V$.arvensis, more or less branched at the base, which, as well as the stem, are erect. A number of specimens of this rare little plant are in the collection of the late Mr. Salt, which is now deposited in the Sheffield Literary and Philosophical Society's Museum, and from which our drawing was taken; they appear to have been collected in the neighbourhoor of Bury. All the specimens are branched at the base, some in a close tuft of many branches, and clothed with short thick hair. The leaves are divided mostly in three lobes, the central one the largest, the upper ones lanceolate entire. Corolla small. Capsule inversely heart-shaperl, broad, compressed, downy, ciliated, with a blunt margin.

Habitat.-About Bury and Thetford, Suffolk ; rare ; first discovered by Sir Joln Cullum, Bart.

Annual; flowering in April.

18. V. arven'sis, (Fig. 24.) Wall Speedwell. Stem nearly erect, leaves ovate, decply serrated, upper or bracteas sessile, lanceolate, flowers nearly sessile, shorter than the bracteas.

English Botany, t. 734.-English Flora, vol. i. p. 24.-Lindley, Synopsis, p. 189.-Hooker, British Flora, vol. i. p. 8.

Stem erect or ascending, hairy, from two to twelve inches high, mostly branched at the base, the central stem generally the longest and most erect. The subspicate flowers are at first short and dense, in maturity long and slender. Leares hairy, the lowest opposite on short footstalks, the upper sessile and cordate, the floral ones or bracteas sessile, lanceolate, serrated or entire, becoming alternate, longer than the flowers. Calyx segments lanceolate, the two onter ones frequently longer than the inner. C'orolla small, light blue, or whitish, about the 
length of the calyx. Capsule inversely heart-shaped, compressed, and ciliated. Seed numerous, oval, with a dark sumk spot on one side, convex on the other.

Habitat.-In cultivated ground, banks, walls; \&ce common.

Annual ; flowering May to July.

This is one of our most variable plants, especially in size: if grown in cultivated ground favourable to its growth, it is frequently found more than a foot in length, much branched at the base, and sprending its branches around it; the leaves of such plants are generally more deeply serrated, and on longer footstalks, with the veins spread out into the leaf from its base. But if grom upon walls, or in situations where the supply of nourishment is scanty, the plant is frequently very small, not exceeding an inch or an inch-and-half in length, erect, without branches, and the whole leaves sessile, oval, (as seen in Fig. 25.) strongly veined, and thickly clothed with pubescence. Although varying so greatly in size, its specific characters are constant; and the student will find but little difficulty in correctly referring any of its varieties to its proper station.

The hairiness of plants we have several times mentioned as being greater or less according to the situation and soil in which they hare grown,-a circumstance beautifully illustrative of the means which Nature adopts for the preservation and support of vegetables under the various circumstances in which they are placed. Hairs are composed of transparent cellular tissue, and formed either of a single elongated cell, or of several arranged in a row; they are either pointed, or divided at the extremity into branches in an elegant stellated manner; or they are branched along their whole length, presenting a toothed or plumose appearance. There are many other modifications of hairs, varying extremely in length, rigidity, \&c. They are distinguished by appropriate names, and arranged under two principal divisions, viz. Lymplatic and secreting: the former appear to be for the purpose of protecting the younger parts of the plant from cold, and for regulating the procsss of evaporation from the surface on which they are placed, and where they become points for the attraction of moisture from the surrounding medium. We have already mentioned several instances illustrative of this part of their cconomy ; it may lo added, that plants growing in a situation where a plentiful supply of moisture is afforded, are generally found thinly scattered with, or without hairs; while other plants of the same species, grown in a hot, exposed situation, with a scanty supply of moisture, and where it is necessary they should be furnished with every means of compensating the disadvantage, are dothed with a greatcr or less abundance of hairs. On the approach of evening, when the atmosphere deposits its dews, the capillary organs stand erect, and spread themselves out for the purpose of attracting the moisture which they, or the stomata (month, or opening in the leaf), absorb and carry into the system of the plant; but when the heat of 


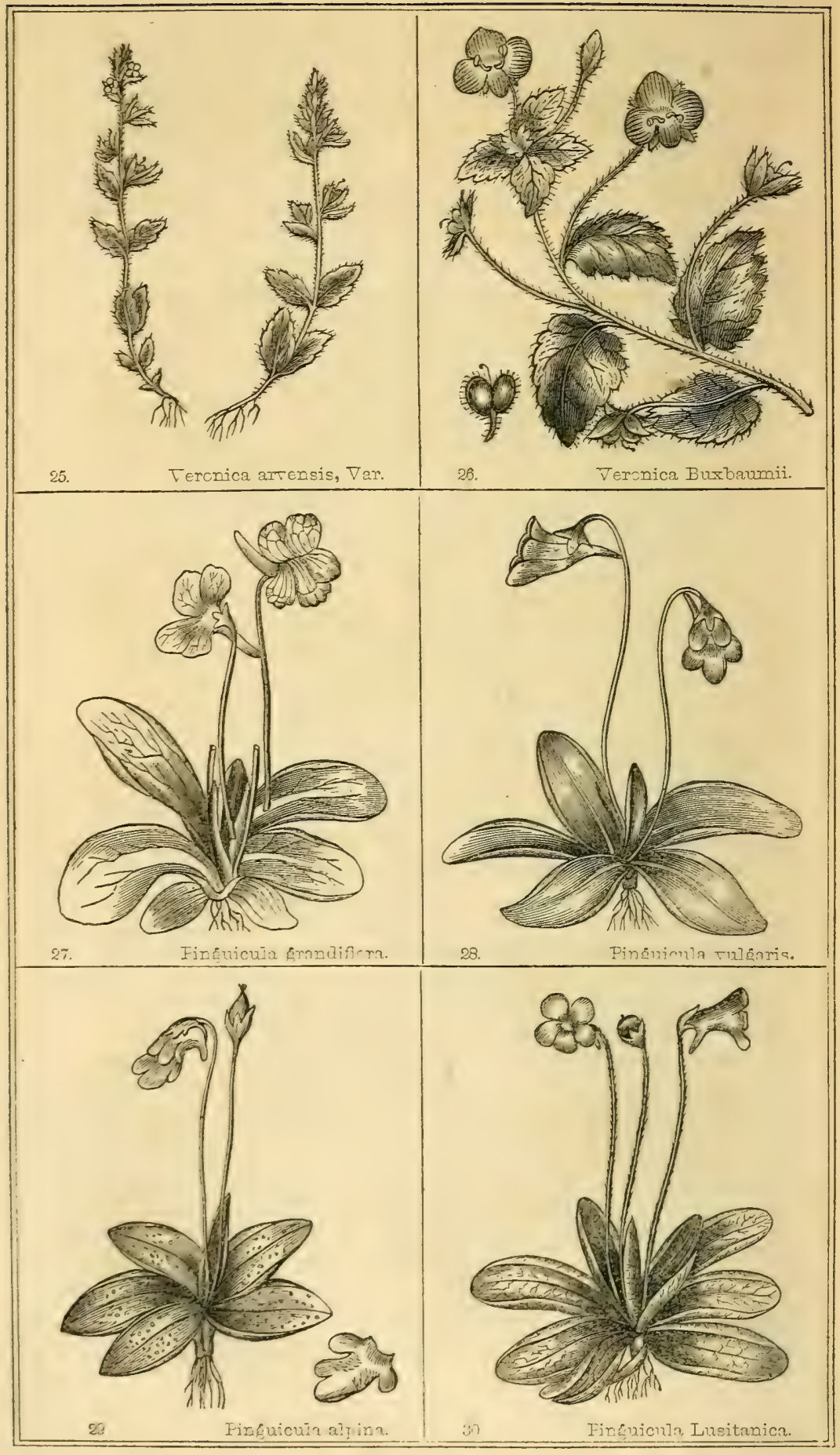


the sun is again experienced, the hairs fall down and form a layer of minute carities above the surface, by which means evaporation is prevented from taking place so rapidly as it otherwise would do. The secretory hairs are those which have, either at the apex or base, distended cellules as the receptacles of secretions; such are the glands on the extremity of hairs of many of the roses, and the sac at the base of the sting of the nettle, \&c.

19. V. Buxbau'mii, (Fig. 26.) Buxbaum's Speeduell. Stem procumbent, leaves petiolated cordato-orate deeply serrated shorter than the flower-stalks, segments of the calyx ovato-lanceolate acute, capsule obcordate, of two tumid spreading lobes, which are keeled and compressed in the upper part, cells mostly eight-seeded.

Borrer in English Botany Supplement, t. 2769.-V. Persica, Ster. -V. filiformis, Johnson's Flora of Berwick-upon-Tweed, p. 225.Hooker, British Flora, ed. 1, p. 6.- V. uyrestis, B. Huok. Br. Fl. ed. 2, p. 8.-Hook. Br. Fl. ed. 3, p. 8 .

Stem from ten to eighteen inches long, procumbent, branching at the hase, the branches taking root. Lectes mostly alternate, inclining to heart-shape, deeply serrated or inciso-serrated, shorter than the axillary flower-stalks. Calyx segments lanceolate acute, longer than the divaricated lubes of the capsule, which are keeled and compressed upwards. Corolla large, bluish purple with dark reins. The whole plant larger, stouter, and more hairy than $V$. agrestis and $V$. polita, for which it might be mistaken.

Habitat.-In fields and cultivated ground; but a doubtiul native. It has been found at Whiterig, Berwickshire-(Dr. Johnson),-near Neweastle, Margate, in Oxfordshire, and near Glasgow, Scotland.

Annual; flowering during the summer months.

\section{GENUS III. PINGUIC'ULA. Butterwort.}

\section{Nat. Ord. LENTIBULA'RIE.}

Gran. Char. C'alyx permanent, two lipped, upper three cleft, the lower bifid. Corolla ringent, spurred, and five cleft. Germen globose. Style very short. Stigma of two unequal lobes. Capsule one-celled. Seeds numerous, and attached to a central receptacle. Named from pinguis, fat; so called because the leares are greasy to the touch.

1. P. grandiflo'ra, (Fig. 27.) large-flowered Butterwort. Spur cylindrical, tapering, acute, the length of the reined limb of the corolla, the lower segment of which is large, spreading and notched, calyx obtuse, capsule orate.

English Butany, t. 2181.-English Flura, vol. i. p. 29.-Lindley, Synopsis, p. 186--Hooker, British Flora, rol, i. p. 9 . 
The whole plant larger, and of a stouter habit, than $P$. vulgaris; the le:tres a much lighter green, and more veiny. Scape from four to nine inches high, supporting a single flower. Corolla rich purple colour, larger, more equally divided and reticulated, with numerous darker veins. The leaves are all radical, and, as well as the scape, more or less covered with a glutinous exudation, but especially the lipper part of the latter.

Habitat.-In elevated marshy ground, in the western part of the county of Cork, and at Kenmare.

Perennial; flowering in May.

The natural order Lentibularix of Richard is composed ui two small genera of British plants-Pinguicula and Utricularia; which are remarkably beautiful water or bog plants. Pinguicula grandiflora and vulgaris may be grown to a high state of perfection by cultivation, especially the former, which is the largest and most beautiful of the genera. This interesting species we have cultivated in various ways, and under circumstances which warrant us in saying, that it is by no means difficult of cultivation. It will grow, and rapidly propagate itself, if planted in a moderately shady situation, in a mixture of equal parts of loam, heath mould, and white sand; during the time of flowering, it should be freely supplied with water. If protected with a common garden-frame, the flowering season will be prolonged, and the richness of colour and beauty of the flowers greatly increased. 'Towards autumn the leaves and roots gradually decay, and there are formed small round leafy buds or hybernacula, about half an inch in diameter, with several small ones attached to its base: each of which being capable of forming new plants, may either be allowed to remain, or be separated in the spring for the purpose of increase. The singular change of this plant, from a tender and exceedingly succulent, foliaceous state, to a compact and comparatively hard leafy bud, is very remarkable, and has evidently been so designed by Hiм who made all things according to his own purpose, in order to its preservation during the cold of winter; for if a plant so delicate as this did not undergo some change in order to its own preservation, or produce seed more abundantly than it usually does, the probability is that it would soon hecome extinct.

2. P. vulya'ris, (Fig. 28.) common Butterwort, Yorkshire Sanicle. Spur cylindrical, tapering, acute, as long as the entire unequally lobed and veinless limb of the corolla, capsule ovate.

English Botany, t. 70.-English Flora, vol. i. p. 28.-Lindley, Synopsis, p. 186.-Hooker, British Flora, vol. i. p. 9.

Leaves radical, ovate, obtuse, thick, fleshy, and glutinous, the margins involute, covered with minute erect crystaline points, which are most abundant on those plants grown in shady situations. Scape from three to nine inches long, single flowered. Corolla purple, its segments unequal, entire; palate covered with white hairs; the spur sometimes 
ighter coloured than the segments. Anther one celled, vertical, covered by the dilated lobe of the stigma. Capsule ovate. Seed numerous, rough.

A variety with white flowers was found by $\mathrm{Mr}$. Wood on a boggy piece of ground about seven miles from Dumfries, on the right hand of the Dalbaettie road, Lochend.

Habitat.-In bogs and damp heathy situations, Yorkshire, Derbyshire, Nottinghamshire, Worcestershire, Norfolk, \&c.; but most abundant in the northern parts of the kingdom.

Perennial; flowering in May and June.

This, like $P$.grandiflora, is capable of cultivation, and is highly ornamental in patches in boggy situations, or alpine borders; it also forms buds or hybernacula, by which it may be preserved during the winter months without difficulty; and with the same treatment in cultivation, it will succeed equally well; and although not so large or handsome, it is nevertheless a beautiful and graceful plant.

The remarkably greasy fecl of the leaves is said to have caused it to be applied to chaps and sore nipples, from whence it has received the name of Yorkshire Sanicle, and Saniculamontana. The word sanicula is derived from sano, to heal or cure. The leaves are also put into hroth by the common people in Wales, and taken as a cathartic. This, like many other marshy plants, has been accused of occasioning the flukes (fascicola hepatica), or rot in shecp; hut whether this or any other plant is the immediate cause of the disease, is very doubtful. The juice of the leaves coagulates milk, and may be userl as a substitute for rennet in the manufacture of clicese. This property is well known among the poor people in the northern parts of Scotland; and Iinnaus says, that when rein-deer's milk, while warm, is poured on the leaves, and allowed to stand a day or two, it becomes ascescent, acquires consistence, and a certain derree of tenacity; ncither the cream nor the serum separate; and in this form it is considered hy the Swedes and Norwegians a very grateful food. From its property of coagulating milk is derived the English name Butterwort. It is sometimes erroneously called Marsh Violet.

3. P. alpi'na, (Fig. 29.) alpine Butterwort. Spur conical and curved, shorter than the unequal limb of the corolla, lower lip retuse, scape smooth, capsule conical.

Graham in English Botany Supplement, t. 2747.-Hooker, British Iilora, vol. i. p. 9 .

Leares radical, oblong, their margins involute, occasionally tinged with purple, about the size of $P$. Lusitanica, but less transparent, and more resembling in texture those of $P$. vulgaris. Corolla light yellow, tinged with green, unequally divided, lower segment larger and more prominent than the others, retuse, haring at the base a tuft of yellow hairs. Spur very short and conical. 
Habitat.-Bogs in Scotland, very rare; Isle of Skye-Mr. James I'Kay; bogs of Aughterflow and Shannon, Ross-shire.

Pereunial; flowering in June.

This is a rery pretty little delicate plant, and a very interesting addition to our list of British plants; it appears to have been overlooked by Sir J. E. Smith, as P. Lusitanica.

4. P. Lusitan'ica, (Fig. 30.) pale Butterwort. Spur cylindrical, obtuse, shorter than the nearly regular limb of the corolla, scape hairy, as well as the leaves, which are thin and veiny, capsule globose.

English Botany, t. 145.-English Flora, vol. i. p. 28.-Lindley, Synopsis, p. 186.-Hooker, British Flora, vol. i. p. 10.

Leares radical, ovate, obtuse, pale green, semi-transparent, and intersected with numerous purple or reddisli veins. Scape from three to six inches high, more or less clothed with hairs, which are tipped with small glands. Corolla pale purple, the throat yellow, beautifully streaked with red. Spur light yellow.

IIabitat.-In wet moors and boggy situations; Dorsetshire, Hampshire; Deronshire, and Cornwall. "Plentiful in the Hebrides and Ireland; but most abundant in the extreme north of Scotland, near Cape Wrath, growing among Jungonnannia cochleariformis and Arbutus alpina"-(Hooker). We have collected it abundantly on the Isle of Arran.

Perennial; flowering in June and July.

\section{GENUS IV. UTRICULA'RIA. Bladderwort.}

Nat. Ord. Lentibulárie.

GEN. Char. Calyx permanent, of two ovate equal leaves. Corolla personate, spurred. Germen globose. Style short. Stigma twolipped. C'apsule one-celled. Seeds numerous, small, attached to a central globose receptacle. Name from Utriculus, a little blad. der or bottle.

1. U. vulga'ris, (Fig. 31.) greater Bladderworl, or Greater-hooded Milfoil. Spur of the corolla conical, upper lip entire, the length of the palate, leaves capillary, repeatedly and unequally divided, bristly at the margin.

English Botany, t. 253,-English Flora, vol. i. p. 30.-Lindley, Synopsis, p. 186.-Hooker, British Flora, vol. i. p. 10.

Root long and fibrous, much branched. Scape erect, from four to twelve inches long, with lauceolate membranous bractea at unequal distances, which, as well as the calyx and upper part of the scape, are of a purplish colour, and bearing numerous large bright yellow flouers 


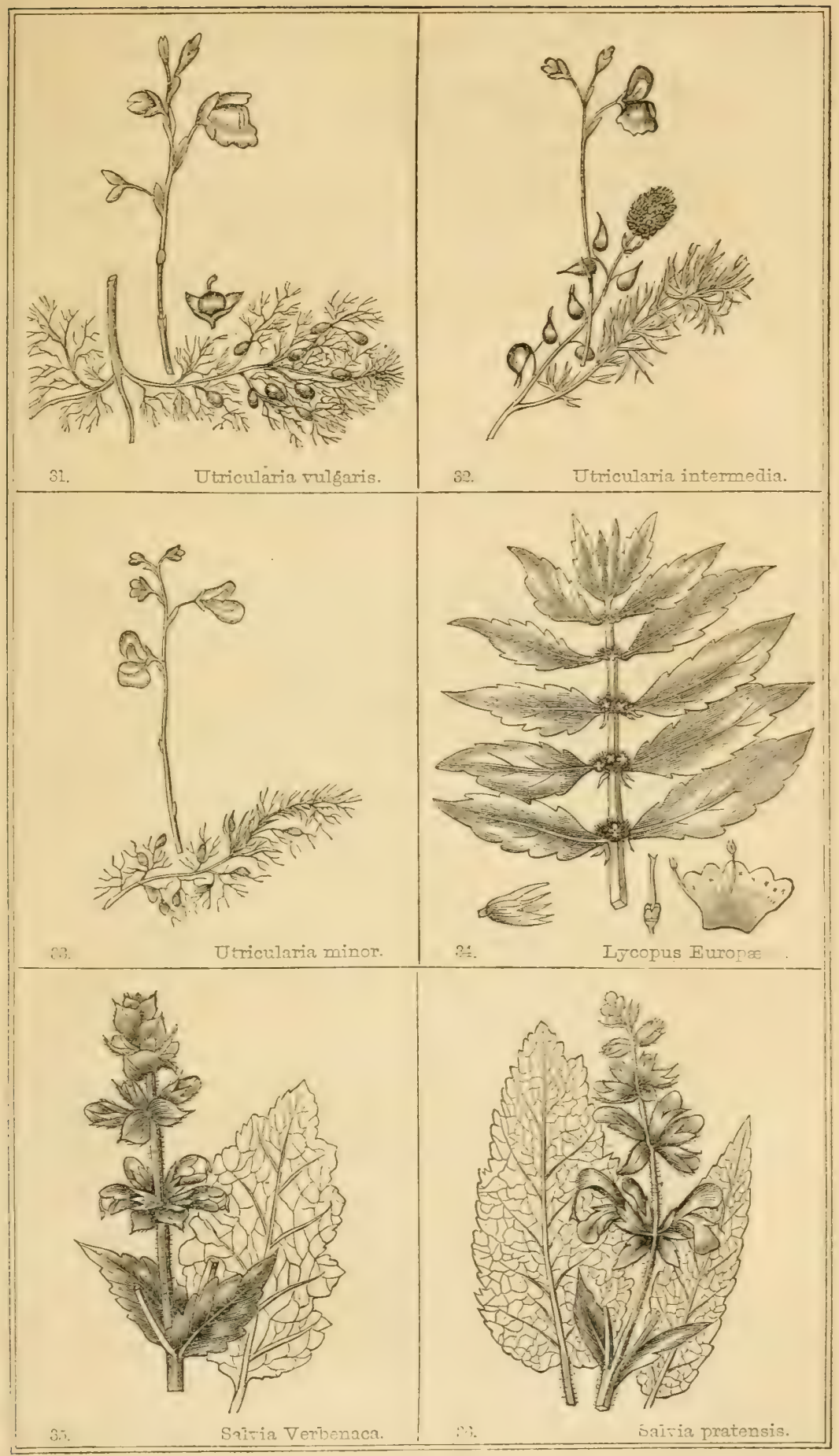



Lower lip of the corolla convex, larger than the upper, with a projecting palate which closes the mouth. Spur short, bent downwards. Leaces growing upon the submerged shoots or rumers without order, are capillary, multifid, mure or less bristly at the margin, and bear numerous small membranous and beauliful reticulated bladders, or resicles.

Habitat.-Ditches and pools, not uncommon. In the neighbourhood of Lincoln, this plant grows in great perfection, from whence we have specimens with the scape about twelve inches loug, and bear. ing numerous flowers, but seldom more than one or two are expanded at the same time.

Perennial; flowering from June to August.

2. U. interme'dia, (Fig. 32.) intermediute Bludderum. Spur of the corolla conical, upper lip entire, somewhat flat, twice the length of the palate, leares tripartite, their segments dichotomous, linear, and flat.

English Botany, t. 2489.-English Flora, vol. i. p. 30.-Lindley, Synopsis, p. 186.-Hooker, British Flora, vol. i. p. 10.

In general appearance, this species much resembles the last, hut is smaller, more leafy, the segments of the leaves broader, with a mid-rib arising from the stem, and branching off through the centre of each segment. The bladders are not mixed with the leaves, but arise from branched stalks scparate from the leares; the flowers smaller, paler coloured. The shoots are frequently terminated by a mass of gemmx or buds (ats seen in our Figure), by which the plant is propagated; in the young state it has the appearance of a number of granular bodies immersed in a mass of short hair or wool.

Habitut.-Ditches and pools; less common than the preceding, but probably passed by as the same. We lave beautiful specimens from the neighbourhood of Wisbeach. It has also heen found about Dublin and Bantry, in Ireland; in Rescubie Lake, Forfar; and in Elginshire.

Perennial ; flowering in June and $\mathrm{July}$.

3. U. minor, (Fig. 33.) lesser Bladderurort. Spur of the corolla very short, obtuse keeled, upper lip about the length of the palate, leaves subtripartite, the segments linear, smooth.

English Botany, t. 254.-English Flora, vol. i. p. 31.-Lindley, Synopsis, p. 186.-Hooker, British Flora, vol. i. p. 11.

The smallest of the British species. Flowers pale yellow, smaller. Spur shorter, the upper lip scarcely closing the palate. The reticulated bladder-like bodies are mixed among the leares, more numerous, and not stalked as in the last species. The leares irregularly tripartite and smooth. Like the preceding, this propagates itself by buds or gemmæ, as perhaps $U$. vulgaris also.

Habitat.-Ditches and wet places, rare; about Edinburgh, Loch 
Sloy, and " in many parts of Scotland, extending its range even to Skye"-(Hook.)

Perennial; flowering June and July.

The plants in this genus are extremely interesting, from the crested vesicular, or bladder-likc, bodies that are developed on their immersed stems, leaves, and even roots. During certain seasons of the year the whole plant is submerged, and if the vesicles are then examined (as was remarked by Hayne) they will be found fised with water; but as the season advances, and the flowers begin to be developed, it is necessary they should be elevated above the surface of the water. To accomplish this, the little bladders, which have an opening closed by an clastic valve, are now found to contain air in place of the water, by which means the whole plant is buoyed up and rises to the surface; the flowers then expand themselves, and perform the functions necessary for the fertilization of the ovules, and the seeds are ripened; after which the air again gives place to water, the whole plant sinks to the bottom, and carries with it its seed, thus depositing it in the situation and soil most fitted for its propagation. The means by which the water is displaced in the vesicles and filled with air, is not satisfactorily known. It " is probably separated by the vital agency of the vegetable, and during its gradual evolution the water is expelled, and is prevented returning either by the mechanical structure of the valve, or by the constant evolution of air"-(Burnett).

Few instances in the economy of regetation more forcibly arrest the attention, than the beautiful contrivance displayed in this curious genus of aquatic plants. They are found both in hot and in cold countries, but far more abundant in the former than the latter. In Great Britain, their natural habitats are for the most part in stagnant pools, lakes, and clear water-frequently attached to the bottom, several feet below the surface; in such situations they remain securely protected from the severity of winter, through the medium of the scarcely varying temperature of the element by which they are surrounded. There are many other arlmirable contrivances of nature which equally illustrate the unerring means by which Providence accomplishes his designs in the rast field of regetable creation. We may here mention the beautiful aquatic, Pontederia crassipes, introduced into this country from Guima in 1825. This, although a water plant, will flourish for a considerable time in a pot of light earth; and when grown in this way, the leaves are large, with fleshy stalks of equal thickness throughout: but if the plant is placed in water, the leaf-stalks become inflated with air, frequently assuming an orbicular form, and equal in diameter to the leaf itself. If the plant be again elevated above the water, the roots still remaining within it, the air will be expelled, and the stalks resume their former appearance. 


\section{GENUS V. I,YCO'PUS.† Gipsywort.}

Nat. Ord. LABIA'T臣.

Gen. Crar. Calyx tubular, permanent, divided into five narrow acute segments. Corolla tubular, nearly equal, four cleft, the upper segment broadest, and notched. Stamens simple. Name from $\lambda u \chi 05$, a wolf, and rovs, a foot; from the imaginary likeness in the leaves of this plant to a wolf's paw.

1. L. Europe'us, (Fig. 34.) common Gipsywort, Water Horehound, or Wolf's Claw. Leares opposite, deeply and irregularly serrated; flowers in whorls.

English Botany, t. 1105.-English Flora, vol. i. p. 33.-Lindley, Synopsis, p. 197.-Hooker, British Flora, vol, i. p. 11.

Root fibrous. Stem upright, spreading by lateral suckers, four-cornered, and slightly hairy. Leaces opposite, on short footstalks, the altemate pairs crossing each other (decussate), orato-lanceolate, deeply and unequally serratel, the lower ones especially, often pinnatifid. Flowers small, sessile, surrounding the stem in dense whorls at the base of the upper leares. Calyx hairy, upper segment the largest. Corolla whitish, with purple dots, the tube hairy within. Stamens rather prominent, spreading. Anther of two pointed lobes. Stigma bifid. Seeds four, obovate, depressed in the centre.

Habitat.-Banks of rivers, ditches, and moist mealows, frequent; less so in Scotland.

Perennial; flowering June to August.

This plant has long been considered a febrifuge. It is astringent, and has been administered to suppress internal hæmorrhages. It abounds in a colouring matter which dyes a good black, and according to Withering, it was formerly used by gypsies, for the purpose of staining their skin; hence the English name Gypsywort.

\section{GENUS VI. SAL'VIA. Sage or Clary.}

Nat, Ord. Labia't $x$.

Gen. Char. Calyx tubular, permanent, unequally two-lipped, the lower bifid, the upper three-toothed. Corolla labiate, tube compressed and dilated upwards, lower lip of three lobes, the upper concave. Filaments with two divaricated branches, one only

$\uparrow$ This and the following genus Salvia, according to their natural affinity, belong to the Class Didynamia, and Order Gymnospermia, to which we were much disposed to remove them; but since it is according to the Linnæan rules first to count the number of stamens to ascertain the Class to which the plant under examination belongs; and the species in this genera having only two, place them in the situation which they now hold, although they agree in every other particular with their natural allies in the Class Didynamia. 
bearing a perfect single-celled anther. Name a derivative of salvere, to be in good health; in allusion to the cordial or healthrestoring properties of the species of this genera.

1. S. Verbena'ca, (Fig. 35.) wild English Clary, or Sage. Leaves sinuated, serrated, and rugose, corolla contracted, and but little longer than the calyx.

English Botany, t. 154.-English Flors, vol. i. p. 35.-Lindley, Synopsis, p. 197.-Hooker, British Flora, vol. i. p. 11.

Stem from one to two feet high, four-cornered, branched and downy. Leaves aromatic, wrinkled with veins, and more or less downy, the lower stalked and orate, the upper ones sessile, acute, scarcely lobed, but more deeply serrated. Bracteas two under each whorl of flowers, as long as the calyx, cordate, acute, ciliated. C'aly $x$ hairy, terminating in a fine point or mucro. Corolla purplish blue, small, upper lip concave, compressed, lower three lobed, the middle one the largest.

Habitat.-In waste land, meadows, and road sides, especially in a gravelly or chalky soil, common. In Scotland rery race, Salisbury Craigs, Burntisland, and Corstorphin.

Perennial; in flower from June to September.

The seeds of this plant produce a great quantity of mucilage when moistened with water, which is innocuous and insipid; it has been used for the purpose of removing dust and sand from under the eye-lids, and, by its enveloping the particles, removes them with safety, from which property it has derived the name of Clary, or clear-eye.

2. S. praten'sis, (Fig. 36.) Meadow Clary or Sage. Leaves oblong, unequally crenate, stalked, upper ones sessile, clasping the stem, bracteas small, calyx much shorter than the corolla, which is glandular at the summit.

English Botany, t. 153.-English Flora, vol. i. p. 34.-Lindley, Synopsis, p. 197.-Hooker, British Flora, vol. i. p. 11.

Whole plant more or less downy, with but little scent, from one to two feet high. Stem square. Lowcr leaves oblong, cordate at the base, stalked, upper sessile and lanceolate. Flowers in numerous whorls. Calyx short. Corolla purplish blue, large, and beautiful.

Habitat.-Dry, meadows and hedges, England, very rare; near Colham, in Kent. Our drawing is made from a specimen in the collection of the Shefficld Literary and Plilosophical Society, which appears to have been communicated by the late Mr. Sowerby.

Perennial; flowering in July.

This plaut is frequently cultivated in gardens, and is a very pretty border flower, flourishing best in a rather dry and sandy soil, and in. creasing, like most other labiate plants, by suckers as well as seed.

The genus Salvia, althongh containing only two British species, and these of little or no value, either as condiments or medicinc, is never- 



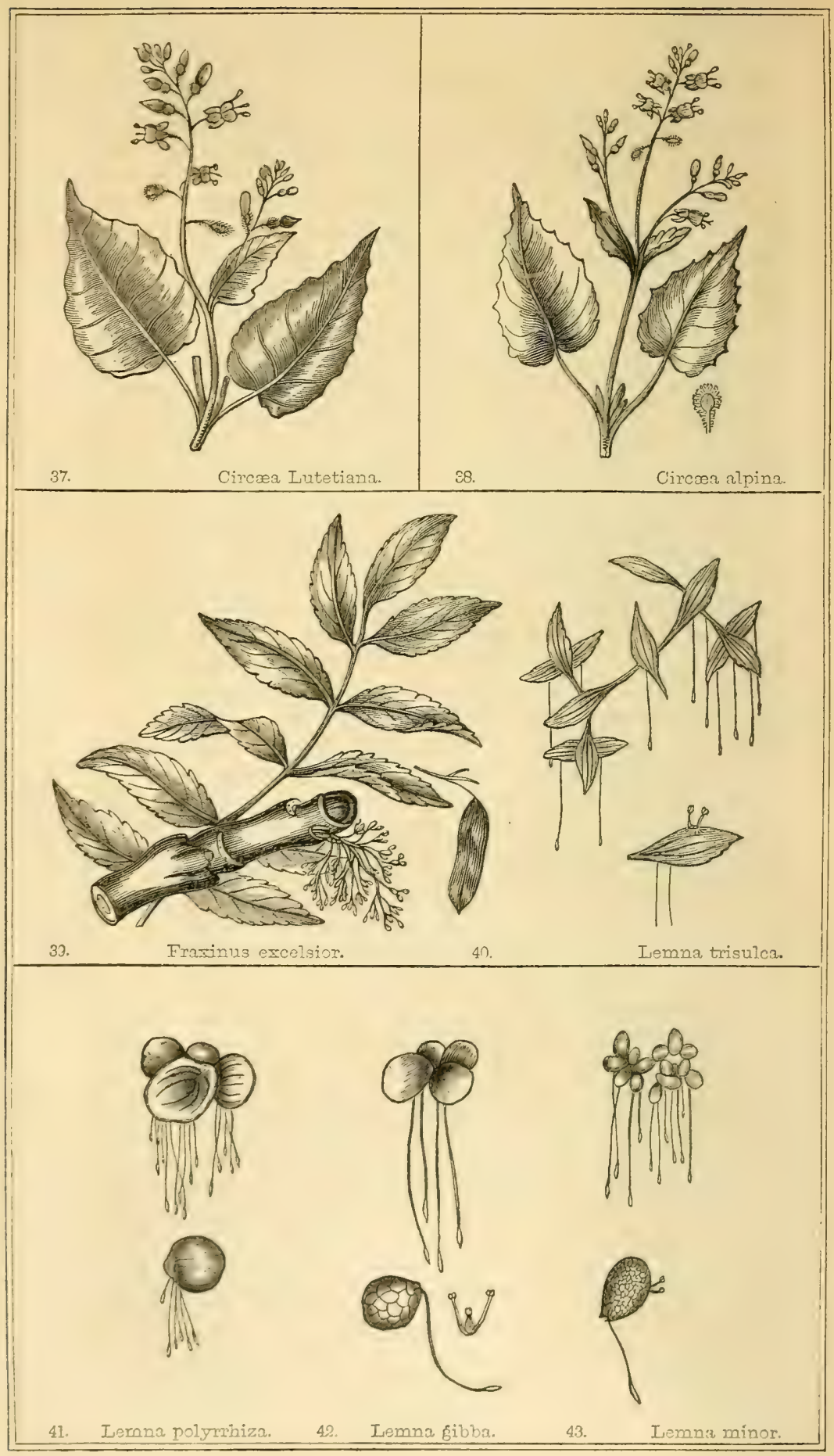


theless extensive, and contains many very elegant and highly ornamental exotic flowers; some are esteemed of great value, either from their cordial or stomachic qualities, or from their tonic and bitter principle; the whole are more or less aromatic, which is owing to the presence of a rolatile oil contained in small vesicles or reservoirs in the leaves. S. splendens, Indica, formosa, \&c. are well known, as adding greatly to the beauty of our warm flower horders and conservatories, by their graceful form and brilliant colvurs. S. officinalis, or common garden Sage, is much used in cookery as a condiment, its aroma and bitterness assisting the stomach to digest fat and luscious meats. In ancient times, Sage was celebrated as a remedy of grent efficacy, but is not now considered an article of so much importance. It possesses the remarkable property of resisting the putrefaction of animal substances, for which reason its infusion is well known as a remedy in cases of ulcerated sore throats; it is also considered serviceable in debility of the stomach and nerrous system. The Chinese are said to prefer its infusion to that of their own tea : the Dutch at one time carried on a profitable traffic with them, exchanging one pound of dried Sage leares for four of China tea. Its oil is remarkable, from containing a large portion of camphor. Rhenish wines owe their flavour in a great measure to the use of the flowers of S. glutinosa. Sage apples, which are greatly esteemed as food in Greece and Turkey, are morbid growths upon the stem of $S$. pomifera and other species of Sage, produced by the puncture of insects, which causes the developement of the apple, in a similar way to which the galls are produced upon the Oak.

\section{GENUS VII. CIRCE'A. Enchanter's Night-shade.}

\section{Nat. Ord. CIRCAA'CEE.}

Gen. Cuar. Calyx superior, tubular at the base, divided into two ovate obtuse deflexed segments. Corolla of two petals, alternate with the segments of the calyx, and inserted into it. Stamens alternate with the petals. Capsule two-celled, with one seed in each.-Named from the famous mythulogical enchantress Circe, who is said to have been well skilled in the uature of poisonous plants.

1. C. Lute'tiana, (Fig. 37.) common Enchanter's Night-shade. Stem erect, downy, leaves opposite, ovato-cordate, acuminate, slightly toothed, stalked, opaque, and downy.

+ Circecacece of Lindley, usually associated with Onagrarice of Jussieu, is separated from it on account of its differing in many important particulars, especially in its large fleshy disk, the ovarium two-celled, with a single erect ovula in each cell. 
English Bolany, t. 1056.-English Flora, tol. i. p. 15.-Lindley, Synopsis, p. 109.-Hooker, British Flora, vol. i. p. 12.

Root freely creeping. Stem downy, from one to two feet high. Lure: opposite, on footstalks, the lower ones nearly corclate, the upper narrower, ovate acuminate, waved or slightly toothed, more or less downy, sometimes quite smooth. Rucemes terminal and lateral, occasionally branched, downy, with narrow bracteas. Calyx reflexed, rerldish green. Corolla pinkish or white, inversely lieart-shaped, patent. Fruit oblong, thickly set, with white hooked hairs. Pedicels solitary, rarely two or three together, reflexed in fruit.

Habitat.-Shady groves and woods, common.

Perennial; flowering' in June and July.

2. C. alpi'na, (Fig. 38.) alpine Enchanter's Night-shade. Stem nearly smooth, ascending, leaves opposite, cordate, toothed, smooth and shining, stalked.

English Botany, t. 105\%.-English Flora, vol. i. p. 16.-Lindley; Synopsis, p. 110.-Hooker, British Flora, vol. i. p. 12.

ß. ma'jor ; larger, and more downy. C. interme'dia, Ehrh.

Differing but little from the preceding; indeed, Greville, in his Flora Edinensis, makes it but a variety, and says- "It has been noticed by D1. Graham, that, in the Edinburgh Botanic Garden, the two species pass into each other, which a minute examination has confirmed." In the specinens which we have collected in various parts of Scotland, the leaves are certainly more cordate, sharper and deeper toothed, more shining, and on longer footstalks, the stem less rowny, and the whole plant of more humble grow th. The flowers and fruit are alike in both species. The variety $\beta$ of Smith we hare not seen.

Habitat.- rroods and moist stony situations in the north of England and in Scotland, growing by the sicle of the Lakes; near the sea-shore, Isle of Arran, plentiful.

Perennial ; flowering July and August.

3) uring the dark ages of superstition, Enchanter's Night-shade was supposed to possess many wonderful properties; but we do not now find it to be either injurious or in any way valuable. "It was much celebrated in the mysteries of witelscraft, and for the purpose of raising the deril, as its name imports. It grows amid the mouldering bones and decayerl coffins in the ruinous raults of Sleaford church, Lincolnshire."

"Thrice round the grave Circeea prints her tread, And chaunts the numbers which disturb the dead."

Darwin's Loves of the Plants. 


\section{GENUS VIIY. IRAX'IYUS, Common Ash.}

Nat. Ord. Olea'ce.t.

Gen. Char. Calyx absent, or in four ovate segments. Corolla absent, or of four linear petals. Capsule flat and foliaceous at the extremity, two-celled, with a seed in each cell (a Samara). Seed solitary, flat, brown, and pendulous. Flowers sometimes without stamens, rarely with stamens only. -The name Fraximus is of doubtful origin : modern botanists, in conformity with the opinion of Linnwus, suppose it to hare been taken from the Greek $\phi_{\rho}$ c $\xi_{b}$, a separation; in allusion to the facility with which the wood may be split. Up to the sixteenth century, and in some instances of later date, the name Fraxinus appears to have been applied by different nations to very distinct plants, and the synonymes are in consequence much confused. According to Parkinson, the Greek name for the Ash is $\mu \varepsilon \lambda \iota \%$, Nelia; while the Latius give it the name of Fraxinus, by which it is now universally known. It may be interesting to our young readers to be reminded that the Syrian plant, Melia Azedarach, is of robust growth, with irregularly pinnate leaves, in general appearance not unlike our common $\Lambda$ sh, Fraxinus excelsior, with which it would seem to have been confounded.

1. F.excel'sior, (Fig. 30.) common Ash. Calyx and corolla wanting, leaves pinnate, leaflets lanceolate acuminate scarcely stalked, serrated.

English Botany, t. 1692,-English Flora, vol. i. p. 14.-Lindley; Symopsis, p. 71.-Hooker, British Flora, vol. i. p. 12.- . heterophyl'la, (simple-leated Ash,) leaves both simple and compound, Eng. Bot. t. 2476 ; Eng. Flor. vol. i. p. 14.-F. simplicifo'lia, IVilld.-F.excelsior, var, 2. With.

One of the most noble, and not the least elegant and ornamental, of our native trees. The young trees, ant the hanches of the old ones are clothed with grey bark, the wood tough and white. Buds of a dark brown or black colour, breaking into leaf late in the season. Leares pinnate. Common leaf-stalk channelled above, with from four to eight pairs and an odd one of opposite, scrrated, acuminated leaflets, which are

+ The natural order Oleacec contains many ornamental shrubs and trees, some of which produce fragrant flowers. The most important and best known genera are the Olive, Olect; the MIanna Ash, Ornus; the Lilac, Syringa; the Privet, Ligustrum; and the Ash, Frazinuts. They were united with Jasminea, and to which they are still referred hy some authors. The most remarkable circumstance, homerer, in favour of their separation, is the fact, as observel by De Candolle, of their capability of being grafted upon each other, proring the similitude of their vascular structure and sap'; but the Jasmine cannot be gralted utuon any of the Olive tribe, which is demonstrative of the dissimilitude of their structure and sap, and confirms the propriety of the separation of thesc two tribes. 
frequently, at the base and angles of the veins on the under side, thickly clothed with shout pubescence. Flouers in axillary clusters, appearing before the leares, at the extremity of the last year's wood, very simple, without either calyx or corolla, sometimes produced with pistil only, while others on the same tree bear hoth pistil and stamens: hence we find that in autumn some trees bear abundance of seed, while others are barren. Filaments opposite, inserted between the petals. Anthers with four furrows. Style short. Stigma divided. Capsule frequently cleft at the extremity. $-\beta$. That this is only a variety is probable from its capability of heing propagated alone by grafting; at least, we know of no instance where it has reproduced itself by seed.

Habitat.-Woods and hedges, common; $\beta$. rare.

Perennial; flowering in April and May.

The graceful form and elegant appearance of the Ash are well known; the tree is justly termed by Virgil "Pulcherrima sylvis." It varies exceedingly in its form: sometimes the lower branches are long and pendent, while the upper are spreading or erect; at others the extremities of the lower branches are curved upwards. The weeping Ash, which gives such a grotesque but highly ornamental appearance to the pleasure-ground and the lawn, is said to have been first discovered in a field at Gamlingay: it can only be propagated by grafting. The Ash is not less useful than beautiful: its white wood is a very valuable timber, tough, light, and straight-grained, which renders it particularly useful to wheelwrights, and for implements of hushandry. The bark, when fresh, has a bitter taste, slightly diuretic and tonic. The leaves, which have a similar flavour, have been employed to adulterate China tea; they are said to be cathartic, but very much inferior to those of senna. It was thought by the ancients, that a snake would not endure the shade of an Ash; and we are informed by Pliny that the $\Lambda$ sh is obnoxious to: pents, and its branches are often hung about children's beds to keep off the gnats. In warm climates, a sort of manna exudes from this species, to which the leaves probably owe their aperient quality. The manna of the shops-which is a peculiar saccharime substance, useful as a laxative for infants-is procured from several spe. cies of Ornus, as $O$. Europaus, rotundifolia, floribunda, \&c., natives of the southern parts of Europe. It exudes spontaneously from the stcms and branches in warm weather, and is collected and sold by the name of "manna in the tear." It is procured in greater abundance, lowever, by making incisions in the bark, from which it exudes in the forn of a thick juice, which concretes in flaky masses: but is procured freer from impurities, and of a finer quality, by making the juice concrete on straws or chips, fastench near the incisions for that purpose. The saccharine matter of mamna differs from common sugar by its not fermenting with water and yeast, for which reason it is considered a distinct principle, and called " mannite." The smooth bark of the Ash 
is a favourite habitat of wany species of exustaeuts Lichens; and cn it alune have we fuund the ieautiful genus of insects, Clulosmm: the species $C$. renipustulare is very plentiful in fiastations in Vuttinghamshire and Forkshire.

\section{GEXUS IX. IEJIXI. Duckueed.}

Nat, Ord. Pis'trhes.

Gex. Char. Perianth single, memoranous, intated. Fruit at thin transparent membranous utricule, single-seeded. Small fuating smooth lenticular plants, with lateral proliferous fromis. Capable of reproduction by seed, but must atundantly by cemax ut bus:; each frond having one er more pendulus threal-like rog:- - Tame said to be derived from $\lambda$ spus, Lemma, the meanigg of which, in reference to the plants in question, is very obscure; some authors suppose it to be from $\lambda: s=6$, Lepis, in allusion to the squamous or scale-lite appearance of the fronis. Jussied, in cunsideratisa of the conrex or lenticular-shaped fronds of this genus, has given them the nore descriptive, and ticrefond letter, nane of Lowicula, for Lemna. Aware, however, of the incontenience, and eren disgust, which is felt at the neeiless change often verommenter in opposition to the advantages which wouli aris? from a less mutable nomenclature, we prefer retaining the latter.

1. L. trisul'ca, (Fig. 40.) Iry-leared Duckuced. Fronds stalked, thin, elliptico-lancolate, serrated at the extremity, root slender, and solitary.

English Botany, t. 25.-English Flora. rel. i. p. 32.-Lindley, Synopsis, p. 251.-Hooker, British Flora, rol. i. p. 13.

Finnds from half to three quarters of an inch bog. pale greea, pellucil at the margin, frequently warel ca semated : youm plants are rapidly prolueed from lateral clefts in the browlest part of the fronds, and grow mostly at right angles with the parent plant, and of the same form : these als, hecome proliferous while actached to the parent fond, thus tecoming repsatedly cempound, each fromd emicting from the centre of its umler sile a solitars pendubus rost, curioukly tipned at the extrenity, with a small conical shenth. Flower resy small, arisis in this and the rest of the genus from lateral clefts in the frunds. Finmens two, unequal. -Anther divided, globular. Srignes ubtuse, scarcely protruding from the perianth.

Habitat.-Clear stagnant waters : wot very common in Englani, hut more so than in Seotland. Plentiful in the drains about Linculn, and Newark, Fottinghamshire.

Annual; tlowering in June and July. 
2. L. polywhi'za, (Fig. 41.) greater Duckweed. Fronds orato-rotundate compressed, roots numerous in clusters.

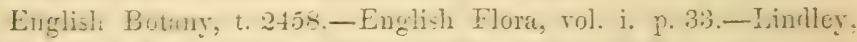

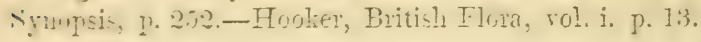

The largest of the genus, and well distinguished by its clustered roots growing from the point of union where the fronds unite. Fronds about half an inch long, and nearly as broad, striated abore with a dark purple margin, somewhat consex beneath, of a purple colour. Flou"ers not known in Britain. "Wiggers records a young German, named Grarer, as haring found the flowers, situated where the fronds verlay each other, in July and August. The seed proved larger and flatter than in L. gibba." - Smith.

Ifrbitut.-Ditches and jogle, not crmmon; Jottingham meariows. Annual.

3, L. gib'ba, (Fig. 42.) gibbous Duckweed. Fronds broadly oborate, slightly conrex above, hemispherical, and pale beneath, roots solitary.

English Botany, t. 1233.-English Flora, vol. i. p. 32.-Lindley, Synopsis, p. 252.-Hooker, British Flora, vol. i. p. 13.

Larger than L. minor. Fronds green above, in a joung state flat, pale leneaih, and gradually swelling until almost hemispherical, first commencing to swell at the base of the root, until at length the enlarged pellucid ceilules t,urst; the frorris then tum yellow, and slortly decay. Roots solitary. Floncers from the margin of the frond, perianth scarcely visible.-This species somewhat resembles $L$. minor, but is rearlily ristinguisher fy its larese celluiar aur griblous, on lemicrlls:rical under surface. "Capsule four-seeded. Sced furrowed, not transwersely placed, but with the hilum towards the top of the capsule."-Wilson in Br. Fl.

Habitat.-In stagnant waters, not so common as the following speries.

Annual; flovering from June to September.

4. L. minor, (Fig. 43.) lesser Duchued. Fronds nearly ovate compressed, slightly convex bencath, roots solitary.

English Botany, t. 1095.-English Flora, rol. i. p. 32.-Lindley,

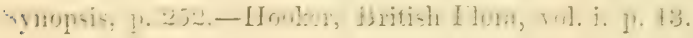

Fronds from one to two lines long, irregular, plane or sliglıtly con$v e \mathrm{x}$ abore as well as theneath, where it is of a pale colour, somewhat fleshy, and of a morc compact texture than $L$. giblı. Filowers similar to the last. "The cupsule is single-seeded; sced transverse, with its hilum "directed towards the narrow end of the frond." "-Hooker.This is the most common of all the species, increasing with great rapirity by gemme or buds, frequently covering the surface of extensive pools of stagnant water, and often considered a troublesome intruder in fish-ponds. Ducks and other water-forrl feerl upon it, hence 
the English name, Duckueed.-W We find a rariety of this species in the pools about Sheffield, with the fronds elliptical, ovate, larger, thimner, slightly convex alove, and of a more ennjact texture, a inteh paler colour, and slightly concave beneath.

Habitut.-Stagnant waters, rery common.

Annual; flowering in June and July.

These minute plants, called Water-lens, Duckmeat, or Duckweed, aithongh frequenty lunked upen with lisgust, and reriled with great acrimony, are nerertheless of vast utility, particularly in corering the surface of water, which becomes, during a great part of the summer, a iepository for the larre of insects, to an extent almust incredible, ani thus affording an abundant supply of food for fish. They are of the syeatest utility in covering, wholly or partially, the surface of preserve ponds for carp and tencl, in which we have observed the fish increase ant? thrive with great rapidity, while in those ponds which are exposed, and in which neither plants nor insects are allowed to accumulate, and consequently the supply of food scanty, the fish do not either increase to that extent, nor are they in that condition, as in the former case. This, howerer, is not their only utility:-there is no doubt but the lajer of vegetating matter, which they form on the surface of stagnant water and pools, is a great means of purifying it of much of the 110:icus effuria which emanates from the decaying matter accumulated in such situations. We thus perceire, eren in these apparently insignificant weeds, the incontrovertihle evilence that nothing has been made in rain.

The reseurch and investigation of scientilic botanists hare of late unveiled many of the secrets of nature, and some of the recent and most valuable discoreries are associater with the names of the noblest benefactors of our age. But in this most interesting, jet intricate and difficult branch of Yratural History- Fegetable Physiology, thcre is yet a vast field to explore, and much remains to be done before the opinions of eren the most eminent physiologists can be reconciled. The causes of irritation of plants hare heen speculated upon, and some hare attempted to account for this singular plienomenon by referring it to mechanical structure, while others hare ascribed it to the presence of a vital principle analagous to that of animals. To show that the latter is most accordant with the sense in which we are accustomed to view oljects enduwed with ritality and possessing spoutaneous motion, we might refer to the lower orders of the animal and regetable creation, and, by tritcing either to their simplest form, descend till the listinction is lost, and we find both united in the same individual. In accorlance with what has just been stated, the roots of the various species of Lemna will lye found interesting, and in some degree illustrattire of the preceding remarks. If a plant of Lemna, with a full-grown root, he removed from the water, and held in an inverted position for a few minutes in a dry atmosphere, the root being composed of a very 
simple and slender tube, it will suddenly but almost imperceptibly collapse. The root will then iñcline a little to one side, and an irregular, jerking, rotatory motion, from south-east to north, will commence. With slight interruptions, this motion will continue until the root is completely twisted, and in appearance not unlike an exceedingly delicate thread of silk. For some time before and after the circular motion has subsided, it will evince a convulsive, tremulous emotion, like the writhings of an insect suffering from acute pain. But if the plant be again carefully placed in water, with its root downwards, the same number of revolutions will be performed in a contrary direction to the first, and when fully untwined, it will assume its original form, appa. rently without injury.

\section{GENUS X. CLA'DIUM. Twig-rush.}

Nat. Ord. CyPera'cee.

Gen. Crar. Perianth single, glumaceous. Glumes concave, of one piece, single-flowered; outer ones smaller, mostly barren. Fruit a nut, which has three slight angles, covered with a loose coat, and destitute of bristles (sete) at the base.-Named from riados, (ramus,) a branch, or twig; probably on account of the manybranched panicle.

1. C. Maris'cus, (Fig. 44.) prickly Turig-rush. Panicle erect, many times divided, and leafy, spikelets capitate, stem round, smooth, leafy, the margins and keel of the leaves finely serrated.

English Botany, t. 950.-English Flora, vol. i. p. 36.-Lindley, Synopsis, p. 281.-Hooker, British Flora, vol. i. p. 14.

Root strong and fleshy. Stem three to five feet high, erect, smooth, round, becoming angulas at the top, leafy, joints polished. Leaves as long as the stem, striated, tapering to the extremity, the margins and keel cartilaginous, finely serrated with sharp almost prickly teeth. Panicle with from two to six pairs of repeatedly divided, angular, and bracteated branches, each bearing a cluster of from six to eight orate spikelets, each of which is composed of six or eight light-brown orate glumes, the inner ones the longest. External coat of the nut large, brown, and shining. Stamens longer than the glume. Style as long as the stamens, capillary, deciduous. Stigmas two or four.

Habitat.-In fens and boggy places, but not common. Lake, near Rosthern Mere, Cheshire,-Mr. Campbell. In Norfolk, Kent, Cambridge, \&c. Very rare in Scotland.

Perennial; flowering from July to August. 


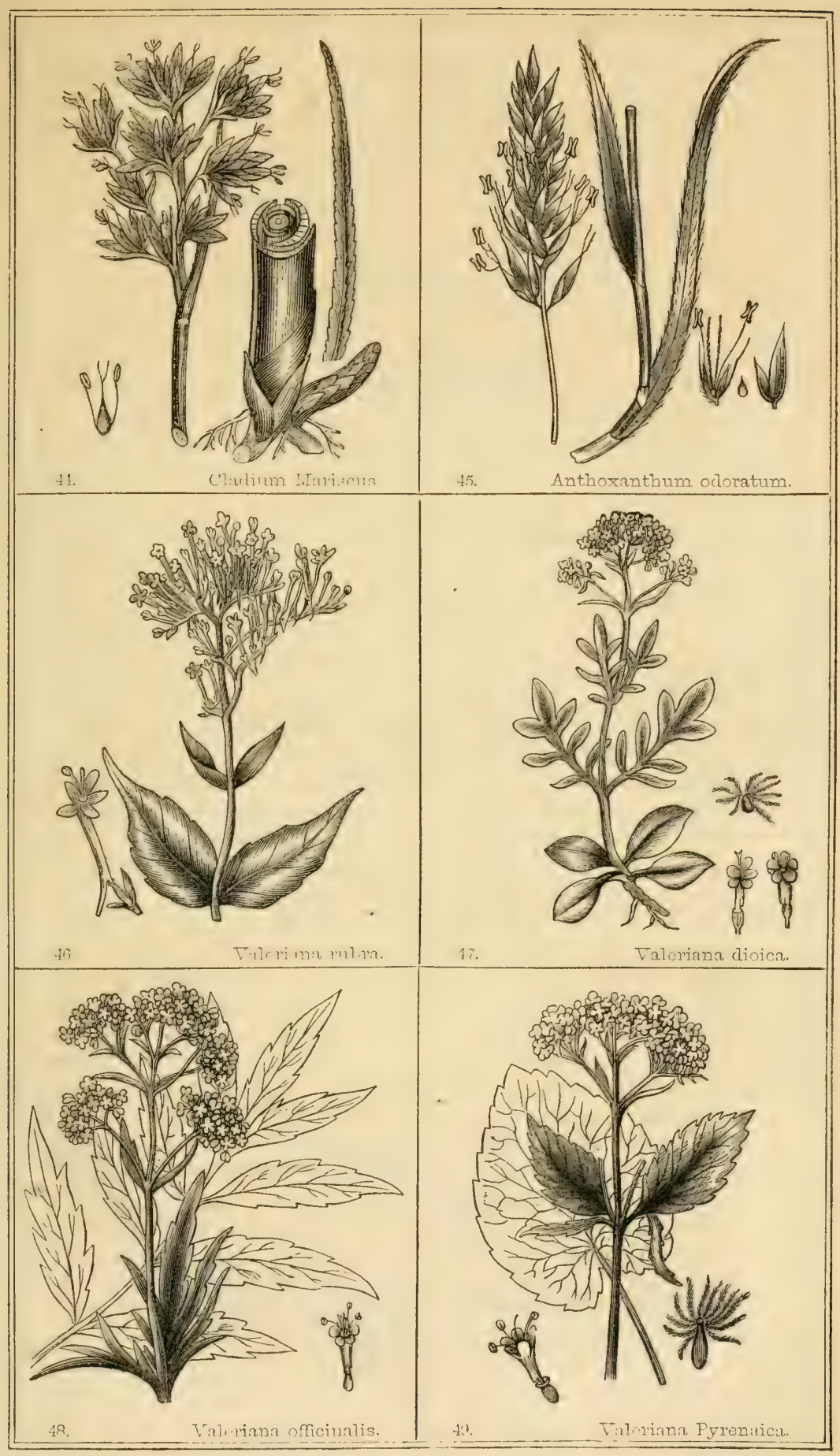





\section{ORDER II.}

\section{DIGYN'IA. 2 PIstils.}

\section{GENUS I. ANTHOXAN'THUM. Vernal Grass.}

Nat. Ord. GramineE.

Gen. Cirar. Glumes of two unequal valres, containing one perfect and two imperfect forets; the middle floret perfect. Glumella of two small awnless valves; the two lateral florets each reduced to a single-awned valve.-Name from cutos, a flower, or bloom, and $\xi \alpha v \theta 05$, yellow; in allusion to the yellowish hue of the spikes.

1. A. odora'tum, Linn. (Fig. 45.) sueet-scented Vernal Grass. Panicle spiked, oblong; florets upon short fuotstalks, and longer than their awns.

English Botany, t. 647.-English Flora, vol. i. p. 37.-Lindley, Synopsis, p. 300,-Hooker, British Flora, vol. i. p. 14.-Sinclair, Hortus Gramineus Woburnensis, p. 134.

Stem ten to eighteen inches high, smooth, slender, two or three jointed. Leares flat, slightly hairy, short, upper ones very short. $P a$ nicle spiked, erect, somewhat acute, becoming yellow with age, the lower florets sometimes distant. Gilumes unequal, sharp-pointed, and as well as the footstalks slightly hairy; the outer largest, with a strong dorsal rib and two slighter on each side; the inner valre about half the length, with a single dorsal rib. Imperfect florets awned, obtuse, brown, hairy; the inner with a straight ainn from the middle of the back, the outer with a longer bent awn from near the base. Glunelles of the perfect floret very small, its valves membranous, obtuse, equal. Stamens only two, slender, longer than the glumes. Stigmas erect, long. Seed glossy, brown, obovate, attenuated at the apex.

Habitat.-Meadows and pastures, very common; most frequent in gravelly situations.

Perennial; flowering in May and June.

It is this grass which chiefly gires the peculiar and well-known agreeable scent to new-made hay. The valves of the glumes are thickly studded with small (when dry) pale-coloured dots, and are probably the organs which secrete the volatile matter, the cause of the odour, which is said to be benzoic acid. It is remarkable that the odour of this plant is not given out while in a growing state, but when cut and in the act of drying, it is the strongest. On account of the early and late produce of this plant, it is valuable to farmers in their permanent pasture lands, and it has been proposed to enrich them with it for the 
purpose of improving the flarour of mutton. This grass alone does not appear grateful to cattle, but is so when combined with other species. It is most valuable in permanent grazing pastures, especially in the latter part of the season, as it continues until that period to throw out luxuriant stems and leaves.

\title{
CLASS III.
}

\section{TRIAN'DRIA. 3 Stamens.}

\author{
ORDER I. \\ MONOGYN'IA. 1 Pistil.
}

\section{GENUS I. VALERIA'NA. Valerian.}

Nat, Ord. Valeria'Nex.

Gen. Char. Calyx superior, a thick slightly crenated margin, ultimately expanding into a feathery pappus. Corolla of one petai, tubular, the limb five cleft, gibbous or spurred on one side at the base. Fruit single-seeded, surrounded at the top with the feathery pappus.-The derivation of the name is differently given by authors: it is probably from valeo, to be powerful; on account of its powerful medicinal properties.

\section{* Flowers with one stamen.}

1. V. rubra, Linn. (Fig. 46.) red Valerian. Tube of the corolla long, with a long spur at the base; leaves ovato-lanceolate.

English Botany, t. 1531.- English Flora, vol. i. p. 42.-Hooker, British Flora. vol. i. p. 22.-Centran'thus ru'bra, De Candolle. Lind. ley, Synopsis, p. 138.

The whole plant smooth, rather glaucous, from one to two feet high, with branching leafy stcms. Leaves opposite, entire, or toothed, sessile, Flnvers scentles, in numerous unilateral cymose spikes, each flower with a pair of opposite bractea about the length of the spur. Corolla rose-colour, rarely white. Fruit crowned with the inrolute pappus.

Habitat.-Old walls and waste places. Matlock, apparently wildMr. Bohler. Chalk pits in Kent, plentiful.

Perennial; flowering from Jume to September.

This species is probably the outcast of gardens, but is now not uncommon in waste unculivated places, and on old walls. It is a very 
common showy plant in flower gardens, flourishing in almost any soil or situation.

\section{** Flovers dicecious.}

2. V. dioi'ca, Linn. (Fig. 47.) small Marsh Valevian. Corolla gibbous at the base; root-leaves simple ovate petiolated, those of the stem lyrato-pinnatific.

English Botany, t. 628.-English Flora, vol. i. p. 43.-Lindley, Synopsis, p. 138.-Hooker, British Flora, vol. i. p. 23.

Plant from six to eighteen inches high. Root leares mostly entire, with fleshy fuotstalks; those of the stem have from two to six pairs of more or less toothed opposite leaflets, terminated by a larger one which is three-cleft, the upper pair reduced to bractea. Flowers diœcious, rose-coloured, becoming paler in maturity, densely crowded. Those plants bearing stamens only are always much smaller and weaker than the fertile plants. Stamens and pistils are sometimes present, but rarely perfect in the same individual.

Habitat.-Bogs and marshy meadows, frequent.

Perennial; flowering in June and July. *** Flowers with three stamens, perfect.

3. V. officina'lis, Linn. (Fig. 48.) Corolla gibbous at the base; leaves opposite, all pinnated; leaflets lanceolate, serrated.

English Botany, t. 698.-English Flora, rol. i. p. 43.-Lindley, Synopsis, p. 138.-Hooker, British Flora, vol. i. p. 23.

Root tuberous, with long fibres. Stem two to four feet high, hollow, furrowed, erect, smooth, sometimes hairy below. Leares pinnate opposite, clasping the stem, hairy at the base, footstalks of the lower ones elongated. Leaflets four to six pairs, opposite or alternate, and a terminal one, mustly lanceolate, strongly veined, and coarsely serrated, nearly uniform, sessile, dark green above, paler and hairy beneath Flowers small, white or light rose-coloured, odorous, in large densebranched corymbs. Bracteas lanceolate connate, waved, ciliated at the base. Corolla tubular, slightly gibbous at the base, divided at the margin into five obtuse nearly equal spreading segments. Stamens longer than the corolla. Style short. Stigma bifid. Capsule oblongo-ovate, emarginate at the base, compressed, three-ribbed on one side, one on the other, containing a solitary ovate pendulous seed.

Habitat.-Banks by the sides of moist woods and rivers, plentiful.

Perennial; flowering in Jume and July.

The roots of this plant are tonic, aromatic, antispasmodic, and vermifugal, and have been long exhibited as a remedy in nerrous affections. The peculiar odour of these roots is not generally agreeable to Europeans, but those of several specics are used in the eastern nations to aromatise their baths, and are highly esteemed as perfumes, Cats 
are remarkably fond of these roots; they chew them, roll and rub themselves on them, and for a time appear intoxicated under their influence. The effect is no less remarkable upon rats, and the root is used by rat-catchers in the same way as oil of anise, to allure them to take their poisonous compounds.

4. V. Pyrena'ica, Linn. (Fig. 49.) heart-leaved Valerian. Corolla gibbous at the base; leaves large, heart-shaped, toothed, serrated, smooth, petiolated, upper ones pinnate, with one or two pairs of small lanceolate leaflets.

English Botany, t. 1591.-English Flora, vol. i. p. 44.-Lindley, Synopsis, p. 138.-Hooker, British Flora, vol. i, p. 23.

Stem two or three feet high, furrowed, hollow, downy below the insertions of the upper leares. The root and lower stem leaves mostly simple, heart-shaped, acute, stalked, unequally toothed, and sometimes serrated, smooth, the upper leaves pinnate, the terminal leaflet ovato-lanceolate, the lateral ones narrower. The stalks, veins, and margins of the upper leaves mostly downy. Flowers in dense com. pound terminal corymbs. Corolla slightly gibbous at the base, light rose-colour, in shady situations nearly while, its margin divided into five segments. Capsule ribbed, but longer and narrower than those of the above species, as is also the solitary seed.

Habitat.-Abundant in the woods near Bretton Hall, Yorkshire, and in rarious places in Scotland; Campsey Glen, and woods near Glasgow; Collington and Abercorn WVood, near Edinburgh; but probably escaped from gardens. "It is peculiar, I believe, to the Pyrenees."-Hook.

Perennial; flowering in June and July.

\section{GENUS II. FE'DIA. VAHL. Corn-Salad.}

\section{Nat. Ord. Valeria'Nex.}

GEn. Char. Calyx of three to five unequal teeth, first very small, at length crowning the fruit. Corolla of one petal, gibbous at the base, the limb of five unequal segments. Capsule indehescent, of one fertile and two abortive cells.-The meaning of the word Fedia is not satisfactorily known. "Fedia is derived from Fedus; an ancient word synonymous with IIcedus, a hid, is not unsuitable to this genus." - Smith.

1. F. olito'ria, Vahl. (Fig. 50.) common Corn-Salad, or Lamb's Lettuce. Flowers capitate, capsule smooth, inflated, subglobose, crowned with three small teeth of the calyx; leaves oblong, obtuse.

English Botany, t. 811.-English Flora, vol. i. p. 45.-Hooker, Britísh Flora, vol, i. p. 23.-Talcrianel'la olitu'ria, Lindley, Synopsis, p. 138. 


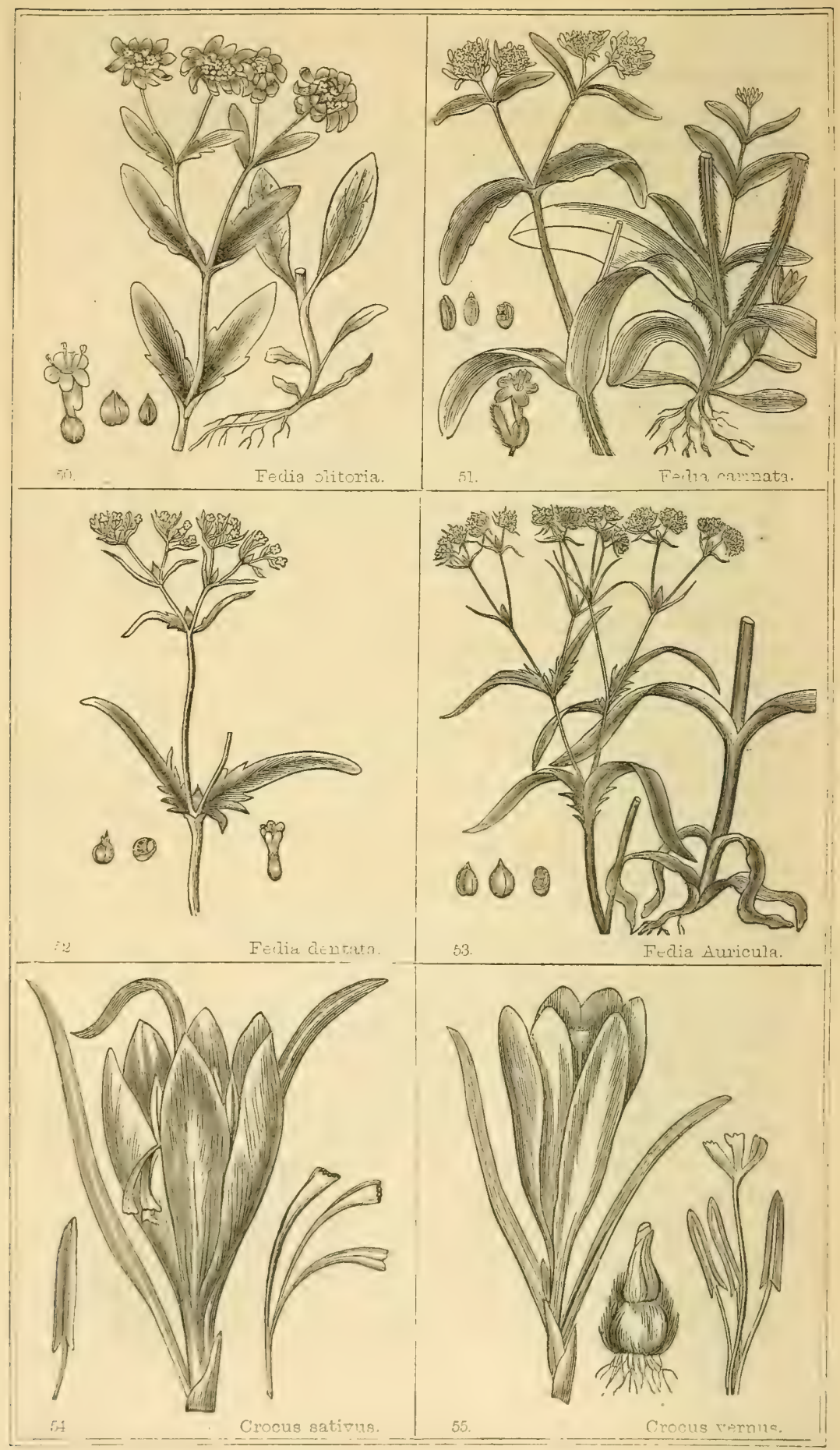


Root small. Stem four to twelve inches high, furrowed, more or less hairy. Leaves opposite, sessile, lower ones spatulate, stalked, mostly mitire, the upper linear, oblong, obtuse, sessile, entire or toothed. Flowers in compact heads, surrounded at the base with linear oblong, sometimes divided bracteas, forming an involucre at the extremity of the forked branches. Corolla small, pale blue, tubular, unequally five cleft. Stamens inserted at the mouth of the tube. Stigma blunt, projecting. Capsule smooth, roundish, unequally ribbed, crowned with three small inflexed teeth of the calyx.

Habitat.-A common weed in corn-fields, and gardens in a light soil.

Annual ; flowering during most of the summer months. Frequently cultivated as an early salad, but not now so highly esteemed as formerly.

2. F. carina'ta, Stev. (Fig. 51.) carinated Fedia. Flowers capitate; capsule oblong, obtuse, deeply furrowed in front between the two abortive cells, which are nearly equal in size to the fertile one, crowned with a short tooth of the limb of the calyx.

Hooker, British Flora, vol. i, additions at the end of the volume.Valerianel'la carina'ta, De Candolle. Prodromus, vol.iv. p. 629.

Plant from twelve to eighteen inches high. Stem branched from the base, roughish, with short rigid reflexed hairs, which arise principally from the edges of the eight nearly equi-distant ribs. Lower leaves spatulate, upper oblong obtuse, sessile, half embracing the stem, entire or slightly toothed, somewhat hairy, especially on the edges towards the base. Flowers in terminal heads, pale blue, surrounded at the base with oblong bracteas. Fruit oblong, obtuse, nearly smooth, deeply furrowed in front by the projecting edges of the two abortive cells, each of which is as large as the fertile one placed at the back, which terminates in a short obtuse tooth; each cell is marked by a narrow Iongitudinal rib.

Habitat.-Near Ongar, Essex-Mi. E. Forster. Sussex?-IIr. Borrer.

Perennial; flowering in June and July.

Seeds of this plant were obligingly sent us by $\mathrm{Mr}$. Borrer, who had not gathered the plant but in a dried-up state; they were sown in the Sheffield Botanic Garden, and from them our drawing and description has been made. It is allied to F.olitoria, but the seed is very different.

3. F. denta'ta, Vahl. (Fig. 52.) smooth narrow-fruited Corn-Salad. Flowers in loose corymbs, capsule smooth, obpyreform, crowned with the cupped unequally four-toothed calyx, convex on the back, plain and ribbed in front; stem forked, with a solitary sessile flower in the axils; leaves oblongo-lanceolate obtuse, upper ones especially cut or deeply toothed at the base.

English Flora, rol, i. p. 45.-Huoker, British Flora, rol. i. p. 23.-m 
Valeria'na denta'ta, Willd. English Botany, t. 1370.-Valerianel'la denta'ta, Lindley, Synopsis, p. 138.

B. Capsule clothed with spreading incurved rigid hairs, cup of the calyx small.-F. mix'ta, British Flora, ed. 2, vol. i. p. 23.

$\lambda$. Capsule clothed with incurved rigid hairs, cup of the calyx large, -F. eriocar'pa, British Flora, ed. 2, vol. i. p. 24.

Root small. Stem smooth, about twelve inches high. Leaves narrow, the lower ones mostly entire, the upper toothed, cut; or pectinated at the base. Flowers light blue or flesh-coloured, small, bracteas small, nurrow, few, and not arranged in the form of an involucre, as in the last species. Fruit obpyriform, the back convex part is the perfect cell, containing a single seed, terminated in a larger and broader tootb, frequently at the base, on each side is a smaller one, the plane front has two projecting ribs, the shrunk abortive cells, each terminating in a small subulate tooth, and between them is also another tooth about the same size.

Habitat.-In corn-fields and cultivated grounds, but not common. About Mansfield and Pleasly, Nottinghamshire, Cambridgeshire, Cornwall, Essex, Edinburgh, and North Wales.- $\beta$. Hedge-banks, neat Halesworth, Suffolk. $-\lambda$. Ormeshead, Caernarvonshire.

Annual; flowering during the summer months.

4. F. Auric'ula, Gaud. (Fig. 53.) sharp-fruited Corn-Salad. Flowers corymbose, with a sessile flower in the division of the flower-stalks; capsule ovate, acuminate, somewhat inflated, slightly grooved in front, smooth, crowned with the single entire tooth of the calyx.

Hooker, British Flora, vol. i. p. 24.-Valerianel'la Auric'ula, De Candolle, Flore Francois, Supplement, p. 492.

Plant from twelve to eighteen inches high, nearly smooth. Stem ribbed, repeatedly forked above, forming a spreading corymbiferous inflorescence, bearing in the axis of the divisions a solitary sessile flower. Flowers numerous, small, pale blue. Fruit ovate, somewhat inflated, smooth, beautifully dotted, having three narrow ribs, and slightly grooved in front, crowned with a single entire, obtuse, concave tooth of the limb of the calyx, and sometimes two others, which are very small, generally obsolete. Leaves opposite, the lower entire spatulate, the upper toothed or pectniated at the base.

Habitat.-Lindulph, Cornwall-Rev. R. T. Brec; Hastinus-Dr. Bromfield.

Annual; flowering in June and July.

Specimens and seeds of this newly discovered plant (as a native of this country) were also last autumn obligingly communicated by $\mathrm{Mr}$. Borrer, since which the seeds have been sown in a sheltered situation in the Sheffield Botanic Garden, and from plants thus procluced our drawing was marle. The fruit, as Dr. Hooker observes, is certainly considerably different from $F_{6}$ dentate. 


\section{GENUS III. CRO'CUS. Crocus.}

Nat. Ord. IRID'E压.

Gen. Char. Perianth divided into six equal coloured segments, its tube longer than the limb, and enveloped in two or more membranous sheaths. Stigma three-lobed, dilated, folded, and variously eut or jagged at the extremity.-The derivation of the word $\mathrm{Cro}$ cus is variously given by authors; x९oros of Theophrastus. Some derive it from Coriscus, a city and mountain of Silesia, and others from x the saffron of commerce, which is the dried stigmas of $C$. sativus.

1. C. sati'vus, Linn. (Fig. 54.) Saffron Crocus. Stigma in three deep linear notched lobes, drooping and protrudiug between the segments of the corolla.

English Flora, vol. i. p. 46.-Lindley, Synopsis, p. 255.-Hooker, British Flora, vol. i. p. 24.-C. autumna'lis, English Botany, t. 343.

Bulbs solid, depressed, enveloped in thin brown reticulated fibromembranous coats. Leaves linear radical, longer than the flower, and enveloped at the base with a thin white membranous sheath, dark green above, with a white stripe running along the middle, paler beneath. Flower of a lilac or violet colour. Stamens shorter than the corolla, but the style about the same length. The stigma of a rich orange colour, odorous.

Habitat.-In meadows in Cambridgeshire and Essex, probably naturalised.

Perennial; flowering in September.

The stigma of this species is alone fragrant, and is the saffron of the shops, for the purpose of procuring which, the plant is extensively cultivated at Saffron-Walden and Stapleford, Essex. 'The flowers are gathered early in the morning, and the stigmas, with a portion of the style, carefully picked out of the flowers; they are then dried upon a kiln, under a pressure, to form cake saffron, - or loosely, which is then called hay saffron. The virtue of saffron appears to reside in a peculiar extractive principle called "polychroite." Saffron was considered by the ancients as a remedy of great efficacy, but in modern practice it is found to possess few sensible qualities, beyond the orange colour which it imparts to water, alcohol; \&c.

2. C.ver'nus, Willd. (Fig. 55.) purple Spring Crocus. Stigma erect within the flower, divided into three jagged wedge-shaped lobes; mouth of the tube of the corolla hairy.

English Botany, t. 344.-English Flora, vol. i. p. 46.-Lindley, Synopsis, p. 255.-Hooker, British Flora, vol. i. p. 24.

Distinguished from the last species by its shorter and broader leaves, the erect pale inodorous stigma remaining within the flower, its wedgeshaped segments, and the tube of the corolla thickly set at its mouth with pellucid hairs. Their times of flowering are also different. 
Habitat.-Meadows between Nottingham Castle and the river Trent, abundant.

Perennial; flowering in March.

Long since naturalised in the abore station, where it has increased to so great an extent, that its beautiful flowers, the harbingers of Spring, cover an extent of a great number of acres with a rich mantle of a bright purple colour.

3. C. min'imus, Red. (Fig. 56.) least purple Crocus. Stigma erect within the flower, longer than the stamens, and divided into three obtuse lobes; bulb clothed with a subcoriaceous coat, separating in rings at the base.

Hooker, in Botanic Magazine, t. 2991.-British Flora, vol. i. p. 24. -C. pre'cox, English Botany, Supplement, t. 2645.-C. reticula'tus, English Flora, vol. i. p. 47.

A small but distinct species, although without much doubl an outcast of the garden. Corolla white, sometimes pale blue or yellow, the three outer segments marked with three longitudinal feathery stripes of a purple colour.

Habitat.-In Sir H. Bunbury's Park, at Barton Hall, Suffolk.

Perennial; flowering in March.

4. C. au'reus, Smith, (Fig. 57.) golden Crocus. Stigma shorter than the stamens; bulbs clothed with a thick smooth compact fibrous coat.

Hooker, in Botanic Magazine, t. 2986.-British Flora, vol. i. p. 25. -English Botany, Supplement, t. 2646.-C. lu'tens, Lindley, Synopsis, note, p. 255.

Floncers small, a golden yellow colour, two or more springing from one bulb. Leaves shorter than the tube, but when the corolla has decayed, they become much longer. It is equally probable that this, with the last species, has emanated from a garden.

Habitat.-With the preceding, in Sir H. Bunbury's Park, at Barton Hall, Suffolk.

Perennial; flowering in March.

5. C. nudifo'rus, Sm. (Fig. 58.) naked-Anwering Crocus. Stigma erect within the flower, in three deeply lacinated tufted lobes about the same height as the stamens. The flowers appear without leaves.

English Botany, t. 491.-English Flora, vol. i. p. 47.-Lindley, Synopis, p. 255.-Hooker, British Flora, vol. i. p. 25.

Root small, clothed with loose reticulated fibrous membranes, and sending out offsets or scaly runners. Lower part of the stem mostly swelling, and, as well as the tube, enveloped in their membranous sheaths. Flowers purple. Leares not appearing until some time after the flowers have disappeared, long, flat, pale coloured. 


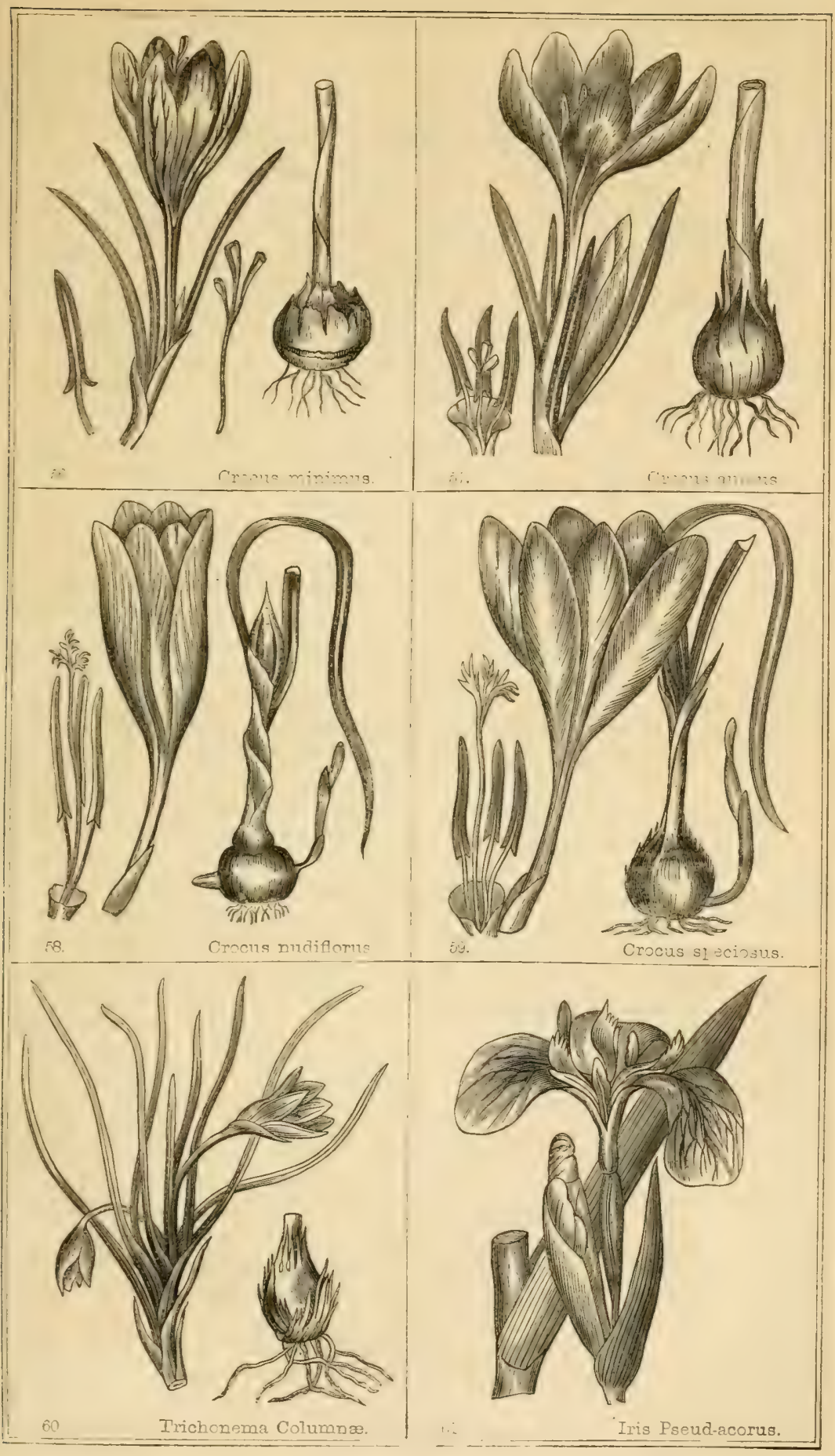



Habitat.-In the meadows between Nottingham Castle and the river Trent. Plentiful, though not in so great profusion as $C$. vernus.

Perennial; flowering in October.

It is remarkable that the same fertile meadows should in early spring be adorned with the rich flowers of $C$. vernus, and in the decline of autumn with the not less beautiful $C$. nudiflorus.

6. C. specio'sus, (Fig. 59.) showy autumnal Crocus. Stigma erect within the flower, in three laciniated tufted lobes, longer than the stamens. The flowers appear without leaves.

English Botany, Supplement, t. 2752.-Hooker, British Flora, vol. i. p. 25 .

Similar to the last species, except in the somewhat longer and less distinctly three-lobed stigma. Characters scarcely sufficiently perma. nent to constitute a specific difference.

Habitat.-In meadows about Warrington and Halifax, probably naturalised.

\section{Perennial; flowering in October.}

The humble, grass-like foliage-the white, gold, or purple-coloured howers-together with the extreme hardiness of the bulbs, has rendered the Crocus an ohject of peculiar interest to lovers of flowers, since, and probably long before, the time of Edward the Third. This beautiful flower would appear to liave attracted especial notice when Floriculture was yet in its infancy; and more than two hundred years ago, Parkinson enumerated no less than thirty-one kinds as having "been carefully sought out and preserved by divers to furnish a garden of denty curiosity." The fact that so great a number of kinds were cultivated at so remote a period, greatly strengthens the probability that the Crocus is not an aboriginal native of Great Britain; and the same author remarks, - "The several places of these saffron flowers have been found out, some in one country and some in another, as the small purple and white and striped white in Spain,-the yellow in Mesia, about Belgrade,-the great purple in Italy; and now by such friends' helps as have sent them, they prosper as well in our gardens as in their natural places : yet I must give you this to understand, that some of these formerly expressed have been raised up ounto us by the sowing of their seed : "-from which it would appear, that by seminal offspring varieties were then raised, and by this means the roots might be increased to a very great extent; consiclered with this, the almost indestructibility and tenacity of life evinced by the Crocus, even under the most unfarourable circumstances, - the facility with which birds might carry either seeds or bulbs to a distance,-and whaterer satisfaction it would afford in being able to prove that these beautiful flowers are really "anchent Britains," it is far more likely they are but naturalised natives.

As a gariten flower, the Crocus is still somewhat in repute; but that

VoL. I. 
particular care and attention which would seem at one time to hare bcen bestowed upon it, has long since been giren to more successful rivals, stch as Tulips, Pinlss, Carnations, and many others; thus illustrating" the lines of the inmortal Shakspeare, that "Novelty is only in request : and it is dangerous to be aged in any kind of course." The above remarks apply to Great Britain only : on the continent, but more especially in Holland, the Crocus is still cultivated with much care, and many new varieties raised. In this country, it is perhaps the most frequently met with decorating cottage gardens often in the most remote situations; and although the late Mr. Haworth, of Norwich, deroted much time and care to the cultiration of this genus, during which time many new and beautiful varieties were brought into existence,-and Mr. Sabine, while connected with the London Horticultural Gardens at Chiswick, collected many interesting and curious varieties, -yet with thcse and a rery few other exceptions, it is now nearly neglected as a florists' flower. By some it is thought that $C$. setivus and C. vermus are the parents of many, or most, of the varicties now in cultivation: both produce and perfect their sceds freely, especially the latter, from which many beautiful kinds have been raiserl.

The cultivation of the Crocus is amongst the most simple operations of gardening, for, while they may be grown to the bighest state of perfection in a rich yellow sandy loam, they will scarcely grow less luxuriant in the most sterile soil; and the prevalent opinion that if the roots are not taken up and replanted once every three or four years, they would gradually rise to the surface of the ground, and be lost, is not substantially correct; for although in some instances this might he the case, it does appear from observation, that many years would elapse before such a result could generally take place.

In this genus the mode of semination is extremely interesting, and can be seen to great advantage in $C$. mudiflora. During the time it is in flower, the three-celled ovarinn is seated on the summit of the bulh, and towards the maturity of the seeds, they are ruised on a long slender peduncle, and perfected at the surface of the ground.

\section{GENUS IV. TRICHONE'MA. Trichonema.}

Nat. Ord. InTD'ES.

Gen. Char. Perianth divided into six deep equal segments; its tube shorter than the limb, and enveloped in a sheath longer than the tube. Filaments short, hairy. Stigma very slender, deeply divided, its lohes bipartite, spreading. Capsule three-celled. Seed.

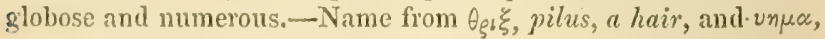
a filament, or thread; in reference to the pilose or pubescent filaments. 


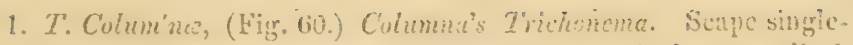
flowered, drooping, slorter than the leaves, which are radical, linear, furrowel and rollexel.

Liudley, Synopsis, p. 255.-Hoolicr, British Flora, rol. i. 1. 25.Trichonéna Bulboco'dium, Englisin Flora, vol. i. p. 48. - Ix'ia Bulbo'o'dium, English Butany, t. 2549 .

Bulb orate, solid, mostly surroundeil with torn membranous sheaths. Leaves numerous, from three to fire inches long, spreading. Scapes several, sometimes branched. Flouers mostly blue or purple, vecasioually white or yellow. Spatha of two lobes, longer than the tube of the corolla. Stamens longer than the stigmas.

Habitat.-Rare. On dry grassy hillocks in Gucrusey, and the Waren, Dawlisl3, Devonshire.

Perennial; flowering in March and Apr:?

It is frequently cultivated in the flower-garden, and thrives best on it sandy soil; the flowers are more numerous, and larger, than when grown in an uncultivated state.

\section{GENUS V. I'RIS. Iris, or Flouer-de-Luce.}

Nat, Ord. IRID'EA:

Gen. Char. Perianth single, of six unequal segments, three altemate ones larger and reflexed. Stigmas three, resembling petals, and forming a cover to the oblong anthers.-Name from Iris, a rainbow; in allusion to the gay and varied colours of the flowers.

1. I. Pseudac'orus, (Fig. 61.) yellow Water Iris, or Corn-flag. Perianth beardless, the three inner segments ereet, smaller than the stigmas, leares sworl-shaped.

English Botany, t. 578.-English Flora, vol. i. p. 49-Lindley, Synopsis, p. 255.-Hooker, British Flora, vol. i. p. 26.

B. citrin' rimth narrower, the inner ones more acute, stem taller." - Iris Pseudacorus, Botanic 1Iagazine, t. 2239.-Hooker, British Flora, vol.i. p. 26.

Rhizona large, fleshy, laying prostrate on the surface of the Bround, simple or variously branched, with mumcrous small fibres on the under side. Stem from two to four feet high, round, smooth, Leaves erect, sword-shaped, ribbed, of a glaucous hue. Flowers from three to six, large, handsome, lemon-coloured, streaked with purple lines, the outer segments of the perianth much the largest, broad, rounded, reflexed, the inner small, narrow-pointed, erect, smaller than the dilated petal-like stigmes, which are cut or fringed, and archedover the anthers. Bracteas pale, thin, membranous at the edges. Capsule angular, three-celled, three-ralved. Seed numerous, globular, or angular. 
Habitat.-Common on the margin of rivers, drains, wet meadows, woods, \&c. B. "Found in Ayrshire by Mr. James Smith, of Ayr."

Perennial; flowering in July.

The fleshy rhizoma of this plant was formerly used medicinally; it is scentless, but its juice is very bitter and acrid, producing great heat and a copious discharge when applied to the lining membrane of the nose or mouth; hence it is used as an errhine and sialagogue, and will sometimes relieve the tooth-ache. The quantity of feculent matter which it contains, combined with its acridity, has causerl it to be used as a eathartic. By drying, it loses these qualities, and becomes astringent, and is then used in the preparation of black dyes, ink, \&c. Orris root, the dried rhizoma of $I$. forenti'na, is known by its agreeable violet udour, and is used in the making of tooth and hair powders. The seed of $I$. pseudacorus are said, when roasted, to form an excellent substitute for coffee.

2. I. fatidis'sima, (Fig. 62.) stinking Iris, or Gladwoyn. . Perianth beardless, the three inner segments spreading, about the size of the stigmas, stem with one angle, leaves sword-shaped.

English Botany, t. 596.-English Flora, rol. i. p. 50.-Lindley, Synopsis, p. 255.-Hooker, British Flora, vol. i. p. 26.

Stem about two feet high. Leaves sword-shaped, emitting when bruised a peculiar odour, which would appear from its specific name to have been particularly disagreeable to some persons, but is compared by others to the smell of roast beef or mutton, from whence it has derived the common English name of mast-beef plant. Flouers a dull purple colour, streaked with dark veins, much smaller than the last species. Capsule three-celled. Seed numerous, globose, a deep orange colour, smooth.

Ilabitat.-In woods, under liedges, and in pastures; common in the southern parts of England. "In Deronshire it is so frequent, that you can hardly avoid walking among it when lerborising, and being annoyed by the smell." Rare elsewhere, and not found in a wild state in Scotland.

Perennial; flowering in May.

When the capsules are ripe, the valves burst open, and expose the bright orange seeds, which remain attached to them for it considerable time after, and have a singularly conspicuous, but beautiful appear. ance.

GENUS VI. CY'PERUS. Cyperus, or Galingale.

Nat. Ord. Cy'Peracee.

GEN. CHar. Flowers in spikes, glumaceous. Spikelets two ranked, imbricated, many flowered. Gilumes of one keeled valve, gene- 



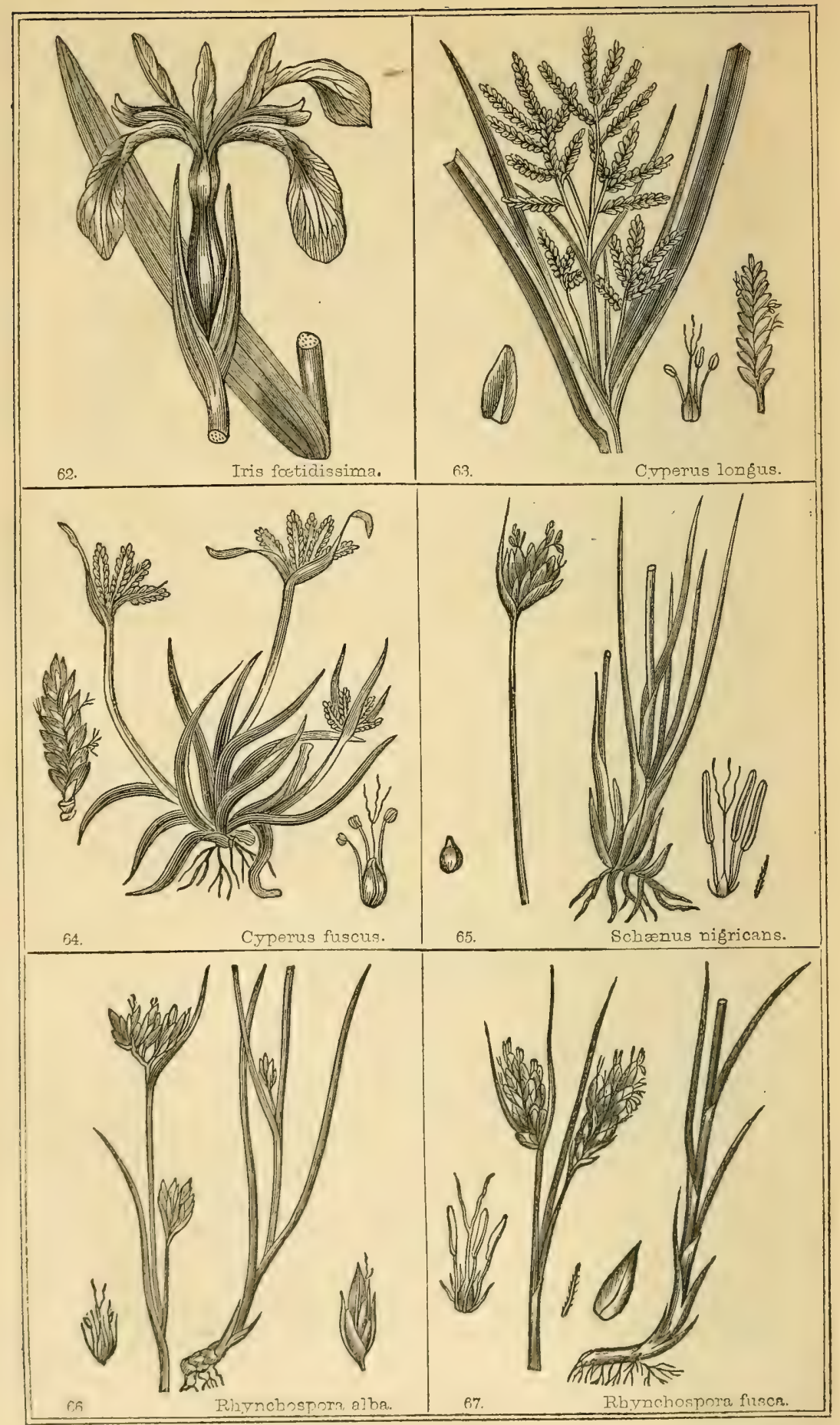


rally fertile, equal. Bristles none. Style simple, deciduous.-

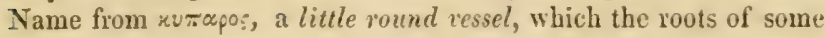
species are said to resemble.

1. C. lon'gus, (Fig. 63.) sucect C'yperus, or English Galingale. Umbels doubly compound, general involucre of several very long leafy bracteas, partial ones small, spikelets linear-lanceolate, erect, spreading, stem triangular.

English Botany, t. 1?09.-English Flora, rol. i. p. 54.-Lindley, Synopsis, p. 279.-Hooker, British Flora, vol. i. p. 26.

Root creeping, twisted, of a brown colour, very aromatic, and astringent. Stem triangular, from two to three feet high, slender, erect, leafy. Leares long, keeled, nearly flat, the erlges smooth, a bright grecu colour. Umbel doubly compound, its partial stalks triangular, and surrounded at the base with close membranous sheaths. Spikelets narrow, from fire to ten together, compressed, of numerous shining brown, green-keeled glumes, arranged in two opposite closely imbricated rauks. Seed pointed. Stigmas three.

Habitat.-Very rare. Marsh, near St. David's, and Walton-inGordon, Somersetshire; near Seabrook, Kent; Boyton, Wilts; Guern. sey.

Perennial; flowering in July.

2. C. fus'cus, (Fig. 61.) broun C'yperus. Umbels compound, involucre of three uneyual leafy bracteas, spikelets linear-lanceolate, glumes spreading, stem triangular.

Euglish Botany, Supplement, t. 26:6.-English Flora, vol. i. p. 54. -Lindley, Synopsis, p. 279.-Hooker, British Flora, vol. i. p. 26.

Root fibrous. Stems several, from four to six inclies long, smonth, spreading, seldom erect, leafy at the base. Leares narrow, radical, sheathing at the hase, shorter than the stems, acuminated, gracefully curved. The longest leaf of the inrolucre often half as long as the stem. L Imbel of about six spikelets, forming a compound terminal cluster. Seed triangular, with a simple heak. Stigmas three, as long as the filaments.

Habitat.-Very rare. In marshy meadows, near Little Chelsea.

Annual; flowering in August and September.

The genus Cyperus is very large, containing about two hundred and furty known species. Most of them are natives of the tropics, and graclually diminish in number towards the colder regions. The two here figured only are known as natives of England, and these found in its southern counties, while not any are known in Scotland. Few of this extensive genus are of much ralue, either as food or medicine. The roots of Cyperus longus have a pleasant odour similar to Violets, are bitter, and have been esteemed as tonics and stomachics. C.esculen'tus hears a number of small tubers upon its subterraneous stems, 
which are eaten in Egypt and other places, and, when roasted, used as a sulsstitute for coffec. C. hy'dra, or mut-grass, is said to be cxeecdingly troublesome in the sugar plantations, as it overruns them, and renders the canes barren. It is stated on the authority of Major-Gen. Hardwick, that the tubers of $C$. rotunda'tus are giren with success by the Hindoo practitioners in cases of cholera. Some few other species are used; hut perhaps the greatest interest attached to the genus is from the classical associations which are comnceterl with the Egyptian papyrus-C. pap'yrus, or Pap'yrus an'tiquorum of some authors; from which the ancients chicfly manufactured their paper, rupes, and cables, and also their boats, from the accuunts of Pliny. The roots werc chewed for the pleasant juice which they contain, and the roasted. stalks were esteemed for their pulpy matter.

\section{GENUS YII. SCHOE'NUS. Bog-rush.}

Nat. Ord. CY'PERACE E.

Ges. Cinar. Spikelets one to three-flowered. Glumes two ranked, the outer ones smaller, barren. Bristles very small, or none. Siyle jointed, deciduous. - Name from *orvos or rkosvos, a rope or cord; because from plants of this tribe a kind of cable and cordage was made.

1. S. ni'gricans, (Fig. 65.) black Bog-r'ush. Spikelets several, collected into a compact terminal head, involucre of two leaves, the outer one terminating in an awl-shaped point, longer than the head, stem round, and leafless.

English Botany, t. 1121.-English Flora, vol. i. p. 52.-Lindley, Synopsis, p. 280.-Hooker, British Flora, vol. i. p. 27.

Root long, black, and excecdingly tough. Stem from six to twelve juches lighl, erect, round, smooth, simple, cnveloped at the base lyy the dark and shining sheaths of the leaves, which are narrow, setaccous, rigid, somewhat rough, shorter than the stem. Head of flowers terminal. Sprikelets crowded. Glumes a dark brown, almost black. Style jointed, darker than the germen. Stigmas three. Bristles, when present, are small, brown, and spiny.

IIabilat.-On turfy waste land. "Rare in S'cotland, except on the west coast."

Perennial; flowering in June and July.

GEYUS VIII. RHYNCH'OSPORA. Beak-rush.

NYat. Ord. CY'PERACER.

Gis. Cusnr. Spikelets few flowered. Glumes of one valve, imbricated on all sides, the outer ones smaller, barren. Bristles various in 
number, spiny, and shorter than the glumes. Sityle bifid, dilated at the base, morc or less articulated, persistent, and crowning the

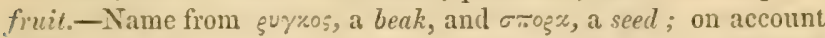
of the beaked appearance of the seed, from the persistent dilated base of the style.

1. R. al'ba, (Fig. 66.) white Beak-rush. Spikelets in compact fasciculated clusters, nearly as long as the bracteas, leares narrow, channelled, linear, tapering.

English Flora, vol. i. p. 52.-Lindley, Synopsis, p. 279.-Hooker, British Flora, vol. i. p. 27.-Sche'nus al'bus, English Botany, t. 985.

Rent fibrous, somewhat creeping, tough. Stem four to twelve inches high, slender, erect, three-cornered, and, as well as the whole plant, smooth. Leares erect, longer than the partial flower-stalks, keeled, ribbed, especially at the base, sheathing the stem. Partial flowerstullis and leares of the siem frequently unilateral. Spilalcts oblong, almost white, becoming lrown with age, generally two-flowererl. Clusters nearly level at the top, mostly shurter than the bracteas. Glumes long, acute, slightly keeled, the outer ones smaller, and barren. Stamens two. Style persistent, bifid at the extremity, and much dilated at the base, but not so broad as the fruit, which is obovate, compressed, margined, tapering at the base, and surroumled with six or more spiny bristles, longer than itself.

IIalitat.-Boggy situation, not uncommon in muntainous districts, but rare elsewhere.

Perennial; flowering in July and August.

A very pretty Rush, growing in tufts, which are rendered very conspicuous by their numerous white heads of flowers amidst the narrow green leares, and readily distinguished from the following species, which has oval heads of flowers of a rich glossy brown colour.

2. R. fus'ca, (Fig. 67.) brown Beak-rush. Spikelets in an oral head, much shorter than the bracteas, leaves setaceous.

English Flora, vol. i. p. 53.-Lindley, Synopsis, p. 279.-Hooker, British Flora, rol. i. p. 27.-Sche'nus fus'cus, English Botany, t. 1575.

Plant smaller, or about the same size as the last. Leaves narrower, channelled at the base, sheaths shorter. Heads of foucers larger, oval, the bracters considembly longer. Spikelets larger. Glumes broader, shining, of a rich reddish-brown colour. Stamens three. Style similar to the last, as well as the fruit; but the stigmas protrude further beyond the glumes. Bristles rarious: Smith and Sturm describe only three in each flower-Hooker six, which we also find in the specimens examined.

Habitat.-Rare. Principally found in bogs in the south-west of England, and near Killarney, Ireland.

Perennial; flowering in July and August. 


\section{GENUS IX. SCIR'PUS. Club-r'ush.}

\section{Nat. Ord. CY'PERACE死.}

Gev. Char. Glumes of one valve, imbricated on all sides, the outer ones sometimes barren. Bristles sometimes wanting. Style simple, deciduous. Fruit terminating in a mucro.-Name of doubtful origin. According to Theis, it is from Cirs, in Celtic, which makes Cors in the plural,-whence chorda in Latin, and cord in English; the stems having been formerly employed for the purpose of making cords, as those of Schcenus.

1. S. lacus'tris, (Fig. 68.) Lake Club-rush, or Bull-rush. Spikelets ovate, in compound lateral umbels, stem round, smooth, without or but few leares at the base.

English Botany, t. 666.-English Flora, vol. i. p. 56.-Lindley, Synopsis, p. 281.-Hooker, British Flora, rol. i. p. 27.

B. glau'cus, smaller, glaucous, umbels more compact, less compound, Hooker, Flora Scot. vol. i. p. 18.-S'cir'pus glau'cus, English Botany, t. 2312.-English Flora, rol. i. p. 58.

Roots long, as well as the thick submerged stems, which frequently spread a considerable distance under water. Stem three, six or eicht feet high, erect, simple, smooth, and terminating above the infloresctus. in a long triangular point, naked, except at the base, which is surrounded with pale sheaths, sometimes terminating in a short leafy expansion. Umbels very variable in size, and in the number of the spikelets, universal involucre rariable, of a few thin membranous bracteas, the partial ones much smaller and shorter. Pedicels of the partial umbels compressed or three-cornered, rough at the edges, of various lengths. Spikelets orate, sometimes nearly sessile. Glumes ovate, fringed, of a rusty brown colour, frequently notched at the end, keel terminating in a point. Stamens equal in length to the two or threecleft stigma. Fruit oborate, flat on one side, conrex on the other. Bristles from four to six. The glumes of $\beta$. glau'cus are generally less fringed and dotted with purplish-coloured spots, but these vary as well as other characters, so as to render its specific distinction untenable, notwithstanding the high authority of Sir J. E. Smith, who states it to be "a very distinct species."

Habitat.-In clear drains, ditches, and margins of lakes; common. - $\beta$. In similar situations, but not so common.

Perennial; flowering in July and August.

The stems, under the name of Rushes, are used to a considerable extent for a variety of domestic purposes, such as thatching for cottages, matting for floors, but most extensively in the manufacturing of rushbottomed chaixs, and by coopers for making tight the spaces between the staves of casks, \&c. They, as well as other of the Scirpuses, are eaten with avidity by cattle. 


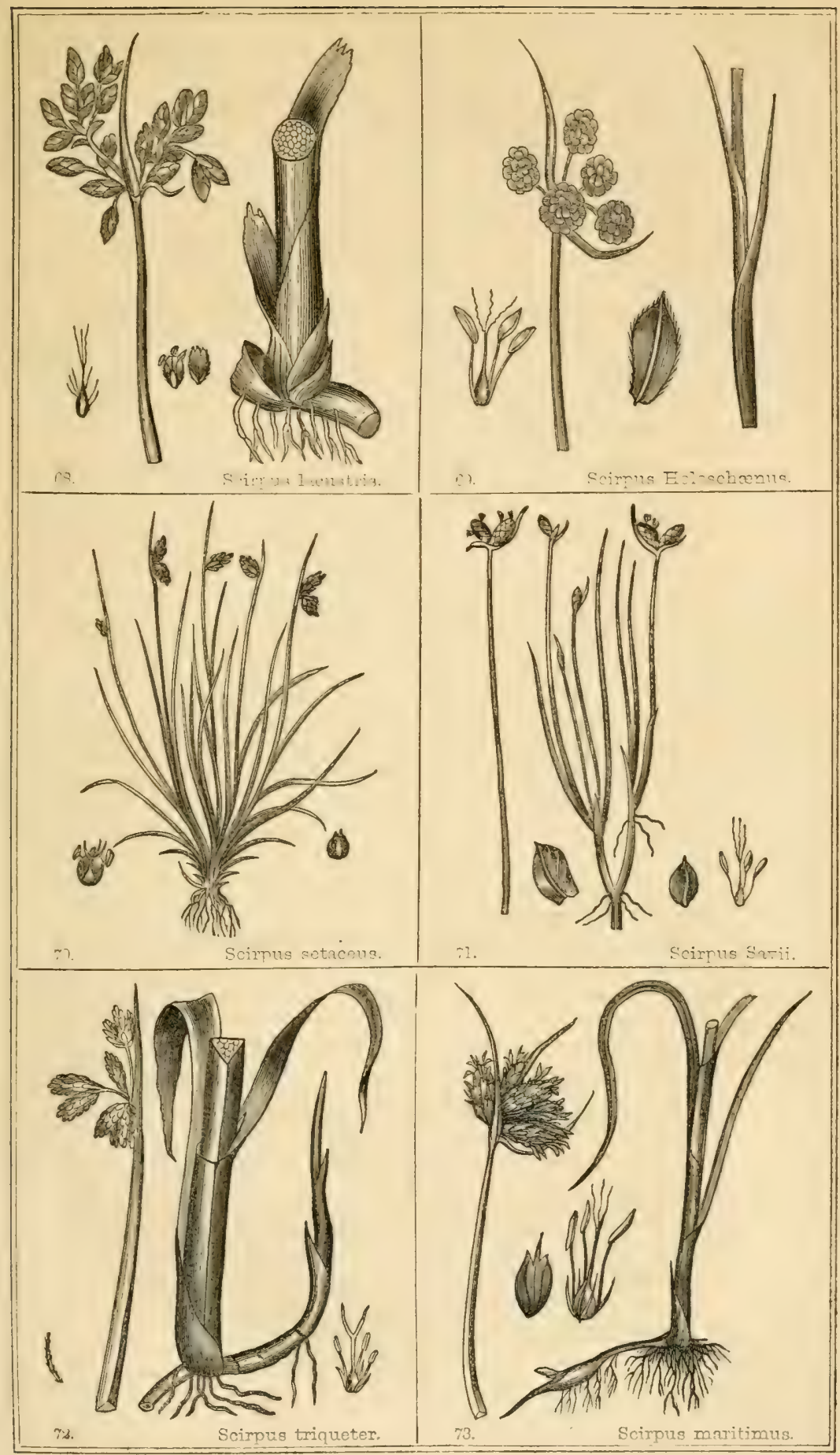



2. S. Holoscho'nus, Linn. (Fig. 69.) round cluster-headed Club. rush. Spikelets in compact globular stalked or sessile lateral heads, bristles none, stem erect, round, and smooth, leares subu. late chanuelled.

English Botany, t. 1612.-English Flora, vol. i. p. 58.-Hooker, British Flora, vol. i. p. 28.-Holschce'nus vulga'ris, I.indley, Sỵnopsis, p. 283.

Root in dense brown tufts. Stem two or three feet high, erect, round, smooth, enveloped at the base with membranous pointed sheaths. Leares narrow, short, acute, aud channelled. Heads of flowers very various in number, stalked or sessile, generally both on the same plant. Glumes obovate, keeled, pointed, and fringed, of an opaque brown colour. Stamens as lung or longer than the three-cleft style. Fruit small, without bristles.

Habitat.-Sandy sea-shores of the southern counties,-Deronshire, Dorsetshire, Hampshire, Somersetshire, \&c. Very rare.

Perennial; flowering in September.

3. S. seta'ceus, Limm. (Fig. 70.) bristle-stalked Club-rush. Spikelets terminal, one or two, rarely more, stem very slender, compressed, terminating in a leafy bractea, elongated beyond the spikelets, fruit ovate, ribbed, and marked with transverse furrows, without bristles at the base.

English Botany, t. 1693.-English Flora, rol. i. p. 59. -Hooker, British Flora, vol. i. p. 28.-Isule'pis setu'cea, Lindley, Synopsis, p. 283.

Roots long and fibrous. Stem from two to six inches high, very slender, compressed, smooth, striated, bearing one, two, or sometimes three spikelets at its extremity, and two or three leaves at the base. Bractea sometimes two, but generally only one, which is an apparent continuation of the stem, leafy, rlilated at the base, with membranous edges. Leaves numerous, bristle-shaped, striated, sheathing at the base, and surrounded with a number of pinkish scales. Spikelets ovate. Glumes nearly round, pinkish brown, margins green, as well as the keel. Stamens two, about as long as the style. Stigmas three. Fruit slightly pointed, orate, ribbed, and beautifully marked with transverse furrows. Bristles none.

Habitat.-Common in moist places, in sandy or gravelly situations, especially in an elevated or hilly country.

Annual ; flowering in July and August.

4. S. Sa'vii, Spreng. (Fig. 71.) Suri's Club-rush. Spikelets sessile, terminal, from one to three, involucre of two unequal leaves, longer than the spikelets, stem round, branched, and leafy below, fruit subglobose, indistinctly three-augled, roughish.

Hooker, in English Botany, Supplement, t. 2782.-British Flora, vol. i. p. 28. 
B. monosta'chys; "spikelets solitars, with a shorter inrolucral braciea."

Root fibrous, with creeping underground stems. Siems from eight to twelre inches high, erect, branched near the base. Leares slender, setaceous, unequal in length, sheathing at the base. Involucre of two unequal opposite leaves, mith longer than the spikelets, which are terminal, orate, sessile, unequal in size. Glumes orate acute, pale, striated and keeled. Stamens three. Stigmas three. Fruit globular, rough, with elerated points. Bristles none.

Habitat.-Bogs, rare. Renoyle, Ireland, Carreg, Ormen, Anglesen, Jersey, Deronshire. $\beta$. Cort.

Perennial; flowering in July.

5. S. tri'queter, Linn. (Fig. 72.) triangular Club-rush. Spikelets orate sessile, and stalked, stem sharply triangular, terminating in a straight tapering point, fruit smooth.

English Botany, t. 1691.-English Flora, rol. i. 1. 60.-Lindley, Synopsis, p. 281.-Hooker, British Flora, rol. i. p. 28.

Root entangled, forming thick matted tufts, and sending out creeping stems. Stems two to four feet high, erect, smooth, acutely triangular, naked upwards, Ieafy at the base. Leaves short, acute, with a long sheath at the base, and numerous imperfect ones surrounding it; frequently there is only one leaf. Spikelets orate or oblong, some sessile, others on short triangular peduncles, growing from a lateral cleft on the side of the stem often sereral inclies below the extremity, occasionally with a short lanceolate bractea. Glumes elliptical, closely and regularly imbricated, keeled, pointed, and beautifully fringed, of a reddish-brown colour. Stamens about the same length as the style. Stigmas tiro. Bristles three, rough. Seed roundish, smooth, shining.B. of Euglish Botany is said to be found near the sea, and to be more lard and rigid in its stem.

Habitat.-Banks and sides of rivers, near London; in the Thames at Lambeth, Battersea, \&c.

Perenuial; flowering in August.

6. S. mari'timus, Linn. (Fig. 73.) salt-marsh Club-rush. Spikelets oblong, terminal, sessile and stalked, involuere of several foliaceous leatlets, stem triangular, leafy, glumes notched, the keel terminating in a point between the segments of the notch.

English Botany, t. 512.-English Mora, vol. i. p. 62.-Lindley, Synopsis, p. 281.-Hooker, British Flora, vol. i. p. 29.

Root fibrous, sometimes with creeping stems, which swell into tubers.

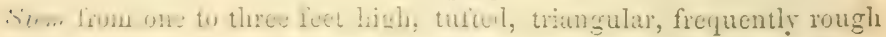
at the angles, leafy. Leares frequently as long as the stem, linear,

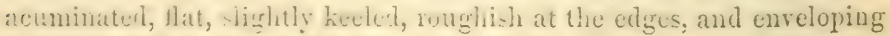
the stem with their strintet -hesthr; sonetines in luxuriant plants the 
stem is leafy neary to the top. Involucre of scrcral foliaccous leaflets; ocersionally there are oniy two, mostly longer than the spikelets. Spikelets large, ovate, or oblung, somutimes single, mostly several crowded, some of which are sessile, others on short stalks. Glumes a reddish-brown colour, corered wit' rery short silky hairs, acutely notched at the end, with a wacro between the segments, which is the termination of the liecl. Sitgmas three. Fruit ohovate, triangular, smooth. Bristles varying in mumber from tro to sis.

Habilat.-In salt-marshes, and the banks of rircrs cxposel to the tide, frequent.

Perennial; flowering in Juls and $\Lambda$ ungust.

The tubers are esculcnt, and Withering says they have been ground and used instead of flowr in times of scarcity. Cattle eat the herbage with an apparent relish.

7. S. carina'tus, Linn. (Fig. 74.) blunt-edged Club-rush. Spikelets oblong, in a terminal cyme, longer than the involucre, stem naked, round at the base, bluntly three-comered abore, stigmas two.

English Botany, t. 1983.-English Elora, vol.i. p. 61.-Lindley, Syuopsis, p. 281.-Hooker, British Flora, rol, i. p. 28.

Roots downy, submerged stems creeping, hard, and contracted. Sheaths several, lenfless, enveloping the base of the stem, which is round, becoming triangular abore, and terminating in an irregular cymose inflorescence. Spikelets oblong, of a rusty-brown colour, singlc or several clustered together. Involucre of one or more unequal leaves, the longest erect, shorter than the inflorescence. Fruit ovate, with several bristles at the base.

This species approaches S. lacustris, in the base of the stem being round, and in the similar arrangement of the intlorescence; and is allied to $S$. triqueter, by the upper part of the stem being triangular, and the style bifid.

Habitat.-Rare. By the side' of the 'Thames about London, and the banks of the river Arun, in Sussex.

Perennial; flowering in August.

8. S. sylrat'icus, Linn. (Fig. 75.) wood Club.rush. Spikelets small, ovate, in a large repeatedly compound terminal cyme, involucre of several foliaceous leaflets, stem triangular, leafy.

English Botany, t. 919.-English Flora, vol. i.p. 62.-Lindley, Synopsis, p. 281.-Hooker, British Flora, vol. i. p. 29.

Root fibrous, with ereeping underground stems. Stem triangular, from two to four feet high, leafy. Leaves numerous, long, flat, linear, somewhat rough at the edges and keel. Spikelets very numerous, small, orate, grecnish. Glumes small, entire, acute, kecled. Involucre of several long flat foliaceous leaflets. The terminal cymose inflorescence very large, repeatedly compound, its branches triangular, and 
enveloped at the base in one or more membranous lanceolate sheathing bracteas. Seed small, light-coloured, triangular, terminating in a blunt dark-coloured point, and surrounded at the base with six or eight long rough bristles.

Habitat.-In moist, shady situations; not very common. In Kent, Norfolk, and about London. It is more plentiful in Scotland, particularly in the southern counties.

Perennial; flowering in June and July.

This is a very distinct, handsome, and graceful species.

\section{GENUS X, ELEO'CHARIS. BRown. Spike-rush.}

\section{Nat. Ord. CY'PERACE E.}

Gen, Char. Spike terminal, solitary. Glumes of one valve, imbricated on all sides, mostly all fertile. Bristles four to twelve, finely toothed, rarely absent. Style dilated at the base, and jointed upon the germen. Stigmas two or three. Fruit lenticular or triangular, crowned by the indurated base of the style. Stem erect, simple, sheathed at the base.-Name from "'l. $\chi$ arge, to delight; on account of the marshy situations in which they grow.

1. E. palus'tris, Br. (Fig. 76.) creeping Spike-rush. Stem round, emitting from its base long underground stems, stigmas two, fruit nearly plain on one sirle, convex on the other, shorter than the four bristles at its base.

English Flora, vol. i. p. 64.-Hooker, British Flora, vol.i. p. 30.Scir'pus palus'tris, Linn. English Botany, t. 131.-Helio'charis palus'. tris, Lindley, Synopsis, p. 280.

Root fibrous. Underground stems long, emitting roots at various intervals, and clusters of three or more erect, smooth, naked flowering stems, from six to eighteen inches high, tapering abruptly at the extremity, terminated by an ovate oblong acute spike, and surrounded at the base with close thin membranous sheaths, the lower external ones black and shining, the upper a reddish-purple colour. Glumes various in size, outer ones the smallest, keeled, brown, with a pale membranous edge. Stigmas two. Fruit pale, smooth, attenuated at the base, crowned by the dilated indurated base of the style, nearly plain on one side, convex on the other, shorter than the four spiny bristles, which are flattened and dilated at the base.

Habitat.-Common on the borders of lakes, ditches, and in wet marshy ground.

Perennial ; flowering in June and July.

2. E. multicau'lis, Sm. (Fig. 77.) many-stalked. Spike-rush. Stem 



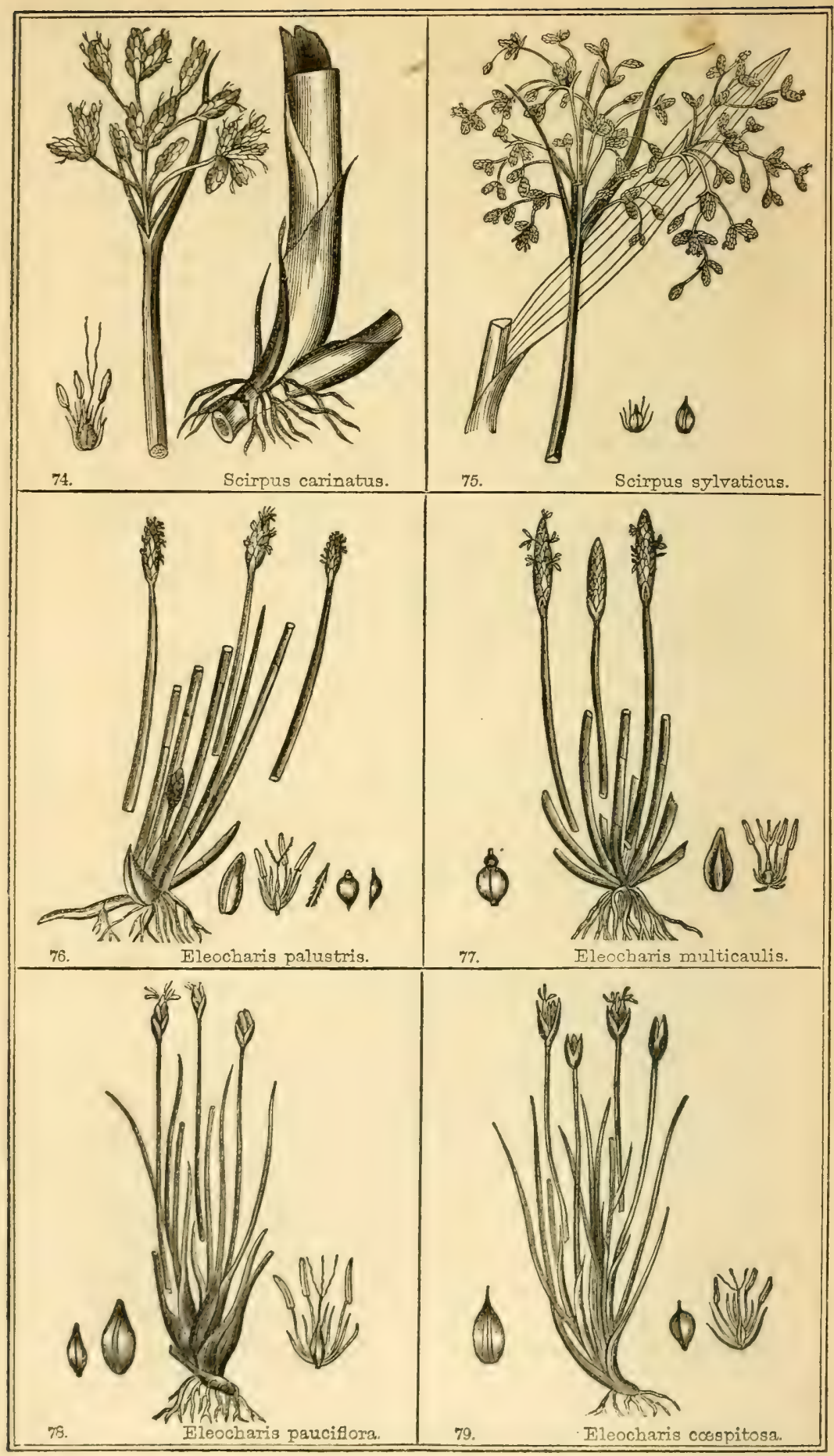


round, with scarcely any underground stems, stigmas three, fruit bluntly triangular, longer than the six bristles at its base.

English Flora, rol. i. p. 64.-Honker, British Flora, rol. i. p. 30.Scir'pus multicau'lis, English Botany, t. 1187.-Helio'charis multicau'lis, Lindley, Synopsis, p. 280.

Roots long, fibrous, tufted, with scarcely any, or very short, underground stems. Flouering stems numerous, round, with a central pith, from eight to twelve inches high, contracted at the extremity, terminated by a slender oblong ovate spike, and surrounded at the base with close dull reddish-brown membranous sheaths. Glumes keeled, brown, with a membranous edge, outer ones the smallest. Stigmas three. Fruit smaller than the last species, brown, smonth, triangular, one side broader and flatter than the others, crowned by the hard dilated trian. gular base of the style, contracted at the base, and surrounded by six short narrow spiny bristles. This is nearly allied to the last species, for which it is probably frequently passed orer, but is coustant to the above characters, and the situation of its growth is also different.

Habitat.-On wet heathy places, common probably throughout the singdom.

Perennial ; flowering in July.

3. E. pancifn'ra, Link. (Fig.78.) chocolate-headed Spike-rush. Stem round, sheaths at the base close, leafless, spike orate, few-flowered, outer glumes the largest obtuse, shorter than the spike, stigmas three, style deciduous.

Hooker, British Flora, vol. i. p. 30.-Sicirpus paucifo'rus, English Botang, t. 1122.-English Flora, vol. i. p. 56.-Helio'charis pauci. flo'ra, Lindley, Synopsis, p. 281.

Root fibrous, sometimes sending out jointed runners. Flower stems erect, slender, simple, smooth, cnveloped at the hase with tight membranous leafless sheaths, and surrounded with a few dark-brown scales; barren stems more or less numerous. Spike small, ovate, brown, of three or four flowers, the two outer glumes obtuse, half as long as the spike. Fruit triangular, pale, obtuse, terminated by the withered style, and surrounded at the base with about six bristles.

Habitat.-Bogs, monrs, and heaths. Fot uncommon in Sentland, less so in England, near Farmouth, Norfolk; Anglesea, and Bangor, in Wales.

Perennial; flowering in July and August.

4. E.ccespito'sa, Linn, (Fig. 79.) scaly-stalked Spike-rush. Stem round, or compressed, striated, leaves sheathed at the base, and invested with numerous scales, outer glumes the largest, as long as the spike, and terminated hy long rigid points, stigmas three, style deciduous.

Hooker, British Flora, rol. i. p. 30,-Scir'pus crespito'sus, English 
Botany, t. 1029.-English Flora, rol. i. P. 55.-Helio'cheris cecspito'se, Lindley, Srnopsis, p. $2 \& 1$.

A small plant, growing in dense tufts. Roots numerous, tough, and wiry. Stem erect, slender, simple, striated, varying in heiglit from two to ten inches, naked, except at the base, which is enveloped in two or three sheaths bearing subulate leares, and surrounded with numerous smooth brown striated scales. Spike small, urate, reddish-brown, two outer glumes largest, longer than the spike, mostly with a foliaceous apex, and generally fertile. Frut triangular, pale yellow, terminating in a fine point, and surrounded at the base by six bristles, longer than itself. Dr. Hooker finds a variety upon Ben Lawers, with the two outer glumes an inch long, four times the length of the spike.

Habitat.-Common on moors and moist turfy situations.

Perennial; flowering in June and July.

This species grows most aluundantly on moist barren moors in many parts of the country, and is fed upon by sheep, and "is called 'Deer's Hair' in the Highlands, and yields an abundent food to sheen on th.c mountains in spring." Hook.

5. E. acicula'vis, Roem. and Sch. (Fig. 80.) least Spike-iush. Stem setaceous, grooved, compressed, sheaths at the base close, leafless, spike small, orate, acute, glumes nearly equal, acumirate, stignas three, fruit without bristles.

English Flora, vol. i. p. 65.-Hooker, British Flora, vol. i. p. 31.S'ir'pus acicula'ris, English Botany, t. 749.-Helio'charis acicula'ris, Lindley, Synopsis, p. 280.

A small, delicate, slender plant, growing in thick tufts. Roots long and fibrous, with slender runners. Stem from two to four inches high, compressed or four-sided. Shenths at the hise tight, reddish, leafless barren stems more numerons and shorter than the fertile oncs, appearing like leaves. Spike very small, four to six flowered. Glumes nearly equal, keeled, brown, with a pale membranous edge; leel, especially of the outer ones, green. Fruit oblong, "pale yellow, beautifully im. Iressed with dotted lines, tipped witli the almost globose dark lase of the style," (IIork.) without bristles at the base, lut the filements are generally persistent, and might be mistaken for bristles.

Habitat. - Sandy borders of lakes, pools, and in marshy places, not unfrequent.

Perennial; flowering in July and August.

GENUS XI. ELIO'GITON. LINK. Water-rush.

Nat, Ord, CY'PERACEx.

Ges. Crinr. Spike terminal. Glumes mearly equal, of one ralve, imbricated on all sides, all fertile. Bristles absent. Style deci- 
duous. Fruit tipped with a short point.-Name from \& $\lambda_{0}$, a marsh, and yaro\%, near or neighbour; on aecount of the species being found near or in the neighbourhood of marshes.

1. E. fu'ituns, Link. (Fig. 81.) flouting Itater-rush. Stem branched, leafy, flower stems alternate, compressed, and naked, spike ovate, of few tlowers, glumes obtuse.

Helio'giton fu'itans, Lindley, Synopsis, p. 283.-Scir'pus fu'itans, Linn. English Botany, t. 216. -English Flora, vol. i. p. 57.-Eleo'charis fu'itans, Hooker, British Flora, vol. i. p. 31.

Stems long, slender, zigzag, mostly floating on water, and emitting roots at intervals from the joints. Flowering stems and branches alternate, the former from two to four inches long, erect, frequently swelled in the middle, contracted at the apex, and hearing a small oral spike. The leares lung, narrow, beeled, sheathing at the base, and spreading at nearly right angles, especially in the upper part, the lower ones narrower, longer, floating on the water. Glumes nearly equal, obtuse, pale green. Style short. Stigmas two, long, feathery. Fruit pale, oborate, with three obtuse angles, tipped with the short narrow base of the style, and without bristles at the base.

Hubitat.-In clear pools, ditches, and lakes, and in similar situations which are occasionally dried up; not common.

Perennial; flowering in June and July.

This species, although capable of existing sereral months in damp situations without water, is nerertheless mostly found floating on the surface of water on the margins of pools, \&c. It is the only British species of the genus, ant was arranger with Eleocharis, from which, howerer, it greatly differs in habit.

\section{GENUS XII. BLYS'MUS. Panzer. Blysmus.}

\section{Nat. Ord. Cy'PeraceE.}

Ge:. Crar. Spike terminal, compressed. Spikelets bracteated, arranged in a distichous manner on a slightly zigzag rachis. Glumes of one valre, imbricated on all sides, outer ones the largest, barren. Bristles often absent. Fruit compressed, terminated by the tapering persistent style.-Name from $\beta \lambda v \sigma \mu o s, q u o d$ ex $\beta \lambda \nu \zeta \omega$, a source or spring, near which the species usually grow.

1. B. compress'us, Panz. (Fig. 82.) broad-leared Blysmus. Bractea of the lower spikelet foliaceous, mostly longer than the spike, spikelets many-fluwered, bristles six, leares flat, linear, rough on the edges.

Iindley, Synopsis, p. 280.-Hooker, British Flora, vol. i. p. 29.Schrenus compress'us, Linn. English Botany, t. 791.-Scir'pus cari'cinus, English Flora, rol. i. p. 59. 
Root fibrous, tough, black, with creeping underground stems, of a brown colour. Stem simple, naked, from six to twelve inches high, striated, leafy below. Leaves flat, linear, above the length of the stem, slightly keeled, which, as well as the elges, are rough towards the end, and sheathing at the base. Spike terminal, compressed. Spikelets compressed, two ranked. Glumes shining, a light-brown colour, keeled and striated, the outer ones empty. Fruit pale, ovate, terminated by the tapering persistent darker style. Stigmas two. Bristles with reflexed spines, six, as long as the style.

Ilabitat.- Wet meadows and boggy situations; not uncommon.

Perennial; flowering in July.

2. B. ru'fus, Link. (Fig. 83.) channel-leaved Blysmus. Bractea of the lower spikelet membranous or leafy, spikelets few-flowered, bristles none, leaves narrow, channelled.

Lindley, Synopsis, p. 280.-Hooker, British Flora, vol. i. p. 29.Sche'nus ru'fus, English Botany, t. 1010._-Scir'pus ru'fus, English Flora, vol. i. p. 60.

A shorter and more rigid plant than the last species. Roots fibrous, tough, contorted and entangled with numerous creeping underground stems, emitting roots from the joints. Stems four to eight inches high, simple, smooth, naked above, leafy at the base. Leaves narrow, smooth, finely striated and channelled, sheathing at the base. Spike terminal, compressed. Spikelets ovate, two ranked, few flowered, bractea of the lower ones short and membranous, or long and foliaceous, sometimes much longer than the spike. Glumes shining, a dark-brown colour, mostly ribbed, the outer ones broader than the inner, and barren. Fruit pale, ovate, flattened on one side, convex on the other, narrow at the base, and terminated by the tapering persistent darker style. Bristles none, a character by which this species is readily distinguished from the last.

Habitat.-In marshy places, principally near the sea; must frequent in Scotland, and found "as far as Shetland"; abundant on the Isle of Arran. On the west coasts of England and Ireland, and in Wales.

Perennial; flowering in July.

\section{GENUS XIII. ERIOPH'ORUII. LINN. Cotton-grass.'}

\section{Nat. Ord. Cy'PERACEx.}

Gen. Char. Spikes terminal, solitary, or numerous. Glumes of one valve, imbricated on all sides, nearly equal. Style deciduous. Stigmas three. Fruit with very long silky hairs springing from

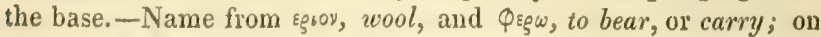
account of the conspicuous woolly heads, or because the seeds are carried or borne on the wind, supported by their long woolly hairs. 


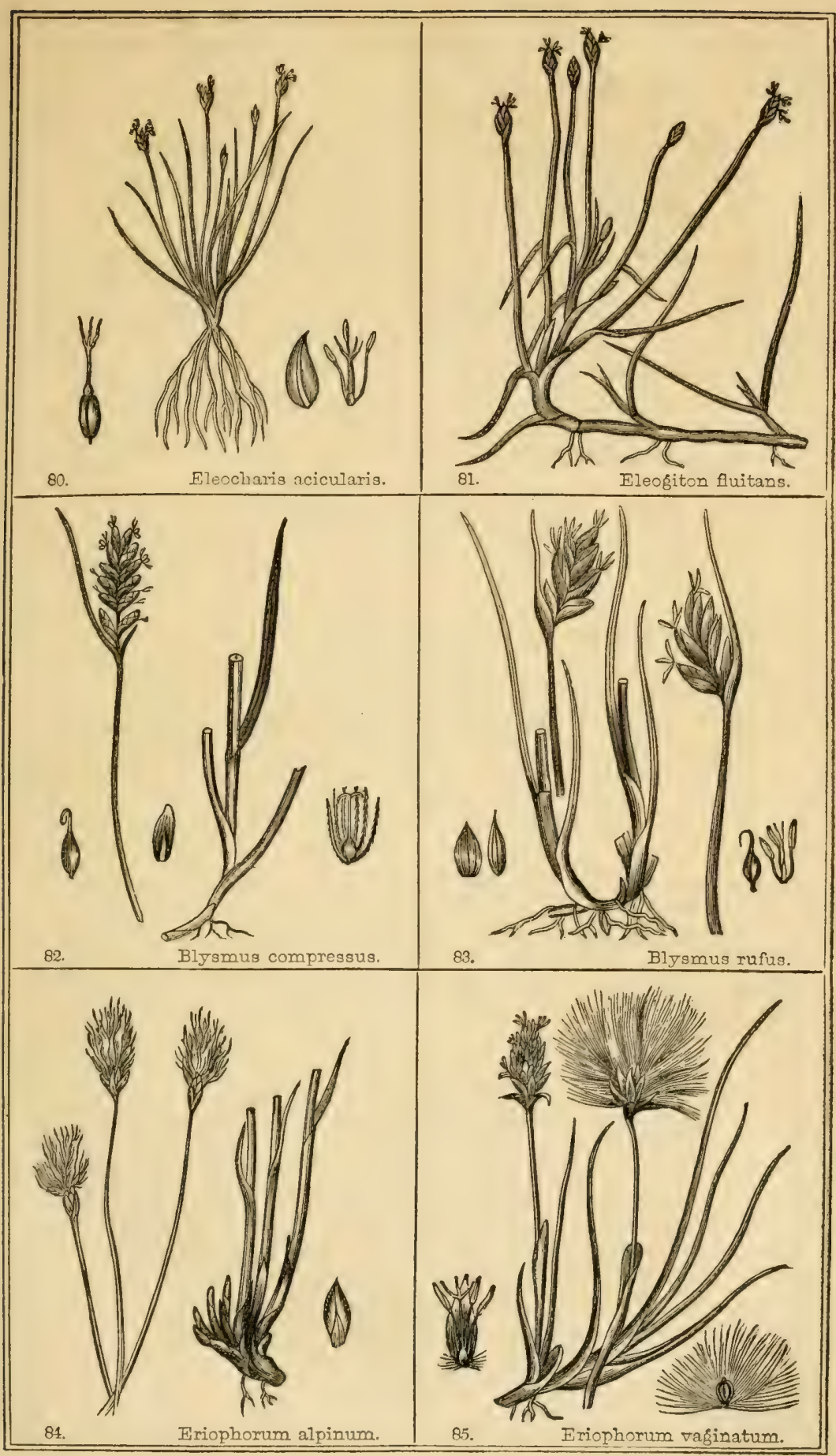





\section{* Spike solitary.}

1. E. alpi'num, (Fig. 84.) alpine Cotton-grass. Stem triangular, naked above, below enveloped in sheaths of various length, the upper ones bearing short leares, spike small, ohlongo-orate, glumes strongly keeled.

English Botany, t. 311.-English Flora, vol. i. p. 67.-Lindley, Synopsis, p. 282.-Hooker, British Flora, vol. i. p. 31.

Root fiblous. Underground stems long and creeping, putting up rows of numerous flouering stems, which are from four to eight inches high, with three rough edges, scaly at the base, and enreloped in sereral striated smooth sheaths. Leares very short, chamnelled, a little rough on the edges. Spike small, oblongo-orate. Glumes few, hrownish, with a strong green keel. Hairs few, erect, fine, white, and glossy.

Habitat.-Bogs in Scotland; "now probably extinct," Hook. Discovered by Mr. Brown and Mr. G. Don in the Moss of Restenet, three miles cast of Forfur; "hut that bog is drained, and the plant has disappeared."

\section{Perennial; flow ering in June.}

Specimens, in an excellent state of preservation, of this very interesting plant, from which our drawing was made, are in the collection of the Sheffield Literary and Plilosophical Society; they appear to have been sent by Mr. Brown to the late Mr. Salt, who has left this excellent and raluable collection, a memento of his indefatigable exertions in the science of Botany, which was pursued apart from the labours of business, and procurerl him the esteem of numerous scientific and learned men.

2. E. ragina'tum, (Fig. 85.) hare's tail Cotton-grass. Stem triangular abore, with obtuse swelling leafless sheaths, below round, and the sheaths mostly terminating in long setaceous leares, spike orate, glumes thin, membranous.

English Botauy, t. 783.-English Flora, vol. i. p. 66.-Lindley, Synonsis, p. 281.-Hooker, British Flora, vol. i. p. 31.-Sinclair, Gramineus Woburnensis, p. 358.

Root fibrous, tough, and wiry. Stems tufted, rarying in height from six inches to two feet, jointed, and arising from each joint above are whuse, inflated, striated sicaths, lielow it is enveloped in several sheaths lerminating in erect setaceous leaves of various lengths. Spike early $\because \because$ he spring a silver grey, from the long, pointed, single ribbed, membiunous glumes, which are heautifully contrasted by the large yellow anthers, and form at this early season of the year a pleasing object on the harren-looking situations of their growth. Seed obovate, triangular, with a short obtuse point, and copionsly surrounded at the base with loug, white, smooth hairs. 
Habitat.-On wet barren moors, not uncommon. Plentiful in boggy situations, in Sherwood Forest, Nottinghamshire, and the moors of Derbyshire and Yorkshire, \&cc.; but most abundant in the mountainous parts of the north; less frequent in the south.

Perennial; flowering in March and April.

3. E. capita'tum, Host. (Fig.86.) round-headed Cotton-grass. Stem round throughout, sheaths inflated, upper ones obtuse, the lower terminating in a uarrow subulate leaf, spike nearly round.

English Botany, t. 2387.-English Flora, vol. i. p. 67.-Lindley, Synopsis, p. 282.-Hooker, British Flora, vol. i. p. 31.

Root fibrous, putting out more freely and longer underground stems than the last, "throwing up here and there tufts of shorter and thicker leaves"-(Smith.) Stem about a span high, entirely cylindrical, straight and stout. Glumes less delicate, the lower ones finely ribbed. Hairs much shorter than in the above species, as is also the whole plant, but of a stouter habit.

Habitat.-Found by Mr. G. Don by the side of a rivulet on Ben Lawers, Scotland, near to perpetual snow. Very rare.

Perennial; flowering in August.

$$
\text { ** Spikes several, pedunculated. }
$$

4. E. pubes'cens, Sm. (Fig. 87.) downy-stalked Cotton-grass. Stem angular, leaves flat, lanceolate, triangular at the point, peduncles rough, hairs of the seed twice the length of the spike.

English Botany, t. 2633.-English Flora, vol. i. p. 69.-Lindley, Synopsis, p. 282.-Hooker, British Flora, vol. i. p. 32.

Roots strong, with creeping underground stems. Stem about eighteen inches high, triangular, smooth, leafy, especially below, and surrounded with numerous brown decayed leaves. Leares sheathing, linear, shorter than the stem, triangular at the point, rough on the edges, especially towards the point, thuse of the stem shorter, with longer sheaths. The leaves and stem frequently assume a diseased appearance, are reddish, swelled, smooth and shining. Bracteas leafy, about the length of the peduncles, dilated and brown below, triangular and rough at the point. Spikes ovate, from three to nine. Peduncles various in length, drooping, angular or compressed, roughish (not downy, as its name would imply), simple, or bearing sereral spikes. Glumes large, ovatoacuminate, single-ribbed, dark brown, pale at the edges and base. Sceds shining brown, obovate, with three unequal sides, terminating in an abrupt point, surrounded with white glossy hairs about twice as long as the spike.

Habitat.-Wet moors, not unfrequent.

Perennial; flowering in April and May.

It is stated in English Botany, that the roots are apparently 
creeping, but broken, in the specimen there figured and described; in reference to which, it may be worthy of remark, that in every instance in which we remember to have met with this species, its strong roots have been invariahly intermixed with those of other plants, in such a manner as to render it difficult to obtain specimens with any portion of the roots remaining attached to them.

5. E. polysta'chion, Linu. (Fig. 88.) broad-leared Cotton-grass. Stem round, leaves linear-lanceolate, flat, triangular at the point, peduncles smooth, hairs of the seed thrice the length of the spike.

English Botany, t. 563.-English Flora, vol. i. p. 68.-Lindley, Synopsis, p. 282.-- Hooker, British Flora, vol. i. p. 32.

Root fibrous, in whorls towards the base of the stalks. Stem crect, from one to more than two feet high, smooth, round, striated, sometimes slightly angular at the top, jointed. Leaves numerous, broad, flat, slightly keelecl, triangular at the point, rough on the edges and keel, especially towards the end, sheathing at the base, which is entire in this and the other species, and not slit on one side, as in the true grasses; the old withered leaves are generally very numerous around the base of the stem. Bracteas leafy, dilated, and dark-brown at the base, with thin pale membranous edges. Spikes several, sessile, and stalked, sometimes the stalks bear sereral spikes. Glumes membranous, lanceolate, pale brown at the base. Anthers linear yellow. The spikes are pendulous when in seed, and the white glossy hairs about three times as long.

IIabitat.-In wet boggy situations, Sherwood Forest, Nottinghamshire, Northamptonshire, Bedfordshire, Yorkshire, \&c., probably not unfrequent.

Perennial; flowering in April and May.

We are unable at all times clearly to distiuguish this species from either the precerling or following: from the former it is sometimes only to be known by the peduucles being smooth, not rough; and from the latter in the leaves being broader and less triangular, and the peduncles mostly bearing several spikes, a circumstance which we have never seen in it.

6. E. angustifo'lium, Roth. (Fig. 89.) common Cotton-grass. Stem nearly round, smooth, leaves linear, triangular, groored towards the base, peduncles smooth, hairs of the seed about four times the length of the spike.

English Botany, t. 561.-English Flora, vol. i. p. 69.-Lindley, Synopsis, p. 282.-Hooker, British Flora, vol. i. p. 32.-Sinclair, Gramineus Woburnensis, p. 356.

Roots strong, with creeping underground stems. Stems from one to three feet ligh, erect, smooth, round below, mostly somewhat angular above. Lcares generally about the length of the stem, sometimes 
longer, linear, triangular, channelled, smooth, round and sheathing at the base, rough towards the point. Bracteas two or three, about the Jength or longer than the peduncles, leafy, triangular, and rough above, dilated and sheathing at the base, where it is dark brown, with pale membranous edges. S'pikes erect, or slightly drooping. Peduncles simple, various in length, smooth, striated. Glumes lanceolate, single-ribbed, membranous, brown with a pale margin. Seed shining brown, triangular, terminating in an obtuse point, surrounded at the base with an abundance of very long white shining hairs, forming large beautiful and conspicuous heads, highly ornamented during the summer months.

Habitat.-On moors, bogs, and wet meadows, common.

Perennial; flowering in April and May.

This is distinguished hy the more upright stem; the spikes single on the peduncles; when in fruit not pendulous, but nearly erect, much larger, with the hairs longer; the leaves narrow, round at the base, not keeled, triangular above, and channelled on the upper side.

7. E. gra'cile, Roth. (Fig. 90.) slender Mountain Cotton-grass. Stem erect, round, slightly angular above, smooth, leaves triangular, grooved, with a membranous ligula at the base, peduncles short, hairs of the seed twice the length of the spike, bractea shorter than the spikes.

English Botany, t. 2402.-English Flora, vol. i. p. 70.-Lindley; Synopsis, p. 282.-Hooker, British Flora, vol, i. p. 32.

Root fibrous, with slender underground stems, jointed, and enveloped with the rudiments of leaves, which are thick and fleshy. Stem itender, from six to eighteen inches high, striated, smooth, slightly anculur. Leares shorter than the flowering stem, (which mostly bears ouly vile, ) smooth, linear, triangular, keeled on the under side, channelled on tie upper, striated, as are the sheaths at their base. Ligula lanceolate, entire. Bractea single, generally shorter than the spikes, leafy, striciterl, dilated and almost black at the base, with a pale thin margin. Spikes from two to five, sessile, or on short peduncles, erect, or slightly drooping. Glumes lanceolate, membranous, almost black, pale on the margins, upper ones single-ribbed, the outer with three. Sced pale brown, shining, elliptical, three-sided, obtuse at the apex, accompanied at the base with white shining hairs about twice as long as the spike.

This is the smallest and most slender of the many spiked Cottongrasses.

Habitat.-On boggy mountainous situations-Ben Lomond. R. D. -Ben Lawers and the Clove Mountains, Scothand, in at micarious soil. G. Don.-Cwm Idwell, North Wales. Mr. Wilson.

Perennial; flowering in July.

The foliage of the Cotton-grasses is much relished by cattle in the early part of the season; but rejected by them when other and finer 


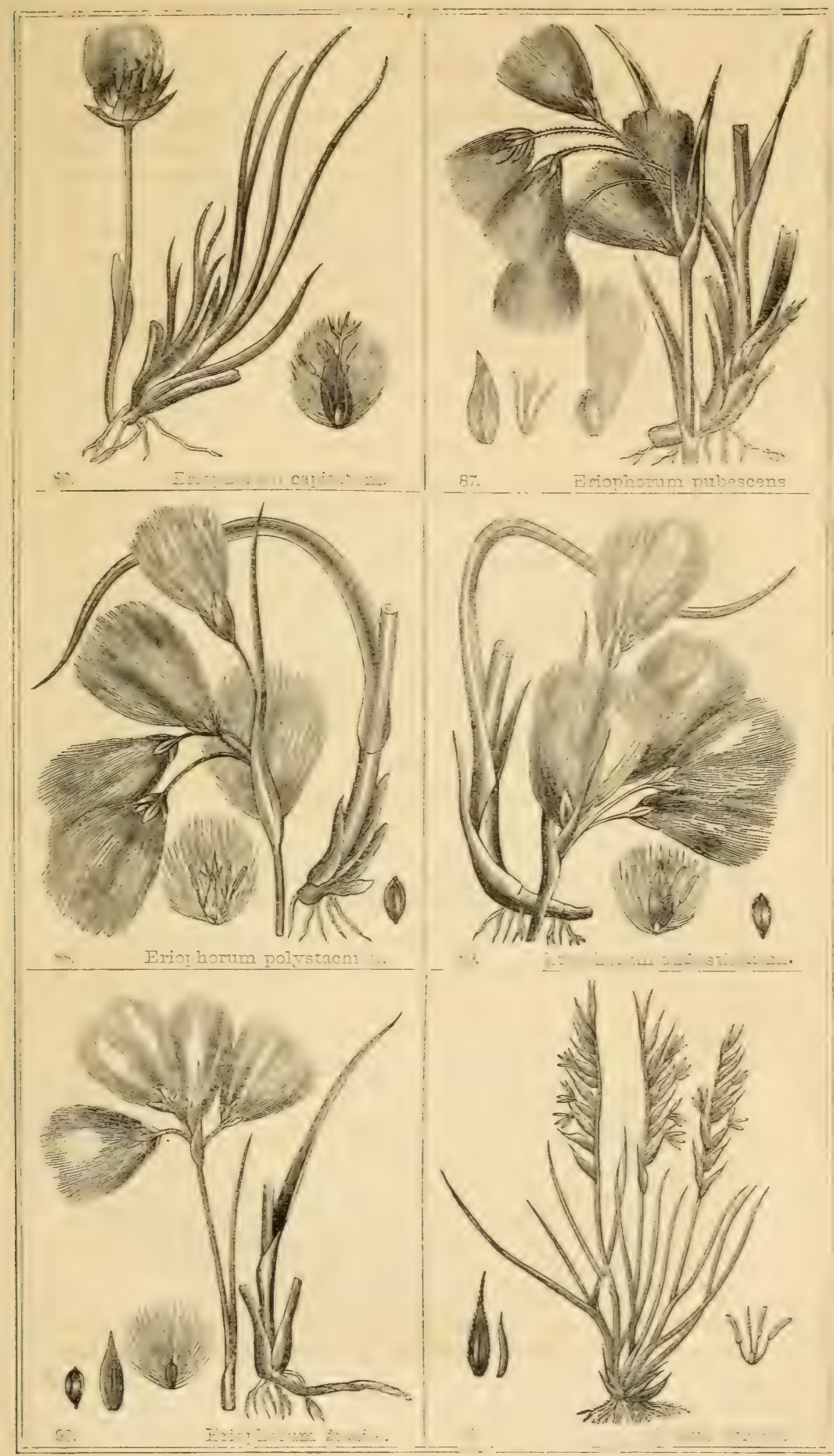



grasses become more plentiful; nor is their produce or nutritive properties sufliciently great to render them worth cultiration. Attempts have been marle to manufacture the long silky hairs into various articles of wearing apparel, but it is too brittle to be used for that purpose. In Lapland, Sweden, and poor mountainous countries, it is used for stuffing mattresses and pilluws; but for this purpose it is also too brittle, and "there is a prerailing opinion of its not being wholesome to sleep on."

\section{GENUS XIV. NAR'DUS. Lix. Mat-grass.}

Nat, Ord. Gramin'E.e.

Gex. Char. Glumes wanting. Glumelles two unequal lanceolate valves, the outer one largest. - Name is derired from yegos, nard, or spike-

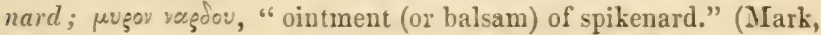
xir. 3.) The plant here spoken of is thought to be the Andropogon nardus, the Indian Nard, or Spikenard, which yields an agreeable essential oil. Nardus, or Nard, is a name anciently applied to several plants, as Nardus celtica (Valeriana celticæ), Nardus italica (Lavendula spicata), Nardus montana (Asarum europeum). Its application to sweet-smelling herbs is celebrated by Milton in the following lines:-

"He now is come

Into the blissful field through groves of Myrrh, And flow'ring odours, Cassia, Nard, and Balm."

It would be difficult to assign a reason for the application of this word to the present genus of plants, which are so utterly deroid of any properties analogous to those alluded to abore.

1. N. stric'ta, Linn. (Fig. 91.) Mat-grass. Spikes slender, erect, florets all pointing in one direction, leaves setaceous, coarse, and vigid.

English Botany, t. 290.-English Flora, vol. i. p. 71.-Lindley, Symopsis, p. 296.-Hooker, British Flora, vol. i. p. 32.-Sinclair, Gramineus IVoburnensis, p. 288.

Roots very strong, fibrous. Stems about a spau high, numerous, erect, wiry, striated, mostly rough on the edges, with short stiff hairs, hard and rigid, as are the setaceous leares, which are numerous, acutely pointed, sheathing at the base, striated, diverging abruptly from the stem, but curved upwards towards the extremity: ligula lanceolate. spike long, slender, usually half the length of the stem, striated, toothed for the insertion of the florets, an $l$ marked with depressions, in which the florets are contained before flowering, at which time they are spread out. Florets arranged alternately in two rows, but all pointing in one direction. Glumes wanting, uuless the border in front of the receptacle is 
to be considered as one; it is membranous, striated, and forms a short pointed sheath around the base of the florets; in some specimens this process is so much elongated, that there would be no hesitation in calling it a ralve, but in others it forms only a narrow border. Glumelles two unequal lanceolate valves, the external one largest, of a dark purplish colour, elongated into a rough rigid awn, coriaceous, and inclosing by its inflexed edges the inner valve, which is smaller, thin, membranous, and awnless. Stamens three, shorter than the glumelles. Anthers linear, yellow. Style short, simple, as well as the elongated feathery stigmas.

Habitat.-Moors, heaths, and waste, uncultivated, moist ground ; very common.

Perennial; flowering in June and July.

This is one of the least valuable of our native grasses. Parkinson, in speaking of its uses in his "Theatrum Botanicum," says it is used "both with us and in the low countries, for mats, hassocks, and divers other such like mean works, very serviceably." It is not now used either for domestic or other purposes, and is equally worthless as a pasture grass. Linnæus observes, that sheep are not fond of it, and that goats and horses eat it; but they never feed upon it from choice; for, of so hard and wiry a nature is this grass, that in the ordinary way, observes Mr. Sinclair, in his excellent work the "Hortus Gramineus Woburnensis," a scythe is passed amongst it without having the effect of dividing a single leaf; and from this it may be conceived how ungrateful it must prove to the mouths of cattle. In dry barren places, the number and strength of its roots are greatly increased, and in such situations they penetrate the crevices of rocks to a great depth. On account of this property, it has been celebrated by Schrank as a safe support to the hands of the alpine botanist and naturalist, in precipitnus situations, although it renders his path slippery.

\section{ORDER II.}

\section{DIGYN'JA. 2 STYLES.}

The whole of this order, together with the genus Anthoxanthum and $N a r d u s$, are true grasses, and constitute the natural order Gramn'EA.

No order of plants is more natural than this-none more extensive, or of so mucls importance to man, not ouly in furnishing him with the principal atricles of his daily sustenance, but as constituting the chief support of the domestic animals; indeed, the raried uses to which they are applied in the natural way, as well as in domestic economy, render 
he grasses of more importance than any other tribe of the regetable kingdom, buth in an agricultural and commercial point of riew.

Grasses, particularly by the young student of Botany, are usually ranked amongst the most difficult divisions of the Flora, and the col. I3.tion and study of them are mostly deferred, or entirely neglected; ist the parts by which they are characterised, though small, are, after a rittle practice, easily distinguished, and as readily and uneringly referred to their proper genus and species as any other tribe of plants. Indeed, no sooner does a person hegin to take an interest in the investigation of this interesting tribe, than "the flower of the grass," to adopt a beautiful Scripture expression, will be found to possess peculiar attractions-" the grace of the fashion of it," becoming strikingly apparent, as the examination proceeds. Grasses differ widely, however, from other flowering plants, both in habit and structure (especially of the flower), which may render it desirable that some explanation of them should be given in this place.

The roots do not differ in any thing remarkable from those of other plants; they are fibrous, tufted, or widely spreading.

The stems are subterraneous and superterraneous, and are intercepted at various intervals by joints, which are formed by the interlacement of the fibres, and constitute an impervious diaphragm or solid knot (nodus). The subterranean stems, or rhizoma, are solid throughout, and the joints much closer together than in the upper part of the stem; from those joints, which lie mostly beneath the surface of the ground, roots are put out; and some species are remarkable from the number of underground or creeping stems (soboles) which they put forth; these creep horizontally below the surface of the ground, emitting at rarious intervals roots, leaves, and flowering stems from their joints. The superterranean stems, or culms, are cylindrical or fistular, but, when first developed, solid, like the rhizoma from whence they spring; but as their growth is much more rapid, they become hollow, and the joints further separated from each other. From each of these joints the leaves spring alternately, and envelope the culms by a sheath-like expansion at their base, which is slit open on one sirle; and frequently at the termination of the sheath, where it expands into the blade, there is a peculiar thin membranous or hairy process called a ligula.

The inflorescence is in the form either of a spike, a raceme, or panicle; each division of which is called a spikelet (spicula), or locusta.

The spikelets may be either one, two, or more flowered; sessile, or supported on a peduncle.

The flowers are mostly hermaphrodite (stamens and pistils in the same flower); sometimes monœcious (stamens and pistils in separate flowers on the same plant); or polygamous (stamens and pis. tils united in some flowers, separate in others, either on the same 
plant, or on two or three different plants). The floral coicrings are gradations of bractece, and are glumaceous, or chaffy; the pieces are called glumes, or valves (valvula). The external valves -gluma of Brown-are empty, and called by Linnæus, Smith, Hooker, and most botanists, calyx; it is the gluma exterior of others, the tegmen of Beauvois, the peristachyum of Panzer, the lepicena of Richard, and the catonium of Trinius. Internal to these glumes there are one or more florets, the valves of which are mostly of a different texture; these are the glumella of De Candolle and Desvaux; the corolla of Linnæus, Smith, Hooker, and others; the calyx of Jussieu; the perianthum of Brown; the gluma of Richard; the palece of Beaurois and Lindley. Within these, and at the base of the germen, are found generally two, sometimes three, rarely one, small pale scales: the glumellula of Desvaux and De Candolle; the nectary of Linnæus and Smith; squamula of Jussieu, Brown, and others; glumella of Richard; lodicula of Beaurois; corolla of Micheli and Dumortier. From these differing, and indeed conflicting terms, it will be inferred how little comparatively is understood of the nature and organisation of these coverings; and until something more definite is known, it is better to call them what most obviously they are, viz. gradations of bracteæ. The external ones are here called glumes, the inner glumelles, and the innermost gl'rmellules. The ribs of the glumes and glumelles are frequently elongated into an awn, beard, or arista, which is of greater or less length, hygrometrical, frequently jointed, twisted or feathery. The inner valve of the glumelles is in some species bifid at the extremity, the sides inflexed, and there are two ribs, one on each side: such a valve, Mr. Brown regards as composed of two confluent valves.

No plants are more widely distributed over the surface of the globe than the grasses, extending their range from the equator to the polar regions; and none are more varied in habit to adapt them to the various circumstances of soil, situation, and climate of the countries in which they grow. In most countries, grasses constitute the chief covering of the otherwise cheerless and desolate-looking earth; ornamenting and enriching the hills, the valleys, and the plains, with the liveliness of their lovely green, and affording abundance of food for multitudes of the animated creation. The CrEator, ever solicitons for the provision and preservation of the various orders of creation, has displayed his wisdom in whatever department of nature we examine; but in the important tribe of grasses, this may be said to be most strikingly apparent, not only in having adapted them for every variety of climate and soil, but in wonderfully providing them with means to compensate for the rarious risadvantages in which they may be accidentally placed, and in overcoming and resisting injurics. For example: the stems or culms, which are mostly rejected by animals, and trodden down, might be thought to be destroyed; but they, in many 
cases, put out routs from their nodi or juints, each of which hecomes a distinct plant; so that, by means of these natural layers, the plants are greatly increased, and the pasture in which they happen to grow materially improved. On the other hand, the leaves and young stems being mostly preferred by grazing cattle, they are cropped close to the ground, and would appear irrecorerably injured; but it commonly happens that the more they are cropped, the more freely do they propagate themselves by oftsets from their roots; this is a means of vast increase, resulting in the formation of large tufts, a property which renders many of the grasses so abundantly productive, and well suited for permanent pastures: it is by this means, that Wheat is often so produc. tive; a single grain having been known to put up above an hundred culns or stems, each bearing from fifty to a hundred grains-a most astonishing increase! Again: many of the alpine grasses, or those growing on high exposed situations, where the heat of summer is not sufficient to ripen the seeds, do not all flower, but are in some instances riviparous; and even those which do produce flowers, are frequently found in that state. The roots of many species of grass are, when growing in a situation faroured with a plentiful supply of moisture, simply fibrous; but if the ground in which they regetate becomes dry, or the plants are removed to a less humid situation, they form bulbs or tubers-a means admirably adapted by nature to lay in store a supply of nourishment for the plant in times of drought. Some grasses grow and flourish best in low swampy marshes, and even in water (but none are marine); others on particular soils, as sand, chalk, clay, \&c.; or they prefer lower or more elevated situations, - as, for instance, $\mathrm{Poa}$ aquatica, Calamagrostis arundinacia, Alopecurus geniculatus, \&c. are found in low swampy or watery places; while Festuca ovina, Poa alpina, Aira alpina, Ec. occur un highlands or mountainous districts; and Ammophila arundinacea, Phleum arenarium, Poa bulbosa, \&c. upon loose, sandy shores.

It might, a priori, be supposed that a sribe of plants su extensive in its characters, and distributed through erery variety of climate, soil, and situation, would present a vast diversity in modification and habits; such, in fact, is found to be the case. The grasses are solitary, or social, multiplying and spreading to a great extent, erect or creeping, simple or branched, of almost every rariety of height, from a few inches to upwards of two hundred feet,-assuming the port and character of trees, with fuliage equally various, and roots not less so. Some species, from the fact of their producing large seeds containing a great portion of farinaceous matter, hare been called Cereal, or Com-grasses; and others, producing smaller seeds, but as furnishing a nutritious herbage for cattle, pastoral or fodder grasses.

The whole order, comprehending about two thousand species, with scarcely more than one exception, are wholesome; abounding in nutritious feculent matter, and sugar; -indeed, the abundance of the latter 
substance, in what is called from that circumstance the Sugar-cane has rendered the cultivation of this grass a matter of great importance, as from it we are so plentifully supplied with an article not only entering into the composition of numberless of our esteemed luxuries, but which seems to have become indispensable in household economy, though formerly it was found only in the apothecary's store of dreaded drugs, being esteemed as a useful medicine in the cure of febrile and other diseases.

Grasses are also remarkable from the fact of their cuticle containing a quantity of silex, similar to that yielded by the Equisetums; it is this which accounts for the vitrified masses which have sometimes been found in the ashes of corn or hay-stacks, when destroyed by fire. This siliceous secretion is perhaps effected at a greater rate in the hotter than in the temperate climates. In the sugar plantations, where the canes, after the extraction of the juice, become the principal fuel used for the fires kept up under the pans, dc., large masses of vitrified substance are frequently found in the grates and amidst the ashes: these masses excited considerable curiosity and speculation, before the circumstance had been properly investigated and explained.

Grasses, though found in almost every part of the globe, are far, however, from being equally distributed. In tropical countries, they are less numerous than in extra-tropical climates; they grow to a much greater size and height, are tougher, more wiry, having broader leaves, the flowers more elegant and downy; nor do they usually grow crowded together in close compact tufts, but are scattered and wide asunder, some species assuming au arhorescent form, and attaining an amazing altitude, as Panicum arborescens, a most extraordinary grass, growing in the woods of Hindostan: its culms or stems, although not so thick as the little finger, grow so high as to o'ertop the loftiest trees, above which they form, as it were, an aerial meadow, gracefully waving in the balmy breeze.

The Bamboo, as already intimated, is one of those surprising tropical grasses, of which we hare no parallel in temperate climates. An idea of the grandeur and beauty which these magnificent arborescent grasses impose upon the face of their native country, may perhaps be best collected from the account of Captain Basil Hall, who, after travelling during the night in a palanquin, from the bare table-land of Mysore, towards the hilly and thickly wooded regions orerhanging the Malabar country, awoke in the morning, when, says he, "I found myself in the midst of one of the most curious and magnificent scenes which $\mathrm{my}$ eyes had ever beheld. It appeared as if I were travelling among the clustered columns of some enormous and enchanted Gothic Cathedral, compared to which the Minster of York, or the Cathedral at Winchester, would have seemed mere baby-houses; the ground extended on all sides, as smooth and flat, and clear of underwood, as if the whole had been paved with grave-stones. From this level surface rose on every 
hand, and as far as the eye could penetrate into the forest, immense symmetrical clusters of hamboo, rarying in diameter at their base from six feet to twenty or thirty, and even to twice that width, as I ascertained by actual measurement. For ahove eight or ten feet from the ground, each of these clusters or columns preserved a form nearly cylindrical, after which they began gradually to swell outwards, each bamboo assuming for itself a graceful curve, and rising to the height, some of sixty, some of eighty, and some even of one hundred feet in the air, the extreme end being at times horizontal, or even drooping gently over, like the tips of the feathers in the Prince of Wales's plume. These gorgeous clusters stood at the distance of from fifteen or twenty yards from one another, and being totally free from the interruption of brush wood, could be clistinguished at a great distance-more than a mile certainly, in every direction, furming under the infiuence of an active imaginatiou, naves and transepts, aisles and choirs, such as none but a Gothic architect ever dared to conceive. Orerhead the interlacing curves of the bamboos constituted as complete a groined roof as that of Winchester or IVestminster, on a scale of grandeur far beyoud the bold conception even of those wonderful artists who devised that glorious school of architecture.

"On counting the seperate bamboos in some of the smallest, and also in some of the largest clusters, I found the numbers to vary from twenty or thirty to upwards of two hundred, and the lieight generally from sixty to a hundred feet from the ground, to the point of intersection of the curves overhead. Most of the bamboos were somewhat thicker than a man's thigh at the ground, where, as I have before said, they are clustered so close as to be almost in contact. They then taper off very gradually to the extrense end, where the point is not thicker than a quill.

"There occurs a joint at about every foot and a half, distinguished not only by a slight flat ring or fillet, but by a set of small branches, eight or ten fcet long, striking out at right angles to the main bamboo. These minor shoots are again divided into joints, from which other series of shoots, still more minute, are thrown out, and so on for many successions, the last always tcrminating in a sharp pointed narrow leat two or three inches loug, and half an inch wide in the middle not unlike a large tea leaf when spread out. As each bamboo of the hundred or more, forming the cluster, sends out shoots from every joint, and as ali the joints of these suborinate plants do the same, a compact mass is formed by these innumerable little branches, which cross one another at evcry possible angle. If a person were to fill a hat full of pins and needles, and shake it about for some minutes, it might gire a notion of the inextricable confusion which is presented to the eye in looking into one of these clustered columns of bamboos. It is only at the top, where the bend tahes places, that the foilage has full room to play, or where the tapering arms of this magnificent plant form, by their meetings and crossings, a complete sistem of pointed arches 
"What surprised me very much, and greatly puzzled me at first. was, to observe that, notwithstanding the multitude of lateral shoots from each of the main bamboos, and from all the subordinate branches, not a single trace of displacement, or the slightest obstruction to the growth of any branch, could be detected. Every person must have heard of the astonishing rapidity of the growth of the bamboo; it is said, indeed, that in one season it starts up to its whole length. I do not know if this be true, but am quite certain that if one of the main bamboos were to spring from the ground in the centre, or even near the sides of the cluster, and that from its joints there were at the same time to sprout out the lateral branches $I$ have described, it would be impossible for the main stem to force its way through the obstructions presented by the network, formed by the little branches growing from the joints of the other bamboos in the cluster." The author goes on to state he thinks we can "perceive how nature manages this difficult affair. When the bamboo first springs out of the ground, it is about as thick as a man's wrist, always highly polished, with an extremely hard point; aud as no lateral shoots are pnt out until it has attained its full height, it readily makes it way through the thickest ramified masses, while the subordinate branches, growing in like manner, find no difficulty in piercing this complicated mass of vegetable life.

"I saw," continues Captain Hall, "bamboos in every different stage of this process, and particularly I noticed sereral of the main stems rising to the height of seventy feet and upwards, of a clear yellow colour, and evidently of recent growth, but without a single lateral branch growing from their joints from top to bottom; and this led me to infer that their extreme height had not been reached, or was but just attained."

Bamboos are applied to many useful purposes both in India, China, and Japan. The tender tops are used to form a pickle; an excellent paper is manufactured from the tissue of the stem; and the stems themselves are used in a great variety of purposes, such as the making of furniture for their houses, cups, tubs, and boxes; also in the construction of dwellings, which are sometimes covered with the gigantic leaves of the Banana; in making water pipes, and in the construction of fences. The substance called in India tabashecr, is procured from the joints; it was found by Dr. Turner to consist of silica, with a minute portion of lime and regetable matter.

In the extri-tropical countries, and cspecially in the temperate regions, the grasses are far more numerous than within the tropics; they aro also much smaller, seldom exceeding three or four feet in height; of a more teuder and succulent nalure, and better suited for the food of frazing cattle. 'They are likewise for the most part found growing in socicty, and that so densely as to form the compact green turf which carlets onr meatows and fields, and clothes the banks of the meandering stream, or borders the acclivitics upon many of our most rapid rivers: in short there appears, as already stated, scarcely any limit to 
their growth, as regards soil or situation. Grasses either in their naturally sticculent state, or when dried in the condition of hay, constitute the chief support of those animals which man has subjected to his service, as well as those which principally supply him with animal food. Here we observe another of those admirable arrangements of a beneficent Providence, in the distribution of the pastoral grasses, which are fitted for the food of so many living creatures, thus becoming an indirect means of administering to the wants of man, in those countries where animal food is wanted to sustain him in health and vigour; while in tropical latitudes, where less animal food is required, gramineous regetables are, as already observed, less numerous, but more stately, and fitted rather to afford shade and protection from the rays of the scorching sun, than as a means of supporting life.

The importance of grasses in the scale of the creation, might be in. ferred from the Creator's command-

"Let the earth

Put forth the verdant grass, herb yielding seed, And fruit-tree yielding fruit after her kind, Whose seed is in herself upon the earth.

He scarce had said, when the bare earth, till then

Desert and bare, unsightly, unadorned,

Brought forth the tender grass, whose verdure clad

Her universal face with pleasant green;

Then herbs of every leaf, that sudden flowered, Opening their various colours, and made gay

Her bosom, smelling sweet."

MiltoN.

Those marked peculiarities which are observable in the attainment of perfection, and the term of existence in regetables, are equally seen in grasses, i. e. some are annual, arriving at a state of perfection and dying away in the course of a year, as Alopecurns agrestis, Poa annua, \&.c.; others are perennial, arriving at perfection in two or three years, and continue growing to an indefinite periorl, as Dactylis glomerala, Phleum pratense, \&.c.; there are, however, very few species that requirc a longer period of time than this, before they attain their greatest state of perfection, supposing them to be grown in the soil and situation suited for them; for peculiar grasses grow best, and can unly be cultivated with profit or arlvantage under those circumstances; hence, those agriculturists who would cultivate their land with the greatest success, must either choose the grasses suited to the soil, or so alter the nature of the soil by tillage as to render it suitable for the grasses themselves. The circumstance, too, of some grasses coming to a state of perfection in a short time, while other's require a much longer period, will have material influence in determining the choice of those species which are wauted either for the alternate husbandry, or for permanent pasturage.

The immense importance which has in all ages and countries been attached to the growth of corn, as affording what has been emphatically designated "the staff of life," has caused the greatest attention to be 
paid to the cultivation of all the cereal gramineæ; while to that paramount object, there has been alded, in this country especially, an almost equal share of consideration in the production, situation, and improvement of the rarious grasses suited for pasturage and hay. The success which has attended this course, identified as it has been with scientific as well as practical skill, and also pursued under the most favourable circumstances of soil and climate, has placed Great Britain in the very highest position among the countries engaged in agricultural experiments.

From the foregoing facts and considerations alune, the value of a botanical acquaintance with this very important tribe of vegetables to the agriculturist, in the successful cultivation of his land, will be obvious.

The Cereal, or corn-grasses, though the least numerous division of this vast tribe, are nevertheless, as already intimated, of the greatest importance, as from them the great mass of mankind directly receive the principal articles of their sustenance. The chief of these grasses, or those which are most fumiliarly known, and cultivated to the greatest extent from the value of their farinaceous seeds, areWheat, Triticum; Rice, Oryza; Maize, Zca; Rye, Secale; Barley, Hordeum; the Oat, Avena; and Millet, Sorghum. These, which are the principal grasses commonly cultivated in this and other countries for the value of their grain, are indebted for the preference which they have obtained in the estimation of mankind, to the large size of the seeds, and abundance of foeculent matter which they contain; not thai even the seeds of the pastoral grasses are less wholesome, with the exception of Lolium temulentum, but on account of their much smaller size, and the little fœculent matter which they contain, they are of comparative little or no ralue as corn-grasses.

For an account of the distribution of the Cerealia, the following is an extract from an interesting paper on the Geographical Distribution of Grasses, by Schouw, from Professor Jameson's Edinburgh Philosophical Journal, for 1825 :- "A detailed representation of the distribution of the cultivated Gramineæ would certainly be very interesting. Here we must restrict ourselves to a short and general outline. We shall endeavour to specify those Graminea which are the prevailing ones in the larger zones and continents, mentioning in passing those plants of other families which either supply the place of, or are associated with, the different kinds of grain, as the chief articles of food. This distribution is determined, not merely by climate, but depends on the civilisation, industry, and traffic of the people, and often on historical events.

"Within the northem polar circle, agriculture is found only in a few places. In Siberia grain reaches at the utmost only to $60^{\circ}$, in the eastern parts scarcely above $55^{\circ}$, and in Kamischatka there is no agriculture even in the most southern parts $\left(51^{\circ}\right)$. The polar limit of agri- 
culture on the north-west of America appears to be somewhat higher; for, in the more southern Russian possessions $\left(57^{\circ}\right.$ to $\left.58^{\circ}\right)$, barley and rye come to maturity. On the east coast of America it is scarcely abore $50^{\circ}$ to $52^{\circ}$. Only in Europe, namely in Lapland, does the polar limit reach an unusually high latitude $\left(70^{\circ}\right)$. Beyond this, dried fish, and here and there potatoes, supply the place of grain.

"The grains which extend farthest to the north of Europe are barley and oats. These, which in the milder climates are not used for bread, afford to the inhabitants of the northern parts of Norway and Sweden, of a part of Siberia and Scotland, their chief vegetable nourishment.

"Rye is the next which becomes associated with these. This is the prevailing grain in a great part of the northern temperate zone, namely, in the sonth of Sweden and Norway, Denmark, and in all the lands bordering on the Baltic; the north of Germany, and part of Siheria. In the latter, another very nutritious grain, buck wheat, is very frequently cultivaterl. In the zone where rye prevails, wheat is also generally found; barley being here chiefly cultivated for the manufacture of beer, and oats supplying food for the horses.

"To these there follows a zone in Europe and western Asia, where rye disappears, and wheat almost exclusirely furnishes bread. The middle, or the south of France, England, part of Scotland, a part of Germany, Hungary, the Crimea and Caucasus, as also the lands of middle Asia, where agriculture is followed, belong to this zone. Here the rine is also found ; wine supplants the use of beer; and barley is consequently less raised.

" Next comes a district where wheat still abounds, but no longer exclusirely furnishes bread; rice and maize hecoming frequent. 'To this zone helong Portugal, Spain, part of France on the Mediterranean, Italy, and Greece; further, the countries of the east, Persia, northern India, Arabia, Egypt, Nubia, Barbary, and the Canary Islands; in these latter countries, however, the culture of the maize or rice, towards the south, is always more considerable, and in some of them several kinds of Sorghum (Dutura) and Poa Ahrssinica come to be added. In both these regions of wheat, rye only occurs at a considerable eleration; oats, however, more seldom, and at last entirely disappear; barley affording food fnr horses and mules.

"In the eastern parts of the temperate zone of the Old Continent, in China and Japau, our northern kinds of grain are very unfrequent, and rice is found to predominate. The canse of this difference between the east and west of the Old Continent appears to be in the manners and peculiarities of the people. In North America, wheat and rye grow as in Europe, but more sparingly. Maize is more reared in the Western than in the Old Continent, and rice predominates in the southern provinces of the United States.

"In the torrid zone, maize predominates in America, rice in Asia, and hoth these grains in nearly equal quantity in Africa. The cause 
of this distribution is, without doubt, historical ; for Asia is the natire country of rice, and America of maize. In some situations, especially in the neighbourhood of the tropics, wheat is also met with, but always subordinate to these other kinds of grain. Besides rice and maize, there are in the torrid zone sereral kinds of grain, as well as other plants, which supply the inhabitants with food, either used along with them or entirely occupying their place. Such are in the New Continent, Yams (Diuscorea alata), the Manihot (Jatropha manihot), and the Batatas (Convolvulus batatas), the root of which and the fruit of the Pisaug (Banana, Musca), furnish universal articles of food. In the same zone, in Africa, Doura (Sorghum), Pisang, Manihot, Yams and Arachis hypogra. In the East Indies, and on the Indian Islands, Eleusine coracana, E. stricta, Panicum frumentaceum; several Palms and Cycadeæ, which produce the sago; Pisang, Yams, Batatas, and the Bread-fruit (Artocarpus incisa). In the islands of the South Sea, grain of every kind disappears, its place being supplied by the Breadfruit tree, the Pisang, and Tacca pinnatifida. In the tropical parts of New Holland there is no agriculture, the inhabitants liring on the produce of the Sago, of various Palms, and some species of Arum.

"In the high lands of South America, there is a distribution similar to that of the degrees of latitude. Maize, indeed, grows to the height of 7,200 feet abore the level of the sea, but only predominates between 3,000 and 6,000 of elevation. Below 3,000 feet it is associated with the Pisang, and the above mentioned vegetables; while from 6,000 to 9,260 feet, the European grains abound; wheat in the lower regions, and rye and barley in the higher; along with which Chenopodium Quinoa, as a nutritious plant, must also be enumerated. Potatoes alone are cultivated from 9,260 to 12,300 feet.

"To the south of the tropic of Capricorn, wherever agriculture is practised, considerable resemblance with the northern temperate zone may he ohserved. In the southern parts of Brazil, in Buenos Ayres, in Chili, at the Cape of Good Hope, and in the temperate zone of New Holland, wheat predominates; barley, howerer, and rye make their appearance in the southernmost parts of these countries, ancl in Tan Diemen's Land. In New Zealand, the culture of wheat is said to have been tried with success; but the inhabitants avail themselves of the Acrostichum furcatum as the main article of sustenance.

"Hence it appears, that, in respect to the predominating kinds of grain, the earth may be dirided into five grand divisions or kingdomsthe Kingdom of Rice, of Maize, Wheat and Rye, and lastly, of Barley and Uats. The first three are the most extensive; the maize has the greatest range of temperature; but rice may be said to support the greatest number of the human race."

Corn, from its inestimable value, has been from time immemorial considered the emblem of Riches; and Ceres, the daughter of Saturn and $\mathrm{Ops}$, has long been its goddess. The broken straw, we are inform- 
ed, from a very early period, even in the history of monarchy, has been used to express the breaking of treaties, and dissatisfaction; it is now, in the emblematic language of Flora, used to express a feeling of dis. sention, or rupture; and Grass, from its extensive distributiou, use, and value, as a token of utility.

Zea Mays is the name of the now-so-generally-known Indian Wheat plant, Maize; this corn is indigenous to America, and is cultivated with success in Italy, and rarious other parts of Europe: it has been grown with partial success in the warmer parts of this country: but the produce of its grain with reference to domestic purposes, is so inferior to wheaten flour, as to render its cultiration here of little value.

Oryza satirr, the Rice plant, produces the grain which, after undergoing certain operations, forms the principal food upon which vast multitudes of the inhabitants in all parts of the eastern world are supported. Large quantities of it are also annually imported into this country, and applied to a variety of domestic purposes. It is from this grain that the spirituous liquor called arrack is made. The cultivation of Rice in those hot countries where it forms a staple commodity, is an exceedingly unhealthy ocrupation; it is chiefly grown in gradually sloping valleys, or upon plains, which are favourably situated for being flooded either by means of the natural rivers, or from large artificial tanks or reservoirs of water, which have been raised with immense labour on the sides or across the valleys; so that the fields are kept in a constant swampy state during certain seasons of the year, which, with the heat of the climate, greatly farours the production of malaria.

It is a remarkable fact, that while ferns of the most delicate character are (as we shall hereafter have occasion to notice more particularly) found enveloped in the shale and other matters of the coal formation, the cereal and pastoral grasses, which constitute so considerable a portion of the regetable covering of almost erery region of the globe, have not, it is beliered, been noticed in a fossil state. The casts of plants found in connexion with the coal are, it is true, for the most part analagous to those of tribes at present flourishing only in tropical climates, where the smaller grasses, as above noticed, are much less common than in temperate latitudes. In corroboration of the foregoing statement, the authority of Messis. Lindley and Hutton may be cited: these competent observers assert, that "no trace of any glumaceous plant has been met with, even in the latest Tertiary Rocks, although we know that grasses now form a portion, and usually a very considerable one, of every Flora of the World, from New South Shetland to Melville Island inclusive. It may indeed be conjectured, that before the ereation of herhiferous animals, grasses and sedges were not required, and therefore are not to be expected in any beds below the Forest Marble and Stonesfield Slate; but it is difficult to conceive how the animals of the upper Tertiary beds could have been fed, if grasses had not then been present."-Fossil Flora, Preface, p. 13. It may, 
howerer, be remarked, that some of the largest animals at present known to exist, are rather browsing than grazing animals.

The injury to which grasses are liable by the depredation of insects, parasetic fungi, and disease, is an extremely interesting part of their history, but cannot with propriety be here treated of.

\section{GENUS XV. ALOPECU'RUS. Linn. Foxtail-grass.}

Gen. Char. Panicle spiked. Glumes of two simple nearly equal valves, mostly united at the base. Glumella of one ralve, with an awn rising from the base.-Name from $\alpha \lambda \omega \pi \eta \xi$, a fox, and ovg $\alpha$, a tail; in reference to the resemblance which the inflorescence has to a fox's tail.

1. A. praten'sis, Linn. (Fig. 92.) Meadow Foxtail-grass. Stem erect, smooth, panicle spiked, nearly cylindrical, obtuse, glumes of two lanceolate acute hairy valves, united at the base, glumella ovate acute, awn twice as long.

English Botany, t. 759.-English Flora, vol. i. p. 80.-Lindley, Synopsis, p. 299.-Hooker, British Flora, vol. i. p. 33.-Sinclair, Hort. Gram. Woburn. p. 139.

Root fibrous. Stems from one to three feet high, erect, (except to the first joint at the base, which is often prostrute, smooth, leafy, striated, tufted at the base. Leaves flat, smooth, or slightly pubescent, a somewhat glaucous green, upper ones much shorter, rougher, with longer, more deeply striated, and slightly swelling sheaths. Ligula short, obtuse. Inflorescence a close paniculed spike, from one to two inches long, soft and silky from the glumes, which are downy and ciliated, remarkably compressed, united at the base (connate), and marked with three green ribs. Aun arising from near the base, about as long again. Anthers yellow, conspicuous. Styles united, longer than the glumella. Stigmas spreading, feathery. Seed small, brown, ovate.

Habitat.-Fields and meadows, common everywhere.

Perennial; flowering from May to July.

Meadow foxtail-grass is one of the most useful and valuable pastoral grasses, especially for permanent pastures on a morlerately light soil, with a good supply of moisture, and "should never," observes $\mathrm{Mr}$. Sinclair, "form a less proportion than one-cight of any mixture of different grasses prepared for that purpose " and the same author further remarks, that "the meadow foxtail constitutes part of the produce of all the richest pastures I have cxamined in Lincolnshire, Devonshire, and in the vale of Aylesbury. In Mr. Westcar's celebrated pastures at Creslew, I found it more prevalent than in those of Devonshire and Lincolnshire." $\Lambda$ s it does not, however, attain its greatest state of productiveness until at least four years after it has been sown, it is not 
a grass fitted for the alternate husbandry. It is of early growth, very productive, of good quality, and highly nutritive, grateful to most cattle, and may be mown with advantage twice a year. Few, if any, of our native grasses possess more raluable properties than this: it is not only remarkable for its early growth, but equally so for its lateness. In certain situations, it may not unfrequently be observed in a vigorous state of growth from the end of March till very late in the autumn. In those pastures where it forms any considerable portion of the herbage, the treatment pursued is often at variance with those means best calculated to secure the full anount of adrantage which, with judicious management, its many excellent properties are calculated to supply. In such pastures, the most prevailing error is in allowing it to become too gross before the cattle are turned in to eat it down; in consequence of which, it may be observed, that a large portion of the pasture is left untouched by the cattle until autumn or winter, by which time this and some other species of rapid growth will have extended themselves, and usurped the place of the less luxuriant kinds, thereby destroying one of the most cssential qualities which pasture land ought to possessthat of an equal and extensive mixture of grasses.

A similar error is often committed in the management of fields devoted to the cultivation of hay, by delaying the mowing season long after this and some other of the carlicr and most nutritious kinds have attained maturity, and their most valuable properties passed into a state of decay. By such delay, the weight of the crop, it is true, may be somewhat increased; but it will always be found that this additional weight in the hay will be obtained by a proportional deterioration both in its quality and nutritious properties, as well as a loss in the produce of the after math.

2. A. alpi'nus, Sm. (Fig. 93.) Alpine Foxtail-grass. Stem ascending, panicle spiked, ovate, glumes of two ovate, abruptly acute, hairy valves, united at the base, awn of the glumella scarcely protruding.

English Botany, t. 1126.-English Flora, vol. i. p. 81.-Lindley' Synopsis, p. 299.-Hooker, British Flora, vol. i. p. 33.

Root somewhat creeping, fibres long and branched. Stem from twelve to eighteen inches high, procumbent at the base, smooth, leafy, striated. Lower leaves longer than the sheaths, linear, striated, smooth, upper one much shorter than the inflated sheath. Ligula short, obtuse. Inflorescence spiked, short, ovate, dense, soft, downy. Glumes united at the base, abruptly pointed, ribs threc, a dark purplish green, ciliated, lairs fine, silky. Glumella ovate acnte, slightity hairy, keel narrow, ribs two on each side, green. Awn arising from near the base, about the same length, rough. Styles combined. Stigmas protruding, feathery.

Habitat.-Very rare. "Discovered by Mr. R. Brown on Loch na Garr, in Aberdeenshire; White Water, and other streams of Clove- 
Mr. H. C. Watson, Dr. Graham." Loch Whorol, Clove-Dr. Hooker, Mr. J. D. Hooker; to whose kindness we are indebted for beautiful specimens of this and other rare plants.

Perennial; flowering in July and August.

This species is readily distinguished from all other of the genera, by the short orate panicle, the short upper leaf with its inflated sheath, the abrupt glumes, and the short rough awn.

3. A. agres'tis, Linn. (Fig. 94.) slender Foxtail-grass. Stem erect, scabrous above, panicle spiked, slender, cylindrical, tapering, glumes nearly smooth, united from the base to about the middle.

English Botany, t. 848.-English Flora, vol. i. p. 81.-Lindley, Synopsis, p. 299.-Hooker, British Flora, vol. i. p. 33.-Sinclair, Hort. Gram. Woburn. p. 283.

Roots numerous, fibrous, sending up numerous flowering stems, which are bent at the base, becoming erect, rough in the upper part, leafy at the base, but more distant above, from one to two feet high, finely striated. Leaves pale, linear, rough on the under side, and edges with fine sharp teeth pointing towards the end. Sheaths striated, upper ones slightly inflated. Ligula somewhat downy, striated, obtuse, mostly jagged or torn at the end. Inflorescence spiked, long, slender, cylindrical, pointed, frequently purplish. Glumes lanceolate acute, united by their edges nearly half the length of the valves, smooth, three-ribbed, which are green or purplish towards the apex, slightly keeled, which is more or less rough. Glumella quite smooth, threeribbed, with the awn arising from near the base about as long again. Styles short, united. Stigmas feathery. Seed orate.

Habitat.-Fields and waysides in a poor soil, common.

Annual ; flowering from June to October.

This is a grass of very inferior quality, and of no value for agricultural purposes, as it is said to be refused by almost all cattle. It prefers a poor exhausted soil, and in some places is a very troublesome weed, difficult to be extirpated, producing flowering stems and an abundance of seed during nearly the whole summer. The seed is of a large size, and affords food for small birds, pheasants, and partridges; and may be sown with advantage on a poor soil in game preserves and shady situations, forming a cover for them during the whole summer, as well as furnishing them with a constant and plentiful supply of food. The appearance of this grass upon cultivated land is a natural witness of its poor and ill-conditioned state: it delights to grow, and thrives best, on those lands exhausted by a repeated rotation of imporerishing crops; and a remarkable circumstance in the habit of this grass is, that when the land is again brought into a good condition, it disappears; but otherwise it is most difficult to be removed, and consequently a most sroublesume weed. 



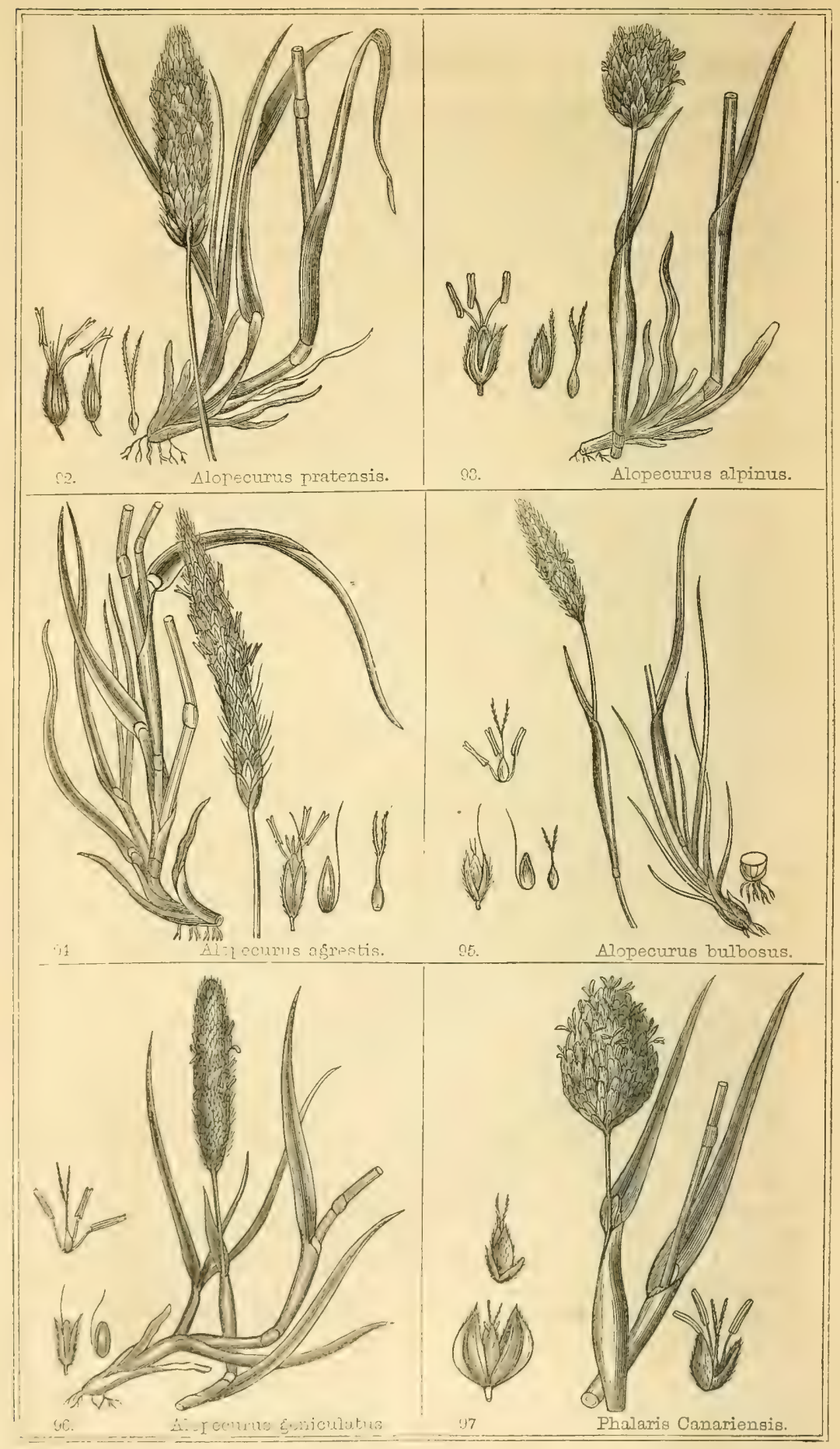


4. A. bulbo'sus, Linn. (Fig. 95.) tuberous Foxtail.grass. Stem erect, panicle spiked, cylindrical, tapering, glumes lanceolate acute, slightly hairy, not united at the base, root with tubers.

English Botany, t. 1249.-English Flora, rol. i. p. 82.-Liudley, Sprnopsis, p. 299.-Hooker, British Flora, rol, i. p. 33.

Root fibrous. Stem erect, from six to ten inches high, solitary, smooth, finely striated, leafy, the lower part frequently bent and swollen into a solid tuber or bulb; sometimes there are several, one above ano. ther, between the joints, which are in this part of the stem near each other, and from each of them roots and a single stem are put out. Leaves narrow, striated, shorter ahove, with long swelling sheaths. Ligula lanceolate, decurrent, striated. Inflorescence subspicate, dense, the pedicels for the most part short, each bearing a fertile and an abortive flower. Glumes lanceolate, acute, and purple at the point, quite free to the base, slightly downy all over, but more so on the keel and ribs, which are purple. Glumella blunt, shorter than the glumes, with an au'n arising from near the base, and about twice as long. Anthers scarcely longer than the glumes. Styles united. Stigmas feathery, protruding. Sead orate.

Habitat.-Salt marshes in England, rery rare; Yarmouth, Weymouth; in Cardiff marshes, Wales.

Perennial; flowering in July.

5. A. genicula'tus, (Fig. 96.) floating Foxtail-grass. Stem ascending, bent at the joints, panicle spiked, cylindrical, obtuse, glumes obtuse, united at the base, slightly hairy, glumella obtuse, the awn arising from its base varying in length.

English Botany, t. 1250.-English Flora, vol. i. p. 83.-Lindley, Synopsis, p. 300.-Fooker, British Flora, vol. i. p. 33.-Sinclair, Hort. Gram. Woburn. p. 353.

B. ful'rus, awn the length of the calyx. Alopecu'rus ful'rus, English Butany, t. 1467.-English Flora, vol. i. p. 83.-Hooker, British Flora, rol. i. p. 34.-Lindley, Synopsis, p. 300.

$\gamma$. bulbo'sus, roots with bulbs,-English Flora, vol. i. p. 83.-Alopecu'rus genicula'tus bulbo'sus, Sinclair, Hort. Gram. Woburn. p. 301.

Root fibrous. Stem rarying in length fiom six inches to two feet, prostrate in the lower part, and frequently sending out roots and branches from the joints, smooth, striated, leafy, erect from the last joint. Leares short, finely ribbed, rough on the upper side and edges, smooth beneath. Sheaths smooth, striated, upper ones inflated. $\mathrm{Li}$ gula oblong, clasping the stem. Inflorescence a dense blunt erect spike, from one to two inches long, often purplish. Glumes obtuse, united at the base, terminating in a minute point, hairy, ciliated at the keel. Glumella obtuse, or slightly notched, shorter than the glumes, smooth, or slightly hairy towards the extremity. Aun arising from near the base, generally as long again as the glumella, but not unfrequently 
about the same length. Anthers mostly yellow, but varying in colour to dark brown or purple. Styles short, united. Stigmas feathery.B. ful'vus, made by Sir J. E. Smith a species, has been, by all succeeding botanists, considered very doubtful; the colour of the anthers we have observed to be very various in specimens both with long and short awns; and although we have not found the awn so often as short as that represented in English Botany, yet still so very variable in length, as to induce us to think it a variety, rather than a species.

Habitat.-Common by the side of pools, in marshes, and wet meadows, sometimes on walls.

Perennial ; flowering from June to August.

This plant is remarkably various in size, which circumstance greatly depends upon the situation of its growth; when grown by the side of pools or wet drains in a rich soil, the stems may be observed more than two feet long, either floating on the surface of the water, or trailing on the wet ground, and taking root from the joints; the leares broader and longer than when grown in drier situations. It is remarkably tenacious of life, and although mosily found in the situations above named, it is vccasionally observed in very dry places, even on the tops of walls, when it has loulbs superadded to its fibrous roots. It is of little or no agricultural utility, both on account of its natural habit and the little nutritive matter it affords.

\section{GENUS XVI. PHA'LARIS. LinN. Canary-grass.}

Gen. Char. Panicle contracted, or spreading. Glumes two, equal, keeled, longer than the glumella. Glumelles of two equal, awnless valves, at length forming an indurated covering to the seed, and accompanied at its base with one or two unequal imperfect florets. Name from $\phi \alpha \lambda \circ$, white, or slining; in reference to the glossy covering of the seed.

1. P. canarien'sis, Linn. (Fig. 97.) cultivated Canary-grass. Stem erect, panicle compact ovate, glumes boat-shaped, compressed, keeled, each valve of the glumella with an abortive floret at the base.

English Botany, t. 1310.-English Flora, vol. i. p. 74.-Lindley, Synopsis, p. 300.-Hooker, British Flora, vol. i. p. 34.-Sinclair, Hort. Gram. Woburn. p. 399.

Root of numerous white fibres. Stem erect, from one to two feet high, leafy, glaucous, striated. Lcares hroad, lanceolate, soft, somewhat pubescent. Sheaths long, striated, upper ones considerably inflated. Ligula obtuse. Inflorescence an obtuse spike. Glumes large, pale, yellow, with two green lines, and a remarkably broad keel at the back, entire at the point, and containing a perfect floret of two pointed shining hard cartilaginous hairy valves, and two imperfect florets, each 
of one membranous scarcely hairy ralve. Stigmas protruding. Seed ovate, light brown.

Habitat.-Waste places and brick-fields that have been some time neglected.

Annual; flowering in July.

These, like many other annual plants, possess in a remarkable degree the property of adapting themselves, not only to an extensire range of climate, but also to situations exceedingly different. This plant, though not unfrequent in rarious parts of both England and Scotland, (for which reason it is admitted into our Floras,) is a "native of the Canary Isles," and cultivated in this cuuntry for the seed, which is well known as the canary-seed, and used for the porpose of feeding canaries and other small birds; the ciraff is relished by horses, but the cultivation of the grass for agricultural purposes possesses no properties by which it can be recommended. It is sometimes cultirated in the flower-garden for the beauty of its variegated spike, and when dried it forms an elegant winter decoration.

2. P. arundina'cea, Linn. (Fig. 98.) Reed Canary-grass. Panicle erect, its branches spreading, spikelets numerous, clustered, turned to one side, abortive florets one or two, small, hairy.

English Botany, t. 402, and t. 2160, fig. 2.-English Flora, vol. i. p. 75.-Hooker, British Flora, rol. i. p. 34.-Sinclair, Hort. Gram. Woburn. p. 359.-Digra'phis arundina'cea, Lindley, Synopsis, p. 301.

Root much tufted with long creeping underground stems. Stems from three to five feet high, erect, strong, smooth, leafy. Leares broad, flat, lanceolate, tapering at the point, spreading, rough, especially towards the points, finely striated, as are also the sheaths, which are smooth, and closely embracing the stem. Ligula obtuse, somewhat decurrent. Inflorescence a large open panicle, its branches spreading, angular. Gl'tmes equal, lanceolate, keeled, ribbed, roughish on the keel, often tinged with brown or purplish. Glumelles two, nearly equal, smooth and shining, cartilaginous, each mostly bearing at its base a small membranous hairy valve of an imperfect floret.

A variety with variegated leares is frequently cultivated in gardens, and is commonly known by the name of Ribbon-grass, Ladies' Traces, Painted Lady-grass, \&c.

Habitat.-Common on the margins of lakes, rivers, and ditches; the variegated variety is occasionally found in a wild state in Cambridgeshire, and "near Cardigan-Rev. J. S. Tozer."

Perennial; flowering in July and August.

This grass was formerly known by the name of Arun'do colora'ta. It does not possess any properties so as to render it worthy the notice of the agriculturist, except in low wet clayey districts. It contains a considerable quantity of nutritive matter, but is not eaten by cattle from choice; nerertheless, as a winter prorender, it might be 
cut up with other hay of a finer quality, either for horses or other cattle, The tough long underground stems are of considerable utility in fortifying the banks, and resisting the encroachments, of rapid streams.

\section{GENUS XVII. AMMo'PHILA. Host. Sea-reed.}

Gen. Char. Panicle spiked. Glumes nearly equal, keeled. Glumelles shorter than the glumes, hairy at the base, the outer valve

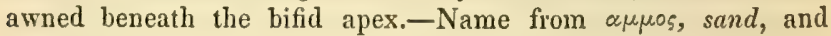
Qryos, a lover; the plant delighting to grow in loose sand.

1. A. arundina'cea, Host. (Fig. 99.) common Sea-reed, Sea Matweed. Panicle spiked, pointed, glumes acute, onter one shortest, glumelles surrounded with short hairs, inner valve with an abor. tive hairy floret at its base.

Hooker, British Flora, vol. i. p. 34.-Ammo'phila arena'ria, Lindley, Synopsis, p. 302.-Arun'do arena'ria, Linn. English Botany, t. 520.English Flora, vol. i. p. 172.-Sinclair, Hort. Gram. Woburn. p. 371.

Root with very long, tough, jointed underground stems. Stem from two to three feet high, erect, often bent near the base, round, smooth, finely striated, very rigid. Leaves long, narrow, the edges rolled inwards, rigid, with a very sharp point, smooth, glaucous. Sheaths close, smooth, striated. Ligula long, lanceolate, generally torn. Inflorescence a compact spiked panicle, swelled in the middle, a pale green or straw colour. Glumes with a slight rib on each side, rough on the keel, especially towards the extremity, the keel of the inner valve terminating: in a short point between the bifid apex. Glumelles of two valves, shorter than the glumes, roughish, with minute points, and surrounded at the base with a tuft of glossy bristles, outer valve the largest, with two ribs on eaeh side, the keel terminating in a rough point, shorter than the acute membranous lobes on each side of it, inner valve smaller, with two slight lateral ribs, and two dorsalones; between the two latter, which run nearly parallel with each other, is a sinus, the whole length of the valve, having imbedded in the lower part of it a hairy awn-like abortive ralve, about one-third the length, which arises from the receptacle above the insertion of the valve of the perfect floret. Glumellules long, lanceolate. Anthers linear, orange or purplish. Styles distinct, erect. Stigmas feathery.

Habitat.-Frequent on loose sandy sea-coasts.

Perennial; fiowering in July.

The long tough creeping underground stems, which send out roots from the numerous joints, are of vast utility in preventing the sand from being drifted inland from the sea coast, and in binding the embankments raised either by natural or artificial means, as a barier to the encroachments of the sea. 



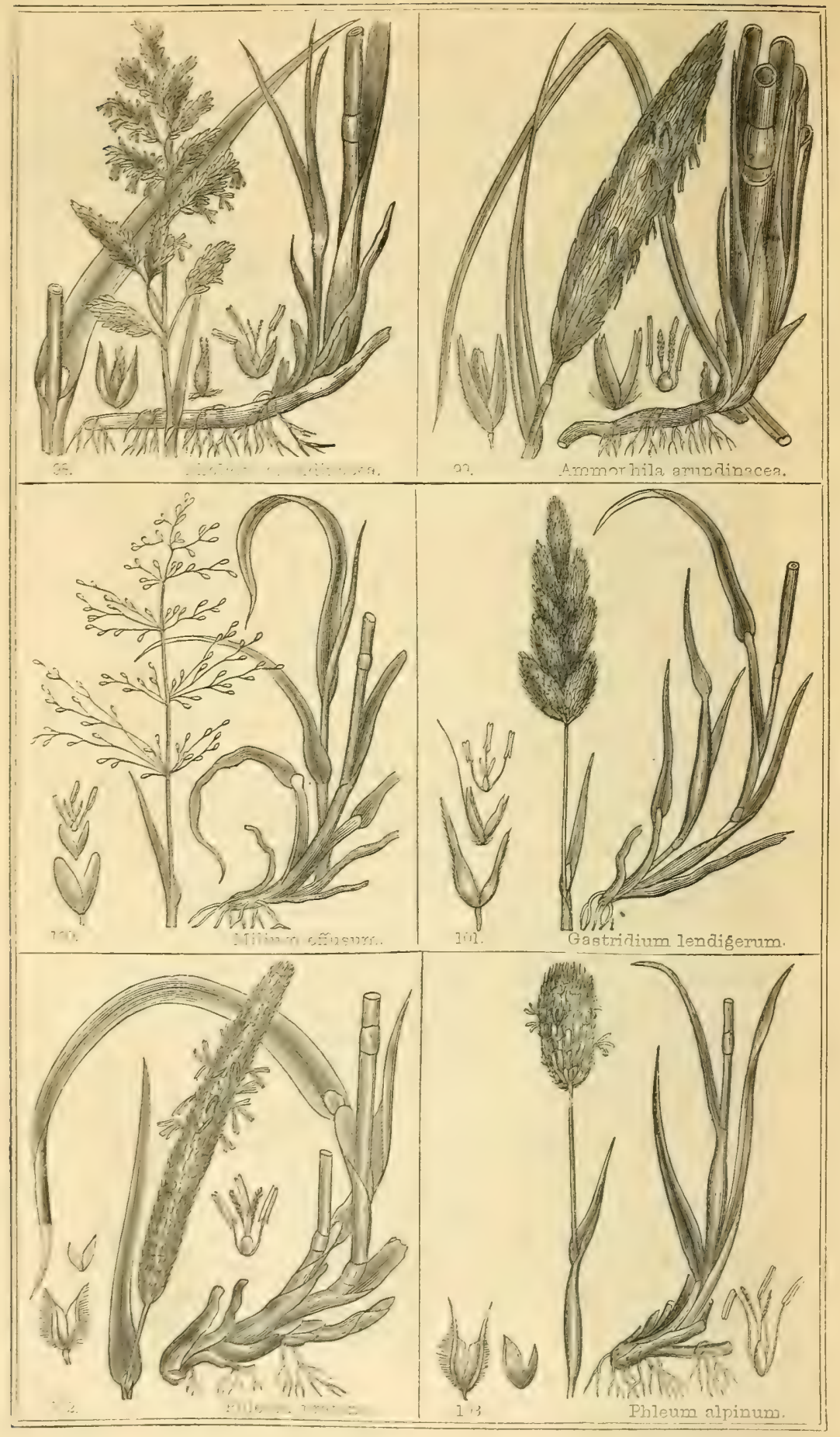


GENUS XVIII. GaSTRI'DIUM. Beavv. Nit-grass.

Gev. Char. Panicle contracted, spiked. Glumes two, unequal, awnless, unequally swelled at the base, much longer than the glumelles, which form a covering to the seed; the outer valve mostly with a dorsal awn.- Name from rasgodor, a little belly, or swelling; on account of the swollen base of the glumes.

1. G. lendi'gerum, Beauv. (Fig. 101.) auned Nit-grass. Glumes unequally lanceolate, glumelles equal membranous, the outer one awned.

Lindley, Synopsis, p. 302.-Hooker, British Flora, vol. i. p. 36.Mil'ium lendi'gerum, Linn. English Botany, t. 1107.-English Flora, vol. i. p. 88.-Agros'tis austra'lis, Linn.?

Ront fibrous. Stem from six to ten inches high, branching at the base, smooth. Leares lanceolate, acuminate, rough on the upper surface and edges. Sheaths striated, smooth, somewhat inflated. Ligula oblong, generally torn. Inflorescence a lobed spiked panicle, erect, tapering towards the end. Glumes shining, singularly swollen at the base, rough on the keel, compressed upwards, the outer valve the largest. Glumelles much smaller, membranous, downy; outer valve the largest, generally with a rough dorsal awn; inner bifid at the apex, hairy at the base. "Sometimes the rudiment of a second floret at the back of the inner valve." Seed covered with the indurated glumelles, and enveloped in the shining glumes.

Habitat.-Rare. In fields near the sea, where water has stagnated. In the Isle of Shepey; at Weymouth; Gillingham; and at Cley in Norfolk.

Perennial; flowering in August.

This is a very distinct genus from Milium, with which it was for" merly united.

GENUS XIX. MIL'IUM. Lrns. Millet-grass.

Gev. Char. Panicle spreading. Glumes two, equal, flattish, awnless, ribbed. Glumelles two, equal, shorter than the glumes, smooth, shining, ribless, without awns, forming a hard permanent covering to the seed.-Name from mille, a thousand; a name applied by the ancients to a sort of corn or grass, remarkable for the abundance of its seeds.

1. M. effu'sum, Linn. (Fig. 100.) spreading Millet-grass. Branchics of the panicle spreading, partly whorled.

English Botany, t. 1106.-English Flora, vol. i. p. 87.-Lindley, Synopsis, p. 301.-Hooker, British Flora, vol. i. p. 36.-Sinclair, Hort. Gram. Woburn. p. 403.

VOL, I. 
Roet fibrous, often with creeping underground stems, and putting up sereral erect, smooth, and leafy flowering stems, from three to four feet high. Leaves broad, lat, lanceolate, with one prominent rib and numerous small omes, the lower leares rough on both sides and the edges, the upper ones less so, and quite smooth on the upper surface. Ligula oblong, blunt, frequently torn. Inflorescence an clegantwide-spreading panicle; its hair-like branches, which are roughish in the upper part, arise in half whorls, mostly on alternate sides, their base having a swollen articulation with the stem. Flowers single. Glumes thin, membranous, mostly three-ribbed, pale green, roughish. Glumelles smaller, very smooth and shining, concare, cartilaginous, persistent, and embracing the seed. Styles short. Stigmas feathery.

Habitat.-Frequent in moist woods and shady situations.

Perennial; flowering in June and July.

The panicles of this graceful and pretty grass are sometimes found. near a foot long, and eight inches wide; the seeds are a farourite food of numerous birds, and the abundance which it produces, together with its naturally preferring to grow in the cool and shade of trees, sufficiently recommend it as a grass of great utility in game preserves; and its elegance and soft green colour would form an ornament of no inconsiderable beauty in the shade of plantations and pleasure grounds where but few other plants will grow.

\section{GENUS XX. PHLE'UM. LIN⿴, Cat's-tail-grass.}

Gen. C'mar. Panicle spikerl, compact. Glumes nearly equal, acuminate, or the keel terminating in an awn. Glumelles two, smaller, awnless, membranous. Seed oblong, loose.-Name from " $\phi \lambda$ sos, or $\phi \lambda_{\varepsilon \omega \varsigma}$, formerly applied, as is supposed, to the Recd-mace (Ty$p h a)$, to which our grass bears some distant resemblance.

1. P. praten'se, Linn. (Fig. 102.) common Cat's-tail-grass, Timothygrass. Panicle spiked, cylindrical; glumes abrupt, longer than its rough awn; keel ciliated at the back.

English Botany, t. 1076.--English Flora, vol. i. p. 76.-Lindley, Synopsis, p. 300.-Hooker, British Flora, vol. i. p. 34.-Sinclair, Hort. Gram. Woburn. p. 195.

B. nodo'sum, whole plant smaller, stem tuberous at the base.Phle'um nodo'sum, Linn. Sinclair, Hort. Gram. Woburn. p. 199.

Root fibrous, sometimes sending out creeping underground stems. Stem erect, from one to four feet high, round, smooth, striated, leafy below, frequently bent at the lower joints, generally sercral from the same root. Leaves linear-lanccolate, flat, striated, rough, with fine points, especially on the under sidc. Sheaths long; striatcd, smooth, close. Ligula obtuse, tom. Inflorescence spiked, cyliudrical, obtuse, varying 
in length from two to six inclies, very densely crowted, green or purplish. Glunes pale, membranuns, with a stroug, freen, ciliated keel, terminating in a somew hat sprealing, rough an $n$; the inner edge of the onter vale hairy. Giume!les unequal, small, obtisse, often crenated, ribberl with green. Stigmas feathery. Seed oblong.

Habitat.-Meadows, pastures, and waste ground, common.

Perennial; flowering from June to September.

This grass varies considerably in size, owing to the varicty of situation in which it may hare grown; the same circumstance is also the cause of the rarious appearances which are observed to take place in the roots. The utility of this grass for agricultural purposes raries considerably, according to the treatmont. It contains, from the accounts of Sinclair, a greater proportion of nutritive matter than any other grass he suhmitted to experiment. Its herbage is early produced in the spring, but unless grazed while young, it becomes so gross as to be aroided by cattle; and its being grazed at this perioul does not decrease the value or quantity of hay which it afterwards produces; it is for the latter purpose that this grass is principally esteemed, but it is also of great value arnongst other grasses, buth for permanent pastures and the alternate hushandy. "This grass is the Highland badge of the clan Sutherlund, whose crest is a cat."

2. P. alpi'num, Linn. (Fig. 103.) alpine Cat's-tail-grass. Stem ascending; panicle spiked, ovite-oblong; glumes abrupt, about as long as its rough awn; keel ciliated at the back; root creeping.

English Botany, t. 2519.-English Flora, rol. i. p. 77.-Lindley, Synopsis, p. 300.-Hooker, British Flora, vol. i. p. 35.

Root with long underground stems. Stem from six to twelve inches high, aseending, branched at tho base, leafy, smooth, striated, tinged with purple towards the top. Leaves flat, linear, with a distinct dorsal michib, which is rough, as are alsu the elges, with fine eartiaginous teeth, pointed towards the extremity; upyer ones short, with long inflated striated smooth sheaths. Inflorescence spicate, short, mostly of a dull purplish colour. Glumes abrupt, thin, smooth, slightly sprinkled with short hairs, prurplish, with a strong green ciliated keel, terminating in a rough awn, about as long as the glume. Glumelles tro, unequa!; the external valve larcest, abrupt, three-ribbel, the dorsal one rough, terminating in a short rough awn, and frequently the two lateral ones also; the internal one shorter, lanceolate, with a dursal rough rib. Glumellula of two lanceolate valres. Seed ovate, dotted, closely invested with the glumella. Style short. Anthers yellow. Stigmas feathery.

Habitat.-Rare. Clove Mountains - Mr.J. D. Hooker; Ben Law ers and Garway Hoor, Scotland.

Perennial; flowering in $\mathrm{J}$ uly 
This rare species of Scotch grass is readily distinguished by its short ovate spike, abrupt glumes, and long awn. It is remarked by Smith that the roots are tuherous, a character which we hare not obserred, but in all the specimens we hare seen they are creeping, with numerous joints and whorls of long fibres sent out from each of them. In Salt's collection there are specimens communicated by "Mr. Sowerby, from Forfar," which bare the leares shorter and much hroader, the sheaths more inflated and striated, and the whole plant much stouter, than is its usual appearance. Probably this difference may be from a luxuriant growth of the plants.

3. P.as'perum, Jacq. (Fig. 104.) rough Cat's-tail-grass. Stem erect, often branched; panicle spiked, cylindrical, dense ; glumes wedgeshaped, rough; awn short, blunt.

English Flora, vol. i. p. 77-Lindler, Srmopsis, p. 301.-Hooker, British Flora, rol. i. p. 35.-Phle'um panicula'tum, English Botany. t. $107 \%$.

Root strong, fibrous. Sitem from eight to twenty inches ligh, smooth and shining, tufted and branched, very leafy. Leares somerwhat rough, linear, sharply pointed. Sheaths smooth, striated, slightly swelled. Ligula oblong, obtuse, mostly torn. Inflorescence densely spicate, slightly tapering at each end, from two to three inches long, often enreloped at the base with the sheath of the upper leaf. Glumes redgeshaped, swelling upwards, rough, with short pointed tubercles, terminated with a short rigid awn. Glumelles unequal, ribbed, and somewhat downy. Anther's short. Stigmas capillary. Seed small, brown, cylindrical.

Habitat.-Rare. In dry elerated fields in Bedfordshire, Gloucester. shire, and Cambridgeshire.

Annual; flowering in July.

This plant, unknown to Linnæus, is the Phala'ris as'per of Retzius, Willdenow, and the French Botanists. E. Bot.

4. P. Boehme'ri, Schrad. (Fig. 105) purple stalked C'at'stail-yrass. Stem simple; panicle spiked, cylindrical ; glumes lanceolate, acuminate, rough, ciliated at the keel.

English Flora, rol. i. p. 78.-Lindley, Synopsis, p. 301.-Hooker, British Flora, vol. i. p. 35.-Sinclair, Hort. Gram. Woburn. p. 317.Phala'ris phle'oides, Linn. English Botany, t. 459.

Root fibrous. Stem simple, erect, sometimes bent below, from six to eighteen inches high, smooth, except near the top, frequently pur. plish. Leares short, rough, lanceolate, of a light-green or glaucous colour. Sheaths long, striated, barsh, scarcely inflated. Ligula obtuse. Inforescence a close silied panicle, from owe to two inclies long, purplish. Glumes iance late, strongls beeled, abruptly terminating in s point; acarcely an ner, the kcel eiliated with white harm. Glumellos 


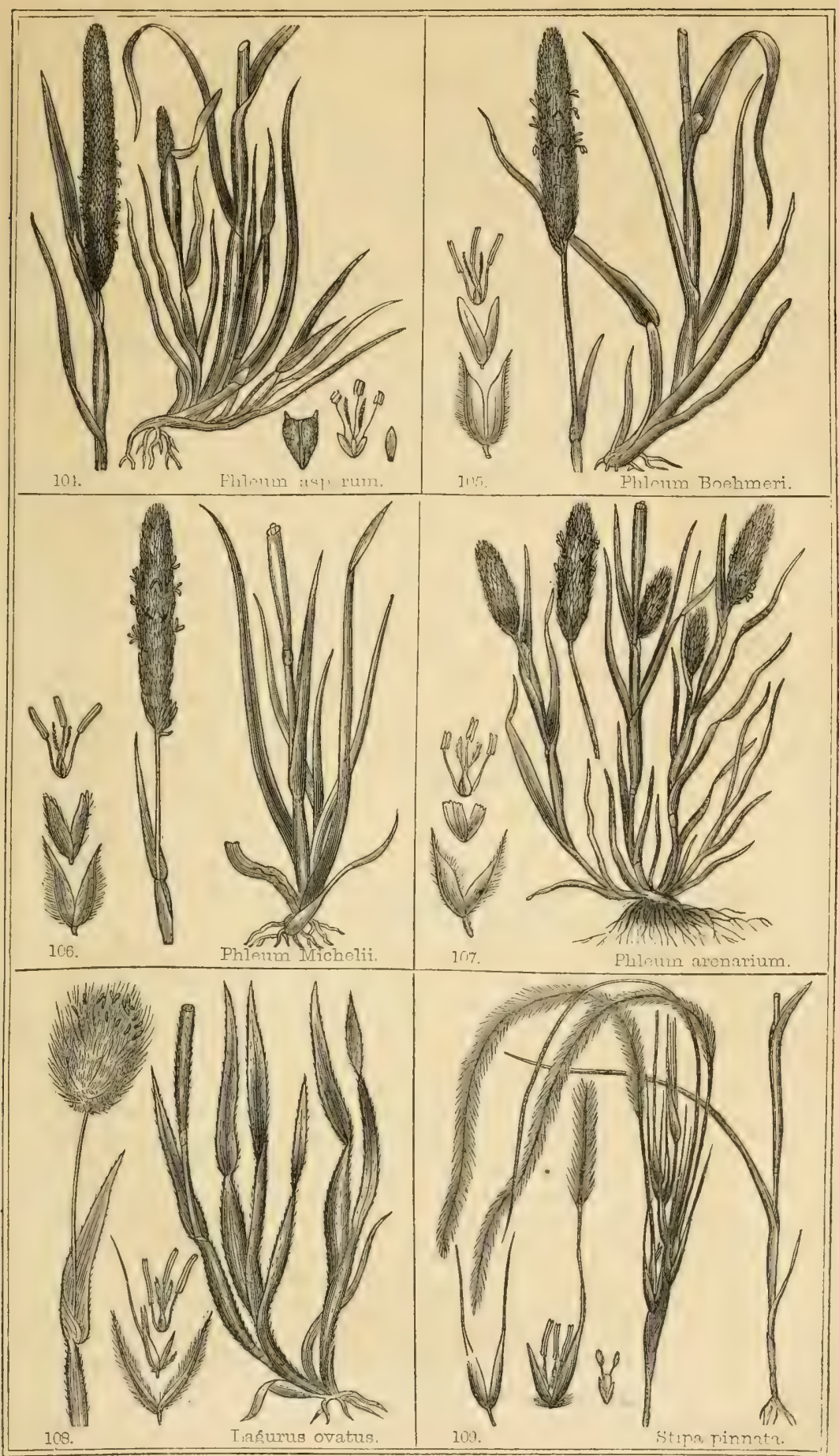



unequal, pale, obtuse, slightly downy, the outer one large t, three or five-ribbed. Styles short. Stigmas feathery.

IIabitat.-Rare. In sandy or chalk fields in Cambridgeshire and Norfolk.

Perennial ; flowering in July.

This grass growing naturally upon a sandy soil, is but little productive of herbage, and that of an inferior quality, rendering it of no ralue for the purposes of cultiration.

5. P. Michel'ii, Allioni. (Fig. 106.) Michelian C'at's-tail-grass. Stem erect; panicle spiked, cylindrical ; glumes lanceolate, taper-pointed, downy, ciliated at the keel.

English Botany, t. 2265.-English Flora, vol. i. p. 78.-Lindley, Synopsis, p. 301.-Hooker, British Flora, vol. i. p. 35.

Root fibrous. Stem erect, sereral arising from the same root, from twelve to eighteen inches high, smooth, leafy below. Leares plane, roughish, tapering at the point. Sheaths rather long, ufper ones slightly inflated. Ligula obtuse. Inforrescence a close spiked panicie, green, or frequently purplish, from one to three inches long. Glumes gradually tapering to a point, rough, with hairs, ribbed, the keel rigid at the point, strongly ciliated at the back. Glumelles unerual, obtuse, hairy, the outer one mostly five-ribbed, the inuer smaller, often cloven at the extremity. Styles short. Sligmas feathery.

Habitat.-Rare. On the rocky parts of the high mountains of Clure, Angusshire, Scotland.

Perennial ; flowering in July.

6. P. arena'rium, Linn. (Fig. 107.) sea Cat's-tail-grass. Stems several from the same root; panicle spiked, oblongo-ovate; glumes lanceolate acute, ciliated on the back, much longer than the abrupt glumella.

English Flora, vol. i. p. 79.-Hooker, British Flora, vol. i. p. 35.Phala'ris arena'ria, t. 222.-Achno'don arena'rius, Lindley, Synopsis, p. 300 .

Rnot of numerous long duwny and simple fibres. Stems nearlyerect, several from a single root, enveloped at the base and low er joints with thin membranous sheaths, branched and leafy, from three to six inches high. Leares linear, thin, somewhat glaucous, rough on the elges, upper ones shorter, with long, smooth, striated, slightly inflated sheaths. Ligula lanceolate, decurrent. Inflorescence spicate, dense, rigid, from half an inch to an inch long, nearly çlindrical, green. Glumes lanceolate, terminating in a short $a \mathrm{~m}$, strongly keeled and ciliated, a rib on each side, green between the ribs and keel, the rest of the valves thin, pale, membranous, hairy on the edee, rough towards the ayex, Gininelda about onethis the length of the glumes, inembrangus, ob. 
tuse, torn or crenated at the end, broad, ribbed with green, slightly hairy on the edge, as is also the narrower inner valre. Anther small, pale yellow. Style short. Seed orate, attenuated at each end. After flowering, the plant remains for some time, and becomes bleached, and not unfrequently may be observed blowing about on the loose sand.

Habitat.-On sandy sea-coasts, frequent; sometimes it is found in sandy situations inland, as "on Swaffham and Newmarliet heaths."

Annual; flowering from May to July.

\section{GENUS XXI. LAGU'RUS. LINN. Hare's-tail-grass,}

Gex. Char. Panicle spiked, ovate. Glumes of two equal, fringed valves, terminating in feathery awns. Glumella of tro unequal valves, external one the largest, with a dorsal awn, bifid at the apex; the lobes long, rough, awn-like.-Name from raros, a hare, and ovge, a tail; from the resemblance which the spize has to the hare's tail.

1. L. ova'tus, Linn. (Fig. 108.) Hare's-tail-grass. Glumella surrounded at the base externally with hairs, the internal valve with a small abortive feathery floret at its base.

Euglish Botany, t. 1334.-English Flora, vol. i. p. 16\%-Lindley, Symopsis, p. 299.-Hooker, British Flora, vol. i. p 35.

Root fibrous. Stem from six to eighteen inches high, erect, or somewhat bending at the base, branched, leafy, round, smooth, shining, waked abore, slender. Lectes broadly linear, acute, ribbed, downy on both sides. Sheaths striated, finely downy, upper one long, inflated in the upper part. Ligula oblong, abrupt, striated, embracing the stem. Inflorescence spicate, orate, pale, remarkably soft and woolly, with numerous long protruding awns. Glumes equal, thin, membranous, spreading, single-ribbel, and, as well as its awn, fringed with long silky hairs; frequently a number of them, surrounding the base of the spike, are empty. Glumella on a short pedicle, of two mequal ralres: the outer one with a geniculated awn, twisted in the lower part, tapering in the upper, and arising from about the middle of the valve; the inner one smaller, awnless, having at its base a small, fnely fringed, abortire floret. Anthers yellow. Style short. Stigmas feathery. Seed oblong, loose in the unchanged glumella.

Habitat.-Very rare. Sandy fields near the sea, in Guernsey.

Annual; flowering in Junc.

This is one of our most beautiful aud ornamental grasses, "the ouly kuown species of the genus," and well wortlyy a place in the flowergarden; it would also form a very pretty addition to the feathery awns of the following and other epceies in decorations during the wintes trionthis: 


\section{GENUS XXII. STI'PA. LINs. Feather-grass.}

Gen. Crar. Panicle erect, simple, or branched. Glumes of two nearly equal valves, longer than the glumella. Glumella of two involute valres, the external one bearing from its apex a long twisted awn, jointed at the base, and finally separating at the joint.-Name from $\sigma \tau \nu \pi n$, silky; from the glossy silk-like appearance of the panicle.

1. S. penna'ta, Linn. (Fig. 109.) common Feather-grass. Stems erect, several from the same root, leaves rigid, narrow, involute, striated, awn very long, feathery.

English Botany, t. 1356.-English Flora, vol. i. p. 162.-Lindley, Synopsis, p. 302.-Hooker, British Flora, vol. i. p. 36.-Sinclair, Hort. Gram. Woburn. p. 282.

Root fibrous, bearing several strms from one to two feet high, erect. Leaves very numerous, long, very narrow, rough, the edges so closely rolled inwarts as to become setaceous, dark-green. Sheaths very long, and striated, especially the upper ones, which are dilated, and envelope the panicle when young, but when in flower it rises above it. Ligula oblong, obtuse. Inflorescence of few flowers. Glumes lanceolate, thin, acutely pointed; frequently by cultivation they are lengthened out into a long, fine, slightly feathery awn. Glumella of two valves, nearly of equal lengths, the extcrnal one largest, involute, and terminating in a jointed awn, about a foot long, twisted at the lower part, elegantly feathery in the upper, surrounded at the base with numerous short rigid bristles, pointing upwards; the inner much narrower, awnless, involute at the edges. Glumellules of two linear lanceolate scales. Anthers linear. Stigmas feathery. Seed pointed at each end, enve. loped by the hardened glumella.

Habitat. - A very doubtful native; said to have heen found, in Dillenius's time, in a little vale called Long Sleadale, Westmoreland.

Perennial; flowering in June.

\section{GENUS XXIII. POLYPO'GON. DEsFont. Beard-grass.}

Gen. Char. Panicle contracted, somewhat spiked. Glumes of two equal awned valves. Glumella of two unequal valves, smaller than the glumes, the outer largest, ohtuse, awned at the extremity. Name from $\pi \circ \lambda \nu \varsigma$, many, and $\pi \omega y \omega \nu$, a beard ; from the bearded appearance of the panicle.

1. P. Monspelien'sis, Desf. (Fig. 110.) annual Beard-grass. Awn rough, thrice as long as the rough hairy valves of the glumes, root fibrous, annual. 
English Flora, vol. i. p. 86.-Lindley, Synopsis, p. 302.-Hooker, British Flora, vol. i. p. 36.-Agros'tis pani'cea, English Botany, t. 1704.

Root fibrous, branched. Stems sereral from the same root, erect, about a foot high, smooth, leafy in the lower part. Leares rather short, especially the upper ones, acute, flat, striated, the margins and ribs rough. Sheaths smooth, striated, the upper one slightly inflated. $L i$ gula long, obtuse, ribbed, frequently torn. Inflorescence from one to two inches long, lobed, pale and silky from the long shining awns. Glumes very sinall, equal, shining from the white silky hairs with which it is more or less clothed : the outer valve cleft at the extremity, the awn arising from between the lobes; the inner scarcely cleft, the awn from the apex. Glumella much smaller than the glumes, external one the largest, bifid, with a short rough awn from between the lobes; internal smaller, awnless. Anthers small, as are also the styles and stigmas.

Habitat.-Rare. In moist pastures near the sea, in Hampshire and Essex; near Cley, Norfolk; Guernsey.

Annual; flowering from July to August.

2. P. littora'lis, Sm. (Fig. 111.) perennial Beard-grass. Awn rough, about the length of the somewhat acute valves of the glumes; root perennial, with creeping underground stems.

English Flora, vol. i. p. 86.-Lindley, Synopsis, p. 902.-Hooker, British Flora, vol. i. p. 36.-Agros'tis littora'lis, English Botany, t. 1251.

Root with branched underground stems. Stems branched, smooth, procumbent, and bent at the joint, the lower ones sending out fibrous radicles, erect in the upper part. Leaves striated, rough on the edges, and also on both sides. Sheaths smooth, striated, scarcely inflated. Ligula oblong, striated, decurrent. Inflorescences two or more inches long, lobed, shining, purplish, dense, from the numerous small crowded florets. Glumes longer, more acuminated, less hairy, awn much shorter, than in the foregoing species: the outer valve is cleft at the extremity, with the awn arising from between the lobes; the inner tapering into its terminal awn. Glumella shorter than the glumes: outer valve bifid at the apex, with a short rough awn arising from hetween the teeth; the inner awnless. Styles short. Stigmas feathery. Seed small, orate, enveloped in the glumella.

Habitat.-Rare. In muddy salt marshes, near Cley, Norfolk; in Fissex; and near Woolwich.

Perennial; flowering in July and August.

This species "was long supposed peculiar to England, but it is now found in Germany."-Hooker. It is a rery distinct species, formerly referred to the genus Agrostis. 



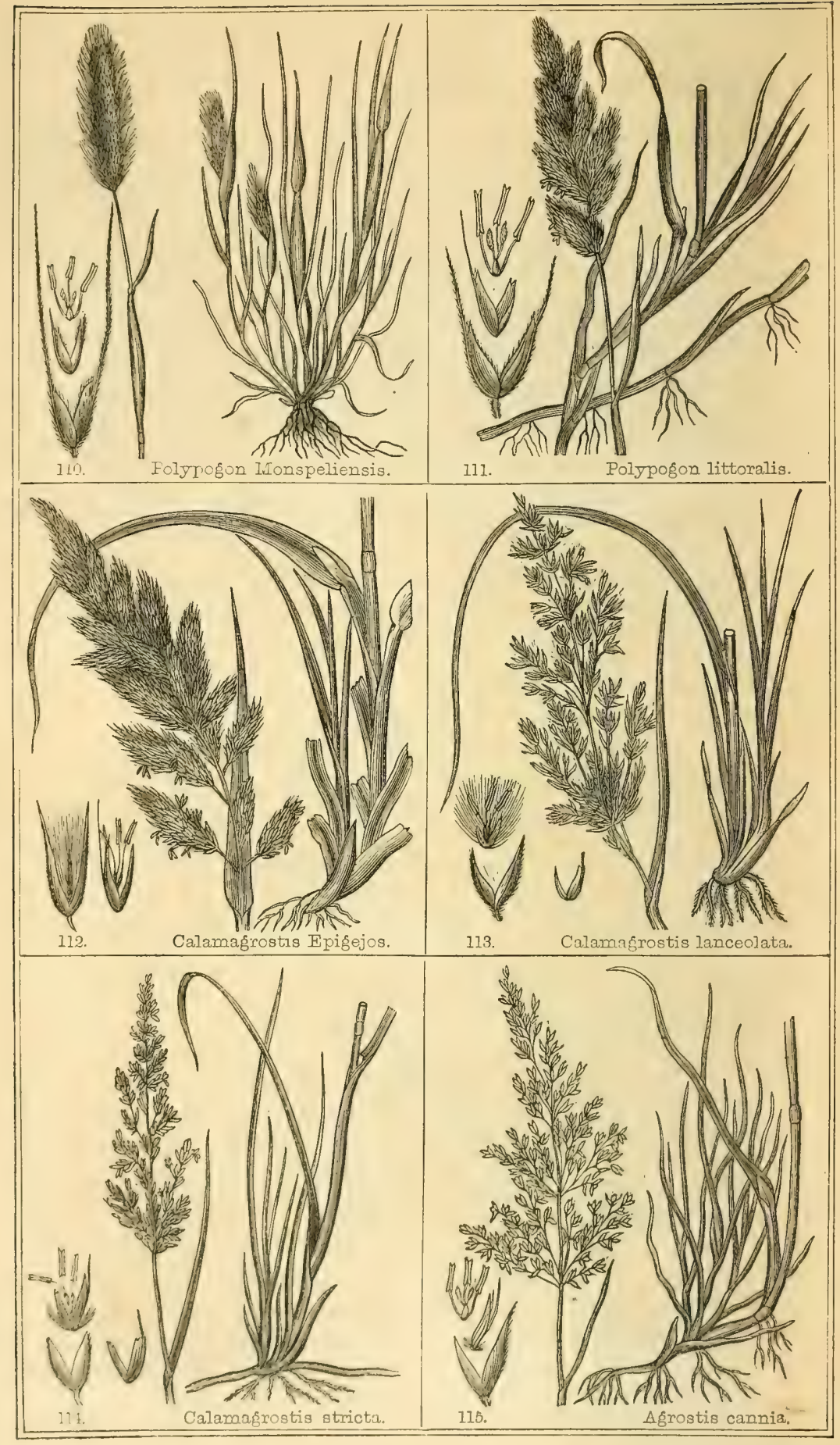


GENUS XXIV. CALAIIGROSTIS. Adans. Small Peed.

Gen. Char, Panicle loose. Glumes two, louger than the glumelles. Glumelles of two unequal valves, surrounded with hairs at the base, the outer valve awned beneath the bifid apex.-Name from

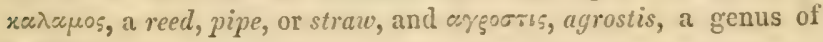
grasses.

1. C. Epige'jos, Roth. (Fig. 112.) small Wood-reed. Panicle erect, close; flowers crowded, unilateral; glumes subulate, their keel rough; awn of the external valre of the glumelles about as long as the hairs and glumes.

Lindley, Synopsis, p. 304.-Hooker, British Flora, vol. i. p. 36.Arun'do epige'jos, Limn. Enghish Botauy, t. 103.-Euglish Flora, rol.i. p. 169 .

Root with creeping underground stems. Stem from four to six feet high, slender, finely striated, smooth in the lower part, yughish in the upper, leafy, frequently branched in the lower part. Leaves linear lanceolate, with a long narrow tapering point, roughish, especially beneatl, glaucous. Sheaths close, striated, roughish, particularly the upper one. Ligula lanceolate, striated. Inflorescence an erect close panicle, from six to ten inches long; its branches rough, almost spiny, spreading when in flow er; the spikelets nunerous, crow ded, turned to one side. Glumes nearly equal, long and narrow, purplish, rough on the keel. Glumelles unequal, thin, and membranous; external valve the largest, about half the length of the glumes, having two marginal ribs and a dorsal one, which teminates between the bifid apex in a roughish aun, nearly as long as the glumes; the inner valve smaller, entire, or bifid, with a single dorsal rib; surounded at the base externally by a tuft of soft, shiniug, silk-like hairs, which are at first shorter than the glumes, hut elongate as the seed ripens, and at length hear it away. The seed is small, attenuated at each end. Stigmas long; united at the base, feathery. Anthers pale yellow.

Habitat.-In moist slady situations. Dalrymple Food, Ayr, Sc tland-Mr. Goldie. Near Roche Abbey, Torkshire-R. D. But most frequent in the South, as about London, Norwich, and Kent.

Perennial; flowering in July.

2. C. lan'ceolata, Roth. (Fig. 113.) purple-flowered Small-reed. Panicle erect, loose; glumes lanceolate, their keel smooth; external valve of the glumelles shorter than the glumes and hairs.

Lindley, Synopsis, p. 304.-Hooker, British Flora, Fol. i. p. 37.Arun'do Calamagros'tis, Linn. English Botany, t. 2159.-English Flora, vol. i. p. 170.

Root fibrous, woolly, a much smaller and slenderer plant thin the last. Stem from three to four feet ligh, smooth, scarcely striated. vol, I. 
Leaves long, narrow, the edges incurved, rough on the under side, the upper more or less scattered with hairs. Sheaths long, finely striated, close, roughish on some plants. Ligula oblong, obtuse, torn, and generally decurrent. Inflorescence an erect spreading panicle, from three to six inches long; its branches slender, rough. Spikelets not so crowded as in the last, more open and spreading every way. Glumes lanceolate, a shining purple, green at the base, keel smooth; the whole valves, particularly in the upper part of the panicle, are hairy, while those in the lower part are quite smooth. Glumelles thin, membranous, unequal; external valve the largest, abont half as long as the glumes, notched or torn at the extremity, with two or four lateral ribs and a keel, terminating in a very short rough awn; inner valve notched at the extremity, surrounded with hairs at the base, which are shorter than the glumes.

Habitat.-In moist woods and fenny situations. Lincolnshire, Cambridgeshire, Norfolk, \&c. Not uncommon.

Perennial; flowering in June and July.

3. C. stric'ta, Lindl. (Fig. 114.) narrow Small-reed. Panicle erect; glunes broadly lanceolate acute, rough on the keel; about the same length as the glumelles; awn not extending beyond them; lairs about half as long; inner value with an abortive hairy floret at its base.

Lindley, Synopsis, p. 304.-Hooker, British Flora, vol. i. p. 37.Arun'do stric'ta, English Botany, t. 2160.-English Flora, vol. i. p. 173.

Root with creeping underground stems. Stem about two feet high; slender, rough, with fine erect teeth, especially in the upper part; striated, branched, and leafy below; the lower joints putting out numerous fibrous roots. Leaves long, narrow, finely pointed; striated rough, more so on the upper than the lower surface. Sheaths close, finely striated, somewhat rough. Ligula short, abrupt, notched or torn, those of the upper leaves longest. Inflorescence an erect close panicle, except when in flower; it is from two to four inches long, the branches partly whorled very rough. Glumes a light brown colour, darker at the base, smooth or finely hairy, broadly lanceolate, frequently torn at the extremity; keel not very prominent and more or less rough, the external valve sometimes with two lateral ribs. Glumelles about the same length as the glumes, menibranous, brownish, surounded at their base with a tuft of glossy hairs, scarce half as long as the valve when in flower, but becoming longer when in sced; the external valve bifid at the extremity jagged, the edges inflexed from the two lateral roughish ribs, a roughish dorsal awn arises from below the middle and extends a little beyond the extremity; the inner value shorter than the outer, entire or slightly jarged at the extremity, with a solitary marginal rib on each side, and at the back is a channel, in which is embedded an abortive hairy awn-like valye about half its length. Styles distinct erect. Stigmas feathery. 
IIabitat.-In Scotland very rare.-White Mir Marsh, Forfar$M r . J . D$. Hooker; where it was first discovered by $\boldsymbol{M} r$. G. Don, "but it does not now exist there. Near Rescobie, Forfar,-T. Drummond." Perennial, flowering in June.

This species, it will be observed, in many respects is nearly allied to Ammo'phila arundina'cea, especially in the shortness of the hairs surrounding the base of the glumelles, and the ahortive hairy valve, a structure which we have not found in either of the other species of this genus, but which is constant in this, and remains unaltered after long cultivation.

\section{GENUS XXV. AGROS'TIS. LinN. Bent-grass.}

Gen. Cran. Panicle loose. Glumes two, unequal, longer than the glumelles. Glumelles two, unequal, the shorter valve largest, with or without an awn, the inner one sometimes absent.-Name from

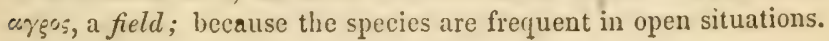

1. A. cani'na, Linn. (Fig. 115.) broun Bent-grass. Panicle spreading, its branches long, slender, rough; glumes lanceolate, unequal; keel rough; glumella of one valve, with an awn from below the middle; stem decumbent and rooting.

English Botany, t. 1856.-English Flora, vol. i. p. 90.-Hooker, British Flora, vol. i. p. 37.-Tricho'dium cani'num, Schrader, Lindley, Synopsis, p. 303.-Ayros'tis cani'na fascicula'ris, p. 279.-A. cani'na capil'laris, p. 300.-A. stric'ta, p. 274.-A. cani'na var. mu'tica, p. 341. Sinclair, Hort. Gram. Woburn.

Root tough and fibrons, putting up numerous tufts of stems, which are decumbent at the base, and taking root from the jointz, erect in the upper part, from one to three feet high; slender, smooth, faintly striated, leafy. Leaves more or less rough on hoth sides, short, narrow, the edges incurved, the radical ones generally so much so as to be setaceous, fleshy, and swollen at the base. Sheaths close, striated, smooth. Lingula lanceolate at length torn. Inflorescence, anl erect panicle, its branches slender, rough, unequally whorled, erect close, spreading only when in flower. Florets erect. Glumes lanceolate, rough on the keel, spreading shining purplish, sometimes green, or a pale yellowish colour; outer valve somewhat larger than the inner. Glumelles of one lanceolate pale membrauous valve, a little shorter than the inner valve of the glumes, eutire, with a dorsal jointed awn arising from the middle of the valve, and two, sometimes four lateral ribs. Smith and Leers have occasionally found a second ralve, but this we have not seen, nor yet has the accurate Dr. Hooker; sometimes at the base of the valve we have observed a few short silky hairs; the aun varies in length, sometimes it extends somo length beyond the glumes, at others it is mithin or scarcely to be 
seein, and occasionally absent, all which varieties may sometimes be seen in the same plant. Anthers yellow. Seed minute. Stigmas feathery.

Habitat.-Heaths, moors, and waste places frequent.

Perennial; flowering in June and July.

This is an extremely sportive species, and from the absence of one of the valves of the glumella, (which from the above authorities, to which we may add that of Greville, in Flora Edinensis, p. 16) it appears by no means a constant character; and upon the value of this character, Snith has remarked, that "such a partial deficiency could hardly afford a specifie, much less a generic, distinction." From this circumstance, however, Schrader has constructed his genus Trichodium, and it is adopted by Lindley. This grass abounds in hilly and poor pastures; the leaves are more or less setaceous, depending upon the situation of their growth being dry or otherwise : in dry situations the root leaves are remarkably so, but become thick and fleshy at the base; by this provision there is formed, as it were, a reservoir of nutriment, and the plants are enabled to sustain themselves during long continued droughts, which often prevail in elerated situations. It is of no agricultural utility, affording but little nutriment, and one which the farmer may consider as a weed, and an indication that his land is greatly capable of improvement by suitable tillage.

2. A. seta'cea, Curtis, (Fig. 116.) bristle-leaved Bent-grass. Panicle erect, its branches short and close; glumes lanceolate, slightly unequal, keel rough; glumelles unequal, outer valve with a long jointed and twisted awn from near the base, inner minute; radical leaves setaceous.

English Botany, t. 1168.-English Flora, rol. i. p. 91.-Hooker, British Flora, vol, i. p. 37.-Tricho'dium seta'ceum, Ræm. and Sch. -Lindley, Synopsis, p. 303.

Root with strong downy fibres. Stems from six to twelve inches, high, nearly erect, slender, smooth or slightly rough, mostly bearing two short leares. Leaves, a pale glaucous green, roughish or downy; the radical ones are erect, almost round, bristle shaped, (setaceous) from the rolling in of the edges, those of the stem broader, much shorter and having longsmooth sheaths. Ligula thin lanceolate, mostly torn. Inflorescence an erect, short branched panicle, close, except when in flower it is spreading. Glumes lanceolate, pale purplish, tapering at the extremity, rough on the licel and edges, and slightly downy all over, outer valye somewhat longer thin the inner. Glumelles very unequal, white thin and membranous, the outer one lanceolate obtuse, having four green merves, the two lateral ones of which terminate in projecting point; the rongh jointed and twisted awn arises from the base of the ralre, and is aljout twice as long; the inner valve 


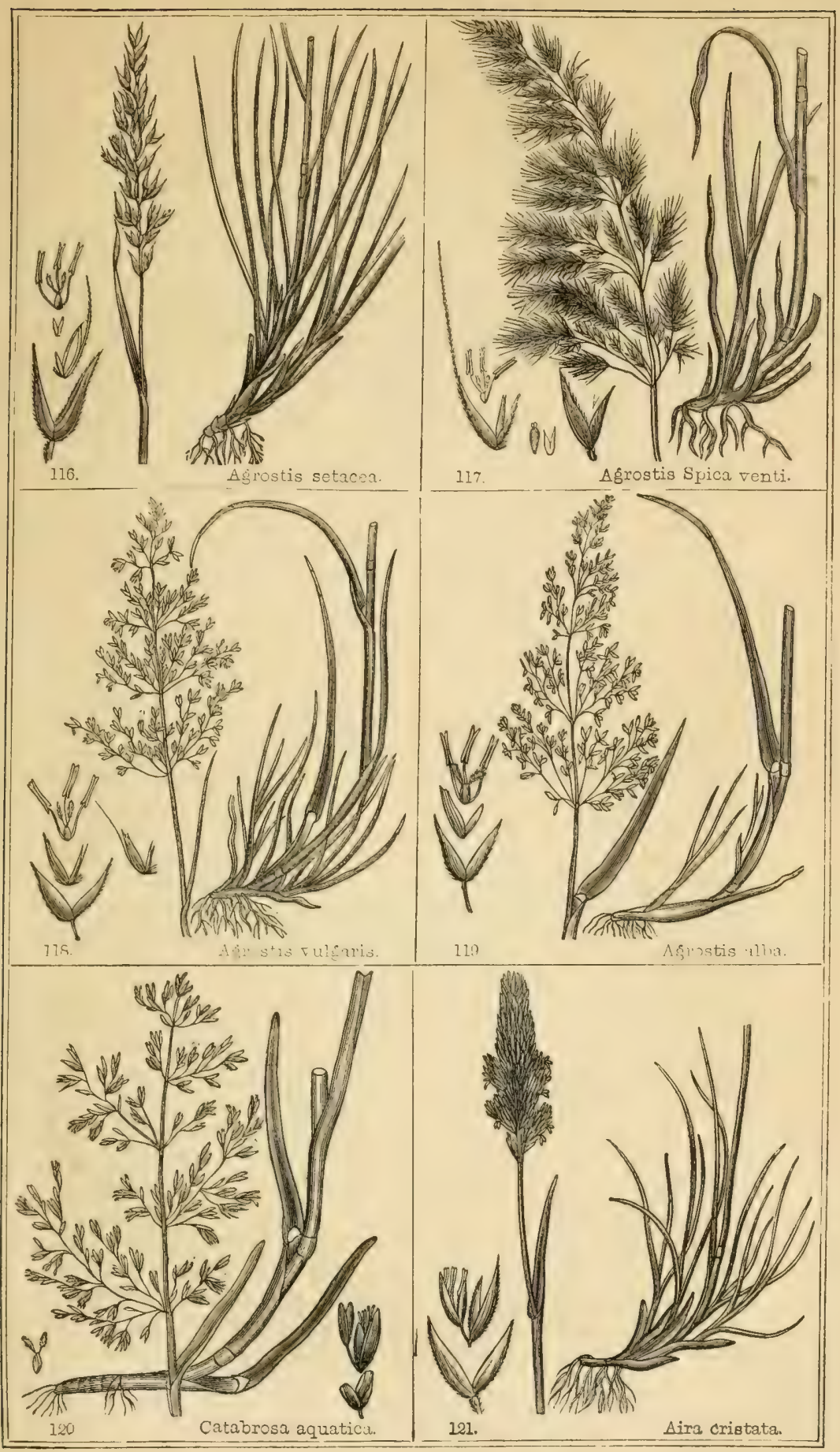



is rery small with a few white hairs at its base on each side. Anther purplish. Styles distinct.

Habitat.-A very lucal grass, almost confined to the south and south-west parts of England ; as Hampshire, Deronshire, and Cornwall, perennial flowering in June and July.

This grass, it is observed by Dr. Hooker, " is now ascertained to be plentiful in Portugal, the native county of Eri'ca cili'aris and Rese'da fruticulo'sa, which MIr. Tozer has also had the good fortune to find truly wild, in Cornwall; affording an additional proof, if any were needed, of the great mildness of the climate in that distriet of England, and of its proximity in that respect to the more southern parts of Europe."

3. A. spi'ca ren'ti, Limn. (Fig. 117.) silky Bent-grass. Panicle loosely spreading; glumes lanceolate, unequal, rough on the keel; glumella of two unequal valves, the external acutely bifid, and between the lobes a long straight rough awn; the inner one smaller, with the rudiment of a second floret at its base.

English Botany, t. 951.-English Flora, vol. i. p. 89.-Hooker, British Flora, rol. i. p. 38.-Anemagros'tis spi'ca ren'ti, Lindley, Synopsis, p. 304 .

Root fibrous. Stems sometimes numerous from the same root, from one to three feet high, erect, repeatedly jointed, and frequently bent at the base, leaff, smooth. Leares linear, striated, slightly downy on the upper side, rough on the under, upper ones short, mostly involute. Sheaths long, striated, smooth. Ligula long, lanceolate, frequently torn. Inflorescence a loose, ample, repeated branched panicle, gracefully leaning on one side, and elegantly waving its glossy silk-like florets with every passing breeze ; its branches are very slender, repeatedly subdivided, each terminater? with a lanceolate floret. The glumes spreading when in flower; outer one the longest, smooth except on the keel, frequently tinged with purple; the inner one shorter, of a thinner texture, except the ronghish keel. Glumella of two valres, the outer largest, hairy at the base, rough towards the apex, terminating in two rather long acute lobes, haring between them a long, straight, rough, shining awn; the inner smaller, enwrapped in the external valve, and bearing at its base the rudiment of a second floret. Styles feathery. Seed rery small, ovate, smooth.

Habitat.-Rare. In sandy fields which are occasionally flooded. In several parts of Nurfolk, near Kingston-unon-Thames, and Camberwell; Warrington, Lancashire.

Annual; flowering in June and July.

This beautiful grass, with its ample and gracefully spreading panitle, does not appear to have been applied to any useful or agricultural purposes. 
4. A. sulga'ris, Withering, (Fig. 118.) fine Bent-grass. Panile loose, its branches smoothish, direrging; glumes nearly equal; glumelles with the onter valre three-ribbed; ligula abrupt, extremely short.

English Botany, t. 1671.-Fnglish Flora, rol. i. p. 92.-Lindley, Synopsis, p. 303.-Hooker, British Flora, vol. i. p. 38.-Sinclair, Hort. Gram. Woburn. p. 269.

B. arista'ta, outer valre of the glumelles bearing an awn.

Agros'tis cani'na, Withering.-A. vulga'ris cani'na, Sinclair, Hort. Gram. Woburn. p. 271.

$\gamma \cdot$ pumil' $a$, whole plant much smaller', scarcely three inches high.Lightfoot, Scot. p. 1081. fig. in tille-page.

Root tufted, putting out roots and branches from the lower joints. Stems mostly numerous, ascending, from one to two feet high, leafy, slender, finely striated, smooth below, roughish abore. Leaves linear, tapering at the point, rough. Sheaths long, close, striated, smooth. Ligula extremely short and truncate, the upper one the longest, but never so long as in the following species. Inflorescence a loose branched panicle, the rachis nearly smooth, the branchlets more or less hispid, slender, capillary. Glumes lanceolate, nearly equal, shining, mostly purple, smooth except on the keel. Glumelles of two unequal pale membranous ralres; the outer scarcely as long as the glumes, threenerred, which terminate in three teeth, awnless, or with a dorsal awn of uncertain length arising from beneath the middle of the valre when it is the rariety $\beta$., but not unfrequently we have seen on the same specimen some florets with awns and others without; inner valve about half the size, two-nerved, bifid. Dr. Hooker mentions his having specimens of this species bearing the rudiment of a second flower upon a rather long footstalk, in the same calyz. It is said to be found in a viviparous state in moist shady situations. Anthers searcely project beyond the glumes, Styles separate. Stigmas feathery.

Habitat.-In pastures, and dry waste places, rery common.

Perennial; flowering from July to August.

The value of this grass for agricultural purposes is very trifling; its best recommendation is its early produce, but this is far from being abundaut, and the nutritire matter which it contains is inconsiderable. It thrives best on a sandy soil.

5. A. al'ba, Linn. (Fig. 119.) Massh Bent-grass, Pauicle loose, its branches rough; glumelles with the outer valve fire-ribbed; ligula oblong.

English Botany, t. 1189.-Englislı Flora, rol. i. p. 93.-Lindley, Synopsis, p. 303.-Hooker, British Flora, vol. i. p. 39.-A. répens, p. 344 ; A. stolonif'era arista'ta, p. 345 ; A. stolonif'era angustifolia, p. 316; A. palus'tris, p. 348 ; A. stulunif'cra latifo'lia, p. 225 , is the celebrated Fiorin gta6s, Sinclair, UIort. Gram. Woburn. p. 342. 
Root fibrous. Stcms smooth, frequently long, decumbent and spreading in the lower part, putting out roots and numerous stems from, the joints. Leaves flat, broader, rougher, and stouter than in the last species. Sheaths striated, smooth, or roughish, particularly in the upper parts, Ligula oblong, obtuse, mostly torn, ribbed, smooth, or minutely downy. By this character all the varieties are essentially distinguished from the above. Inflorescence, a loose branched panicle, somew hat contracted from two to six inches long; the rachis smooth in the lower part, the branches rough and angular. Glumes nearly equal, lanceolate smooth, except on the keel, shining, green or purplish. Glumelles unequal, pale, thin, membranous, the outer valve largest lanceolate five nerred, which terminate in more or less distinct teeth, the inner much smaller, two nerved, and bificl. Dr. Hooker, who has bestowed much labour upon this grass, remarks that "in some there is a short awn at the base of the onter valve of the corolla (glumella), this constitutes the $A$. connpressa, Willdenow, and sometimes the flowers are viviparous, which is the $A$. sylratica, Linn. I believe all are now agreed that $A$. stolonifera of authors is the same as $A$. alba. The famous Fiorin grass of Dr. Richardson and the Irish agriculturists is what I have called $A$. alba, as I ascertained by the aid of specimens gathered in the company of Dr. Richardson himself. I know not of any British awnless Agrostides, which may not be reduced either to A. vulyaris or A. alba. The two species are indeed very closely allied."

Habitat.--In dry pastures, road sides, and waste places, abundant.

Perennial, flowering from June to August.

The utility of this grass for the purposes of cultivation, is the early period at which it furnishes herbage in the spring; it also is one of the latest in autumn: the latter property renders it one of the most raluable grasses in permanent pastures, a part of which it ought always to form, though from the spreading habit of the plant, which has been compared to that of the strawberry, it should not constitute so large a proportion of the mixture as some other species. This grass is not so advantageously cultirated by itself for the purpose of pasturing, as it is making hay, on account of the peculiar maimer of its growth; and for when in this (way cultivated, it is necessary, to obtain the full amount of profit, that the plants should be kept free from weeds; and as its spreading roots in a considerable degree exhaust the surface of the soil, a top dressing of manure will be found necessary. This grass, which was found from seven to ten feet long, constituted a part of the hay grown in the neighbourhood of Salisbury, an account of which is published in the Linnæan Transactions: two acres and a half of land, according to this account, produced the astonishing quantity of ten tons of hay in one ycar. The creeping under-ground stems contain much nutritions matter and sugar, from which circumstance, in some parts of France and Italy, they are collected as food for horses, and from the presence of the saccharine matter it has been proposed to ferment them, and brew table.beer. 
GENUS XXVI. CATABRo'SA. Beauvis. Whorl-grass.

Gen. Char. Panicle loose. Spikelets two or three-flowered, sometimes with a fourth imperfect floret. Glumes unequal, membra. nous, obtuse, much shorter than the florets. Glumelles nearly equal, ribbed, awnless, the extremity truncated, erose-Name from $x a \tau * \sigma_{\rho} \omega \sigma t s$, a gnawing; because of the erose extremity of the valves of the glumelles.

1. C. aquat'ica, Beauv. (Fig. 120.) Water Whorl-grass. Panicle with whorled spreading branches; leares broadly linear, flat, obtuse.

Lindley, Synopsis, p. 306.-Hooker, British Flora, vol. i. p. 39.Air'a aquat'ica, Linn. English Botany, t. 155\%.-English Flora, vol. i. p. 102.-Sinclair, Hort. Gram. Woburn. p. 351.

Root of long white whirled fibres. Floating stems frequently long and numerous. Flowering stems bent and branched at the base, and rising from twelve to eighteen inches abore the water, leafy, smooth and striated. Leares linear, short, broad, flat, obtuse, smooth, striated, of:en floating on the surface of the water, a deep pleasant green. Sheaths loose, smooth, striated. Ligula broad acute. Inflorescence a loose branched panicle, erect, large smooth. Glumes very unequal, thin, smooth, purplish, ribbed, the obtuse outer valre irregularly notched, the inner about half as long. Florets much longer than the glumes, the upper ones on short stalks (pedunculated), the valves equal, brownish green, a thickish texture, with strong green ribs, white and membranous, at the blunt erose extremity. Anthers yellow. Stigmas short, feathery. Seed small pale.

Habitat.-Drains, pools and on the banks of rivers.

Perennial flowering in May and June.

A very variable plant in size, it has been found with decumbent stems, by Mr. Neill, near Edinburgh, "about two yards in length," and Mr. Wilson, "finds in the wet sand of the north shore at Liverpool a variety not two inches high, each calyx (gluma) containing in general but one perfect floret." It will not long flourish, except in a wet muddy situation, consequently it is one that cannot be applied to any agricultural purpose.

GENUS XXVII. AI'RA. Linn. Hair-grass.

Ger. Char. Panicle loose or close. Spikelets two flowered. Glumes unequal. Glumelles unequal, the outer valve mostly awned neur the base. Fruit free. Name from abgw, tares, darnel, a name anciently applied by the Greeks to the Lolium temulentum, aud signifying dangerous or deadly; but that is a plant very dif- 



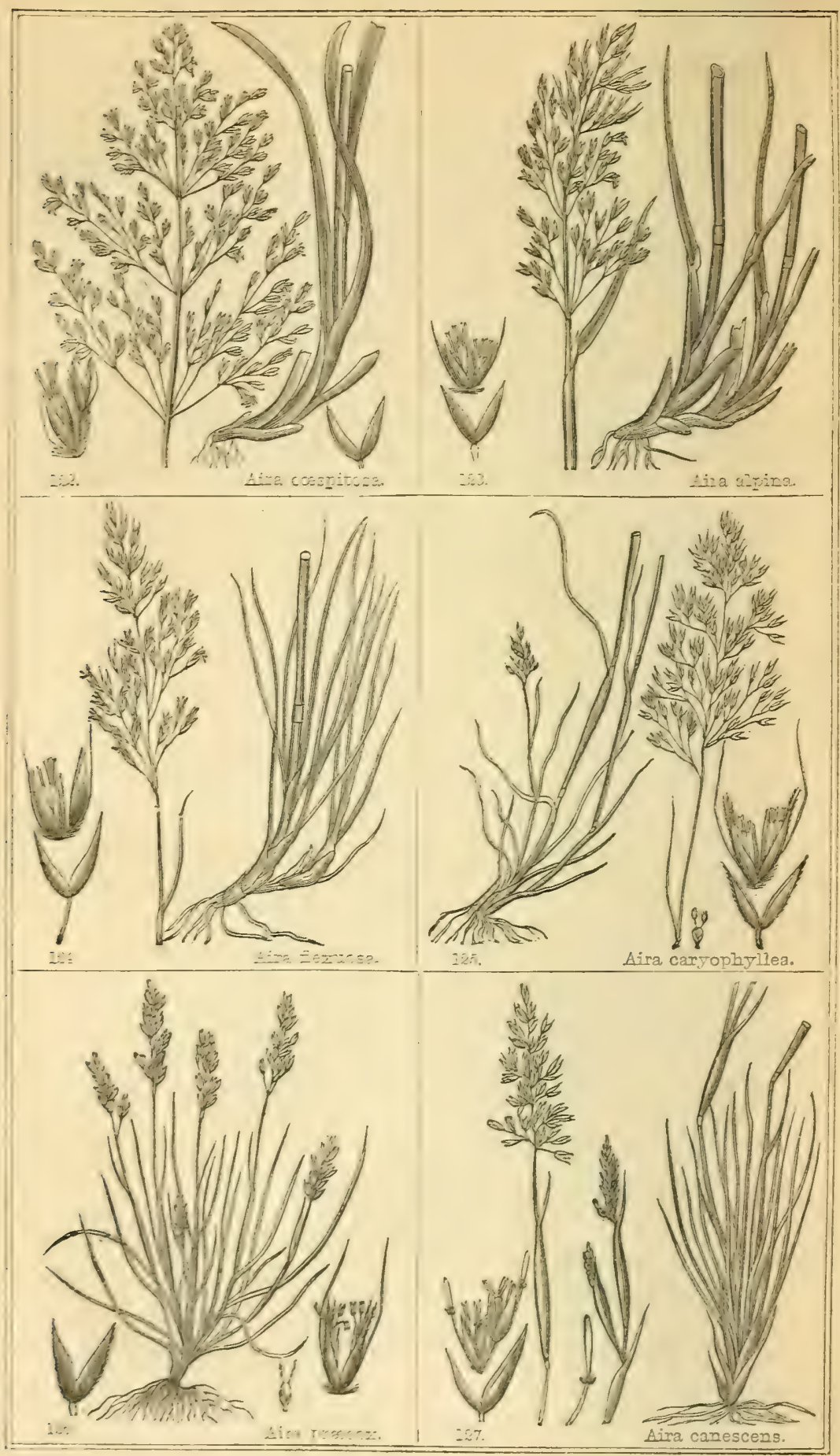


ferent to the present genu's, and to which there does not appear any obvious reference.

\section{* Panicle close. Glumella awnless.}

1. A. crista'ia, Linn. (Fig. 121.) crested Hair-grass. Panicle spiked, florets longer than the glumes, leaves hairy.

English Botany, t. 648.-English Flora, vol. i. p. 101.-Hooker, British Flora, vol. i. p. 39.-Sinclair, Hort. Gram. Woburn. p. 304.Airoch'loa crista'ta, Lindley, Synopsis, p. 207.

Plant forming close tufts. Root fibrous, downy. Stem from six to twelve inches ligh, simple, bent in the lower part, erect in the upper, and thickly clothed with short white down, leafy and smooth below. Leaves linear, glaucous, smooth or downy. Sheaths close, striated, more or less downy, upper ones long. Ligula very short, crenate fringed. Inflorescence a close, lobed, spiked panicle, from one to three inches long, its branches shorter than the glumes. Glumes unequal, lanceolate, acute, smooth or slightly downy, pale, thin, compressed, with a roughish keel. The lower floret sessile, the upper on a short stalk, which is smooth or downy. Glumelles equal; the outer one pale green, with membranous edges, and mostly three-ribbed; the inner. white, roughish, thin, membranous, with two ribs, which terminate in acute points, between which it is cleft, and from them the edges of the valve fold inwards. Anthers yellow. Stigmas feathery.

Habitat.-In dry, chiefly elevated pastures, most frequent in the north, sometimes on old walls, not very commou.

Perennial ; flowering from June to August.

'This grass thrives well upon sandy land, or even upon stronger lands of a clayey nature, but is not much relished by cattle, and is mostly avoided by them when other grasses can be obtained: this is probably owing to the softness of the leaves, independent of which, however, it does not appear to possess any advantage over many of the other grasses, which the cattle prefcr.

\section{** Panicleloose. Glumelles awned.}

2. A. cospito'sa, Linn. (Fig. 122.) turfy Hair-grass. Panicle spreading, its branches slender, roughish; florets rather longer than the glumes, hairy at the base, the outer valve with a straight awn about as long as itself, and proceeding from near the base; leaves long.

English Botany, t. 1453.-English Flora, vol. i. p. 102.-Hooker, British Flora, vol. i. p. 40.-Sinclair, Hort. Gram. Woburn. p. 304.Deschamp'sia caspito'sa, Iindley, Synopsis, p. 309.

Plant forming large thick tufts. Root fibrous, long, tough. Stems from two to four feet high, erect, smooth and shining, except at the top, leafy, particularly in the lower part. Leares very long, narrow, 
linear, flat, ribbed, rough on the edges and upper side, with very sharp teeth pointing towards the extremity, smooth leneath. Sheaths close, short, striated, smooth. Ligula lanceolate, three ribbed, smooth, often torn. Inflorescence a large slender widely spreading panicle, its branches fine, liair-like, roughish, and angular. Glumes unequal, lanceolate, silvery.grey, green or purplish, pale and membranous on the edges, the outer valve smallest, with a roughish keel, the inner with a roughish keel and two lateral ribs. Florets rather longer than the glumes, with a few white silky hairs at the base, the lower one sessile, the upper on a short hairy stalk, the valves ovate, obtuse, erose, the outer generally with five short teeth, and arising from near the baso is a straight roughish awn about as long as the valve, the inner bifid; at the base of the inner valve of the upper floret, there is generally a short hairy stalk, on abortive floret. Anthers yellow or purplish. Stigmas short, feathery.

It is sometimes found with viviparous flowers.

Habitat.-In moorish and shady situations, the border's of roods, marshes, \&c., common.

Perennial ; flowering from June to August.

The coarseness of this grass, and the small proportion of nutritive matter that it contains, renders it totally unfit for any agricultural purposes; cattle never eat it, even when in a young state, but from great necessity. It forms dense unsightly tufts in pastures, which are called by farmers, hassocks, bulls' faces, \&c., are difficult to be extirpated, and can only be retarded in their growth by early and frequent mowing; to remove them entirely, the only effectual mode, according to Sinclair, is to first pare and burn the surface of the land, and by making proper drains, to correct, as much as possible, the tenacious nature of the soil; in this case surface drains are as necessary as those termed hollow.

3. A. alpina, Linn. (Fig. 123.) smooth alpine Hair-grass. Panicle rather close, its branches smooth; florets as long as the glumes, hairy at the base, the outer valve with a straight awn proceeding. from about the middle, and extending a little beyond the extremity; leaves short.

English Flora, vol. i. p. 103.-Lindley, Synopsis, p. 308.-Hooker, British Flora, rol. i. p. 46.

Root fibrous. Stems from twelve to eighteen inches high, quite smooth, enveloped to the top in the sheaths. Leares short, linear, ribbed rough on the upper side, smooth beneath. The edges rolled so firmly inwards that they appear awl shaped. Sheaths long, smooth, striated. Ligula oblong, obtuse, mostly tom. Inflorescence an erect, rather small smooth branched panicle, much smaller and far less spreading than the last, except when in a viviparous state, which is mostly the case, then it is more drooping and spreading. Glume lanceclate, someivhat unequal, smooth. Florets two, surrounded at the 
base with a tuft of fine hairs, mostly sessile, the partial stalk of the upper one when present is rery short and quite smooth. Glumelles lancolate acute, grecnish, mostly enlarged into a bud. Awn arising from ahout the middle of the onter ralve, and extending a little beyond it.

Habitat.-Rare, on high mountains in Scotland and Wales.

Perennial; flowering in June and July.

4. A. flexuo'sa, Linu. (Fig. 124.) waved Hair-grass. Panicle loose, spreading when in flower ; florets as long as the glumes, hairy at the base; awn arising from near the base of the outer valve, and much longer, rough twisted and jointed; leaves bristle shaped.

English Botany, t. 1519.-English Flora, vol. i. p. 105.-Lindley, Synopsis, p. 398.-Hooker, British Flora, vol. i. p. 40.-Sinclair, Hort. Gram. Woburn. p. 279.

Root long and fibrous, sometimes woolly. Stem from one to two feet high, erect, slender, smooth, leafy below. Sheaths close, striated, roughish, upper ones rery long, the lower short. Ligula oblong acute, frequently torn. Leaves very narrow, bristle shaped, roughish, the lower long and numerous, the upper very slort. Inflorescence a loose branched panicle, erect, but spreading when in flower, its branches long, slender, hair like, waved, roughish, especially its ultimate divisions. Spikelets few. Glumes unequal, broally liuccolate, thin, membranous, smooth except on the keel, shining, of a yellowish copper colour, the outer one frequently ribbed. Florets about the length of the glumes, surrounded at the base with a tuft of shining white hairs, the upper oue on a short hairy stalk. Glumelles lanceolate, unequal, smooth, greenish copper-colour, with membranous edges; the outer valve with three slight rils, and a twisted jointed awn arising from near its base, and extending often considerably beyond the extremity ; inner valve bifid at the extremity, with two lateral roughish rihs, from which the edges are inflexed, and enwrap the lanceolate glumellules supporting its small brown seed. Anthers yellow or purplish. Stigmas feathery.

Habitat. - Waste sandy heaths, moors, and hilly situations, abundant.

Perenuial ; flowering in July and August.

For the purpose of cultivation, this grass possesses but little to recommend it. On its natural sandy or heathy soil it is most productive, and will be found to form a part of those grasses which are most advantageously sown for the improvement of such lands. Like many other mountainous plants, it is liable to great variation; depending upon the elevation, the ariduess, or humidity of the situation in which it has grown.

5. A. caryophyll'ea, Linn. (Fig. 125.) silvery Hair-grass. Panicle spreading; florets shorter than the glumes, scarcely hairy at the base; awn arising from below the middle of the outer valre; jointed, and about as long again; leaves bristle-shaped. 
English Butany, t. 812.-English Flora, rol, i. p. 100.-Lindley, Synopsis, p. 303.-Hooker, British Flora, vol. i. p. 40.

Root of many slender branched fibres. Stem from two to twelvo inches high, slender and shining, smooth and leafy on the lower part, roughish above. Leares few, short, slender, bristle-shaped, the upper o.xes very short, with long, rough, striated, slightly swelling, and some: t.mes purplish sheaths. Ligula lanceolate, embracing the stem, large compared to the size of the leares, the root leaves longest, soon withering. Inflorescence a loose sprending panicle, its branches fine, shining, and hair-like, smooth in the lower part, roughish towards the extremities. Spikelets small, a shining silvery grey, sometimes puiplish, not very numerous. Glumes nearly equal, lanceolate, longer than the florets, the edges white and jellucid, frequently uneren, green at the base, the keel mostly rough. Florets sessile, roughish, with minute shining points, and a few short glossy hairs at the base; external valve the largest, lanceolate, with a long narrow bifid point, and arising from near the base is a jointed dorsal awn, twisted in the lower part, roughish in the upper, and about as long again as the valve; the inner valve ciosely embraced by the inflexed edges of the outer, is thin, pale, and membranous. Anthers small, yellow. Stigmas feathery. Seed minute.

Habitat.-Sandy fields, heaths, and gravelly places, frequent.

Perennial; flowering in Jume and July,

This is an early grass, and greedily eaten by sheep; but, from tho small quantity of herhage which it produces, and the dry situations in which it delights to grow, it is soon withered up, and is consequently a comparatirely valueless pasture grass, as is also the following; and they do not possess any properties by which any advantage could be obtained by their cultivation.

6. A. pre'cox, Linn. (Fig. 126.) early Hair-grass. Panicle close, somewhat spiked; florets about as long as the glumes, scarcely hairy at the base; awn arising from below the middle of the outer valve, jointed, and about as long again; leaves bristle-shaped.

English Dotany, t. 1296.-Euglish Flura, vol. i. p. 106.-Lindley, Synopsis, p. 308.-Hooker, British Flora, vol. i. p. 41 .

Root of many slender branched fibres. Stem erect, from onc to four inches high, sercral from the same root, simple, slender, smooth and shining above, roughish about the joints, leafy in the lower part. Leaves few, short, narrow, blunt, bristle-shaped, the lower ones soon withering. Sheaths angulin, ribbed, mostly roughish, somewhat inflated. Ligula lanceolate, closely embracing the stem, very large. Inflorescence a shori, erect, close, somewhat lubed pavicle. Spikelels few, a pale silvcry green. Glumes efual, lanccolate, roughish, with minute points, the keel rough. Florets sessile, about as long as the glumes, surrounded at the base with a fow short white shining hairs, and rouglish towurds the extremity, wih shining points; the outer valve banceolate, with a long darrovy pule bitid point, and a dorsal am axising 
from below the middle, which is twisted in the lower part, jointed in the middle, and about as long again as the valve. Anthers small, pale yellow. Stigmas ieathery.

Habitat.-In similar situations to the last, but not so frequent.

Annual; flowering in May and June.

\section{*** Panicle contracted. Au'n club-shaped.}

7. A. canes'cens, Linn. (Fig. 127.) grey Hair-grass. Panicle rather dense; florets shorter than the glumes; awn club-shaped, arising from below the middle of the outer valve, the length of the glumes; leaves bristle-shaped.

English Botany, t. 1190.-English Flora, rol. i. p. 105.-Hooker, British Flora, rol. i. p. 41.-Coryneph'orus canes'cens, Beaur. Lindley, Synopsis, p. 307.

Root with long slender white fibres. Stem slender, from four to eight inches high, bent in the lower part, erect in the upper, where it is smooth and shining, below roughish, and thickly clothed with short, rigid, bristle-shaped, roughish, glancous leares, the upper ones very short, with long, striated, inflater, and roughish sheaths. Ligula lanceolate, mostly toru, and decurrent. Inflorescence a close erect pauicle, about an inch long, spreading when in flower, its branches short and roughish. Spikelets small, green or purplish. Glumes somewhat unequal, lanceolate, smooth, thin, and membranous on the edges, longer than the florets, the keel roughish; the florets thin aud delicate, the lower oue sessile, the upper elevated on a hairy stalk, half the length of the valves; the outer valve largest, lanceolate, the back channelled, in which is imbedded the lower part of the aun, which arises from near the base of the ralve, and generally when in seed as long again, but previous to this it is not so long. The structure of the awn is remarkable: the lower part, which is generally the length of the valve, is rather thick, bruwn, and twisted; the extremity is jointed, and surrounded by a few short rigid pale bristles, from the centre of which arises a thin delicate process mostly about as long again, gradually thickening towards the extremity; this part is highly hygrometrical, moving with the least moisture applied by breathing upon it. Anthers dark purple. Stigmas feathery.

Habitat.-On the sandy sea-coasts of Norfulk and Suffolk; plentiful near Yarmouth.

Perennial ; flowering in July.

The form of the awn is considered hy Beauvis sufficient to constitute this a distinct genus, in which opinion he is followed by Lindley. The name, Corynephorus, by which it is distinguished, differs only in its termination from a genus of Alge, and may lead to some confusion. Perhaps the Latin word Claviger, which has the samemeaning, (should both genera be adopted by succeeding botanists,) may be substituter for one or other of them. 


\section{GENUS XXVIII. HOL'CUS. Linn. Soft Grass.}

Gen. Char. Panicle loose. Spikelets two-flowered. Glumes nearly equal, longer than the florets; lower floret perfect and awnless; upper with stamens only, and awned. Fruit coated with the in. durated glumelles.-Named ó $\lambda$ *os, from $\varepsilon^{\imath} \lambda \varkappa \omega$, to draw or extract: on account of the property which this, or snme other grass formerly bearing this name, was supposed to possess in the drawing of wounds and thorns from out the flesh.

1. H. mol'lis, Linn. (Fig. 128.) creeping Soft-grass. Glumes acuminate; upper floret with a jointed awn extending beyond the glumes; joints of the stem with tufts of hairs; root with creeping underground stems.

English Botany, t. 1170.-English Flora, vol. i. p. 108.-Lindleyr Synopsis, p. 306.-Hooker, British Flora, vol, i. p. 42.-Sinclair, Hort. Gram. Woburn. p. 165.

Root fibrous, downy, with creeping underground stems, which put out whorls of fibres from their numerous joints. Stem from one to three feet high, bent at the base, smooth and finely striated, leafy joints clothed with thick short hairs, and sometimes the whole plant is sllghtly downy. Leaves linear lanceolate, roughish. Sheaths striated, somewhat inflated roughish, the upper one much the longest. Ligulo obtuse, mostly turn. Inflorescence an erect branched panicle, close before flowering, afterwards spreading, its branches slender and downy. Spikelets numerous, pale green, sometimes purplish. Glumes nearly equal lanceolate, with a tapering point longer than the florets, the outer valve with a strong green roughish keel, the inner with a keel and two lateral ribs. Florets a pale green, orate lanceolate, the lower one nearly sessile, smooth and sbining, sometimes with a few scattered huirs, containing both stamens and pistils, the upper one elevated on a short hairy stalk, surrounded at the base with a tuft of short white shining hairs, generally more hairy, containingstamens only, the outer valve with a jointed awn arising from near the extremity and extending beyond the glumes. Anthers yellow. Seed small, inclosed in tho hardened glumelles.

Habitat.-Pastures, hedges, and waste sandy places, frequent.

Perennial; flowering in July.

This plant, from the experiments of Sinclair, contains a large portion of nutritive matter, but the small quantity and lateness of herbage which it produces, together with the poor sandy soil in which it delights to grow, renders it one of the least valuable pasture grasses, and especially as cattle will never eat it unless from extreme necessity. The long spreading underground stems, are extremely troublesome and difficult to be expelled from light arable lands when they have once established 
themselves in it. They, however, contain much nutritive matter, and as Sinclair observes, much relished by pigs.

2. H. lana'tus, Linn. (Fig. 129.) Meadow Soft-grass. Glumes unequal, somewhat obtuse, the keel terminating in a short point, upper floret with a curved awn included within the glumes; joints of the stem without tufts of hairs; root simply fibrous.

English Botany, t. 1169.-English Flora, vol. i. p. 107.-Lindley, Synopsis, p. 305.-Hooker, British Flora, vol. i. p. 42.-Sinclair, Hort. Gram. Woburn. p. 163.

Root of numerous, strong downy fibres. Stems numerous, erect, single, from one to three feet high, smooth, or more generally clothed with thick short down. Leares linear lanceolate, striated, downy on both sides. Sheaths long, striated, soft and downy. Ligula short, blunt. Inflorescence au erect branched spreading panicle, larger than the above species, a pale green or more generally purplish, its branches slender, repeatedly divided, and clothed with soft hairs. Glumes dotted or downy, unequal, the outer valve smallest, keeled obtusely pointed, the inner obtuse with two strong lateral ribs and a keel, which terminates in a short rigid point. Florets shorter than the glumes, pale, smooth and shining, the upper one on a short smooth stalk, containing stamens only, the outer valve largest, with a short curved smooth awn arising from near the extremity, and included within the glumes, the lower floret largest, containing both stamens and pistils. Anthers yellow or purple. Seed coated with the bardened glossy glumelles.

IIabitat.-In meadows, pastures, by the side of hedges and woods, common.

Perennial ; flowering in June and July.

This very common grass, like the last, is of little value for the purposes of cultivation, and is equally disliked by cattle in its succulent state as well as when made into hay, a circumstance which appears to depend upon its soft woolly nature; and as Sir H. Davy has observed, the bland mucilaginous taste of the nutritive matter of this grass, is not such as is found to be contained in those kinds which are most liked by cattle, which are those of a subacid or saline nature; and he further observes, that this grass might probably be made more palatable to cattle by being sprinkled over with salt,- -a practice which ought to be followed by all persons whose meadows or tields contain any great proportion of this grass.

GENUS XXIX. ARRHENATH'ERUM, BEAUvis. Oat-like Grass.

Gen. Crar. Panicle loose. Glumes two, unequal, two-flowered; louer floret with stamens only, and a long jointed awn axising 
from near the base of the outer ralve; the upper perfect, and the outer valve with a short straight bristle from near the apex.-

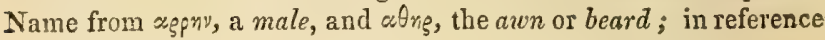
to the male floret bearing an awn.

1. A. avena'ceum, Beauv. (Fig. 130.) common Oat-like grass.

Lindley, Synopsis, p. 305.-Hooker, British Flora, vol. i. p. 42.Hol'cus avena'ceus, Scop. English Botany, t. 813.-English Flora, vol. i. p. 109.-Sinclair, Hort. Gram. Wohurn. p. 169.-Ave'na ela'tier, Linn. Hudson.-Arrhenath'erum bulbo'sum, Dumortier, Lindley.

Root of numerous strong woolly fibres. Stem erect, from one to three feet high, the base frequently swollen into knots or tubers, which are smooth or hairy, the joints in the lower part of the stem are generally numerous and they also are frequently swollen, and are more or less hairy, the stem smooth, leafy. Leaves linear lanceolate, rough above, smooth beneath. Sheaths striated, smooth, long, especially the upper ones. Inflorescence a long loose spreading panicle, its branches roughish, of various lengths, arising in half whorls, and mostly drooping on one side. Spikelets numerous. Glumes unequal, smooth, thin membranous, the upper valve largest lanceolate, three ribbed, the lower much smaller, single ribbed. Florets two surrounded at the base with a tuft of short white bristles, the lower sessile, neuter, bearing stamens only; the outer valre lanceolate, roughish, six-ribbed, bifid at the apex, thin and membranous on the edges, and arising from above the base is a long jointed rough awn, twisted in the lower part, tapering above; inner valve thin, membranous, bifid at the apex, the margins inflexed from the two lateral greenish and hairy ribs; the upper floret on a short bairy footstalk, outer valve five-ribbed, the dorsal one terminating between the bifid apex in a short straight rough awn, the margins membranous. Anthers mostly pinkish. Stigmas long, feathery. Seed invested by the hardened glumelles.

Habitat.-Herlges, pastures, and waste places, common.

Perennial ; flowering in June and July.

This grass, the only known species of the genus, has the habit of, and in natural affinity is nearly allied to, Avena. The enlarged joints and tuberous base of the stems vary, as well as their hairiness according to the more or less humid situation in which they have grown. It is a grass of considerahle agricultural value, is eaten by all kinds of cattle, and ought to form a part of all permanent pastures, though not in too great a proportion, as, according to the cxperiments of Sinclair, it contains too large a proportion of bitter extractive and saline matter; tho quantity of herbage which it produces during the whole summer, is very considerable. In dry, sandy arable lands, the tubers spread about, nnd it becomes a very troublesome weed. 


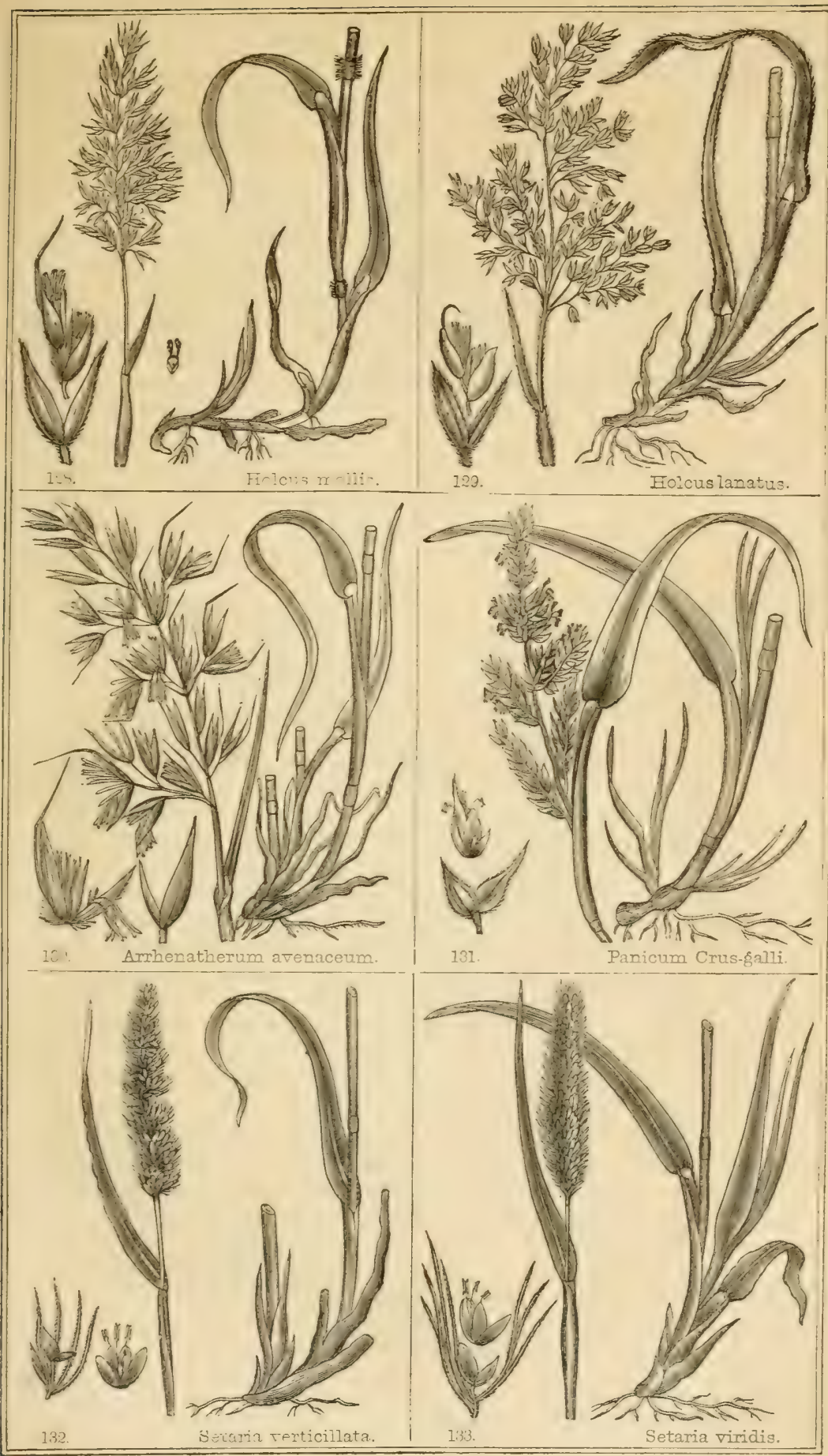





\section{GENUS XXX. PAN'ICUM. Linn. Panick Grass.}

Gen. Crar. Panicle erect, compound. Glumes two, unequal, twoflowered; the lowest valve smallest, pointed; the upper concave pointed or awned. Florets dissimilar. Glumelles of the fertile floret two, cartilaginous, the external one concave, the internal plane; glumelles of the neuter or male floret one or two; the external membranous, pointed, or awned; the inver smaller, often absent. Name from paris, bread; the seeds of some of the species of this genus, it is thought, having been earliest used for the making of bread.

1. P. Crus'-gal'li, Linn. (Fig. 131.) loose Panick-grass. Spikes of the panicle alternate, mostly simple; flowers imbricated, unilateral; rachis rough; leaves without ligulæ.

English Botany, t. 876.-English Flora, vol. i. p. 100.-Hooker, British Flora, vol. i. p. 43.-Echino'chloa C'rus'-gal'li, Lindley, Synopsis, p. 305.

Root fibrous. Stems several from the same root, about two feet high, branched and leafy in the lower part, smooth, striated. Leaves broad, lanceolate, smooth, except on the edges, which are sometimes waved or crenated. Sheaths large, compressed, smooth, and striated. Ligula absent. Inflorescence a compound spiked panicle, the lower spikes rather distant; the uppor crowded, shorter tufted; rachis compressed, rough elged, mostly zigzag. Glumes unequal, the inner largest, concave ribbed, pointed or awned and scattered with short rigid bristles; the outer smaller, thinner, partly embracing the other at the base, pointed at the extremity. Glumelles of the perfect floret, two, obscurely ribbed, smooth and shining; the lower or outer one concave, downy at the apex, the sides inflexed; the upper or inner one plane, the sides slightly inflexed, pointed. Glumelles of the imperfect floret very unequal, the outer one large concave, thin, membranous, ribbed, the edges scattered with bristles, the sides inflexed, terminated with a rough awn, about as long as itself or shorter; this valve has a great resemblance to the outer glume, for which it is not surprising it should have been mistaken; the inner one much smaller, sometimes wanting, very thin, plane pointed or notched at the apex; this floret is generally empty, sometimes it contains stamens only. Stamens about the length of the glumelles. Anthers small. Stigmas feathery. Seed flat, truncated, remaining attached to the hardened glumella.

Habitat.-Rare, in fields in the vicinity of London, "but probably introduced."-Hooker.

Annual; flowering in July. 


\section{GEXUS XXXI. SETA'RIA. BEAUr. Bristle Grass.}

Gex. Cear. Panicle spiked, crlindrical. Glumes two, unequal, twoflowered; the spitelets supported on short branched pedicles, two or three of which are surrounded by a bristly involure. Florets dissimilar. Glumelles of the perfect floret two, unequal, cartilaginous; glumelles of the neuter or male fl oret one or two, membranous; the smaller one sometimes absent.- Name from Seta, a bristle, on account of the bristly appearance of the spikes.

1. S. verticilla'ta, Beauv. (Fig. 132.) rough Bristle grass. Panicle spiked, lobed in the lower part, branches whorled, bristles of the involure, sereral, prominent, rough, with reversed teeth.

Lindley Synopsis, p. 309.-Hooker, British Flora, vol. i. p. 43.Pan'icum verticilla'tum, Linn.-English Botany, t. 875.-English Flora, rol. i. p. 98.

Root fibrous. Stems one or several from the same root, from eight inches to two feet high, erect, leafy, striated, smooth below, angular at the top and rough, with sharp erect teeth. Leaves rather broad, lanceulate, taper pointed, rough on loth sides, the edges very rough, especially near the base where it not unfrequently has a narrow pale cartilarinous boider, aud one eqge of the leaf waved. Sheaths long, striated, smooth. Ligula a tuft of short hairs, which are continued, but scattered for some distance on the edge of the sheath. Inflorescence conpound, from one to three inches long, erect, crlindrical, irregularly lobed, the branches short, rough, from three to six in a whorl, each hearing sereral flowers, crery Irair of wich is subtended by about two long rough bristles. Glumes very unequal, thin, membranous, with greenish ribs, the lower valve the smallest, about half the length of the upper, and shortly pointed, the upper valre oval, concave, many ribled, as long as the florets, suriolinded at the base by the outer ralre. Florets generally in pairs. Glumelles of the perfect fioret of two cartilagrinous unequal ralve, shining and benutifully impressed with close dotted leares; the outer concare with inflexed edges, enclosing the plane inner valve. Glumelles of the imperfect floret unequal, thin, membranous; the outer large ribbed, corcare, greatly resembling the inner glume; the inner plane rery thin, smaller, or absent. Anthers short, cloven. Stigmas feathery. Seed orate, dark-coloured, enclosed in the hardened glumelles, which are enveloped by the persistent glumes.

Halitat.-Pare, between Lonrlon and Putncy, Battersea fields, and near Norwiclı; " probably not indigenous."-Hooker.

Annual; flowering from July to August.

2. S. vi'ridis, Beaur. (Fig. 133.) Green Bristle grass. Panicle spilet, continuous brisiles of the involure, nore numorous, and rough, with erect tcetl. 
Lindley, Synopsis, p. 309.-Hooker, British Flora, rol. i. p. 43.Pan'icum vi'vide, Linn. English Botany, t. 875.-English Flora, vol. i. p. 98.

This plant is generally smaller than the abore species, which it greatly resembles. It would appear, the only character of distinction upon which reliance can be placed is the bristles of the involure haviug the small teeth with which they are closely set with the points directed upwards, while in the former they are directed downwards; the spike is also more compact, less distinctly lobed, more bristly; the florets are the same in both species, except that in the latter the inner valve of the neuter floret is more frequently wanting, and sometimes the whole floret is suppressed.

Habitat-Rare; in sandy fields about London and Norwich; "scarcely indigenous."-Hooker.

Annual; flowering in July and August.

\section{GENUS XXXII. SESLE'RIA. ARdur. Moor grass.}

Grn. Char. Panicle spiled. Glumes two, nearly equal, pointed or awned at the apex. Glumelles nearly equal; the outer jagged, awned at the apex; the inner bifid.-Named from Leonard Sesler, an Italian Physician aud Botanist.

1. S. cceru'lea, Scop. (Fig. 134.) Spike ovate, with altermate membranous bractea at the base.

English Botany, t. 1613.-English Flora, rol. i. p. 114,-Lindley, Synopsis, p. 309.-Hooker, British Flura, vol. i. p. 42.-Sinclair, Hort. Gram. Woburn. p. 303.

Plant forming close thick tufts, the roots numerous, long, tough, and wiry. Stem from four to twelve or eighteen inches high, smooth, and striated, thickly clothed at the base with the remains of withered leaves, naked abore. Leares numerous, linear obtuse, smooth, except the edges and heel, which are freaunitly runghish, striatch, single ribbed, a glaucous green, the upper ones very short. Sheaths short, close. Ligula absent. Inforescence close, a sliort ovate, shining bluish-green, spiked panicle, the lower spikelets having thin membranous, jagged, toothed or ciliated bractea at their base. Glames ncarly equal, thin,

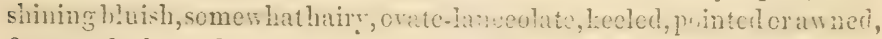
frequently jagged, toothed, or ciliated towarts the extremity, mostly containing two florets longer than themselves. Glumelles nearly equal, external one the largest, shining hluish towards the extremity, from three to fire toothed, ciliated, and slightly hairy ribhed, the keel terminating in the middle tooth, mostly lengthened into a short roughish awn; inner valve with two roughish ribs terminating in a bifid extremity, the edges inflezed and membranous. Anthers large, yellow tipped with parple 
Habitat.-Frequent in the mountainous districts in the North of England and in Scotland; plentiful at Settle, on the moors, and limestone districts in Yorkshire and Derbyshire.

Perennial; flowering in April and June.

'This grass appears to be a farourite fond of sheep, and is one of the superior alpine grasses, as containing a considerable proportion of nutritive matter; it is an early spring grass, but the quantity of herbage which it produces is inconsiderable, and its growth, after being cropped, is very slow. It appears to possess no other properties by which it can be cultivated with advantage in other than its natural place of growth, but in such situations it is one of the best and most nutritious grasses.

\section{GENUS XXXIII. HIERO'CHLOE. GMelin. Holy-grass.}

Gen. Char. Panicle loose. Glumes two, nearly equal, three-flowered, the two lateral florets neuter, each containing three stamens; the terminal one perfect, containing two stamens and pistils. Glumelles nearly equal, with or without an awn. Fruit free.-Name from

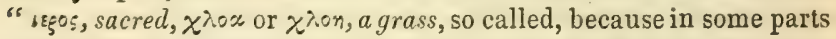
of the Prussian dominions it is dedicated to the Virgin Mary, and strewed befure the doors of the churches on festival days, as the Sweet-flag (Acorus Calamus) is in England."

1. H. borea'lis, Reom et Schult. (Fig. 135.) northern Holy-grass. Panicle nearly erect, somewhat unilateral, flower stalks smooth, florets awnless, roughish; outer valve ciliated on the margin, leaves flat.

English Botany, Supplement, t. 2641-English Flora, rol. i. p. 110. Lindley, Synopsis, p. 306.-Hooker, British Flora, vol. i. p. 42.-Hol'cus odora'tus, Linn. Sinclair, Hort. Gram. Woburn. p. 167.

Root fibrous, the plant rapidly extending itself by numerous underground stems. Flowering stems from twelve to eighteen inches high, erect, round, smooth, striated, leafy in the lower part, naked above. Leares linear, with a long narrow point, smooth, finely striated, rough on the elges, beneath shining bright green, paler abore, and sometimes slightly downy, those of the stem very short. Sheuths long, close, smooth, ribbed. Ligula broad, acute, torn or jagged on the edge. Inflorescence an erect or slightly drooping smooth branched spreading panicle. Spikelets three-flowered. G'lumes two, nearly equal, smooth and shining, orate, broadly pointed, membranous, a little longer than the florets, sometimes jaggerl or serjated towards the apex. Florets three, on short stalks, the lateral ones neuter (male flowers) having three stamens, (triandrous) pistils wanting, the central or terminal flower smallest, perfect, lut with only two stamens (diandrous) and pistils. Glumelles unequal, the outer valre largest, of a firm almost cartilaginous 


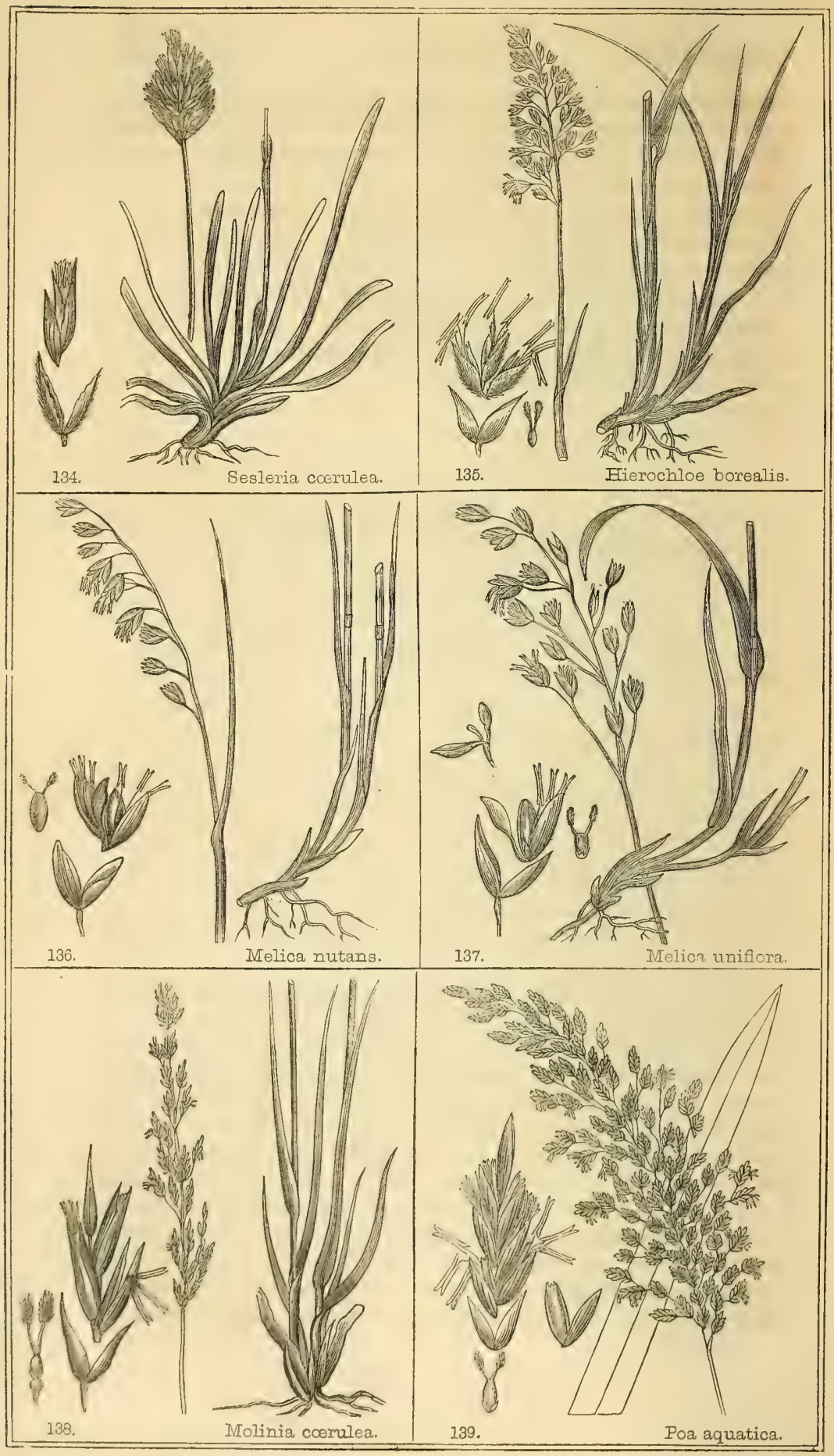


texture, shining, roughish, the margins fringed, pointed, not awned; inner valve about half as narrow, thin, membranous, ribbed, smooth, bifid at the apex. Glumellules linear, lanceolate. Stigmas large. Anthers large, yellow.

Habitat.-Very rare. This interesting plant was discovered by Mr. G. Don, in a narrow valley called $K$ ella, in Angus-shire, Scotland.

Perennial; flowering in July.

This species like all others of the genus has the peculiar smell of new mown hay, similar to Anthoxan'thum odora'tum, but in a much greater degree, so much so, that according to Dr. Hooker, in Iceland, it is so plentiful as to be used by the people to scent their apartments and clothes; and it is said to be esteemed in Sweden for its narcotic effects. The produce of this grass in spring is very small and of a very tender nature; these, together with its strong spreading underground stems, render it a grass of no agricultural merit, a circumstance which is to be regretted, as it contains a greater proportion of nutritive matter than many of the early grasses.

\section{GENUS XXXIV. MEL'ICA. Linn. Melic Grass.}

Gen. Char. Panicle loose. Spikelets one or two flowered, with the rudiments of one or more imperfect ones. Glumes two, nearly equal, about as long as the florets. Glumelles two, unequal, awnless, becoming hard, and investing the fruit.-Name probably derived from $\mu: \lambda \alpha$, honey, mel. Melica, or Melliga, is also a name given in Italy to the common Millet (Sor'ghum vulga're); and some resemblance between it and the present genus, may have been the reason of Linnæus giving it this name.

1. M. nu'tans, Linn. (Fig. 136.) mountain Melic-grass. Panicle drooping, nearly a simple raceme; spikelets pendulous on one side, containing two perfect florets.

English Botany, t. 1059.-English Flora, vol. i. p. 113.-Lindley, Synopsis, p. 307.-Hooker, British Flora, vol. i. p. 41.

Root with creeping underground stems. Stem from one to two feet high, nearly erect, simple, slender, roughish, striated and angular, leafy below. Leaves narrow, linear, acute, the lower ones much shorter than the upper, with a roughish margin. Sheaths striated, roughish. Ligula very short. Inforescence a slightly drooping nearly simple raceme, sometimes quite simple. Spikelets on short rough stalks, hanging to one side. Glumes ovate, nearly as long as the florets, smooth, a deep purplish brown, the margins pale, nearly equal, the external one smallest, each fire or seven-rihbed. Perfect florets two, the lower sessile, the upper on a short stalk. Glumelles unequal, cartilaginous; the outer valre orate lanceolate, concare, roughish, strongly and nume- 
rously ribbed, purplish green, the margins pale and nembranous; inner valve pale, ovate acute, flat, smooth, except on the two strong marginal ribs, from the inner edge of which is inflexed a narrow thin membranous border. Imperfect florets paler, one, two, or three, each rising on a short stalk from the base of the inner valve of the floret below it. I have occasionally observed three perfect florets, in fine luxuriant specimens. Anthers yellow. Stigmas distant, rather long, feathery. Seed ovate attenuated, loose, in its covering of the hardened glumelles.

Habitat.-Woods in subalpine districts; not common. Middleton Dale, and other parts of Derbyshire. Most frequent in the north of England and in Scotland.

Perennial; flowering from May to June.

2. M. uniflo'ra, Retz. (Fig. 137.) wood Melic-grass. Panicle branched; spikelets ereet, spreading, containing one perfect floret.

English Botany, t. 1058.-English Flora, rol. i. p. 112.-Lindley, Synopsis, p. 307.-Hooker, British Flora, vol. i. p. 41.

Root with creeping underground stems. Stem erect, from one to two feet high, slender, smooth, striated, leafy, simple. Leaves flat, broader than the preceding species, thin, striated, roughish. Sheaths close, striated, nearly smooth. Ligula very short. Inflorescence a long branched, nearly erect, spreading panicle; its branches distant, slender, nearly smooth. Spikelets few, distant, erect. Glumes unequal, smooth, purplish brown, as long as the florets; outer valve smallest, lanceolate, with a single dorsal rib; inner larger, ovate lanceolate, five-ribbed. Perfect floret sessile, cartilaginous. Glumelles unequal; outer valve ovate, ribbed, pale green, with a purplish tinge, very concave; inner flat, smooth, except the two strong lateral ribs, from the inner edge of which is inflexed a broadish border. Glumellula of one thick notched yellow piece at the base of the outer valve of the glumella. Imperfect floret elevated on a smooth bent stalk, half as long as the perfect floret: the outer valve concave, of a very irregular shape, embracing the much smaller inner valve, and the rudiment of second still more imperfectly formed stalked floret. Anthers yellow. Sirgmas distant, feathery. Seed small, truncate.

Habitat.-In the shade of woods and groves; frequent.

Perennial; flowering from May to July.

GENUS XXXV. MOTIN'TA. Manch.

Gen. Char. Panicle loose. Spikelets two or more flowered, and sometimes with an imperfect floret. Glumes two, unequal, much shorter than the florets. Glumelles two, nearly equal, awnless.Name in honour of Giovanni Ignatio Molinia, who published an account of the plants of Chile in 1782. 
1. M. cœru'lea, Mœnch. (Fig. 138.) purple Mulinia. Panicle erect, rather close, purplish, leaves much shorter than the stem.

Lindley, Synopsis, p. 307.- Hel'ica ceru'lea, Limn. English Botany, t. 750.-English Flora, vol. i. p. 113.-Hooker, British Flora, vol. i. p. 41.-Sinclair, Hort. Gram. Woburn. p. 286.

B. Panicle pale.green; spikelets few-flowered.

Mel'ica alpi'na, Don.-MIolin'ia depaupera'ta, Lindley.

Roots of numerous strong wiry fibres. Stem, erect, from one to two feet high, numerous, smootl, finely striated, the base frequently swollen, surrounded with numerous leares, single-jointed near the bottom. Leaves numerous, long, narrow, linear, acuminate, finely striated, roughish especially on the upper surface. Sheaths close, smooth, striated. Ligula a tuft of short fine glossy hairs. Inflorescence a rather close, erect, roughish branched panicle, from two to six inches long. Spikelets numerous, erect, bluish-purple; "rarely, and perhaps only when growing in much sheltered situations, green." Glumes unequal, purple, becoming brown with age; the ouicr valve lanceolate, shorter than the inner, which has a longer sharper point, each with a single dorsal rib. Florets from three to six, the upper one or two imperfect, shining; outer valve lanceolate, three-ribbed, with a sharp point; the inner pale-green with two lateral ribs from which the inner margins are inflexed, the extremity acute. Anthers purple. Stigmas a dense purple feathery tufts. Seed small, loose, inclosed in the hardened glumelles.

Habitat.-On exposed moors, and on barren heathy situations, common.

Perennial; flowering in August.

For the purposes of cultivation this grass is of little or no value. The tough stems, we are informed by Withering, are used in some parts of England to make brooms, and used as a substitute for the more expensive ones made of hair; and Lightfoot says, that in Skye, the fishermen twist them into excellent ropes for their nets.

\section{GENUS XXXVI. PO'A. LINN. Meadow-grass.}

Gen. Char. Panicle loose. Spikelets three, or many-flowered. Glumes two, shorter than the florets. Glumelles two, nearly equal, awnless. Name from roo, grass, or herb. This genus is so named in reference to their value as pasture grasses.*

* The above, there can be little doubt, is the derivation of the word Poa; but there are other words of the same meaning, as $\pi 0$ < $\alpha$ and $\pi \circ n_{\text {. While }}$ speaking of the derivation of the word Grass, it may be interesting to notice a remarkable coincidence between a systematic arrangement of the rogetable kingdom, (which has been adopted only within the last fow years, aftor the 


\section{* Spikelets linear or linear-ovate.}

1. P. aqua'tica, Linn. (Fig. 139.) reed Meadow-grass. Panicle erect, large, much branched, and spreading, florets numerons, obtuse; outer valve seven-ribbed; leares broad lanceolate.

English Botany, t. 1315.-Hooker, British Flora, vol. i. p. 43.Glycéria aqua'tica, English Flora, vol. i. p. 116. -Sinclair, Hort. Gram. Woburn. p. 354.-Hydro'chloa aqua'tica, Hartman, Lindley, Synopsis, p. 316.

Root with jointed creeping underground stems and numerous whorled fibres. Stems erect, from three to six feet high, striated, smooth, and leafy in the lower part, naked and roughish above, slightly compressed. Leaves long, linear-lanceolate, broad, flat, single-ribbed, rough on the edges and under side. Sheaths smooth, close, finely striated. Ligula obtuse, torn. Inflorescence a large nearly erect panicle, from six to twelve inches long, its branches arising in alternate half whorls, long, rough, repeatedly branched, spreading. Spikelets numerous, linear. Glumes unequal, membranous, smooth; outer valve smallest, single. ribbed; inner with a strong dorsal and two smaller lateral ribs; forets from fire to ten or more, obtuse; outer valve with about nine strong ribs, smooth, or minutely downy; inner narrower, with two lateral ribs, from which the membranous margins are inflexed, bifid at the extre-

labours and investigations of ages, ) and the divisions which are distinctly stated by the sacred historian Moses, in his account of the creation, given in the Book of Genesis, where we read that on the third day, or epoch, vegetables were created. In our translation, it is thus stated:-_ "God said, Let the earth bring forth grass (Deshe), the herb yielding seed, and the fruit-tree yielding fruit after his kind, whose seed is in itself, upon the earth: and it was so. And the earth brought forth grass, and herb yielding seed after his kind, and the tree yielding fruit, whose seed was in itself, after his kind." The primary divisions of what is called the Natural System of Botany, are three, (which appear to have been made without the least suspicion that they were the same as those given by MIoses,) and were called by Linnæus, Cryptogama, Fruges, and Plantæ, which are synonymous with Cellulares, or Acotyledons,-Endogenæ, or Monocotyledons,-and Exogenæ, or Dicotyledons; and by some botanists they have been called Spore-bearing, or seedless plants, Grain-bearing, and Seed-bearing plants. These three divisions agree precisely with those of the Mosaic account above quoted. The word DESHE in the original Hebrew, which is translated in the text grass, is satisfactorily pointed out, both by an able writer in the 25 th Number of "Jameson's Journal," and by the late Professor Burnet, to signify springing or shooting plants, or tender herbs. And we may also state, in corroboration of these opinions, that of Rosenmüller, in his Scholia on Genesis, ch. 1, v. 11 : "Itaque in hoc commate in tres veluti classes, quidquid emittit terra, dividitur: 1. est tenera herba, sine semire, saltem conspicuo: 2. quae semen profert majorque est: 3 . arbores, sub quibus arbusta continentur." So that, in this sentence, whatever the earth sends forth, is divided, as it were, into three classes: 1. There is the tender herb without seed, at least any that is observable (Acotyledons); 2. That which produces seed, and is larger (Monocotyledons); 3. Trees, under which shrubs are included (Dicotyledons). 
mity. Glumellules small, acute. Anthers yellow. Stigmas feathery.

Habitat.-On the banks of streams, drains, and swampy situations ; common.

Perennial; flowering in July and August.

This, though a large coarse grass, is eaten by cattle with an apparent relish, and contains a large proportion of nutritive matter. It furms the principal winter provender in some parts of the fens of Lincolnshire and Cambridgeshire, where it grows with so great rapidity and luxuriance, that it is sometimes mown three times during the summer. Its quick growth and rapid wide-spreading stems, render it exceelingly troublesome in drains and rivers; so much so in the Isle of Ely, we are informed by Mr. Curtis, as to render it necessary to eleanse them with an instrument called a bear-a sort of roller, with numerous sharp projecting pieces of iron, which is dragged up and down the river, to cut or tear up the roots.

2. P. flu'itans, Scop. (Fig. 140.) floating Meadow-grass. Panicle long, nearly erect, scarcely branched; florets numerous, sevenribhed, with short intermediate ones at the base; leaves linear, acute.

English Botany, t. 1520.-Hooker, British Flora, vol. i. p. 43.Glyce'ria flu'itans, English Flora, vol. i. p. 117. - Lindley, Synopsis, p. 315.-Sinclair, Hort. Gram. Woburn. p. 349.-Fes'tuca fu'itans, Linn.

Root with long, creeping, prostrate stems, thick, succulent, often partly floating in water, putting out roots and stems from the joints; upper part erect, from one to three feet long, smooth, striated, leafy. Leaves linear-lanceolate, acute, flat, roughish, the lower ones floating on the surface of water. Sheaths long, smooth, finely striated, close, and slightly compressed. Ligula oblong, acute, often torn. Inflorescence a very long, nearly erect, slender panicle, branched mostly at the base, and spreading; the upper spikelets on short, simple stalks, and erect. Spikelets linear, cylindrical, or slightly compressed. Glumes unequal, thin, membranous, each with a single green rib. Florets from eight to twelre. Glumelles equal; the outer valve acute, or obtuse, membranous towards the extremity, minutely hairy, seren-ribbed, with short intermediate ones between them; inner membranous, two ribbed, the margins inflexed, notched at the extremity. Glumellula of one thick piece. Anthers small, yellow. Stigmas feathery. Seed oblong, furrowed on one side.

Habitat.-Pools, slow streams, and wet places; frequent.

Perennial; flowering from July to September.

This grass is of little or no agricultural utility. The seeds are purchased in the shops under the name of mamu-sceds, and are said to be VOL. I. 
used in some parts of Germany and Holland, as well as in Poland, as a great delicacy in soup and other articles of food. In some parts of Germany, Schreber says, it is cultirated for the value of the seeds, Small birds are rery fond of the sweet unripe seeds; and the fine sharp bran is said to be useful in destroying intestinal worms in hurses, but Sinclair observes, "they must be kept from water some hours afterwards."

3. P. marit'ima, Hudson, (Fig. 141.) creeping Sea Meadorv-grass. Panicle erect, rather close; spikelets of about five obtuse florets, outer valve five-ribbed; leaves involute; root with creeping stems.

English Botany, t. 1140.-Hooker, British Flora, vol. i. p. 44.-Glyce'ria marit'ima, English Flora, vol. i. p. 118.-Sclero'chloa marit'ima, Lindley, Synopsis, p. 315.

Root with numerous creeping underground stems, putting out numerous fibres and stems from the joints. Whole plant a glaucous-green. Stems numerous, bent at the base, about a foot high, rigid, smooth, and leafy, except at the top it is rather rough. Leaves linear, the edges mostly rolled inwards, sharp-pointed, the upper side and margins roughish. Sheaths long, rather swelled, smooth, finely striated. Ligula obtuse. Inflorescence a rather close, rough, branched panicle, arising mostly on one side, and spreading only when in flower. Spikelets linear, cylindrical. Glumes unequal; the outer smallest; single. ribbed; the inner with a sharp point and tro rough ribs, the membranous margins inflexed. Glumellules acute. Anthers yellow. Stigmas feathery. Seed small, pointed at each extremity.

Habitat.-In wet places on the sea-coast; frequent.

Perennial; flowering in July and August.

4. P. dis'tans, Linn. (Fig. 142.) reflexed MLeadow-grass. Panicle erect, spreading, its branches at length deflexed; spikelets of about five obtuse florets, outer valve with fire indistinct ribs; leaves flat; root fibrous.

English Botany, t. 986.-Lindley, Synopsis, p. 318.-Hooker, British Flora, rol. i. p. 44.-Sinclair, Hort. Gram. Woburn. p. 323.Glyce'via dis'tans, English Flora, vol.i. p. 118.

Root fibrous. Whole plant a glaucous green, tufted. Stems uиmerous, bent at the base, round, smooth, leafy, from one to two feet high. Leares linear, flat, smooth on the under side, roughish on the upper. Sheaths smooth, striated, the upper ones longest, slightly inflated. Ligula short, striated, obtuse, notched or torn. Inflorescence an erect, spreading panicle; its lranches slender, angular, roughish, attached to the rachis ly a swollen joint, in alternate half whorls, singularly bent downwards as the plant artrances to maturity, by which character it may readily be distinguished from its allied species. Spikelets short, somewhat compressed, shining, and sometimes tinged 
with purple. Glumes membranous on the edges; the outer valve smallest, single-ribbed; the inner with three ribs. Florets from three to seren. Glumelles nearly equal; the outer one acute and membranous at the extremity, with five indistinct ribs; the inner pointed or bifd at the extremity, with two roughish lateral rils, from which the inner membranous margins are inflexed. Glumellules acute. Anthers yellow. Stigmas large, feathery.

Habitat.-In sandy situations, principally near the sea-Hooker. Near Dublin-Mr. Ir. Wilson. Nottingham Meadows, and Lenton, rare-Dr. Howitt. Near Rotherham-Salt's Herb. Attercliffe near Sheffield, Forkshire, and road sides about Worksop, Nottinghamshire, plentiful-R, $D$.

Perennial; flowering in July and August.

The singular deflection of the branches of the panicle arises from the peculiar structure attached to their base. In a newly dereloped panicle, the branclies are erect: it may then be distinctly seen that tho two external angles are formed by two of the ribs or stria passing from the stem along the branch, and between them is a pale compact membrane. The inner surface is a pale yellow, scarcely swollen; this, however, is limited to a rery short distance at the base, and as the plant advances to maturity, this part gradually enlarges, and forms a projecting tubercle. The outer surface, formed as above stated, is capable of resisting the pressure of the gradually swelling tubercle; consequently, it forms, as it were, a hinge, which allows the branches to be bent backwards as the tubercle is developing. A thin transverse section of the tulvercles, examined with a strong magnifying power, shows them to be composed of cells of an hexagonal figure, much smaller and more compact in the lower part and middle, gradually hecoming larger towards the upper and external surface.

5. P. procum'bens, Curtis, (Fig. 143.) procumbent Sea Meadowgrass. Panicle rather close, ovato-lanceolate; spikelets leaning one way, linear, of about four florets, outer valves with five ribs.

English Botany, t. 532.-Hooker, British Flora, vol, i. p. 44.-Glycéria procum'bens, vol. i. p. 119.-Sclero'chloa procum'bens, Lindley, Synopsis, p. 316.

Whole plant a glaucous green, and rigid. Root fibrous. Stems procumbent at the base, fron: six to eight imches high, smooth, leafy, and branched at the hase. Leares flat, linear, obtuse, ribbed, roughish on the edges and upper surface, smooth beneath. Sheaths long, somewhat inflated, striated, smooth. Ligula short, obtuse, often torn. Inflorescence a close, roughish branched, two-ranked panicle, about two inches long, more spreading when in flower. Spikelets two-ranked, turned to one side. Glumes unequal: the outer obtuse, with three strong ribs; the inner acute, with a single rib. Florets about four, oblong, 
rather distant. Glumelles nearly equal: the outer obtuse, five-ribbed; the inner membranous, with two marginal hairy ribs, mostly bifid at the apex. Glumellules acute. Stigmas feathery. Anthers small, yellow. Seed compressed.

Habitat.-In salt marshes near the sea. St. Vincent's Rock, Bristol; Essex; Scarborough; Yarmouth; and other places. Apparently not rare.

Annual ; flowering from June to August.

6. P. ri'gida, Linn. (Fig. 144.) hard Meadow-grass. Panicle erect, rigid, lanceolate; spikelets two-ranked, leaning one way, linear, of about seven nearly ribless florets; root tibrous.

English Botany, t. 1371.-Hooker, British Flora, vol. i. p. 44.Glyce'via rigida, English Flora, vol. i. p. 120.-Sclero'chloa ri'gida, Lindley, Synopsis, p. 316.

A very rigid and wiry plant, varying from a light green to a dark purplish colour. Root of numerous branched fibres. Stem from two to six inches high, branched, and bent at the base, or simple and erect, smooth, repeatedly jointed and leafy below. Leaves short, striated, the margins more or less rolled inwards, roughish on the upper side, smooth beneath. Sheaths short, smooth, striated. Ligula oblong, obtuse, mostly torn. Inflorescence a rather close, two-ranked panicle. Spikelets linear, turned to one side, arising from the angular zigzag rachis on short, smootin, angular, simple, or branched stalks. Glumes unequal, lanceolate, the smaller with a single dorsal rib, the larger with a dorsal and two lateral ribs. Florets about seven, rather distant, smoothish. Glumelles nearly equal: outer valve obtuse, with membranous edges, scarcely ribbed; inner with two lateral, roughish ribs, bifid at the apex. Anthers short. Stigmas feathery.

Habitat.-Crevices of walls and rocks, and dry sandy situations; not uncommon.

Annual; flowering in June.

\%. P. compress'a, Linn. (Fig. 145.) flat-stemmed Meadow-grass. Panicle rather close, spreading when in flower, partially leaning one way; spikelets ovate, oblong; florets from fire to seven, connected by a web at the base; stem compressed; root with creejing stems.

English Botany, t. 365.-Euglish Flora, vol. i. p. 121.-Lindley, Synopsis, p. 316.-Hooker, British Flora, vol. i. p. 45.-Sinclair, Hort. Gram. Woburn. p. 306.

The whole plant is more or less of a glaucous green. Root with creeping stcms. Stems procumbent, leafy, and often branched at the base, naked abore, roughish, striated, and remarkably compressed. Lectes slort, flat, linear, liceled and striated, smooth beneath, roughish on the upper sirte and erleres. Shealhs rather long, somew hat inflated, 


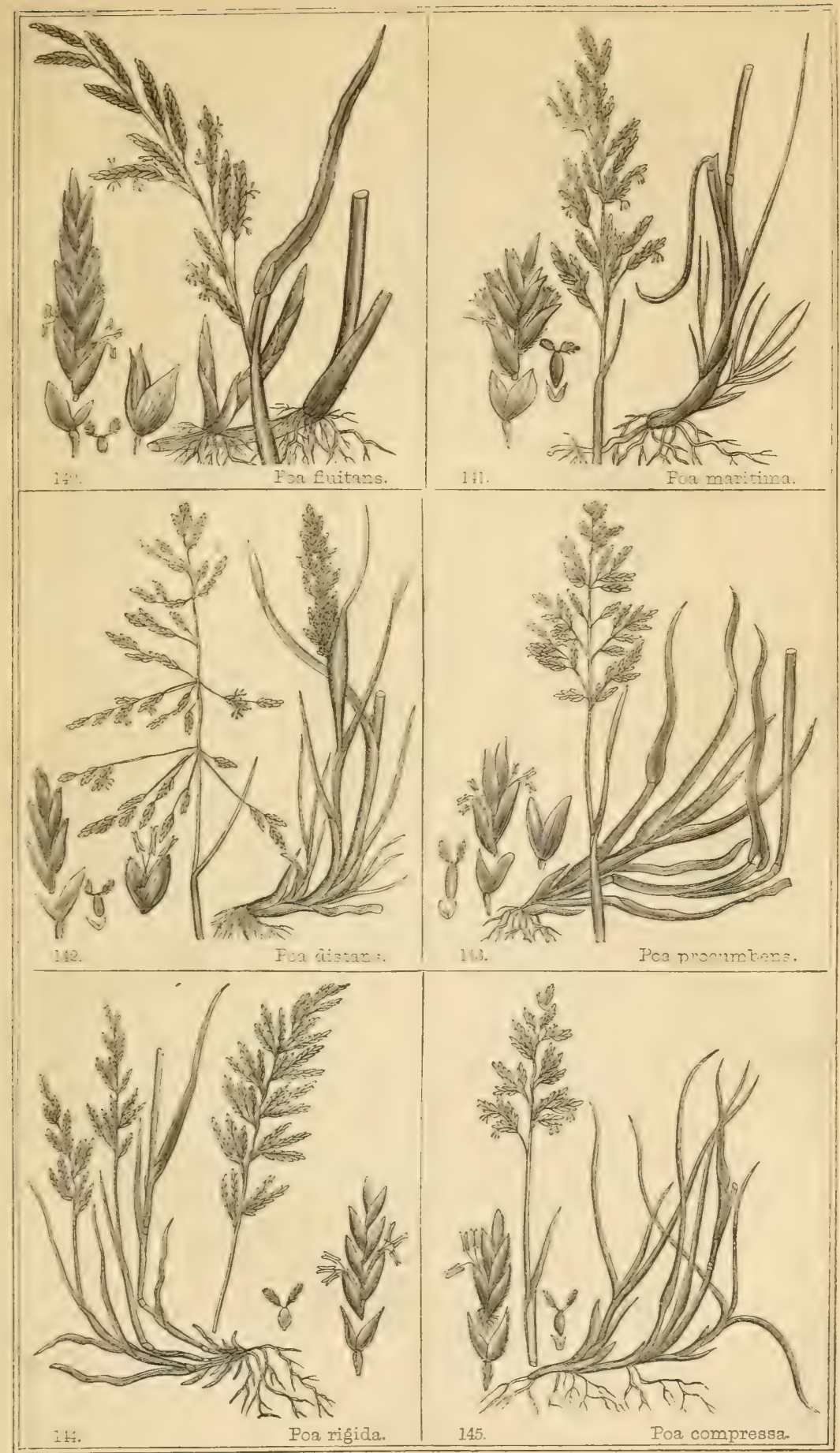



striated, and roughish. Ligula short, obtuse. Inflorescence an erect panicle, rarying in length from one to three inches, according to the situation of its growth; spreading when in flower, but rather close both before and after. Spikelets orate, oblong. Glumes nearly equal, ovate, acute, each three-ribbed, the dorsal one roughish. Florets from five to seren, the lower ones connected at the base, and partly up the keel and edges of the glumelles, by a soft, tine white web of some length: the outer valve of the glumelles ovate, acute, with a strong dorsal and four rather indistinct lateral ribs; inner valve with two lateral, roughish ribs, bifid at the apex; the margins membranous, inflexed. Anthers small. Stigmas densely feathery.

Habitat.-On walls, rocks, and dry, waste places; frequent.

Perennial; flowering from June to August.

For purposes of cultivation, this grass is of little utility, although it contains a considerable proportion of nutitire matter; the quantity of herbage which it produces is too scanty in comparison with many other valuable grasses, so as to render it scarcely worthy the attention of the farmer.

\section{* Spikelets orate.}

8. P. alpi'na, Linn. (Fig. 146 ) alpine Meadow-grass. Panicle loose, spreading; glumes nearly equal; florets four or five, hairy at the base; leares broadly linear, obtuse; ligulæ of the upper leaves oblong, acute, - of the lower short, obtuse.

English Botany, t. 1003.-English Flora, rol. i. p. 122.-Lindley, Synopsis, p. 316.-Honker, British Flora, vol. i. p. 45.-Sinclair, Hort. Gram. Woburn. p. 301.

B. glomera'ta; spikelets densely crowded. D. Don, Hooker's Flora Scotica, vol. i. p. 34 .

Root fibrous. Stem erect, from six to twelve inches high, sometimes bent at the base, and branched and leafy, naked above, round, smooth, finely striated, mostly purplish. Leaves smooth, sometimes roughish on the edges and upper side; the lower numerous, tufted, linear, flat, striated, rather short, obtuse, with a fine bristle point; their sheaths short; the ligula short, ohtuse : upper leaves much shorter, narrower; the margins inflexel ; the sheaths much longer; the ligulie lanceolate, mostly torn. Inflorescence an erect, loose, spreading panicle; its branches smooth, mostly in pairs. Spikelets ovate, rather large. Florets mosily four, sometimes fire. Glumes ovate, lanceolate, green or purplish, with a strong keel, terminating in a short point or awn, and two lateral ribs; the margins membranous. Glumelles green or purplish: outer valve ovate, lanceolate; the keel roughish at the apex, silky at the base; the margins thin and membranous: inner valve with two lateral ribs, finely fringed; the apex notched; the margins membranous, inflexed. Anthers rather large. Stigmas feathery. 
The florets, instead of being as above described, are frequently found in a viviparous state.

Habitat.-Frequent on the lofty Scotch and Welsh mountains, and not unfrequent in Ireland.- $\beta$. Banks of the Esk,-D. Don. (Hook.)

Perennial; flowering in July and Angust.

9. P. lax'a, Hæk. (Fig. 147.) wavy Meadow-grass. Panicle loosely spreading, drooping; glumes nearly equal; florets about three, hairy, and conneeted by a web at the base; leaves narrow, linear, acute; ligules all lanceolate.

English Flora, vol. i. p. 123.-Lindley, Synopsis, p. 316.-Hooker, British Flora, vol. i. p. 45.-Po'a flexuo'sa, English Botany, t. 1123.

Root fibrous, often arising from the lower joints of the stem. Stem ascending, more or less bent at the joints, about a foot high, very slender, especially in the upper part, which droops with the weight of the panicle; roughish above. Leaves narrow, linear, lanceolate, more numerous than in the last species, roughish on the edges and upper side. Sheaths long, close, striated, slightly compressed, and smooth. Ligula lanceolate, acute. Inflorescence a loosely spreading panicle. Glumes nearly equal, downy on the keel: the outer smallest, singleribbed; the inner with three ribs. Florets mostly three, tinged with purple. Glumelles acute, obscurely ribbed; the outer downy on the rib and keel, and connected at the base with a complicated web; the margin thin and membranous. Anthers small, yellow.

The whole plant has somewhat of a glaucous hue, and much smaller and slenderer than the last species; the flowers, like it, are frequently found in a viviparous state.

Habitat.-On Ben Nevis, Scotland; first found by Mr. T. Mackay. Perennial; flowering in July.

10. P. bulbo'sa, Linn. (Fig. 148) bulbous Meadow-grass. Panicle close; glumes nearly equal ; florets about four, downy at the keel, and connected by a web at the base; leaves short, finely serrated on the margins; stems swollen into bulbs at the base.

English Botany, t. 1071.-English Flora, vol. i. p. 123.-Lindley, Synopsis, p. 317.-Hooker, British Flora, vol. i. p. 46.

Root of numerous, long, branched fibres. Stem from four to six inches high, mostly bent in the lower part, erect above, smooth, the base formed into an oblong bulb by the swelling of the base of the leaves, and surrounded with dry and withered sheaths. Leaves numerous, linear, short, lieeled and striated, the edges with a narrow, serrated, pale, cartilaginous margin. Sheaths smooth, striated, loose, mostly purplish, the upper ones long, the lower short. Ligula lanceolate, embracing the stem, and decurrent on the margins of the sheath. Inflorescence an erect, simple, scarcely branched panicle. Glumes nearly equal, lanceolate, smooth, except the upper part of the keel. 
Florets three or four, more or less tinged with purple. Glumelles nearly equal: the outer valve acute, obscurely ribbed, finely downy; the keel with long down, especially at the base, which is webbed: the inner valre with two marginal, more or less fringed ribs, bifid at the apex. Stigmas small, feathery. Anthers slender, yellow.

Habitat.-On the east and southern parts of England, principally on the sea-shores.

Perennial; flowering in April and May.

This singular species of grass is peculiarly fitted to dry, sandy situations. The bulbs formed at the base of the stems and leares, are blown about on the surface of the sand during the greater part of the summer months, until the ground becomes humirl, when they also become fixed, and shortly put out their fibrous roots deep into the sand, aud, during the early part of spring, shout forth an abundance of leaves, which form a grateful, and the principal part of the herhage for cattle on the Denes at Yarmouth, and other places, until there is a greater abundance of other summer food, by which time they have withered away. This species, Sir J. E. Smith obserres, "abouuds in Germany, France, and Italy;" and that those collected "in the streets of Rome are usually viriparous;" and Sir TV. J. Hooker adds, "So are my specimens from Germany ;" but it has not, that I am aware of, been found in that state in this country.

*** Spikelets ovate-oblong.

11. P. praten'sis, Linn. (Fig. 149.) smooth stalked Meadow-grass. Panicle spreacling; glumes nearly equal, three-ribbed; florets about four, fire-ribbed, connected by a web at the hase; stem and leaves smooth; ligula short; root with creeping stems.

English Botany, t. 1073.-English Flora, rol, i. p. 126.-Lindley, Synopsis, p. 317.-Hooker, British Flora, vol. i. p. 46.-Sinclair, Hort. Gram. Woburn. p. 142.

B. angustifo'lia; smaller, with narrower involute leares. Poa angustifolia, Linn.

$\gamma$. sub-caru'lea; smaller; the leaves short, broad, and the whole plant of a glaucous hue. Poa sub-carulea, Smith, English Botany, t. 1004 .

Root fibrous, with long horizontal underground stems, which frequently give out numerous leares, and erect, smooth, flowering stems, from one to two feet high. Leares numerous, linear, spreading, obtuse, striated, and smooth, sometimes roughish on the keel and margins. Sheaths close, smooth, striated, upper ones rather long. Ligula short, obtuse, a character by which this species is readily distinguished from the following, to which it is nearly allied. Inflorescence an erect, smooth, branched, spreading panicle. Glumes nearly equal, threeribbed, smooth, except the upper part of the keel. Florets about four, 
green or purplish. Glumelles nearly equal: the outer valve fireribbed; the margins and point membranous; the ribs and keel downy, and copiously webbed at the base: the inner valve lanceolate, with two roughish ribs, from which the narrow membranous margin is inflexed. S'tigmas rather long, feathery, branched. Anthers yellow.

Habitat.-Meadows and pastures; common. $\beta$. In woods. $\gamma$. Tot uncommon in dry barren places, and on walls, especially in alpine countries.

Perennial; flowering in June and July.

This grass, though nearly allied to the following species in its general appearance, is rery different in its habit and utility as an agricultural grass, and ought to be carefully distinguished in making selections of seeds to be suwn in different kinds of land. All plants with creeping underground stems imporerish the land much more than those with simple fibrous roots, and ought not to be chosen if the latter can be substituted for them, that possess other equal advantages. The value of this species is the earliness with which it produces its herbage; but the quantity which it produces-for it puts out flowering stems but once in the season, and is of slow growth-compared with manr other grasses, together with its habit, cannot, obserres Mr. Sinclair, justify its claim to a place in the composition of the best natural pastures, and on this account should be carefully aroided as an unprofitable plant for that purpose.

12. P. trivia'lis, Linn. (Fig. 151.) roughish Meadou-grass. Panicle spreading; glumes unequal, pointed, and roughish; florets about three, five-ribbed, connected by a web at the base; stem and leaves roughish; ligula oblong; root fibrous.

English Botany, t. 1072.-English Flora, rol. i.p. 124.-Lindley, Srnopsis, p. 317.-Houker, British Flora, rol. i. p. 46.-Sinclair, Hort. Gram. Woburn. p. 146.

Root fibrous. Stems sereral, bent at the base, erect abore, from one to two feet high, roughish, and leafy, frequently purplish. Leaves spreading, flat, linear, lanceolate, roughish, as well as the long, slightly compressed, striated sheaths. Ligula acute, oblong, or lanceolate. Inforescence an erect, rather large, much branched, spreading panicle; the branches angular and rough. Glumes unequal, roughish: the outer valve smallest, single ribhed; the inner with three ribs. Florets mostly tliree, sometimes purplish. Glumelles roughish: the outer rille acute, five-riblued, the edges thin and membranous at the extremity, the base with rery long, conroluted, slender filaments; the inner valve lanceolate, with two lateral ribs, from which the membranous margins are inflexed. Stigmas feathery, and branched. Anthers yellow or purple, small. Seed small, angular.

Habitat.-Neadows and pastures; common.

Perennial; flowering from June to August. 



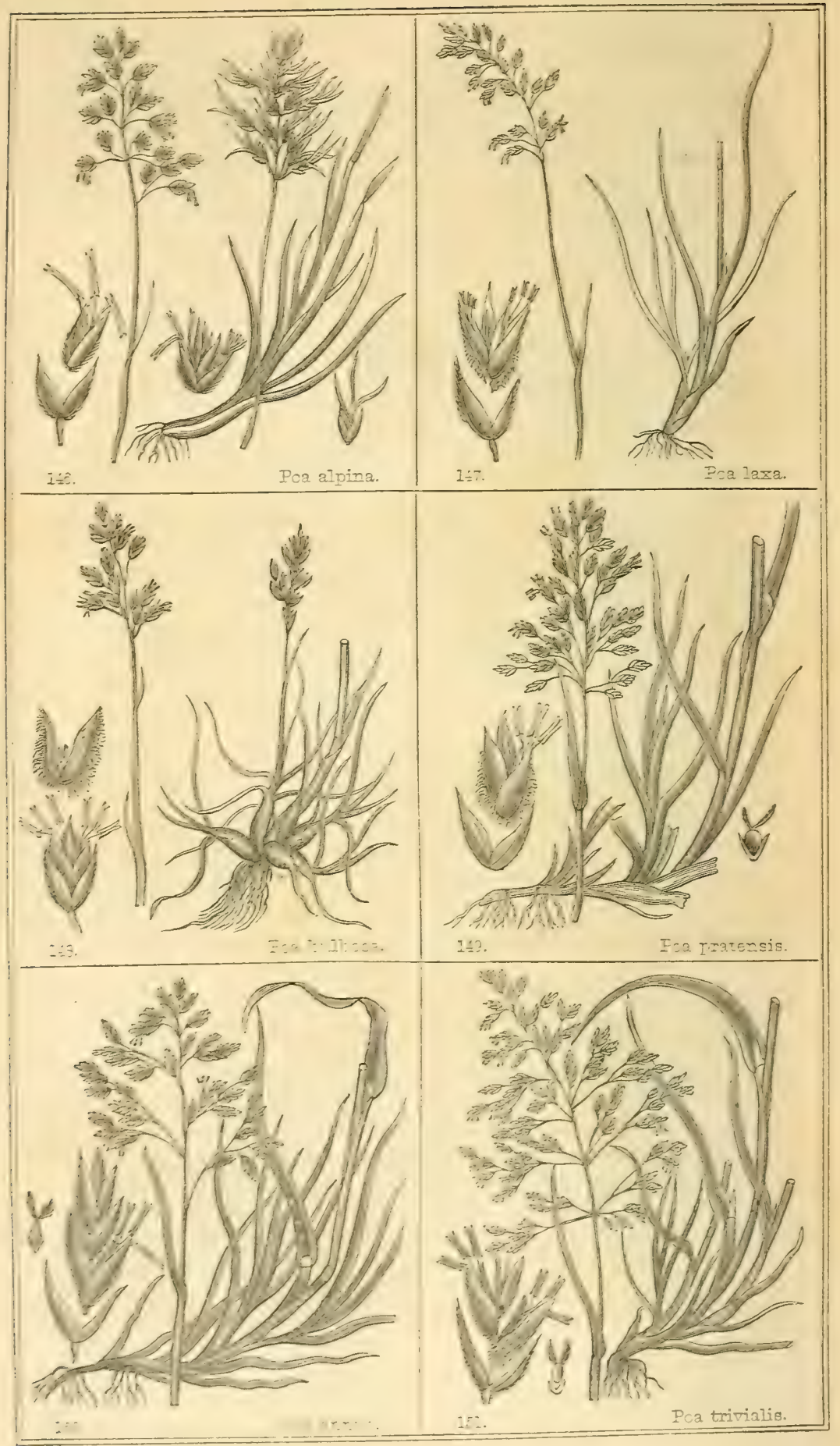


The roughish Meadow-grass is one of the most raluable of our native grasses : it possesses highly nutritire properties, arrives at perfection at the most seasonable period, and is preferred by cattle before almost any other grass, as is erident by those parts of pastures where it is most abundant being more closely eaten down than any other. It grows to the greatest perfection in moist, rich soils, in sheltered situatious, or amongst a mixture of other grasses, where it will get a partial covering : under such circumstances, it has been found to nearly double the quantity of its produce. This grass is most valuable for permanent pastures, and in sowing the seed it should be in the proportion of about seren pounds to the acje. Valuable, however, as this grass is in moist, rich soils, and sheltered situations, it cannot with adrantage be cultirated in dry exposed land, as the quantity of herbage which it produces is far less, and it gradually diminishes, and frequently dies off in the course of a few years.

13. P. an'nua, Linn. (Fig. 150.) annual Meadow-grass. Panicle spreading; glumes unequal; florets about five, a little remote, five-ribbed, hairy, but without web at the base; stem compressed; root fibrous.

English Botany, t. 1141.-English Flora, vol. i. p. 127.-Lindley, Synopsis, p. 317.-Hooker, British Flora, vol. i. p. 46.-Sinclair, Hort. Gram. Woburn. p. 400.

Root fibrous. Stems numerous, bent and branched at the base, smooth, pale, and striated; the lower joints often putting out roots. Leure's linear, flat, flaccid, blunt, frequently waved, a bright palish green, smooth, except a slight roughness on the eilges. Shecths close, compressed, smootl. Ligula obtuse in the lower leares, acute in the upper. Inflorescence an erect, spreading, smooth, branched panicle. Glumes unequal, smooth, or roughish: the outer ralre smallest, lanceolate, single-ribbed the inner orate-lanceolate, three-ribbed. Florets about five, rather remote, green tinged with purple, smooth, shining, the margins pale and membranous. Glumelles unequal: the outer orate-lanceolate, acute, fire-ribhed, lairy, without web at the base; the inner valve with two marginal, roughish ribs, bifid at the apex. Anthers yellow. Stigmas large. Seed small, angular, pale.

Habitat.-Common ererywhere.

Annual; flowering from April to November.

This is one of the most common of the grasses, growing almost anywhere upon walls, roofs, the crevices of parements, road-sides, Sc. It is also very various in size, depending upon the place of its growth. It is a very troublesome weed in court-yards, gravel walks, fic., and difficult of extirpation, for it produces seed mearly all the year round: in such like places, it has been recommended to destroy it by boiling water, lime, Sc.; but perhaps the most effectual method is to sprinkle the places pretty well orer with common salt, once or twice during the

vol. I. 
year. For agricultural purposes it is of no value, compared with many ather grasses.

14. P. nemora'lis, Linn. (Fig. 152.) wood Meadow-grass. Panicle slender, slightly drooping, spreading; glumes unequal; florets ahout four, a little remote, silky, scarcely webbed; stem slightly compressed; ligula short, obtuse.

English Botany, t. 1265.-English Flora, vol. i. p. 129.-Lindley, Sfyuopsis, p. 317.-Hooker, British Flora, vol. i. p. 46.-Sinclair, Hort. Gram. Wobuin. p. 182.

B. glau'ca, (Fig. 153.) Thlole plant much smaller, and glaucous.

Hooker, British Flora, rol. i. p. 46.--Po'a glau'ca, English Botany, Ł. 1720.-English Flora, vol. i. p. 128.-Lindley, Synopsis, p. 317.Sinclair, Hort. Gram. Woburn. p. 192.

Root fibrous. Stem from one to three feet high, slender, erect, Eranched at the base, smooth, slightly compressed. Leaves narrow, flat, Iinear, acute, ribbed, roughish on the edges and keel. Sheaths short, close, striated, smooth. Ligula very short, obtuse, notehed. Inflorescence a loose, slightly drooping, spreading, waved, slender, rough, branched panicle. Glumes unequal, ovate-lanceolate, acute, keeled, and obscurely ribbed. Florets from three to fire, rather distant, a shining green tinged with purple. Glumelles nearly equal: the outer Falve with a thin membranous margin, the keel and two lateral ribs silky, the base scarcely webbed; the inner with two strong, smooth, Gateral ribs, the membranous margins inflexed, the point bifid. Stigmas Ieathery. Anthers yellow.

Habitat.-Frequent in woods and shady places.- $\beta$. Frequent on the Welsh and Scotch mountains.

Perennial; flowering in June and July.

The rariety glauca was regarded by Sir J. E. Smith as a distinct species; but from the examination of both wild and cultivated specimens, we think with Sir W. J. Hooker, that it is but an alpine state of Pou nemoralis,

\section{GENUS XXXVII. TRIO'DIA. Brown. Heath-grass.}

GeN. Char. Panicle racemed. Spikelets many-flowered. Glumes two, nearly equal. Glumelles two, unequal: the external one with three nearly equal teeth; the middle one stiff, straight.Name from $\tau_{p}$ ss, three, and oovs, a tooth; in reference to the three-toothed apex of the outer glumella.

2. T. decum'bens, Beaur. (Fig. 154.) decumbent Heath-grass. Panicle a nearly simple raceme of few spikelets; glumes smooth, as long as the florets; ligula a tuft of hairs. 
English Flora, vol. i. p. 131.-Lindley, Synopsis, p. 311.-Hooser British Flora, vol. i. p. 47.-Sinclair, Hort. Gram. Woburn. p. 377.Fes'tuca decum'bens, Linn.-Po'a decum'bens, English Botany, t. 792.

Root with strong fibres, sometimes slightly creeping. Stems mostly numerous, from six to twelve inches high, bent in the lower part, erect in the upper, tough, smooth. Leares linear, acuminate, striated, seattered, with rather long hairs, smooth except towards the point. Sheat?s close, smooth, striated, hairy. Ligula a tuft of rather long whitish hairs. Inflorescence a nearly simple raceme, of from six to twelve spikelets, their footstalks and the rachis rough. Glumes nearly equal, lanceolate, acute, keeled and more or less distinctly ribbed, purplish, the margins thin and pale, smooth except the keel. Florets about four. Glumelles unequal : the external one ovate, smooth, shining, ribbed ; the base with a tuft of short fine white hairs on each side, and frequently the margins are fringed nearly their whole length; the aper with three teeth: the internal valve ovate, obtuse, with two strong, green, ciliated, lateral ribs, from which the thin membranous margins are inflexed. Seed ovate, flat. Stigmas feathery.

Habitat.-On heaths, poor sandy and mountainous districts; no: uncommon.

Perennial; flowering in July.

\section{GENUS XXXVIII. BRI'ZA. LinN. Quaking-grass.}

Gen. Char. Panicle loose. Spikelets many-flowered. Glumes two, equal. Glumelles two, unequal, awnless; the outer convex swelled at the base; the inner small and flat. Fruit closely invested with the glumelles.-Name from " $\beta_{p} b \omega$, to balance; tho spikelets being most delicately suspended."

1. B. me'dia, Linn. (Fig. 155.) common Quaking-grass. Spikelets broadly ovate, of about seven florets; glumes shorter than the florets; ligula short, obtuse.

English Botany, t. 340.-English Flora, rol. i. p. 133.-Liniley, Synopsis, p. 315.-Hooker, Eritish Flora, vol. i. p. 4\%.-Sinclair, Wort. Gram. Wobum. p. 205.

Root fibrous, often woolly. Stems mostly numerous from the same root, erect, from one to two feet high, slender, smooth, surrounded with numerous leaves at the basc. Leares rather short, linear, acuminate, roughish, especially towards the point. Sheaths close, smooth, striated. Ligula short, obtuse. Inflorescence a wide-spreading, slender, roughish, repeatedly branched panicle. Spikelets numerous, broadly ovate, smooth, and shining. Glumes orate, obtuse, very concare, slightly compressed, three-ribbed, purple, with a pale, narrow, membranous margin. Florets about seven. Glumelles unequal: the outer ralvo 
like the glumes, but larger and more concare; the inner much smaller, plane, with two lateral roughish ribs, the apex bifid. Stigmas long: feathers. Fruit triangular, closely invested with the glumelles.

\section{Habitat.-Pastures; very common.}

Perennial; flowering in May and June.

The appearance and size of this grass varies considerably: it is not uncommon to find it in some situations two, or even three, feet high, and in others not more than four or six inches. The elegant and graceful panicles, supporting their orate spikelets upon slender, silklike stalks, are put into a tremulous motion by the slightest passing breeze; hence its popular name of Quaking, or Trembling Grass: and the various shates of colour which they are found, (often in the same locality, from a dark shining purple to a pale sellowish-green, have rendered them a farourite winter decoration and ornament. It is a grass containing a considerable proportion of nutritire matter, is eaten by most cattle, and is cultirated with the greatest adrantage in poor sandy or strong tenacious soils; but in rich pasture or meadow lands, it is not cultirated with the same adrantage or profit, but is injured by a too great supply of manure.

2. B. minor, Linn. (Fig. 156.) small Quaking-grass. Spikelets triangular, of about seren florets; glumes longer than the fiorets; ligula elongated, acute.

British Flora, rol. i. p. 133.-English Botanr, t. 1316.-Lindler, Synopsis, p. 315.-Hooker, British Flora, vol. i. p. 47.

Root fibrous, downy. Stem from three to six inches high, smooth, often branched at the base. Leaves linear, roughish on the edges. Sheaths close, smooth. Ligula elongated, acute, more or less decurrent. Inflorescence similar to the last, but smaller, as is the whole plant. Spikelets triangular, smooth, green or white, shining, sometimes purplish. Glumes longer than the florets, which are generally seren in number. Glumelles unequal: the outer valve very concave, and swollen at the base; the inner much smaller, and flat, with two marginal ribs, and bifid at the apex. Stigmas long, feathery. Fruit closely invested by the glumelles.

Habitat.-Fields in the South of England; very rare. About Bath; in Cornwall, Jersey, and Guernsey.

Annual; flowering in July.

\section{GENUS XXXIX. FESTU'CA. Linn: Fescue-grass.}

Gex. Char. Panicle loose or contracted. Spikelets many-fiuwered. Glumes two, unequal. Glumelles two, the outer valve acuminate or arned at the apex.-The derivation of the name is doubtful: 


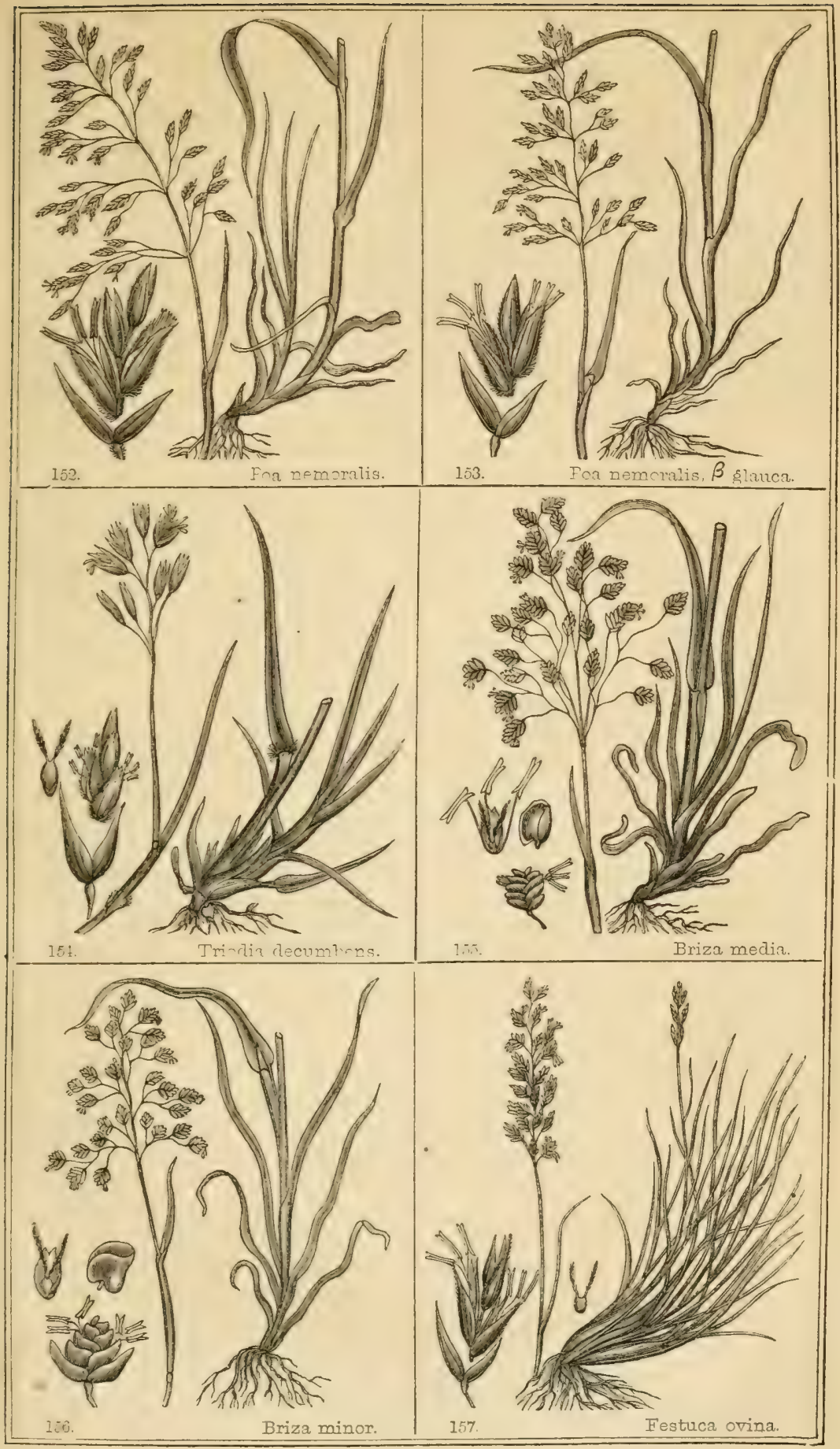






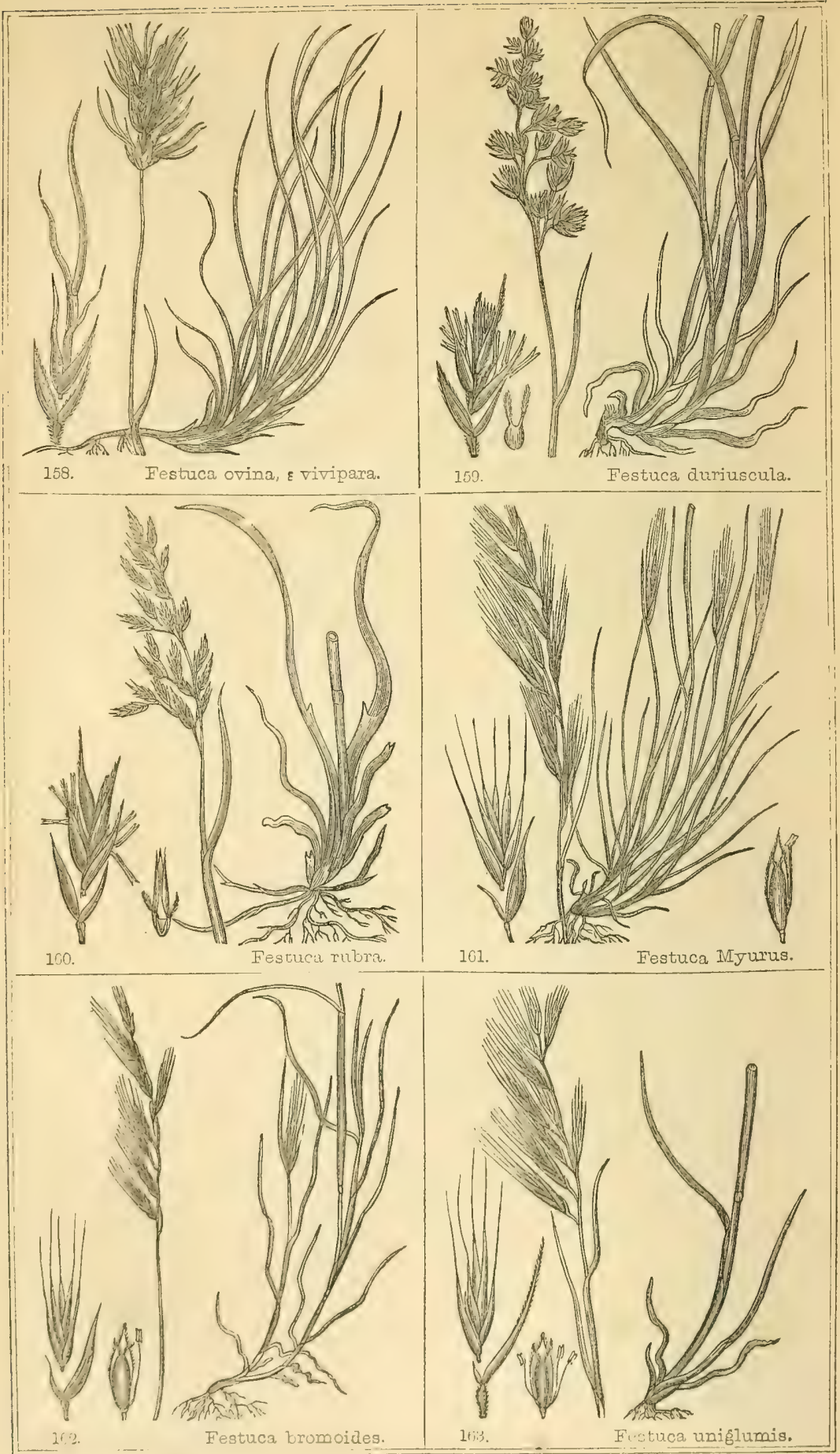


according to Pheis, it is from the Celtic word fest, which signifies food or pasturage; in Iatin, the word festuca signifies the shoot or stalk of a tree or herb.

\section{* Glumelles with a short awn.}

1. F. ovi'na, Linn. (Fig. 157 and 158.) Sheep's Fescue-grass. Panicle rather close; spikelets mostly turned to one side, oblong, of about five florets; stems square upwarls; leaves bristle-shaped.

English Botany, t. 555.-English Flora, vol. i. p. 139.-Lindley, Synopsis, p. 313.-Hooker, British Flora, vol. i. p. 48.-Sinclair, Hort. Gram. Woburn. p. $25 \%$.

ß. Sm. ru'bra; panicle purplish. Festu'ca ru'bra, Withering.

$\gamma$. Sm. cœ'sia; whole plant glaucous. Festu'ca ce'sia, English Botany, t. 1917:

S. Sm. tenuifo'lia; leaves more numerous, longer, and slenderer; glumelles acuminate, awnless. Festu'ca tenuifo'lia, Sibthorp, Schrader.

E. Hook. vivip'ara, (Fig. 158.); plant taller; florets viviparous. Festu'ca ovi'na, $\beta$. Linn. $\gamma$. Schrader.-Festu'cu vivip'ara, English Botany, t. 135̃̃.-English Flora, vol. i. p. 140.-Lindley, Synopsis, p. 313 .

Root of numerous, long, smooth, branched fibres. Stems numerous, from three to eighteen inches high, erect, smooth, slender, round and leafy in the lower part, naked and square in the upper. Leares very numerous, tufted, narrow, acute, their margins so closcly rolled inwards as to appear bristle-shaped, smooth at the base, roughish towards the apex, mostly of a somewhat glaucous-green, and varying considerably in their length. Sheaths close, smooth, striated. Ligula very short, projecting on each side. Inflorescence an erect, short, rough branched, rather close, one-sided panicle. Spikelets oblong, often purplish. Glumes unequal, acute, nearly smooth, keeled, and with two more or less distinct lateral rilss. Florets about five, rather distant. Glumelles equal: the outer valve keeled and ribbed, smooth, except towards the apex, which is more or less rough; sometimes downy, especially in the viviparous variety; acuminated or awned at the extremity; the awn roughish, variable in length, but not longer than half the length of the ralve: the inner valve with two lateral roughish ribs, and bifid at the apex. Stigmas feathery.

Habitat.-On dry, elevated pastures; common.--. On the mountains of Scotland, Wales, and Ireland; frequent.

Perennial; flowering in June and July.

This grass, which is found abundant on downs, high moors, and dry sandy situations, is a favourite food of sheep, and its fine succulent foliage is well fitted for their organs of mastication. It is said to be from the sheep feeding on this grass, that the South Down and Forest mutton obtains its superiority. For cultivation, this grass is little 
capable of improvement; it is true that a greater produce is obtained when it is grown in a rich loamy soil, but not in proportion to the quantity that can be produced from other grasses in the same situation. Its value as a pasture grass is limited to the natural places of its growth, to which it is admirably adapted by its long, penetrating, fibrous roots,-the close, tufted manner of its growth,-and its narrow, thread-like leaves. Mr. Curtis has pointed out the advantage of this grass for making grass-plats, lawns, or bowling-greens: it does not require so frequent mowing, and keeps greener in dry weather, owing to the length of its roots: for this purpose it will be found to answer best in a light sandy soil.

2. F. durius'cula, Linn. (Fig. 159.) hard Fescue-grass. Panicle spreading; spikelets mostly turned to one side, oblong, of about six awned florets; stem round; stem-leaves nearly flat, lower ones bristle-shaped; root fibrous.

English Botany, t. 470.-English Flora, vol. i. p. 141.-Lindley, Synopsis, p. 314.-Hooker, British Flora, vol. i. p. 49.-Sinclair, Hort. Gram. Woburn. p. 156.

Root fibrous, tufted. Stem erect, from one to two feet high, smooth, striated, round. Upper leaves nearly flat, with long, close, smooth, striated sheaths; the lower leaves numerous, much longer, striated, and keeled; the margins closely rolled inwards, so as to appear bristleshaped; their sheaths shorter, hairy or downy. Ligula very short, obtuse. Inflorescence an erest, somewhat spreading, one-sided panicle; its branches short, angular, rough. Spikelets oblong, green or purplish, smouth, or sometimes roughish. Glumes unequal: the outer valve shortest, keeled; the inner keeled and ribbed. Florets about six, rather distant. Glumelles equal: the outer keeled, ribbed, and awned, the awn not more than half the length of the valve; the inner valve with two lateral, roughish ribs, the apex bifid. Stigmas protruding, feathery. Anthers yellow.

This species is nearly allied to the above, from which it is ance distinguished by its greater size and stoutcr habit.

Habitat.-In pastures, meadows, and waste places; plentiful.

Perennial; flowering in June and $J$ uly.

This is always found among the grasses of a natural pasture, especially where the soil is rather of a light rich nature. It is one of the best grasses for sheep, springing early, and producing fine sticculent herbage, though not very abundant; and its long fibrous roots enable it to withstand the injurious effects of continued dry weather. Mr. Sinclair remarks, that " it attains to the greatest perfection when combined with the Festu'ca praten'sis and $P_{0^{\prime}}$ a txivialis," and that it is entitled "to a place in the composition of the best pastures, though in a small proportion." 
3. F. ru'bra, Linn. (Fig. 160.) creeping Fescue-grass. Panicle spreading; spikelets turned to one side, oblong; florets longer than their awns; leaves downy on their upper side, more or less involute; root with extensively creeping, underground stems.

English Botany, t. 2056.-Fnglish Flora, vol. i. p. 142.-Lindley, Synopsis, p. 314.-Hooker, British Flora, vol. i. p. 49,-Sinclair, Hort. Gram. Woburn. p. 261.

Root with extensive creeping, underground stems, - the only character by which this can be distinguished from the above species; " and may not this," Sir IV. J. Hooker observes, " be owing to a peculiarity in soil and other accidental circumstances?" According to the opinions of Smith, Schrader, and Sinclair, this character is sufficient to distinguish it as a species.

Habitat.-Sandy pastures near the sea, plentiful; and "in mountainous pastures and alpine precipices."

Perennial; flowering in July.

This, Mr. Sinclair says, " has no superior merit orer those species it resembles in habit, to compensate for the imporerishing effects of its creeping roots to the soil."

\section{** Glumes very unequal; glumelles with a long awn.}

4. F. Myu'rus, Linn. (Fig. 161.) Wall Fescue-grass. Panicle elongated, rather close, somewhat drooping; spilelets leaning one way; florets shorter than the awn, containing only one stamen; stem leafy in its upper part.

English Botany, t. 1412.-English Flora, vol. i. p. 143.-Hooker, British Flora, vol. i. p. 49.-Sinclair, Hort. Gram. Woburn. p. 266.Vul'pia Mryu'rus, Gmelin. Lindley, Synopsis, p. 314.

Root small, fibrous. Stem from twelve to eighteen inches high, erect, smooth, striated, leafy nearly to the top. Leaves short, awlshaped, striated, and smooth. Sheaths close, smooth, striated. Ligula short, obtuse. Inflorescence a slightly drooping, angular, roughbranched, lax panicle, from two to live inches long. Glumes pointed or awned: the outer smallest, keeled; the inner kecled and ribbed. Florets narrow, tapering, cylindrical. Glumelles nearly equal: the outer valve ribbed, roughish towards the apex, terminating in a fine rough awn, longer than itself; the inner valve thin, with two lateral greenish ribs, roughish and bifid at the apex. Stigmas very small, feathery. Stamen only one. Anther yellow. Fruit long, narrow, deeply channelled on one side, downy towards the apex.

Habitat.-Walls, and barren sandy grounds; not uncommon in England,-less frequent in Scotland and Ireland.

Annual; flowering in June and July. 
5. F. bromoid'es, Linn. (Fig. 162.) barren Fescue-grass. Panicle erect; spikelets turned to one side; florets shorter than the awn, containing only one stamen; stem leafless in the upper part.

Euglish Botany, t. 1411.-English Flora, rol.i. p. 142.-Hooker, British Flora, rol. i. p. 49.-Vul'pia bromoid'es, Dumort. Lindley, Synopsis, p. 315.

Greatly resembling the abore species, except in being much smaller. Stem from six to twelre inches high, naked in the upper part. Leares varrow, tapering, bristle-shaped, from the inflexed edges; the upper ones shorter than the close, striated, smooth sheatlis. Ligula rery short. Inflorescence a short, scarcely branched panicle, sometimes racemerl. Spikelets mostly turned to one side. Glumes rery unequal: the larger keeled, and with two lateral ribs; the smaller keeled. Florets narrow, tapering, about six. Glumelles nearly equal: the outer roughish, terminating in an awn longer than itself; the inner with two marginal, roughish, green ribs, scarcely bifid at the apex. Stigmas small, feathery. Stamen only one. Anther yellow. Fruit long; deeply channelled on one side:

Habitat.-Walls and dry places; not very common in England and Ireland,-less so in Scotland. About Edinburgh, and Isle of Arran, on the sandy beach.

Annual; flowering in Jume.

6. F. uniglu'mis, Soland. (Fig. 163.) single-glumed Fescue-grass. Panicle an erect, two-ranked raceme; florets compressed, shorter than their awn; outer valve of the glumes very small.

English Botany, t. 1430.-English Flora, vul. i. p. 144.-Hooker, British Flora, vol. i. p. 50.-Vul'pia uniglu'mis, Dumort. Lindles, Synopsis, p. 314.

Font fibrous. Stem erect, sereral from the same root, from six to eighteen inches high, smooth and leafy, almost to the top. Leares short, acute, striated, smooth, or sometimes scattered with hairs. Sheaths long, striated, smooth, close. Ligula short, obtuse. Inflorescence an erect, simple, two-ranked racemose panicle; its branches sbort, dilated, and roughish. Spikelets mostly turned to one side. Glumes rery unequal; the outer almost obsolete. Florets tapering, compressed. Glumelles nearly equal: the outer ralve terminating in a roughish awn, longer than itself; the inner with two marginal, roughish rils, scarcely bifid at the apex. Stigmas short, feathery. Stamens three. Anthers yellow. Fruit oblong, deendy channelled on one side.

Hatitat.-On the sandy sea-coast, chiefy of Sussex. Portmarnock Sandhills, Ireland.

Biennial-Smith; annual-Hooker; flowering in June. 
*** Glumes unequal; glumelles acute, scarcely awaed.

7. F. calama'ria, Smith, (Fig. 164.) Reed Fescue-grass. Panicle nearly erect, nuch branched, spreading; spikelets oblong; florets from three to five; leaves linear, lanceolate.

English Botany, t. 1005.-English Flora, vol. i. p. 146.-Hooker, British Flora, rol. i. p. 50.-Schedon'orus sylvat'icus, Beauris, Lindley, Synopsis, p. 313.

B. minor, Hook.; smaller, with scarcely more than two perfect florets.-Festu'ca decid'ua, Smith, English Botany, t. 2266.

Root fibrous. Stem erect, sereral from the same root, from two to three feet high, round, and smooth. Leaves large, broad, linear, lanceolate, from six to eighteen inches long, ribbed and striated, the edges rough, and sometimes the whole leaf. Sheaths close, striated, roughish. Ligula short, torn, sometimes pointed. Inflorescence a nearly erect, spreading panicle; its branches angular, repeatedly divided, and generally roughish towards the extremity. Spikelets oblong, mostly purplish or brown. Glumes unequal, narrow, lanceolate: the outer valve keeled; the inner keeled, and with two lateral ribs. Florets rather distant. Glumelles equal: the outer valve lanceolate, with an elongated membranous point, keeled and remotely ribbed, roughish; inner thin, membranous, with two lateral smooth or roughish ribs, bifid at the extremity. Sigmas feathery. Fruit small.

Habitat.-M Iountainous woods, not unfrequent.

Perennial; flowering in June and July.

8. F. praten'sis, Hudson, (Fig. 165.) Headow Fescue-grass. Panicle nearly erect, brauched, spreading; spikelets linear, compressed; florets numerous; leares linear; root tibrous.

English Botany, t. 1592.-English Flora, wol. i. p. 148.-Honker, British Flora, vol. i. p. 50.-Sinclair, Hort. Gram. Woburn. p. 149.Schedon'or'us praten'sis, Beauris, Lindley, Synopsis, p. 312.

Root fibrous, tufted. Stems erect, numerous, from one to two feet high, smooth, leafy. Leares linear, flat, pointed, spreading, rough on the edges, and frequently on both sides of the upper ones. Sheaths close, smooth, and striated. Ligula short, obtuse, generally torn. Inflorescence an erect, spreading, roughish, angular, branched panicle. Spikelets linear-oblong, compressed. Glumes unequal, acute, smooth : the outer smallest, keeled; the inner lanceolate acute, keeled, and two or four ribbed. Florets about eight. Glumelles equal: the outer ralre ovate-lanceolate, acute, keeled and obscurely ribbed, and roughish towards the apex, which is membranous, sometimes cloven, and the keel elongated into a short roughish awn; inner valve with two marginal, roughish, green ribs, bifid at the apex. Glumellules "with four diraricated points." Stigmas feathery. Fruit small, lanceolate.

YOL. $I$. 
Habitat.-Meadows and pastures, frequent.

Perennial ; Howering in June and July.

The Meadow Fescue, observes Mr. Sinclair, "constitutes a very considerable portion of the herbage of all rich natural pastures and irrigated meadows; it makes excellent hay, and though a large plant, the leaves or herbage are succulent and tender, and apparently much liked by cattle, as they never form rank tufts, which is the case with the larger grasses. It does not appear to arrive at its full productive powers from seed so soon as either the Cocksfoot or Foxtail Grass, and though essential for permanent pastures, is not by itself very well adapted for the alternate husbandry, but should be combined with Cocksfoot, Rye-grass, and Rough-stalked Meadow-grass."

9. F. ela'tior, Linn. (Fig. 166.) tall Fescue-grass. Panicle large, much branched, somewhat drooping; spikelets ovate-lanceolate; florets numerous, somewhat awned; leaves linear-lanceolate; root with creeping stems.

English Botany, t. 1593.-English Flora, vol. i. p. 148.-Hooker, British Flora, vol. i. p. 50.-Sinclair, Hort. Gram. Woburn. p. 161.Schedon'orus ela'tior, Beauvis, Lindley, Synopsis, p. 313.

Root with downy fibres, and creeping underground stems. Stems erect, stout, from three to four feet high, striated, smooth and leafy. Leares linear-lanceolate, striated, smooth, except the margins. Sheaths very long, close, smooth, striated. Ligula short, obtuse, mostly torn. Inflorescence a large, much branched, spreading, slightly drooping panicle. Spikelets numerous, ovate-lanceolate, scarcely compressed. Glumes unequal : the outer smallest, keeled; the inner keeled, ribbed, ovate-lanceolate. Florets from eight to ten. Glumelles equal: the outer valre ovate-lanceolate, ribbed, membranous, and bifid at the point, the keel mostly terminating in a short awn; the inner valve with two green, hairy, marginal ribs. Glumellules similar to the last. Fruit ovate. Stigmas feathery.

Habitat.-Moist meadows, banks of rivers and ditches; much less frequent than the above species.

Perennial; flowering in June and July.

This is one of the best grasses that can be cultirated in clayey lands, either for the purpose of grazing or making into hay. Its herbage is abundant, and produced early in the spring, containing a considerable proportion of nutritive matter, and is eaten by most cattle.

10. F. lolia'cea, Linn. (Fig. 167.) spiked Fescue-grass. Spikelets. arranged in an elongated, two-ranked spike; spikelets linearoblong, nearly sessile, distant ; florets numerous, awnless.

English Botany, t. 1821.-English Flora, vol. i. p. 147.-Hooker, British Flora, vol. i. p. 50.-Sinclair, Hort. Gram. Woburn. p. 178. Schedon'orms lolia'cea, Dumort, Lindley, Synopsis, p. 313. 
Root fibrous. Stem erect, simple, from one to two feet high, smooth, and leafy. Leaves short, linear, acute. Sheaths rather long, close, smooth. Ligula very short. Inflorescence a simple, slightly drooping, two-ranked raceme, from three to eight inches long. Rachis wared, angular, alternately channelled, in which the spikes have been placed in an early stage of their growth, the angles roughish. Spikelets nearly sessile, linear-oblong, rather distant, ahout six-flowered. Glumes unequal, lanceolate, acute, seven-ribbed; the inner valve smallest, sometimes wanting. Glumelles nearly equal, ovate-lanceolate, compressed, membranous towards the point, and slightly five-ribbed, smooth, except a slight roughness on the ribs. Stigmas densely feathery. Fruit ovate, but seldom perfected.

Habitat. - In meadows and pastures, especially such as are occasionally orerflowed; common.

Perennial ; flowering in June and July.

This grass at first sight might be mistaken for Lo'tium peren'ne, (Rye-grass,) from which, however, it is readily distinguished by having two glumes, while that just named has only one. This grass, which grows in similar situations to the Rye-grass, is much more valuable for agricultural purposes, affording a greater proportion of nutritive matter, and producing its herhage in greater abundance; it comes also earlier in the spring, and improves by age-qualities which strongly recommend it for cultivation in place of the Rye-grass; but unfortunately the seed is seldom perfected, and its propagation by the dirision of its roots would be too expensire a process.

\section{GENUS XL. BRO'MUS. LINN. Brome-grass.}

Gen. Char. Panicle loose. Spikelets many-flowered. Glumes two, unequal. Glumelles two, the outer awned below the bifid apex.

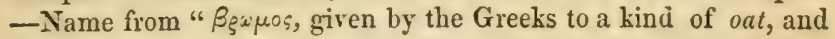
that again from $\beta_{\xi} \omega \mu \alpha$, food." $-H o o k$.

* Spikelets lanceolate; glumes rery unequal, lanceolate-acute.

1. B. gigan'teus, Vill. (Fig. 168.) tall Brome-grass. Panicle large, branched, spreading, drooping towards one side; spikelets compressed, from three to six-flowered, ribbed; awn longer than the floret; leares linear-lanceolate.

Hooker, British Flora, vol. i. p. 50.-Festu'ca gigan'tea, English Botany, t. 1820.-English Flora, vol. i. p. 144.-Lindley, Synopsis, p. 314,-Sinclair, Hort. Gram. Woburn. p. 376.

B. triflo'rus, Hook.; a smaller and more erect plant; spikelets three-10wered,-Festu'ca triflo'ra, E. Bot. t. 1918. 
Root of many strung, more or less downy fibres. Stem erect, sim. ple, round, smooth, striated, and leafy, from three to four feet high. Leares broad, linear-lanceolate, nearly erect, ribbed, rough on the upper side and margins, pale and smooth beneath. Sheaths long, close, smooth, striated. Ligula very short, mostly torn, with a projecting portion on each side, which clasps the stem. Inflorescence a large, compound, spreading panicle, its branches angular and rough, drooping on one side. Spikelets orate-lanceolate, compressed, from three to six-flowered. Glumes very unequal: the outer small, frequently awlshaped, keeled; the inner lanceolate, acute, the keel and two lateral ribs rough. Glumelles nearly equal: the outer lanceolate, smooth, membranous, and obscurely ribbed towards the extremity, the apex bifid, awn long, inserted below the point; inner valve membranous, with two lateral downy ribs, the apex bifid. Stigmas feathery. Fruit oblong.

Habitat._-Noist shady woods and hedges. $\beta$. In drier situations. Saham, Norfolk; and near Forfar, in Scotland.

Perennial; flowering in July and August.

This is a coarse grass, containing but a small proportion of nutritive matter; and although a native of woods and shady situations, it will flourish in open exposed places; but it appears to possess no properties to render it worthy the notice of the agriculturist.

2. B. as'per, Linn. (Fig. 169.) hairy Wood Brome-grass. Panicle branched, drooping; spikelets compressed ; florets remote, hairy ; awn shorter than the floret; leaves uniform, the lower ones hairy.

English Botany, t. 1172.-English Flora, vol. i. p. 158.-Lindley, Synopsis, p. 312.-Hooker, British Flora, vol. i. p. 54.

Root of many strong branched fibres. Stem erect, simple, striated, round, smooth, and leafy upwards, from four to six feet high. Leaves broad, spreading, lanceolate, rough, the lower ones hairy, many-ribbed. Sheaths long, close, striated, and more or less clothed with deflexed hairs. Ligula short, obtuse. Inflorescence a very lax, wide-spreading, drooping panicle, its branches slender, subdivided, rough. Spikelets compressed, about an inch long. Florets about eight, rather remote. Glumes very unequal, sharply pointed, rough: the outer valre smallest, keeled; the inner keeled, and with two lateral ribs. Glumelles nearly equal: the outer lanceolate, ribbed, roughish, and hairy, membranous on the edges towards the extremity, and bifid at the apex; the aun stout, straight, rough, shorter, or about the length of the valve; the inner valse shortest, obtuse, its lateral ribs finely hairy. Stigmas densely feathery. Fruit linear, blunt, and downy towards the summit, furnowed on one side.

Habitat.-Moist woods and hedges, not very common.

Annual or biennial; flowering from June to August. 


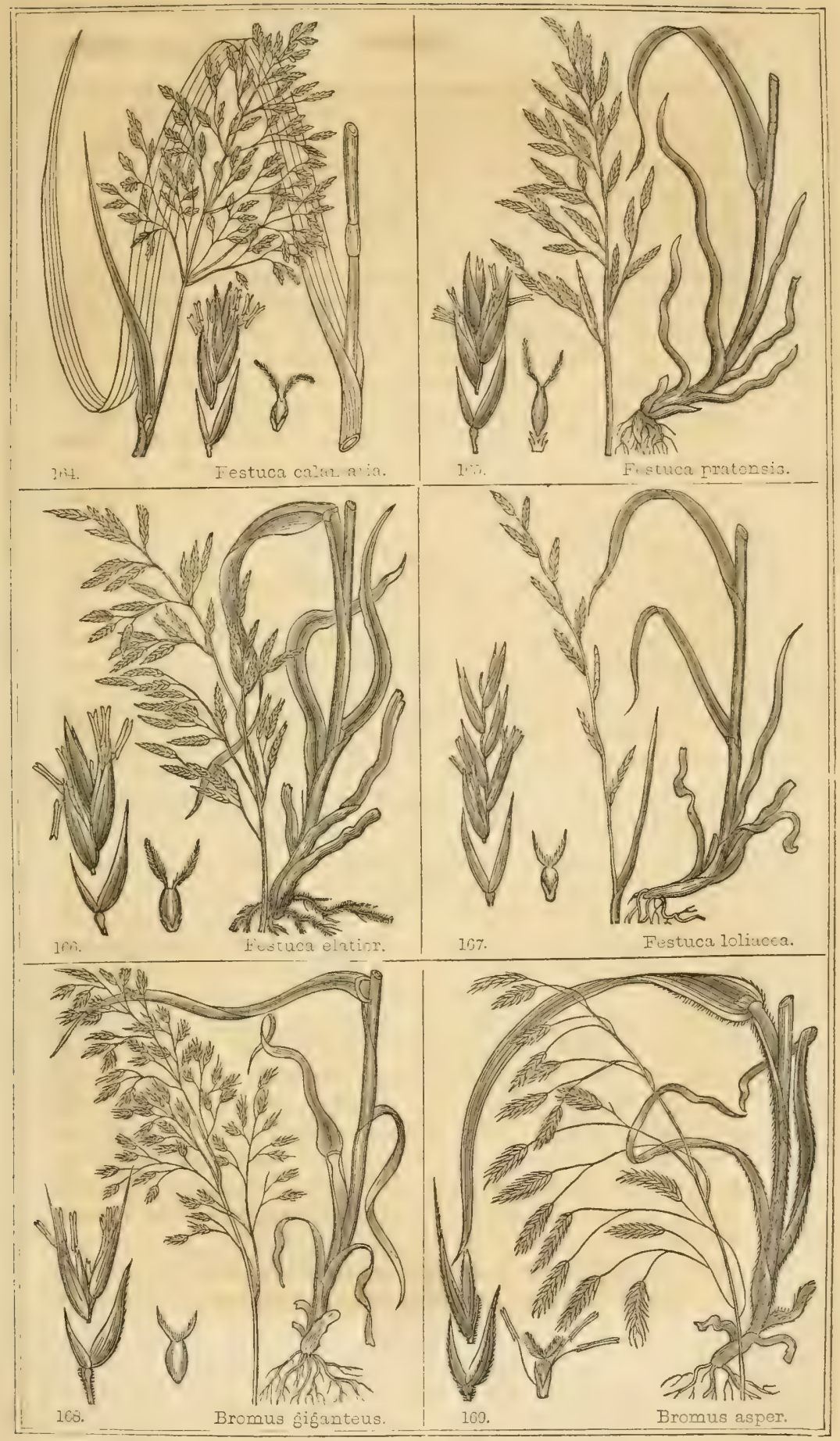






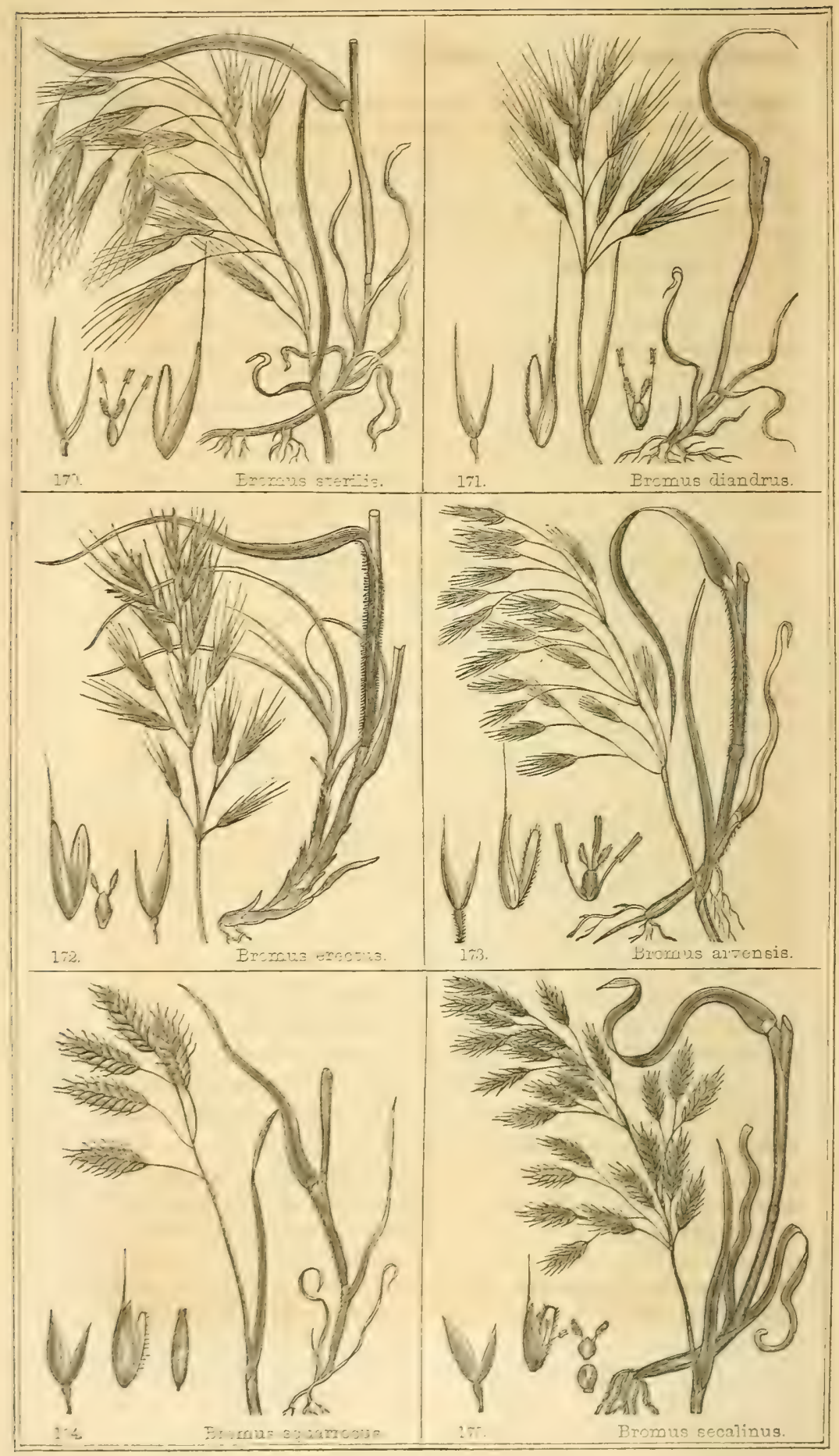


3. B. ster'ilis, Linn. (Fig. 170.) barren Brome-grass. Panicle scarcely branched, drooping; spikelets compressed on long stalks; florets remote, rough; awn longer than the floret; leares flat, linear, downy.

English Botany, t. 1030.-English Flora, vol, i. p. 159.-Lindley, Synopsis, p. 312.-Hooker, British Flora, vol. i. p. 51.-Sinclair, Hort. Gram. Woburn. p. 296.

Root small, fibrous, woolly. Stem from one to two feet high, round, slender, striated, leafy even to the panicle. Leares narrow, ribbed, soft and downy, with a few scattered hairs towards the base. Sheaths rather short, close, striated, downy, and more or less clothed with deflexed hairs. Ligula short, mustly torn. Inflorescence a large, gracefully drooping, wide-spreading panicle; its branches long, slender, rough, angular, scarcely subdivided, dilated near the extremity. Spikelets about an inch long, drooping, compressed, about eightflowered, purplish towards the extremity. Glumes very unequal, rough: the outer keeled, awl-shaped; the inner lanceolate, membranous towards the extremity, keeled, and with two lateral ribs. Glumelles very unequal, rough: the outer valve long, narrow, memhranous on the upper part of the margin, and bifid at the apex, t..e beel and numerous ribs uniting and forming a long, stiff, rough awn; the inner valve thin, pale, membranous, its two green lateral ribs ciliated, with short white hairs. Stigmas small, feathery. Frutit long, narrow, hairy at the apex, deeply furrowed on one side.

Habitat.--Tcry common in waste places, hedges, and shady situations.

Annual; flowering in June and July.

The name sterilis, which distinguishes this grass, is not given to it from its producing but a small quantity of seed, as supposed by some authors, but from the innutritious quality of its herbage, and its inutility as food for cattle.

4. B. dian'drus, Cun. (Fig. 171.) upright annual Brome-grass. Panicle erect, slight!! branched and spreading; spikelets compressed on short stalks; florets remote, scarcely rough; awn as long as the floret; stamens mostly two; leares nearly smooth.

English Botany, t. 1006.-English Flora, vol. i. p. 160.-Lindley, Synopsis, p. 312.-Horker, British Flora, vol. i. p. 51.-Sinclair, Hort. Gram. Woburn. p. 297.-Bro'mus Madriten'sis, Linn.

Root small, fibrous. Stem erect, several from the same root, from twelve to eighteen inches high, round, striated, smooth, and leafy. Leaves narrow, smooth, or downy. Sheaths close, striated, smooth, os sometimes downy. Ligula short, mostly torn. Inflorescence an erect, somewhat spreading panicle, its branches dilated towards the extremity, short, stiff, and roughish, scarcely ever subdivided. Spikelets 
erect, mostly tinged with purple or brown, about an inch long, and eight-flowered, roughish. Florets inserted upon the flower-stalk by a swollen base. Glumes very unequal, roughish : the outer keeled, awlshaped; the inner with a keel and two lateral ribs. Glumelles unequal: the outer valve long, narrow, the margin membranous towards the extremity, the apex bifid, having four lateral ribs and occasional intermediate ones, the keel terminating in a long rough awn. Stamens two, hence its specific name. Stigmas feathery. Fruit very long, narrow, channelled on one side, the apex hairy.

Habitat.-Rare, on dry sandy ground and on walls, principally in the South of England. About Edinburgh, Scotland-Mr. Arnott.

Annual; flowering in June and July.

5. B. erec'tus, Hudson, (Fig. 172.) upright Brome-grass. Pauicle erect, slightly branched; spikelets compressed, smooth; awn about the length of the rather remote florets; root leaves very narrow and ciliated.

English Botany, t. 471.-English Flora, vol. i. p. 157.-Lindley, Synopsis, p. 312.-Hooker, British Flora, vol. i. p. 52.-Sinclair, Hort. Gram. Woburn. p. 203.

Root strong, tibrous. Stem erect, smooth, leafy, slender, from two to three feet high. Leaves numerous: the upper ones broad, linear, nearly smooth; the lower ones narrower, clothed with hairs. Sheaths close, striated, downy, and more or Jess hairy. Ligula short, mostly torn. Inflorescence an erect, rather close, more or less branched panicle. Spikelets erect, about an inch long, nearly smooth. Florets mostly seven, purplish, spreading when in flower. Glumes very unequal: the outer awl-shaped and keeled; the inner lanceolate, acute, keeled and ribbed. Glumelles equal, acute: the outer one lanceolate, its margins membranous, the apex bifid, smooth or scabrous at the back, with two strong ribs and one or two slight intermediate ones, the keel tapering into a straight awn. Stigmas feathery. Anthers yellowish saffion colour.

This plant has much the habit of Brachypo'dium sylvat'icum.

Habitat. - In fields and by road-sides, especially in a sandy soil over chalk, not common. About Edinburgh, frequent. On a calcareous soil, Lands of Santry and Coolock, Ireland-Mr. J. White.

Perennial; flowering in July.

6. B. arven'sis, Linn. (Fig. 173.) taper Field Brome-grass. Panicle spreading, at length drooping, its branches subdivided; spikelets compressed, smooth; awn about the length of the imbricated florets; leaves hairy.

English Botany, t. 1984.-English Flora, vol. i. p. 156.-Lindley, Synopsis, p. 312.-Hooker, British Flora, vol, i. p. 52.-Sinclair, Hort. Gram. Woburn. p. 173. 
Root fibrous. Stem sometimes procumbent at the hase, and rooting from the lower joints; the upper part erect, round, striated, slender, emooth, leafy. Leaves spreading, many-ribbed, either nearly smooth or clothed with short deflexed pubescence. Sheaths close, striated, neariy smooth, or clothed with defiexed pubescence. Ligula short, obtuse. Inflorescence a rather large, partly whorled, drooping, at length pendulous panicle; its branches roughish, subdivided, and spreading; the lowermost whorl surrounded at the base with varioussized notched scales. Spikelets smooth or minutely downy, purplish. Florets about eight, imbricated. Glumes unequal, sharp-pointed. Glumelles nearly equal: the outer with four lateral ribs, and a keel which terminates in a purplish rough awn about the length of the valve; the inner with two green lateral ciliated ribs. Stigmas feathery. Anthers purple.

Habitat.-Corn-fields and rich meadows, rare. Durham, near the coast. Less rare in Scotland. Near Cullenagh, Queen's County, and fields near Sandy Mount, Ireland.

Annual; flowering in June and July.

* Spikelets ovate-lanceolate; glumes unequal, orate-lanceolate.

7. B. squarro'sus, Linn. (Fig. 174.) Corn Brome-grass. Panjcle drooping, scarcely branched; spikelets somewhat compressed; florets imbricated, nearly smooth; awn the length of the floret, spreading; leares downy:

English Botany, t. 1885.-English Flora, rol. j. p. 155.-Lindley, Synopsis, p. 311.-Hooker, British Flora, rol. i. p. 52.

Root small, fibrous. Stem erect, simple, about a foot high, smooth, striated. Leaves narrow, linear, striated, and more or less clothed with soft pubescence. Sheaths short, covered with deflexed hairs. Ligula short, obtuse, hairy. Inflorescence a short, nearly simple, drooping panicle. Spikelets few, large, ovate, somewhat compressed, about an inch long. Florets imbricated, compressed, about twelve. Glumes unequal, ribbed: the outer lanceolate acute; the inner orate lanceolate. Glumelles nearly equal: the outer ovate oblong, the margins somewhat inflexed, the apex bifid, ribs prominent, three or four on each side; the aun inserted between the bifid extremity, about as long as the valve, strong, rough, twisted, and remarkably spreading; inner valve obtuse, its green lateral ribs strongly ciliated. Stigmas feathery. Fruit long, narrow, channelled on one side, and hairy at the apex.

Habitat.-Rare. Corn-fields in the South of England. ScotlandMr. G. Don. "Not indigenous"--Hooker.

Annual; flowering in June and July.

8. B. secali'nus, Linn. (Fig. 175.) smooth Rye Brome-grass. Panicle spreading, scarcely branched; spikelets compressed; florets about 
ten, smooth, somewhat cylindrical, remote, longer than the rough awn.

English Botany, t. 1171.-English Flora, rol, i. p. 151.-Lindler, Synopsis, p. 311.-Hooker, British Flora, rol. i. p. 51 .

Root of numerous downy fibres. Stem erect, smooth, round, simple, from two to three feet high. Leares long, broad, striated, rough and hairs abore, beneath smoother. Sheaths short, close, smooth, striated. Ligula very short, obtuse, torn. Inflorescence a large, erect, or slightly drooping panicle: the lower branches half whorled, and subdirided; the upper mostly short and simple; al! roughish and angular. Spikelets orate-lanceolate, nearly erect when in flower, but drosping when in seed. Florets about ten, at first closely imbricated, afterwards more remote, and nearly cylindrical, by the sides becoming more inflexed. Glumes unequal, the margins pale and membranous; the outer sinallest, keeled, and each side with two prominent ribs; the inner ralre oratelanceolate, keeled, and with several more or less distinct ribs. Glumelles equal : the outer orate oblong, the margins and bifid extremity membranous, the sides inflexed, smooth, or the extremity sometimes roughish, with minute points; the three ribs on each side, as well as the keel, obseurely marked; aun frequently shorter than the vaire, rough and wared: inner ralre membranous, with two lateral green ribs, ciliated with white hairs. Stiymas feathery. Seed oblong, channelled on one side, the apex downy.

Habitat.CCorn-fields, not uncommon.

Annual; flowering from July to August.

In some countries-as Hanorer and Germany-this species of grass grows in such abundance amongst the Wheat and Rye, as to render the crops of rery inferior value. The flour produced from its seed is small in quantity, and is said to impart a bitter taste to the bread, and to produce effects similar to Lo'lium temulen'tum. It was an opinion entertained by the ancients, that Wheat and other grain degenerated into grasses, and that this and the following species have gradually lost their claim amongst the grain-bearing grasses, and to have degenerated from Rye; hence they were called smooth and douny Ryegrasses.

9. I. veluti'nus, Schrad. (Fig. 176.) downy Brome-grass. "Panicle : zeauing, scarcely subdivided; spikelets of from ten to fifteen crowded, elliptical, downy florets; awn is long as the glumes; leares slightly hairy." - Smith.

English Flora, vol. i. p. 152.-Lindley, Synopsis, p. 311.-Hooker, British Flora, rol. i. p. 51.-Bro'mus multiflo'rus, English Botany, t. 1884 .

\&. nin'nor, Hook.; "sheaths of the leaves densely clothed with defezed hairs."-Hooker, British Flora, rol. i. p. 52. 


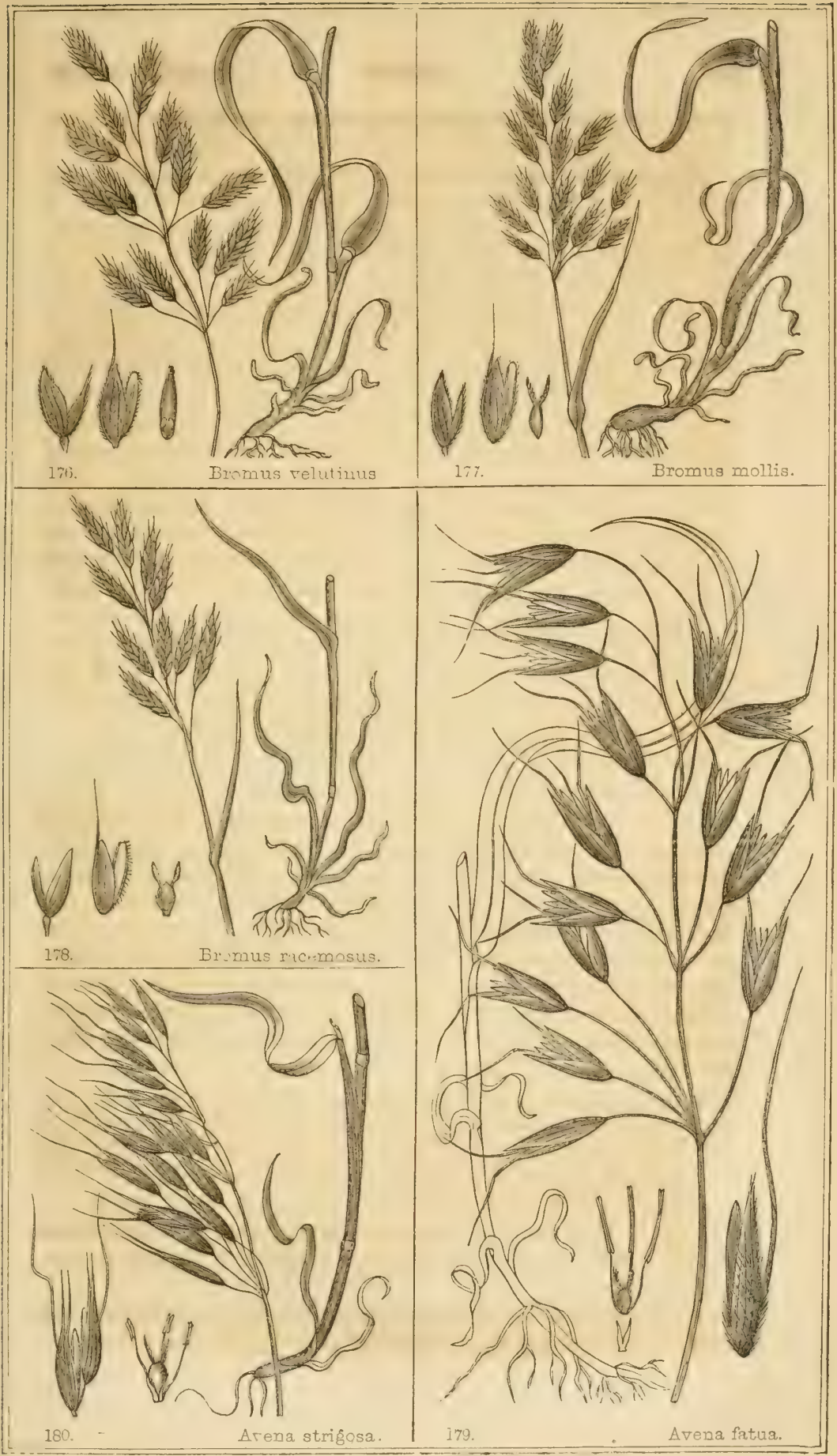



Stem smooth. The lower leaves naked towards the base on the under side, above on the margin somewhat hairy; the upper ones clothed with a downy pubescence on the under side, and hairy above; all rough on the margin. Inflorescence a wide-spreading, nearly simple panicle; its branches rough; its spikelets orate-lanceolate, compressed. Florets never becoming separated or cylindrical, but remaining contiguous or crowded. Glumes, as well as the outer valve of the glumelles, very pubescent. Awn longer than the florets, at length spreading. "The variety found by Mr. Johns is scarcely a span high, and has the glumes very soft with silky down, and the sheaths of the leaves densely clothed with copious soft deflexed hairs"-Hook.

Habitat.-Corn-fields. Rare. About Edinburgh-Smith. $\beta$. Sandy ground by the sea, near the Soap Rock, Lizard, Cornwall-Mr. C. A. Johns.

Annual; flowering in June and July.

We have not been able to obtain other than cultivated specimens of this plant: the description is taken from Smith. It is nearly allied to B. secalinus.

10. B. mol'lis, Linn. (Fig. 177.) soft Brome-grass. Panicle erect, branched, rather close; spikelets slightly compressed; florets imbricated, downy; awn straight, about as long as the glume; leaves very soft and downy.

English Botany, t. 1078.-English Flora, rol. i. p. 153.-Lindley, Synopsis, p. 311.-Hooker, British Flora, vol. i. p. 52.-Sinclair, Hort. Gram. Woburn. p. 176.

Root fibrous. Stem erect, from one to two or three feet high, striated, smooth or downy. Leates linear, striated, very soft and downy, as well as the close sheaths. Ligula short, obtuse, torn. Inflorescence an erect, brancherl panicle, close, except when in flower, slightly spreading, its branches rough and angular. Spikelets numerous, nearly erect, slightly compressed, of from five to ten imbricated downy florets. Glumes unequal, keeled, numerously ribbed, and downy; the margins membranous, pale. Glumelles equal: the outer valve ovateoblong, numerously ribbed; the margins and hifid extremity membranous, concave, downy; aun straight, roughish, about the length of the valve: inner valve membranous, obtuse, with two green, ciliated, lateral ribs closely attached to the long, narrow, channelled seer. Stigmas feathery.

Habitat.-Fields, waste places, banks, and old walls; very common.

Biennial ; flowering in June.

This grass, which is extremely common, especially in poor exlatusted soil, is, like all other of the Brome-grasses, of little or no utility to the agriculturist. Their herbage is coarse and innutritious, and the quantity which they produce is mostly small, and refused by almost ail cattle.

VoL. I. 
11. B. racemo'sus, Linn. (Fig. 178.) smooth Brome-grass. Panicle erect; stalks unbranched; spikelets slightly compressed; florets imbricated, smooth; awns straight, about as long as the glumes; leaves slightly hairy.

English Botany, t. 1079.-English Flora, vol. i. p. 154.-Lindley, Synopsis, p. 311.-Hooker, British Flora, vol. i. p. 52.

Root small, fibrous. Stem erect, from one to two feet high, finely striated, smooth, or slightly downy. Leaves linear, narrow, acuminated at the point, striated, and slightly hairy. Sheaths rather long, close, striated, smooth, or slightly downy. Ligula short, obtuse, torn. Inflorescence an erect or slightly drooping, close, simple panicle; its branches simple, very rarely divided, angular, and slightly downy. Spikelets similar to the last, except being quite smooth and less numerously ribbed: this, together with the smaller and nearly unbranched panicle, appear to be the only characters by which they can be distinguished from each other; and it is doubtful if this is any more than a variety depending upon difference in the situation of growth.

Habitut.-Fields and road-sides; not unfrequent.

Annual or bienuial; flowering in June and July.

\section{GENUS XII. AVE'NA. LrNn. Oat-grass.}

Gen. Char. Panicle loose. Spikelets two or more flowered. Glumes two, nearly equal. Glumelles two, lanceolate, nearly equal; the outer bifid at the apex, and bearing a twisted dorsal awn."Name of doubtful origin; the ancients applied it to the Bromegrass. Oat,. Theis tells us, comes from the Celtic word atan, the oat; and that again from etan, to eat." - Hook.

1. A. fat'ua, Linn. (Fig. 179.) wild Oat. Panicle erect, spreading; florets about three, roughish, and hairy at the base, shorter than the glumes; awn long and stout.

English Botany, t. 2221.-English Flora, vol. i. p. 163.-Lindley, Synopsis, p. 310.-Hooker, British Flora, vol. i. p. 53.

Root fibrous, rooting from the lower joints. Stem erect, round, smooth, striated, three or four feet high, leafy below, naked above. Leaves broad, linear, flat, acuminated, numerously ribbed and striaied, rough, and sometimes hairy. Sheaths long, close, striated, thin, smooth, or slightly hairy. Ligula short, obtuse, torn. Inflorescence a large, spreading panicle; its branches in half alternate whorls, slender, angular, rough, swollen at the base and upper extremity, simple or branched. Spikelets large, more or less drooping. Glumes large, membranous, green, lanceolate, with a long point, which, as well as the margins, are shining and pale; ribs numerous, prominent, Flo- 
rets about three, shorter than the glumes, tawny, at length brown. Glumelles unequal: the outer thick and coriaceous, lanceolate, the margins and long tapering point bifid at the apex, membranous, numerously ribbed, roughish, the base clotlied with long, flat, twisted, pale-brown, and glossy hairs; aun from below the middle of the back, about two inches long, stout and roughish, with minute points, the lower part twisted: inner valve lanceolate, with two marginal, finely cilinted ribs. Stigmas feathery. Fruit downy, enveloped in the hardened glumelles.

Habitat.-Corn-fields; not unfrequent.

Annual; flowering from June to August.

The awn of this species forms an excellent hygrometer, but is not so large, or so sensible to the changes in the moisture of the atmosphere, as that of the exotic Avena sterilis, which is kept constantly in an apparent spontaneous motion, and has some resemblance to an insect; hence it has received the name of "animal Oat." The florets are sometimes used by anglers in the place of artificial flies. It is sometimes mistaken for the common cultivated Oat, $A$. sativa, which has one or more of its upper florets imperfect and awnless; the florets are also without hairs at the base, and the awn is not so stout or so long. The Oat is the grain grown in cold countries, where it is considered the bread-corn, and used as the food of man-as in some parts of England and Scotland, part of Siberia, and the northern parts of Norway and Sweden; but in warmer latitudes, the ears become so small, and the grain so poor, as to be scarcely worth cultivation. The grain deprived of the skin is known by the name of "groats," of which there are several kinds, as the common, split, patent, and Embden; ground down they form meal or oatmeal, which is variously prepared as an article of diet, or used medicinally. The great productiveness of the Oat, like that of Wheat, is sometimes rery remarkable. In Turner's "Sacred History of the World," it is stated, that "an Oat-stalk taken from a field at Sealand, near Chester, had 237 grains. Another, on a field lately part of Cockermouth Common, had 251. A wild Oat at Milton was ten feet high, and had 150 grains. One ear at Mansfield was fifteen inches long, and contained 283. In 1824 a single grain of Oats having fallen on a quantity of burnt clay, produced 19 stems and 2945 grains."

2. A. strigo'sa, Schrad. (Fig. 180.) bristle-pointed Oat. Panicle erect, the branches all turned to one side; florets two, as long as the glumes, the outer ralve terminated by two bristles, the back with a long awn.

English Botany, t. 1226. -English Flora, vol. i. p. 163.-Lindley, Synopsis, p. 310.-Hooker, British Flora, vol. i. p. 53.

Root fibrous. Stem erect, from two to three feet high, smooth, striated, and leafy. Leaves breadly linear, acute, striated, a glaucous- 
green, roughish. Sheaths close, striated, and smooth. Ligula obtuse, torn. Inflorescence an erect, rather close panicle; its branches scarcely subdivided, rough, slender, all turned to one side, abruptly swollen at the extremity. Spikelets two, very rarely three or four-flowered. Glumes nearly equal, thin, membranous, smooth, except a slight roughness on its numerous ribs; the margins and point white, very thin. Florets elevated on a short smooth footstalk, that of the second having near its extremity a lateral tuft of hairs. Glumelles unequal : the outer concare, lanceolate, bifid at the extremity; the points long, narrow, terminating in two rough purplish awns, besides the dorsal aun, which is nearly as long again as the valve, and inserted above its middle; the valve is smooth, sometimes slightly scattered over with flat twisted hairs, obscurely ribbed, except towards the point, where it is also roughish : inner valve lanceolate, flat, with two lateral downy ribs and a bifid apex. Stigmas short, feathery.

Habitat.-Frequent in corn-fields in England, Scotland, and Wales. Near Cork, Ireland-Mr. J. Drummond.

Annual; flowering in June and July.

The habit and size of this species have a greater resemblance to the cultirated Oat, A. sativa, than the last; but its oblong, rather crowded, one-sided panicle, and the awned extremity of the florets, essentially distinguish it from all other species, and give the whole panicle a remarkably strigose or bristly appearance; hence its specific name.

3. A. praten'sis, Linn. (Fig. 181.) narrow-leaved Oat-grass. Panicle an erect, nearly simple raceme; spikelets erect; florets from three to five, longer than the glumes; leaves long, narrow, smooth except on the margins, the lower ones with the margins closely rolled inwards.

English Botany, t. 1204,-English Flora, vol. i. p. 155.-Lindley, Synopsis, p. 310.-Hooker, British Flora, vol. i. p. 53.-Sinclair, Hort. Gram. Woburn. p. 312.

Root fibrous, tufted. Stems erect, several from the same root, tufted, from one to three feet high, striated, smooth, with a single joint near the base, from whence arises the upper and almost only leaf of the stem, which is very short, narrow, striated; the sheath very long, close, deeply striated, smooth, except a slight roughness upon the edge of the stria. The lower leares long, tufted, narrow; the margins closely rolled inwards, and minutely serrated; their sheaths short, and enveloped in the withered remains of the older ones. Inflorescence an erect, simple raceme, or a slightly branched panicle; the upper spikelets sessile, the lower on simple or branched, angular, and rough stalks. Glumes unequal, lanceolate, with a long narrow point, frequently terminating in a roughish awn, each with two smooth lateral ribs and a keel, rough towards the extremity. Florets from three to five or six, each upon a short stalk, the upper part clothed with short, stiff, white, shining hairs. 



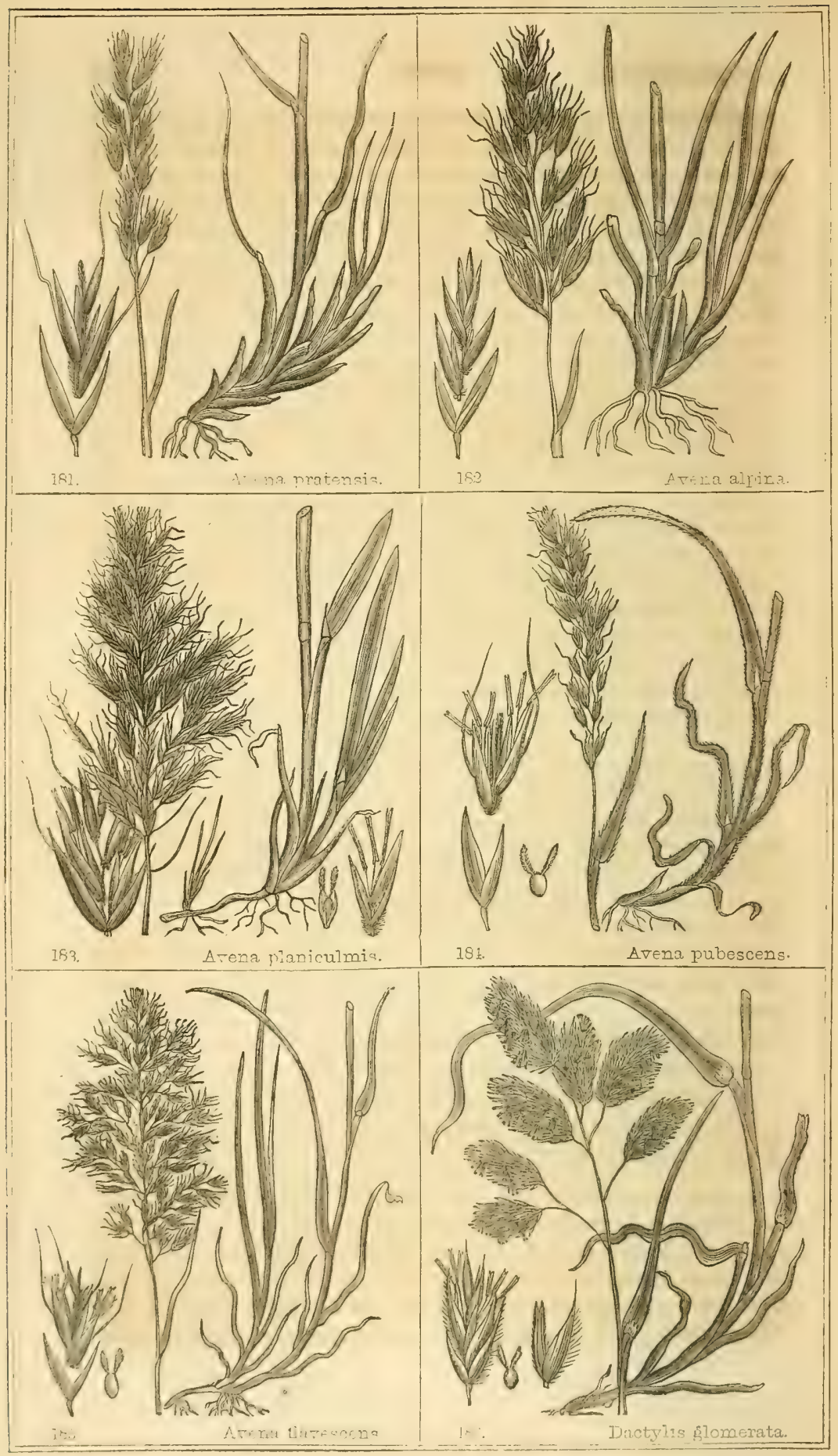


Glumelles nearly equal, lanceolate; the outer smooth, scarcely ribbed except towards the apex, where it is membranous and pale, often torn; the lower part green, variegated with purple, as well as the glumes; awn from above the middle of the back, purplish, with a white slender point. Glumellules long, lanceolate; the inner ralve thin, white, and membranous. Stigmas short and feathery.

Habital.-Dry pastures and mountainous places in a chalky or calcareous district, as well as in meadows of a clayey soil; not uncommon.

Perennial ; flowering in July.

4. A. alpina, Smith, (Fig. 182.) great Alpine Oat-grass. Panicle erect, slightly branched; spikelets erect; florets five or six, louger than the glumes; leaves roughish, hroad, flat, linear, acumiuated; the margins rough; sheaths and stem round.

English Flora, vol. i. p. 165.-Lindley, Synopsis, p. 310.-Hooker, British Flora, rol. i. p. 53.-Ave'na planicul'mis, English Botany, t. 2141.

Ront fibrous, downy, tufted. Stem erect, about two feet high, round, smooth, striated, leafy below. Leaves linear, broad, flat, striated, which as well as the edges are rough, with minute points; the lower ones folded, not rolled inwards. Sheaths round, close, deeply striated, rough; the upper ones long; the lower very short. Ligula acute, torn. Inflorescence an erect, rather close panicle, from three to four inches long; its branches angular, rough, simple or subdivided, tumid at the extremity. Spikelets erect, often an inch long. Glumes lanceolate, unequal, nembranous ; the margins and acute points thin and pale; the two lateral ribs and heel roughish. Florets five or six, rather remote, each upon a smooth footstalk, except a tuft of stiff, white, shining hairs, which are slightly decurrent. Glumelles lanceolate: the outer with fire rough ribs; the apex deeply cloven; the colour a pale yellowish-green, variegated with brown: aun long and tapering, rough, brown, arising from about the middle of the valve: inner valve thin, white, membranons, minutely downy, the point acute. Stigmas short, feathery.

Habitat.-Rocky places on mountains; rare?

Perenuial; flowering in June and July.

This species is nearly allied to the last, from which it is distinguished by its larger and more compound panicle, its stouter habit, and broader, flatter, and rougher leaves.

5. A. planicul'mis, Schrad. (Fig. 183.) fat-stemmed Oat-grass. Panicle erect, branched; spikelets erect; florets from five to seren, much longer than the glumes; leares broadly linear, suddenly acute, flat, minutely serrated, rough, as well as the flat, sharplykeeled sheaths; lower part of the stem slightly compressed, twoedged. 
Hooker, British Flora, vol. i. p. 53.-Lindley, Synopsis, Supplement, p. 333.-English Botany, Supplement, t. 2684.

Root fibrous. Stem erect, stout, compressed, especially helow, striated and rough, about three feet high. Sheaths long, close, remarkably compressed and sharply keeled, strongly striated, and very rough. Leaves broad, flat, nearly of the same width throughout, with a broad, acute, shary point, rough, the margins serrated with sharp cartilaginous teeth, striated, and at the back having a remarkably sharp, thin, projecting keel, the upper leaves very short. Ligula pale, thin, and membranous: those of the upper leaves lanceolate acute; of the lower oblong, mostly torn. Inflorescence an erect, spreading panicle, about four inches long; its branches rough and angular, scarcely subdivided, arising in alternate half-whorls. Spikelets erect, long, close, linear, afterwards spreading, and flattish. Glumes lanceolate-acute, unequal, pale, thin, and membranons : the outer smallest, with a rough keel; the inner with two lateral rough ribs and keel. Florets from five to seven, rather remote, each (except the lower one) upon a roughish footstalk, and having towards the top a tuft of white shining hairs. Glumelles unequal: the outer obscurely four-ribbed and keeled, roughish, variegated with green purple and white; the upper part pale, thin, and membranous, often torn at the extremity, the keel above the middle of the valve terminating in a long, slender, rough, twisted awn; inner valve thin, pale, and membranous, with two slender, downy, lateral ribs. Stigmas loose, feathery. Anther long, narrow, yellow.

Habitat.-Glen Sannox, on the ascent of Goat-fell from Loch Rannoch, Isle of Arran, Scotland-Mr. Stuart Murray.

Perennial; flowering in July.

For specimens of this rare and distinct species of grass, I am indebted to the kindness of Mr. Murray, who had the good fortune to discover it in one of his botanical excursions on the interesting Isle of Arran during the summer of 1826 , and who has since that time grown it in the Glasgow Botanic Garden, where it has remained unaltered in all its characters.

6. A. pubes'cens, Linn. (Fig. 184.) downy Oat-grass. Panicle erect, nearly simple; spikelets erect; florets about three, rather longer than the glumes; leaves flat, downy, the margins smooth.

English Botany, t. 1640.-English Flora, vol. i. p. 164.-Hooker; British Flora, vol, i. p. 54.-Sinclair, Hort. Gram. Woburn. p. 285.Trise'tum pubes'cens, Pers. Lindley, Synopsis, p. 308.

Root fibrous, and somewhat creeping. Stem erect, except at the base, from one to three feet high, round, smooth, simple, leafy. Leaves flat, spreading, short, linear, acute, hairy. Sheaths long, close, striated, the upper ones nearly smooth, the lower hairy. Ligula of the lower leaves short and acute; of the upper oblong, and mostly torn. Inflo- 
rescence an erect, long, slightly branched panicle; its branches arising in alternate half-whorls, slightly angular, and roughish. Spikelets erect, spreading when in flower. Glumes unequal, lanceolate: the outer smallest, keeled; the inncr keeled, and with two lateral ribs. Florets two or three, each on a short footstalk, densely clothed with shining, white, rigid hairs; the upper one mostly imperfect, often only a footstalk terminating in a tuft of hairs. Glumelles lanceolate, unequal: the outer longest, obscurely five-ribbed, variegated with green and purple; the upper part thin and membranous, white and shining, jagged at the extremity; awn arising from above the middle, and about as long again: inner valve membranous, folded, the apex bifid. Stigmas protruding, densely feathery.

Habitat.-Dry pastures, most abundant; on a chalk or limestone soil, not uncommon.

Perennial; flowering in June and July.

This grass possesses considerable merit as forming a part of the grass of permanent pastures in a dry soil : it is hardy, and very productive; but the nutritive matter which it affords, observes Mr. Sinclair, contains a greater proportion of the bitter extractive principle than the nutritive matter of those grasses that affect a similar soil, which lessens its merits in those respects, ani must prevent its being employed in any considerable quantity as a constituent of a mixture of grasses for laying: down such soils to grass.

7. A. flaves'cens, Linn. (Fig. 185.) yellow Oat-grass. Panicle erect, loose, much branched; florets about three, equal in length to the unequal glumes; the outer valve with two terminal bristles; leaves flat, slightly downy.

English Botany, t. 952.-English Flora, vol. i. p. 166.-Hooker, British Flora, vol. i. p. 54.-Sinclair, Hort. Gram. Woburn. p. 161.Trise'tum flaves'cens, Beauv. Lindley, Synopsis, p. 309.

Root fibrous, with more or less creeping underground stems. Stem erect, from one to three feet high, smooth, except occasionally hairy about the joints, finely striated, slender, leafy. Leaves linear, narrow, flat, tapering at the point, striated, hairy, especially on the upper side. Sheaths close, striated, more or less scattered with deflexed hairs. Ligula very short. Inflorescence an erect, rather close panicle; its branches arising in alternate half-whorls, long, slender, angular, roughish, and repeatedly subdivided. Spikclets numerous, small, of a shining yellowish-green. Glumes unequal, lanceolate, membranous except about the keel and ribs: the outer valve smallest, with a rough keel; the inner with a rough keel, and two lateral ribs. Florets from two to four, longer than the outer valve of the glumes, each elevated on a short hairy footstalk. Glumelles nearly equal: the outer valve with membranous margins, from three to five-ribbed; the apex bifid, terminated by two short, roughish awns; the roughish dorsal anen from 
above the middle of the valve spreading : inner valve pale and membranous, with two lateral roughish ribs; the apex bifid. Stigmas protruding, feathery.

Habitat.-Dry meadows, pastures, and heathy places; frequent.

Perennial; flowering in June and July.

This grass will grow in almost all kinds of soil and situation, from the dry upland heath to the moist irrigated meadow; it prefers, however, a dry calcareous soil, where it is the most productive and useful, and is always found a component of the grasses in the richest meadow pastures: but it never is so productive when cultivated alone, as when mixed with other grasses. The nutritive matter which it contains is combined with a considerable proportion of bitter principle, which renders it very agreeable to cattle, especially in combination with other grasses containing a less quantity.

\section{GENUS XLII. DAC'TYLIS. LINN. Cock's-foot-grass.}

Gen. Char. Panicle loose or contracted; branches solitary, the lower ones long; the upper very short. Spikelets clustered, three or fourflowered. Glumes two, unequal. Glumelles two, lanceolate, nearly equal; the outer with a short awn.-Name from darrนגog, a finger or foot.

1. D. glomera'ta, Linn. (Fig. 186.) rough Cock's-foot-grass. Spikelets in dense, globular tufts, tumed to one side; leaves flat, roughish.

English Botany, t. 335.-English Flora, vol. i. p. 134.-Lindley, Synopsis, p. 310.-Hoolser, British Flora, vol. i. p. 48.-Sinclair, Hort. Gram. Woburn. p. 136.

Rnot with long stout fibres, tufted. Stem erect, or bent in the lower part, from one to three feet high, rough, especially towards the top, leafy, particularly in the lower part. Leaves linear, flat, with a tapering point, dull green, striated, and roughish. Sheaths close, striated, somewhat compressed and keeled, roughish. Ligula elongated, embracing the stem, mostly torn. Inflorescence a large, one-sided panicle; its lianches arising singly on alternate sides of the stem, rough and ang:i.ar, the lower long and mostly spreading, the upper short, each bearing a dense ovate or globular tuft of crowid spikelets all turned to one sille. Spikelets three or four-flowered. Glumes unequal, membranous, lanceolate, the point long, sometimes awned, smooth except on the kecl; the outer keeled only; the inner keeled, and with two lateral rihs. Florels compressed, on short smooth footstalks. Glumelles equal: the outer valve lanceolate, cartilaginous, with a narrow, pale, membranous margin, four lateral ribs, and a rough keel, termínating between the bifid apex in a short au $n$; inner valve membranous, 
with two lateral, green, roughish ribs, and a bifd apex. Stignus spreading, feathery. Anther yellow, brown, or purplish.

Specimens may occasionally be observec, varying considerably from the general appearance of the plant; having a short, dense, scarcely Brunched panicle, with the uuter valve of the glumella much elongated.

Habitat.-Meadows, hedges, and waste places; rery abuniant.

Perennial ; flowering from June to August.

As a pasture grass, this is undoubterlly one of the best of our native grasses, very productive, and highly nutritious; but if allowed to grow rank and coarse, either from the want of more frequent cropping or mowing, it loses much of its nutritive matter; hence its greater value as a pasture grass than for lay : "Yet even for this purpose," ubserves Mr. Sinclair, "it will be found more valuable than Rye-grass, Lolium. perenne, and many other grasses. The produce does not increase if left standing after the time of flowering, but rather decreases in the weight of root leares; and by reason of the rapid growth of the latter math, which succeeds an early cropping, the loss incurred by letting this hay crop stand for seed, will be found considerable." In the selection of grasses either for pasturage or mowing, the nature of the soil upon which they are to be sown must be duly considered. The loss in not attending to this important particular, is witnesset in the failure of the attempts to renew original pastures in rich meatow lands, by the neglect in selecting the seeds of tlose grasses stited to the soil and situation. It is true that Nature herself will, in the course of time, produce those kinds of grasses suited to the soil, and they only will remain permanent; but if, by the observance of her laws, we can assist her in the process, and accomplish that in a short time which mould otherwise have required a long period, then knowledge ant axt will have advanced to their confines; for the laws of Yature, although they may be perverted, still remain unchanged. In illustration oi these remarks, the Dactylis glomerata fumishics an excellent example. In a soil of a porous nature, its fibrous roots penetriate to a considerable depth, the plant flourishes well, producing a remarkable quantity of herbage, and remains permanent. If, on the contrary, it is sown in a situation where the surface of the soil is thin, upon a cold net clay, it succeeds rery imperfectly, or altogether fails : its pioduce at first may be abundant, but this is not permanent; its roots are small and short, the plants are easily pulled or trodden up by cattle, and from the same cause, should dry or hot weather occur, the produce will gradualiy diminish, and at length the plant will altogether lisappear.

GENUS XLIII. CYNOSU'RUS. Luns. Dog's-tail-grass.

Grn. Cuar. Panicle spiked. Spikelcts two or many-fowered, fixed upon pectinate bracter. Glumes two, equal. Glumelles two, vox. 1. 
nearly equal, lanceolate; the outer pointed or awned at the apex. -Name from xuwy, a dog, and ovpr, a tail; from the resemblance of the spike to a dog's tail.

1. C. crista't!, Linn. (Fig. 187.) crested Dog's-tail-grass. Panicle spiked, linear; florets with a short awn or point.

English Botany, t. 316.-English Flora, rol. i. p. 137.-Lindley, Synopsis, p. 306.-Hooker, British Flora, vol, i. p. 48.-Sinclair, Hort. Gram. Woburn. p. 152.

Root of long, smooth fibres. Plant tufted. Stem erect, from one to two feet high, round, smooth, striated, slender, leafy below, naked above. Leaves narrow, with a lung point, quite smooth, striated. Sheaths close, smooth, striated. Ligula short, obtuse, crenated or torn. Inflorescence an erect, close, linear, one-sided, spike-like panicle; the spikelets on short, simple, or subdivided branches, fixed alternately upon an angular, waved, smooth, or slightly hairy rachis, from three to five-flowered, each spikelet haring at its base a compressed pectinated bractea, its divisions narrow, linear, acute, the margins pale and membranous, the keel rough. Glumes nearly equal, linear-lanceolate, pale and membranous, as long as the florets, the keel green and rough. Glumelles equal: the outer ralre lanceolate-acute, roughish especially towards the apex, obscurely ribbed, the keel terminating in a short rough awn: inner ralve membranous, with two strong, green, roughish lateral ribs, terminating in a short point, the apex bifid. Stigmas long and feathery. Fruit oblong, furrowed on one side. Anther yellow or purple.

Habitat.-Dry meadows and pastures; common ererywhere.

Perennial; flowering in June and July.

This grass is no less useful than it is common. From its flowering stems being mostly refused by cattle, and left to stand withered and bleaching in the sun, it has been estimated as a grass of inferior value: this, however, is not found to be the case. The long fibrous roots with which it is furnished, produce a thick tuft of herbage, and support it in a green and succulent state during a long continuance of dry weather: hence it is a grass well suited for dry lands, and is found to flourish equally well in dainp situations. Its foliage is short, and of rather slow growth,-circumstances which render it less fitted for purposes of making hay, or for the alternate husbandry; but for permanent pastures, especially for sheep, it is most admirably adapted.

2. C'. eckina'tus, Linn. (Fig. 188.) rough Dog's-tail-grass. Panicle spiked, ovate; florets with a long awn.

Englis'. Botany, t. 1330.-English Flora, rol. i. p. 138.-Lindley, Synopsis, p. 306.-Hooker, British Flora, rol. i. p. 48.-Sinclair, Hort. Gram. Woburn. p. 320.

Root with downy fibres. Stem erect, round, smooth, slender, leaff, 
from one to two feet high. Leaves short, broad, tapering at the point, striated, rough, especially on the upper side. Sheaths striated, inflated in the upper part, roughish. Ligula large, lanceolate. Inflorescence a dense, orate, spike-like panicle. Spikelets small, one or two-flowered, the bractea larger and more elegant than the last species, each valve with a long tajering point, more or less awned. Glumes equal, longer than the florets, lanceolate, with a long narrow point, membranous, the point roughish, as well as the keel. Glumelles equal, lanceolate: the outer obscurely ribbed, roughish towards the point, and terminating in a loug, rough, slender awn; the inner membranous, bifid at the apex, with two lateral roughish ribs, terminating in a short point. Stigmas feathery. Anther rather large and pendulous.

Habitat.-Sandy ground towards the sea in the South of England, as near Hastings, Kent,-and Sussex; but principally in Jersey.

Annual; flowering in July.

The inflorescence of this genus is very remarkable in its structure : the bractea subtending each spikelet are composed of valves similar in arrangement to the perfect floret, and are supposed, with apparent $j u s-$ tice, to be florets in an abortive state.

\section{GENUS XLIV. ARUN'DO. LINN. Reed.}

Gen. Char, Panicle loose. Spikelets many-flowered: the lower floret bearing stamens only, and naked; the upper perfect, and surrounded by a tuft of hairs. Glumes two, unequal, shorter than the florets. Glumelles two, unequal.-Name, Arundo, the Latin word for Reed, which is supposed to be derired from ardeo, because the plants soon become dry.

1. A. phrag'mites, Linn. (Fig. I89.) common Reed. Panicle spreading; florets about five; leaves lanceolate, with a long rigid point.

English Botany, t. 401.-English Flora, vol. i. p. 169.-Lindley, Synopsis, p. 310.-Hooker, British Flora, vol. i. p. 54.

Root with long, creeping, underground stems. Sitem erect, from fire to cight feet high, stout, hard, round, smooth, striated, and leafy. Leaves long, broad, lanceolate, with a very long, tapering, hard point, striated, smooth, and somewhat glaucous, the margins rough. Sheaths long, close, striated, somewhat rough. Ligula a tuft of short hairs. Inflorescence at first an erect, afterwards slightly drooping, spreading, ample panicle, its branches arising in alternate half whorls, the lower one surrounded with a tuft of pale, shining hairs; the branches long, angular, smooth, slender, and much subdivided. Spikelets linear. Glumes unequal, lanceolate, keeled and many-ribbed, brownish-purple. Florets about fire, close, afterwards spreading, each elerated on a 
short foutctalk; the lowcr foret bearing stamens only, and naked; the upner witl stamens and pistils, and the footstalks clothed with white and shining hairs, at first short, afterwards much elongated and spreading, giving the elegant waring panicle a beautiful silky appearance. Gilumelle, unequal, linear-lancoolate : the outer ralve brownish-purple, with a keel and two lateral ribs, the margins membranous: the inner. short, pale, thin, membranous, with two lateral roughish ribs, the apex bifid. Stigmas densely feather. Frat small, enclosed in the glumelles, but loose.

Habitat.-On the banks of lakes and rivers, the margins of pools and marshy situations; abundant.

Pereunial ; flowering in July.

This is the largest of our native grasses, growing abundantly on the banks of many rivers, where it is encouraged on account of its long, crecping, underground stems, which are of great use in confining the banks, and preventing their l)eing so much washed away by the action of the running stream. The tough, hard stems are extensirely used for thatching cottages, and for the ceilings and floors of drellings, which are afterwards corered orer with plaster, \&c. It is used for making fences, and by artists to male reed-pens for sketching. In some parts of England, particularly on the eastern side, extensive tracts of this plant occur, which harbour many aquatic birds, and others which feed upon insccts, and may be seen often in great numbers, actirely engaged in their sportive morements. Some exotic species of Arundo have a great tendency to become arhorescent. The $A$. donax, a native of the South of Europe, has much stronger and stouter stems than our species, and is used for vine-poles, fishing-rods, \&zc.; for the latter and other purposes, the are exported from Spain and Portugal into this country in considerable quantities. The Reed has from time immemorial been regarded as the pastoral instrument of music:

"Arcadian pipe, the pastoral reed

\section{Of Hermes."}

Mrrtor.

Pan, the grod of shepherds, is said in mythological history to have been enamoured of the beautiful Srrinx, and to hare pursued her one day to the borders of the riser Ladon, in Arcadia. The nymph implored the help of the river, which received lier into its waters, and metamorphosed her into Reeds. Pan, in the bitterness of his disappointment, $s$ recorded to have cut several of these Reeds of different sizes, and formed of them the first sheplierd's pipe. Hence has arisen the name of Pandean pipe.

GENUS XLV. ELYMUS. Liss, Lyme-grass.

Ges. Curar. Inflorescence spized. Spikelets two or three from the same point, two or three-fluwered. Glumes two, both on one side 


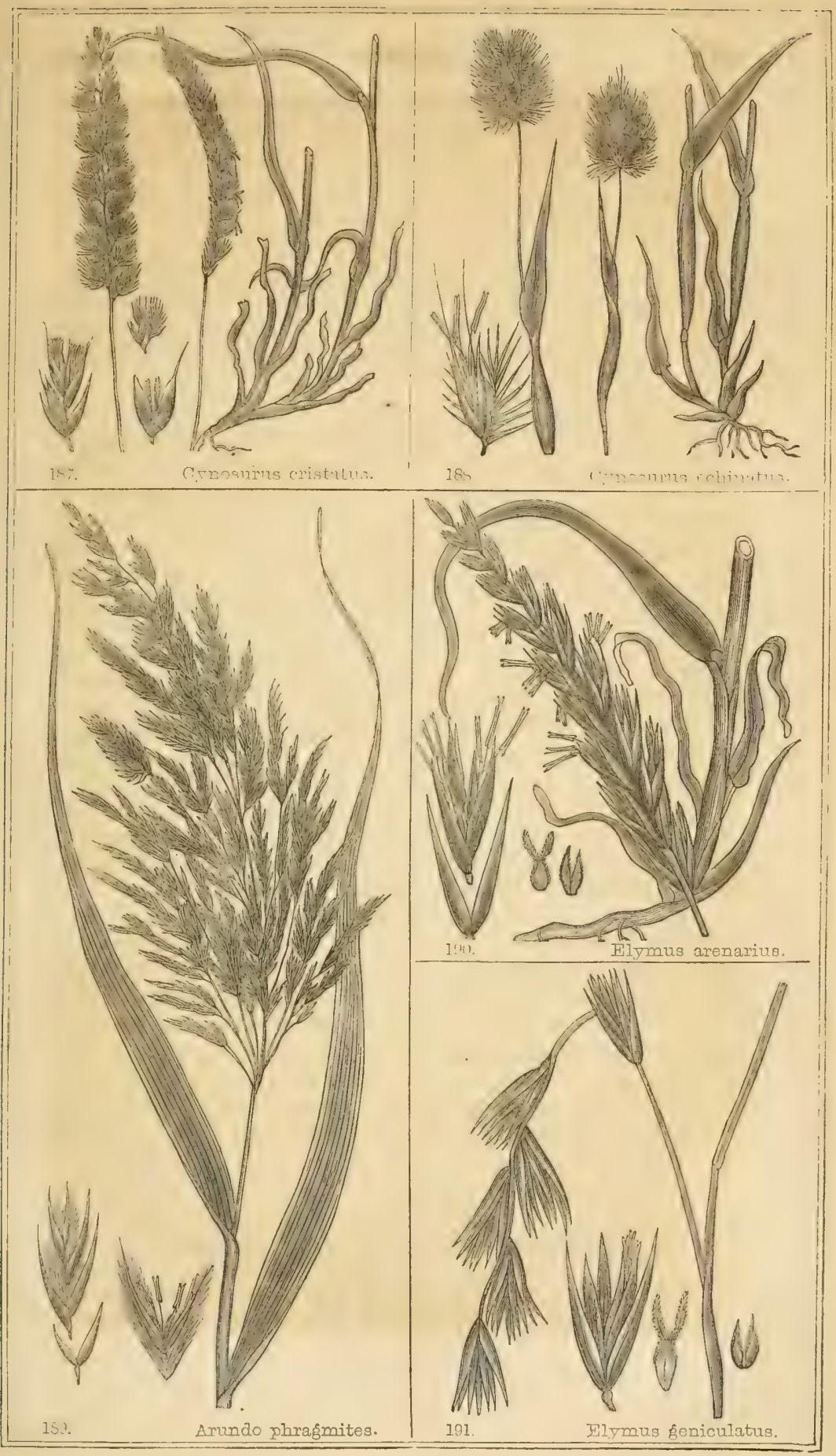





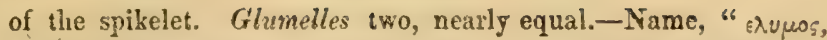
given by the Greels to the Panic-grasses, perhaps because they grew alundantly about Elyma, in Greece. Theis."-(Hook.)

1. E. arena'rius, Linn. (Fig. 190.) upright Sea Lyme-grass. Spike erect, close; spikelets in pairs; florets as long as the lanceolate glumes.

English Botany, t. 1672.-English Flora, pol. i. p. 177.-Lindley, Synopsis, p. 296.-Hooker, British Flora, 1 ol. i. p. 55.-Sinclair, Hort Gram. Woburn. p. 368.

Root with numerous long, tough, creeping underground stems. Stew from three to four feet high, round, smooth, striated, leafy, stout. Leaves long, the margins rolled inwards, the point acute, hard, smooth, glaucous, the upper side with numerous strong stria, the under quite smooth. Shenths long, close, smooth, striated. Ligula very short, obtuse. Infloressence an erect, close spike, from four to twelve inches long, pale glaucons-green, the rachis notched and wared. Spikelets about threc-flowered, two, sometimes three, from the same point. Glumes lanceolate, with a largish sharp point, keeled, and more or less distinctly ribbed, smooth or slightly downy. Florets elevated on short downy footstalks. Glumelles equal, lancolate, downy : the outer valve keeled, and with four lateral ribs; the inner thin, membranous, with two lateral ribs and a slightly bifid apex. Glumellules lanceolate, downy, and ciliated. Stigmas feathery. Fruit linear, the apex hairy, furrowed on one side.

Habilat.--Sandy sea-shores; frequent.

Perennial; flowering (but rarely) in July.

Neither this nor the following snecies are grasses of any agricultural atility, although they contain a large proportion of nutritive matter, remarkable for the quantity of saccharine substance which it contains. They are, nevertheless, grasses of considerable importance in preventing the encroachments of the sea, especially the $\boldsymbol{E}$. arenaria, which is frequently found growing in company with Ammophila arenaria and Carex arenaria, all of which have long, tough, creeping underground stems, with numerous fibrous downy roots interweaving themselves together, and forming a kind of network, which, together with their stout tufted stems and wide-spreading leaves, form a natural barrier admirably adapted by Nature to prevent the encroachment of the loose and flowing sands, which would otherwise advance, and convert many of the now fertile meadows or the luxuriant plains into deserts of moving sand. Mich land has been lost at various periods by the encroachment of the sea, as well as by the inundation of sand, owing to these natural protections haring been destroyed by reckless people. Of so much importance hare these grasses been esteemed, even so far back as the reign of William III., as to induce the Scottish Parliament of that period to render its destruction penal; and these provisions 
were extended to the coast of England by the British Parliament in the reign of George II. Vast tracts of fertile country in Egypt have, by means of these drifting sands, been converted into barren deserts. The Dutch owe to the protecting power of these grasses the existence of considerable tracts of their country; and the sand-hills on various parts of the French coast, are covered and kept firm by these matgrasses. Spurnhead, on our own coast, is a projecting sand-bank at the mouth of the river Humber, firmly tixed by roots of the matgrasses, and receives the full force of the swelling sea, breaking its power before reaching the town of Hull, which is so situated that it is supposed, unless it was thus protected, it would ere now have been destroyed, and its site have formed part of the sea.

2. E.genicula'tus, Curtis, (Fig. 191.) pendulous Sea Lyme-grass. Spike lax, becoming bent downwards with an angle; spikelets in pairs; florets shorter than the subulate glumes.

English Botany, t. 1586.-English Flora, vol. i. p. 178.-Lindley, Synopsis, p. 296.-Hooker, British Flora, rol. i. p. 55.-Sinclair, HortGram. Woburn. p. 370.

Root with numerous downy fibres and slightly creeping underground stems. Stem from two to three feet high, round, smooth, striated, and, like the rest of the plant, a pale glaucous-green. Leaves long, the upper side with numerous strong, close, roughish stria, the under smooth, the margins rolled inwards, the point hard, acute. Sheaths long, close, smooth, striated. Ligula very short, obtuse, crenated. Inflorescence a long spike, at first erect, becoming when in flower bent downwards at an acute angle, a remarkable circumstance characteristic of the species. Spikelets two together, at the rather distant notches of the zigzag rachis. Glumes equal, smooth, and shining, awl-shaped, longer than the florets, keeled and obscurely ribbed. Florets three or four. Glumelles equal: the outer valve ribbed, and thickly clothed with short soft down; inner thin, with two marginal ciliated ribs, the apex bifid. Glumcllules ovate, lanceolate, ciliated. Stigmas long, feathery. Fruit linear, furrowed, the apex hairy.

Habitat.-Near Gravesend, in a salt marsh; very rare.

Perennial; flowering in July.

\section{GENUS XLVI. HOR'DEUM. LINN. Barley.}

Gen. Cirar. Inflorescence spiked. Spikelets single-flowered, three together, the lateral ones mostly imperfect. Glumes two, lateral. Glumelles two, the outer valve awned. Fruit closely invested with the glumelles.-Name of doubtful origin: it is said to be derived from hordus, heary; on account of the heary and inelastic bread made with its @lour, 
1. H. sylvat'icum, Hudson, (Fig. 192.) Wood Barley-grass. Spike erect, compact ; florets two or three, mostly perfect; glumes linearlanceolate, awned, roughish.

Hudson, Flora Anglica, p. 57.-Ely'mus Europa'us, Linn. English Botany, t. 1317.-English Flora, rol. i. p. 178.-Lindley, Synopsis, p. 296.-Hooker, British Flora, vol. i. p. 55.

Root of numerous strong fibres, tufted. Stems numerous from the same root, erect except at the base, from two to three feet high, round, striated, roughish, leafy, especially below. Leares broad, linear-lanceolate, rough, with a micl-rib, and numerously striated. Sheaths rather short, close, striated, roughish, and more or less clothed with deflexed hairs. Ligula very short, obtuse, mostly crenated. Inflorescence an erect, close, imbricated spike, from two to three inches long; its rachis angular, rough, wared and notched. Spikelets three together, from each notch of the rachis, elevated on short roughish footstalks, each spikelet mostly containing a single, sometimes but rarely two florets, all mostly perfect. Glumes two, on the outer side of the floret, linearlanceolate, ribbed, smooth at the base, rough towards the point, and terminating in a roughish awn. Glumelles lanceolate, equal: the outer concare, mostly smooth and shining in the lower part, roughish and ribbed towards the point, and terminating in a long, rough au'n; the inner flat, smoothish, with two strong, roughish, lateral ribs; the apex slightly bifid, and at its base a rough, strong awn, about half its length; an abortive floret, which sometimes becomes dereloped. Glumellules acute, the margins ciliated. Stigmas short, feathery. Fruit downy at the apex, furrowed on one side, and closely insested with the glu. melles.

Habitat.-Woods and thickets in a chalky or calcareous soil; not uncommon in the midland counties of England, but unknown to Scotland or Ireland.

Perennial ; flowering in June and July.

This grass, united by many botanists with Elymus, I have, after Hudson, Knapp, and others, placed among the Hordeums, not, however, without a minute and careful examination of numerous specimens collected in various situations; and upon comparing these with the various species of Hordeum, not only in their habit but structure, I cannot but agree with the above authors, in thinking this a much more natural arrangement. It is true that the florets are mostly perfect, and that sometimes there are two in one spikelet; this, Lowever, is not more than occurs among the Hordeums; and at the base of the inner valve of this, as in all our British species of Hordeum, there is an abortive or undereloped floret, reduced in most instances to a simple awn.

2. H. mu'rinum, Linn. (Fig. 193.) Wall Barley. Spike erect; glumes of the intermediate floret linear-lanceolate, ciliated; those of the lateral fiorets bristle-shaped. 
English Botany, t. 1971.-English Flora, vol.j. p. 179.-Lindley, Synopsis, p. 296.-Hooker, British Flora, vol. j. p. 55.-Sinclair, Hort. Gram. Woburn. p. 268.

Root fibrous and downy. Stem bent in the lower part, erect in the upper, from twelve to eighteen inches high, leafy, round, smooth, and striated, slender. Leaves flat, spreading, narrow, linear, rough, sometimes hairy. Sheaths rather long, loose, striated, smooth. Ligula short, obtuse. Inflorescence a close round spike, from two to three inches long. Spikelets three together, elevated on a siort, fat, ciliated stalk; each spikelet single-fiowered; the two lateral ones mostly imperfect, on short hairy footstalks, the central one nearly sessile and perfect. Glumes of the two lateral forets bristle-siaped, rough, sometimes ciliated; those of the centre lincar-lanceolate, rough, ribbed, terminating in a rough awn, the margins ciliated. Glumelles lanceolite, equal: the outer concave, smooth and shining, except roughish towards the point, obscurely three-ribbed, and terminating in a long, rough awn: the inner flat, somewhat downy, with two strong lateral ribs, and at its base on the inner side is a strong, roughish bristle. Stigmas feathery ; apex of the fruit downy, furrowed on one side.

Habitat.-Walls and road-sides; common in England; about Edinburgh, "and at Elgin, its most northerly range," in Scotland; and Dublin, in Ireland.

Annual ; flowering from $J$ une to August.

The Wall or Mouse Barley is one of the rnost inferior grasses, apparently refused by all cattle.

3. H. praten'se, Hudson, (Fig. 194.) Mcadow Barley. Glumes all bristle-slaped and rough.

English Botany, t. 409.-English Flora, vol. i. p. 180.-Lindley, Synopsis, p. 296.-Hooker, British Flora, vol. i. p. 55.-Sinclair, Hort. Gram. Woburn. p. 315.

Root fibrous, "becoming bulbous in barren ground, occasionally overfiowed." Stem erect, from one and a half to two feet high, smooth, round, scarcely striated, slender, leafy. Leaves rather short, narrow, linear, roughish, especially on the upper sile, and sometimes hairy. Sheaths close, striated, smooth, except the lower ones, which are more or less thickly clothed with deflexed hairs. Ligula short, torn. Inforescence an erect, elose spike, from one to two inches long. Spikelets three together, elevated on a short, flat, ciliated stalk; each spikelet single-flowered; the lateral ones imperfect, small, scarcely awned, sometimes only a simple, awn-like valve, elevated on short, roughish footstalks; the central floret sessile and perfect. Glumes all bristleshaped and rough. Glumelles equal, lanceolate: the outer smooth, obscurely ribhed; the apex of the perfect floret terminating in a long, rough awn, the inside of the valve more or less clothed with hairs: the 



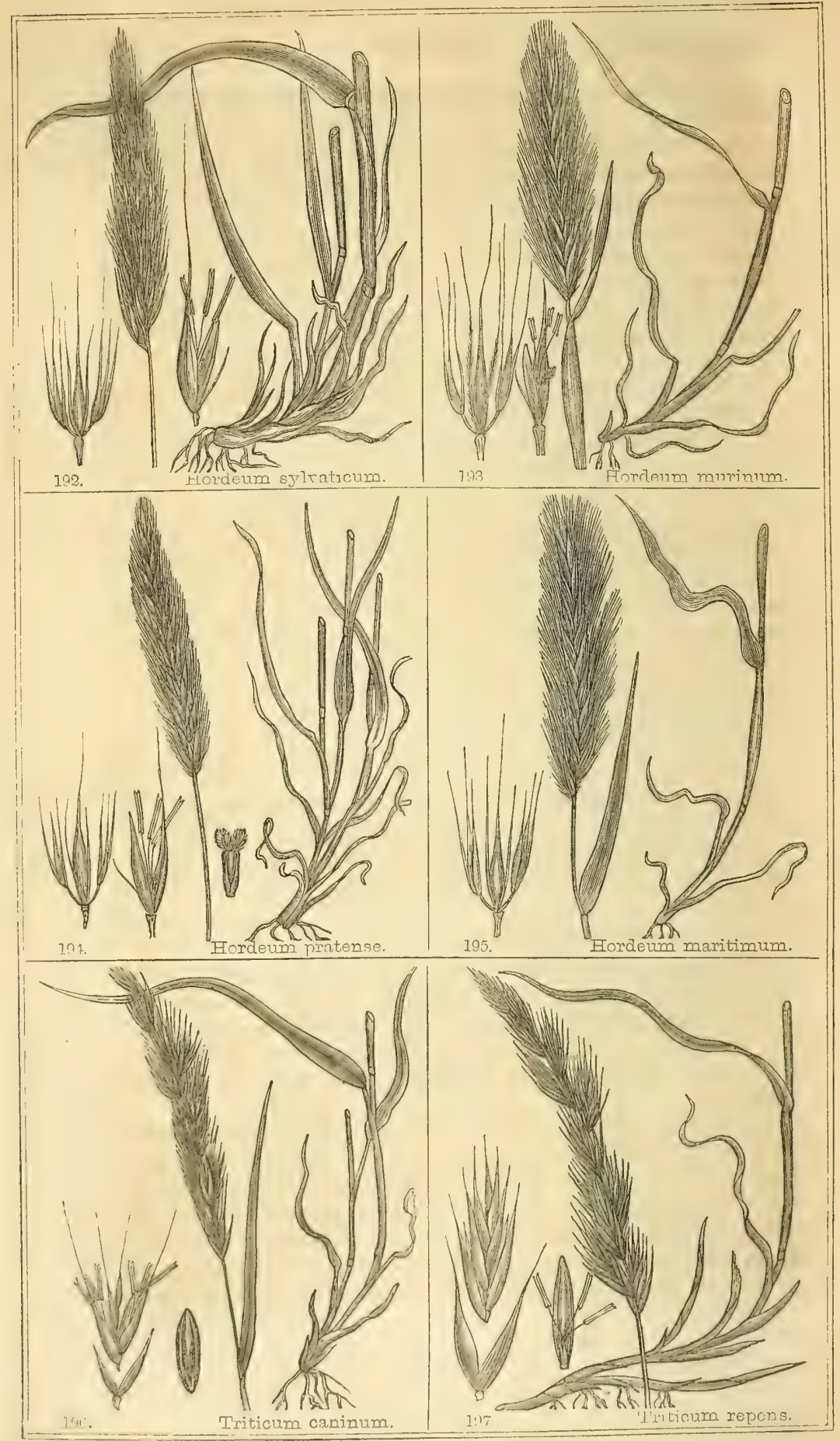


inner valve smooth, with two lateral roughish ribs. Stigmas loosely feathery.

Habitat.-Fields and meadows; not unfrequent in England and Ireland; Salisbury Craigs, near Edinburgh, Scotland.

Annual; flowering in June and July.

This grass, though found to form a part of many pastures, does not possess those qualities by which it can be recommended to the notice of the agriculturist, although it is said to form the principal part of the herbage of some pastures in Norfolk, that are esteemed for the superior kind of sheep that feed upon it.

4. H. marit'imum, Withering, (Fig. 195.) Sea-side Barley. Glumes smoothish, the interior one of the lateral florets semi-lanceolate, the rest bristle-shaped.

English Botany, t. 1205.-English Flora, vol. i. p. 181.-Lindley, Synopsis, p. 296.-Hooker, British Flora, vol. i. p. 55.

Root fibrous, tufted. Stem bent at the base, erect above, about a foot high, smooth, striated, leafy, and, as well as the whole plant, of a pale glaucous-green. Leares numerous at the base, narrow, linear, smooth, or slightly hairy. Sheaths loose, the upper one inflated, striated, smooth. Ligula very short, obtuse, crenated. Inflorescence similar to $H$. murinum, to which this plant is nearest allied. Glumes smoothish, all bristle-shaped cxeept the inner one of the lateral florets, which are dilated on one side towards the base into half lance-shaped. Glumelles equal, smooth: the outer scarcely ribbed, and terminating in a long roughish awn, those of the lateral florets with short awns; inner valve with two lateral ribs, and from its base arises a smooth bristle.

Habitat.-Dry pastures and sandy ground near the sea. Not uncommon in England. In Angusshire, Scotland. Between Swords and Rush, Ireland?

Annual; flowering in June and July.

This plant, like $H$. murinum, is injurious to pastures and hay-fields, on account of the brittleness of the spikes, and the roughness of the glumes, which hurt the mouths of cattle so much, that in the Isle of Thanet, where it is very common, it is said to be one of the best recommendations of an inn to have hay without squirrel tails, or beard grass, amongst it.

The common cultivated Barley, $\boldsymbol{H}$. distichon, is a well-known cereal grass of considerable importance, though not so much as an article of food with us at the present time as it was formerly. By the Romans it was cultivated as food for their horses, and also ground down and made into bread for themselves; and it was considered so superior in its nutritious properties, as to be regularly supplied to the army. It was also the food of gladiators when training: hence, it is said, they

voL. 1. 
were called Hordearii. Barley in this country, and indeed in all the temperate parts of Europe, (see page 71,) is chiefly cultivated for the food of cattle, and for forming malt liquors and ardent spirits. During the process of malting, the albumen and mucilaginous substances which the seeds contain are changed into saccharine matter, which is afterwards by fermentation converted into spirit. Pearl, Scotch, or French Barley is formed by depriving the seevis of their coverings in mills; and various preparations are made from it, especially the decoction, which is used as a drink, and is an article of considerable utility in inflammatory affections of the chest, \&c. Amongst the ancients, decuctions of Barley were the principal medicines, as well as aliments, in acute diseases.

\section{GENUS XLVII. TRIT'TCUM. LINN. Wheat, or Wheat-grass.}

Gen. Char. Inflorescence spiked. Spikelets many-flowered, all fertile. Glumes two, nearly equal, placed transversely, the sides (not the back of one of them) directed to the rachis. G'lumelles two, lanceolate; the external one mostly awned at the apex.Name Triticum, "quod tritum est e spicis," because it is thrashed or beaten from the spikes, or, according to Varre, from the mechanical process of grinding to which the seeds are subjected before being used as food.

\section{* Spikelets distichous (in two opposite rows).}

1. T. cani'num, Hudson, (Fig. 196.) fibrous-rooted Wheat-grass. Glumes acute, or slightly awned, from three to five-ribbed ; florets about four; awn long, slender; leaves flat; root simple, fibrous.

English Botany, t. 1372.-English Flora, vol. i. p. 184.-Hooker, British Flora, vol. i. p. 56.-Sinclair, Hort. Gram. Woburn. p. 202.Agropy'rum cani'num, Beauv. Lindley, Synopsis, p. 298.

Root fibrous, simple, or downy. Stem erect, from two to three feet high, round, smooth, finely striated, slender, and leafy. Leaves flat, linear-lanceolate, with a tapering point, rough, sometimes hairy. Sheaths close, striated, smooth, the lower ones sometimes hairy. $L i$ gula very short, scarcely observable. Inflorescence an erect, often rather loose spike; the angles of the zigzag rachis hairy. Spikelets alternate, except the lower ones, which are sometimes in pairs, and rather distant. Glumes somewhat unequal, lanceolate, acute or slightly awned, with three or five strong roughish ribs. Florets from three to five. Glumelles equal, lanceolate, smooth: the outer concave, scarcely ribbed except towards the point, which terminates in a long, slender, roughish awn; inner flat, with two latcral downy ribs. Stigmas small. Fruit oblong, furrowed on one side. 
Habilat.-Woods, banks, and hedges; frequent.

Perennial ; flowering in July.

For agricultural purposes, this grass might be cultivated with advantage for pasturage in a light soil. It produces an abundant and carly nutritious herbage, but very little in the latter part of the scason ; this, however, is the same, with very few exceptions, with all tho grasses that produce their foliage early in the spring. It is nearly allied to the following species, and in some instances is only to be distinguished by its fibrous root.

2. T. re'pens, Linn. (Fig. 197.) creeping Wheat-grass, or Couch-grass. Glumes lanceolate, awned, many-ribbed ; florets from four to cight, pointed or awned; leaves flat; root with crecping underground stems.

English Botany, t. 909.-Euglish Flora, vol. 1. p. 183.-Hooker, British Flora, vol. i. p. 56.-Sinclair, Hort. Gram. Woburn, p. 402.Agropy'rum re'pens, Beauv. Lindley, Synopsis, p. 298.

Roots with numerous creeping, branched, underground stems, the joints having membranous sheaths. Stem erect, smooth, striated and leafy, round, slender, from two to three feet high. Leaves flat, linear, lanceolate, striated, spreading, smooth at the base, rough towards the point, especially on the upper surface, which is also sometimes hairy, of a pale somewhat glaucous-green. Sheaths long, close, smooth, striated. Ligula very short, crenated. Inflorescence an erect spike, from three to four inches long; the augles of the zigzag rachis slightly hairy or serrated. Spikelets alternate, distant or crowded. Glumes lanceolate, with a long point or awn of variable length, roughisl, keeled, and from four to eight-ribbed. Florets from four to eight each, on a short, round, smooth footstalk, at first close, fpreading when in flower. Glumelles equal: the outer smooth, lanccolate, with from four to eight more or less distinct ribs; the keel roughish, terminating in an acute point, or a rough $a u n$, of variable length; inner valve thin, membranous, obtuse, with two lateral rough ribs. Stigmas long, feathery. Anthers yellow. Fruit furrowed on one side.

Habitat.-Fields and waste places; very common.

Perennial; flowering during the summer months.

This grass, on account of its long underground stems, which grow and spread very rapidly, is a most troublesome weed in gardens and cultivated lands, especially of a light soil. It readily breaks off at its numcrous joints, from every one of which it is capable of putting out roots and stems, which render it difficult of extirpation. These underground stems of the Couch-grass contain a large proportion of nutritive matter, much more than in cither the flowering stems or leaves; and on the Continent they are collected and estecmed as food for horses and other cattle; indecd it has been stated, on the authority of a 
French veterinary surgeon, that exhausted and worn-out horses are very speedily restored to strength and condition by giving them, daily, one or two bundles of Couch-grass, of ten or twelre pounds each, mixed with carrots. The expressed juice of these stems was reeommended by some of the ancient physicians to be taken liberally as a drink in obstructions of the bowels, \&c. The leaves, which Sinclair says contain an excess of bitter extractire and saline matter, are eaten by dogs to excite romiting.

3. T. jun'ceum, Linn. (Fig. 198.) rushy Sea Wheat-grass. Glumes obtuse, many-ribbed; florets four or five, awnless; leares with the margins rolled inwards; root with creeping underground stems.

English Botany, t. 814.-English Flora, vol. i. p. 182.-Hooker, British Flora, vol. i. p. 56.-Agropy'rum jun'ceum, Beauv. Lindley, Synopsis, p. 298.

Root with downy fibres, and numerous long, creeping underground stems. Whole plant a pale glaucons-green, rigid. Stem bent at the base, and sumetimes purplish, erect above, from one to three feet high, round, quite smooth, finely striated, leafy. Leares linear, with a long narrow point, the under side quite smooth, the upper with numerous prominent rough strix, the margins rolled inwards. Sheaths close, quite smooth, finely striated. Ligula very short, obtuse, crenated. Inflorescence an ereet spike, from two to four or fire inches long. Spikelets compressed, distant or crowded. Glumes oblong, nearly equal, with three obtuse teeth at the extremity, quite smooth, manyribbed, and containing from three to six awnless florets. Glumelles nearly equal: the outer quite smooth, keeled, and with four more or less distinct lateral ribs; the apex with three obtuse teeth, most distinct in the upper florets; inner valve obtuse, with two lateral roughish ribs. Glumellules lanceolate, ciliated. Stigmas feathery. Fruit downy at the apex, furrowed on one side.

Habitat.-Sandy banks on the sea-shore; frequent.

Perennial ; flowering in July.

The long, tough, creeping, underground stems of this grass are useful, like Elymus arenarius, \&c., in binding the loose sands of the seashores, and are much sought after by pigs, who eat them with an apparent relish.

4. T. crista'tum, Schreb. (Fig. 199.) crested Wheat-grass. Glumes awl-shaped, with a prominent keel, terminating in a rough awn, obscurcly ribbed; florets about four, awned; spikelets much crowded.

English Botany, t. 2267.-English Flora, vol. i.p. 184.-Hooker, British Flora, vol. i. p. 56.-Sinclair, Hort. Gram. Woburn. p. 316.Agropy'vum crista'tum, Beauv. Lindley, Synopsis, p. 298.

Rurt of strong woolly tibres. Stem bent at the base, becoming erect, 



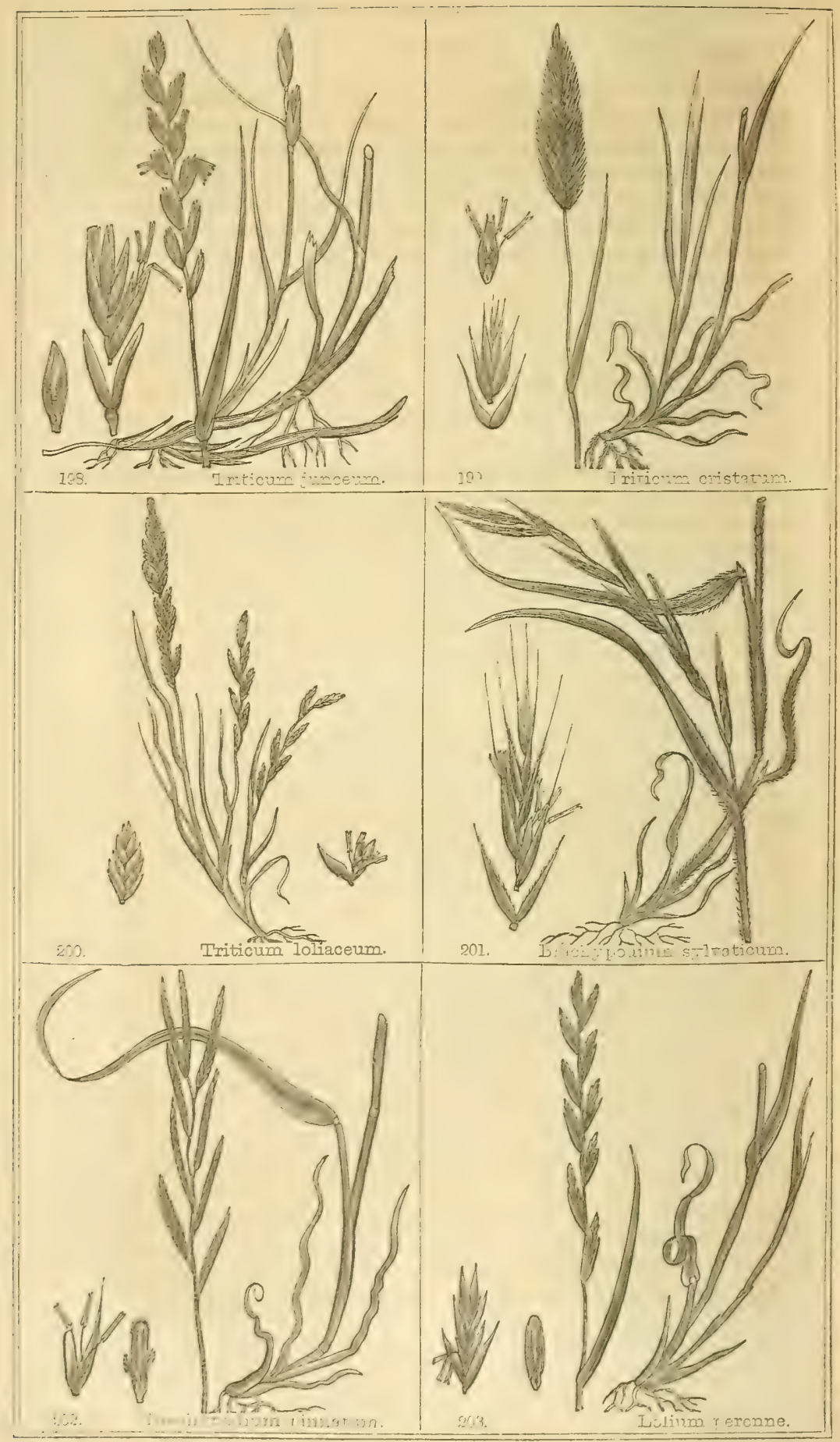


round, striated, roughish, especially in the upper part, slender, leafy, from twelre to eighteen inches high. Leaves flat, linear, tapering at the point, numerously striated, smooth on the under side, hairy on the upper. Sheaths close, striated, smooth. Ligula rery short, scarcely observable. Inflorescence an erect, crowded, compressed spike, about an inch long. Spikelets compressed, crowded, two-ranked. Glumes nearly equal, awl-shaped, with a keel terminating in a rough awn about as long again; one side of the valve with a single rib; the other side narrower and the rib obsolete. Florets from three to six, compressed, smooth or hairy. Glumelles nearly equal, lanceolate: the outer obscurely four-ribbed, with a keel terminating in a roughish an'n; the inner valve bifid at the apex, with two lateral roughish ribs. Glumellules small, lanceolate. Stigmas loose, feathery. Fruit downy at the apex.

Habitat.—"Sea-side between Arbroath and Montrose-Mr. G. Don; where, however, I should fear it cannot be considered wild. It is a native of the south-eastern parts of Europe."-Hook.

Perennial ; flowering in July.

\section{** Spikelets turned to one side.}

5. T. lolia'ceum, Sm. (Fig. 200.) duarf Sea Wheat-grass. Glumes obtuse; florets numerous, awnless, indistinctly ribbed; stems rigid, branched; root fibrous.

English Botany, t. 221.-English Flora, rol. i. p. 185.-Hooker, British Flora, vol. i. p. 56.-Catopo'dium lolia'ceum, Link. Lindley, Synopsis, p. 297.

Root of numerous long, branching, downy fibres. Stem erect, remarkably stiff and wiry, branching from the base, and erect, ol bent; from two to four inches high, smooth, shining, finely striated, leafy. Leares linear, striated, flat, smooth, or roughish on the back. Sheaths close, smooth, striated. Ligula short, obtuse, torn. Inflorescence an erect, one-sided spike; the rachis flat, waved, and striated. Spikelets ovate, flat. alternate, distant or crowded, sessile, or elevated on a short stalk, smooth. Glumes unequal, orate, obtuse, with a membranous margin, keeled, and with two or four more or less distinct ribs. Florets numerous, imbricated. Glumelles two, nearly equal: the outer ovate, acute, smooth, keeled, two or four-ribbed, the margin pale and membranous; the inner lanceolate, with two lateral downy ribs. Stigmas feathery.

Habitat.-On the sandy sea-shores of Norfolk, Suffolk, and Essex. North Wales and Isle of Man-Mr. Wilson. East coast of Scotland, not uncommon. Saudymount, Howth, \&c., aud on the northern and southern coasts of Ireland.

Amnual; flowering in June and July.

This plant has much the habit and appearance of Poa rigide. 
The genus as it here stands is considered by some author's as distinct from the exotic species which are so extensively cultived as bread-corn, rather than a mere division or group of the genus. One division (to which all our native species belong) are small perennial or annual plants, useful only as pastoral grasses, to which, except $T$. loliaceum, they have given the name of Agropyrum. The other division, to which they have retained the name of Triticum, is the cereal or corngrasses, of which there are several species cultivated in the temperate regions of the globe (see page 71) as bread-corn.

The native country of Wheat and other cereal grasses is uncertain. Wheat varies considerably in its quality, and the quantity which it produces, according to the climate and soil in which it is grown. Sicilian Wheat, of which there are two kinds, the thin and thick skinned, according to the experiments of Sir H. Davy, contains more nutritive matter than any grown in Britain; and Wheat grown in the county of Middlesex is more nutritious than that grown in the morthern counties. The flour obtained from the grain of Wheat by grinding it between stones, is superior to any other for making into bread, owing to the large quantity of gluten that it contains, which is in combination with starch. These two (its principal constituents) are readily separated by washing the flour or bruised grain with water, by which means the starch is carried away with the water, and, if allowed to stand, settles to the bottom: pressed in cloths, and gradually dried, it forms white columnar masses-the starch of the shops. Starch is also obtained in considerable quantities from potatoes, and this is superior to the wheaten starch for domestic purposes. It also forms the greater part of the nutritive matter of the different farinaceous substances which are so much used during the time of sickness-such as sago, which is produced from several species of Palm, in many of the East Indian islands. Salep is prepared from the roots of several species of Orchis, as the mascula, morio, and pyramidalis. Tapioca, a well-known nutritire substance, the cassava of the West Indies, and called by the negrocs manioc or magnioc, is prepared from the root of the Jatropha manihot, which yields upon pressure a highly poisonous juice, used by the sanvages to envenom their spears, arrows, and darts; and a draught of the juice is the means by which the life of the condemned slaves is taken away. This highly poisonous principle, however, is dissipated by drying, or washing the pulp of the root with water, and immediatcly by heat; what remains is chicfly starch, which is passed through a kind of sicve and dried, and is highly nutritive.

Gluten, the substance which remains after washing away the starch from the flour, is prepared in considerable quantities in Italy, both for home consumption and for exportation, and is obtained in the shops under the names of macaroni, rermicelli, Sc. This forms the ordinary food in many parts of Ttaly, where it is sold by the ynud.

Wheat, Oats, Barley, \&c. are liable to the attacks of sereral kinds of 
Fungi, known by the names of blight, mildew, bunt, \&e., which produce great injury, not only in diminishing the quantity, but also in deteriorating the quality, of the produce. Uredo Caries, known to the farmer by the names of canker-brand, balls, bladder or pepper-brand, stinking brand, and bunt, is distinguished by the intolerable stench which it gives out when crushed. It has been found hitherto to attack only the cars of Wheat, and is the most injurious of this tribe of parasitical fungi. It carries on its destructive operations secretly, and often com. pletes its work without creating in the mind of the owner any suspicion of its presence; for there are no external changes cffected in the grain, with the exception of making them a little xounder, so that a botanical eye is necessary to its detection. When the ears are thrashed or bruised, however, the ravages which these secret plunderers have made will be apparent, not only by their fetid smell, but the whole farina of the grain will be found to be destroyed, and its place occupied by a dense blackish-brown mass, composed of an immense number of ininute globular fungi: so minute are these plants, thit it is computed by Bauer that "no less than two millions five hundred and sixty thousand individual fungi would be required to cover one square inch."

$U$. segetum, the smut or dust-brand, attacks indiscriminately the ears of corn and various grasses, doing great injury to the crops, like the former species, by destroying the fruit. Fig. 215. represents an ear of Barley affected by $U$. segetum, with a section of one of the grains in a young state. This species is readily distinguished from the last by its want of smell, its bursting through and destroying the glumes, and the smaller size of the fungi, for Mr. Bauer states that " no less than seven millions eight hundred and forty thousand would be required to cover the same space" as $U$. Caries. Each of the fungi appears, when highly magnified, to consist of an external membrane or tunic of a reticular texture, and containing within it a vast number of sporules, -according to the calculation of Fries, upwards of ten millions, - and each of these sporules or seeds are capable of reproducing the plant-a division so infinite in living organised matter, as cannot but create in our minds feelings of wonder and astonishment at the means adapted by the Great Author of Universal Nature to accomplish his purposes.

Many laborious experiments and researches have been made by the late Sir Joseph Banks, Mr. Bawer, M. Fee, and others, to elucidate the history of these extraordinary parasitical plants, from which it appears that the reproductive contents of the fungi are absorbed by the roots of the growing grasses, together with the water and other matter from the soil in which they are grown, and conveyed through the sap-ressels into various parts of the plant. Such being the case, the judicious cultivatur will guard against the evil by an appropriate rotation of crops, a careful choice of seed, and by the use of those means, both as manure to the land and "dressing" for the seed, which hare been found to destroy the sporidia: for this purpose, lime and its solutions 
appear to be very useful. $\nmid$ But their growth depends upon so many accidental circumstances, that even by the most judicious management, and careful treatment, their appearance will not be altogether prevented.

\section{GENUS XLVIII. BRACHYPO'DIUM. BEAUv. False Brome-grass.}

Gen. Char. Inflorescence somewhat racemose. Spikelets alternate, somewhat compressed, many-flowered, footstalks short. Glumes unequal, transverse. Glumelles two, the outer valve mostly awned

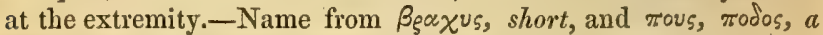
$f_{Q} \circ t_{;}$in reference to the short footstalks of the spikelets.

+ The following experiments in the preparation of Wheat for seed from a smutty sample were made on the 15th of October, 1835, in the middle of an eight acre field, a clover Jayer. The results have been communicated to the Essex Herald by Mr. Smyth Luingley, of Church Hall, Kelvedon; and we have no doubt the information thus conveyed will be acceptable to our agricultural readers:-

No. 1. - Wasbed three times in clean water, and skimmed every time; then dipped in wood.ashes lees with 21 bs. of arsenic boiled in 20 gallons of the liquor, after which, the Wheat well limed and sown. No bladder or smutty ears.

No. 2.- Not washed; steeped in the liquor and skimmed, and well limed. About 1500 bladdered or smutty ears to the acre.

No. 3.-Not washed; wetted with lees and no arsevic, but salted instead, and limed. A bout 2250 smutty ears to the acre.

No. 4. - Washed as the first, in three clean waters; no arsenic, no salt, but dipped in the lees, and well limed. About 2250 smutty ears to the acre, the same as No. 3.

No.5.-Steeped in lees only for ahout four hours, and limed; not washed, nor any arsenic or salt. A bout 4500 smutty ears to the acre.

No. 6. - Sown perfectly dry. A bout 11,500 smutty ears to the acre.

No. 7,-The seed Wheat rubbed well in the hands with a quantity of bladders or smut balls, of course not washed, but dipped in the lees and arseric, and well limed. About $18,7,70$ smutty ears to the acre.

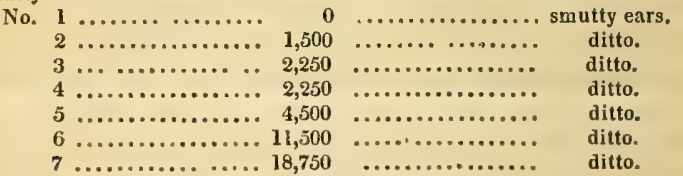

280 average ears of $W$ heat tbrashed is a pint measure.

No. 1.-No loss or waste or damage by smut.

2. $-5 \frac{1}{2}$ pints loss per acre, and Wheat injured.

3. -11 ditto................. ditto.

4.-11 ditto............... ditto.

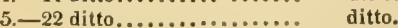

6 - 36 ditto ................ ditto.

7. -67 ditto loss to the acre, or about one bushel, and the Wheat much injured.

In the field where the experiment was tried, there were 750 sheaves to the acre, on the average. The smutty ears were gleaned from several sheaves, which in No. 7 averaged about 25 smulty ears to the sheaf, which makes the above quantity. The other sheaves were gleaned accordingly.

It is not the loss of smutty Wheat altogether (which amounts to a bushel in No. 7), but the damage done to the Wheat that goes to market. When good Wheat is worth $£ 1210 \mathrm{~s}$. per load, if Wheat is much smutty it will lessen the value 50s a load.

In some fields this year, from 50 to 100 smutty ears may be gleaned out of one sheaf ; that is, from to four bushels per acre waste. 
1. B. sylvat'icum, Beauv. (Fig. 201.) slender Fulse Brome-grass. Spike drooping; spikelets mostly turned to one side, hairy; awn slender, longer than the florets.

Lindley, Synopsis, p. 297.-Hooker, British Flora, vol. i. p. 57.Bro'mus sylvat'icus, English Botany, t. 729.-Festu'ca sylvat'ica, English Flora, vol. i. p. 149.-Hort. Gram. Woburn. p. 374.

Root fibrous. Plant tufted. Stem erect, from one to three feet high, round, smooth and shining, slender, leafy, more or less hairy, particularly about the joints. Leares broally linear, flat and spreading, with a strong midrib and several slender lateral ones, rough, and hairy, of a dark bright green. Sheaths short, close, striated, somewhat keeled, smooth and hairy. Ligula obtuse, torn, and hairy. Inflorescence a drooping, somewhat racemose spike. Spikelets nearly cylindrical, alternate, and placed transversely with the waved rachis, elevated on short downy footstalks. Glumes unequal, lanceolate, numerously striated, more or less lairy, and a narrow membranous margin. Florets numerous. Glumelles unequal: outer lancelate, the keel terminating in a slender, rough awn, longer than the floret, having about six lateral ribs, rough, sometimes hairy; inner valve obtuse, roughish, and with two lateral ciliated ribs. Stigmas short, feathery. Fruit loose, furrowed.

Habitat.-In dry woods and hedges. Not uneommon in England, Scotland, and Ireland.

Perennial; flowering in July.

2. B. pinna'tum, Beauv. (Fig. 202.) Heath False Brome-grass. Spile erect; spikelets two-rankel; awn slender, shorter than the floret.

Lindley, Synopsis, p. 297.-Hooker, British Flora, vol. i. p. 57.Bro'mus pinna'tus, Linn. English Botany, t. 730.-Festu'ca pinna'ta, English Flora, vol. i. p. 150.-Hort. Gram. Woburn. p. 375.

Root fibrous. Stem erect, round, smooth, hard, shining, leafy, from one to three feet high. Leaves narrow, linear, long, more or less rigid by the inflexed margins, smooth, or more or less hairy. Sheaths long, close, striated, smooth, or rough with deflexed hairs, especially the lower ones. Inflorescence an erect, somewhat racemose spike. Spikelets linear, numerously flowered, each elevated on a short, sometimes rather long, angular, downy footstalk, attached to the notched, angular, waved, roughish rachis; sometimes there are two inserted at a notch, and the footstalk of the lower spikelet, occasionally the two or three lower ones, have a pale, cartilaginous, lanceolate bractea. Glumes unequal, lanceolate, ribbed, and, as well as the florets, quite smooth or downy. Glumelles unequal: the outer lanceolate, acute, with a rough awn, slender and shorter than itself, or scarcely any; inner valve obtuse or notched, with two lateral ciliated ribs. Stigmas feathery. Fruit furrowed, loose. 
Habitat.-Open fields and heathy places. Oxfordshire and Kent. Roche Abbey and other places, Yorkshire. Near North Queensferry, Scotland. Doubtful if found in Ireland.

Perennial ; flowering in July.

This plant, which we find plentiful in the open fields about Roche Abbey, is quite smooth, or, thickly clothed with shurt rigid bairs, especially the spikelets and lower sheaths, and tho whole plant is of a pale zellow hue. This species, together with the above, according to Sinclair, may be considered the least useful of the British grasses.

GENUS XLTX. LO'LIUN. Linn: Darnel.

Ge:r. Caar. Infloiescence a two-sided spike. Spikelets alternate, compressed, many-flowered. Gluma a single valre. Glumelles two, nearly equal; the outer valve awnless, or with an awn below the apex.-The derivation of the name is rariously given by au-

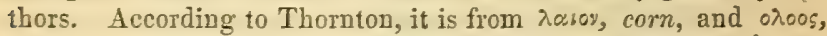
injury. Hooker gives the following:-" "Quasi dolium, dodıov, quod dolosum sit vel adulterimum. Fit enim e corruptis Tritici ac Hordei seminibus.' The ancients, as well as the moderns, attributed poisonous qualities to the $L$. temulentum; and even now it is beliered in sume countries, that the Wheat changes into Darnel."

1. L. peren'ne, Linn. (Fig. 203.) perennial Darnel, or Rye-grass. Spikelets much longer than the gluma; florets amnless; root perennial.

English Botane, t. 315.-English Flora, rol. i. p. 173.-Lindley, Srnopsis, p. 295.-Hooker, British Flora, vol. i. p. 57.-Sinclair, Hort. Gram. Woburn. p. 211.

Root fibrous. Stems several, erect in the upper part, bent in the lorrer, roundish, smooth, striated, leafy. Leares linear, with a long narrow point, smooth and shining beneath, striated and roughish on the upper side. Sheaths somewlat compressed, close, smooth, striated, long, especially the upper ones. Ligula short, acute. Inflorescence an erect, two-ranked spike, from two to twelve inches long. Spikelets compressed, many-flowered, sessile, upon the notehes of the more or less waved, smooth, and angular rachis. Gluma lanceulate, ribbed, smooth, shorter than the spikelet. Glumelles two, equal: the outer Talve lanceolate, keeled, with a membranous margin and point, which is often more or less cloren; inner membranous, with two lateral roughish ribs. Stigmas feathery. Fruit linear.

There are sereral rarieties of this species, depending upon the more or less luxuriant state of their growth; and sometimes, according to Sinclair, it is found with the florets in a riviparous state. 
Habitat.-Fields, meadows, and waste places; very common.

Perennial; flowering in June and July.

This common species of grass, known by the name of Rye- or Raygrass, appears to have been cultivated since the year 167\%; and much has been said in its praise as a grass of great agricultural utility. Its natural habit is to produce an abundance of seed; it arrives at perfection early in the season, and produces a good supply of herbage the first year of its growth. It is a favourite food with most cattle, and hence its value as a grass for the alternate husbandry, especially when combined with a portion of Cock's-foot (Dactylis glomerata), Timothy (Phleum pratensis), Meadow Fescue (Festuca pratensis), and Meadow Foxtail grasses. By this mixture an early crop of grass is procured, and the after-math very superior: but when Rye-grass is cultivated alone, it is found that the after-math is very small, and rendered coarse by its numerous flowering stems, which are mostly rejected by cattle. Although this is a perennial plant, it is said seldum to continue more than six Jears; but the abundance of seed which it bears, falling among the root-leares, produces new plants, with a plentiful succession of herbage.

This grass, in common with many other of the fockler-grassest, as well as Wheat, Oats, Barley, and Maize, among the Cereal, but especially $R y e$, are liable to the attacks of a peculiar Fungus, Spermo. édia Cla'vus, commonly called Sec'ale cormu'tum,-ergot, horned, or spurred grain, (Fig. 215. as seen upon the spikelets of Lolium perenne, with one of the spurs separated and drawn the natural size.) This Fungus is much less frequent in this country than in France, and is remarkable, not only, like the uredo (p. 159), in depriving the grain of its nutritise matter, but is itself an injurious, or even poisonous substance. Like many other poisouous substances, however, ergot, when pruperly administered, is found of the greatest utility as a medicine, and is now admitted into the materia medica of this and other countries. It is singular that this production, when occurring in great abundance on the ears of corn, especially Rye, as it does in wet situations or seasons, where that grain is extensirely cultivated, as on the Continent, where it composes the whole or a considcrable part of their bread, by its cuntinued use, tends to produce that most extraordinary malady, the dry gangrene, one of the most fearul and distressing diseases to which the human race is heir to, and which has often prevailed epidemically in different parts of the Continent. It commenecs its attack with greater or less sererity, either with severe convulsions or with general weakness, weariness, and a feeling as of insects creeping over the skin: when these symptoms have continued some time, the extremities become

+ Phalaris canariensis, Phleum pratensis, Alopecuris pratensis, Agrostis alba, Aira cristata, Poa fluitans, Festuca duruiscula, Arundo arenaria, Elymus arenarius, Triticum junceum and repens, Holsus lanatus, Arrhenatherum avenaseum, \&sc 
cold, white, stiff, benumbed, aud at length quite insensible, after which succeed excruciating pains, together with fever, headach, and sometimes blceding from the nose; finally, the affected parts, and in the first instance the fingers and arms, afterwards the toes and legs, shrivel, dry up, and drop off by the joints, when the parts heal up-or before this, life is exhausted. Such is the account of this dreadful disease, given by Lang, a physician of Lucerne.

The manner in which ergot is produced, is variously stated by authors. According to Willdenow, it may be produced at any time in Rye sown in a rich soil, by watertng the plants excessirely in warm weather. Fontana has alleged that ergot may be propagated from plant to plant, and that he has expressly transmitted it by contact from ear to ear. Hertwig, however, by rery careful expcriments, came to a different conclusion. Others again assert, that it is produccd by an insect, a species of butterfly; and General Martiu Field, having observed flies to puncture the glumes of Rye during its milky state, imitated the process by puncturing them with a needle, and found that in both cases the juice exuded, and in four days a little black point was visible, which he affirms gradually became a spur. But De Candolle and others maintain that it is a distinct parasitic plant. 'The only way, as Mr. Berkeley observes, of deciding the point, would be to institute inquiries as to the manner in which it commences its growth, as Brongniart has done respecting Uredo segetum, as stated in Ann. des Sciences, vol. $\mathrm{xx}$. p. 171.

2. L. temulen'tum, Linn. (Fig. 208.) bearded Darnel. Spikelets equal in length with the gluma; florets awned; root annual.

English Botany, t. 1124.-English Flora, rol. i. p. 174.-Lindley, Synopsis, p. 295.-Hooker, British Flora, rol. i. p. 57.-Sinclair, Hort. Gram. Woburn. p. 397.

B. (Fig. 205.) Florets without or with a short awn. Lo'lium arven'se. English Botany, t. 1125.-English Flora, vol. i. p. 175.-Lindley, Synopsis, p. 295.-Hooker, British Flora, vol. i. p. 57.

Root fibrous, downy. Stem from one to three feet high, round, striated, leafy, smooth and shining below, roughish above. Learcs linear, with a tapering point, roughish, especially on the upper side. Sheaths striated, roughish. Ligula short, obtuse, mostly torn. Inforescence an erect spike, from six to twelve inches long; the rachis notched, angular, slightly waved, and roughish. Spikclets alternate, compressed, the lower oncs having mostly two glumes: the outer one as long as the spikelets, freçucntly half as loner again, lanceolate, numerously ribbed; the inner small, membranous, close pressed to the channel of the rachis, grartalilly diminishing in size in each upper spilelet, at length entircly disappering. Glumelles equal: the outer concave, with four indistinct ribs near the memhranous margin, and a slight keel terminating in a roughish aun of greater or less length and 



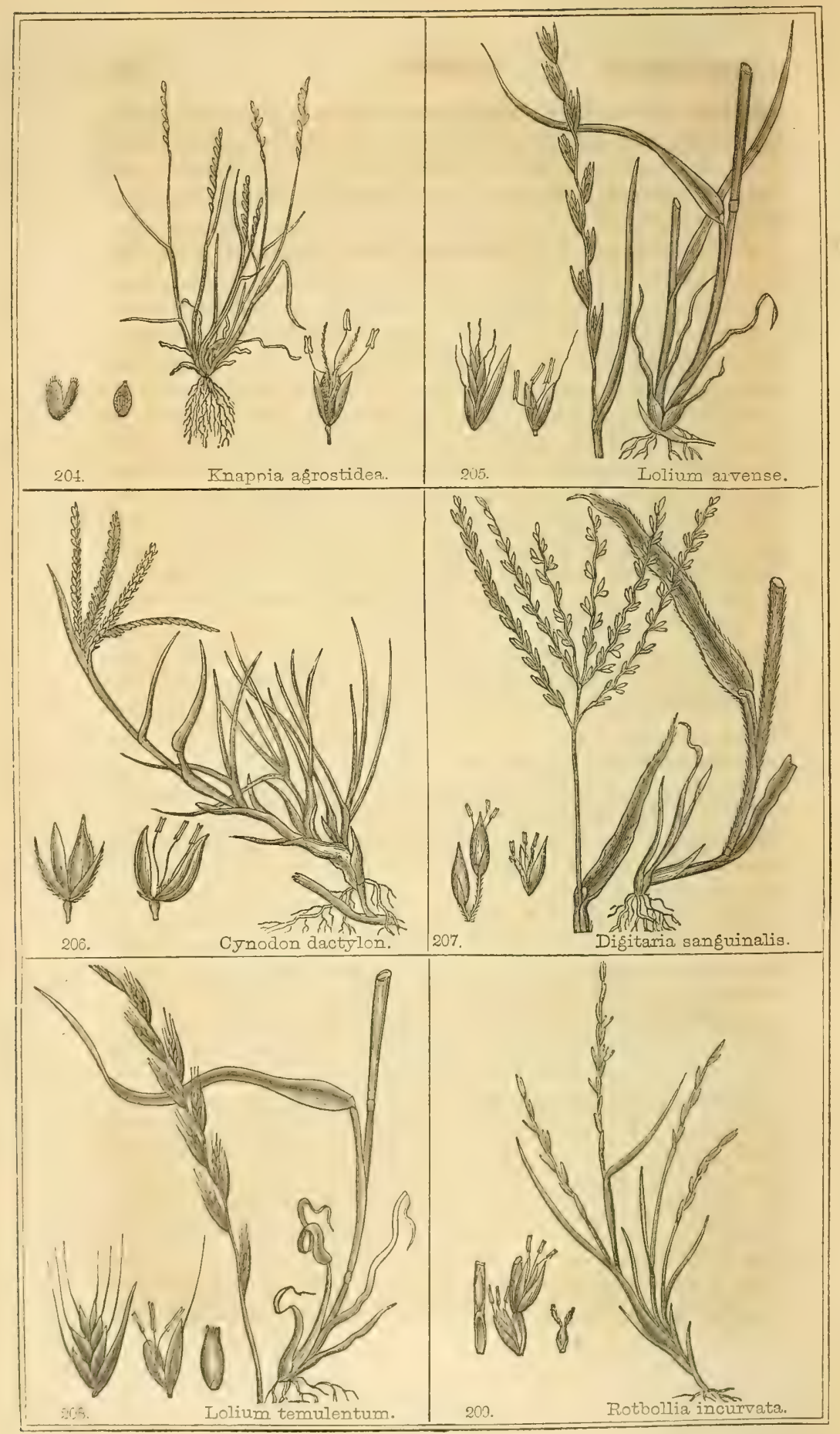


rigidity. The awn is the only character by which $\boldsymbol{L}$. areensis is considered as a distinct species from the present; but the variable length which it is found lcads me to consider it only as a variety: the inner valve membranous, with two lateral roughish ribs. Fruit oblong, furrowed on one side.

Habitat.-Corn-ficlds. Frequent in various parts of England and Ireland, less so in Scotland.

Annual ; flowering in July.

This is the only species among the grasses that produces grain with any deleterious properties. It appears to possess powerful narcotic, and at the same time acrid qualities, producing disagrecable and even fatal effects. Seeger, in the experiments which he made with it, found it always to cause general tremor of the body; and Cordier found, by experiments which he made upon himself, that, by eating bread made with the flour, le felt confusion of sight and ideas, languor, heaviness, and alternate attacks of somnolency and romiting. Serious accidents have sometimes occurred by its accidental mixture with wheaten flour, but in this country it does not grow in sufficient quantity to be often of any serious consequence. It is said to be used sometimes for giving an intoxicating quality to fermented liquors; and in China and Japan, where it also grows, its use is forbidden by law. The deleterious effects of lolium appear to luave been long known. Among the Arabs it is called ziran, and it is thought the word rosch in some instances means the same thing. It is generally supposed that it is this plant which is referred to by Virgil-

\section{"___ interque nitentix culta \\ Infelix Lolium, et sterilis dominantur avenæ ;"}

for, in warm climates, Lolium and the barren Oat sometimes grow so rank and abundant as to choke the Wheat. The late Sir J. D. Mi-

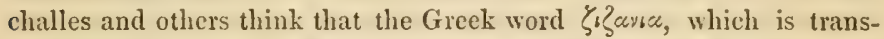
lated tares in our text of the 13th chapter of St. Matthew's Gospel, the 25 th and following verses, would be better darnel, and would convey the meaning of the parable more fully. From the parable above quoted, it will appear with what care the Jews disposed of the base grain, hy destroying it in the field with fire, after selecting it from the Wheat.

\section{GENUS L. ROT'TBOL'LIA. LINN. Hard-grass.}

Gen. Char. Inflorescence a two-sided spike. Spikelets alternate, one or two flowered. Glumes of two valves, sometimes single, lateral. Glumelles two, awnless, imbedded in the notches of the rachis.Named in honour of Rottböll, a Professor of Botany at Copenhagen.

1. R. incurva'ta, Linn. (Fig. 209.) Sea Hard-grass, Spike cylindrical, tapering; glumes united at the base. 
English Botany, t. 760.-. English Flora, vol. i. p. 175.-Hooker, British Flora, vol. i. p. 68.-Ophiu'rus incurva'tus, Beauv. Lindley, Synopsis, p. 295.

B. more slender'; spike nearly erect. Rottbol'lia filifor'mis, Roth.

Root small, fibrous, downy. Stems numerous, procumbent, and spreading at the base, the upper part erect, from six to twelve inches long, round, hard, smooth and shining, leafy. Leaves narrow, linear, striated, smonth on the under side, rough above and on the margins. Sheaths slightly swelling, smooth, and striated. Ligula short, obtuse. Inflorescence an erect, cylindrical, incurved spike. Rachis remarkably flexuose, forming a joint at the base of each floret, at which it readily separates, especially when matured, carrying with it the floret containing the ripe fruit. Spikelets spreading when in flower, but, both before and after, close pressed within the notches of the rachis, so as to form a round, smooth surface. Glumes lanceolate, united at the base, sometimes the whole length, and forming a single valve closely fitting the notches of the rachis, ribbed. Florets one or two, but only one perfect, the second mostly rudimentary. Glumelles two, lanceolate, equal, membranous. Anthers yellow. Stigmas feathery, spreading. Fruit oblong, enclosed within the florets.

Habitat.-Sea-coast, in salt marshes; not very common. Abundant in Ireland. $\beta$. Aberlady Bay, Scotland-G. Don.

Annual; flowering from July to August.

\section{GENUS LI. KNAP'PIA. SM. Knappia.}

Gen. Cirar. Inflorescence racemose, simple. Glumes two, truncated, nearly equal, awnless. Glumelles two, equal, obtuse, awnless, hairy.-Named in honour of Mr. Knapp, an English botanist, and author of "Gramina Britannica," or representations of the British grasses.

1. K. agrosti'dea, Sm. (Fig. 204.) early Knappia.

English Botany, t. 1127.-English Flora, vol. i. p. 84.-Hooker, British Flora, vol. i. p. 58.-Agros'tis min'ima, Linn., Chamagros'tis min'ima, Borkh., Lindley, Synopsis, p. 301.

The whole plant very small and delicate, not more than an inch or two inches and a half high, and "only one species is known." Root long, of numerous small branched fibres. Stems several from the same joot, erect, smooth, slender, triangular. Leaves short, linear, obtuse, roughish: sheaths nearly as long, pale, thin, membranous at the base, somewhat inflated; the lower ones shortly fade and decay: ligula obtuse, torn at the extremity. Inflorescence a simple raceme of few erect flowers, rachis somewhat zigzag in the upper part. Glumes two, uearly ecual, truncated at the aper, compressed and green or purplist 
at the back, pale and membranous on the edges. Glumelles two, equal in length, shorter than the glumes, delicate, thin, white, membranous, clothed and ciliated with fine silky hairs; the outer valve broadest, embracing the inner. Stamens longer than the glumes, anthers with two small terminal beaks. Stigmas long, feathery. Fruit obovate, slightly compressed, pale brown, striated and "beautifully dotted," as observed by Sir IV. J. Hooker.

Habitat.-Very rare, sandy fields near the sea, Essex, near the mouth of the Thames. Wales, and on the south-west coast of Anglesea, frequent-Rev. H. Davis.

Annual; flowering in March and April.

This diminutive grass is more interesting as a rare and beautiful botanical curiosity than from any known or valuable properties that it possesses; but, though so small, like all other of the productions of Nature, it affords to the reflecting mind abundant matter for investigation :

\footnotetext{
"By every pleasing image they present, Reflections such as meliorate the heart, Compose the passions, and exalt the mind."
}

Its habit will forcibly remind the student of the beautifully expressive allusion to the frailty of grass, made by the Apostle James in the 1st chapter of his Epistle, where he says, "The sm is no sooner risen with a burning heat, but it withereth the grass, and the flower thereof falleth, and the grace of the fashion of it perisheth." The young, the expanding mind, rising in intelligence, cannot be too soon led to the investigation of the simple yet wonderful works of the CREATor, which are so profusely spread around, and erer display his perfection, supreme intelligence, and infinite wisclom.

\section{GENUS III. SPARTI'NA. WILLD. Cord-grass.}

Gen. Chan. Inflorescence a one-sided spike. Spikelets one-sided, single-flowered, in two rows pressed close to the rachis. Glumes two, unequal, lanceolate, compressed, pointed or awned. Glumelles two, nearly equal, lanceolate, compressed. Styles partly united."Name derived from its similarity to the Lygeum Spartum, or Bastard Mat-ueed. Esparto (from which some authors say it is derived) is a name given to Stipa tenacissima by the Spaniards, who make ropes, \&c. of it." Hooker.

1. S. stric'ta, Smith, (Fig. 211.) twin-spiked Cord-grass. Spikes two or three, with very smooth stalks; glumes downy, the outer valve smallest.

English Flora, vol. i. p. 135.-Lindley, Synopsis, p. 298.-Hooker, British Flora, vol. i. p. 58.-Dac'tylis stricta, English Botany, t. 380. 
Root with strong fibres and creeping underground stems. Plant somewhat tufted, tough, and rigid. Stem erect, from one to two feet ligh, simple, round, smooth, clothed with leaves to the top, the base surrounded with numerous withered sneaths. Leaves short, rigid, striated, smooth, tapering to the point, the margins closely rolled inwards. Sheaths close, smooth, striated, long. Ligule short, torn. Inflorescence an erect, compound, one-sided spike; rackis angular, smooth, with a furrow for each spikelet. Spikelets in two lateral rows. Glumes unequal, lanceolate, more or less dlowny: the outer shortest, narrow, with an acute point, and keeled; inner with a strong keel, the margins membranous, tapering at the point, sometimes cloven, having between the lobes a short rigid awn, the termination of the keel. Florets single. Glumelles two, lanceolate, more or less membranous, both keeled, and less downy than the glumes. Glumellula wanting. Styles united together about three-fourths of their length. Stigmas slender, feathery. Fruit oblong, enclosed in the unaltered glumelles.

Habitat.-Salt marshes on the east and south-east coast of England, not common.

Perennial; flowering in August.

GENUS LIII. CYN'ODON. RicH. Dog's-tooth-grass.

GeN. Char. Inflorescence a compound spike. Spikelets one-sided, in two or more rows. Glumes two, nearly equal, keeled, spreading. Florets one-flowered. Glumelles shorter than the glumes, awnless, compressed, keeled; the outer valve broadest, enwrapping the shorter inner one, becoming hard and forming a coat to the ovate seed.-Name from xvwy, a dog; and odous, a tooth.

1. C. Dac'tylon, Pers. (Fig. 206.) creeping Dog's-tooth-grass. Spikes from three to five together; glumelles smooth, external one somewhat ciliated, internal with a bristle at its base.

English Flora, vol. i. p. 95.-Lindley, Synopsis, p. 298.-Hooker, British Flora, vol. i. p. 58.-Sinclair, Hort. Gram. Woburn. p. 290.Pan'icum Dac'tylon, Linn. English Botany, t. 850.

$R o n t$ long, fil,rous, branched, with numerous hard, branched underground stems. Stems long, prostrate, numerously branched and matted, and frequently sending out roots from the numerous joints; branches very leafy, and copiously clothed around their base with sheath and decayed leaves; flowering stems at length ascending leafy to the top, and terminating in from three to five straight, spreading, rigid spikes. Leures short, tapering to the point, slightly hairy, and glaucous. Sheaths long, striated, smouth, upper ones terminating in a bristle-shaped leaf, or frequently without. Ligula hairy. Spikes linear: the florets arranged in two or more close alternate rows, nearly 
sessile, on an angular, somewhat rough, striated, zigzag rachis, glossy, mostly purplish. Glumes narrow, actute, keeled, rough towards the point, spreading, which makes the spikes appear rough and spiny. Glumelles unequal, smooth, compressed, keeled; the outer valre much the broadest, slightly hairy on the keel and inner border, enwrapping the smaller inner valve. Glumellules two small scales. Styles distinct, long. Stigmas feathery. Fruit small, orate, enclosed in the hardened glumelles.

Habitat.-Very rare; on the sandy shore between Penzance and Marazion, Cornwall.

Perennial; flowering in July and August.

The long, branched, and rooting underground stems of this plant are admirably suited to the loose sandy situation of their growth.

This species, according to A. B. Lambert, Esq. in the 6 th vol. of the "Transactions of the Linnean Society," is identical with the famous doobgrass of the Hindoos, who worship it in the most extravagant manner, as the "Dirinity not subject to age or death-the armour of India, the preserver of regions, the destroyer of enemies, a gem that gives increase to the fields," Sc.-(See the Works of Sir Wm. Jones, rol. ii.)

\section{GENUS LIV. DIGITA'RIA. Scorotr. Finger-grass.}

Gen. Cirar. Influrescene' a compound spike. Spikelets arranged on one side of the wared rachis. Glumes of one or two very unequal valves; the outer sometimes wanting. Florets two: the perfect one of two cartilaginous, nearly equal valres; the imperfect one a single valve. Fruit coated with the hardened glumelles.-Named from digitus, a finger.

1. D. sanguina'lis, Scop. (Fig. 207.) hairy Cock's-foot-or Fingergrass. Leares and sheaths hairy; glumes oblong; smooth, the larger one rough on the margins only.

English Flora, rol. i. p. 96.-Linclley, Symopsis, p. 299.-Hooker, British Flora, rol. i. p. 58.-Sinclair, Hort. Gram. Woburn. p. 294.Pan'icum sanguina'le, Linn. English Botany, t. 849.

Root fibrous. Stems uumerous, bent and branched at the base, erect above, from iwelve to eighteen inches high, slender, round, smooth, striated, leafy. Leaves short, hroal, lanceolate, the margins waved, striated, smooth on the under side, roughish above, and, as well as their long, somewhat inflated sheaths, scattered orer with hairs, those on the latter arising from small tubercles. Ligula short, mostly torn. Inflorescence of from three to six or eight spreading spikes, terminating the stem. Rachis wared, angular, deeply furrowed, roughish, with a broad flat rib on one side. Spikelets two together, the footstalks an- 
gular, rough, one longer than the other, arranged alternately at each flexture of the rachis. Glumes of two very unequal valves: the outer one very small, ribbed, often absent; the inner oblong, the length of the florets, with about five ribs, purple, smooth except on the margin, which is rough or downy. Florets two, smooth, and glossy, becoming hard and cartilaginous: the perfect one of two nearly equal valves; the outer convave with inflexed nargins, the inner flat: the imperfect floret of one valve. Anthers small. S'tyle thread-shaped, as long as the stamens. Stigmus short, feathery. Fruit enclosed in the hardened glumella.

Habitat.-In cultivated fields, Battersea Fields, near London. The other statious given in English Flora, \&c. it is thought belong to the following species.

Annual; flowering in July and August.

This plant is of no agricultural utility. Birds are very fond of the seeds. In some parts of Germany they are said to be 11sed as sago, and, when boiled in milk or wine, to form an extremely palatable food. The specific name, sanguinalis, is said to have heen given to it, not from its colour, but on account of boys in Germany mischievously thrusting the spikes up the noses of their companions, by which means it makes them bleed.

2. D. humifu'sa, Pers. (Fig. 210.) smooth Cock's-foot- or Fingergrass. Leaves and sheaths smooth; glumes orate, downy.

Hooker, in English Botany, Supplement, t. 2613.-British Flora, vol. i. p. 59.-Lindley, Synopsis, Supplement, p. 333.

Root of numerous branched fibres. Plant tufted, and of a more or less purplish hue. Stems numerous, bent at the base, and spreading, becoming erect, slender, round, smooth, striated, from three to six inches high, leafy. Leares broadly linear, lanceolate, quite smooth to the touch, except a roughness in the margins, with a rather prominent midrib, and several slenderer lateral ones. Sheaths swollen, striated; the upper long, and quite smooth; the lower short, and with a few occasional hairs on the margins, but otherwise quite frce from hairs or roughness. Ligula short, obtuse. Inflorescence similar to the last, the spikes varying in number from two to four. Rachis with a broad, striated wing, having pale, narrow, rough margins. Spikelels two, sometimes three together, one on a longer footstalk than the others, nearly smooth, angular. Glumes very unequal: the outer a small, smooth, blunt, membranous scale, sometimes wanting; the inner ovate, equal in length to the florets, downy, with from three to five smooth green ribs. The imperfect floret of one valve, similar to the larger valve of the glumes; the perfect one of two dark purple, shining, concave valves, beautifully marked with numerous close dotted lines, the margins pale and membranons, rolling inwards, at length forming a hardened investment for the fruit. Anthers small, purple. Style 
threat-shaped, as long as the ralves. Stiymas protruding, short, ferthery.

Habitat. - On loose sand at Weybridge, Sussex-Mr. Borrer; who says that the Ipswich $D$. sanguinalis is this, and thinks that the Norfolk and Suffolk stations, assigned to that plant in E. Flora, probably belong to the present. Once found at Dalheth, near Glasgrow -Mr. Hopkirk." Yarmouth-Mr. J. D. Hooker.

Annual; flowering in July and August.

\section{ORDER III.}

\section{TRIGYN'IA. 3 PIsTIJ.s.}

\section{GENUS LV. MON'T1A. Linn, Blinks.}

Nat. Ord. Portula'ces.

Gen. Chan. C'alyx inferior, of two orate abrupt pieces, united at the base. Corolla of five unequal petals, united at the base. Capsule one-celled, with three valves and three seeds.-Named in honour of Joseph de MTonti, a Professor of Botany and Natural History at Bologna.

1. M. fonta'na, Linn. (Fig. 212.) Water Blirks, or Water Clickueed. English Butany, t. 1206.-Einglish Flora, vol. i. p. 186.-Lindley, Synopsis, p. 62.-Hooker, British Flora, vol. i. p. 59.

Root small, fibrous. Plant varying in height from one to four inches, of a shining pale-green, often with a yellowish hue, quite smooth and succulent. Stcms much brauched and spreading, often putting out roots from the axils of the leaves. Leares small, opposite, spatulate, entire. Flowers small, white, arising from the base of the leaves, or terminating the stems, at first drooping, and expanding themselves only in the bright sunshine; their footstalks simple, or branched. Calyz: of two, sometimes three, permanent pieces. Corolla. of five petals, three smaller than the others, and having the stamens inserted into them. Styles very short. Stiymas three, with spreading hranches. Capsule erect, roundish, one-celled, containing three black, shining, dotted secls; its three ralses, after discharging the seeds, nro spreading, and have their margins rolled inwards.

Ilabilut.-On the side of streams, springs, and in wet places, fre. quent.

Annual; flowering from May to July. 


\section{GENUS LVI. HOLOS'TEUMI. Linn. Jagged Chickweed.}

Nat. Ord. Carqo'phyleze.

Gen. Char. Calyx inferior, of five ovate pieces. Petals five, jagged towards the extremity. Capsule one-celled, opening at the apex with six teeth. Seeds numerous, furrowed on one side, and dotted,

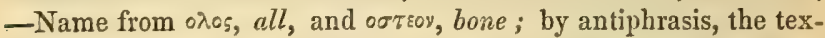
ture of the plant being the rery reverse of the meaning-soft and delicate.

1. H. umbella'tum, Linn. (Fig. 213.) umbelliferous Jagged Chickweed. Flowers umbellate, reflexed after flowering, at length erect; leaves ovate, acule.

English Botany, t. 27.-English Flora, p. 187.-Lindley, Synopsis, p. 50.-Hooker, British Flora, vol. i. p. 59.

Root small, fibrous. Stems weak, bent and branched at the base, the upper part erect, from four to five inches high, round, the lower part smooth and leafy, the upper naked, mure or less clothed with glandular hairs. Leares opposite, spreading, ovate, oblong, with an acute point, single-ribbed, glaucous, and of a somewhat succulent texture; the footstalks dilated, and often combined at the base. Flowers in a terminal umbel, mostly fire, their stalks simple, spreading, or reflexed, having at the base several small bractec. Calyx of five ovate, acute, permanent pieces. Corolla of five oblong, unequally jagged or toothed petals, of a white or reddish hue. Anthers roundish. Styles short, slender. S'tigmas downy. Capsule cylindrical, its six teeth finally separating into as many valves. Seeds numerous, attached to a central placenta, rough, roundish, its embryo folded back in tho albumen.

Habitat.-On old walls; rare. About Norwich and Bury.

$\Lambda$ nnual; flowering in $\Lambda$ pril.

This genus is nearly allied to Cerastium. The jagged, not cloven, extremity of the petals, and the number of stamens, will, however, readily distinguish it.

\section{GENUS LVII. POLYCAR'PON. LINN, All-seed.}

Nat, Ord. ILLECE'BREXE.

Gen. Cinsn. Calyx inferior, of five ovate mucronate pieces, with membranous margins, and united at the base. Pctals five, notched at the extremity. Stamens from three to five. Capsule one-celled,

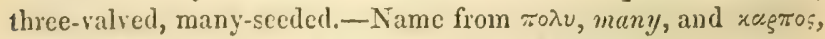
fruit; on account of the abundance of secd which it produces. 


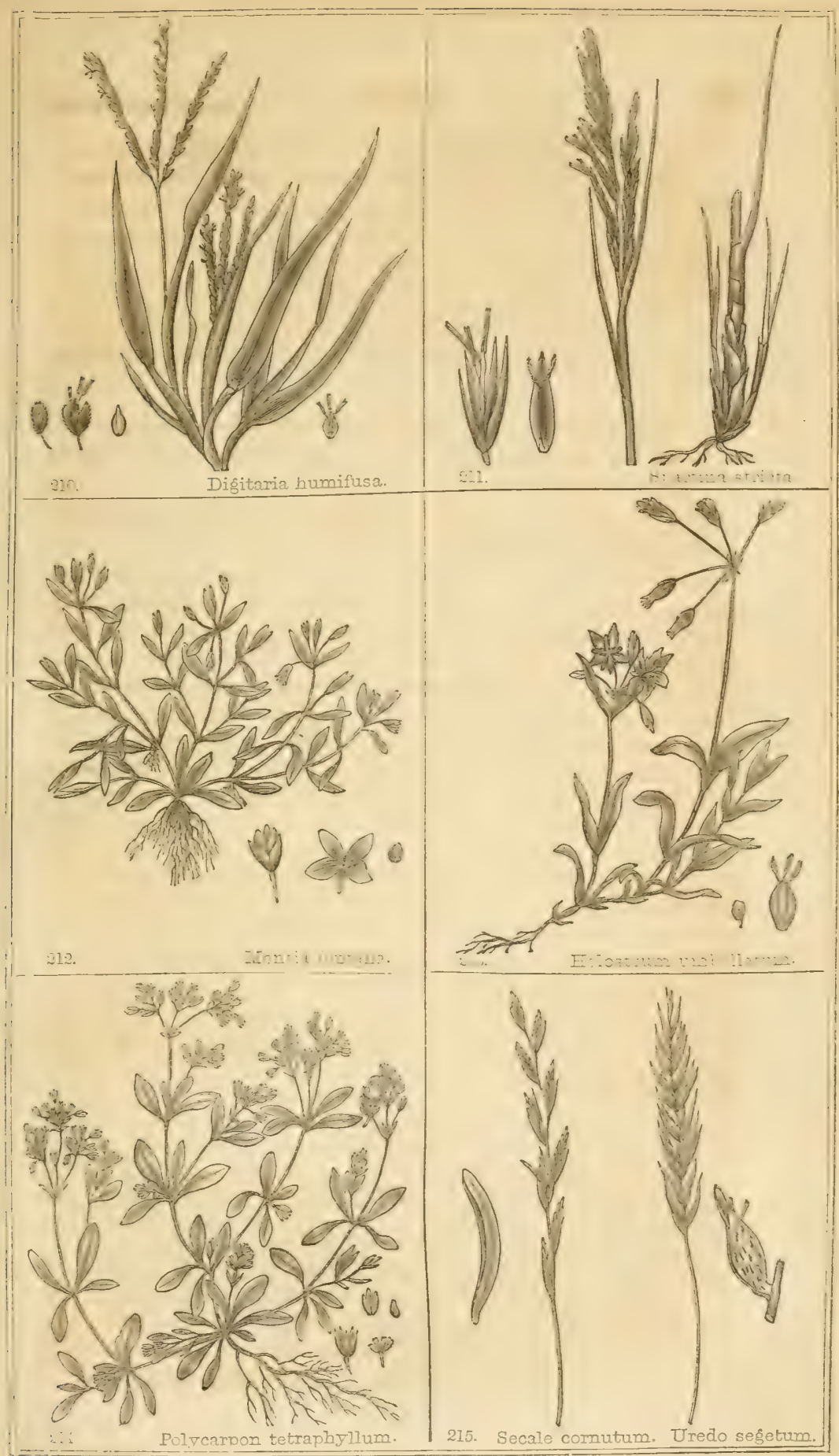



1. P. tetraphyl'hm, Linn. (Fig. 214.) four-leaved All-seed. Leaves of the stem whorled in fours, those of the branches opposite.

English Botany, t. 1031.-English Flora, vol. i. p. 188.-Lindley, Synopsis, p. 61.-Hooker, British Flora, vol. i. p. 59.

Root long and tapering. Stems numerous, spreading upon the surface of the ground, repeatedly branched, and somewhat downy. Leaves obovate, on short footstalks, entire, smooth, and rather succulent, arranged in whorls of four on the stems, and two on the branches, having at the base thin membranous stipula, pointed, with a jagged margin. Flowers terminal, in corymbose branches, each division of which having at its base a pair of acute, membranous, pointed, and jagged bractec. Calyx of five ovate, keeled, pointed pieces, with pale membrauous margins, slightly united at the base. Petals five, obovate, notched at the extremity, white, smaller than the calyx leaves, and alternating with them. Stamens from three to five. Styles short. Capsule ovate, of one cell, opening with three valves. Secds small, numerous, attached to a central placenta.

Habitat.-Southeru coasts of England-Devonshire, Dorsetshire and Portland Island.

Annual; flowering during the summer months.

\section{CLASS IV.}

\section{TETRAN'DRIA. 4 STAMENS (equal.)}

\section{ORDER I.}

MONOGYN'IA. 1 PIsTIL.

\section{GENUS I. DIPSA'CUS. Linn. Teasel.}

Nat. Ord. Dipsa'CE.E.

Gen. Char. Flowers in heads, surrounded by a many-leaved involucrum. Involucellum with four sides, and eight little excavations. Calyx cup-shaped, thickly clothed with short rigid hairs. Receptacle with spiny, glumaceous bractea, shorter than the leaves of the involucrum. - Name from $\delta \cdot \psi \alpha \omega$, to be thirsty; the upper united leaves holding water in their hollows, by which the thirsty traveller may be relieved. 
1. D. Fullo'num, Limn. (Fig. 216.) Fuller's Teasel. Leaves opposite, mostly united; scales of the receptacle hooked backwards at the extremity; involucrum spreading:

English Botany, t. 2081.-English Flora, rol. i. p. 192.-Lindley, Synopsis, p. 139.-Hooker, British Flora, vol. i. p. 163.

This plant differs from the following, in the leaves being more frequently united at the base, the leaves of the involucrum spreading, the scales of the receptacle hairy, the points recurved and rougher. "These hooks, however, become obsolete by long cultivation in a poor soil, and there is every reason to belicre that $D$. Fullonum is but a rariety of D. sylvestris."

Habitat.-Waste places and hedge banks, but rare.

Biennial; flowering in July and August.

The Teasel is a plant of great importance to the manufacturers of woolleu goods, and is cultivated to a considerable extent in our southern counties, as well as in some parts of Yorkshire, and on the Contiuent. The plants are grown best, and to the greatest perfection, in a strong soil: they are generally cultivated by the joint interests of the farmers and labourers, the former agreeing to find land free of expense, together with mantre and the use of his horses, while the latter are at the remaining expense and all the lubour, and finally the profits arising from the sale of the heads are equally divided between the two parties. The heads are used in dressing woollen cloths, for which purpose the honked scales of the receptacle are admirably adapted: indeed, no mechanical contrivance has yet been invented that cun supersede or equal them. The plants require much trouble and care in their cultivation, and in the collecting and drying of the heads. The crops are often unequal, and sometimes a complete failure; consequently, their value is very rarious, according to circumstances, sometimes selling at $£ 4$, and at wher times at $£ 22$ the pack: an acre of land often produces 15 or 16 packs. The packs contain various numbers. The larger terminal heads are called "kings," and there are about 9,000 in a pack; these are used for the dressing of the coarser kinds of cloth. "The middlings, sometimes termed "princes," have from 18,000 to 20,000 in a pack, and are used for the finer and more delicate qualities of cloth; and the "scrubs," which are the smallest of the heads, are of but little value. The heads are used by the manufacturers, by fixing them upon frames covering a cylinder, which is rapidly revolved, when the liooks at the extremity of the elastic scales slightly catch the cloth, while another part of the machine draws it under them; by this means the nap is raised to the desired length. The holluw furmed by the united base of the leaves, called "Venus's cup," often contains nearly half a pint of fluid, which is esteemed a cosmetic, but with what pretensions ve know not. 
2. D. sylves'tris, Linn. (Fig. 217.) wild Tetsel. Leares opposite, rarely united; scales of the receptacle straight at the extremity; involucrum curved upwards.

English Botany, t. 1032.-English Flora, vol. i. p. 193.-Lindley, Synopsis, p. 139.-Hooker, British Flora, vol. i. p. 64 .

Root tapering and branched. Slew from four to six feet ligh, erect, stout, strongly furrowch, rough, with stout prickles, hollow, and haring opposite branches to *arks the top. Leares opposite, oblong or oblonglanceoiate, obtusely and irregularly serrated or jagged, with a strong prickly midrib, and sometimes united at the base, especially the upper ones, forming hollows which are capable of retaining water. Inflores. cence a close oval head, surrounded by an involucrum of numerous narrow, spreading, prickly leares, as long as the head of flowers. Flowers numerous, whitish or pink. Inrolucellum four-sided, each side haring two narrow excavations, and the margin having a shrivelled appearance. Calyx eup-shaper, superior, its tube investing the or $(t-$ rium, and adhering to it, at least at the summit. Corolla of one piece (monopetalous), tubular, downy, inserted into the calyx obliquely, fourcleft. Stamens alternate with the segments of the corolla. Otarium inferior, one-cellerl, with a single pendulous ovalum. Fruit crowned by the calyx. Each floret arises from the base of a lanceolate, membranous scale, with a straight, roughish point, the margins hairy.

Habitat.-Roal sides, hedges, Ec. in damp situations; frequent in England and Ireland-less common in Scotland. Inchcolm, near Edinburgh-Maughan. South siche of Duddingston Loch-Mr. Neill. River sides about two miles from $\mathrm{Ayl}-M r$. J. Wilson.

Biennial ; flowering in July.

3. D. pilo'sus, Linn. (Fig. 218.) small Teasel. Leares on footstalks, with a small leafiet at the base on cach side; inrolucrum deflexed, about the length of the heads.

English Botany, t. 877.-English Flora, rol. i. p. 193.-Lindley, Synopsis, p. 139.-Hnoker, British Flora, vol. i. p. 6-1.

Root tapering. Stem erect, from three to four feet high, furrowed, Fugh with prickles, especially towards the top, with spreading, oppo. site branches. Leares opposite, on rough angular footstalks, ovatelanceolate, with a tapering point, unequally serrated, accompanied at its base on each side with a small ovate leaflet, and, like the leares, more or less hairy. Heads of flowers rather small, round, hairy. Involucrum of numerons narrow, lanceolate, pungent, hairy leaves, the margins brist?y, about the length of the head, shortly reflexed. Scales of the receptacle with straight rigid points, clothed with short down, and fringed with rigid bristles. Flouer's similar to the last, except that the corolla is larger, white, four, or, according to Smith, fire-cleft.

Habitat.-Moist shady situations; not common. In rarious parts 
of Norfolk, Suffolk, and Derbyshire; Arundel Castle, Sussex; Guildford, Surrey ; "River Don side, about a mile below Conisbro"," Yorkshire-Salt's Herbar. Rare in Scotland-Lightfoot.

Biennial; flowering from July to September.

\section{GENUS II. KNAUTIA. LiNn. Knautia.}

\section{Nat. Ord. DiPSA'CEE.}

Gen. Char. Flower's in heads, surrounded by a many-leaved involucrum. Involucellum compressed, with four little excavations. Calyx cup-shaped. Fruit placed upon a short stalk. Receptacle bristly.-Named in honour of Christopher Knaut, a botanist of Saxony, who flourished in the latter half of the seventeenth century.

1. K. arven'sis, Coulter, (Fig. 219.) Field Knautia. Heads manyflowered; involucellum with very minute teeth; calyx with from eight to sixteen awn-like bristles.

Hooker, British Flora, vol. i. p. 64.-Lindley, Synopsis, p. 140.Scabio'sa arven'sis, English Botany, t. 659.-English Flora, vol. i. p. 195.

Root tapering, with spreading fibres, putting out several round, hollow, branched, erect stems, from two to three feet high. The whole plant hairy. The lower leaves on footstalks, lanceolate, more or less serrated; the upper ones deeply cut in a pinnatifid manner, and without footstalks. Sometimes the whole of the leaves are lanceolate, and with the footstalks of variable lengths. Flowers large and handsome, in somewhat convex terminal heads of numerous lilac flowers, on longish simple stalks, surrounded by an involucrum of numerous lanceolate hairy leaves, and fixed upon a convex bristly receptacle: inner florets perfect, and with equal segments; the outer ones larger, with imperfect stamens, the segments unequal, of a darker colour, and disposed in a radiated manner round the head. Fruit on a short, glandular stalk, onc-celled, enwrapped in the somewhat hairy tube of the involucellum, and crowned by the persistent, cup-shaped, bristly, pappus-like calyx.

Habitat.-Pastures and corn-fields; frequent.

Perennial; flowering from June to August.

The whole plant has a bitter, somewhat astringent, natseous flavour, and was formerly much employed in the cure of some affections of the skin and diseases of the lungs. Sheep and goats are said to eat it, but it does not appear to be generally relished by domestic cattle. 



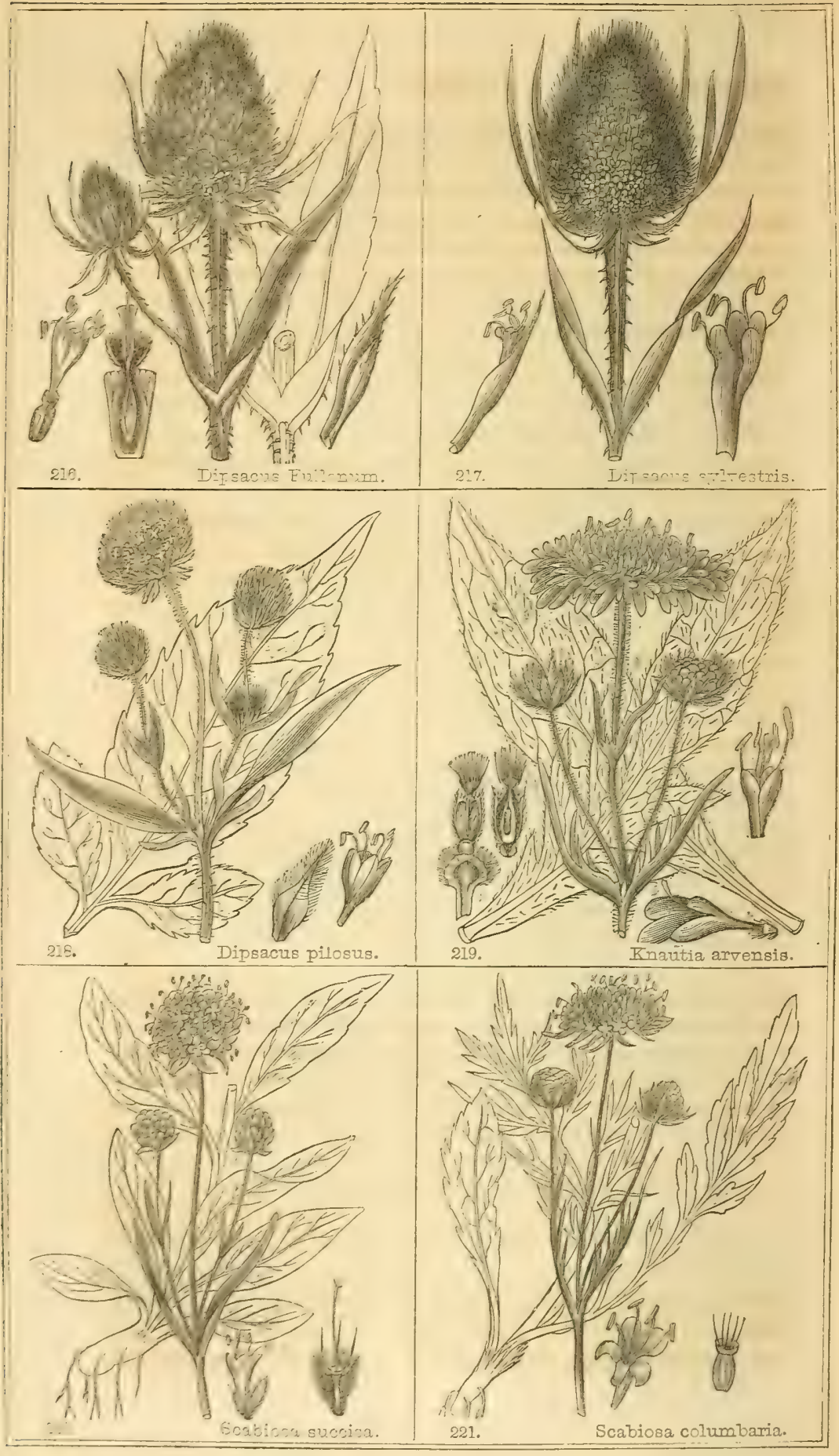




\title{
GENUS III. SCABIO'SA. LIns. Scabious.
}

\author{
Nat. Ord, DIPSA'CEX.
}

Ges. Char. Flowers in heads, surrounded by a many-leaved involucrum. Intolucellum nearly cylindrical, with eight little excavations, and a membranous plaited limb. Calyx with a limb consisting of about five bristles. - Name from scaber, rough; on account of the roughness of the surface of the plants.

1. S. succi'sa, Linn. (Fig. 220.) Devil's.bit Scabious. Heads of flowers nearly globular; corolla in four equal segments; rootleaves ovate, entire; upper ones lanceolate, toothed.

English Botany, t. 876.-English Flora, rol. i. p. 194.-Lindley, Synopsis, p. 139.-Hooker, British Flora, vol. i. p. 64 .

Root with numerous branching fibres, abrupt at the extremity, as if bitten off. Stem erect, from one to three feet high, nearly simple, hairs in the upper part pointing upwards, rougher below, with the hairs pointing downwards. The lower or radical leaves ovate-entire, with long footstalks; those of the stem, or cauline ones, oblong-lanceolate, unequally toothed, sessile or with short stalks, and united at the base, all harsh and hairy. Flovers in roundish heads, blue, purplish, or flesh-coloured, on long simple stalks, surrounded by an involucrum of numerous lanceolate, hairy leaves; receptacle hairy. Florets numerous, equal, each accompanied with a lanceolate bractea. Corolla downy, with four nearly equal segments. Fruit crowned by the persistent calyx of about five darkish bristles, and enwrapped in the hairy tube of the involucellum, the margin of which is membranous and toothed. Stamens large, yellow or purplish. Pistil long, with a capitate stigma.

Habitat.-Meadows, pastures, and waste places; frequent.

Perennial; flowering from July to September.

The origin of the rulgar name of this plant, we are informed by ancient writers, is from the superstitious notion which they entertained, that the root had been bitten off by the Deril; for they supposed he enried mankind the medicinal benefit they might derive from its virtues. Hence alone, as Sir J. Smith observes, those virtues were presumed; and in proportion as the Deril and his operations are little thought of, they have fallen into oblivion in these our unbelieving days.

2. S. columbaria, Linn. (Fig. 221.) small Scabious. Heads of flowers somewbat convex ; corolla in fire unequal segments ; rootleares orate, notched or lyrate; those of the stem pinnatifid, with narrow segments.

English Botany, t. 1311.-English Flora, vol. i. p. 195.-Lindley Synopsis, p. 140.-Hooker, British Flora, rol. i. p. 64.

Root tapering, woody, fibrous. Stem erect, from one to two feet voL, I. 
high, round, hairy, especially in the lower part, hollow, leafy, slightly brancherl above. Root leaves various, on footstalks, ovate, oblong crenate, decply cut or lyrate; those of the stem sessile, pinnatifid, with linear segments. Flover's in somewhat cunvex, terminal heads, pale purplish, on long naked stalks. Involucrum of narrow hairy leaves, longer than the flowers. Receptacle scarcely hairy. Florets numerous, hairy, five-cleft, unequal; the outer ones larger than the others, and forming a ray around the head. Fruit crowned by the persistent calyx of about five long, dark, roughish bristles. Involucellum hairy, forming a tubular envelopement to the fruit; the limb, thin, pale, membranous, crenated, and plaited.

Habitat.-Pastures and waste places, in chalky, limestone, and clayey districts, in England. Rare in Scotland: near Arbroath, Ayrshire, with white flowers $-M i r$. G. Don : plentiful near Montrose and Blackford-Mr. Murvay.

Perennial; flowering from July to August.

\section{GENUS IV. GA'LIUM. Linn. Bed-straw.}

Nat. Ord. STELIA'TA.

Gen. Char, Corolla wheel or bell-shaped, four or five-cleft. Fruit a dry, indehiscent pericarp, with two cells and two sceds, not crowned by the calyx.-Name from raia, milk; some species having the property of curdling milk.

\section{* Fruit smooth. Flowers yellow.}

1. G. ve'rum, Linn. (Fig. 222.) yellow Bed-straw. Leaves about eight in a whorl, linear, grooved, entire; flowers in dense panicles.

English Botany, t. 660.-English Flora, p. 208.-Lindley, Synopsis, p. 130.-Hooker, British Flora, vol. i. p. 65.

Root with creeping underground stems, of a reddish hue. Flowering stems erect, from one to two feet high, smooth or somewhat downy, square, branched at the base with numerous whorls of linear reflexed leares, grooved, and of a bright green above, pale on the under side, the margins rolled back, more or less rough, with short rigid points. Inflorescence a dense, terminal, downy, branched paniele. Floners small, yellow, very numerous, having a luscions, honey-like smell. Fruit blackish.

Habitat.-Dry, waste, sandy places; common.

Perennial; flowering from June to August.

This plant, known by the names of Yellow Ladies' Bed-straw, Cheese Renning, Petty MIugnet, and Yellow Goose-grass, is said to have been used in cheese countries for the purpose of coagulating milk, and 
giving a rich colour to the curd, for which purpose it is still used by the Highlanders, in combination with the leaves of the common Nettle,

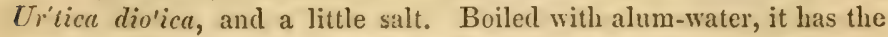
property of tinging woollen goods of a yellow colour; and the flowers were long employed in various forms as a cure in epileptic and lysterical complaints, but are now out of use. The roots, according to Mr. Curtis, yield a fine red colouring matter not inferior to malder, and are boiled by the Highlanders with the yarn, adting alum to fix the colour. The roots are too small to render its cultivation as a substitute for madder profitable.

2. G. crucia'tum, Linn. (Fig. 223.) Crossunt Bed-strau, Muguecd. Leaves four in a whorl, ovate, hairy ; flowers in small, stalked, axillary clusters, each with a pair of small leares.

English Botany, t. 143.-English Flora, vol. i. p. 199.--Liudley, Synopsis, p. 129.-Hooker, British Flora, rol, i. p. 65.

Root with creeping underground stems. Stem from ten to eighteen inches high, branched at the base, weak, angular, simple above, clothed with simple hairs. Leaves ovate, four in a whorl, sessile, soft with lairs, having a strongish midrib and sereral lateral, slender, parallel ones. Inflorescence in small axillary corymbs, the common stalk bearing a pair, sometimes a whorl of four small leares. Flowers on short stalks, small, yellow, from three to fire-cleft; some perfect, bearing stamens and pistil; others with stamens or pistils only. Fruit concealed by the leaves, which gradually rise and are leflexed orer them as they become perfect, thus forming a protection to them, and concealing them from birds.

Habitat.-Hedges, banks, and shady places; frequent.

Perennial; flowering from Mlay to June.

*\% Fruit smooth. Flowers white.

3. G. palus'tre, Linn. (Fig. 224.) white Watcr Bed-strau: Leaves from four to six in a whorl, unequal in size, oblongo-lanceolate, obtuse, tapering at the base; stem weak, spreading, branched, and, as well as the leaves, more or less rough.

थ. Stem and leaves smoothish.-Hooker, British Flora, vol.j. p. 65. -Galium palus'tre, English Botany, t. 1857.-English Flora, p. 200.-Lindley, Synopsis, p. 128.

$\beta$. Nerves at the back and margins of the lcaves, and angles of the stem, distinctly rough, with mostly reflexed prickles.-Hooker, British Flora, vol. i. p. 65.-Galium Witheringii, English Botany, t. 2206.-English Flora, vol. i. p. 200.-Lindley, Synopsis, p. 128.

Root with somewhat creeping underground stems. Stems very various in size, mostly tall, weak, and slender, angular, much branched, 
widely spreading their branches, and supporting themselves upon the stronger plants which grow near, smooth, or more generally the angles are rough, with reflexed sharp points, sometimes only slightly so, at others much more. Leaves from four to six together, in rather distant whorls, spreading, oblong or oblong-lanceolate, tapering at the base, obtuse at the apex, sometimes but rarely with a short point; the margins and midrib on the under side mostly rough, with points turned towards the apex : the whorls, especially in the upper part of the stem, of irregular leaves, having two opposite ones narrower and shortex than the others. Inflorescence a terminal, ternate, wide-spreading panicle, each division having at its base two or more leaves. Flowers white or cream-coloured, numerous, with broad, acute, not pointed segments. Fruit quite smooth, frequently abortive.

Habitat.-On the margin of drains, lakes, rivulets, and wet situations; common.

Perennial; flowering in July and August.

G. Witheringii of Smith appears to have been first considered a variety of the present species by $\mathrm{Mr}$. W. Wilson, as quoted by Sir W. J. Hooker, in his British Flora. The transition from the smooth to the rough state of the plant, as $\mathrm{Mr}$. Wilson has stated, may be frequently observed on the margins of pools : indeed, the whole plant varies so greatly, as at one time to be not higher than a few inches, and very slender; at others two feet or more, stout, and of a robust habit. It turns blackish in drying, while the following, which grows in similar situations, remains green.

4. G. uligino'sum, Linn. (Fig. 225.) rough Marsh Bed-straw. Leaves six in a whorl, lanceolate, bristle-pointed, their margins, like the angles of the stem, rough, with recurved prickles.

English Botany, t. 1972.-English Flora, vol. i. p. 201.-Lindley, Synopsis, p. 129.-Hooker, British Flora, vol. i. p. 66.

Root small, with creeping underground stems. Stems weak and slender, from one to two feet high, angular, the edges rough with reflexed bristles, branched and very brittle. Leaves pretty regularly six in a whorl, except the terminal branches, lanceolate, tapering at the base, with an acute discoloured point, which is terminated by a sharp bristle; the margins generally rolled back, and beset with a row of recurved priekles; and not unfrequently there is another less perfect row near it, which are pointed in the contrary direction; the midrib on the under side is also rough, but less so than the margins: sometimes the leaves on the branches approach an ovate, rather than a lanceolate figure. Inflorescence in small, terminal, branched panicles of white flowers. Fruit small, minutely dotted, seldom both perfected.

Habilat.-Wet meadows, marshes, the sides of drains, \&c.; not un. common. 


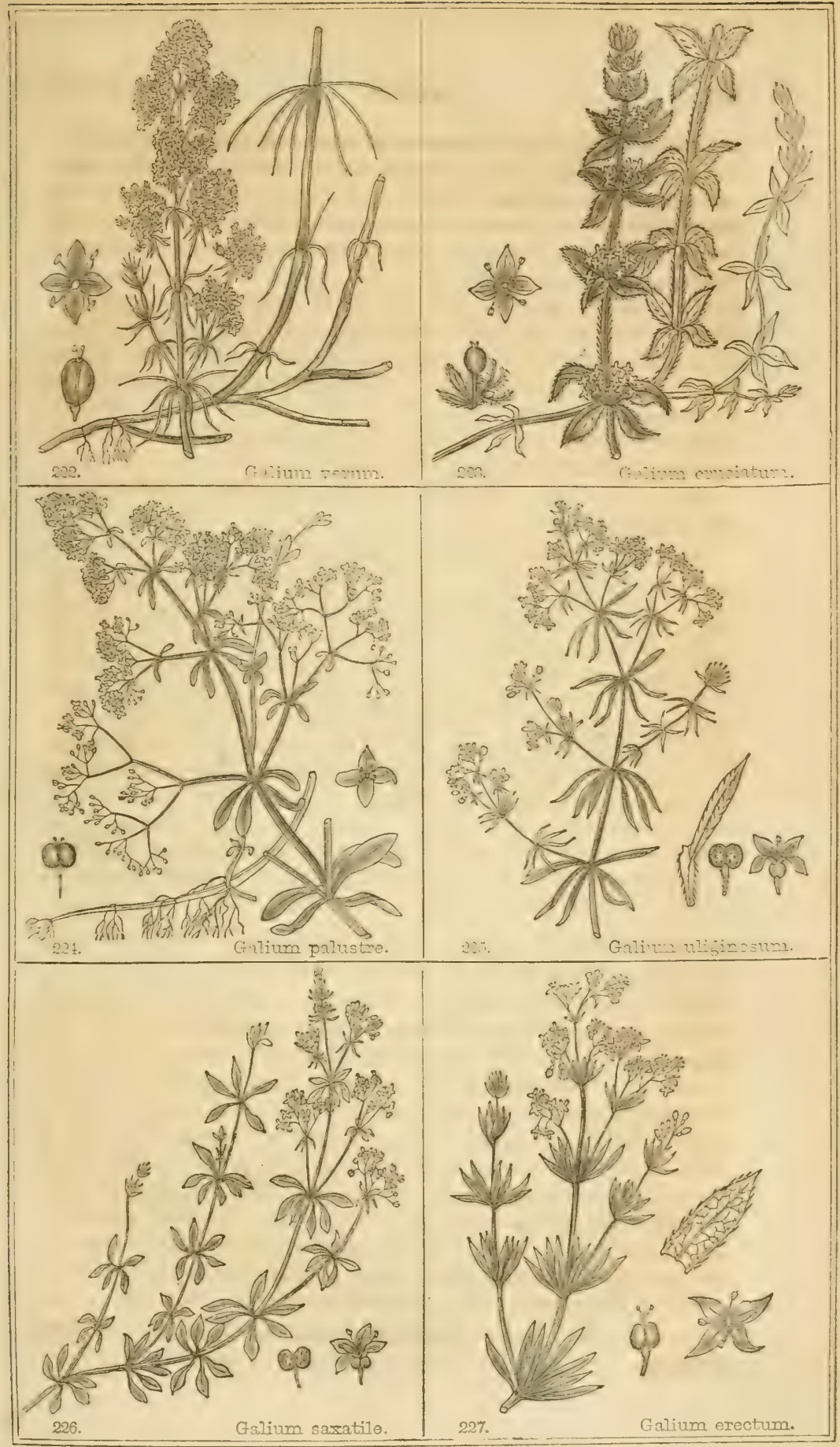



Perennial; flowering in July and August.

The whole plant is of a pale-green colour, which it retains after drging. This circumstance, together with the shape of the leaf, readily distinguish it from the preceding species, although specimens occasionally occur with characters intermediate between the two.

5. G. saxa'tile, Linn. (Fig. 226.) smooth Heath Becl-straw. Leaves six in a whorl, obovate, obtuse, with a bristle point; stem smooth, prostrate, much branched.

English Botany, t. 815.-English Flora, vol. i. p. 201--Lindley, Synopsis, p. 129.-Hooker, British Flora, vol. i. p. 66.

Root with long, creeping underground stems. Stems smooth, much branched, procumbent and slender at the base, varying considerably in length and luxuriance, according to the situation of their growth, bearing numerous whorls of six obovate or oblong, obtuse, or shortly acute leares, the midrib terminating in a short rigid bristle; the margins smootb, or beset with prickles pointing towards the apex, otherwise smooth and shining like the stem. Inflorescence in terminal, spreading, three-branched panicles, bearing an abundance of small white flowers. Fruit small: when young, crowned with the capitate stigma upon a rather long style, of a reddlish hue, and minutely dotted; when ripe, covered with minute prominent granulations.

Habitat.-Heaths, moors, and mountainous districts; abundant.

Perennial ; flowering from June to September.

This plant often grows abundantly on heaths and moors, producing so great a profusion of its milk-white flowers, as completely to clothe the surface; and during the summer months, it may frequently be observed to hang in thick festoons from the orerhanging rock or mountain's craggy side.

6. G. erec'tum, Hudson, (Fig. 227.) upright Bed-straw. Leares about eight in a whorl, lanceolate, bristle-pointed, thcir margins with prickles pointing forward; panicle much branched; stem smooth, weak; segments of the corolla taper-pointed.

English Botany, t. 2067.- English Flora, vol. i. p. 202.-Lindley, Synopsis, p. 129.-Hooker, British Flora, vol, i. p. 66.

$\beta$. Leaves downy beneath.-Hooker, British Flora, vol. i. p. 66 .

Root with creeping underground stems. Stem erect, much branched, square, with rather acute angles, pale, smooth [somewhat hairy beneath the whorls-Smith], spreading, from one to two feet high. Leares about eight in a whorl, lanceolate, acute, with a discoloured point terminated by a bristle, quite smooth, and reticulated with veins; the margins slightly reflexed and rough, with pale prickles in a single or mostly double row all pointing forwards; the lower leares, and sometimes those of the branches, are somewhat ovate, and all are of a pale glaucous bue, especially on the under side. Inflorescence in compound 
terminal and lateral much-branched pauicles, bearing numerous crowded, rather large, white flowers; the segments of the corolla spreading, their points acute, tapering into an awn-like point. Sir W. J. Hooker remarks that the variety which he received from Mir. Banls, agrees in every particular with the $E$. Bot. plant, except that the leaves are all minutely, but distinctly and thickly, downy beneath.

Habitat. - Hedges and pastures; not common. Norfolk- $I I r$. Croave. Portslade, Sussex, and near Cambridge-MIr. Borrer. Fish uires' Causeway, Portobello, near Edinburgh-Maugham. On the north side of Killiney Hill, Ireland-Miss Green. B. Near Plymouth -MI. G. Banks.

Peremnial; flowering from June to July.

7. G. cine'reum, Allion. (Fig. 228.) grey spreading Bed-straw. Leaves six to eight in a whorl, linear, bristle-pointed, their margins with prickles pointing forwards; stem weak, much branched, smooth; segments of the corolla taper-pointed.

English Botany, Supplement, t. 2783.-English Flora, vol. i. p. 203. -Lindley, Synopsis, p. 129.-Hooker, British Flora, rol. i. p. 66.

Stem loosely spreading, from one and a half to two feet high, square, smooth, pale, repeatedly branched, and bearing numerous whorls of from six to eight leaves, linear, slightly tapering at the base, with an acute point terminating in a pale bristle, smooth and somewhat glaucous, the margins slightly reflexed and rough, with pale prickles, especially towards the point, in a single row, and pointing forwards; they are either spreading or close pressed. Inflorescence in terminal and lateral branched panicles of few flowers: the corolla white, larger than in the abore species, with horizontal segments, each tipped with a short taper, not bristly point, various in length and direction. Fruit smooth, or slightly granulated.

Habitat.-On the banks of the river I,eitl, near Slateford, three miles from Edinburgh, and near Kinnaird, Angusshire, Scotland-Mr. G. Don.

Perennial; flowering in August.

This, Sir J. E. Smith observes, comes very near G. erectum, and experience must prove how far its differences are constant. We have been obligingly faroured by Sir W. J. Houker with specimens found near Bath, which appear intermetiate between the two: the leaves are linear, scarcely lanceolate, with reiny reticulations; the margins, especially towards the point, with two rows of prickles; the panicles fewflowered, and the segments of the corolla tapering at the point.

8 G. arista'tum, Linn. (Fig. 229.) bearded Bed-sivaiv. "Leaves six in a whorl, stalked, lanceolate, flat, reticulated with veins, bristle-pointed, with miuute marginal prickles pointing forward; stem much branched, spreading, smooth; seeds smooth, kidneyshaped, senarated; corolla taper-pointed," 
Fnglish Botany, Supplement, t. 2r84.-English Flora, vol. i. p. 204. - Lindley, Synopsis, p. 129.-Hooker, British Flora, vol. i. p. 67.

"The stems are numerous, a foot high, upright, with copious spreading branches, square, very smooth. Leares six in a whorl on the main stem, and often on the branches, though sometimes but four or five; the largest above an inch long, on short broal stalks, elliptic-lanceolate, flat, pliant, deep-green on both sides, with many interbranching veins, smooth except the edges, which are very minutely prickly. Flowers white, in terminal, forked, aggregrate, compound panicles, with perfectly smooth, slender, but not capillary stalks. Segments of the corolla spreading, each tipped with a taper point of its own substance. Seeds becoming kidney-shaped as they ripen, with a central vacancy, smooth, or slightly granulated."

Habitat.-In Angusshire, Scotland; but not common-MIr.G. Don.

Perennial; flowering from July to August.

This plant we have not had an opportunity of examining. The description is that of Sir J. E. Smith, in English Flora.

9. G. Mollu'go, Linn. (Fig. 230.) great Hedye Bed-strat. Leaves about eight in a whorl, ovate, obtuse, bristle-pointed, the margins rough; panicle large, loose, branched, spreading; segments of the corolla taper-pointed.

English Botany, t. 1673.- English Flora, vol. i. p. 208.-Lindley, Synopsis, p. 129.-Hooker, British Flora, vol. i. p. 67.

Stem from two to four or five feet high, with numerous long, straggling branches, square, pale and shining, swelling about the joints, especially the upper ones, quite smooth or slightly hairy. Leares in rather distant whorls, mostly eight, green above, palc beneath, the margins smooth, or with prickles pointing forwards; the upper leaves ovate-lanceolate; the lower ovate-obtuse, except having a very short acute bristle point; all single-ribbed, and quite smooth or scattered over with hair. Inflorescence a much-branched spreading panicle of very numerous white flowers. Corolla spreading, its seginents threeribbed, and tapering into a long, bluntish, hair-like point. Fruit small, smooth, globular, frequently abortire.

Habitat.-Dry banks, hedges, and thickets : not unfrequent in England ; less frequent in Scotland; and more common about Dublin than in any other part of Ireland.

Perennial; flowering from July to August.

We have observed this plant growing so profusely in various parts of the midland counties, as to overtop the hedges, and cover them for several yards with its profusion of snow-white flowers: in such situatiuns few plants can be conceived more lovely in their wild luxuriance, contrasting beautifully with the dark-green foliage of the Hawthorn.

10. G. pusil'lum, Linn. (Fig. 231.) least Mountain Bed-straw. 
Leaves about eight in a whorl, linear-lanceolate, bristle-pointed, hairy; panicle loose, branched, spreading; segments of the corolla acute.

English Botany, t. 74.-English Flora, vol. i. p. 206.-Lindley, Synopsis, p. 129.-Hooker, British Flora, vol. i. p. 67.

Root with slender, creeping underground stems. Stems erect, numerous, branched, from four to twelve inches high, square, slender, varying from quite smooth and shining to thickly clothed with short, pale, rigid hairs; the hairiness, however, is limited to the lower part of the stem; the upper, as well as the branches, quite smooth, except occasionally a few hairs about the joints. Leaves about eight in a whorl, crowded in the lower part of the stem, lanceolate, tapering at the base, the point acute, terminating in a pale bristle, the margins somewhat recurved; the lower leaves scattered, or thickly clothed with short hairs, the hairiness diminishing in the upper whorls of leaves, which are not unfrequently quite smooth, and sometimes the whole plant is altogether free from hairs; at other times the leaves may be observed with a few hairs on the margins and towards the extremity, which are either spreading or pointed downwards. Inflorescence in terminal and lateral branched, spreading panicles. Flowers white, with acute, three-nerved segments. Fruit small, globular, smooth, and granulated, of a dark-brown colour.

Habitat.-Kendal, Westmorland. Matlock Bath : on the rocks and crevices of the walls opposite Saxton's Hotel, \&c., plentiful; Ashwood, near Buxton, and other places in Derbyshire-Mr. Marnock. Habbie's How, in the Pentland Hills; Strathblane Hills; and the lower rocks of Clove, in Scotland-G. and D. Don. Rocks at Mucruss, Killarney, near Corrofin, and at Rock Forest, County Clare, Ireland.

Perennial; flowering in July and August.

This plant is extremely variable in its hairiness. Some specimens which I collected this last summer (1836) at Matlock, have the whole of their leaves thickly clothed with hairs; other specimens have the leaves hairy only on the margins; while others again are quite free from the least pubescence: in other respects, however, they entirely agree with those plants $I$ have from Habbie's How and other places.

11. G. Parisien'se, Linn. (Fig. 232.) Wall Bed-siraw. Leaves about six in a whorl, lanceolate, bristle-pointed, rough on the margins; flowers in small axillary clusters, with slender spreading branches; stems slender, spreading, rough.

Hooker, British Flora, vol. i. p. 67.-Lindley, Syuopsis, p. 130.G. gra'cile, Mertens and Roch.

c. Fruit hispid. G. Paris'iense, Linn.

B. Fruit smooth, slightly tuberculated. G. Angli'cum, Hudson,English Botany, t. 384.-English Flora, vol. i. p. 209. 



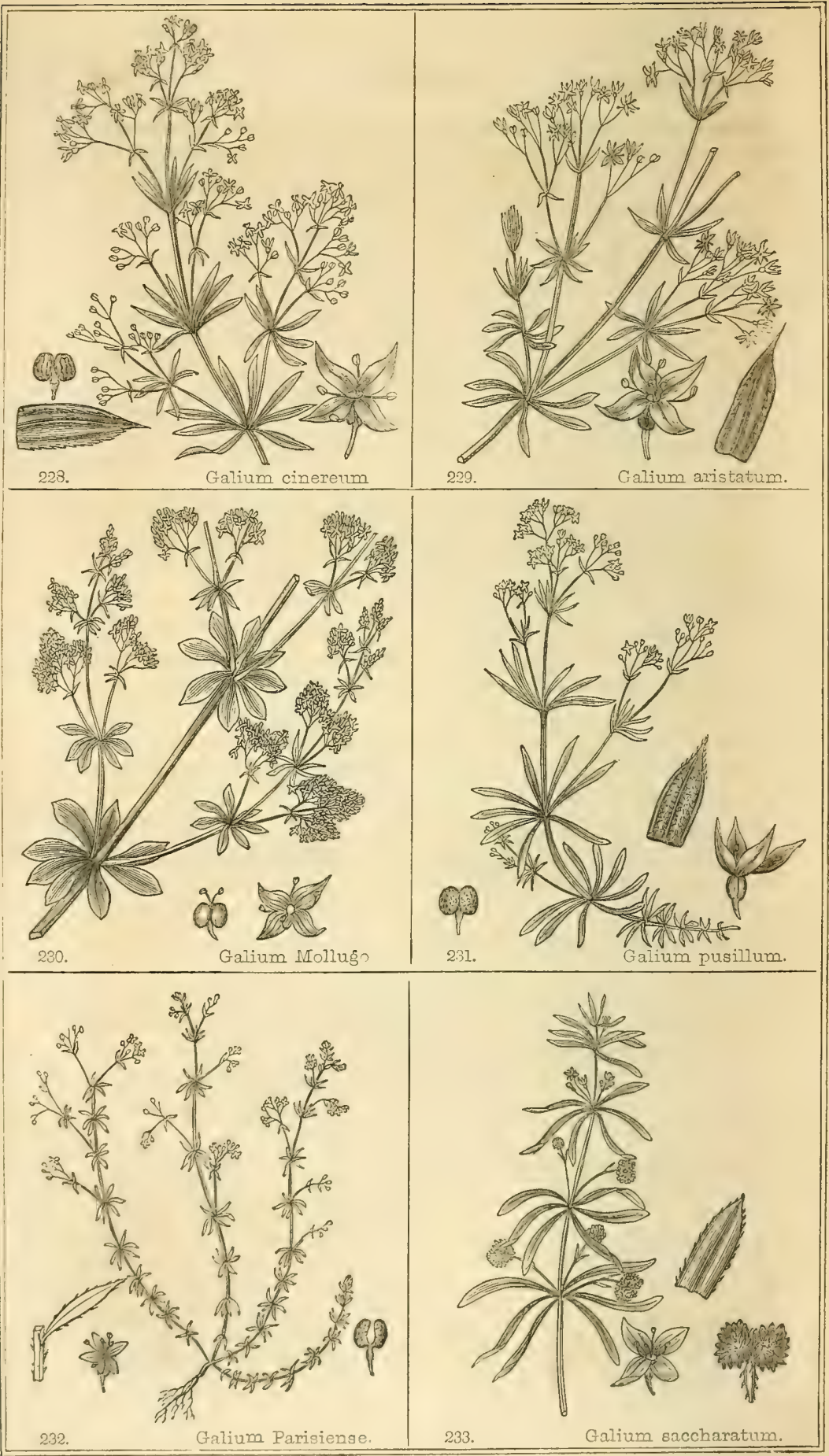


Root small, fibrous, hearing numerous simple slems, from three to twelve inches high, slenler, augular, rough, with reflexed prickles, aml hearing numerous whorls of small reflexed leares; the lower ones somewhat ovate; the upper lanceolate, with an acute, pale, bristle point; the margins reflexed, rough, with prickles poiuted forward. Inforescence in small terminal and axillary clusters, the peduncles one or two from the base of almost every whorl of the upper leaves, sometimes from every whorl from the base to the extremity of the stems; and each peduncle hears a pair of narrow bractece at the hase of the first divarication, where it separates mostly into three branches, each of which is again subdivided. Flouers small, pale, greenish-white; each segment of the corolla ribbed, acute. Fruit mostly numerous, somewhat kidney-shaped, smooth, slightly tuberculater, in maturity quite separated from each other, or having a central vacancy.

Habitat.-Old walls and dry sandy ground, but rare. In Kent, Norfolk, and Suffolk; Outwell church-yard wall, and near Wisbeach, Cambridgeshire.

Annual; flowering in June and July.

12. G. sacchara'tum, All. (Fig. 233.) warty-fruited Bed-straw. Leaves six in a whorl, lanccolate, the margins rough, with prickles pointing forwards; flower-stalks axillary, three-flowered; fruit reflexed, tuberculated.

Lindley, Synopsis, p. 129.-Hooker, British Flora, vol. i. p. 6\%.G'a'linm rerruco'sum, Linglish Botany, t. 2173.-English Flora, vol. i. p. 204.-Valen'tia Apari'ne, Linn.

Root small, slender, becoming reddish with drying. Stems several, spreading, from six to twelve inches high, somewhat branched, square, the angles rough, with reflexed prickles. Leares lanceolate, acute, with a pale point, six in a whorl, plane, the margins rough, with prickles pointed forwards. Inflorescence in axillary clusters of three flowers; the peduncles about as long as the leaves, bearing three small pale yellow flowers, the two lateral ones of which are abortive, not hearing pistils. Fruit a large double globe, rough, with pyramidal tubercles, becoming reflexed.

Habitat.-Corn-fields, rare. Discovered by $M_{\%}$. G. Don, in cornfields in the Carse of Gowrie, Scotland. Near Malton, YorkshireMr. R. Miller.

Annual; flowering from Jume to August.

13. G. tricor'ne, Withering, (Fig. 234.) rough fruited Corn Bedstraw. Leaves about eight in a whorl, lanceolate; the margins, midrib, and angles of the stem rough, with reflexed prickles; flower-stalks axillary, three-nowered; fruit reflexed, granulated.

English Bolany, t. 1641,-English Flora, vol. i. p. 205.-Lindley, Synopsis, p. 129.-Hooker, British Flora, vol. i. p. 68.

$$
\text { VoL, I. }
$$


Root small, fibrous. Stems several, slender, weak, square, the angles rough, with reflexed prickles. Leaves in numerous whorls of about eight, lanceolate; the margins, and sometimes the midrib, rough, with reflexed prickles, which character, togcther with the granulated, not tuberculated fruit, distinguishes it from the preccling species, for which it appears to have been mistaken.

Habitat.-Dry fields in England. Isle of Thanet; in Surrey; and near Stamford, Lincolnshire-Hudson. Oxfordshire, Yorkshire, Gloucestershire, Norfolk, Suffolk-Rer. G. R. Leathes. Fields near Carisbrook, Isle of Wight-Turner and Borrer.

Anuual; flowering in July.

This and the following species, Professor Henslow thinks it probable, have been introduced by the agency of man.

14. G. spu'vium, Linn. (Fig. 235.) smooth-fruited Corn Bed-straw. Leaves about eight in a whorl, lanceolate, their margins as well as the stem rough with reflexed prickles; flower-stalks axillary, many-flowered; fruit smooth, spreading.

English Botany, t. 1871.-English Flora, vol. i. p. 206.-Lindley, Synopsis, p. 129.-Hooker, British Flora, vol. i. p. 68.

Root small, fibrous. Stem spreadiug, branched, square, its angles rough with reflexed prickles, as well as the margins and midribs of the lanceolate leares, which are in whorls of from six to nine; the point of each is pale, and terminated by a rather long bristle. Inflorescence in axillary clusters; the peduncles about the length of the leaves, slender, rough, and bearing from six to eight small yellowish flowers, and one or two small bractece. Fruit of two small, brown, kidney-shaped lobes, having a central vacancy between them, quite smooth and even, erect or' spreading, never recurved.

Habitat.-Corn-fields, near Forfar, rare-Mr: G. Don.

Annual; flowering in $\mathrm{July}$.

So nearly allied is this plant, both in habit and appearance, except in the fruit, to the following species, as to induce Sprengel to assert that they are one and the same.

\section{*** Fruit bristly. Flower's white.}

15. G. Apari'ne, Linn. (Fig. 236.) Goose-grass, or Cleavers. Leaves from six to eight, in a whorl, lanceolate, bristly; the inargins, midrib, and angles of the stem rough with rellexed prickles; flowerstalks axillary, few-flowered.

English Botany, t. 816.-English Flora, vol. i. p. 210.-Lindley, Synopsis, p. 130.-Hooker, British Flora, vol. i. p. 68.

Root filrous. Stem much lranched and spreading, adhering to other plants near which it grows, often from four to six feet lomg, square and shining, its angles more or less beset with sharp, reflex l, looked 
pricbles. Leaves in rather distant whorls of from six to eight, lanceolate, tapering at the base, pale at the point, and tcrminating in a bristle of variable length, green, and scattered over with somewhat hooked brivles on the uprer side; the under side pale, smouth, except the midrib, which, like the margins, is fringed with reflexed prickles. Inforescence in axillary clusters of few flowers; peduncles about as long as the leaves, supporting from one to four pale yellowish flowers. Fruit a double globe, thickly clothed with hooked prickles.

Habitat.-Hedges and bushes; ahundant.

Annual; Howering during the summer months.

This plant was called by the Greeks Philanthropon, from an idea which they entertained, that the ready manner in which the seeds attach themselres to our habiliments was owing to their love of the human species. The heoked extrenity of the hairs by which they are covered, will give a more satisfactory solution of their adhesion, and afford a ready means of dispersing them into various situations suitable to their growth. The seeds are said to form, when roasted, a very good substi. tute for coffee, far superior to roasted corn. 'The plant, we are informed by Linnæus, is used in Sweden as a kind of siere, for which purpose the roughness of its stems and leares renders it very suitable. It is thought lyy some country-people to be a great purifier of the blood, for which purpose it is often found to form a part of their sping or herbbroths. The expressed juice is said to be a useful aperient in some kinds of dropsy, and extolled as a remedy against cancerous affections; but the test of experience does not confirm its utility iu such diseases.

16. G. borea'le, Linn. (Fig. 237.) cross-leared Bed-strar. Leaves four in a whorl, lanceolate, three-ribbed, smooth, with rough edges; stem erect.

English Botany, t. 105.-English Flora, vol. i. p. 209.-Lindlcy, Symopsis, p. 130.-Hooke1, British Flora, rol. i. p. 68.

Root with reddish, creeping underground stems. Stem erect, from one to two feet high, square, smooth and shining, or roughish with short rigid pubescence; branches short, numerous, opposite, bearing numerous whorls of four lanceolate or oratc-lanceulate leaves, green and smooth abore, paler and with three prominent ribs beneath; the margins, the ribs, and frequently the whole of the under side, roughish. Inflorescence iu compound terminal and latcral branched panicles, each division having one or twi floral leaves. Flowers numerous, white. Corolla of four spreading, somewhat hairy, acute, three-ribbed segments. Fruit of two globose or hidney-shaped seeds, thickly clothed with pale hooked bristles.

Habitat,-Moist rocky places; not unfrequent in the North of England, Scotland, and Ireland.

Perennial; flowering in June and July: 


\title{
GENUS V. RU'BIA, LINN. Madder.
}

\author{
Nat. Ord. STELLA'TAE.
}

Gen. Char. Corolla rotate or campanulate, with from three to fire spreading segments. Fruit a succulent, smooth, two-lobed berry. -Name from ruber, red; on account of the red matter which the roots afford.

1. R. peregri'na, Linn. (Fig. 238.) wild Madder. Leaves from four to six in a whorl, lanceolate, persistent, smooth and shining; the margin and keel rough, with reflexed prickles; flowers five-cleft.

English Botany, t. 851.-English Flora, vol. i. p. 211.-Lindley, Synopsis, p. 131.-Hooker, British Flora, vol. i. p. 69.

Root with numerous creeping, fleshy, reddish underground stems. Stems branched, spreading, square and striated, the angles rough with reflexed prickles, stout, somewhat shrubby. Leaves lanceolate or ovatelanceolate, in whorls of from four to six each on the stem, frequently on the branches only two or three, evergreen, and remaining attached to the plant; the margin pale, somewhat reflexed when dry, and rough, with stout reflexed prickles, as well as the stout prominent midrib. Inflorescence in small terminal and lateral branched panicles of yellowish-green flowers, each subdivision having at their base a pair of lanceolate bractea. Corolla rotate or campanulate, of mostly five broad ovate segments, suddenly contracted into a slender point, concave when newly expanded, becoming convex. Fruit a smooth, juicy, black and shining, double berry; frequently one of them is abortive.

Habitat.-Stony and sandy ground, in the South-west of England. Not unfrequent in South Wales: Anglesea-Mr. Wilson. South side of Howth and Killiney Hill; limestone rocks at Mucruss and Killarney; hedges near Passage, County. Cork, Ireland.

Perennial ; flowering from June to August.

This species is nearly allied to Ru'bia tincto'ria, the roots of which furnish us with one of the most useful dyes with which we are acquainted, known by the name of madder. The roots are infused in water, to which it imparts its colouring matter, which is afterwards precipitated from it by the addition of alum; it is then collected and prepared either as a pigment or dye-stuff. Madder is Tut little grown in this country, on account of its leeing obtained much cheaper from France, Holland, Italy, and Turkey, than it can be grown at home. It has the property of tinging the secretions and excretions of animals that are allowed to feed upon it; and by its means curious bony preparations are made, which shew that the deposition of osseous matter and its removal is continually going on in the animal conomy, by the alternate layers of red and white in the bones of animals altematcly fed upon madder and ordinary food, and the disappearance of all ad- 


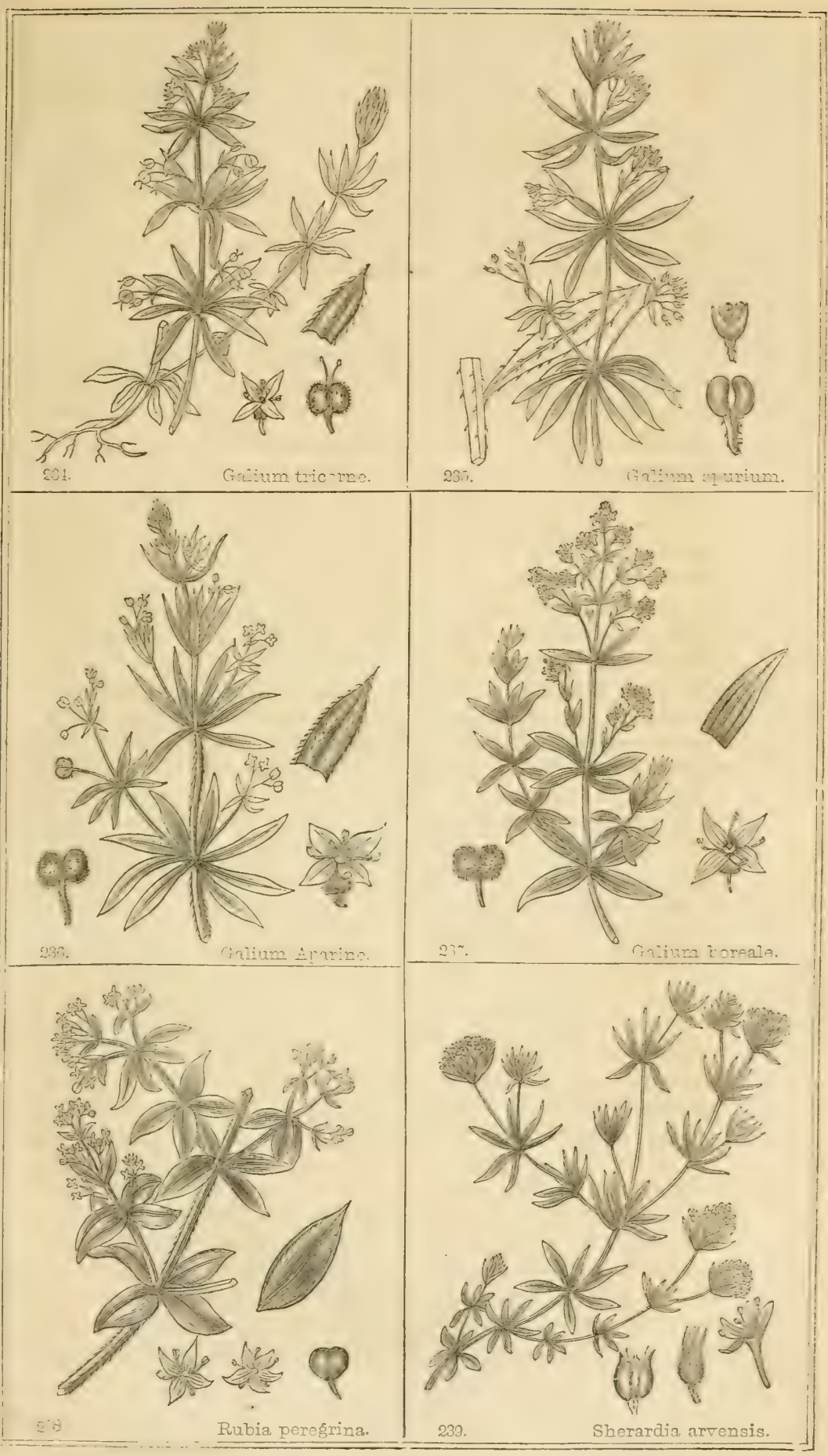



ventitious.colour when madder as a food has been discontinued for a sufficicnt length of time. Formerly madder was considered a useful deobstruent and diuretic medicine, but it is now seldom or never used for such purposes.

\section{GENES VI. SHERAR'DIA. Lixi. Shererdiu, or Field Madder.}

Nat. Ord. Stelda'te.

Gen. Char. Corolla fummel-shaped, with four segments. Fruitcrowned with the persistent tecth of the calyx._- Named in honour of James Sherard, an English botanist and patron of botany, whose fine garden at Eltham in Kent gave rise to the famous 'Hortus Elthamensis' of Dillenius."

1. S. arren'sis, Linn. (Fig. 239.) blue Sherasdia, Little Ficld Madder. Leares about six in a whorl; flowers in terminal heads.

Euglish Botany, t. 891.-English Flora, vol, i. p. 196.-Lindley, Syuopsis, p. 130.-Hooker, British Flora, vol. i. p. 69.

Root small, somewhat creeping. Stems procumbent at the basc, crect in the upper part, from four to eight inches long, simple or branched, smooth, or more or less rough with spreading hairs, square, and bearing numerous whorls of about six leares, the lower ones ovate, acute, gradually becoming lanceolate in the upper part of the plant, the margins rolled back ant the midrib prominent on the under side; the uppermost whorl of leaves seven or eight united at the base, where they are pale and membranous, forming an involucrum to a small head of about eight sessile, small, blue flowers. Calyzx superior, of four roughish lobes, the two opposite ones bificl, its tube adhering to the germen. Corolla funnel-shaped, its tube cylindrical, and the limb of four equal, spreadiug, acute segments. Fruil of two united pericarpia, separating at maturity, each containing a solitary erect seed, and crowned by three teeth of the calyx, one being the single tooth; the two lateral ones, each lalf of the opposite cleft ones.

Habitat.-C'orn and fallow fields, especially in a light soil; frequent. Annual ; flowering during the summer months.

This species has much the habit and appcarance of a Galium, from which, however, it is reudily distinguished by the form of its inflorezcence and fruit.

\section{GENUS VII. ASPER'ULA. Lrsw. Woodruff:}

Nat. Ord. Stella'te.

Gen. Char. Corollu funnel-shaped, with from three to four segments. Fruit not crowned with the caly.x.-Name from asper, rough; on account of the roughness of some of the species of the geius. 
1. A. odot'a'ta, Yinw. (Fig. 240.) sweet Woodruff.' Lẹves about eight in a whorl, lanceolate; flowers few, in long-stalked panicles; fruit bristly.

English Botany, t. 755.- English Flora, rol. i. p. 197.-Lindley, Synopsis, p. 130.-Hooker, British Flora, vol. i. p. 69.

Root with branched, creeping underground stems. Stems erect, from six to twelve inches high, square, smooth. Leaves from seven to nine in a whorl, spreading; the lower ones ovate-lanceolate, with an acute point; the upper lanceolate, a bright green on the upper side, and minutely dotted when dry, paler beneath, with a rather prominent midrib, which, as well as the margin, is rough, with prickles pointed forwards. Inflorescence in small terminal panicles of few white flowers, on longish smooth stalks; each division without, or having at its base one or more narrow linear bractece. Calyx of four small teeth, disappearing after flowering. Corolla funnel-shaped, with a short tube, and four equal, obtuse, spreading segments. Fruit of two closely united pericarpia, granulated and clothed with white tubular hooked bristlcs.

Habitat.-Woods and shady places; frequent.

Perennial; flowering from May to June.

'The specific name of this plant is giren to it on account of the highly aromatic flavour which it exhales during the process of drying, resembling that of Anthoran'thum odora'tum, which, like it, depends upon the benzoic acid which it contains. The flowers are said to excel in flavour, when made into infusion, that of China teas. In Germany, the whole plant is used to give a grateful favour to some of their wines; and in many parts of this country it is kept among clothes to protect them from insects.

The English name of this plant is variously spelt by old authors. Dr. Withering says that in some it is spelt Woodderonoffe; the spelling of which frequently affords great amusement to children- $w$ oo dd $e$ $-r \circ w . f(e)$.

2. A. arven'sis, Limn. (Fig. 241.) Field Woodruff. Leaves from six to ten in a whorl, linear-lanceolate, obtuse; flowers in terminal clusters, surrounded by long ciliated bractex; fruit smooth; annual.

Banks, in Plymouth and Devonport. Flora. Lob. Ic. t. 801, f. 2.English Botany, Supplement, t. 2792.-Hooker, British Flora, vol. i. p. 69 .

Root fibrous, annual. Stem crect, from six to twelve inches high, simple, or with altemate or opposite branches, square, roughish, especially below. Leaves from six to ten in rather distant whorls, linearlancelate, obtuse, tapering at the base, the lower ones ovate-lanceolate, a bright green above, pale bencath, the margins somewhat reflexed and rough, with prickles pointed forwards. Inflorescence in 



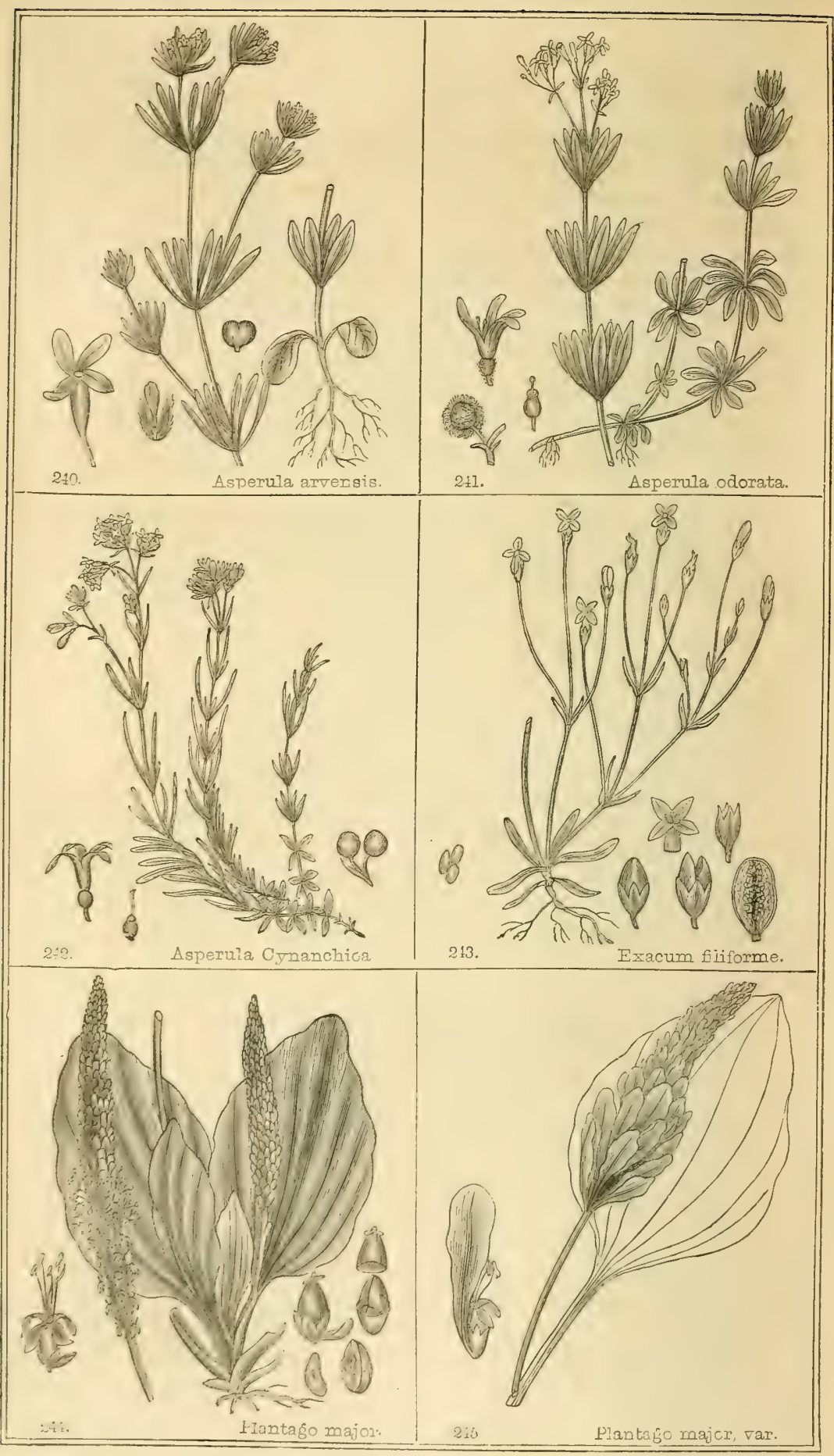


small terminal heads, surrounded by linear downy bractece the margins, especially near the hase, ciliatel, with long, shining, white hairs. Corolla small, bright blue. Fruit smooth, large, and conspicuous.

Habitat.-Near Devonport-Mr. C. A. Johns, 1830 ; "but where, however, the plant is now nearly, if not quite lost, in consequence of the construction of a railroad."

Annual.

This species is frequent on the opposite Cuntinent, and appears to be occasionally introduced into this country. Although we have here figured and describer it from specimens communicated by Sir W. J. Hooker, we are nevertheless of opinion that it onght not to be admitteri into the British Flora, except supplementarily.

3. A. Cynan'chica, Linn. (Fig. 242.) small Woodruff. Leaves linear, four in a whorl, the two opposite leaves gradually diminishing in size in the whorls towards the upper part of the stcm.

English Botany, t. 33.-English Flora, vel. i. p. 198.-Lindley, Synopsis, p. 130.-Hooker, British Flora, vol. i. p. 69.

Root fibrous, and usually putting out tufts of numerous square stems, from three to six inclies high, procumbent, and branched at the base, becoming erect, smooth. Leaves four in a whorl; the lower ones small, ovate, and mostly regular; the upper ones linear, having the two opposite ones gradually reduced to small lanceolate stipules, quite smooth, with the margins somewhat reflexed. Inflorescence in small terminal branched panicles, of white or lilac flowers. Corolla with four acute, three-ribbed, spreading segments. Fruit granulated.

Habitat.-Warm situations, especially in chalky districts. We have fine specimens also, grown on clayey soils, from Brodsworth, near Doncaster, and Lincoln Common. It is not found in Scotland or Wales. Abundant on limestone rocks about Corrofin and other places in the County of Clare, and the large Island of Arran, Ireland.

Perennial; flowering in June and July.

This plant was formerly used both as an outward and inward remedy for the cure of Squinancy, or Quinsy; hence its specific name. It appears, however, in modern times, to have entirely lost its reputation, even among the domestic remedies.

GENUS VIII. EXA'CUM. Linn. Gentianella.

Nat. Ord. Gentia'nes.

Gen. Char. Calyx of one piece, with a four-cleft extremity. Corolla four-cleft, salver-shaped, with a globose tube. Anthers bursting longitudinally. Stigma capitate, entire. Capsule one-celled, two-yalved. Seeds numerous, attached to the inflexed margin of 
the valies. - Name from " $\varepsilon \xi$, out, and ayw, to conduct; anciently applierl to the Erythre' a Centau'vium, a genus allied to this, and which was supposed to have the property of ejecting poisons from the stomach."

1. E. filifor'me, Smith, (Fig. 243.) least Gentianella. Leaves linear, lanceolate, sessile; stem branched, slender; flower-stalks long.

English Botany, t. 235.-English Flora, vol. i. p. 212.-Lindley, Synopsis, p. 177.-Hooker, British Flora, rol. i. p. 70.

Root of numerous small brancherl fibres. Stem slender, erect, from one to four inches high, with mostly opposite branches, arising from the base of the small, opposite, lanceolate leaves; the lower ones largest, spatulate. Flouers small, yellow, solitary, on long, slender stalks. C'alyx of one piece, divided nearly half way down into five acute segments, with membranous erlges. Corrolla salver-shaped, the tube longer than the calpx, thin and pale, minutely dotted, globose, and enlarging with the capsule; the limb yellow, of four spreading, acute segments, imbricated in the bud, and expanding only on bright sunny dars. Stamens alternating with the segments; the anthers oblong, of two cells, bursting longitudinally. Style slender, terminating in a rather large, capitate stigma. Capsule ovate, compressel, of one cell, opening hy two valves, the margins of which are considerably inflexed, so as to apparently divide it into two cells. Seeds sinall, numerous, attached to the margins of the cells.

Habitat.- Sandy or turfy bogs, in the South and South-west of England, as Dnrsetshire, Cornwall, Devonshire, Sussex, and Guernsey Tear Cork, on Dursey Island, and at Glengariff, in Ireland.

Annual; flowering in July.

This plant is nearly allied to the Gentians, from which it differs in the number of the stamens, and the divisions of the calyx and corolla.

\section{GENUS IX. PLANTA'GO. I.INv. Plantain.}

Nat. Ord. Plantagines.

Giv. Cirar. Corolla of one piece, with four reflexed segments. Stumens very long. Capsule of two or four cells, membranous, twoor many-sceder, hursting with a transwcrse incision.-Name from planta, the sole of the fort; either on account of the shape of the leaves, or because it grows frequently by road-sides, and is trodden upon.

* Leares ovate.

1. P. major, Limn. (Fig. 244.) greater Plantain. Leares broarlly ovate, on longisls footstalks; spitie very long; cylindrical; cells of the capsule many-seeded. 
English Botany, t. 1558.-English Flora, rol. i. p. 213.-Lindley, Synopsis, p. 169.-Hooker, British Flora, vol. i. p. 70.

Root of numerous long, stout fibres. Leares numerous, radical, hroadly ovate, the margin toothed or waved, mostly smooth, large, with from seren to nine prominent parallel ribs, united at the base into a footstalk, mostly as long and frequently longer than the leaf. Inflorescence a long, cylindrical spike of rery numerous flowers, closcly imbricated in the upper part, somewhat distant in the lower, supported on a rather long, round, naked stalk. Florets small, each having at its base a small, concave, lanceolate bractea. Calyx of four acute, membranous, keeled segments, united at the base. Corolla of one piece, with four reflexed, dry, thin segments. Capsules small, oral, acute, membranous, each cell containing from six to eight small seeds.

The rariety (Fig. 245.) called by Ray the "Besome Plantain, or Plantain with spoky tufts," has been noticed since the year 1632, w len it was found by Dr. Johnson in the Isle of Thanet, and has since been occasionally observed in various parts of the country. The peculiarity of their form is owing to the bracteas becoming foliaceous, which beautifully shews that bractex are only diminutive forms of leares. Another rariety is sometimes found, called the " Rose Plantain," on account of the bracteas forming whorls at the end of the scape, and expanding so as to bear some resemblance to a Rose.

Habitat.-Pastures and road-sides; frequent.

Perennial; flowering during the summer months.

This species was formerly supposed to possess rare medicinal properties, but these are now almost forgotten. The seeds are a favourite food of small birds. The common name of way-bred is not inapplicable to this plant, from its seeming to prefer way-sides for its situation of growth. We are also informed by Bumet that it has a peculiar tendency to follow the migration of man, as if domesticated or sympatheticall yattached to the human race. Thus, although not purposely conveyed, it has followed our colonists to every part of the world, and, amongst the natives in some of our settlements, has been emphatically named the "Englishman's Foot;" for, with a strange degree of certainty, whereser it is found, there our countrymen have trod.

2. P. me'dia, Linn. (Fig. 246.) hoary Plantain. Leares downy, sessile, or tapering into short, broad lootstalks; spike cylindrical; cells of the capsule single-seeded.

English Botany, t. 1559.-English Flora, vol. i. p. 214.-Lindley, Synopsis, p. 169.-Hooker, British Flora, rol. i. p. 70.

Root large and woody. Leaves spreading, pressed close to the ground, ovate-acute, entire or slightly toothed, with about six ribs, and more or less clothed with a soft pubescence, sessile, or on a short, broal footstalk. Inflorescence similar to the last; the scape mostly long; slender, roL, I, 
bearing a shorter, broader, denser spike. Bractens at the base of the florets pale, thin, and shining, with a green keel. Calyx pale and shining, as well as the lanceolate reflexed segments of the corolla, which gives the spikes a silvery appearance. Stamens long. Stigmas long, downy. Cells of the capsules single-seeded.

Habitat.-Meadows and pastures. Very frequent in England; less so in Scotland. Pea-hill, below Feltrum, Ireland-Mr. J. White. But native specimens have not been seen by Mr. Mackay.

Perennial; flowering during the summer montlis.

\section{* Leaves lanceolate or linear.}

3. P. lanceola'ta, Linn. (Fig. 247.) Ribwort Plantain. Leaves lanceolate; scape angular; spike orate; capsule with two cells, each single-seeded.

English Botany, t. 507.-English Flora, vol. i. p. 214.-Lindley, Synopsis, p. 169.-Hooker, British Flora, vol. i. p. 70.

Root somewhat woody, with numerous spreading fibres. Leares mostly numerous, spreading or erect, lanceolate, tapering at the base into a channelled footstalk of greater or less length, and surrounded at its insertion with long, soft, glossy hairs, smooth or downy, especially heneath, with about five prominent rilss; the margin smooth, or slightly toothel. Inflorescence a compact orate or orate-lanceolate spike, upon a long, sleuder, angular, channelled, downy scape. Bracteas hairy, pale at the base, dark-brown at the point and keel. Corolla with four pale, spreading, lanceolate, single-ribbed segments. Stamens long; with large pale anthers. Cells of the capsules single-seeded.

Habitat.-Meadows and pastures; abundant.

Perennial; flowering during the summer months.

This is an extremely variable plant as regards the size to which it attuins. Fig. 248. represents a state in which it is found in poor gravelly situations; the leaves not an inch long, sessile, or on very short footstalks, and the spike of flowers small and globular. These specimens contrast remarkably by the side of luxuriant plants, with leares six inches long, and spikes of flowers on stalks cighteen inches high, the bracteas of which are developed into leares, and forming a large tuft disposed in a rose-like manner. Specimens are also occasionally found, bcaring several spikes on the summit of the stalk. Others are also found, with the terminal spike bearing several others in a proliferous manner; some sessile, others on short stalks. WVe do not, however, apprehend the student $w$ ill find any difficulty in recognising any of the various states in which it is found, as being other than monstrosities, or varieties depending upon the soil or situation of its growth. This species has heen cultirated under the name of Rib-grass, and was thought to possess valuable properties; but it does not appear to be reliched by cattle, and has ceased to be ecteemed among agriculturists. 
4. P. marit'ina, Linn. (Fig. 249.) Sea-side Plantain. Leaves linear, chaunelled, fleshy; scape rounded; spike cylindrical; capsule of two cells, each single-seeded.

English Botany, t. 175.-English Flora, vol. i. p. 215.-Lindley, Synopsis, p. 169.-Hooker, British Flora, vol. i. p. 71 .

B. ma'jor, Hook. Leaves almost plane, inclining to lanceolate, toothed, smooth; seape densely hairy.-B1. Fl, vol.i. p. 71.

$\gamma$. minor, Hook. Leaves linear-lanccolate, densely hairy, as well as the scapc.-Br. Fl. vol. i. p. 71 .

Ront tapering, with filbrous, spreading branches. Lcares numerous, spreading, linear, fleshy, entire or toothed, channelled above, convex beneath, smonth or hairy, of a deep, slightly glaucous green; the base somewhat sheathing, and more or less woolly. Inflorescence a slenter, cylindrical spike, of numerous small, densely crowded, or loosely imlricated flowers, on round, slender, smooth, or downy scapes, longer than the leaves. Bracteas fleshy, lanceolate, sometimes with a long tapering point. Corolla of four pale, linceolate, single-ribbed, spreading segments. Capsule of two cells, each containing a single seed.

IIabitat.-Pastures and muddy salt marshes near the sea, or the margins of fresh-water lakes; at the base and also on the tops of the loftiest mountains in Wales and Scotland; frequent.- $\beta$. On the Island of Cumrac, among rocks-Sir W. J. Hooker.- $\%$ Among rocks by the House of Skaile, Pomonde, Orkney-G. Anderson, Esq.

Perennial; flowering from June to September.

This, like the above species, varies extremely in its size, sometimes not exceeding two incles ligh, at others twelve or more. The leaves vary from thread-shape to linear-lanccolate; the margins entire, toothed; and the whole plant is found to vary from quite smooth to being densely cluthed with hairs. It is, however, readily distinguished from the other species, by its succulent channelled leaves, its rounded scape, aud narrow cylindrical spike.

5. P. coro'nopus, Linn. (Fig. 250.) Buck's-horn Plantain. Leaves linear, pinnatifid; scape rounded; spike cylindrical; capsule with four cells, cach single-seeded.

English Botany, t. 892.-English Flora, vol. i. p. 216.-Lindley, Synopsis, p. 169.-Hooker, British Flora, vol. i. p. 71.

Root tapering, with numerous spreading, branched fibres. Leaves numerous, linear, with many narrow-pointed segrments, entire toothed, or again divided, pale green, mostly hairy, gencrally lying close to the ground, and spreading in a radiated manner. Inflorescence similat to the last, on long, round, spreading, hairy scapes. Capsule with four cells, each containing a single seed.

Habitat.-Poor gravelly or sandy soil; frequent.

Anuual; flowering from Junc to $\Lambda$ ugust. 
This plant, frequently called Star of the Earth, varics greatly in size and hairiness. We have specimens with leares not an inch long, and other specimens with them more than four; the scapes varying in the same proportion; and the spike varies from small and ovate, with few flowers, or cylindrical, two inches long, and closely imbricated.

\title{
GENUS X. CENTUN'CULUS. Linn. Chaffivecd.
}

\author{
Nat. Ord. Primuláce.r.
}

Gen. Char. Corolla of one piece, the tube swelling, the limb fourcleft. Stamens short. Capsule of one cell, many-sceded, bursting with a transrerse incision.- "Name, it appears, anciently given to Pimpernel, a genus allied to this; and derived, according to Theis, from cento, a covering, because it was a little weed that covered the cultirated fields." - Hook.

1. C. min'imus, Linn. (Fig. 251.) small Chaffuced, or Bastard Pimpernel. Flowers sessile; corolla without glands at the base.-Sm.

English Botany, t. 531.-English Flora, vol. i. p. 217.-Lindley, Synopsis, p. 183.-Hooker, British Flora, vol. i. p. 71.

Root small, fibrous. Stem erect, from one to two inches high, simple or branched at the base, slightly angular, smooth, and leafy. Lcares opposite below, alternate above, ovate, sessile, entire, smooth, and spreading. Flovers very minute, sessile at the base of the leaf, solitary, of short duration, and expanding only in the brilliant sunshine. Calyx with four lanceolate, acute segments. Corolla white or pale pink, shorter than the calyx, withering and remaining upon the capsule; its tube almost globular; the limb in four orate, acute, spreading segments. Capsule globose, crowned by the persistent style, bursting all round with a transverse incision, and containing numerous angular seeds, fixed upon a central receptacle.

Habitat.-Moist sandy or gravelly places, about London; in Kent, Norfolk, Suffolk; the Lowlands of Scotland; marshes at Glengariff, on the Ross Islands, County of Donegal, coas! ncar Colcraine, Irelaud, but not common.

Annual; flowering in June and July.

This is one of the least of our flowcring plants, seldom exceeding 1wo inches in height, and very slender. It is nearly allical to Anagallis.

GENUS XI. EPIME'DIUM. LinN. Bermonvort.

Nat. Ord. Berberídes.

Gev. Cinar. Culyz of four picces, deciduous, Preals four, inforior, 


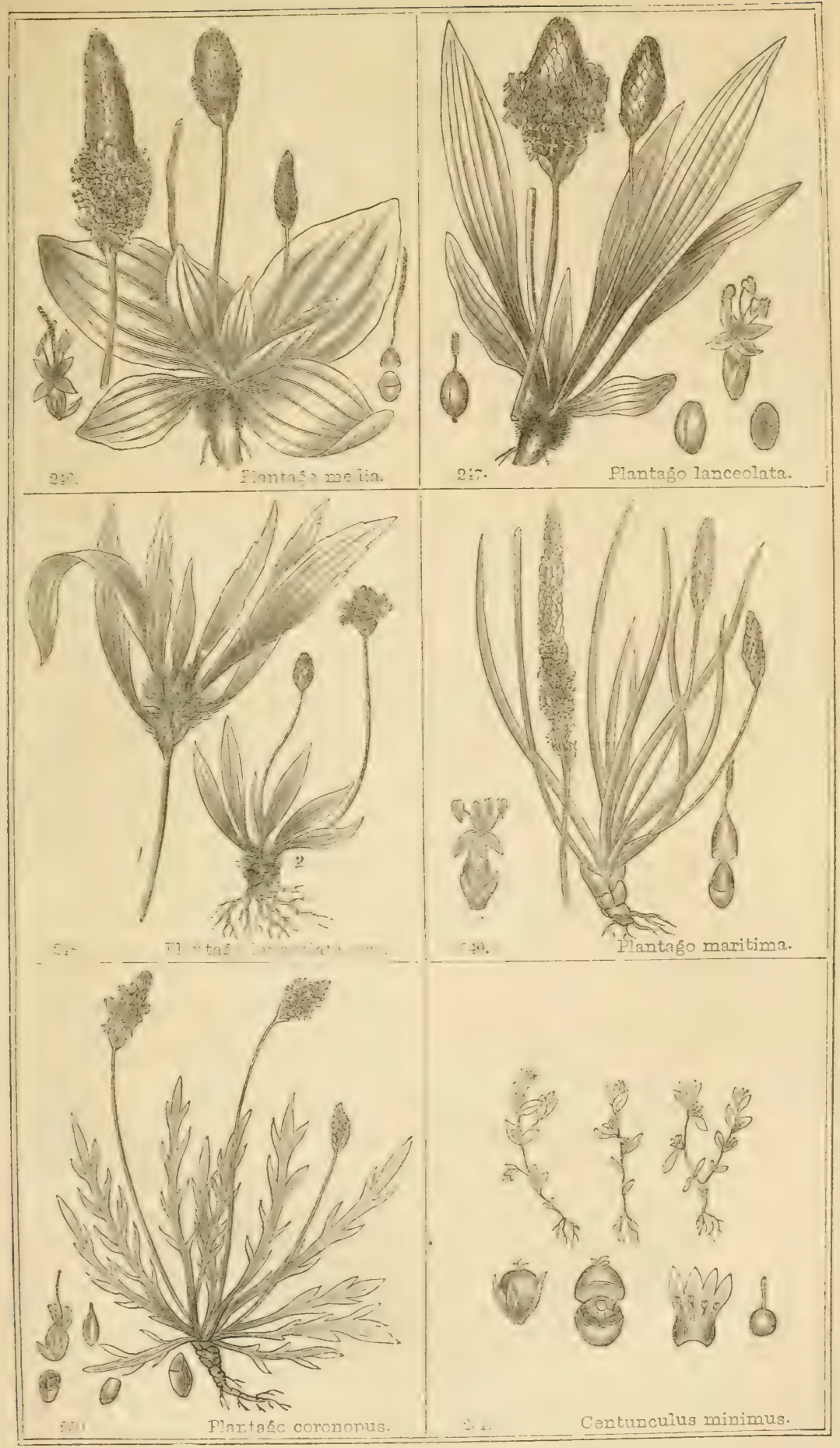



with a large infated nectary at the base. Pod oblong, two-valved, onc-celled, many-seeded.- " Name of obscure origin; applied by Dioscorides to some plant which grew plentifully in MIedia." Hook.

1. E. alpi'num, Linu. (Fig. 252.) alpine Barrenworl. Root-leaves none; stem-leaf twice ternate.

English Botany, t. 438.-English Flora, vol. i. p. 219.-Lindlcy, Synopsis, p. 14.-Hooker, British Flora, vol. i. p. 71.

Root slender, somewhat creeping. Stems erect, about a foot high, round, smooth, tender, each bearing a twice or thrice compound leaf. Leafets from one to two inches long, heart-shaped, extremely delicate, veiny, smooth alove, glaucous, and somewhat hairy beneath; the mar. gins ciliated, and more or less finely scruted; the lateral leaflets obliquely heart-shaped, the stalk of each swollen at its insertion. Inflorescence an irregular branched panicle, arising from the swollen base of the leaf, elegantly drooping, and bearing a number of very beautifu! and singular flower's their footstalks with glandular hairs, and having at the base one or two small scales. Calyx of four inferior, ovate, concave, green pieces, falling away as the flower expands. Corolla of four dark, blood-red, ovate, concave, spreading petals, each having at its base a curious, large, yellow, inflated, membranous nectury. Anthers very curious, formel of two oblong parallel cells, each opening from the bottom to the top by an elastic valve, which, bursting at the bottom, rolls upwards, and allows the discharge of the pollen. Pod oblong, pointed, of one cell, formed by two valves, and containing numerous seeds.

Habitat.-Subalpine woods and mountain thickets; very rare. Bingley Woods, about six miles from North Bicrley, and Fountain's Abbey, Yorkshire. On Carrock Fell and Skiddaw, Cumberland. About the ruins of Mugdoch Castle, near Glasgow. Hunters' Tryste, near Edimburgh.

Perennial; flowering in May and Jume.

The singular flowers of this remarkable and pretty plant will richly repay the student for a careful investigation of their curious structure. The sepals of the calyx, the petals of the corolla, the nectaries, and stamens, arc all inserted opposite each other, and not alternate, as is found to be the arrangement of most flowers. It is a doubtul naturalised plant, and perhaps ought not to be admitted into the list of the British Flora. It is cultivated in the flower-garden, and will grow in any situation, but flourishes best in the shate : its pale-green, delicate, pendent leaves, trembling with each circling breeze, and its rather large, graceful panicle of singular-looking flowers, give it an extremely pleasing and interesting appearance. 


\title{
GENUS XII. COR'NUS. LINN. Corncl.
}

\author{
Nat. Ord. Caprifolia'Cese. § Cor'nex.
}

Gen. Char. Calyx of four deciduons pieces. Corolla superior, of four oblong, acute petals. Drupe with a two-celled, two-seeded nut.-Name from cornu, a horn; on account of the hardness of the wood, it being thought to be durable as horn.

1. C. sanguin'ea, Linn. (Fig. 253.) wild Cornel, of Doguood. Arborescent: branches straight, dark-red when full grown; leaves opposite, ovate, green on both sides; cymes flaked.

English Botany, t. 249.-English Flora, vol. i. p. 221.-Lindley, Synopsis, p. 133,-Hooker, British Flora, vol. i. p. 72.

A shrub, from four to five feet high, with straight, round, smooth branches, when full grown, of a dark-red colour. Leaves opposite, ovate-acute, entire, strongly ribbed, quite smooth, or scattered over with short hairs, green on both sides, but somewhat paler beneath, from one to three inches long, on short channelled footstalks, and clanging before falling off to a more or less deep-red colour. Inflorescence a flat, terminal, naked cyme, of more or less numerous, greenish-white fowors, having an unpleasant smell. Calyx of four minute picces, shortly falling away. Petals four, oblong, spreading, the margins somewhat rolled inwards, and, as well as the ovarium and their partial stalks, mostly scattered with hairs. Fruit a roundish, dark-purple drupe, its wut two-celled, each cell containing a single seed.

IIabitat.-Woods and hedges, especially on a chalk or limestone soil. Frequent in England; scarcely wild in Scotland-Hooker. South Isles of Arran. Abundant in bedges below Coolock, Ireland; but scarcely indigenous-Mackay.

Shrub; flowering in June and July.

Cornel, or common Dogwood-tree, is so named, according to Parkinson, because the fruit of most of the species is not fit even for dogs: it is probable, however, that it may have obtained this name on account of the fruit, as well as the bark and leaves, which possess bitter and astringent propertics, having been used for the cure of the mange and other diseases in dogs. The wood is hard, and used for the purpose of making butchers' skewers, toys, \&c.; but in former times, when bows and arrows were used as arms of defence, its straight tough branches were highly estecmed for making the arrows. The fleshy part of the fruit contains a considerable proportion of oil, from which it is extracted in France and other parts of the Continent by boiling and pressure, and used for burning, the making of soap, and for the table use; there the young branches are also made into ramrods for guns, and, when bored, used as tubes to pipes. The wood is excellent fuel, and affords one of the best charcoals for the manufacture of gunpowcler, It is a 
common shrub in plantations, where it is particularly valuable on account of its flourishing under the drip of other trees. The present is readily clistinguished from all other species of Cornus hy its dark-purple fuit, and its leares changing to a dark-red before they are shed: it is probably from this last circumstance that it has received its specific name.

2. C'. succi'ca, Limn. (Fig. 254.) duarf Cornel. Herbaceous: leares opposite, sessile, orate-acute; flowers in a small umbel, surrounded by a four-leaved, whitish, petaloid involucrum, and springing from the axil of the forked extremity of the stem.

English Botany, t. 310.-English Flora, vol. i. p. 221.-Lindley, Synopsis, p. 133.-Hooker, British Flora, vol. i. p. 72.

Root with long, creeping underground stems. Stem herbaceous, erect, from three to six inches high, square, leafy above, naked below, except one or two pairs of membranous scales, abortire leares. Leares opposite, scssile, orate-acute, strongly ribbed, pale-green, smooth and somerhat glaucous bencath, mostly scattered with hairs above, the margin entire or wared. Inflorescence a small terminal umbel of darkpurple flowers, arising from the axil of two young branches, which do not exceed the general flower-stalk in height, till the fruit is ripe. Involucrum surrounding the base of the umbel, of four large, ovate, ribber leaves, white, tinged with red, at length turning green, and may, by a careless observer, be taken for petals: each flower is elevated on a short partial stalk, scattered with hairs, and, with the exception of the stamens, of a dark puple. Fruit a round red drupe, of a sweetish taste.

Habitat.-Moist alpine pastures. Cheviot Hills, Northumberland; and in Scotland, especially on the Highlaud Mountains.

Peremial; flowering in July and August.

The fruit is said to possess tonic properties, and to increase the appetite; and hence, according to Lightfoot, it is called by the Highlanders Lus-a-chranis, or plant of gluttony. It is nearly allied to the American plant, C. canaden'sis; but is smaller, and at once distinguished liy its terminal branches; and it is not so readily cultivated.

\section{GENUS XIII. PARIETA'RIA. Linn. Wall-Pellitory.}

\section{Nat. Ord. URTI'CEF.}

Gen. Char. Flouer's polygamous, surrounded by a two-leaved inrolucrum. Perian th single, inferior, four-cleft, persistent. Stamens at first incurved, at length expanded by the elastic force of the filaments. Fruit single-seeded, enclosed by the enlarged perianth. Name from paries, a acall; from the circumstance of the species mostly growing on walls and old ruins, 
1. P. nfficina'lis, Linn. (Fig. 255.) common Pellitory-of-the-Wall. Leaves orate-lanceolate, three-ribled al:ore the base; each leaf of the involucrum with about seren segments, surrounding seven flowers, the central one fertile.

English Botany, t. 879.-English Flora, rol. i. p. 222.-Lindley, Synopsis, p. 218.-Hooker, British Flora, vol. i. p. 72.

Root somewhat woody, with numerons downy fibres. Stem from one to two feet high, erect, or procumbent at the base, angular, or deeply furrowed, branched and leafy, reddish, and more or less thickly clothed with soft pubescence. Lcures altermate, ovate-lanceolate, on slender footstalks, three-ribbeci above the base, dark-green and nearly smooth above, paler and hairy beneath. Inflorescence small, axillary, hairy clusters, arising from the base of the leaves. Involucrum formed of two pieces, each cut into about scren ovate segments, containing three apparently fertile flowers, but the central one has a pistil only, while the lateral ones have both stamens and pistil; and arising between the two portions of the involucrum is a seventh fertile flower, with an entire perianth which closely surrounds the pistil, and remains but little altered as the plant advances to maturity, while the perianth of the perfect flowers becomes much lengthened; the stamens at first incurved, the anthers closely surrounding the pistil in the centre of the flower; when the flower is completely expanded, the filaments, which are remarkably jointed, have become highly elastic, but retain their original curved position, until further progress of regetation is made, or some excitement is giren to them by external canses; the stamens are suddenly thrown backwards by the elastic power of the filaments, the shock at the same time bursting the anthers, and the pollen is profusely scattercel around. This remarkable property in the filaments may be best observed on a hot summer's day, and they are readily excited into motion by agitation of the plant. Fruit small, ovate, black and shining, closely invested by the calyx.

Habitat.-Walls, the crevices of rocks, and amongst rubbish; fre. quent.

Perennial; flowering during the summer months.

This plant was formerly in great repute as a diuretic: the expressed juice was used externally as a fermentation, or sweetened with sugar, and taken internally. It is without smell, and its taste is simply herbaccous. In the practice of the present day, it is seldom or never used. It is reported that this plant, laid in bunches, or scattered among corn in granaries when infested with the corn-weevils, will either destroy or drive away those destructive insects. It is said to contain so great a proportion of nitre, that in making an extract from it, the mass las been known to take fire. 



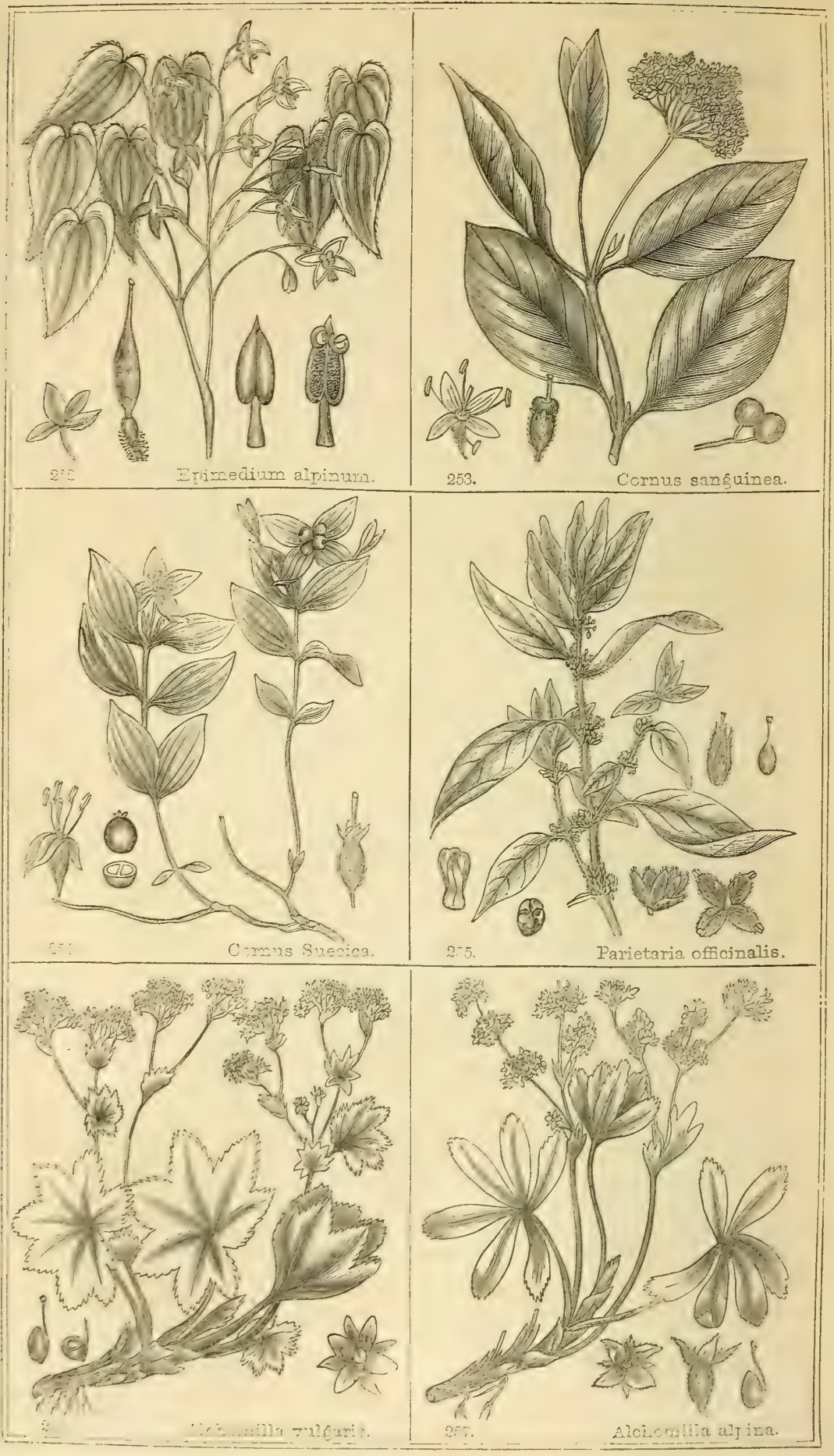


GENUS XIV. ALCHFIIL'LA. Lis. Lady's Mantle.

Nat, Ord, Rosi'CF,

Gev. Criar. Periunth single, inferior, eight-cleft; the fonr outer al. ternate ones smallest. Fruit a solitary or double nut, surrounded by the persistent perianth. Seed suspended.-Name from the Arabic alkan clyeh, alchemy; from its pretended alchemical virtues.

1. A. vulga'ris, Linn. (Fig. 256.) common Lady's Mantle. Leaves plaited, lobed, and scrrated.

English Botany, t. 597.-English Flora, vol. i. p. 224-Lindley, Synopsis, p. 103.-Hooker, British Flora, vol. i. p. 73.

ß. minor, Hudson. Leaves very downy.

Root woody, with numerous long, branched fibres. Plant from four to sixteen inches high. Stem procumbent at the base, becoming erect, round, hairy, with alternate branches. Root leares numerous, large, handsome, plaited, with numerons zumled scmeted lobes, hairy, especially beneath, on long, channeled, hairy footstalks, slender, and, like the stems, surrounded with pale, dry, brown, nembranous seales. Stem leares very small, nearly sessie, alternate, with two lare, deenly toothed stipules, united at the base. Inflorescence in uumerous lax, small, terminal, corymbose clusters of yellowish-green hairy flowers; the perianth inferior, of one piece, tubular; the limb in eight acute sprearling serments, the four altemate outer ones smallest.

Habitat.-Pastures, wooks, and meadows, common; especially in alpine districts.

Perennial; Howering from June to $\Lambda$ ugust.

This is one of our more elegant litile plants, and is said by Hoffman and others to possess the power of restoring feminine beauty, however faded, to its earliest freshness.

2. A. alpi'na, Linn. (Fig. 257.) alpine Lady's Mantle. Learez in about six serrated segments, green above, white and sating beneath.

English Botany, t. 244-English F'lora, vol. i. p. 225.-Lindley, Synopsis, p. 103.-Hooker, British Flora, rol. i. p. 73.

Root somewhat woody, with Inng spreading fibres. Stem from four to eight inches high, round, slender, and downy, erect, or slightly pro. cumbent at the base, alternately branched. Ront leaves on long, round, slender, hairy stalks, the segments rarying from five to seren, ovate, lanceolate, closely serrated at the extremity, green and nearly smooth above, thickly clothed heneath with snft, white, silvery hairs, which give it a most heautiful appearance. Stem leaves smal!, sessile, or on short stalks, with two twothed or deeply serrated stipules. Inflorescence similar to the last. The outer alternate segments of the perianth very small.

vol. I. 
IIubiful.-Alpine and mountainums districts in the North of England. Pientiful in Scotland. Braudon Mountoin, County of Ferry, aud Ben Bulben, County of Sligo, Ireland.

Perennial; flowering in July and August.

Few of our native plants are more elegant than this, and none surpass it in the beauty of its foliage, especially in the splendid silvery appenrance of its under side.

3. A. arven'sis, Sm. (Fig. 258.) Field Lady's Manlle, or Parsley Piert. Leaves in three deep and irregularly cut lobes, pubescent.

English Botany, t. 1011.-English Flora, vol. i. p. 225.-Liudley, Synopsis, p. 103.-Hooker, British Flora, vol. i. p. 73.

Root small, fibrous. Stems numerous, more or less prostrate, much branched, very leafy, and from four to six inches long, round, and clothed with soft spreading hairs. Leaves alternate, on short stalks, downy, in three deep lobes, each of which is irregularly cut. Stipules large, irregularly cut. Inflorescence small axillary clusters of palegreen, hairy flowers. Stamens varying in number from one to four.

Habitat.-Sandy or grarelly situations on the tops of old walls, \&c, frequent.

Annual; flowering during the summer months.

\section{GENUS XV. ISNAR'DIA. LINs. Isnardia.}

\section{Nat. Orl. ONAGRA'RIEA.}

Gcr. Char. Calyx superior, the limb of four lobes, persistent. Petals four, or wanting. Stigma capitate. Capsule oborate, with four angles, four valves, four cells, and many-seeded.-Named after Antoine d'Isnard, a Botanist and Professor at Paris, in the beginning of the last century.

1. I. palus'tris, Linn. (Fig. 259.) Marsh Isnardia. Stem procumbent, rooting, smooth; leaves opposite, ovate, acute, tapering at the base into the footstalk; flowers axillary, solitary, sessile, witl.. out petals.

Hooker, in English Botany, Supplement, t. 2595.-English Flora, vol. i. p. 223.-Lindley, Synopsis, p. 109.-Hooker, British Flora, rol. i. p. 73 .

Roat with longr, crepping winderground stems, putting out numerous branched fibres from the lower joints of the prostrate stem. Stem round, and, as well as all other parts of the plant, quite smooth, with opposite branche:, reddish above, darker below. Leaves opposite, entire ovate, acute, tapering at the base into a short footstalk, which is reddish, and terminates in the leaf in a branched midrib, somewhat succulent, 
green, sometiunes with a reddish or purple hue. Flowers solitary, sessile, at the base of the footstalks, small, "having two small tubulate bracteas at the base." Limb of the calyx of four ovate, acute, green, spreading segments. Cumlla wanting. Stumens small, placed opposite to the segments of the calyx. Style short, with a capitate stigna. Capsule crowned by the persistent limb of the calyx.

Habitat.-Ponds and marshy plates, very rare. In a pool at Bux. ted, Sussex-Mr. Borrer. Abundant in a bog on Peterstield Heath, Hampshire-Miss Riekman and J.Barton, Esq.

Annual; How ering in July.

\section{GENUS XVI. SANGUISOR'BA. Lis. Bumet.}

Nat, Ord, RosícE.⿱一𫝀口.

Gev. Cirar. Perianth superior, of four coloured lobes, with two or four scales at the base. Nuts one or two, strrounded by the dry persistent tube of the perianth. Seed suspended.-Name from sanguis, blood, and sorbeo, to absorb; from the astringent properties which the plant possesses, and its power of stopping the hæmorrhage from wounds.

1. S. officina'lis, Limn. (Fig. 250.) great Bumet. Spike orate.

English Botany, t. 1312.-English Flora, rol. i. p. 218.-Liudley, Synopsis, p. 103.-Hooker, British Flora, vol. i. p. 73.

Root large, thick, woody. The whole plant quite smootl. Stem erect, from one to two fect high or more, branched, especially abore. Leaves pinnate, with a terminal leaflet; the rest opposite, sometimes alternate, each orate, cordate at the base, strongly serrated, green above, paler bencatis, with a strongish midril and numerous l,ranching veius; at the base of almost every foot-iail is a small twothed stipule, larger in some, smaller or entirely wanting in others; the radiral leares with long stalks, those of the stem much shurter. Iufforescere a teminal, dense, orate spike, of a dark dull purple hte, on long naked stalks. Spikes generally about an inch long, but rery various in size, the upper fluwers expanding first. Perianth single; the limb of four dart-red or purple, ovate, spreading segments; its tule investing the germen, and having at its base a greenish, futr-sualed, ciliated bractea. Nuts one, or rarely: two, enclosed in the tube, and crowned by the persistent limb of the perianth.

Habitat.-Rather moist limestone ur clayey countries, especially iu the Forth of England. Less frequent in the Lowlands of Scotland.

Perennial; flowering in June and July.

This plant does not appear to posses either the medicinal or agricul. tural properties for which at one time it was thought raluable; it is bitter and someu hat astringeut, and not a fond much relished by cattle. 
2. S. mc'dia, Smith, (Fig. 261.) oblong Bumet. Spikes cylindrical. English Flura, vol. i. p. 219.-Lindley; Synopsis, p. 103.-Hooker' British Flora, vol. i. p. 75 .

"Taller and larger than the foregoing, with a nuch longer and truly cylindrical spike, of rather pale flowers. Mr. Don, who sent it, had scarcely an idea of its being more than a variety."

Habitat.-Pastures in the West of Scotland-Mr. G. Don.

Pereunial; flowering in July.

This plant we only know from cultirated specimens, and from these our drawing has been made. The spike is longer, and the flowers paler, than in S. officina'lis; but whether these characters are constant, and sufficient to distinguish it as a species, experience must prove.

\title{
ORDER II.
}

\section{DIGYN'IA. 2 Pistris.}

\section{GENUS XVII. BUFFO'NIA. Sauvages. Buffonia.}

\author{
Nat. Ord. CARYOPHYL'EER.
}

Gen. Char. Calyx of four pieces. Corolla of four entire petals. Capsule compressed, one-celled, two-valved, two-seeded.-Name given by Sauvages in honour of the celehrated Buffon, "who had indeed very slender pretensions to botanical honour; a circumstance supposed to have been indicated by Linnæus in the specific name teunifolia." Smith.

1. B. an'nua, De Candolle, (Fig. 262.) annual Buffonia. Stem loosely panicled from the base, with short, spreading; firm branches; furrows on the calyx straight, parallel; capsules scarcely so long as the calyx; leaves subulate, spreading at the base.

Lindley, Synopsis, p. 47.-Hooker, British Flora, vol. i. p. 74.

B. tenuifo'lia, English Botany, t. 1813.-English Flora, rol. i. p. 226.

Root fibrous. Siem erect, about six inches high, round, smooth, aiternately branched, leafy. Leaves erect, opposite, awl-shaped, threeribhed, dilated and somewhat sheathing at the base. Floucrs erect, small, white, solitary, on the roughish terminal and axillary stalks. C'aly.x of funr lanecolate, three-ribhed pieces, with rather hroad, white, membranous margins. Corolla of four oblong, entire, white petals, shurter than the calyx. Capsule flattish, ovate, of one cell and two valves, containing two large, ovate, comprcssed, roughish seeds. 


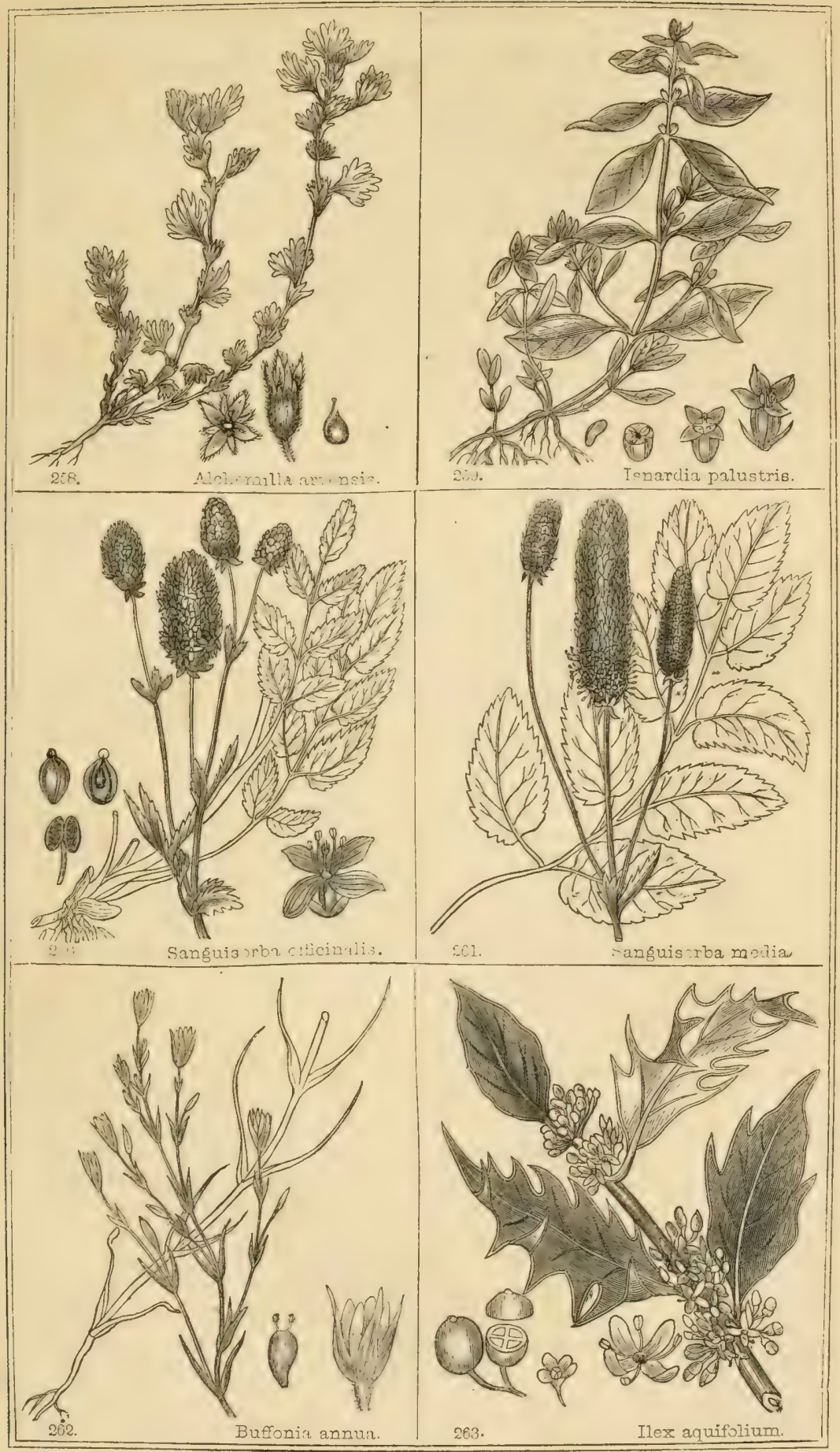



Habitat.-The sea-coast; very rare. Said to have been found, in Plukenet's and Dillenius' time, buth about Boston, in Lincolnshire, and on Hounslow Heath; but no one has since met with them, and Sir Joseph Bails, who often examined the coast near Boston, was persuaded that Bupleu'rum tenuiss'imum hat been mistaken for the Buffónia.

Annulal ; flowering in June.

\section{ORDER III.}

\section{TE'TRAGYN'IA. 4 PIstLLs.}

\section{GEYUS XVIIT. I'LEX. Lins. Holly.}

Niat. Ord. ILICI'xEx. Brongniart.

Ges. Char. Calyx persistent, of four or five teeth. Corolla of four or five petals, distinct or combined at the base. Stamens four, sometimes five. Fruit fleshy, containing four or fire hard, oneseeded nuts.. Seed inverted.-Name Ilex is supposed to have been given to this genus on account of the resemblance of its leares to those of the Quercus Ilex, the true Ilex of Virgil.

1. I. aquifo'lium, Linn. (Fig. 263.) common Holly. Leaves ovate, acute, slining, waved and spinous; thowers numerous, axillary, short, subumbellate.

English Botany, t. 496.-English Flora, vol. i. p. 227-Lindley, Synopsis, p. 74.-Hooker, British Flora, vol. i. p. 74.

A very handsome and ornamental evergreen tree, with a smooth, greyish bark. Leuces alcernate, on short stalbs, a deep shining green above, paler beneath, the margins cartilaginous, waved, and with stout, sharp, spinous, divaricating lobes; the niper leares, especially of old trees, entire, with an acute point. Inflorescence short, somewhat umbellited clusters of numerous white foncers, arising from the axils of the leaves. Calyx small, slightly hairy, with four or five small teeth, remaining upon the fruit. Corolla cither of four or five distinct, spreading, concare petals, or united at the base. into a wheel shape, much larger than the calys, white, often tinged with pink on the outside. Fruit roundish, bright scarlet, tleshy berries, containing four or fre hard, single-seeded nuts, umbilicated at the apex.

Habitat.-Hedges aud woods; frequent, expecially in a light sandy or gravelly soil. 
Tree; flowering in May and June.

Few trees have been more admired and variously cultivated from the earliest period, than the Holly, also known by the names of Hulver, Hulferl, and Holne. Numerous very beautiful varicties are obtained by cultivation, or accident, as to the shape, size, and a more or less spinous state of the leaf, as well as in its variation of white or spotted colours. When the Dutch fashion of horticulture prevailed in this country, hedges of Holly were planted and kept well clipped in various forms. The celebrated Evelyn, it is said, planted a helge of it at Say's Court, Deptford, (at the suggestion of Peter the Great, who resided at his house when he worked in the dock-yards at Deptford,) four hundred feet long, nine feet high, and fire feet broad; and he asks, "Is there under hearen a more glorious and refreshing object of the kind, than such an impregnable hedge, glittering with its armed and rarnished leaves, the taller standards at orderly distances, blushing with their natural coral."

No plant forms better or more desirable fences than the Holly, and few will bear the shears so well; and when a liedge is once formed, perhaps it is the least expense of any other kind to keep it in repair; but it is of tarly growth, and malies very slow progress for a number of years after it is plinted. The wood is hard, white, fine-grained, and takes a good polish. It is used for a great variety of purposes, especially by turners and the makers of mathematical instruments.

The bark affords a tenaceous substance, which, when separated by bruising, boiling, and fermentation, forms the substance known by the name of birdlime.

'The leares, as well as the bark, are bitter, and have been used in the cure of coughs and intermittent ferers; and it appears, from experiments made by Dr. Rousseau, of Paris, as detailed in the Transactions of the Medico-Botanical Society of London, that they contain a new vegetable principle called Ilicine, which is equally cficacious with Quinine and Peruvian bark. The remarkable difference observable between the leaves in the lower part of the tree having their edges strongly armed with stout spines, and those on the upper part having their margins quite smooth, is very singular; it would appear to be a means of protection against the injury of cattle, and is the reason of the Holly being considered, in the emblematic language, the token of foresight. This peculiar circumstance in the leaves has not escaped the nutice of the poets, and is thus spoken of by Dr. Southey:

O reader! hast thou ever stood to seo

'The Holly tree?

The eyo that contemplates it well, perceives

Its glossy leaves

Order'd by an Intelligenco so wise,

As might confound an atheist's sophistrics. 
Below a circling fence, its leaves are seen

Wrinkled and keen;

No grazing cattle through their prickly round

Can reach to wound;

But, as they grow where nothing is to fear,

Smooth and unarm'd the pointless leaves appear.

Varions reasons are giren by authors as to the origin of decorating churches and dwelling-houses with the branches of Holly during the Christmas festival, but nothing appears to be known with certainty as to its origin, beyond that of its great antiquity. Dr. Chandler supposes this custom to be derived from the Druids, who, he says, decorated their dwelling-places with evergreens during winter, "that the sylran spirits might repair thither, and remain unnipped by frost and cold winds, until a milder season harl renewed the foliage of their darling abodes."-"The Holly (Creil Thionn, in Gaelic) is the badge of the clan Drummond."

\section{GENUS XIX. POTAMO'GeTON. Lins. Pondweed.}

Nat. Ord. Fluvia'les.

Gen. Char. Flowers in spikes, arising from a sheathing bractea, or spatha. Perianth single, of four pieces. Stamens, with the unthers, nearly sessile, opposite the pieces of the perianth. Pistils four, alternating with the stamens, becoming compressed. Nut.: each containing a suspended, curved, more or less spiral seed.-

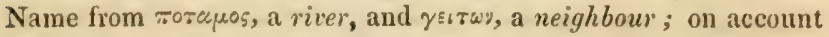
of the species all growing in water.

\section{* Leaves all opposite; stipules none.}

1. P. den'sus, Linn. (Fig. 264.) opposite-leaced Pondweed. Leaves upposite, embracing the stem, crowdel.

English Botany, t. 397.-English Flora, vol. i. p. 231.-Lindley, Synopsis, p. 248.-Hooker, British Flora, vol. i. p. 75.

Roots fibrous, arising from the lower joints of the long creeping stems. Stem naked below, forked and thickly clothed above with opposite, ovate, acuminate or lanceolate, sessile, spreading leares, embracing the stem, recurred, having a strongish midrib formed of numerous longitudinal cells, and two or three lateral parallel reins united hy distant fibres, the margins waved, entire. Inflorescence a small round spike of about four green flowers, on a short round stalk, erect when in flower, recurved in seerl. "The head is just out of the water during impregnation, after which, by the increase of the branches, it sinks, and ripens the seed, whilst other flowers come forth above. The deeper the water, the larger is the whole plant." 
Habitat.-Ditches and slow streams; frequent.

Perenuial; flowering in June and July.

** Leaves alternate, sheathing, with adnate stipules.

2. P. pectina'tus, Linn. (Fig. 265.) Fennel-leaved Pondweed. Leares linear or bristle-shaped, single-ribbed; nuts very large, keeled at the back.

English Botany, t. 323.-English Flora, vol. i. p. 237.-Lindley, Synopsis, F. 248.-Hooker, British Flora, vol. i. p. 75.

Root tuberous, with long, creeping, branched stems. Stem very slender, numerously branched, and rery leafy. Leaves narrow, linear, long, slender, acute, altemate, single-ribbed, dilated at the base into thin. pale, membranous sheaths, elongated, and cloven at the top, similar to the ligula in grasses. Spikes terminal, on a slender stalk, of a few interrupted flowers, which rise above the surface.

Habitat.-In rivers, ponds, and ditches, whether of fresh or salt water.

Perennial; flowering in July.

This is an exceedingly variable plant, especially in the size of its foliage; in elear running streams it is mostly very large, but seldom produces flowers.

*** Leaves alternate, all linear, submersed; stipules free.

3. P. pusil'lus, Linn. (Fig. 266.) small Pondweed. Leaves linear, narrow, opposite or alternate, three to five nerved, with slender lateral veins; peduncle many times longer than the spike.

English Rotany, t. 215.-English Flora, vol. i. p. 236.-Lindley, Synopsis, p. 249.-Hooker, British Flora, vol. i. p. 75.

B. ma'jor; stem more compressed. Hooker, British Flora, vol. i. p. 74.-P. compress'us, Linn. English Butany, t. 418.-English Flora, sol. i. p. 234.

Root fibrous. Stem slender, slightly compressed, branched, submersed, except the spike. Leaves alternate below, opposize ahove, mostly acute, under a line in breadth, often two inches long, the miclrib slightly reticulated, lateral veins towards the margin very faint. Stipules brivader than the leaves, sheathing. Spikes short, lateral, from the axils of the leaves, at first short and close, but in maturity lonse and interrupted.

B. P. major, although distinguished ly Linnæus and later botanists as a species, is considered by others a vaxiety only, a conclusion with which we fully agree.

Habitat.-Ditches, ponds, and slow streams.

Perennial; flowering in July. 



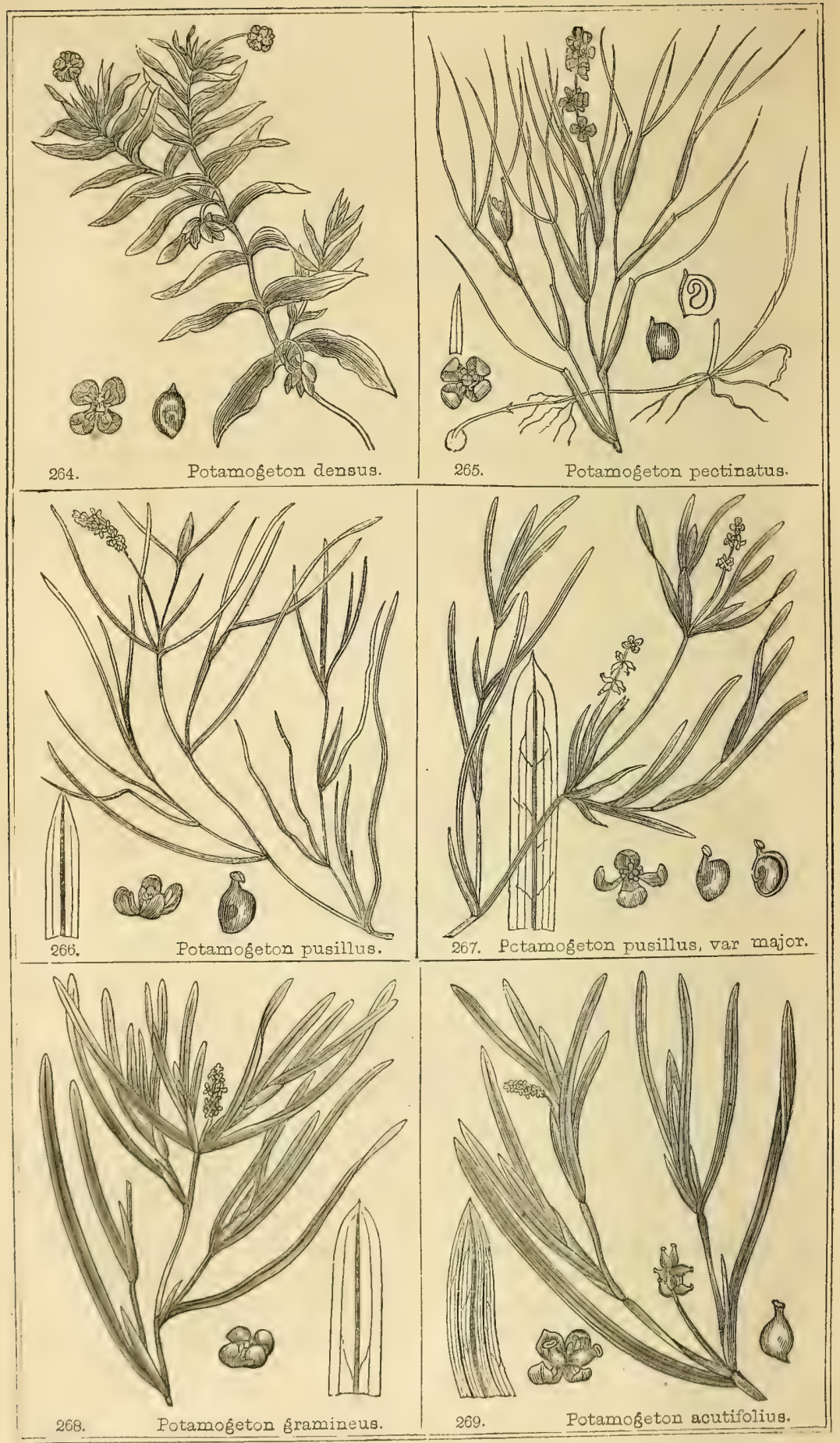


4. P. gramine'us, Lim. (Fig. 268.) grassy Pondweed. Leaves broadly linear, obtuse, three-nerved, lateral reins slender, obscure; peduncle from the axils of the leaves, scarely longer than the oval spike.

English Botany, t. 2253.-English Flora, vol. i. p. 235.-Hooker, British Flora, vol. i. p. 75.-P. obtusifo'lius, Lindley, Synopsis, p. 249.

Stem slender, wary, more or less branched, especially near the upper part. Leares about three inches long, crowded, spreading, alternate, except at the extremity, whore they are generally opposite, linear, but gradually contracted towards the base. The main rib is accompanied by numerous lateral, parallel, obscure reticulations, with the two outer veins solitary, very slender, sometimes scarcely visible. Stipules narrower than the leaves. Peduncles invariably axillary. Spikes equal in length to the peduncle, which is very short, oval, close, rising above the surface of the water.

The characters founded on the veins of the leaves of this species, are remarkably constant.

Habitat.-Ponds, ditches, and slow streams. Norwich; Deptford; Lancashire; Beverley, Yorkshire.

Perennial ; flowering in July.

5. P. acutifo'lius, Link. (Fig. 269.) sharp-leared Pondueed. Leaves linear, acuminate, three-nerved, with numerous intermediate parallel veins running throughout the whole surface; spikes compact, oval, the length of the short peduncle.

Hooker, in English Botany, Supplement, t. 2609.

This and the following species are well distinguished by the many close and parallel nerves.

Habitat.-Ponds and ditches. About Amberley, Henlield, and J.ewes, Sussex.

Perennial; flowering in July.

6. P. zostercfo'lius, Schum. (Fig. 270.) Grass-u'rack-like Pondaceed. Leaves broadly linear, with an oblique acuminate point, three principal nerves, with numerous intermediate ones, occupying the whole surface; stem compressed; peduncles long; spikes cylindrical.

Hooker, British Flora, vol. i. p. 76.-Lindley, Synopsis, p. 249.$P$. cuspida'tus, English Flora, vol. i. p. 235.

Leares intersected into three equal portions by the principal veins, which, as well as the intermediate ones, are distinct.

Sir James Smith says this has often been confounded riah P. compressum, but is more robust and of larger growth than that species; and adds, that Professor Schrader had communicated it to him as the $P$. cuspidatum of his Flora Germanica, and this name Sir James had also adopted.

VOL, I. 
Habitat.-Ponds and rivulets. Hovingham, Yorkshire; in the Lake of Forfar, and also the Lake of Roscobie; and Sir William Hooker, in lis British Flora, says he possesses specimens gathered in the Lake of Forfar by Mr. Drummond, with peduncles three to four inches, and spikes cylindrical an inch long.

Perennial; flowering in July.

* pules free.

7. P. cris'pus, Linn. (Fig. 271.) curled Pondweed. Leares lanceolate, waved, serrated, three-nerred.

English Botany, t. 1012.-English Flora, vol. i. p. 233.-Lindley, Synopsis, p. 249.-Hooker, British Flora, vol. i. p. 76.

B. serra'tus; (Fig. 272.) leaves serrated, not waved.

Leaves alternate below, opposite above, nearly sessile, crispecl at the edges, and about two inches in length, slightly reticulated on each side the rib. Spikes short, and loose.

B. serra'tus is $P$. seria'tum of Hudson, acknowledged by himself to be too near $P$. crispum to deserre to be regarded as a species. It is marked as a rariety, with more of the leaves opposite, serrated, and less undulated, than crispus.

Habitat.-Ditches, ponds, and risulets; common.

Perennial ; flowering in June and̉ July.

8. P. perfulia'tus, Lim. (Fig. 273.) perfoliate Pondweed. Leaves heart-shaped, clasping the stem, with fire to seren principal and numerous smaller intermediate nerves.

English Botany, t. 168.-English Flora, vol. i. p. 230.-Lindley, Synopsis, p. 249.-Hooker, British Flora, vol. i. p. 76.

Leares sessile, rather orate, crowded at the upper part of the stem, mostly under two inches in length, brittle to the touch, and of an olive colour, presenting a pellucid oily appearance. Stems rather turned upwards. The whole plant is submersed, except the flower-spikes, which, during July and Angust, rise a little above the surface of the water, and become for a time conspicuous, displaying on the surface their little spikes, corged with a profusion of white pollen.

Habitat.-Ponds and rivers; common.

Perennial; flowering in July and August.

It is justly remaxked by Sir James Smith, that the respiration of aquatic plants differs greatly from that of such as inhale atmospheric air, and may be said to bear some analogy to that of fishes when compared with beasts and birds. In aquatic plants, the leaves are altogether different in texture, their cuticle being, like that of fishes, invariably destitute of hairs.

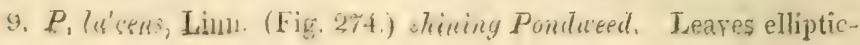




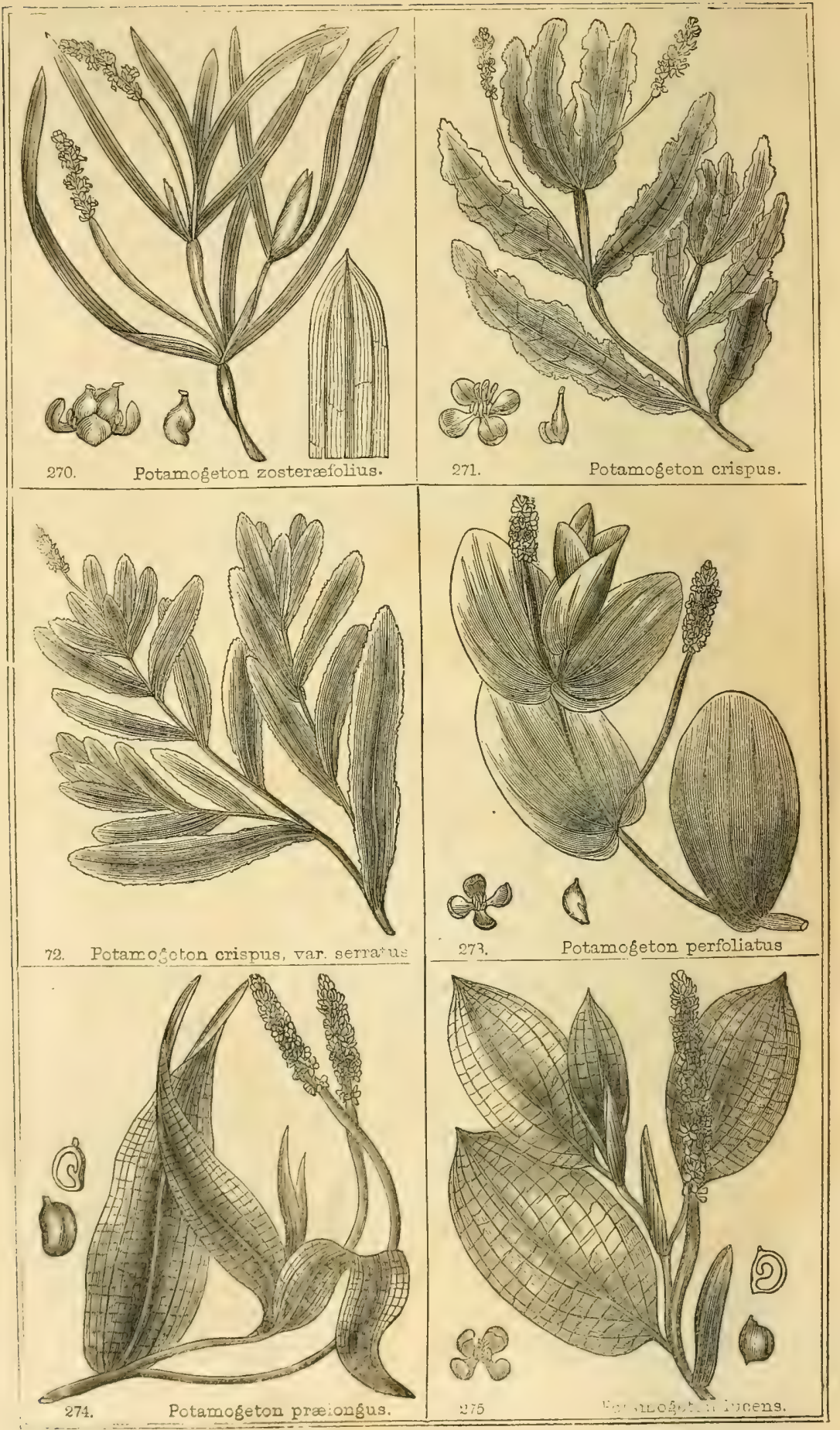


lanceolate, pointed, with from five to seven lateral parallel veins, springing from the midrib.

English Botany, t. 376.-English Flora, vol. i. p. 232.-Hooker, British Flora, vol. i. p. 76.-P. Pro'tcus, Lindley, Synopsis, p. 250.

Leaves on short footstalks, alternate below, frequently opposite above, slightly waved, entire, frequently tapering into a rounderl footstalk at the base, well distinguished by the numerous transverse connecting veins, uniting the five or seven main ribs. Stipula large and foliaccous. Stem long, round, scarcely branched. Spike about two inches long, crowded, of a green colour, supported on a strong peduncle, mostly thickened upwards.

" The largest of our species, and rery beautiful in the nervation of its leaves. Chamisso and Schlechtendal include this in a division of the genus which has sometimes floating and coriaceous leaves (folia accessoria), as it is found by Mr. WVilson at Lyn Maclog. They change its name to $P$. Proteus, and consider the $P$. heterophyllus a variety of it. To me they appear distinct; but aquatic plants of all kinds are extremely liable to vary."-_ Coriaceous leaves rare, ovato-lanceolate, moderately acute, less evidently stalked than in $P$. heterophyllus; foliage more crowded, and stipules larger and (in proportion) narrower, than in that species. Spikes twice as long." - Wilson, Hooker's British Flora.

Habitat.-Lakes, ponds, and ditches; common.

Perennial; flowering in Jume and July.

10. P. pralon'gus, Wulf. (Fig. 274.) long-stalked Pondweed. Leaves oblong, principal nerves three, connected by reticulations witl! scveral lesser ones; peduncle long.

Hooker, British Flora, vol. i. p. 77.-Cham. in Linnex, vol. ii. p. 191.-Rich. Iconogr. t. 185.

Leaves invariably oblong, obtuse, also distinguished by the lateral parallel nerves springing from the base, where they clasp the stem, and by the lengthened peduncle. In size it is nearly equal to $P$. lucens.

IIabitat.-Lakes and pools. Moss of Litic, Nairnshire; Boyrwickshire; Brechan.

Percnnial; flowering in July.

***** Leaves alternate; upper ones floating, broader than the rest Stipules free.

11. P. helerophyl'lus, Schreb. (Fig. 276.) rarious-leared Pondwced. Upper leaves elliptical, stalked, floating; lower ones lanceolate, sessile; flower-stalks swelling upwards.

English Botany, t. 1285.-English Flora, vol. i. p. 229.-Lindley, Synopsis, p. 250.-Hooker, British Flora, vol. i. p. 77.

Tpper or floating leares often absent (Wilson), mostly under two 
inclies in length, cu foutstalks about their own length; subnersed ones with frum three to five nerres, sessile, linciri, lanceolate, wared, one to two inches long, and under half an inch in breadth. Stipules under water, close, lanceolate, those above strongly marked with two principal ribs, broad and spreading. Peduncle swelling upwards, about three times the length of the dense syike.

Habitat.-Pouds and ditches; not uncommon.

Perennial; flowering in June and July.

12. P. lanceola'tus, Sm. (Fig. 277.) lanceolate Pondueed. Leaves lanceolate, tapering at the base, membranous, from five to seven ribs, with transverse reticulations near the widdle rib; floating ones elliptic lanceolate; peduncle scarcely as long as the leares; spike ovate.

B. without floating leares.

English Botany, t. 1985.-English Flora, rol. i. p. 233.-Lindley, Synopsis, p. 250.-Hooker, British Flora, vol. i. p. 77.

Leares alternate, except at the flower-stalks, when they are mostly in pairs, sometimes more, generally under two inches in length; the upper ones are filled througlout with a curious chain-like reticulation, whilst in those under water it is observable only on each side the main rib. Stipules narrow, lanceolate. Peduncles scarcely as long as the leaves. Spike small, oval.

This is nearly allied to the preceding, but is altogether a smaller and less robust growing plant.

Habitat.-Ponds and slow strcams. Anglesea, Kincardineshire; Linthuthen Loch, Angusshire. $\beta$. Found with the preceding in a rirulet in Anglesea.

13. P. rufes'cens, Schrad. (Fig. 278.) reddish Ponduecd. Floating leaves elliptic, oblong, stalked, coriaceous; submersed ones lanceolate, nembranous, many-nerverl, with numerous connecting veins and linear reticulations.

Hooker, British Flora, vol. i. p. 78.-Lindley, Synopsis, p. 250.P. rufrécens, English Butany, t. 1286.-English Flora, vol. i. 1. 231.

There is also in this a rery close affinity to the preceding species, and it is not casily distinguished by any permanent and markerl chanacter. It u4nally precents a lurid or reddish olive colum, and by this its general appearance it is follatpe the most readily detcetcel. "This does in some situations much rescmble $P$. lucens: the coriaccous floating leares are nearly as acute as the lower ones, differing only in their firmer texture, aind in heing stalked; the ribs, shape, and size are much the same in both. The lateral ribs or nerves are by no means separate to the base of the leaf, but arise from various parts of the central ril,; some of then we-third the length of the leaf from its basc; they are six to seven in number on sach side, two of them more evident 
than the rest; flower.stalk not thickened upwards."-Wilson, in Hooker's British Flora.

Habital.-Ditches and slow streams; not unfrequent. Beverley, Yorkshire; in the Garldie Premnay, Aherdeenshire; Anglesea; near Glasgow, and Forfar; Lilleshall Mill-pond, Shropshire.

Perennial; flowering in July and August.

14. P. oblon'gus, Viv. (Fig. 279.) blunt-fruited broad-leaved Pondweed. Leaves floating, coriaceous; lower ones sometimes submersed, without leafless petioles.

Hooker, British Flora, vol. i. p. 78.-Lindley, Synopsis, p. 250.

Floating leates more or less coriaccous, submersed ones often absent. Fruit rounded, and obtuse at the back.

Habitat.-Ditches near Henfield-Mr. D. Turner.

Perennial ; flowering in July.

15. P. na'tans, Linn. (Fig. 280.) sharp-fruited broad-leaved Ponduced. Submersed leaves linear, membranaceous, not always present; floating ones elliptical, stalked, coriaceous, and many-nerved.

English Botany, t. 1822.-English Flora, vol. i. p. 229.-Lindley, Synopsis, p. 250.-Hooker, British Flora, vol, i. p. 78.

Roots creeping. Stem round, several feet in length, much branched. Upper leaves two or three inches long, elliptical or heart-shaped, on long footstalks, nearly opposite, with five or more main ribs springing from the centre one; lower ones often wating in slallow water, narrow, sessile, alternate. "The lower leaves appear to me to differ from the submerser leaves of all the others (except the last perhaps) in having their substance composed of the same small but distinct cells, or reficulations, as the floating oncs." (IIooker.) Stipules lanceolate, large, and foliaceous. Peluncle long, thickened upwards. Spike dense, cylindrical, rising sereral inches above the water.

Habitat.-Ditches and stagnant pools; common.

Perennial; flowering in June and July.

It is at all times a matter of much greater difficulty to cultivate apuatic plants successfuly, than such as only require a suitable soil, and free exposure to the common atmospherc of our climate. The arpuatic may be indiflerent to the particular hind of earth to which its youis are exposed, provided the watery element in which it is immersed be adapted to its habit and nature; hut to insure success in its culture, it is not enough that the plant be placed in water, with its roots sur. rounded with earth, nor dves it requirc extended observation to prove, that it is an important fact, in their natural habitation, that while one is detected revelling in all the luxurianec of growth, amid volumes of pernicious gasses hourly poured forth frum some stagnaut pool, anothe inay be sought in rain, except iu some 
Mountain rill,

Wand'ring its wild course from the mountain's breast, Now, with a brink fantastic, heather-drest, And plaring with the stooping flowers at will.

It is therefore erident that few gardens possess such facilities for the cultiration of aquatics, as to afford an opportunity of placing the rarious kinds in situations at all approximating to that in which they are found in nature. The truth of these remarks is borne out by the fact, that although numerous and extensire collections of terrestial plants are to be found in many parts of Great Britain, ret nowhere are aquatic plants cultirated to the same extent, and with equal success. In the genus in question, we have a striking illustration of this truth; for, although all the species possess foliage of peculiar beauty, yet when remored from their natural habitations, some of them defy the skill of the cultivator to preserve them alive for any length of time. Whilst, however, a few of the genus are impatient of cultivation, others are of remarkably robust growth; and it is stated by Haller, that in the lakes of Switzerland, the stems of $P$. serratum extend to twenty fathoms in length, and form, as it were, immense woods in the midst of these rast reservoirs. The leaves and seeds of $P$. crispum afford an agreeable food for ducks, and the roots of $P$. natans are eaten by swans and other large aquatic birds; whilst the leares of all afford shelter, shade, and spawning places for fish, as well as harbour for insects, from which both birds and fish derive a great portion of their food.

\section{GEYUS XX. RUP'PIA. LIN Ruppia.}

\section{Nat. Ord. Fluvia'zes.}

Gen. Char. Flowers two, from the base of the leaves. Calyx and corolla none. Seeds four, conrex on one side, slightly keeled on the other, and elevated on a short peduncle. Named in honour of H. Bernard Ruppius, a botanical author.

Ruppia differs from Potamogeton in being entirely destitute of calyx, and also in having stalked seeds.

1. R. marit'ima, Linn. (Fig. 281.) Sea Ruppia.

English Botany, t. 136.-English Flora, vol. i. p. 238.-Lindley, Synopsis, p. 251.-Hooker, British Flora, vol. i. p. 79.

Rorts fibrous, growing in tufts from the lower joints of the slendicr, fexuose, branched, leafy stem. Leares alternate, linear, narrow, channelled, more or less acute, and clasping the stem at the base, forming a sheath more or less dilated. Spikes alout two-fiowered, one below the other, on short, solitury, axillary stallss. Anthers sessile, large, onccelled, aud bursting horizontally; churing the time of flowering, the 



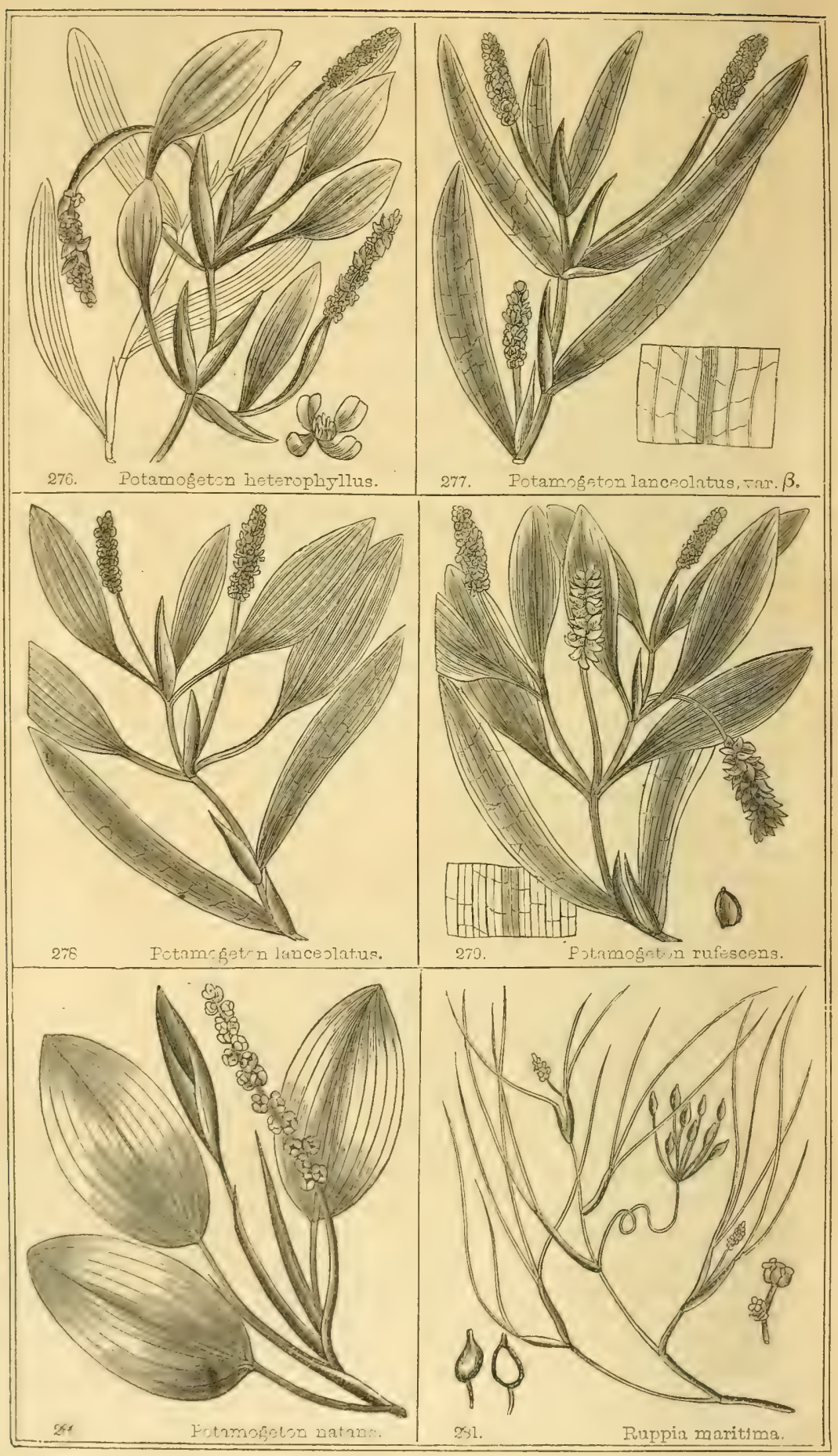


spulix lengthens to the height of six or more inches, becoming spirally twisted, by means of which the blossoms rise to the surface of the water. As the germens become enlarged, their base is extended, and becomes an elongated footstalk of sereral inches in length. The fruit is oblique, acuminated, with a beak, often varying greatly in length. "This drupe is sometimes more beaked than at other times, and the sheaths of the leares are sometimes but little dilated: then the plant becomes $R$. rostellata of Koch, and Reichenbach in his Iconog. t. 174, f. 306 , which indeed is the more common state of the plant with us. I have only seen such large sheaths as are figured for the true $R$. mar $i$ tima, Linu. (Reichenb. I conog. t. 174, f. 307,) on specimens from the south of Europe. Yet the latter authority quotes my figures in Flora I.ond. as admirably characteristic of his maritima." (Hooker.)

Habitat.-Salt -water ditches.

Perennial; flowering in July and August.

As the body, by habit and contiuued exercise, becomes enabled to support particular conditions in life without inconvenience, in like manner does the mind, by the frequent recurrence of the same object, become insensible, and even truths of the most striking hind pass before it without producing the least impression. We are led to make these remarks from observing the importance which hotanists attach to the peculiar structure of the flower-stem of the above species $(R$. maritima), which we have already said is twisted in a spiral form, and this is particularly observable about the time the fower makes its first appearance above the surface of the water; but this is only one of the many instances that might be adduced to show the harmony and design displayed throughout the whole of the works of the Great Architect of Nature. There is, in fact, nothing more wouderful in the spiralformed flower-stem of this plant, than in that of the flower-stem of the common Water Lily (Nymphcea alba), and numberless others that might be mentioned. At the season of flowering, the Water Lily raises its unexpanded flower upon a small cylindrical stem, and whether the water be six inches or six feet deep, this stem is inrariably proportioned to the exact depth of the water, and ceases to elongate the moment the blossom reaches the surface. Here, then, is enough to excite the admiration of the contemplative mind. It is true the external structure of the flower-stem is more simple than that of Ruppia maritima, yet it is not the less adapted to the end for which it is designer. That we cannot account for all the phenomena in nature, is no prof whatever that regetables, when found in their natural situations, possess one appendage unnecessary to their condition, or one that could be added to render them more complete. We have seen that the simple stem of the Nymphcea is in every way fitted for the office it has to perform; and although some might be disposed to ascribe the peculiarly twisted stem of the Ruppia to a mere freak of Nature, we shall also see that this singular structure is indispensable to the plant when in a state of 
nature. Its natural habitation, as has already been stated, is that of salt-water ditches, under the influence of the ebbing and flowing of the tides: there is, therefore, in this spiral stem the most admirable proof of design; for by this beautiful contrivance it relaxes or contracts according as the tides ebb and flow, by which means the flower is enabled to support itself above the surface of the water, until its season of flowering be past, when it again descends within its watery element.

Here may be added with propriety the exquisitely beantiful lines of Sir Richard Blackmore :

Your contemplation farther yet pursue;

The wondrous world of regetables view!

Observe the forest oak, the mountain pine,

The towering cedar, and the humble vine,

The bending willow, that o'ershades the flood,

And each spontaneous offspring of the wood!

The oak and pine, which high from earth arise,

And wave their lofty heads amidst the skies,

Their parent earth in like proportion wound,

And through crude metals penetrate the ground;

Their strong and ample roots descend so deep,

That fixed and firm, they may their station keep,

And the fierce shocks of furious winds defy,

With all the outrage of inclement sky.

But the base brier, and noble vine,

Their arms around their stronger neighbour twine.

The creeping ivy, to prevent its fall,

Clings with its fibrous grapples to the wall.

Thus are the trees of every kind secure,

Or by their own, or by a borrowed power.

But every tree from all its branching roots

Amidst the glebe, small hollow fibres shoots,

Which drink with thirsty mouths the vital juice,

And to the limbs and leaves their food diffuse:

Peculiar pores peculiar juice receive,

To this deny, to that admittance give.

-Hence varions trees their various fruits produce,

Some for delightfnl taste, and some for use.

Hence sprouting plants enrich the plain and wood,

For physic some, and some designed for food.

Hence fragrant flowers, with different colours dyed, On smiling meads unfold their gaudy pride.

-Review these numerous scenes, at once survey

Nature's extended face, then, sceptics, say,

In this wide field of wonders can jou find

No art discovered, and no end design'd? 


\section{GENUS XXI. SAGI'NA, Linn. Pearl-wort.}

Nat. Ord. Cartophyleza.

Gen. Char. Calyx inferior, of four permanent leares. Petals four, shorter than the calyx, sometimes absent. Capsule of one cell and four equal valves. Seeds numerous, each attached to the receptacle by its own stalk. Insignificant weeds, with axillary. white and greenish flowers. So named, as we are informed by Linnæus, on account of its nourishing qualities.

1. S. procum'bens, Linn. (Fig. 282,) Procumbent Pearl-urort. Stems procumbent, smooth, leares pointed. Petals shorter than the calyx.

English Bot. t. 880.-English Flora, vol, 1, p. 239.-Hooker, British Flora, vol. i., p. 79.-Lindley's Synopsis of the British Flora, p. 49.

Stems and every 'part of the plant glabrous, spreading, and often covering three to four inches in thick concealed tufts, with the stems rnoting at the joints, and often remaining evergreen throughout the winter. "In alpine situations growing amongst Spergula subulata, from which it is with difficulty distinguished." (Hooker.) Leaves linear, subulate, membranous, united at the base, and about half an inch in length; rather obtuse, but terminated by a minute bristle. $P e$ duncles axillary, solitary, longer than the leaves. Flowers drooping at first, with whitish petals.

"The late Rev. H. Davies gathered, on a green near Beaumaris, in July, 1817, a very pretty variety, with rose-like double flowers, of from twenty-seven to thirty petals. This has found its way into some curious garlens." - Smith.

Habitat.-Damp grarel walks, sandy soils, and moist places; fre. quent.

Perennial; flowering May and June.

2. S. ape'tala, Linn. (Fig. 283,) Annual Small-flowered Pearl-wort. Leaves fringed, bristle-pointed, slightly hairy. Petals much smaller than the calyx.

English Bot. t. 881.-English Flora, vol. i., p. 240.-Lindley's Synopsis, p. 49.

Root fibrous. Stems upright or ascending, but not rooting when in contact with the ground; generally more or less covered with rough, scattered hairs. Leares resembling the preceding, but fringed at the edges, more glaucous, rarely glabrous, and terminated by a distinct bristle. Peduncles long, slender, and hairy. Petals white, entire or noiched, sumetimes absent. Capsule twice the length of the calyx.

Habitat.-Barren ground, walls, and waste places; common.

Annual; May and June.

3. S. mari'tima, Don. (Fig. 284,) Sea Pearl-u'ort. Stems erect or procumbent near the base, divaricated, smooth, leares obtuse, fleshy, Petals absent.

English Bot. t. 2195.-English Flora, vol. i., p. 240,--Lindley's Synopsis, p. 49,-Hooker, British Floza, vol. i., p. 80.

voL, $I$. 
Root tapering, fibrous below. Stem at the base creeping, ascending at the extremity; about fuur inches high; leafy, round, smooth, and branched; green or purplish. Leares shorter than the last, obtuse, sometimes terminated hy a minute point, and rounded on the hack. Peduncles smooth, ahout an inch long, erect and slender. Caly $x$ leaves membranous a; the edge, ovate or obtuse. Petals entirely wanting.

"Mr. Don found sometimes eight stamens. Professor Hooker says the petals are entirely wanting, nor can 1 find any. The edges of the calyx are occasionally violet-coloured."-Smith.

\section{GENUS XXII. MCEN'CHIA, Hooker, Manchia.}

Gen. Char. Calyx inferior, of four permanent equal leares. Petals, four, shorter than the calyx. Capsule slightly orate, the leugth of the calyx, of one cell, opening at the summit, with eight to ten minute teeth. Seeds, many, attached to the receptacle. Named. in compliment to Conrad Mœnch, Professor of Botany at Hesse Cassel.

Herbaceous, small, smooth herbs, having the habit of cerastium.

1. $M$. erec'ta, Smith, (Fig. 285,) Upright Monchia.

English Bot. t. 509.-English Flora, rol, i., p. 241.-Hooker, British Flora, vol. i., p. 80.-Lindley's Synopsis, p. 49.

A small, erect, smooth, glaucous herb, rising to the height of from two to four inches. Leaves opposite, lanceolate, sessile, entire. Calyx leaves large, white, membranous at the margin. Petals, length of the calyx, white, and shining.

This is the Sagina erecta of Linnæus, and of Smith, in English Botany, t. 609 ; and the latter author, in the English Flora, has the following remarks:-"An elegant little plant, certainly misplaced in Sagina, as its habit and the structure of its capsules evince. The uncertainty of its genus is hinted at in Fl. Brit. and English Bot., though 1 had not then seen Ehrhart's work, to consider his characters. The original specific name erecta ought not to be changed: we may be thankful to get rid of Quaternella."

\section{GENUS XXIII. TILLE'A, Lins. Tillaa.}

Calyx, three to four deeply spreading, ovate segments. Capsules, three to four, two-secded, oblong, recurved, bursting lengthways, twocelled and two-valved. Named in compliment to Michael Argelo Tilli, an Italian Botanist, and author of a Catalogue of Plants grown in the Medical Garden at Pisa, 1723.

1. T. musco'sa, Linn. (Fig. 286,) Mossy Tillace. Stems procumbent, branched. Flowers axillary, sessile, three-cleft.

English Botany, t. 116.-Euglish Flora, vol. i., p. 242.-Lindley's Synopsis, p. 63.-Hooker, British Flora, p. 80.

Ruots fibrous. Stencs round, leafy, about two inches long, at first 


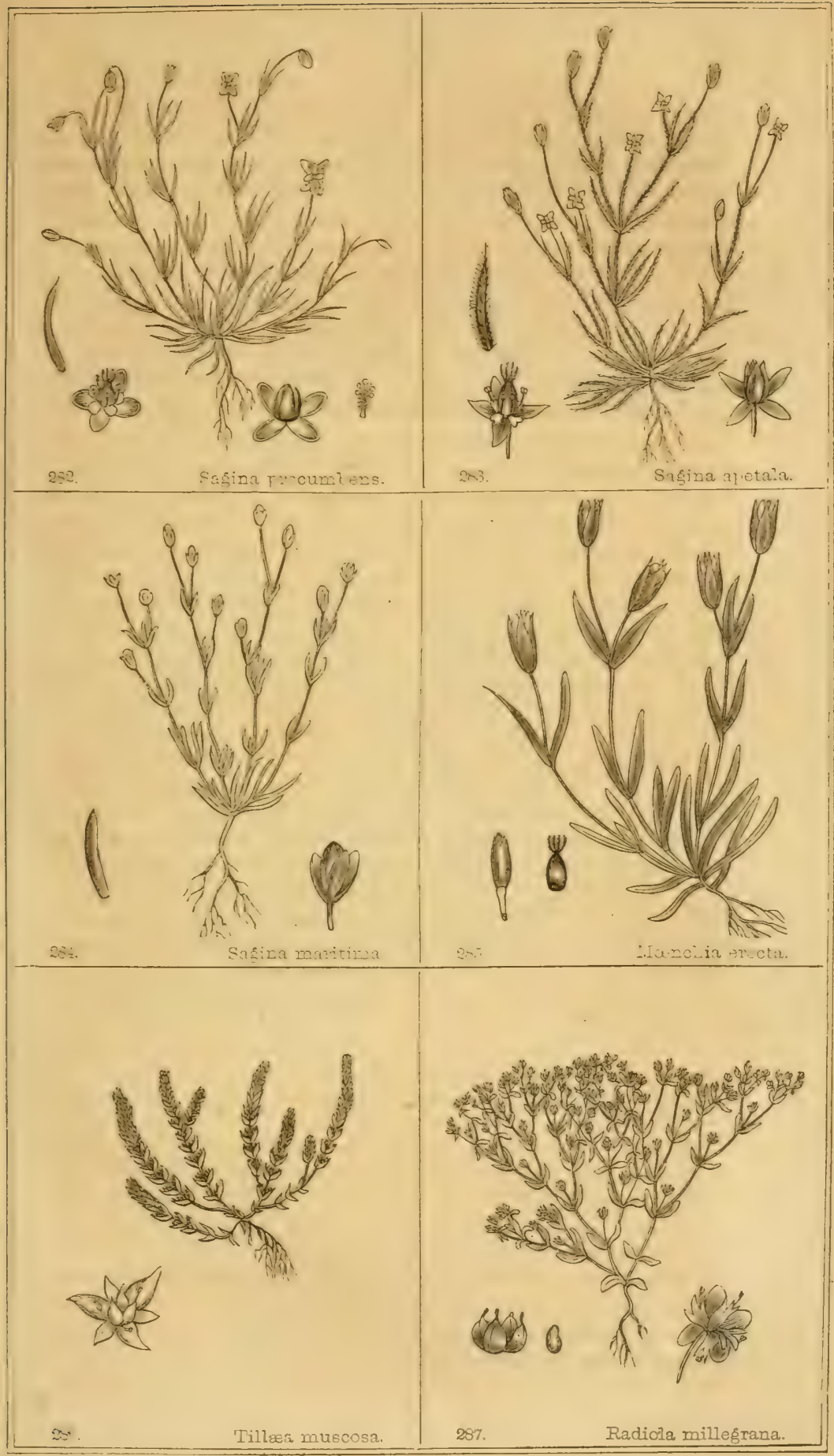



erect, but soon becoming numerous and decumbent. Leares opposite, combined at the base, oval, obtuse, smooth, succulent, and of a reddish colour. Flowers axillary. Peduncles often accompanied by a pair of smaller leaves. Caly, leaves three, pointed. Petals uarrow, pointed, white or tinged with red.

This minute and depressed plant becomes conspicuous only in ample reddish patches, which it presents to the eye, throughout the sandy wastes where it delights to grow. The whole plant is smooth. "The flowers are naturally three-cleft, and of course triandrous, but they are sometimes four-cleft in strong plants, and Gritener says five-cleft. Still the want of necturies keeps them generally distinct from the chiefly $\Lambda$ frican genus Crassula."

Habitat.-Common in Norfolk and Suffulk.

Annual; May and June.

\section{GENUS XXIV. RADIO'LA.-GreL. Flax-seed.}

Calyx of four leaves, united, half-way up dividing into four segments, each deeply three-cleft. Petals four, uncivided. Germin superior, four-lobed. Capsules round, of eight cells, and eight valves. Seeds orate, solitary, compressed, and polished. Named from radius, a ray, on account of the ray-like segments of the calyx.

1. R. millegra'na, SiM, (Fig. 287.) Thyme-leaved Flax-seed.

English Bot. t. 890.-English Flora, rol. i. p. 243.-Hooker, British Flora, vol. i. p. 80.-Radiola linoides of Lindley, Synopsis, p. 54.

Root tapering, more or less fibrous. Stem one to two inches high, erect, frequently branched, rather spreading, and somewhat corymbose. Leaves opposite, sessile, distant, ovate, entire, smooth. Flaners solitary, axillary, terminal, stalked, and un short peduncles. C'alyx ay parently of one piece, numerously and distinctly toothed.

Habitat.-Wet, sandy places.

Annual; July, August. 


\title{
CLASS V. \\ PENTAN'DRIA. 5 Stamens.
}

\author{
ORDER I. \\ MONOGYN'IA. 1 Pistil.
}

\section{GENUS I. E'CHIUM.-Linv. Viper's Bugloss.}

Natural Order, BORAGIN'EA. DE CAND.

Gemeric Character. Corolla irregular, with a short tube, the limb campanulate, obliquely five-lobed, the two upper largest, the lower acute and reflexed. Stigma deeply cloren. Nuts covered with little tubercles. Name $\varepsilon \chi$ เ , a viper; so called because it was said that it and some allied plants would heal a wound made by the sting or bite of a viper.

1. E. vulga're, Linn. (Fig. 288.) common Viper's Bugloss. Bristly and warty, stem simple, herbaceous, leaves lanceolate, flowers in short lateral spikes, tube of the corolla shorter than the calyx. Stamens longer than the corolla.

English Botany, t. 181.-English Flora, vol. i. p. 269.-Hooker, British Flora, vol.i. p. 98.-Lindley, Synopsis, p. 163.

Root long tapering. Stem from one to three feet high, round, erect, simple, hairy, (as is the whole plant), and rough, with pale rigid bristles arising from a tuberculated base. Leaves lanceolate, single ribbed, the lower ones with footstalks spreading, the upper narrower and sessile, of a dull green. Inflorescence terminating the stem in a long compound spike. Spikelets arising from the axis of the upper leares, crowded, recurved. Flowers unilateral, sessile, from the axis of a narrow bractea. Calyx of five linear segments, mostly of unequal lengths. Corolla bell-shaped, downy, its tube shorter than the calyx, the segments acute. Stamens longer than the corolla, frequently of variable lengths, and one is often not longex than the corolla. Anthers oval. Pistil longer than the stamens. Style hairy. Stigma deeply cloven, spreading. Nuts four, spreading, rough, with tubercles.

Habitat.-Old walls, road sides, and waste places frequent, espe. cially in a light, sandy, or gravelly soil.

Biennial; flowering from June to August.

Of whatever use this plant may have been formerly, it is now entirely neglected; but, as an ormament to the road sides and fields, perhaps none of our native plants surpass it, either in the beauty or duxation of their flowers. Its rows of rosy buds, as they expand, contrast admira- 
b!y with the tine blue or varied purple of the full expanded blossoms, densely crowded into a long terminating spike: it would be a much greater ornament to the flower border than numerous other plants that are cultivated with much care and great trouble.

The rigid hairs with which the whole plant is covered, are deserving the student's minute examination, those of the stem arising from a dark rounded callous tubercle, while thuse upon the leaves are from the centre of a flattish circular scale, of a vitreous appearance, delicately striated with lines radiating from the centre, and having a minutely crenated margin.

Varieties are occisionally met with, having the corolla white, and sometimes rose colour; the length also of the corolla, as well as the stamens, is various, and frequently the whole appearance of the plant is much altered as it advances to maturity, by the elongation of the spikelets, which are sometimes lengthened into leaf branches six or eight inches long, and the segments of the calyx, as the seeds ripen, are elongated.

We have sereral times found luxuriant plants growing in a warn situation, near IVorksop, Nottinghamshire, having much the character of $E$. pustulatum, which is distinguished by being rougher, the tubercles larger, the tube of the corolla as long again, the stamens inserted higher in the tube, and more spreading. It is not of unfrequent occurrence on the continent, and it is not improbable that it may be found in England. In the northern parts of Portugal I have found it very abundant, together with $E$. violaceum, a species readily distin. grished from either of the above, and introduced into the British Flora, from having been found at Jersey. We can scarcely admit its claims to this rank, hut its character may be a guide to the student $E$. violaceum.-Linn. Stem herbaceous, branched, hispid, leaves ovate, lanceculate, the lower petiolated, the upper oblong, cordate, and somewhat amplexicaul at the base, spikes simple elongated, stamens as long as the corolla.

Habitat._- "Plentiful on the sandy grounds about St. Hilary, Jersey.-Kay. Since fuund in the same spot by Captain Finlay, and by Mr. Trevelyan." - Hooker.

Annual or biennial; tlowering in August. The spikes are lax, few flowered, of a beautiful violet-blue colour.

\section{GENUS II. PULMO'NARIA,-LINN. Lungwort.}

Nat. Ord. Boragi'nex. DE CAND.

Gen. Char. Calyx bell-shaped, with five angles, five cleft. Corolla funnel-shaped, five-lobed. Stigma obtuse.-Name from Pulmo, the lungs, from its supposed virtue in affections of the luugs. 
1. P. officinalis, Linn. (Fig. 289), common Lungwort. Lower leaves ovato cordate on footstalks, the upper ovate sessile.

English Botany, t. 118, (excluding the root leaves which belong to the next species.)-English Flora, vol. i. p. 202.-Hooker, British Flora, vol. i. p. 99.-Lindley, Synopsis, p. 164.

Root fibrous. Stem eight to twelve inches high, angular, hairy, mixed witl rigid bristles, having a tuberculated base. Root leaves, and those on the lower part of the stem ovate or ovato heart-shaped, on broad fout-stalks, the upper ones ovate, or ovate lanceolate, sessile, all hairy, and more or less hispid, the under side pale green, the upper frequently marked with pale green spots. Flowers in small terminal corymbs. Calyx campanulate, with five lanceolate segments, five angles, and mostly five alternate ribs, hairy, or hispid. Corolla funnel-shaped, the tube about the length of the calyx, somewhat hairy at the top, the limb blue or purple, of fine rounded lobes. Stamens about the middle of the tube, sessile, or on very short filaments. Style as long as the tube. Stigma obtuse, emarginate. Nuts four, free.

Habitat.-Woods and Groves, rare; Durham, Bedfordshire, Hampshire, Arniston woods near Edinburgh, and in waste places about Glasgow.

Perennial; flowering in May.

This plant, which is common in gardens, and is much more frequently found indigenous on the continent than with us, was formerly highly esteemed in the cure of affections of the chest, and was known by the name of Jerusalem couslip, Jerusalem sage, Pulmonaria maculata; but what virtues it may possess is probably owing to the small quantity of nitre which it contains, in combiuation with a slight degree of astringency and mucilaginous taste; it is now, howerer, entirely fallen into disuse. In the north of Europe it is used as a pot herb, and, according to Ray, it was brought to table in Scotland in his time. The flowers of this genus are as in the last pink, changing, as they expand, to purple and blue.

2. P. angustiffolia, Linn. (Fig. 290.) narrow-leaved Lungwart. Leaves rough lanceolate, the lower on foot-stalks, the upper sessile.

British Botany, t. 1628.-English Flora, vol. i. p. 262.-Hooker, British Flora, vol. i. p. 99.-Lindley, Synopsis, p. 164.

Root small fibrous. Stem from one and a half to two feet high, rough, with hairs, simple or branched at the base, lower leaves eliptical lanceolate, on long tapering font stalks, the upper lanceolate, sessile, sometimes decurrant, rough, with hairs and hristles, arising from a callous tuberculated base, seldom spotted as in the above species. Floums in terminal racemes, on short declining foot-stalks. Calyx lroadly bell-shaped, with five deep lanceolate segments, scarcely angulated or ribbed, hairy, becoming much larger after 



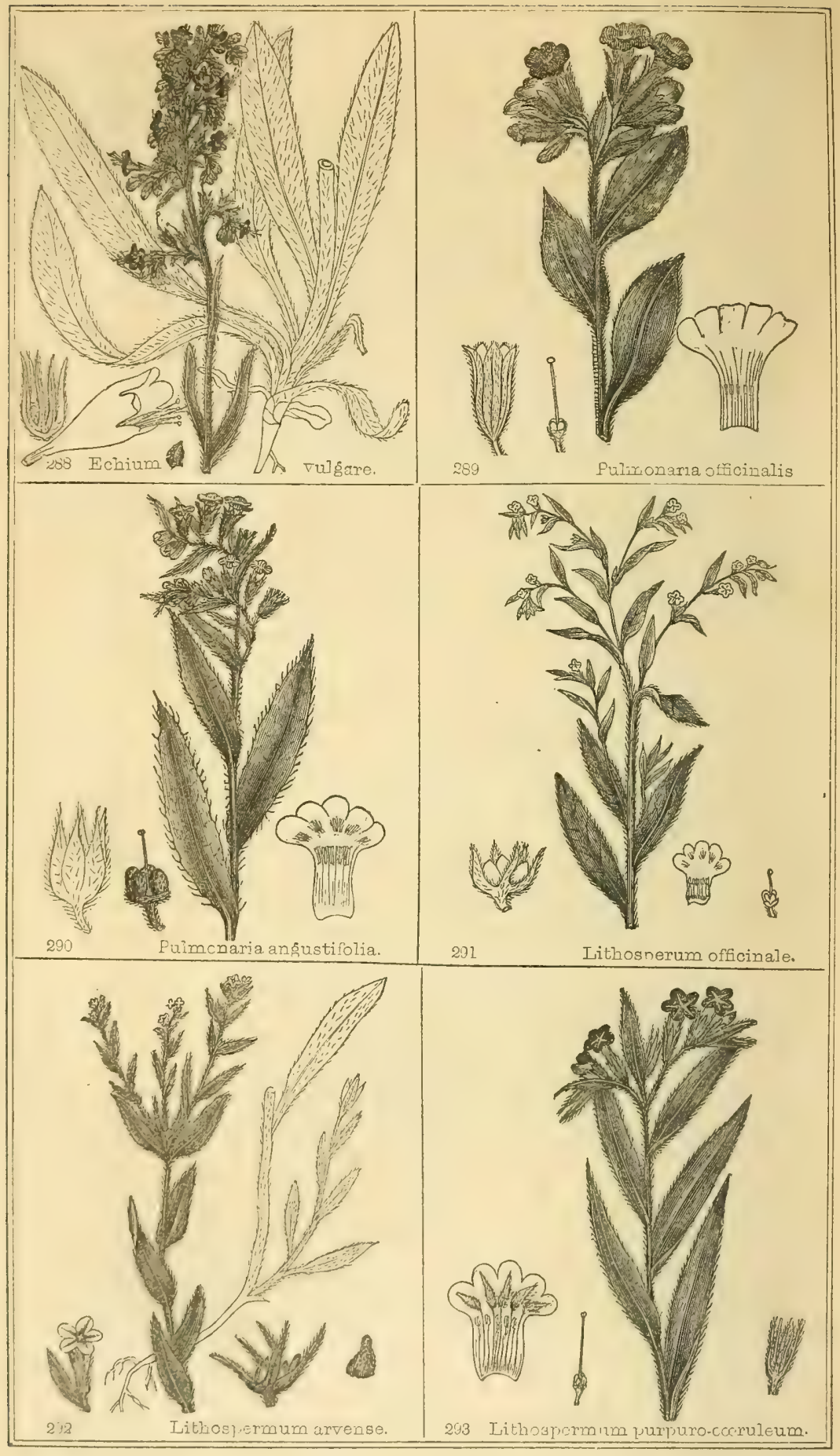


flowering. Corolla scarcely the length of the calys, ribbed, the limh of five rounded lobes, within the throat of the tube is a circle of fine hairs. Nuts four, large, spreading, tuberculated, and downy.

Habitat.-Woods and thickets, rare; Isle of Wight, Hampshire, and in Flintshire, Scotland.

Perennial; flowering in May and June.

The leaves of this species vary from linear-lanceolate ir " "atelanceolate, which characters were deemed by some of the continental Botanists, sufficient to make them into distinct species, as $\boldsymbol{P}$. oblongata Schrad, $P$. media Reicheub. This plant was supposed to contain the same medicinal properties as the above, but like it, is now out of use.

\section{GENUS III. LITHOSPER'MUM.-LinN. Gromwell.}

Nat. Ord. Boragin'ex. De Cand.

Gen. Char. Calyx in five deep segments. Corolla funuel-shaped, five-lobed. Stigma obtuse bifid. Nuts smooth and shining, or

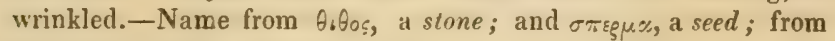
the hardness of the seeds or nuts.

1. L. officina'le, Linn. (Fig. 291.) common Gromwell, Grey Mill or Grey Millet. Stem erect, very much branched, leaves lanceolate, acute, ribbed, very rough above, hairy beneath, nuts smooth and shining.

English Botany, t. 134.-English Flora, vol. i. p. 256.-Hooker, British Flora, vol. i. p. 99.-Lindley, Synopsis, p. 164.

Root tapering. The whole plant rough, with close pressed hairs pointing upwards. Stem from one to two feet high, or more, round, striated, very much branched, especially in the upper part, leafy; the leaves lanceulate, or ovate-lanceolate, with a strong mid-rib, and several lateral ones, pale green, and hairy beneath, above rough, with short rigid bristles arising from a flat callous tuberculated base. Inflorescence a recurred leafy spike. Flowers from the axis of the leaves, on short stalks. Calyx in five deep lanceolate acute segments, mostly 'equal, very hairy. Corolla small, pale buff colour, funnel-shaped, the tube mostly rather longer than the segments of the calyx, the limb hairy externally, of tive-lobed spreading obtuse segments, each having at its base a small hairy protuberance. Stamens about the middle of the tube. Anthers oblong, on short filaments. Pistil shorter than the corolla. Stigma obtuse bifid. Fruit four, spreading obovate. Nuts brownish white, highly polished, very hard, and brittle, seldom more than one or two ripening on each calyx.

Habitat.-Dry, waste, uncultirated places; frequent in England and Ireland, but rare in Scotland. 
Perennial; flowering in May and June.

The hardness of the pericarps in this genus is very remarkable, much resembling both in brittleness and lustre globules of porcelain, and upon examination are found to contain a greater portion of earthy matter than any other organised substance. According to Captain Le II unte, as given in Hooker's British Flora, he found " the stony shells of sixty seeds weighed upwards of seven grains. Heated to redness these seven were reduced to three, of which four-tentbs of a grain were pure silica. There was also a considerable quantity of phosphate of lime and iron." It was from the circumstance of the stony hardness of the nuts that the ancients esteemed this plant as a cure for stoneand gravelly diseases; and it is still used as a diuretic and solvent by the country dames, in their infusions and diet drinks; but whatever relief may be obtained by its use is doubtless from the quantity of fluid which is taken, and not from any beneficial lithontriptic properties which it possesses.

2. L. arven'se, Linn. (Fig. 292.) Corn Gromwell, or Bastard Alkanet. Stem erect, branched, leaves lanceolate, acute, hairy, the lower petiolated and obtuse, nuts rough and wrinkled.

English Botany, t. 123.-English Flora, rol. i. p. 256.-Flooker, British Flora, vol, i. p. 99.-Lindley, Synopsis, p. 164.

Kont small, tapering, its bark a deep red. The whole plant thickly covered with close pressed hairs, arising from callous tubercles. Stem round, or striated, from one to two feet high, or higher, branched above, seldom helow. Leaves alternate, lanceolate, acute, single ribhed, very hairy, each hair swollen vr tubereulated at the base, the lower leares oblong, lanccolate, obtuse on foot-stalks, the upper lanceolate, acute, sessile. Inforsonce a terminal raceme at first compact incurved, becoming mucis elungated. Flowers from the axis of the leaves, on short stalks. Calyx of five narrow segments, becoming much larger when in fruit, and spreading. Corolla white, funnelshaped, the tube rather longer than the calys, hairy, the limb of five obtuse lobes, each having at its hase a small hairy protuberance. Stamens about the middle of the tube. S'tigma bifid. Fruit four, spreading obovate. Nuts shining, pitted, and wrinkled.

Habitat.-Corn fields and waste places; frequent.

Annual; flowering in May and June.

The tlower is very small, mostly white, or light buff. $\Lambda$ variety is said to have been found with blue flowers, as well here as the continent, where the species is equally common as with us.

3. L. purpuro-caru'leum, Linn. (Fig. 293.) Creeping or Purple Gromwell. Stems erect, scarcely branched. 'The barren ones prostrate, leaves lanceolate, acute, corolla much longer than the calyx. Nuts smootl. 
English Botany, t. 117.-English Flora, vol. i. p. 256.-Hooker, British Flora, rol. i. p. 99.-Lindley, Synopsis, p. 164.

Root woody, branched, and tufted. Stems several, round, rough, with spreading hairs, leafy, the barren stems simple, spreading on the surface of the ground, others erect, from one to one and a half feet high, divided into two or three branches at the extremity. Leaves numerous, alternate, lanceolate, acute, tapering at the hase, sessile, single ribbed, paler beneath, rough, with close pressed hairs. Inflorescence terminal, leafy, erect, spikes, Flowers on short footstalks. Calyx of five linear segments. Corolla funnel-shaped, much larger than either of the above, hairy externally, its tube pink, longer than the calyx, the limb fine purplish blue, spreading, of fire obtuse lobes, each having at its base a pink swelling, slightly downy. Stamens about the mouth of the tube. Anther's oval, on short filaments. Pistil as long as the tube. Stigma bifid. Fruit about four, orate, hard, white polished. Nuts mostly a little rugged.

Habitat.-Thickets, in a chalky soil ; rare; North Side of Denbigh, in Wales; near Taunton, Somersetshire; Mary Church, Devonshire; Darenthwood and Greenhithe, Kent; Carsewell Bay, Glamorganshire.

Perennial; flowering in June and July.

This is the most beautiful species of the genus, readily distinguished by its fluwers, which are larger than the above, at first of a beautiful rose colour, becoming a fine purplish blue, and sometimes purple. It is of frequent occurrence on the continent, more especially in Portugal, Spain, and Italy, where few flowers surpass it in the richness of their colour.

4. L. marití mum, Lehm. (Fig. 294.) Sea-side Gromuell. Glaucous, stems procumbent branched, leaves ovate, on broad footstalks, rougb, with callous points, fleshy. Nuts smouth.

English Botany, t. 36S.-Pulmonaria maritima.-English Flora, vol. i.p. 257.-Honker, British Flora, rol. j. p. 99. - Lindley, Synopsis, p. 164 .

Root tapering. Whole plant of a beautiful glaucous hue, which becomes black with drying. Stems several from the same root, much branched, and leafy, procumbent, and spreading from one to two feet long. Leares alternate, ovate, or ovate-lanceolate, with a mid-rib, and frequently several lateral ones waved, the lower on broad footstalks, the upper nearly sessile, fleshy, of a beantiful pale glaucous hue, sprinkled over with minute callous points, white, becoming more apparent after drying; when examined by a lens they appear like glistening stars, radiating from a brilliant point in the centre, destitute of hairs, as indeed is the whole plant; thus widely differing from the above species. Inflorescence in loose terminal leafy racemes, often clustered at the extremity of the main stem. Flowers on rather long naked pedicles. Calyx in fire broadly lanceolate segments, with a mid-rib. Corolla 
small, not much longer than the calyx, the tube short, limb of five rounded segments, of a beautiful purplish blue, equal, erec!. Stamens fire, on short filaments from the mouth of the tube, alternating with small pale protuberances. Stigma obtuse bifid. Fruir four, smooth. Nuts oborate, pointed and keeled, large, not spreading, as in the abore, but closely converging around the pistil attached to their base.

Habitat.-Sea coast, amongst sand and loose stones; rare; in the North of England; Wales; in the North and West of Scotland pleniful; and between Balbriggan and Skerries; at the Murrow of Wicklow ; near Dindrum, county of Down, Ireland.-Flora Hibernica.

Perennial; Alowering from May to July.

This interesting plant appear's to be known only in the northerm countries, " extending to the Arctic regions." It is of a peculiar habit, spreading itself orer the loose sand and stones within the influence of the saline atmosphere of the sea, out of which it does not appear as though it would flourish; and the pedestrian, in his rambles, placing one of the leaves in his mouth, may fancy he is in possession of an oyster, from the flarour which it imparts. The synonyms of this plant are very numerous, from the various opinions entertained by Botanists as to its genus.

\section{GENUS IV. SYMPHY'TUM.—LINN, Comfrey.}

Nat. Ord. BORAgIN'Eze. DE CAND.

Gen. Char. Calyx fire-cleft. Corolla cylindrical, swollen upwards, limb with five short round lobes, its orifice closed with subulate connivant scales.-Named from $\sigma \nu \mu \varphi v$, to unite; so called because it was supposed to close and unite the erlges of wounds.

1. S. officina'le, Linn. (Fig. 293.) common Comfrey. Stem branched winged above, leares ovate lanceolate, decurrent, the lower on footstalks, the upper sessile.

English Botany, t. 817.-English Flora, vol. i. 1. 264.-Hooker, British Flora, vol.i. p. 100.-Lindley, Synopsis, p. 164.

Root tapering, branched, fleshy, externally black. Stem from one to three feet high, succulent, branched, especially above, much winged from the base of the decurrent leaves, clothed with hairs, mostly pointing downwards. Leares numerous, the lower and radical ones orate, lanceolate, on footstalks, the upper and floral ones lanceolate, sessile, all decurrant (especially above), more or less wared on the edges, and clothed with hairs, spreading or pointing downwards. Inflorescence terminating the branches, in pairs of incurred une-sided racemes. Flower's on short footstalks, very rough, and hairy; as is the caly. of fice lanceolate erect segments. Corolla cylindrical, its tuhe longer 
than the calys, the limb swollen, somewhat bell-shaped, terminating in five obtuse short segments, the orifice closed by five subulate valves, with glaudulous margins, which unite together in the form of a cone over the mouth of the tube, and nearly as long as the limb; alternate with these ralves arise the stamens on broal short filaments, bearing Anthers twice as long, but nearly concealed by the valves. Pistil with a style protruding beyond the corolla, bearing a slightly swollen stigma. Fruit four, orate tumid. Nuts attached by an excarated base to the enlarged culyx.

Habitat.-Banks of rivers, and wet places; frequent.

Perennial; flowering in May and June.

Varieties of this species are found with white, rose, and violet or purple coloured flowers, the calyx spreading, and the style of rarious lengths. The corolla purple and calyx spreading is the S. patens, of Sibthorp. The corolla white and style exerted is the $\mathbf{S}$. bohemieum.Schm. boh. n, 212. The purple flowered plants are mostly smaller than the others, much more hairy, and of a darker green.

The roots abound with a viscid juice, and are used when Althea (Marshmallow) roots cannot be ohtained, in coughs and colds, and as a demulcent. It forms a part of almost all the collections of medicinal plants, cultivated in the gardens of rural districts; and the leares, boiled slowly with lard and a portion of bees wax, compose the famed healing ointment of the rillage doctress for wounds and ulcers; the belief is still entertained of its surpassing healing properties; it is needless to say how little of this faith it deserves.

2. S.tubero'sum, (Fig. 296.) tuberous-rooted Comfrey. Stem simple or bifid at the top, leares ovate, oblong, the luwer on footstalks, the upper sessile, slightly decurrent.

English Botany, t. 1502,-English Flora, vol. i. p. 264.-Hooker, British Flora, vol. i. p. 100.-Lindley, Synopsis, p. 164.

Root oblique, flesby, tuberous, and branched, externally white. Stem from one to two feet high, unlranched, except sometimes bifid at the top, simple, not winged, hairy, the hairs pointed downwards or spreading. Leaves very slightly decurrent, the lower on rather long footstalks, orate, or ovate-lanceolate, the upper ovate, oblong, pointed, sessile, or on short footstalks, alternate, or in pairs, hairy, scarcely waved. Inflorescence similar to the abore. The Flowers fewer, on longer pedicles. The calyx of longer lanceolate segments. Corolla yellowish white. Nuts excavated at the base.

Habitat.-Shady woods, and banks of rivers; freyuent in Scotland, particularly the lowlands; rare in England, Durham.-MIr. Robson. On the banks of the river Don, below Attercliffe, Yorkshire-R. D.

Perennial; flowering in June and July.

The habit of this plant is similar to the last, from which it will be VOL. I. 
readily distinguished, and is, perhaps, more frequent than is at prescnt known; it is also found in the mountainous districts of Germany, Italy, and France.

\section{GENUS V. BORA'GO,-Linn. Borage.}

Nat. Ord. Boragin'EzE. DE CAND.

Gen. Char. Calyx fire cleft. Corolla wheel-shaped, the limb of five mostly spreading segments, the orifice of the tube closed with five ubtuse emarginate scales.-Name from cor, the heart; and ago, to affect; formerly written Corage, because it was supposed to comfort the heart and spirits.

1. B. officin'alis, Linn. (Fig. 297.) common Borage. The lower leaves obovate, tapering at the base, segments of the corolla ovate, acute, spreading, those of the calyx lanceolate.

English Botany, t. 36.-English Flora, vol. i. p. 263.-Hooker, British Flora, vol. i. p. 100. Lindley, Synopsis, p. 164.

Root tapering. The whole plant clothed with rough hairs, those of the stem pointed downwards. Stem from one to two feet high, round, succulent, mostly much branched. Leaves alternate, irregularly toothed or crenated; the lower obosate, obtuse, tapering at the hase, on long footstalks, the upper becoming narrower, nearly lanceolate, sessile, or on short footstalks, winged at the base. Inflorescence racemose; large and numerous. Flowers on drooping periuncles, elongated by age. Calyx of fire linear lanceolate segments, very hairy, spreading with the corolla until after flowering. Corolla wheel-shaped, the limb large, of five orate acute brilliant blue spreading segments, the tube short, its orifice surrounded with fire short obtuse notched valres, sometimes awl-shaped. Stamens five, on short dilated filaments. Anthers large, awl-shaped, notched, converging together with the scales in a cone-shaped manner over the mouth of the tube. Pistil as long as the stamens. Stigma obtuse. Fruit four, orate. Nuts depressed at the base, rough or tuberculated, inclosed in the converging calyx.

Habitat.-Rubbish and waste places, not unfrequent. Supposed to be naturalised.

Biennial; flowering in June and July.

This, the type of the natural order Boragin'ere, is a highly ornamental plant, from the great abundance of beautiful flowers that it bears; it appears to have been considered of much greater value as a medicinal plant in former times than at present, and obtained a place in the ranks of pharmacopxial remedies as a refrigerant, and is, I believe, still used in some countries as a syrup in pleurisies and inflammatory fevers; hut in this country its principal use appears to 
have been an ingredient with some other herbs in wine, water, lemon, and sugar, forming the fumed old English beverage, known by the name of cool tankard, though the old adage of

\section{"I Borage always bring courage"-}

would lead to a contrary belief; and old Gerarde, quoting Dodonæus, says "Those of our times do use the floures in sallads, to exhilarate and make the minde glad. There be also many things made of them, used for the comfort of the heart, to drive away sorrow, and increase the joy of the minde."

We are not told what was the composition of the "many things" of which these flowers formed a part; but surely there was something of a very different nature to the flowers, to produce the exhilarating effects that are here spoken of: for we do not now find that it possesses any such properties. The whole plant is viscid and mucilaginous, with an unpleasant odour, something like that of a cucumber.

\section{GENUS VI. LYCOP'SIS.-LINN. Bugloss.}

\section{Nat. Ord. Boragin'efe. De Cand.}

Gen. CHar. Calyx five cleft. Corolla funnel-shaped, the limb of five lobes, the tube curved, its orifice closed with five convex connivent scales.-Name from $\lambda u x \circ$, a wolf; and 0 $\downarrow \xi$, a face or aspect; so called from its roughness, and being the colour of a wolf, or from the circumstance of the corolla having some fancied resemblance to a griuning mouth, or the head of a wolf.

1. L. arven'sis, Linn. (Fig. 298.) small Bugloss. Stem erect, branched, leaves lancelate, repando-dentate, very hispid, the lower on foolstalks, tube of the corolla curred in the middle.

English Botany, t. 938.-English Flora, vol, i. p. 268.-Hooker, British Flora, vol. i. p. 100.-Lindley, Synopsis, p. 165.

Root small, tapering. 'Tlie whole plant very rough, wilh spreading hairs and brisiles. Siem ercet, branched, somewhat angular, from one to two feet high. Leaves numerous, alternate lanceolate, the lower ones tapering at the base into a footstalk of variable length, the upper sessile, embracing the stem, the margin irregularly waved and toothed, the bristles arise from the centre of at callous tubercle. Inflorescence a leafy raceme. Flowers on short peduncles. Calyx of five narrow lanceolate segments. Corolla funnel-shaped, its limb bright blue, spreading, of five somewhat irregular rounder spreading segments, the tube longer than the calyx, white, curved in the middle, its orifice closed with five white concave obtuse hairy scales. Stamens about the middle of the tube, filaments short. The Anther ovate. Pistil about half as long as the tube. Stigma obtuse notched. Fruit four, orate. 
Nuts enveloped in the cnlarged calyx, hard wrinkled and dotted, excavated at the base, with an enlarged plicated margin.

Habitat.-Corn fields and waste places, especially in a sandy soil ; frequent.

Annual; flowering in June and July.

This plant, equally common cn the continent as with us, is nearly allied to the following genus, from which it is distinguished by the curvature of its tube. The flower's are very beautiful, the white hairy valves closing the mouth of the tube form a delicate contrast with the rich blue of the limb, and they entirely close up the organs of fructification from the entrance of insects, \&c.

\section{GENUS VII. ANCHU'SA.-LinN. Alkanet.}

Nat. Ord. Boragin'E.⿻一丿 De Cand.

Gen. Char. Calyx five-cleft. Corolla funnel-shaped, the limb of five lobes, the tube straight, its orifice closed with five convex

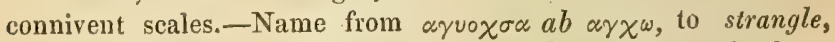
suffocate; the ancients believing that this species of plants strangled or choked serpents; or, as others suppose, from its con-

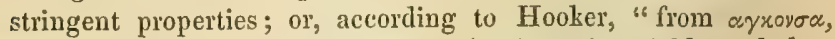
paint. The roots of one species, $A$. tinctoria, yield a red dye, which was used in former times to stain the face."

1. A. officina'lis, Linn. (Fig. 299.) common Alkanet. Leaves lanceolate, hispid, bracteas ovate lanceolate, segments of the calyx acute, racemes terminal crowded, unilateral.

English Botany, t, 662.-English Floxu, vol. i. p. 259.-Hooker, British Flora, vol. i. p. 101.-Lindley, Synopsis, p. 665.

Root long, small, tapering, blackish. The whole plant rough, with deflexed bristles from a callous base; from one to two feet high, erect, slightly angular, somewhat branched, and paniculated above. Leares lanceolate, or oblong lanceolate, the lower ones with footstalks, the upper sessile, and mostly very narrow. Inflorescence an incurved terminal raceme, generally in pairs. Flower's numerous, crowder, unilateral on short peduncles. Calyx of five acute segments, more (15 less deeply divided, the bristles npon it close pressed and pointed up. wards, the bractea ovate or ovate-lanceolate. Corolla funnel-shaped, the limb of five spreading, rounded blue or purplish segments, the tube white or yellow, its orifice closed with fire broad obtuse hairy scales. Stamens sessile at the top of the tube, altemating with the scales. Anthers lanceolate. Pistil as long as the tube. Stigma cloven. Fruit four, ovate, acute. Nuts dotted and wrinkled, the base cxcavated and surromded with a swollen plicated margin. 


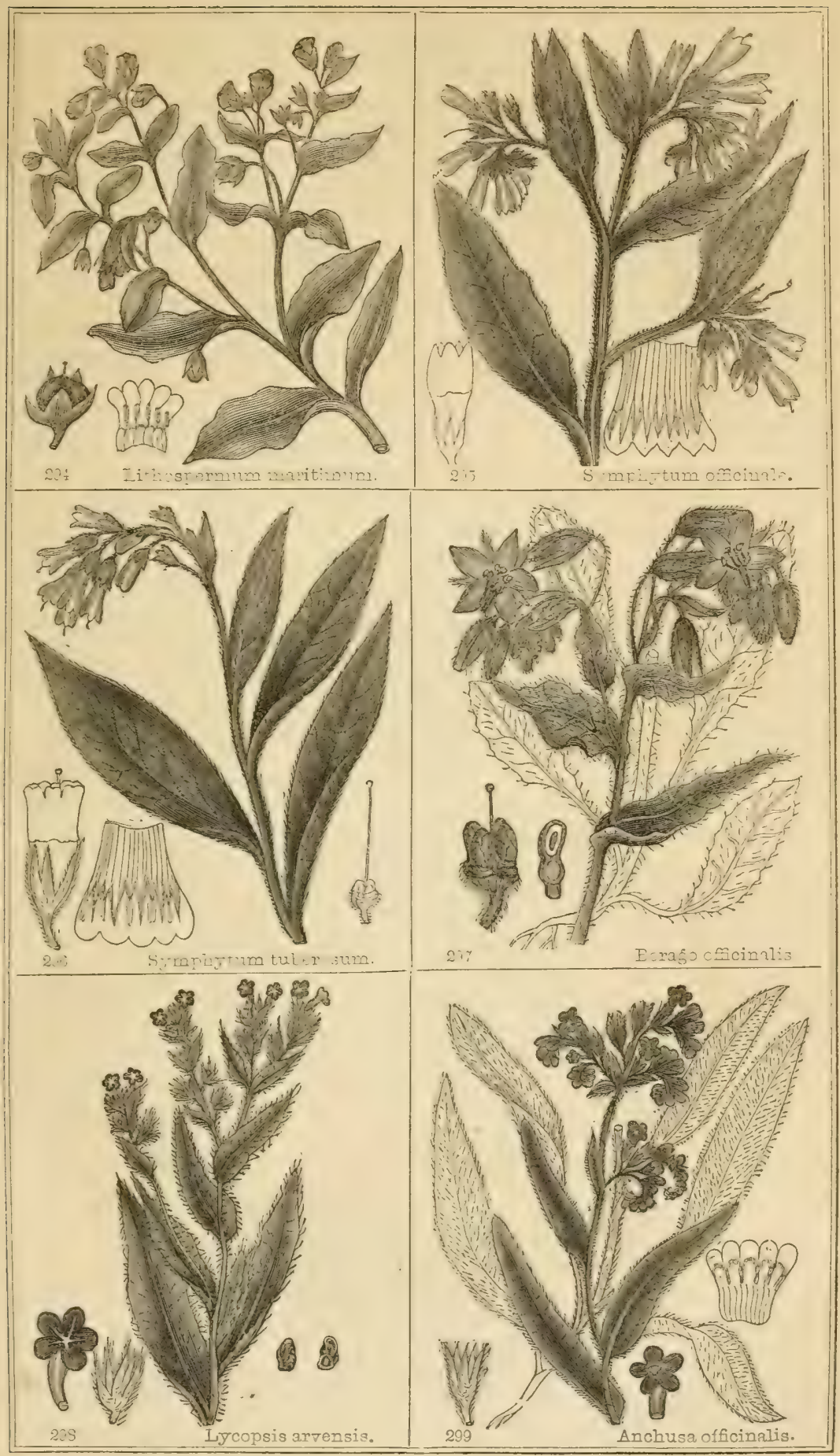



Habitat.-Uncultivated stony places, rare; on the Links near Hartley pans, Northumberland.

Bienuial or Perennial; flowering in June and $\mathbf{J} u l y$.

It is doultful if either this or the following species are natives of this country; they are frequently cultivated in gandens for the beauty of their flowers. The above has had the reputation of being useful in similar cases as the Borago, but is now justly rejected. It is of frequent occurrence on the continent, and is sometimes mistaken for the A. tinctoria, the roots of which contain much colouring extract, of a deep red colour.

2. A. semper'virens, Linn. (Fig. 300.) evergreen Alkunet. Leaves ovate hispil, the lower ones on footstalke, flowers axillary, on long peduncles, accompanied by two small leares.

English Botany, t. 45.-English Flora, vol. i. p. 259.-Hooker, British Flora, vol. i. p. 101.-Lindley, Synopsis, p. 165.

Root thick tapering, blackish. The whole plant rather hairy than bispid, deflexed on the stem, which is from one to two feet high, erect, angular branched. Leaves ovate acute, dark green, the lower on long footstalks, the upper sessile, from which arise the long naked peduncles, terminated by two ovate-lanceolate leafy bracteas, and two small crowded racemes, having a single flower in the axis of these devarications. Flowers on short stalks. Calyx very hispid, of five narrow segments. The corolla is "rather salver than funnel-shaped," its tube short and swollen, the limb of a brilliant light blue, in five deep rounded segments, each hasing at its base a white obtuse hairy scale, from which a white line runs nearly half way up each segment; interrening between the scales are the sessile, ovate. Stamens at the top of the tube, and inclused together with the pistil within the tube by the connivent scales. Fruit four. Nuts similar to the last.

Habitat.-Waste stony places, among ruins and uncultivated places; not unfrequent in England, Ireland, and Scotland.

Perennial ; flowering in May and June.

This plant is almost always in foliage, from which circumstance it has obtained the name of semperivens. The structure of its beautiful corolla much resembles that of the genus Myosotis, and it seems to be the connecting link between the two genera.

\section{GENUS VIII. MIOSO'TIS.-LINx. Scorpion:Grass.}

Nat, Ord. BORAGIN'EA. DE CAND.

Gen. Char, Calyx fire-cleft. Corolla salver-shajed, the limb of 
five flat obtuse lobes, tube short, its oritice nearly clused with

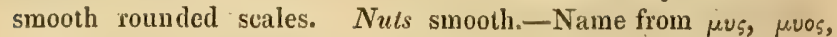
a mouse; and ous, wros, an ear ; from the supposed resemblance of the leaves to the ear of a mouse.

* Hairs of the calya straight, close pressed.

1. M. palus'tris, With. (Fig. 310.) great Water Scorpion-grass, or Forget $M e$ Not. Calyx five-cleft, when in fruit campanulate, open, shorter than the divergent pedicle, limb of the corolla flat, longer than the tube, pubescence of the stem spreading, or absent.

English Botany, t. 1973.-English Flora, vol. i. p. 250.-Hooker, British Flora, rol. i. p. 101.-Lindley, Synopsis, p. 165.-Myosotis scorpioides, $\beta$.palustris, Linn. Sp. Pl. vol. i. p. 188.

Root creeping. Stem from one to two feet higb, succulent, round, or slightly angular, erect or reclining at the base, mostly branched, clothed more or less abundantly with soft spreading hairs, or sometimes it is quite smooth, on the upper part of the stem and stalks of the racemes close pressed. Leaves oblong lanceolate, the lower tapering at the base into a broad footstalk, obtuse, sometimes ovate or ovate. lanceolate, the upper narrower, longer, tapering towards the cxiremity, or acutely lanceolate, sessile, and frequently slightly decurrent, forming a slight angle some way down the stem, all with a rather strong mid-rib, and a more or less distinct marginal one running from the base, and uniting again at the extreme point, where it is mostly terminated with a hard point bristly, and scattered over equally on both sides more or less profusely with soft white depressed hairs pointing upwards, except on the margin and footstalks they are spreading. Inflorescence terminal, racemes single, or mostly in pairs, with a single flower from the axis of divarication; this, though general, is not constant; sometimes it is accompuned by a small lanceolate leaf. At first the racemes are rolled in and crowded, but as the flowers gradually expand, they become more distant from each other. Flowers numerous, arranged in two rows, alternate on pedicles, at first very short and erect; but after flowering elongate, becoming longer than the calyx, patent and curved downwards. Calyx bell-shaped, rounded at the base, scattered over with close pressed hairs, limb dividel about one-third its depth into five broad acute segments, each baving a distinct mid-rib, and two scarcely distinguished lateral ones uniting in a callous point like the leaves, open when in fruit. Corolla, when in bul, a delicate pink, tube short, yellow, its orifice nearly closed by five obtuse yellow scales, the limb of five rounded or slightly cmarginated lobes, flat, a beatiful bluc colour, with a white line from the base of cach Jube. Stamens altemating with the scales at the orifice of the tube. Pistil about the leugth of the tube of the corolla. Sitigma capitate. Fruit four. Nuts smooth, compressed before, obtuse behind, with a slight edge, the base obtuse, with a minute perforation. 
Habitat.-The sides of ditches, rivers, and in damp places; frequent. Peremial; flowering during the summer months.

The flowers of this plant are amongst the largest of our species, of a brilliant blue, with a yellow eye, and white radiating lines around it. Nothing can be more ornamental to our rivers, banks, and ditches; its numerous clusters of flowers raising their curled heads from amidst the delicate green of their leaves, fail not to attract the attention of every rambler among the pastoral scenes where it grows, in all parts of Europe. We are toli that it obtained its name of Forget Me Not, and is selected as the emblem of affection, from the circumstance that "Two lorers were walking by a river, (the Rhine, I helieve,) when the lady seeing and wishing for a flower of the Myosotis palustris, the cavalier attempted to gather it for her, but in so doing, slipped into the river and was drowned, exclaiming as he sunk, 'Vergils mich nicht'-' Forget Me Not.'"

2. M. re'pens, Don. (Fig. 311.) creeping Water Scorpion-grass, Calyx deeply fire-cleft, when in fruit mostly connirent, shorter than the rlivergent pedicle; limb of the corolla flat, longer than the tube, pubescence of the stem spreading.

English Botany, t. 2703.-Hooker, British Flora, rol. i. p. 101. under M. palustris.-Lindley, Synopsis, p. 326.

This is usually a smaller plant than the above, seldom more than a foot high, frequently not half that height, putting out runners from its base, which take root, and the individual plant is continued. The racemes are similar to $\boldsymbol{H}$. palustris, except that the perlicles are longer, especially in their deflexed state, and from the base of the first, and often also from two or three above it, there is a small lanceolate leaf. These, however, are not constant. The calyx is more deeply divided, its segments narrower, not so open when in fruit, and the base more hairy than in $\boldsymbol{M}$. palustris. The corolla is also generally smaller, more concave than flat, its lobes paler coloured, the hairiness of the stem is variable, but generally more abundant than in $M$. palustris.

Habitat.-Wet, boggy situations; Scotland.-Mr. G. and D. Don, Dr. Murray. Kent.-Mr. D. Don. Sussex.-Mr. Borrer. Yorkshire, (higher parts).-Mr. Backhouse. Glen Cree, Ireland.-J. Bell. Banks of the River Don, above Sheffield; and the Moors, Derbyshire.R. $D$.

Annual; flowering, according to Mr. Backhouse, in Hooker's British Flora, two months earlier than $\boldsymbol{M}$. palustris.

It is not without some hesitation that we have followed Mr. Don, in considering this more than as a variety of $M$. palustris. It is, however, probably as much deserving the distinction of a species, as some others that are considered so. I have gathered it from boggy places on the Cintra mountains, not more than six inches long; and about 
Oporto and other parts of Portugal, not unfrequent. It is stated in English Botany to have been found at Madeira, and is described as a German plant.

3. M. caspito'sa, Schultz. (Fig. 312.) iufied Water Scorpion-grass. Calyx deeply five-cleft, when in fruit campanulate, open shorter than the divergent pedicles, limb of the corolla flat, equalling the tube, leaves linear, oblong, hairs of the stem close pressed.

English Flora, vol. i. p. 251.-Hooker, British Flora, vol. i. p. 102.-Lindley, Synopsis, p. 165.-Borrer in English Botany Suppt. t. 2661.

Root fibrous, not creeping, but tufts of fibres are frequently thrown out from the lower part of the stem. Stems mostly several from the same root, erect, or more or less curved at the base; from a few inches to two feet high, with axillary branches from the base upwards, which are generally much less leafy than the stem, generally scattered over with close pressed hairs, pointed upwards. Leares pale green, linear, oblong, or ligulate, the lower obtuse, tapering at the base into a broad footstalk, the npper narrower, acute, sessile, sometimes slightly decurrent, hairs short, rigid, scattered freely over the upper side, very sparingly on the under, the mid-rib prominent, the marginal ones, one or two, scarcely elevated above the surface of the leaf, united at the extremity in a blunt point. Racemes mostly in pairs, with a solitary flower, sometimes accompanied with a small leaf from the axis of devarication. Flowers numerous, at first crowded, becoming more distant as the common stalk extends, the pedicles when in flower about the length of the calyx, erect, becoming three times as long, and, as the fruit advances to maturity, deflexed, the two or three lower flowers are sometimes accompanied with a lanceolate leaf, but this is far from being constant. Calyx bell-shaped, somewhat rounded at the base, and scattered over with pale close pressed hairs, the $\operatorname{limb}$ divided about half way into acute spreading segments, each with a prominent midrib and a delicate marginal one, united at the point. Corolla generally smaller than $M$. palustris, flat, or somewhat concave, the lobes rounded, rarely emarginate. Style shorter than the tuhe of the corolla. Stigma capitate, concave. Fruit four, spreading. Nuts oval, compressed in front with a sharp edge all round the base, wilh a slight depression, and perforated in the middle.

Habitat.-Watery drains, and side of slow streams, especially in a clayey or strong soil; frequent.

Annual or Biennial; flowering from May to July.

There is a great resemblance in this to $\boldsymbol{M}$. repens. Its leaves are, however, longer, the hairs of the stem close pressed, the calyx less hairy, its segments more spreading when in fruit, and the corolla is smaller, and there are no rumners by which it is propagated from its base. 



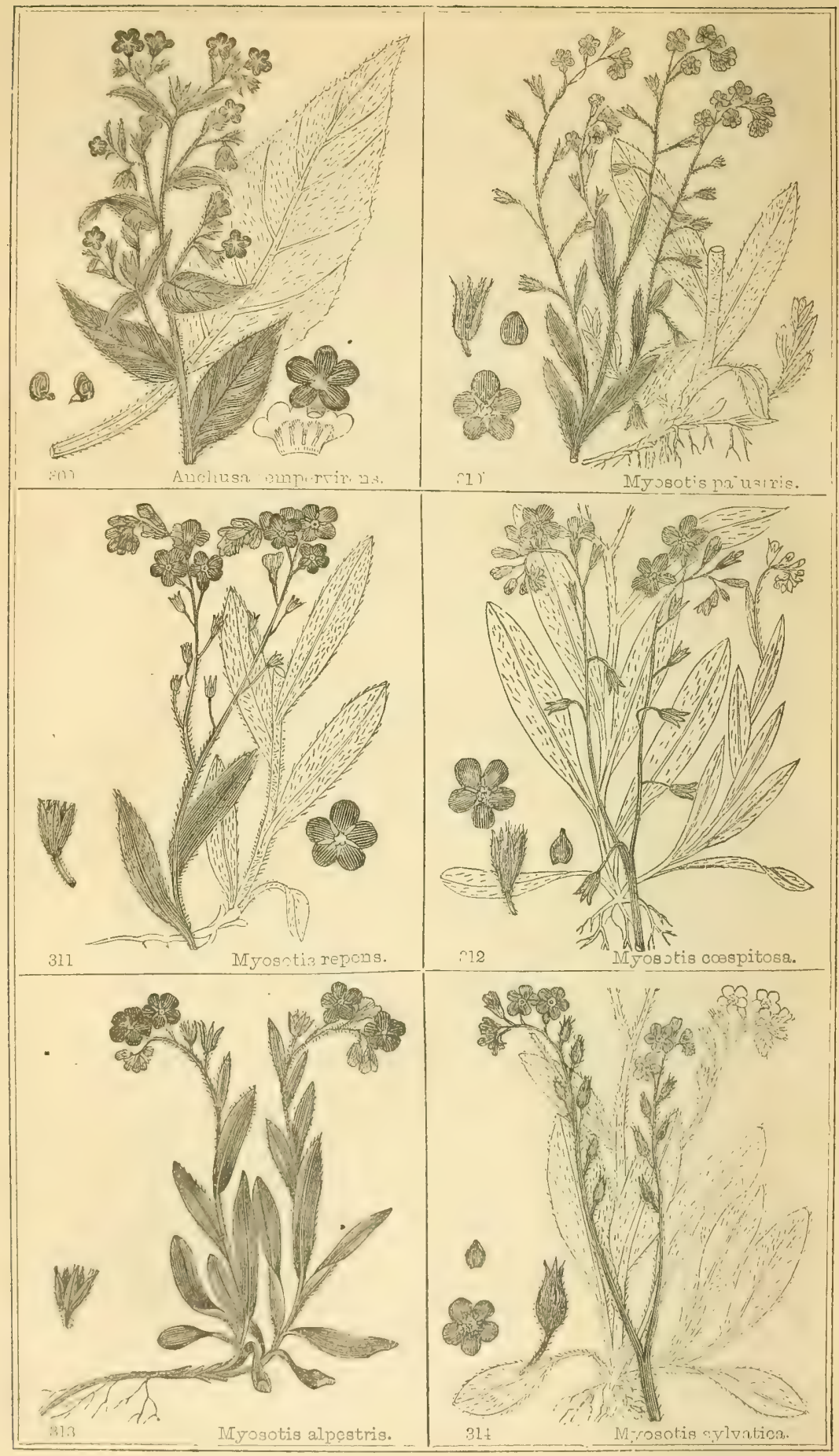


** Hairs at the base of the calyx spreading, and hooked at the extremity, those of the limb straight.

4. M. alpes'tris, Schmidt. (Fig. 313.) ruck Scorpion-grass. Calyx deeply fire-cleft, when in fruit campanulate and open, shorter than the slightly spreading pedicles, a few hairs only at the base, curved, lower leares on long narrow footstalks, limh of the corolla flat, lnnger than the tube.

English Flora, vol, i. p. 253.-Hooker, British Flora, vol. i. p. 102. -Lindley, Synopsis, p. 165.-M. rupicnlı-Ẹnglish Botany, t. 2559.

Root somewhat creeping. Stems sereral, from the same root, erect, or bent at the base, from four to six inches or more high, round, simple, or slightly striated, clothed with soft spreading hairs. Leaves numerous, hairy, the lower ovate, or orate oblong, obtuse, on long narrow footstalks, the upper, lanceclate, acute, sessile, mid-rib strong, the lateral ones scarcely observable. Racemes terminal, in pairs, with a solitary flower, and very rarely a small leaf at the axis of devarication, at first in dense clusters of numerous large splendid blue flowers, on short stalks, which, howerer, elongate with the common stalk, and become longer than the calyx, and slightly spreading; the hairs of the common stalk and pedicles of the calyx very short and close pressed. Calyx large, for the size of the plant, of five lanceolate segments, more than half cleft to the base, clothed in soft straight silky hairs, especially towards their extremity, and with a few curved ones intermixed with those at the base, the segments straight, not clusing over the fruit. Corolla large, as $\boldsymbol{M}$. palustris, of a darker more brilliant blue, the limb flat, rounded, longer than the tube; the style as long as the tube of the corolla. Stigma capitate. Fruit four; smooth nuts.

Habitat.-Highland mountains, at a great elevation; but, observes Sir W. J. Hooker, "I am not sure that it is found except on the Breadalbine range; extending as far as Schechallion."

Perennial; flowering in July and August.

The spleudid colour of the flowers of this plant, crowderl at the extremity of their short stems, is extremely striking; and it is the collecting of these mountain gems in the lofty regions of their birth, that the true pleasure of possessing so great a prize gathered by ourselves is felt; indeed, the beauty of this Myosotis is justly appreciated culy when seen blooming in its native place. It is found also on the mountain ranges of Germany, France, Switzerlaud, Italy, and others of the Continent, and is regarderl by some Botanists as a variety of M. sylvatica.

5. M. sylv'atica, Hoffin. (Fig. 314.) upriglit Wood Scorpion-grass. Calyx deeply five-cleft, with spreading hooked bristles at the base; when in fruil orate, and closed, shorter than the divergent pedicles;

VOL. I. 
limb of the corolla flat, longer than the tube, lower leaves on long footslallis.

English Flora, vol. i. p. 252.-Hooker, British Flora, vul. i. p. 102.-English Botany, Suppt. t. 2630.-Lindley, Synopsis, p. 166.

Root somewhat creeping. Stems uumerous from the same root, erect ur bent at the base, from four inches to twelve or more high, simple or branched; the lower leaves ovate or obovate, obtuse, on long narrow footstalks, the upper lanceolate, sessile; the whole plant clothed with spreading soft hairs. Racemes in pairs, longer than in $M$. alpestris; the pedicles more spreading; the calyx with more numerous hooked hairs at its base; the segments narrower, less hairy, and the hairs straighter, and not so soft, the segments converging orer the fruit, though not closely. The corolla is generally longer than in M.alpestris, but this is variable, and its colour is not so deep a blue. It seems an intermediate species between $\boldsymbol{M}$. alpestris and $\boldsymbol{M}$. arrensis, in which it partakes of some characters of each, but with so slight a difference in others, as to render it difficult to determine to which species it belongs.

Habitat.-Dry shady places, North of England; Lowlands of Scotland, frequent; Rokeby Park; Thorp Arch; and Moor Hall, near Sheffield, Yorkshire; Woods, Welbeck, and other places, Nottinghamshire; iu Essex, Kent, and Norfolk.

Perennial; flowering in June and July.

We have no douht this plant occurs more frequently than is sup. posed, being collected for $M T$. arvensis, from which there is some difficulty in distinguishing it, since both vary greatly according to the situation of their growth. $M$. sylvatica, when grown on a poor dry soil, in an open situation, is much smaller than when grown otherwise, and is scarcely distinguishable from the following species; but $\boldsymbol{M}$. sylvatica appears to be a pereunial plant, and the arrensis is an annual.

6. M. arvensis, Hoffm. (Fig. 315.) Field Scorpion-grass. Calyx with half five-cleft spreading hooked bristles, when in fruit ovate, closed, shorter than the spreading pedicles, limb of the corolla concare, equalling the tube in length.

English Botany, Suppt. t. 2629.-Hooker, British Flora, vol. i. p. 103.-Lindley, Synopsis, p. 166.-MI. scorpioides, a arvensis, Linn. Sp. P1. p. 188.

Root fibrous, annual. Stems from a few inches to two feet high, mostly numerous from the same root, erect, or curred at the base, simple, or lsanclied, roundish or angular, clothed more or less abundantly with spreading hairs. Leaves various, those from the root ovate or spatulate, on a sonnewhit clilated footstalk of variable length, upper ones sessile, lanceolate, tapering towards the base. Racemes mostly in pairs, often having one or two leaves at the base; when 
single there is generally one flower distant from the rest, and frequently from the axis of a small leaf; the hairs of the common stalk, at least in the upper part, close pressed. Flowers numerous; pedicles spreadiug when in fruit, at length curred downwarls. Calyx about half-cleft, less deeply than in $7 \Gamma$. sylratica; its segments lanceolate, narrow, folding over the fruit more closely than in $M$. sylratica, consequently more oval, and all the hairs, except a few towards the points of the segments, hookf ; these straight hairs are, however, moro numeruus on some plants than others, but are not so numerous as in MI. sylvatica. Corolla mostly small; tube the length of the calyx; the limb concave, as long as the tube. Style about the length of the tuhe.

Stigma capitate. Fruit four, ovate, acute; two-edged black nuts.

Habitat.-Fields, uncultivated grounds, \&c.; frequent.

Annual ; flowering during the Summer months.

Few plants vary more in size than this. In the sandy fields of Nottinghamshire we have gathered it not more than three inches, and in rich land, amongst corn, one and two feet high; it raries also considerably in the size of its flowers, but which are pretty constant to the characters, as described above. The more constant marks of distinction are to be sought for in the calyx. We hare some specimens also that are covered with soft spreading white hairs; while others are rough, from short hairs arising from callous tubercles.

7. M. col'lina, Hoffm. (Fig. 316.) early Field Scorpion-grass. Calys with spreading hovked bristles, deeply five-cleft, open when in fruit, and as long as the spreading pedicles; limb of the corolla concave, shorter than the tube. Raceme usually with a distant flower at the base.

Borrer in English Botany, Suppt. after t. 2558.-Hooker, British Flora, vol. i. p. 103.-Lindiey Synopsis, 1) 1 6, MI. arvensis.-English Botany, t. 2558.-t. 253.

Root annual, fibrous. Whole plant very hairy. Stem from four to eight and twelve inches high, usually sereral from the same root, erect or spreading, simple or branched, round, thick, elothed with spreading soft hairs. Leaves mostly numerous below the roots, and on short dilated footstalls, orate, obtuse, the upper sessile, oblong, obtuse, or acute. Racemes long, very lax after flowering, the coinmon stalk round, hairs close pressed, having a single flower distant from the others at its base, either alone or from the axis of the leaf. This distant flower is, however, not constantly present, especially in our continental specimens. Flowers numerous, rery small. Calyx on an extremely short pedicle when in flower, but elongating to about its own length when in fruit, and spreading at length curved downwards; the limb cleft, into five narrow segments, clothed with hooked spreading bristles, except near their extremities; they are straight, and open, 
not closed orer the fruit. Corolla very small, concave, shorter than the tube, of fire rounded lohes. Fruit four black smooth oral nuts.

Habitat.-Dry sandy places, wall tops, \&c.; not very common.

Annual; flow cring in Airil and May.

The size of the plant is rery variable according to its habitat, particularly as to the greater or less supply of moisture it can obtain. It is, howerer, regular in the characters abore given, and can only be mistaken for the following species, with which it has been identified by some Botanists, when it has grown rery luxuriant.

8. M. versicolor, Lehm. (Fig. 31\%.) yellow and blue Scorpion-grass. Calyx with spreading hooked bristles, deeply fire-cleft, closed when in fruit, and longer than the nearly erect pedicles; limb of the corolla concave, about half as long as the elongated tube.

Englisb Botany, t. 2558, (not the fig.)-English Flora, vol. i. p. 254.-Hooker, British Flora, vol, i. p. 104 -Lindley, Synopsis, p. 166. II. scorpioides. English Botany, t. 480, fig. 1.-M. scorpioides, $\gamma$. Linn. Sp. Pl. p. 189.

Root fibrous, annual. Stem very rariable, in height from two to twenty inches, erect, or curved at the base, simple or branched, round, or slightly angular, rough, with spreading hairs, as is the whole plant. Leaves rariable in number, sometimes very numerous, at others very scanty; the radical ones on broadish footstalks, orate, obtuse, the upper sessile, long, narrow, olutuse, or acute, mostly thickly clothed with spreading hairs. Racemes rery long, and lax after flowering; hairs much less numerous than on the stem, and close pressed. Flover:s numerous, on shurt nearly erect pedicles, one or two of the lower ones, sometimes arising from the axis of a small leaf. Calyx large, longer than its pedicles, deeply divided into five narrow segments, closed when in fruit, clothed, except at the extrewities where they are siraight, with short rigid booker bristles. Corolla with a tuhe, longer than the calyx, and twice as long as the limb, which is small, concave, when first expanded rellow, becoming hlue, and often purple. Fruit four orate black nuts.

Habitat.-Not uncommon in wet, as well as in dry places.

Annual; flowering from A yril to July.

The flowers commencing in their lower part amongst the leaves, we do not find umeommon in luxuriant specimens; in corn fielels and other places, in Nottinghamshire and Yorkshire.

The whole of tii- genns of plants presests demuleent propertics, and have been occasionally used as such in the form of tea, in cases of ferer; they are not now thought of any value, but superseded by others. It was thought also that the leaves bruised and made into a proutice, were ucful in rem.ring inflaumation of the eyes, as well as the decoction to hathe them; but this is also gone out of use, more potent remedies being suhstituted. 


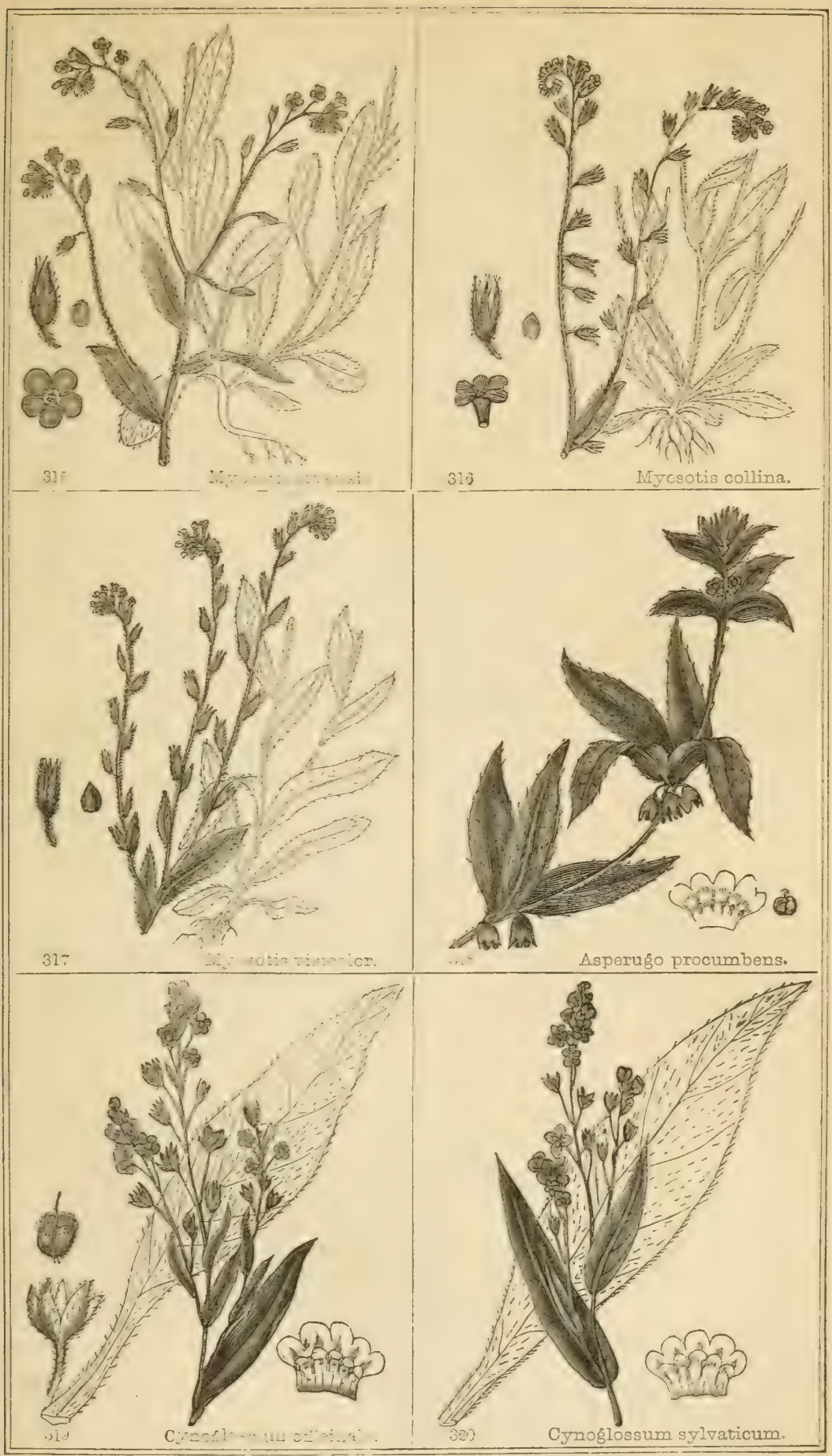





\section{GENUS IX. ASPERU'GO.-Linn. Madwort.}

Nat. Ord. Boragin'Ex. DE CAND.

Gen. Char, Calyx five-cleft, unequal with intermediate teeth. Corolla funnel-shaped, with a short tube; its orifice closed wilh convex connivant scales. Nuls four, compressed, covered by the folded compressed calyx.-Name from asper, rough.

1. A. procumb'ens, Linn.(Fig. 318.) German Madwort. Stem procumbent; flowers axillary.

English Botany, t. 661.-English Flora, vol. i. p. 266.-Hooker, British Flora, vol. i. p. 105.-Lindley, Syuopsis, p. 165.

Root small. Stem spreading upon the surface of the ground, from one to two feet long, square, and rough, with short hooked prickles pointing downwards. Leaves mostly numerous, oblong, lauceolate, the margin rough, with prickles pointed forwards, and more or less hairy with cluse pressed hairs, sessile, or on short foutstalks, single, or two, three, or four, arising from near the same point of the stem. Flowers small, single from the axis of the leaves, at first on short erect peduncles, which become longer, and curved downwards when in fruit. Calyx small, dceply divided into five teeth, with a small intermediate onc, nuch enlarged when in fruit, veiny, compressed, and folded over the fruit. Corolla with a slsort cylindrical tube, its orifice closed by five ultuse convex valves; the limb longer than the tube, divided into five rounded blue segments. Stamens on short filaments, alteruating with the valves, by which they are enclosed within the tube. Style as long as the tube. Stigma obtuse. Fruit four compressed roughish ovate nuts, attacied laterally to the base of the persistent style, and without any perforation at the base.

Habitat.-Waste places, but rare; most frequent in the North of England and Scotland. "Boxley, Sussex; Wrangford, near Brandon." Durham; about Dunbar, Guillon Links, near Edinburgh, and Purfleet, Scotland.

Annual; flowering in June and July.

\section{GENUS X. CYNOGLOS'SUM-Linn. Hound's tongue.}

Nat. Ord. Boragrn'eze. De Cand.

Gen. Cirar. Calyx five-cleft. Corolla funnel-shaped; the tube short, its orifice closed with five convex connivant scales. Nuts four, depressed, muricated, attached to the base of the persistent style.-Name from $x \nu \omega \nu$, a dog; and $\gamma \lambda \omega \sigma \sigma \alpha$, a tongue, fiom the shape and texture of the leaf. 
1. C. officina'le, Linn. (Fig. 319.) common Hound's tongue. Leaves lanceolate, downy ; the upper ones subcordated at the base, sessile; the lower on footstalks; stamens shorter than the corolla.

English Botany, t. 921.-English Flora, vol. i. p. 261-Hooker, British Flora, rol. i. p. 105.-Lindley, Synopsis, p. 166.

Root tapering. The whole plant very soft and downy, of a dull green, exhaling when rubbed a nauseous fœtid odour. The stem from one to two feet high or more, erect, round, striated, branched, and leafy; lower leaves oblong, lanceolate, tapering into a broad stout long footstalk, the upper narrower, the margin waved, dilated towards the base, where it is more or less cordate, embracing the stem; mid-rib strong, with several branched lateral ones. Inflorescence terminal, branched, spreading racemes. Flowers numerous, on short pedicles, which elongate after flowering. Calyx of five deep ovate acute segments, very downy, becoming much larger after fowering; reflexed as the fruit advances to maturity, and sometimes falls off, but mostly persistent. Corolla funnel-shaped, with a short wide cylindrical tube; its orifice closed by five obtuse convex ralves; the limb oi live rounded obtuse segments, of a dull red or purplish colour. Stamens on short filaments, alternating with the valves at the orifice of the tube. Style about the length of the tube, becoming much larger as the fruit advances, and forms an angular column, round which they are attached. Fruit four ubovate flattish nuts, attached in the centre to the enlarged base of the style, very rough, with rigid (hollow when dry) conical points, having at the extremity a great number of minute spreading cartilaginous teeth, by which the nuts attach themselres to cloches, animals, \&c.

Habitat.-Waste and rubbishy places; frequent in England and Ireland, less so in Scotland.

Perennial; flowering in June and July.

This plant is mucilaginous and narcotic, and was esteemed as an anti-spasmodic, haring an extremely unpleasant odour, like that of mice. It is not now used in England, but is still retained amongst the list of preparations used by the Italian physicians; but with what advantage over the other more elegant remedies that we possess, having similar properties, we have yet to learn.

2. C. sylvat'icum, Hanke. (Fig. 320.) green leaved Hound's tongue. Leaves lanceolate, shining, slightly hairy and roughish, especially beneath, the upper ones subcordate at the base, semi amplexicaul, sessile, the lower on footstalks; stamens shorter than the corolla.

English Botany, t. 1642.-English Flora, vol. i. p. 261--Hooker, British Flora, vol. i. p. 105.-Lindley, Synopsis, p. 166.

Root tapering. The whole plant of a pale shining green, sparingly scattered over with hairs, having, unlike the last, little odour when 
rubbed. The stem from ove to two feet high, round, branched, somewhat striated, erect. Leares mostly hairy beneath, and rough with tubercles, the luwer ones on long footstalks, broadly lanceolate, the upper oblong lanceolate, sessile, broader at the hase, and more or less embracing the stem; all hare a strong mid-rib, and several small lateral branching veins. In other respects it is the same as the above, except that the flowers are mostly a duller purplish colour.

Habitat.-Road sides, and shady situations; rare. In Essex, Worcester, Kent, Surrey, Oxford, and near Norwich. Carse of Gowrie, in Scotland.-MY. G. Don. Near Balbriggan, Ireland.Dr. Scott.

Perennial; flowering in June and July.

\section{GENUS XI. CYCLA'MEN.-Lins. Cyclamen.}

Nat. Ord. Primulac'ex. Vent.

Gen. Char. Calyx campanulate, fire-cleft. Corolla with a campanulate tube, the limb of five reflexed segments. Capsule globose, opening with five teeth. -Name from $x$ wxios, a circle, "probably from the circles formed by the spiral peduncles," or from the shape of the leares.

1. C. hederafo'lium, Willd. (Fig. 321.) Ivy leaved Cyclamen, or Sow-bread. Leares ovate, angular, and crenate, deeply cordate at the base, orifice of the tube of the corolla with ten teeth.

English Flora, vol. i. p. 274.-Hooker, British Flora, vol. i. p. 107. -Lindley, Synopsis, p. 183.-Cyclamen Europaum.-English Botany, เ. 548 .

Tubers large, globose, which put out branched fibrous roots. Leaves all radical, on long slender footstalks, ovate, or roundish oblong, angular, wared and crenated, deeply heart-shaped at the base, smooth, the upper side beautifully variegated with dark and pale glaucous green, with a central rib, and several smaller ones from the base, more prominent on the under side, and somewhat glandular, the surface of the leaf is somewhat paler than the upper, with a purplish tinge. Flouer's single, drooping on a long slender scape, thinner aud waved in the lower part, thicker in the middle, reaching above the leares after flowering, and as the seed advances to maturity, the scape becomes twisted up in a spiral manuer, and conveys them to the earth. Corolla white, or pinkish, purplish about the orifice of the tube, which is short, somewhat bell-shaped; the limb of five deep acute reflexed twisted segments, with two obscure teeth at the base of each. Calyx deeply divided in five ovate acute segments. Stamens within the tube, 
on short filaments. Style as long as the stamens. Stigma oblust Capsule globose, opening with five teeth. Seeds numerous.

Habitat.-Groves and shady places, a doubtful native; Bramfield, Suffolk.-D. E. Davy, Esq. Sandhur'st Green.-Mr. Chrisiy. And Goudhurst, Kent. $-\mathbf{M}$ r. Borrer.

Perennial; flowering in April.

The common name of Sow-bread, by which this plant is known, appears to have arisen from the circumstance of its tubers being much sought after by swine. In the Island of Sicily it forms a considerable portion of the food of the wild boars, although it possesses acrid and stimulating properties. It has been thought useful in schirrous affections, the fresh root being scraped into a pulp, and applied externally as a poultice; taken internally, its action is that of a drastic purgative, which is said to procure abortion, and is for that purpose taken, but is a very doubtful and dangerous medicine. "Ierarde believed that merely stepping orer this herb caused abortion, and very prudeutly guarded it in his garden with sticks." Its acrid principle is thought to be of a peculiar character, and is named arthanitine.

No gardener considers his flower borders well stocked with early flowering plants, unless this forms a part; it is one of the earliest to put out its tender bud, and expand its fair bloom, gracefully pendant on its slender stem, amid its shining leaves of varied hues, which at all times are highly ornamental. Sereral species of this genus are cultivated for the greenhouse, and, by careful management, a regular succession of the flowers may be had all the year round.

It is frequent in the woods and shady places in various parts of Italy; and so profuse in some districts about Pisa, as to give the surface of the ground an apparent clothing, at a short distance, of a delicate pink tissue.

\section{GENUS XII. PRIMULA.-LINN. Primrose.}

\section{Nat. Ord. Primuláces. Vent.}

Gen. Char. Calyx tubular, five toothed. Corolla salver-shaped, or furnel shaped. The tube about the length of the calyx, cylindrical, dilated at the orifice. The limb of five lobes. Capsule ovate, opening with five or ten valves.-Name from Primulus, the beginning, on account of the early appearance of the flowers in Spring.

1. P. vulya'ris, Huds. (Fig. 322.) common Primrose. Leaves oblong, ovate, narrowing at the base, wrinkled, irregularly toothed, scape single flowered; limb of the corolla flat. 



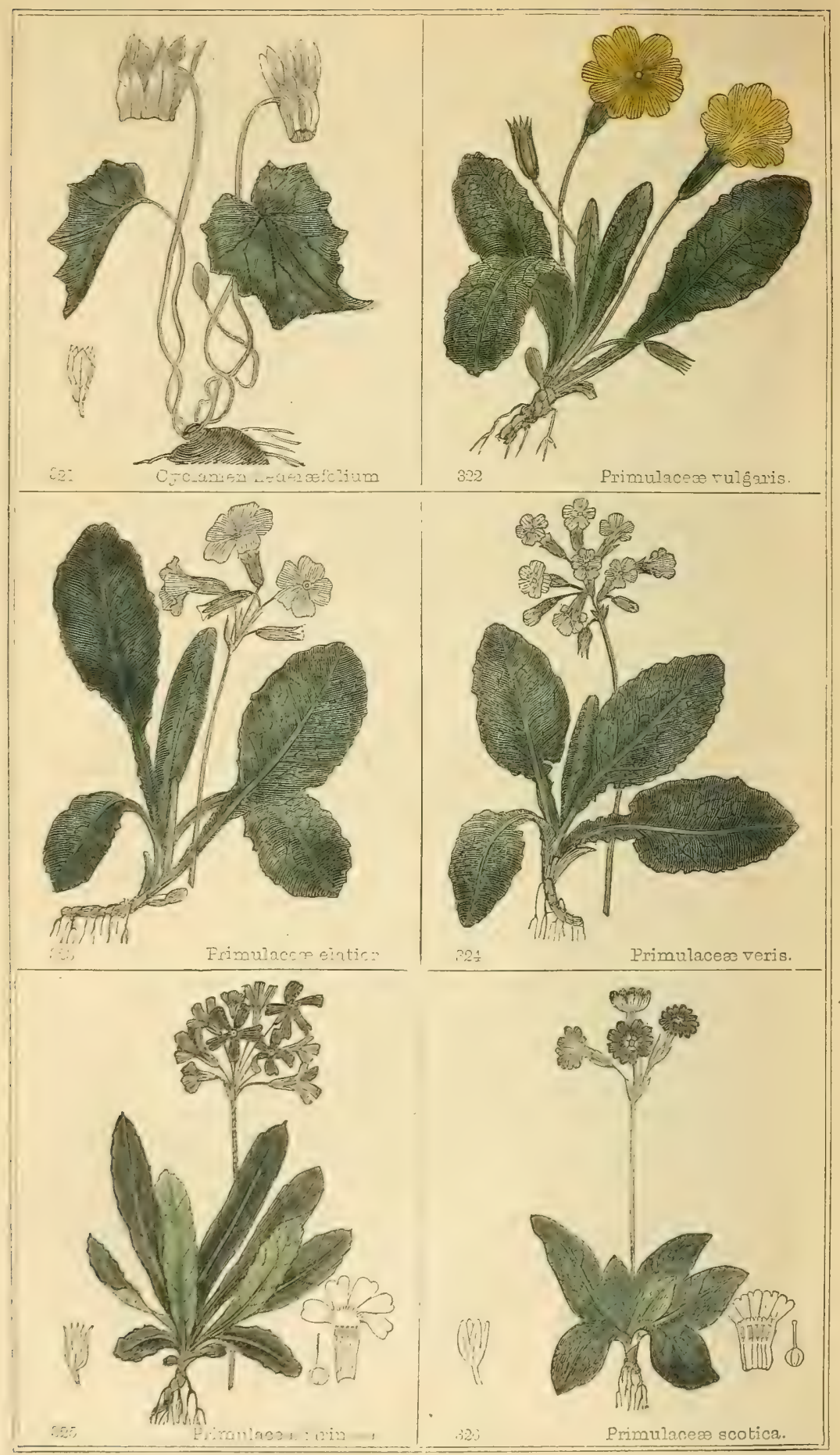


English Botany, t. 4.-English Flora, vol. i. p. 271.-Hooker, British Flora, vol. i. p. 107.-Lindley, Synopsis, p. 184.-Primula veris, $\gamma$. acaulis, Linn. Sp. 205.

Root scaly, semewhat abrupt, with numerous long branched fibres. Leares numerous, radical, oblong, ovate, gradually tapering at the base into a broadish footstalk, wrinkled, the margin somewhat waver and irregularly toothed, a dark smooth green on the upper side, pale beneath, with a strong hairy mid-rib and numerous branched lateral veins. Flowers numcrous, each on a slender scape, from two to eight inches high, and which, as well as the calyx, is generally thickly clothed with soft woolly bairs; at the base of the stalk is a small subulate scale. Calyx tubular, with five angles, and five lanceolate teeth. Corulla large, pale sulphur coloured, with five dark radiating spots in the centre; the limh of five flat obcordate lobes; the tube as long, or rather longer than the calys, dilated upwards. Stamens on short filaments, near the bottom of the tube. Style as long as the tube. Sirgma globular. Capsule ovate, opening with five or ten valves. Seeds smail, numerous.

Habitat.-Woods, hedge banks, and shady pastures abundint.

Perennial; flowering in April and May.

This is thought by some Botanists not distinct from the following species. It is true that the flowers are sometimes found elevated on at common stalk, in a simple umbel, but, as Sir W. J. Hooker obserres, if the scapes are traced to their very base, they will be found to spring from one common point, and to constitute a sessile umbel. Varieties are sometimes found with pale purplish flowers, but by cultivation many very beautiful varieties are obtained, well known as ornaments to the flower border; amongst these, perhaps the most curious and elegant, is a double pale sulphur coloured one, which appears as if one corolla had been placed within the other. Upon examination, it will be found to be the stamens at the bottom of the tube of the outer corolla, expanded into a perfect corolla. The expansion of stamens into petals is a curious, though frequent occurrence, in cultivation, by which many rery beautiful and admirable flowers are obtained, especially in the compound flowers; but in the present instance we have the developement and the union of the five stamens into a blossom of one piece, with five lobes! The student will find these transformations an extremely interesting subject of investigation, to which we can here only ciirect his attention, as we shall have occasion to do in reference to other subjects for his inquiry, that cannot be here discussed. The primrose is one of the early harbingers of Spring, which has claimed the attention of poets of almost every age in their praise of Spring's return, or strains of tender lore. When

"Beaux and Beauties crowd the gaudy groves,

Avd And woo and win their regetable loves."

"The love sick violet, and the primrose pale, vOL, I, 2k Bow their sweet heads and whisper to the gale." 
2. P. elu'liur, With. (Fig. 323.) Oxlip Primrose. Leaves ovate, contracteil belus the midrle, wrinkled, and irregularly toothed; stalk many flowered; limb of the corolla flat.

English Botany, t. 513.-English Flora, vol. i. p. 271.-Hooker, British Flora, rol. i. p. 107.-Lindley, Synopsis, p. 184.-Primula veris, ß. elatior, Linn. Sp. 204.

Prot scaly, with numerous branched fibres. Leaves ovate, wrinkled, wared, and irregularly toothed, cuntracted about the middle, by which they differ from the leares of $P$. vulgaris. This character is not, howerer, a constant one. Flowers mostly numerous, elevated nn a round down stalk, in an umbellate manner, from two to eight inches high. Perlicles of variable lengths, but ultimately all becoming the same, each baving at its Tase a small thin subulate scale. Calyx less downy than $P$. vulgaris, and the corolla smaller, the dark ray around the orifice of the tabe mostly darker.

Habitat.-Woods and groves; not uncommon.

Perennial; flowering in April and May.

Much duabt is entertained of this being a distinct species from the aloove, some persons supposing it to be an hybrid between it and the following. It certainly is very rariable in its appearance, and those characters by which it is distinguished are by no means constant; for iustance, the leaves are freruently found without the contraction in the middle, while the flowers on the same rot have been found single on a scape, and others numerous in an umbel. It varies greatly in the colour of its flowers, and by cultiwation many rery beatiful shades are obtained, known by the name of Polyanthus.

3. P. ve'ris, Linn. (Fig. 324.) common Cowstip or Paigle. Leaves urate, contracted about the middle, wrinkled, and incegularly trothed; stalk many flowered; limb of the corolla concave.

English Botany, t. 5.-English Flora, vol. i. p. 272.-Hooker, British Flora, rol. i. p. 107.-Lindley, Synopsis, p. 184.-Primula veris, a. officinalis, L. Sp. 204.

Root similar to the above. Leaves ovate, contracted about the middle, frequently heart-shaped at the base, wrinkled and reiny, the margin waved, and more or less toothed, the eages curled back, particularly in a young state, dark green above, paler heneath, and more or less downy, especially towards the margin. Flowers numerous, in a cimple umbel, ris a round stalk, from three to eight inches long, clothed with soft clese prediclos of wrialle lengths, drooping, each laving at its base an orate subulate scale. Calyx downy, its teeth acute, or obtuse, sometimes emarginate. Cimbllu smaller than cither of the alouve. The tube as long, or longer than the calyx. The limb concave, of five notched lobes, each having at its base a dark orange spot. Stamens nearly sessile above the milldle of the tube. Pistil longer than the tube, Stigma capitate. 
Mabilut.-Meadows and pastures ; freqnent in England and Ireland ; very rare in Scotland; King's Park and C'aroline Park, near Edinhurgh.

Perennial; flowering in April and May.

Whateser doubt may be entertained with regard to the distinction of the two former species, this will be foun? more constant in its characters. The smaller darker coloured concave corolla, the stamens inserted in the middle of the tube, the elongation of the style, and the more obtuse segments of the somewhat inflated calyx, are characters which we have observed to remain unaltered (especially the corolla) by cultivation. The modest cowslip is one of the welcome forerunners of Spring, which is liailed with delight by the lover of rural enjoyments, who perambulates the green meadows and pastures, where

\section{"The sight is pleas' $\mathrm{d}$,}

The scent reyards each odoriferous leaf,

Each opening blossom freely breathes abroad,

Its gratitude, and thanks him with its sweets."

'The flowers of the cowslip are much used to make an elegaint kint of wine, which is mild, and pleasantly impregnated with their fragrance, an infusion is made either of the fresh or dried flowers, and is esteemed as an anodine and sudorific. A beautiful coloured syrup is also made of them, and sold in the shops; it is agreeahly flavouted, and is used mostly for children. The fragrance of the flowers was supposed by Shakspeare to reside in the dark spots aroum the mouth of the tube. He says-

"The cowslip tall her pensioners be;

In these gold coats spots you see;

Those be rubies, fairy flowers,

In those freckles live their savours,

I must go seek some dew drops here,

And hang a pearl in every cowslip's ear."

Midsummer Nights' Drcam.

1. P. farino'sa, Linn. (Fig. 325.) Bird'sueye Primrose, Leaves () hwate, lanceolate, obtuse, crenulated, smooth, mealy. Calyx oblong ovate; limb of the corolla flat; mouth of the tube nearly closed with a notehed horder; segments ubcordate, attezuated at the hase, distant, nearly as long as the tube.

English Botany, t. 6.-English Flora, vol. i. p. 273.-Hooker, British Flora, vol. i. p. 108.-Lindley, Synopsis, p. 184.

Root with long branched fibres. Leaves numerous, radical, obovate, lancrolate, obtuse, the outer ones frequently roundish, quite smootl, a palish green above, veiny, and covered with a white powder beneath, the margins crenulated in a more or less regular manner, rolled back in a young state. Flowers numerous, in a simple umbel at the top of a round smooth more or less powdery stem, erect, from six to twelro inches high, each pedicle having at its base a subulated scalc, dilated 
and thickened in its lower part. Calyx oblong, ovate, mealy, with five prominent angular ribs, and about half-cleft into five lanceolate segments. Corolla a beautiful reddish purple, with a yellow eye, paler beneath; limb of five flat spreadirg obcordate segments, narrowing at the base, and distant from each other; tube about the length of the limb, its orifice nearly closed with a yellow thickened notched border. Stamens nearly sessile at the mouth of the tube. Pistil about half the length of the tube. Stigma capitate. Germen broadly obovate. Seeds small, numerous.

Habitat.-Wet mountain pastures; in the North of England, especially in Yorkshire; very prevalent in Teesdale. "Very rare in Scotland: only seen, I believe, South of Edimburgh. The stations given in $F l$. Scotica all belong to the following species."-Hooker.

Perennial ; flowering in June and July.

5. P. scot'ica, Hooker. (Fig. 326.) Scottish Primrose. Leaves obovate, lanceolate, mealy, scarcely crenulated; calyx swollen, ovate; limb of the corolla flat; mouth of the tube with a glandular border; segments broadly obcordate, close, half the length of the tube.

Hooker in Fl. Lond. N. S. t. 133.-English Flora, vol. i p. 273.English Botany, Suppl. 2608.-Hooker, British Flora, vol. i. p. 108.Lindley, Synopsis, p. 184.

Root with spreading branched fibres. Leaves numerous, ovate, lanceolate, smooth, shorter and smaller than the above, as is the whole plant, the mealiness greater, the margins scarcely crenulated. The flowers less numerous. The stem from three to four inches high. The calyx ovate, swollen, with less prominent angles, more mealy, not so deeply cleft, the segments obtuse, and the scales at the base of the pedicles oblong ovate. Corolla of a deep purple colour, with a yellow eye; the limb with flat obcordate spreading segments, broader, more nearly approximating each other than in $P$. farinosa. The stamens are placed lower in the tube, and its mouth is distinctly surrounded with glandular scales, and is longer than the calyx. Pistil as long as the stamens. The stigma with five points. The Germen globose.

Habitat.-Sandy shores; very rare; found on the North Coast of Caithness by $M r . W$. Gibb, North Coast of Sutherland, and in the Orkney Islands.

Perennial; flowering in May.

This most beautiful and distinct Northern species, appears peculiar to the countries above mentioned, while $P$. farinosa is found abundantly in the elevated pastures on the continent. They are both beatiful plants for the garden; their small umbels of simple flowers arising from amid their white powdery leaves are very delicate, and seem intermediate species hetween the Cowslip and $A$ uricula. They are readily cultivatcil either in the open borders, or in pots, in a damp open situation. 


\section{GENUS XIII. HOTT'ONIA.-Lins. Featherfoil.}

Nat. Ord. Primclac'ex. Vent.

Gen. Char. Calyx five parted. Corolla salver-shaped, with a shurt tube; the limb of five flat lobes. Stamens vearly sessile at the mouth of the tube. Capsule globose, tipped with the long persistent style.-Named after Pierre Hotton, a Professor at Leyden during the latter half of the seventeenth century.

1. H. prilus'tris, Linn. (Fig. 327.) common Water Violet, or Featherfoil. Flowers in whorls, on a long naked stalk; corolla much longer than the calyx; leaves pectinated.

Euglish Botany, t. 364.-English Flora, vol. i. p. 277.-Hooker, British Flora, vol. i. p. 108:-Lindley, Synopsis, p. 185.

Root long slender whorled fibres. Leares in whorls, dark green, crowded, two to four inches long, beneath the surface of the water, having a mid-rib, with very numerous narrow simple or branched segments, dirided in a pectinate or pectinato-pinnatifid manner; from the axis of the leaves are frequently sent out long spreading branches, crowded with whorls of leaves, all submerged. Stem rising out of the water erect, from one to two feet long, smooth, round, simple. Flowers in fire or six terminal whorls, each whorl of from four to eight flowers, ou short pedicles, arising from the base of a narrow scale nearly its own length. Calyx divided to the base in five linear segments, scattered over more or less profusely with short glandular hairs, as also are the pedicles and the stem between the whorls. Corolla of a delicate pale purple or rose colour. The limb of five flat spreading orate or notched segments. The tube about as long as the calys, cylindrical. Stamens five; the filaments as long as the anther, inserted about the middle of the tube. Anthers ovate oblong around the orifice of the tube. Style as long, or longer than the tube, sometimes not so long, thickened at the base. Stigma globose. Capsule globose, surrouncled by the persistent calyx, and crowned with the enlarged style, upening with five valves. Seeds numerous.

Habitat.-Ditches, pools, and streams of water; not uncommon in England; Downpatrick, Ireland; not found in Scotland.

Perennial; flowering in June and July.

This beautiful species of aquatic plant is highly ornamental to the drains and ditches or slow streams of water, in rarious parts of Eugland; about Lincoln it grows profusely in the clay, and often not less beautifully in the gravelly districts of many other counties. It is cultivated with success amongst other ayquatic plants in streams of water and ponds in pleasure grounds, forming an admirable covering for fish, and at the same time its spreading much divided loaves, sending from their hosom thcir elegant stem of Howers make 
it peculiarly fitted for this purpose. Flowers are sometimes found with six, seveu, and eight segments, in their corolla, and with the same number of stamens. The style also is of variable lengths, sometimes rery short, at others as long as the tube of the corolla, and sometimes it projects beyond it. The flower is nearly allied in its structure to Primula, with the exception of its deeply divided calyx. It is found in similar situations to the above mentioned in almost all parts of the Continent, flowering in Italy in April aud May, and in Germany in May and $J$ une.

\section{GENUS XIV. ANAGAL'LIS.-IINN. Pimpernel.}

Nat. Ord. Prisuláceze. VEnT.

Gen. Char. Calyx five parted. Corolla wheel-shaped, five lobed. Stamens hairy, inserted in the base of the corolla. Capsule glo-

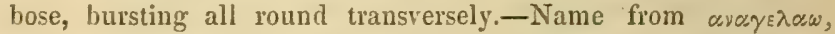
to laugh, because it was thought that it remored obstructions of the spleen, and thus disposed persons to be cheerful.

1. A. arvensis, Linn. (Fig. 328.) Scarlet Pimpernel, or Poor Man's Weather-glass. Stem widely spreading; Jeaves opposite, ovate, sessile, dotted beneath. Corolla crenate on the margin, and fringed with small glandular hairs.

English Botany, t. 529.-English Flora, vol. i. p. 281.-Hooker, British Flora, vol. i. p. 105.-Lindley Synopsis, p. 185.

B. ccerulea. (Fig. 329.) Corolla blue toothed on the margin, scarcely with any glandular hairs.-A. ccerulea. Schreb.-English Bot. t. 1823. - English Flora, vol. i. p. 281.-Lindley, Synopsis, p. 185.

Root of small branched fibres. Stem square, smooth, much branched, and widely spreading in the lower part, frequently dotted like the under side of the leaves, with purple dots. Leares opposite, scssilc sometimes, though rarely three or four together, ovate, acute, with three principal ribs from the base, smooth, bright green, sometimes slightly downy. Flowers axillary, solitary, on a square slender pedicle, longer than the leaves, erect when in flower, elongated and recurved when in fruit. Calyx of fire lanceolate segments, with a green keel and pale membranous margin. Corolla wheel-shaped, with a very sbort tube. The limb of five deep flat segments, of a bright surlet colour, crenated on the margin, and with short glandular hairs, most numerous when in bud, or when first expanded ; these hairs are far less numerous on the more deeply notched margins of the $\beta$. cerrelea, which appears to be the only character of distinction between the two, cxcept the dark splendid blue of the latter, which, instead of being purple 
round the orifice of the tube, as is the scarlet flower, it is scarlet. Stamens inserted around the orifice of the tube. Filaments dilated at the base, shorter than the limb of the corolla, and more or less thickly closed with glandular hairs. Anthers heart-shaped. Style longer than the stamens. Stiyma obtuse, notched. Capsule globose, smooth, with five ribs, crowned with the persistent style, and bursting open all round into two hemisplieres. Seeds numerous, angular, arranged in a globose manner around the central receptacle.

Habitat.-Corn fields, road sides, and waste places; frequent.

Annual; flowering from June to August.

Much doubt has been entertained as to whether the blue flowered plant is a distinct species or not; it is still retained as such by some Botanists: but the Rer. Professor Henslow has proved, by cultiration from seed, that they are varicties of the same species; and certainly in the greater number of specimens which we have collected, both in various parts of England and the Continent, we are unable to perceive any difference in their character, except the fugacious one of the colour of the corolla, not eren those above mentioned of the more deeply notcbed corolla, and fewer glandular hairs are by any means constant.

This pretty ormament to our cultivated fields and road sides is one of those remarkable plants which close their petals orer the stamens and pistil, to protect them from injury, on the approach of rain. Hence it is that it has obtained the common name of poor man's weather-glass. It has beeu landed as a remedy in cases of epilepsia, and even hydrophohia was said to he conquered by its use, for which it was used both in powder extract and infusion, but has now entirely lost its reputation.

2. A. tenel'la, Limn. (Fig. 330.) Bog Pimpernel. Stem creeping prostrate, filiform, leaves opposite, ovate, or roundish, on footstalks.

English Botany, t. 530.-English Flora, vol. i. p. 282.-Hooker, British Flora, vol. i. p. 106.-Lindley, Synopsis, p. 183.

Root fibrous, frequently put out from the axis of the leaves of the franched prostrate stemis, which lay close to the earth, and are thus continued for some distance around the central root; the stem is slender, thread-like, smooth, angular, from two to three inches long. Leaves numerous, opposite on short footstalks, roundish, or ovate, smooth, shining, pale green, reiny, and mostly finely dotied beneath. Flowers axillary, on long slender pedicles, large for the size of the plant. Caly.x of five lanceolate segments. Corolla three times as long as the calyx. The tube rery short. The limb deeply divided in five orate segments, of a beautiful pale rose colour, deeply pencilled with veins. Stamens nearly as long as the corolla. Filaments dilated at the hase, fringed with long-headed hairs, each of which is terminated with a small gland. Anthers small. Pistil longer than the stamens. 
Stigma obtuse. Capsules similar to the last, but smaller; its pedicle recurved or twisted.

Habitat.- Damp, mossy, or boggy situatious; not unfrequent in England and Ireland; less common in Scotland.

Perennial ; flowering in July and August.

This elegant little plant, growing in thick tufts, is cultivated with great ease either in situations in pleasure grounds similar to its native habitat, or in pots in a cool place in the greenhouse, where, with a sufficient supply of moisture, it flowers abundantly, and is extremely pretty, hanging over its slender branches of pale green leaves and delicate flowers. The hairs of the stamens are very beautiful and curious in their structure; when viewed with a strong magnifying power, each appears a string of minute delicate transparent beads; and the manner in which the capsules burst open for the escape of the seeds is also remarkable.

\section{GENUS XV. LYSIMA'CHIA.-LINN. Loosestrife.}

Nat. Ord. Primula'ce压. Vent.

Gen. Char. Calyx five parted. Corolla wheel-shaped, five lobed. Stamens scarcely hairy, inserted into the base of the corolla. Capsule globose, opening with fire valves.-Named in honour of King Lysimaichus, who, it is said, first discovered it.

* 2. L. vulga'ris, Linn. (Fig. 332.) Great Yellow Loosestrife. Stem erect, leaves ovate lanceolate, two, three, or four in a whorl, panicle, terminal, many flowered.

English Botany, t. 761.-English Flora, vol, i. p. 278.-Hooker, British Flora, vol. i. p. 106.-Lindley, Synopsis, p. 184.

Roots with spreading underground stems. Stems erect, from two to three feet high, leafy, angular, simple or branched, more or less downy. Leaves ovate lanceolate, on short footstalks, with a strong mid-rib, and numerous lateral branched veins, mostly downy, paler on the underside, the upper frequently scattered over with small glands. Inflorescence a terminal whorled panicle of numerous yellow flowers, its branches downy, each pair subtended by two small floral leaves. Flowers on short pedicles, with an awl-shaped bractea. Calyx downy, in five deep lanceolate segments, the erlges pink, glandular, and finely fringed. Corolla large, of five ovate, acute, spreading lobes. The tube very short. Stamens shorter than the corolla. Filaments somewhat downy, dilated and united at the base, inserted around the orifice of the tube of the corolla. Pistil longer than the stamens. Stigma obtuse. Capsule globose, opening with five valves. Seeds ovate. 


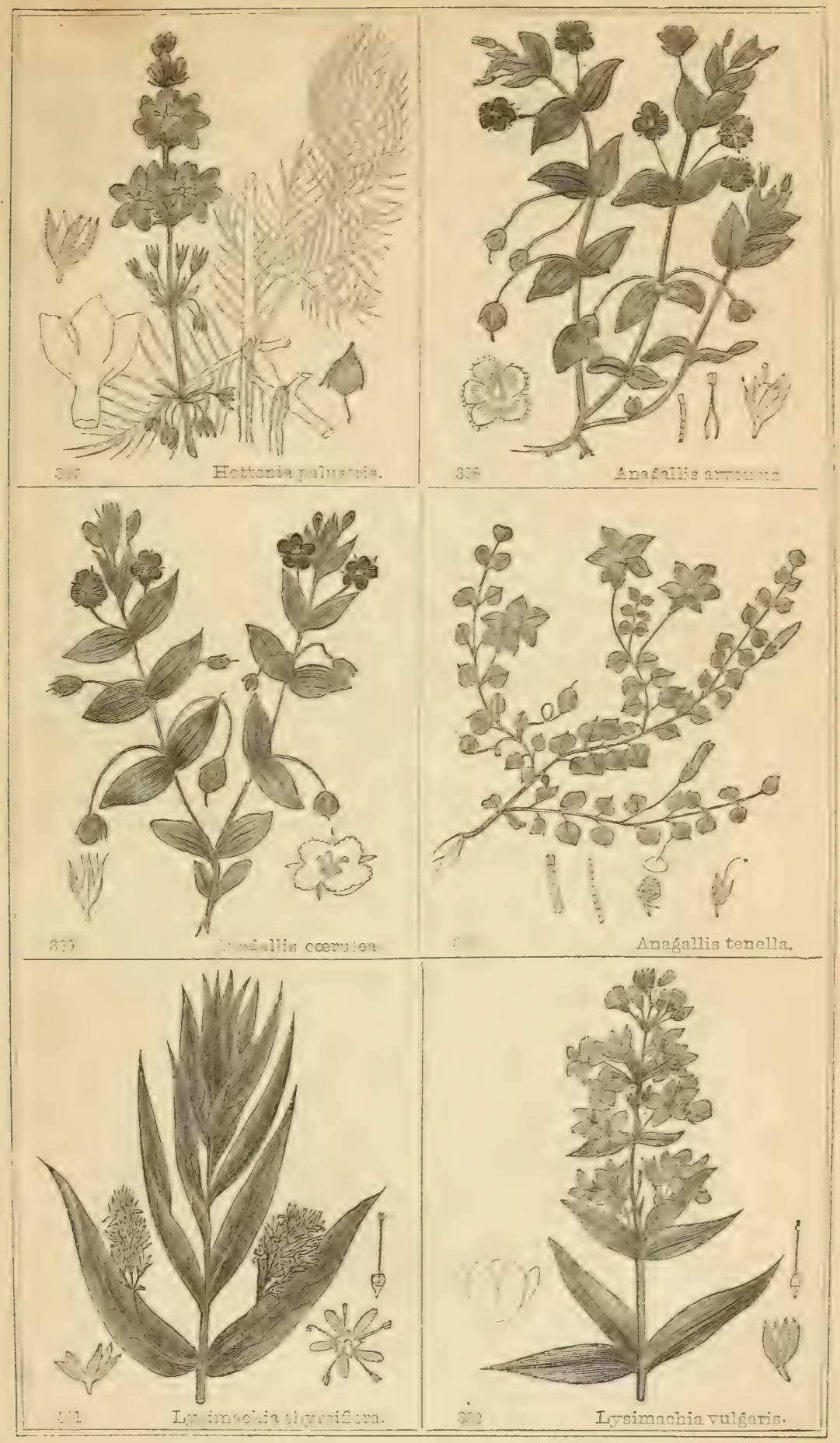



Habitat.-Damp situations; on the banks of drains and rivers; not unfrequent in England and Ireland, but less so in Scotland.

Perennial; flowering in Jume and July.

This ornamental plant is frequently cultivated in gardens, where it seems to flourish equally well in a dry as a damp situation, beneath the shade of trees, or on the open border; and its large handsome panicle of gay flowers keeps a long time in bloom, which is an additional recommendation.

1. L. thyrsifo'ra, Linn. (Fig. 331), tufled Loosestrife. Stem erect, leares opposite, lanceolate, racemes axillary, of numerous crowded fluwers.

English Botany, t. 176.-English Flora, vol. i. p. 279.-Hooker, British Flora, vol. i. p. 106.-Lindley, Synopsis, p. 184.

Root in whorled fibres, with numerous creeping underground stems. Stem erect, from one to two feet high, round, smooth, succulent, and leafy ; simple. Leares sessile, opposite, sometimes three or four in a whorl, lanceolate, narrower upwards, quite smooth, paler on the under' side, with a strong mid-rib. Inflorescence axillary, racemes on long erect stalks. Flowers numerous, densely crowded, small, yellow, spotted with orange. Pedicle short, downy from the axis, with a thin awl-shaped downy bractea. Calyx with narrow lanceolate segments, a strong mid-rib, and mostly scattered over with small orange coloured glands. Cornlla in five narrow spreading segments, with small intermediate teeth, and, like the calyx, scattered orer with small orange coloured glands. Stamens longer than the corolla, inserted into the orifice of its very short tube. Filaments dilated at the base, and united together. Pistil longer than the stamens. Stigma obtuse, notched. Capsule globose. Seeds small, smooth, with a very narrow margin.

Habitat.-Marshes, and sides of water; rery rare in England; East Riding of Yorkshire; King's Langley, Hertfordshire; in Anglesea. More frequent in Scotland; near Forfurshire, and at Duddingstone Loch on the East; Canal side, near Possil; and near Rossahue, by Ioch Lomond. Not found in Ireland.

Perennial; flowering in $\mathrm{J}$ une and $\mathbf{J}$ uly.

It is doubtful if this plant is now found in a vild state in England; but in Scotland we have collected it abundantly, where it not only grows on the bank sides, but in the water. The number of the parts of the flower are variable; the segments of the calyx and corollat are frequently ten, as well as the stamens, and the leaves sometimes four in a whorl. The small glands on the flowers are frequently numerous, but sometimes absent on the leaves; they are mostly very numerous, and are best seen when in a dry state.

3. L. puncta'ta, Linn. (Fig. 333). four-leaved Loosestrife. Stem erect, downy; leaves on short stalks, whorled, orate-lanceolate; peduncles axillary, single flowered. 
Hooker, British Flora, vol. i. p. 106.-Lindley, Synopsis, Suppt. p. 327.

The whole plant clothed wil' soft spreading glandular down. Root with creeping underground stems. Stem erect, simple or brancher?, from one to two or three feet high, round and leafy. Leaves in whorls, of from three to five, on short stalks, orate-lanceolate, with a stroug mid-rib, and numerous lateral branched reins, paler and more downy beneath, especially near the margin, more or less profusely scattered over with small glandular dots. Flowers large, yellow, in axillary whorls, each on an erect slender hairy pedicle, shorter than the leares from the axis of which they arise. Calyx of fire narrow lanceolate segments, clothed with short glandular hairs. Corolla of five oratelanceolate segments, united at the base into a very short tube. The margins ciliated with short glandular hairs, and mostly scattered over with minute glandular spots, Stamens about half as long as the corolla. 'The filaments dilated at the base, and united about half their length into a tube, scattered orer with glandular hairs. Pistil about as long as the stamens. Stigma obtuse. Capsule globose, dotted.

Habitat.-Moist banks of rivers; rare. "Discovered by the late IIr. Nathan Backhouse, in 1803, on the margins of the Skern, north of Darlington; most frequent on the west side of the river, both abore and below the railway bridge." -Hookes. Who in a note adds, "I regret that the existence of this plant in the station above quoted, has not been confirmed by Botanists, who have subsequently risited the spot ;" and that "it will probably, ere long, be found in other situations."

This is a frequent plant on the Continent in shady places, and especially in Italy. We have found it in damp groves and shady places, by the side of rills and the mountain streams of the Apennines, growing from one to three and four feet high, branched, especially above, or simple, and the stem thickly clothed with a soft down.

Perennial; flowering in June.

4. L. Ne'morum, Linn. (Fig. 334). yellow Pimpernell, or Wood Loosestrife. Stem procumbent; leares opposite, ovate, acute, smooth; peduncles axillary, single flowered; segments of the calyx linear, subulate; filaments smootl.

English Botany, t. 527.-English Flora, vol. i. p. 279.-Hooker', British Flora, rol. i. p. 106.-Lindley, Synopsis, p. 184.

Ronts fibrous from the axis of the lower leaves. Whole plant smooth and shining. Stems slender, angular, reddish, from twe elve to eighteen inches long, simple w branched in the lower part, where it puts out roots from the axis of the leaves, loosely spreading above. Leaves opposite, ovate, acute, on short footstalks, shining above, paler beneath, with a mid-rib, and two or four lateral nnes from the base. Flowers 
bright yellow, axillary, one only froin the axis of the upper leaves, on a long slender peduncle, straight when in flower, becoming recurved and twisted when in fruit. Calya in five linear subulate segments, nearly as long as the corolla. Corolla divided nearly to the base in five ovate acute segments. Stamens shorter than the corolla, with slender smooth filaments, free at the base. Anthers long, narrow. Pistil longer than the stamens. Stigma obtuse. Capsule globose, crowned by the persistent style.

Habitat.-Woods, banks, and shady places; frequent.

Perennial; flowering during the summer months.

This gay little plant is a great ornament to wood banks and shady groves, and is admirably suited for the sides of walks and banks in pleasure grounds and plantations, which are rather moist; its loose spreading stems chothed in their bright shining leaves, intermixed with the glowing yellow fluwers, which are continually opening out during the whole of summer, make gay the bank, and flourishes where but few ormamental plants will grow. In similar situations, we have also seen the following species; it, however, prefers a wetter soil than the above, and is best suited for the banks of ponds and streams, where it spreads its branches, and soon covers the ground with a thick mat of its stems, leaves, and numerous flowers.

5. L. nummula'ria, Linn. (Fig. 335). creeping Loosestrife, Moncywort, or Herb Tropence. Stems prostrate; leaves opposite, rotundate, cordate, smooth; peduncles axillary, single flowered; segments of the calyx ovate cordate; filaments glandular.

English Botany, t. 528.-English Flora, vol. i. p. 280.-Hooker, British Flora, vol. i. p. 107.-Lindley, Synopsis, p. 184.

Roots fibrous from the axis of the lower leaves. Whole plant smooth and shining, jale green, and scattered over with glandular spots, which are best seen after the plant is dried. Stem slender, angular, brancherl or simple, from a few inches to two feet long, lying close to the ground, and sending out roots from the lower leaves. Leares mostly rery ummerous, and crowded in the lower part, opposite, on short footstalks, roundish, and more or less cordate at the base, obtuse or acute at the apex, with a prominent mid-rib, and numerous lateral branches, the margins more or less waved. Flowers rather large, of a pale yellow, each on a peduncle, arising singly from the axis of the leaves. Peduncles of variable lengths, sometimes as long as the leaves, at others much longer, angular. Calyx of five heartshaped segments, sometimes orate, acute. Corolla of tive ovate acute segments, united at the base, scarcely forming a tube, veiny, scattered over with small glands, the margin ciliated, with short glandular hairs. Stamens abont half the length of the corolla. Filaments dilated at the base; and scatlered orer with glandular hairs. Anthers 
ovate oblong. Pistil about the length of the stamens. Stigma ob. tuse notched. Capsule seldom perfected, globose.

Habitat. - Wet shady pastures and banks; not so common as the last.

Perennial ; flowering in June and July.

Infusions or decoctions of this plant are said to be vulnary and antiscorbutic, and useful in dysentery. Pliny, moreover, says it tames restive horses; but now-a-days we do not find it to have any of these virtues, either for one complaint or other, much less for the purpose in which Pliny says it is so potent.

\section{GENUS XVI. MENYAN'THES.-LN:. Buckbean.}

Nat. Ord. Gentid'NeE. Juss.

Gen. Char. Calyx five parted. Corolla funnel-shaped. The limb of fire spreading segments, bearded within. Stigma capitate, two lobed. Capsule two valved. Seeds numerous.-Name from "

1. M. trifolia'ta, Linn. (Fig. 336.) common Buckbean, or Marsh Trefoil. Leaves ternate.

English Botany, t. 495.-English Flora, vol. i. p, 275.-Hooker, British Flora, vol. i. p. 168.-Lindley, Synopsis, p. 179.

Root long, branched fibres from the joints of the long creeping underground stems, which are mostly very numerous, and matted together, round, smouth, stout, succulent, passing into flowering stems, which are procumbent at the base, mostly clothed with the dry membranous sheath of old leaves, frequently branched, ascending towards the summit, where it is leafy. Leaves ternate, on a long stout footstalk, terminating in their mcmbrawous sheaths enfolding the stem, leaflets ovate or obovate, sometimes acute, or orate-lanceolate, smooth, with a stout mid-rib, and numerous lateral branches, the margins waved, or somewhat toothed. Inflorescence a raceme, or thyrsus, of numerous flowers, on a round smooth succulent stalk, from four to eight inches long, arising from the axis of the leaves. Flower's crowded, white or flesh coloured, tipped externally with pink, on round, smooth, short pedicles from the axis, of a small ovate or orate acute bractea. Calyx of five orate decjly divided segments, about half as long as the funnel-shaped corrollre. The tube short, dilated upwards. The limb of fire segments, orate, acute, reflexed, smooth and reiny extermally, much bearded within, with long slender waved filaments. Stamens the length of the corvlla. Filaments slender, from about the 



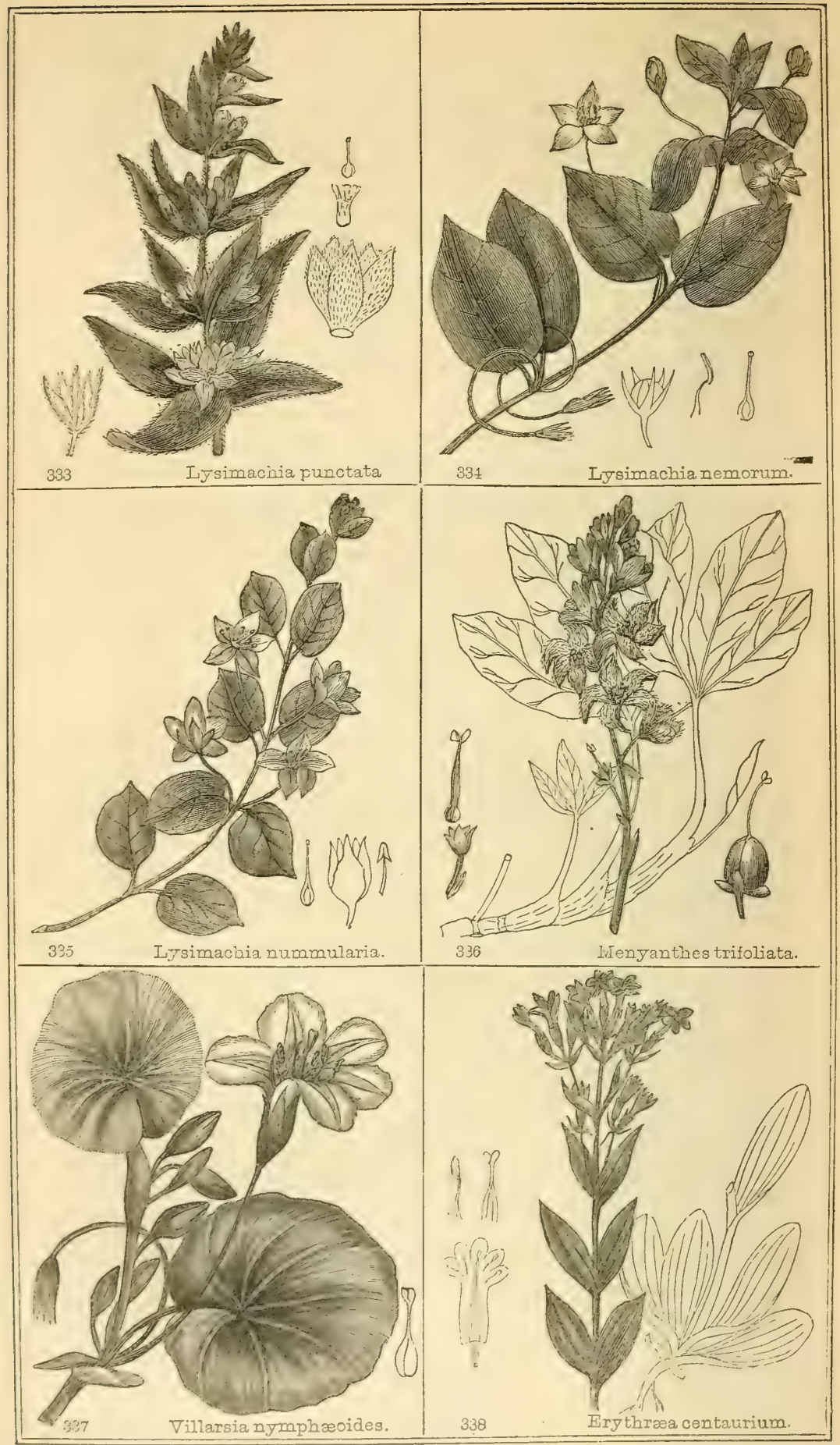


middle of the tube. Anthers deeply cloven at the base. Pistil about as long as the corolla. Stigma of two lobes. Capsule ovate, surrounded at the base by the persistent calyx, opening with two valves, the seeds attached to the parietal placenta, formed by the inflexed margins of the dissepiments. Seeds numerous, light brown, smooth polished. Embryo straight, in the axis of the albumen. The radicle placed next the hilum.

Habitat.-Marshes and hoggy situations; frequent.

Perennial; flowering in June and July.

The leaves of the Buckbean have a rery bitter nauseous taste, with a faint disagreeable smell. On account of its bitter property, it is used in some places as a substitute for hops, but is far from possessing the fine aroma of the flowers of that plant. It is tonic, somewhat diuretic and purgative, and is said to have been useful in some cases of fever, rheumatism, and painful affections of the joints; and also in diseases of the skin. It is used by making an infusion of half an ounce of its dried leaves in half a pint of boiling water, and taking a wine glass of it two or three times a day. It is also taken in doses from a scruple to a drachm of its leaves in fine powder. It is, however, seldom used in modern practice, since a more elegant substitute is found in other plants of the Gentian tribe. In cattle it is said to cure the disease called dam; in doses, of course, proportionately larger than those stated above. Its roots, like those of many other plants, are useful in rendering boggy ground more firm by their matting themselves together ; and, by their gradual decomposition, deposits of vegetable matter are formed, which, by a succession of years, is raised abuve the water, when other plants take possession of it, and at length a firm footing is ohtained, and it becomes subservient to the use of the animal creation. Lands thus rescued from the watery element, it is well known, are extremely productive for a very considerable period after; and if boggy grounds, such as we see in many parts of the kingdom, were artificially drained, instead of being left to this slow process of nature, there can be little doubt but they would well repay the expense and labour bestowed upon them in the course of a very short time, as we see exemplified in many districts of Lincolnshire, and in other counties.

\section{GENUS XVIT. VILLAR'SIA.-VeNT. Villarsia.}

Nat. Ord. Gentian'ex. Jús.

Gen. Char. Calyx five parted. Corolla rotate. The limb of five spreading segments, the margins inflexed in astiration, bearded in 
the throat, five glands alternating with the stamens. Stigma fivecleft. Capsule two ralved. Seeds numerous. Leares simple.Named in compliment to $\boldsymbol{M}$. de Villars, author of Flora des Dauphine.

1. V. nympho'oides, Vent. (Fig. 337.) Nymphoa-like Villarsia. Leares floating, orbicular, cordate; flowers in axillary sessile umbels; corolla ciliated.

Hooker, British Flora, rol. i. p. 109.-Lindley, Synopsis, p. 180.Menyanthes nymphcooides, Linu.- E. Botany, t. 2I7.-English Flora, vol. i. p. 276 :

Roots long, round, cord-like. Stems long, round, smootb, succulent, much branched, and spreading. Leures floating on the surface of the water, roundish, heart-shaped at the base, the margins more or less waved or toothed, smooth, shiniug, pale variegated green above, a darkish purple beneath, and thickly scattered orer with small elevated spots. Footstalks long, round, dilated and membranous at the base, and from their axis arise the flowers, in a sessile umbellate manner. The pedicles round, smooth, erect when in flower. Calyx in five lanceolate obtuse segments, about half the length of the corolla, smouth. Corolla large, yellow, rotate, in fivespreading segments, the margins curiously inflexed in æstivation, and more or less fringed, with a smooth darker radiating disk; the orifice of the short tube fringed with simple litirs, around which also are placed the stamens on short filaments, alternating with five oblong glands. Pistil about half as long as the corolla. Stigma five-cleft. Capsule orate, of one cell, two valves, many seeded.

Habitat.-Rivers and still waters; rate. In the Thames; abundant in the Canal, near Dowhiam Market, and Wisbeach; and several places in Yorkshire.

Perennial; flowering in $\mathrm{J}$ uly and August.

This rare but beautiful plant is readily cuitirated in ponds or streams of water; and when it has once estal)lished itself, it is afterwards difficult of extirpation. It is highly ornamental in the drains and rivers of Holland, and mayy other parts of the continent, entirely covering the surface of the water with its benutiful floating leaves and stems, and its rather large elegant flowers successively rising and expanding their curions structured corollas, making gray the abute of the croaking frog, (Rana temporaria), and undulating leech, (Hirudo medicinalis) two sleek animals, known to most persons, but favourites with few. We once in one of our botanical perambulations, in search of aquatic plants, had our attention attracted by them. The frog, evidently in a state of perturhation, was endeavouring to escape with all the exertion that it could make from an attack of the wily leech; but with all its leaping, swimming, and croaling, it could not shate of its close companiou, "lou had attached itself firmly upon its leg: and to judge 
from the swollen and increasing size of the lecch, we supposed he was making a very hearty meal at the expence of the vivifying blood of the poor animal. We watched them some time; but the frog, what with rxhaustion from the loss of blood, the exertion it had made, and the f:ight which it appeared to be in, leaped upon a leaf of the Villarsia, a bark which being unable to sustain such a cargo, suuk, and its burden disappeared.

\section{GENUS XVIII, ERYTHR玉'A.-ReNealu, Centaury.}

Nat. Ord. GENTIAN'Ex. Juss.

Gev. Char. Calyx fire-cleft. Corolla funuel-shaped, its limb short. Anthers after bursting spirally twisted. Style erect. Stigmus two. Capsule linear, of two cells, with the margin of the valves turned inwards. - Name from $\xi_{\xi} f_{\xi} \circ:$, red, the colour of the flowers in most of the species.

1. E. Centau'rium, Pers. (Fig. 338). common Centaury. Stem somewhat branched; leaves ovate oblung; flowers nearly sessile, in fasciculated corymbs. Calyx half as long as the tube of the corolla. The segments of the corolla oral.

English Flora, vol. i. p. 321.-Hooker, British Flora, vol. i. p. 109. -Lindley, Synopsis, p. 178.-Chironia C'entaurium.-English Botany, t. 417.-Gentiana Centaurium. Linn.

Root tapering, with branched fibres. Stem erect, simple, or mostly with short branches, from eight to eighteen inches high, smooth, square. Leares opposite, smooth, sessile, the rarlical ones bright green, sometimes on short broad footstalks, spreading, mostly broader than those of the stem, all orate oblong, with three main ribs, in luxuriant specimens, the lower ones have five, and the upper ones in clistant pairs are narrower, and become somewhat lanceolate. Inflorescence a branched, more or less dense fasciculated corymb. Flnwers numerous, nearly sessile, each liule pedicle haring a narrow bractea, and sometimes round, the base of the calyx there are several small awl-shaped scales. Caly.x in five deep linear segments, with a pale narrow membranous margin, about half the length of the tube of the corolla. Corolla salrer-shaped. The tube long, pale, with numerous slender veins. The $\operatorname{limb}$ a beautiful pink, of tire orate segments, spreading only in the sunshine, closed in the dark, and cloudy weather, and inmediately after gathering the plant. Stamens inserted around the contracted orifice of the tube. The filaments slender, threadshaped, about balf as long as the limb of the corolla. Anther's ublong, of two cells, becoming spirally twisted after the escape of the pollen. Pistil 
with a narrow oblong compressed germen, a shortish slyle, somewhat oblique or recurved, and stigma of two roundish lobes. Capsule closely invested with the persistent corvlla, linear of two imperfect cells, two valves, and many seeded.

Habitat.-Diy gravelly fields, and road sides; frequent.

Annual; flowering from July to August.

So extremely delicate are the flowers of this plant, that they will only shew their blushing beauty at the solicitation of a glowing sun, when they may expect numerous passing visits from the insect throng to pay homage to their beaty, and inspect the curious structure of their spiral cells.

The whole plant is without odour; but the stem, leaves, and petals, are strongly impregnated with a bitter resinous matter or mucus, which is imparted to boiling water, or spirits of wine. It is tonic and antiseptic; and before the introduction of cinchona bark, was used in cases of fever: it is not, however, used in modern practice, but is one of the great remedies of the village doctress, and is, no doubt, useful in some dispeptic complaints, taken in the form of powder, or half an ounce of the herb in half a pint of boiling water, taking a fourth of it two or three times a day.

2. E. pulchel'la, Hooker. (Fig. 339.) Dwarf-branched Centaury Stem much branched; leaves ovate oblong; flowers on short stalks, in loose panicles; calyx nearly as long as the tube of the corolla; the segments of the corolla oblong.

Hooker, Flora Scotica, vol. i. p. 79; and British Flora, vol. i.p. 109.-English Flora, vol. i. p. 323.-Lindley, Synopsis, p. 178.Chironia pulchella.-English Botany, t. 458.-Gentiana Centaurium, B. Linn.

We are much disposed to follow Linnæus in considering this as a variety of the $E$. Centaurium. We have frequently met with specimens in the dry sandy districts of Nottinghamshire, differing in no respect from those grown on the sea shores in various parts of the coast, except that they had been cropped down by cattle, consequently had become much branched and lax, fewer flowered, and with shorter leaves.

Habitat.-Sandy sea shores. England and Scotland; Cape Clear Island; and near Bangor, county of Down, Ireland.

Annual; flowering from July to August.

3. E. littora'lis, Hooker. (Fig. 340). Duarf-tufted Centaury. Stem simple, or branched; leaves linear-obovate obtuse; flowers nearly sessile, in cluse capitate corymbs; calyx as long as the tube of the corolla; the segments of the corolla ovate.

Hooker, Flora Scotica, vol. i. p. 80; and British Flora, vol. i. p. 



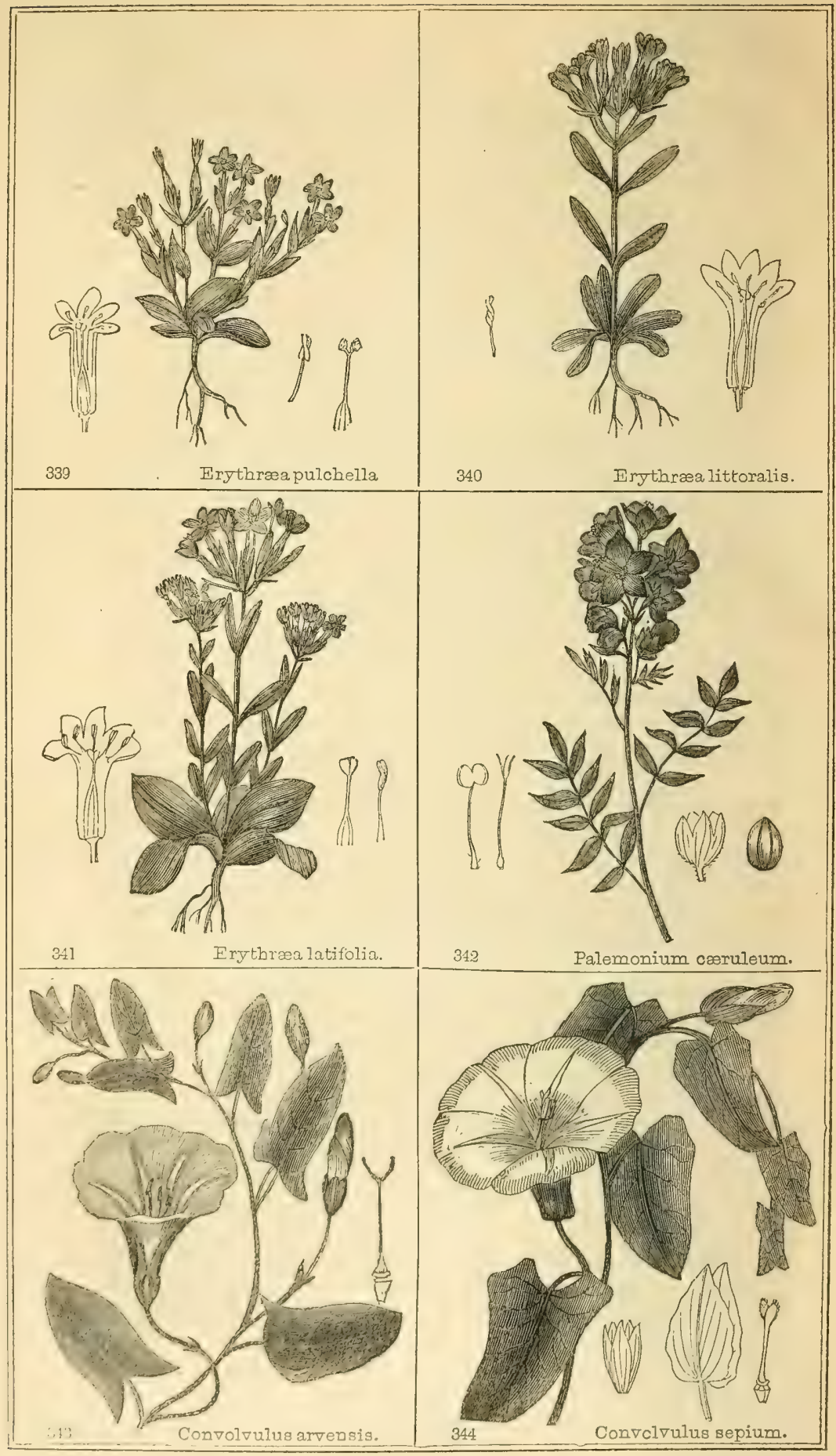


109.-English Flora, vol. i. p. 321.-Lindley, Synopsis, 1) 178.Chironia littoralis._English Botany, t. 2305.

This, we also think, would be more properly regarded a variety of $E$. Centaurium; we have found it equally common with the preceding. It differs in the lenves, being narrower, and in more distant pairs, with one or three ribs, the margins sometimes minutely toothed. The stem simple or branched from the base or stem, often obscurely angular. The calyx as long as the tube of the corolla; and the limb of the corolla with ovate segments, larger in proportion to the size of the plant; and the flowers more crowded into a capitate corymb. One or other of these characters are so variable from the variety of situations of growth, as to render it difficult to determine (if they are to be regarded as species) to which to refer it.

Habitat.-Sandy districts, especially near the sea; England, Scotland, and Portmarnock, Ireland.

Annual ; flowering in June and July.

4. E. latifolia, Smith. (Fig. 341.) broad-leaved tufted Centaury. Stem three branched at the top; flowers in dense forked tufts; calyx as long as the tube of the corolla; segments of the corolla lanceolate; lower leaves broadly elliptical, with five or seven ribs.

English Flora, vol. i. p. 322.-English Botany, Suppt. t. 2718.Hooker, British Flora, vol. i. p. 110.-Lindley, Synopsis, p. 178.

Whether this is a species or a variety of $\boldsymbol{E}$. Centaurium we are unable positively to determine, fur so variable are the characters of the British plants of this genus, that it is diflicult to say which is a species and which a variety. The present is, perhaps, more distinct from $E$. Centaurium than those above mentioned; its leaves are broader, larger, and more obtuse, especially the radical ones. The stem is short, three branched at the top; and the calyx segments as long as the tube of the corolla, but yet not any of these characters are constant : and we camnot think it is more than a variety. It is not uncommon in sandy districts, growing with others in every intermediate stage between this and $E$. Centaurium. IVere we disposed to multiply species, or enumerate varieties, many might be mentioned. We have now before us specimens nearly two feet high, some single, and others with numerous stems from the branched root, and obscurely angular; the leaves lanceolate, three and five ribbed; the stem three branched at the top; the fluwers in dense tufts, almost capitate; the calyx as long, or longer than the tube of the corolla; the bractea long as the tufts of flowers, narrow, awl-shaped, and the style somewhat bent; but we cannot think that it is any thing more than a variety of $\boldsymbol{E}$. Centaurium. It was grown in a moist sandy situation amongst corn.

Habitat.-Sea shores, and sandy situations.

Annual; flowering in July and August.

VOL. I. 


\section{GENUS XIX. POLEMO'NIUM.-Linn. Jacob's Ladder.}

Nat. Ord. Polemonia'cez. Juss.

Gen. Char. Calyx five-cleft. Corolla wheel-shaped, with a short tube. The limb of five lobes. Stamens dilated and hairy at the base, closing the mouth of the tube. Stigmas three-cleft. Anthers incumbent. Capsule of three cells and three valves. Seeds numerous.-Name from $\pi \circ \lambda_{\varepsilon} \mu \mathrm{s}_{\text {, }}$ war ; on account, according to a tale related by Pliny, of its having been the occasion of a war between two Kings, from a dispute that arose between them as to who was the discoverer of its uses. He further states that the Polemonium of the ancients was called Chilodymamia, from

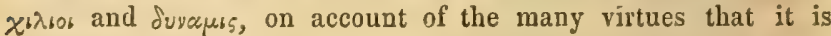
related to possess.

1. P. carn'leum, Linn. (Fig. 342.) Jacob's Ladder, or Greek Valerian. Stem smooth, leafy; leaves pinnated; leaflets oblonglanceolate, smooth, panicle clothed with glandular hairs; flowers erect.

English Botany, t. 14.-English Flora, vol. i. p. 287.-Hooker, British Flora, vol. i. p. 113.-Lindley, Synopsis, p. 168.

Root of branched fibres. Stem erect, smooth, slightly angular, from one to two feet high, leafy, green, or sometimes pinkish. Leaves alternate, the lower ones on long common stalks, the upper short. Leaflets smooth, sessile, or on short footstalks, oblong-lanceolate, opposite or alternate, with an odd one at the end, and all of nearly an equal size. Inflorescence a branched panicle, more or less clothed with soft glandular hairs. Flowers numerous, large, blue, sometimes white, on short stalks, mostly crowded. Calyx about half five-cleft; the segments ovate-lanceolate, acuminate, more or less thickly clothed with glandular hairs, especially at the base, and each segment with one or three simple or branched ribs, persistent, and enveloping the capsule, enlarging after flowering as it advances to maturity. Corolla wheel. shaped, with a short tube, and large five lubed spreading limb, regular or somewhat unequal, imbricated in estivation, mostly waved on the margin, and beautifully pencilled over with dark purple veins. Stamens alternating with the segments of the corolla, and nearly as long. The filaments dilated and hairy at the base, closing over the mouth of the tube. Style simple, as long as the corolla. Stigma three-cleft. Capsule triangular, of three cells, three valves, each valve with an external furrow and prominent internal rib attached to the central placenta, and forming the internal walls of the cells. Seeds angular, or oval,

Habitat.-Banks and bushy places; rare. On the banks of the river Derwent, uear Fox Inn, and Castleton Dale, Derbyshire, not 
unfrequent; Craven and Gordale, Yorkshire; about Queensferry, Arniston and Delvine Woods, Scotland; Knockmaroon Hill, near Chapelizod, Ireland.

Perennial; flowering in June and July.

This pretty plant, known by the name of Greek Valerian, or the more common one of Charity, is a garden flower, much cultirated, continuing in flower a long time, and varying greatly in its colours from a dark blue to a pure white. This, like many other plants distiuguished by ancient names, is not found to possess the many virtues that it is related to have had in former times; or it is that we apply the names to other plants than they formerly distinguished. In the present case, the plant appears scarcely to have any sensihle medical qualities, much less those of such great importance as to have induced Kings to have waged war against each other, to settle a dispute as to who was to hare the honour of being cousidered the discoverer of so rave and valuable a plant.

\section{GENUS XX. CONVOL'VULUS.-Lins. Bindweed.}

Nat. Ord. Conrolvula'cex. Juss.

Gen. Char. Calyx fire-cleft. Corolla bell-shaped, folded in five plaits. Stigmas two. Capsule of from one to four cells, with as many valves. Seeds one or two in each cell.-Name from Convolvo, to entwine.

* Flowers with tu'o distant bracteas.

1. C. arven'sis, Linn. (Fig. 343.) small Bindreed. Stem climbing; leares arrow-shaped, their lobes acute; peduncles mostly single flowered; bracteas small, distant from the flowers.

English Botany, t. 312.-Euglish Flora, vol. i. p. 285.-Hooker, British Flora, vol. i. p. 112.-Lindley, Synopsis, p. 167.

Root with very Jong creeping underground stems, spreading to a considerable clistance, and difficult of extirpation. Stem slender, angular, simple or branched, smooth below, downy towards the end of the branches, prostrate, unless near some plant, round which it can entwine and support itself. Leaves alternate, arrow-shaped, round, or obtuse at the apex, the lobes at the base acute, spreading, sinooth or downy, with a mid-rib and slender lateral veins, on a slender channelled footstalk. Flowers arising from the axis of the leares, solitary, or in pairs, on a slender angular stalk about as long or longer than the leaves, and, like them, more or less hairy, each flower having a distant pair of awl-shaped bracter. Calyx of five orate obtuse hairy segments. 
Corolla bell-shaped, about an inch broad at the mouth, mostly a delicate pink or rose colour, with white rays from the yellowish centre, having five plaits, and five indistinct lobes. Stamens from the base of the corolla, dilated below, slender, about half as long as the corolla, two mostly shorter than the others. Anthers arrow-shaped. Style as long as the stamens. Stigmas two, oblong, spreading, downy. The capsules are seldom perfected; it propagates itself by the underground stems.

Habitat.-Corn fields, hedges, and gardens; very common, especially in a light soil.

Perennial ; flowering from July to August.

This is a very troublesome plant to the farmer, though greatly ornamental to his fields. The flowers are beatiful in colour, and delicately formed, exhaling a fragrant odour in dry warm weather, and closing closely up in rain, or when the sky is cloudy. It contains a cathartic resin, but in a far less proportion and much less actire than the well known Scammony or Jalop, as well as other plants belonging to this order.

The leaves are very variable in size, and their having acute, obtuse, or elongated lobes at the base, being smooth or downy, together with the variable depth of colour in the flowers, seem to depend upon the situation of its growth, or rather the nature of the soil, as to the lightness or richness of its quality.

** Flowers with two large bracteas at the base. Calystegia.-R. Brown.

2. C. se'pium, Linn. (Fig. 344.) great Binduced. Stem climbing; leaves arrow-shaped, their lobes truncate, often toothed peduncles, single flowered, four sided; bracteas large, heart-shaped, close beneath the calyx.

English Botany, t. 313,-English Flora, rol. i. p. 285.-Hooker, British Flora, vol. i. p. 113.-Calystegia sepium.-Lindley, Synopsis, p. 167.

Root with long creeping somewhat fleshy underground racemes. Stem slender, angular, twisted, smooth, wondy, much branched, climbing and spreading, many fect around. Leaves large, arrowshaped, alternate, acute at the apex, lobes at the base abruptly cut, or obtusely toothed, or eren as the rest of the margin generally is, quite smooth, a lively green, paler and somewhat glaucous beneath, with a mid-rib, and numerous smaller lateral branched veins, on a slender furrowed footstalk, which frequently twists around other plants to assist in supporting itself. Floners large, solitary, from the axis of the leaves, very handsome, pure white, or with a pale pink ray, about two inches across the mouth, on a rather slender square smooth stalk, scarcely as long as the leares, having two large dilated oblong heart-shaped veiny bractcas immediately bencath, and enclosing the 


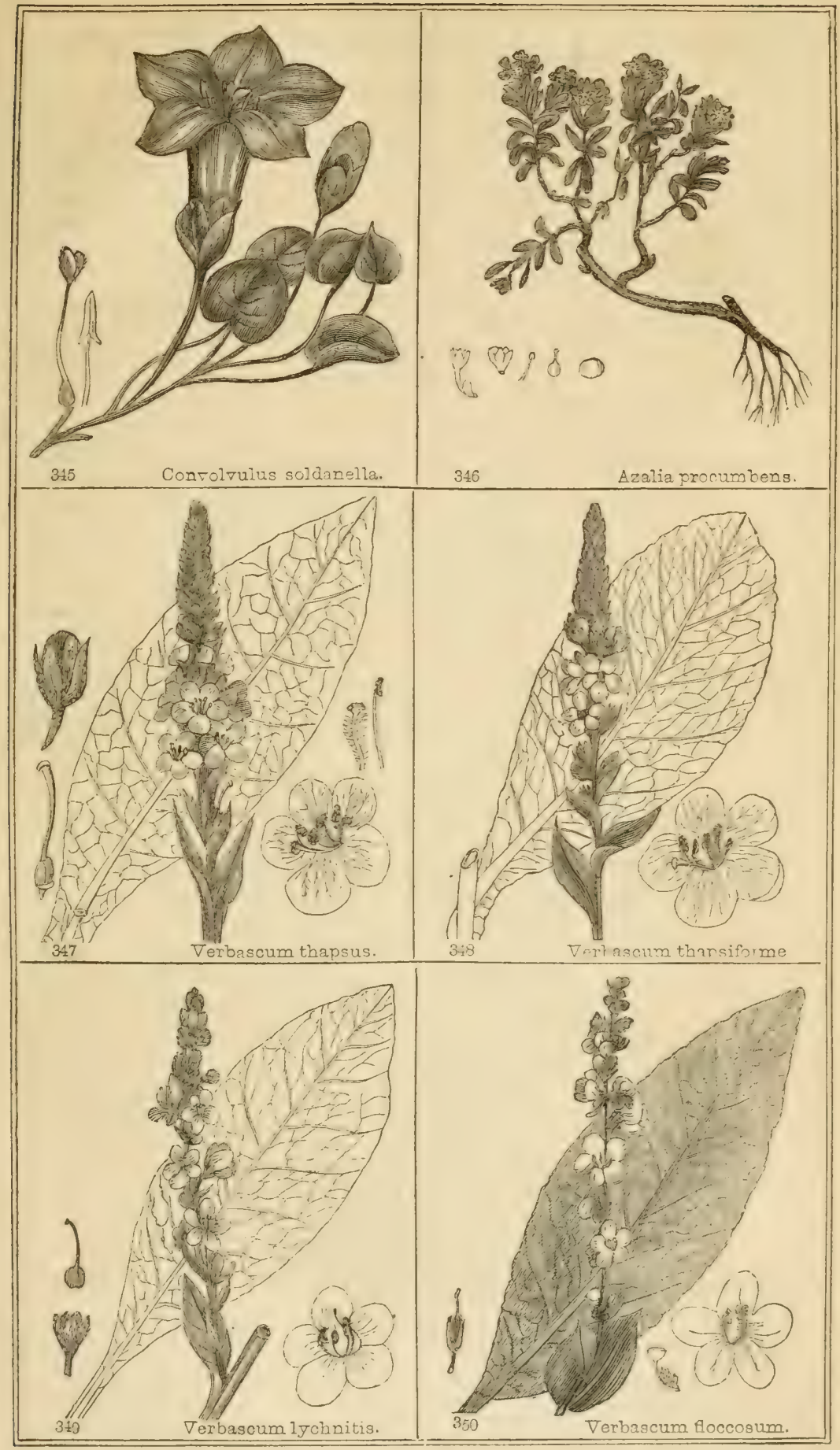



calyx, leafy, quite smooth. Calyz of five ovate segments, about half as long as the bractea. Corolla bell-shaped, folded with five plaits, and indistinctly lobed. Stamens arising from the base of the corolla, equal in length, nothalf as long as the corolla. The filaments dilated downwards, downy. Anther's oblong, arrow-shaped. Style smooth, longer than the stamens, slender. Stigma of two spreading ovate downy lobes. Capsules of one or four imperfectly formed cells. Seeds ovate, few. The capsules are seldom perfected; the plant increasing by its underground stems.

Habitat.-Woods, hedges, and thickets, especially in a moist soil; frequent.

\section{Perennial; flowering from June to August.}

This beautiful species of Convolvulus is much larger than the last, and highly urnamental to our rural lanes and sequestered dells, throwing its slender arms around perhaps the fragrant woodbine, and mingling with its sweets its gay and more conspicuous attire, adorning the sylvan bower in rich festoons of varied hues; or climbing some tree hard by, it hangs pendent from its outstretched boughs its lengthened folds of living drapery. It is readily distinguished from $C$. arvensis, by its large bracteas beneath the calyx. The flowers are mostly much larger, and the stigmas two obtusely ovate lobes.

3. C. soldanel'la. Linn. (Fig. 345). Sea-side Bindweed. Stem prostrate; leaves kidney-shaped, fleshy; peduncles single flowered, four sider, somewhat winged; bracteas large, ovate, close beneath the calyx.

English Botany, t. 314.-English Flora, vol. i. p. 286.-Hooker, British Flora, vol. i. p. 113._Calystegia soldanella._Lindley, Synopsis, p. 167.

Root with numerous long creeping branched underground stems. The whole plant smooth and succulent. Stem branched, spreading on the surface of the sands, angular, from six to twclve inches long, or longer. Leaves alternate, sometimes opposite, roundish, heart or kidney-shaped, pointed, lobed, and obtusely toothed, with a mid-rib and several radiating veins, on a rather long broadish channelled footslalk. Flowers solitary from the axis of the leaves, large, very handsome, a delicate rose colour, with a palish yellow ray, nearly two inches across the mouth, and almost as long, on a long square stalk, dilated upwards, the angles more or less distinctly winged, and somewhat pinkish, having two large ovate leafy bractea immediately beneath the calyx, with a mid-rib, and finely reticulated with veins. Calyx of five ovate segments, longer than the bractea, with a minute point and pinkish mid-rib. Corolla bell-shaped, with fire broad plaits, and five somewhat pointed lobes. Stamens arising from the base of the corolla, and about half as long, nearly equal; the filaments dilated 
downwards, and more or less downy. The anthers large, arrowshaped. Style longer than the stamens. Stigmas of two orate downy spreading lobes. Capsule roundish, large, of four lobes, single celled, containing generally four large black dotted seeds.

Habitat.-Sandy sea shores; frequent.

Perennial; flowering from June to August.

The flowers only expand in the sunshine, and continue a short time; but there is a continual succession of them for two or three months. It is found on the sandy shore of almost all parts of the European continent; but has not, that we are aware of, been applied to any useful purpose.

\section{GENUS XXI. AZA'LEA.-LINs. Azalea.}

Nat. Ord. ERI'CEA. Juss.

Gen. Char. Calyx five-cleft. Corolla bell-shaped, regular. Stamens straight, inserted at the base of the corolla. Anthers bursting longtitudinally. Capsule two or three valved, two or three celled, disseppiments formed by the inflexed margins of the bifid valves. Seeds attached to a central, at length free, receptacle.Name from ofa $\alpha$ sos, parched, dry; from the plants growing in parched or dry situations.

1. A. procumb'ens, Linn. (Fig. 346.) trailing Azalea.

Euglish Botany, t. 865.-English Flora, vol. i. p. 283.-Hooker, British Flora, vol. i. p. 113.-Lindley, Synopsis, p. 172.

A low shrubby plant, with long twisted branched dark roots, a much branched and tortuous stem, smooth dark brown scaly bark. The branches short, wiry, and leafy. The leaves rigid, ovate oblong, above dark, smooth, shining, and channelled, the margins reflexed; beneath a pale glaucous green, with a broad pale smooth prominent mid-rib, a continuation of the short broad footstalk, fringed with short hairs. Inflorescence small terminal racemes. Flowers few, small, rose coloured, on short reddish stalks, each with a small ovate convex bractea at its base. Calyx of five, sometimes six, deeply divided oblong fleshy purple segments. Corolla somewhat bell-shaped, its limb deeply diviled in fire oblong obtuse spreading segments, mostly equal. Stamens a little shorter than the corolla, with slender filaments inserted at the hase of the corolla, into a somewhat fleshy disk at the base of the germen. "Anthers of two oval cells, opening distinctly by a longtitudinal fissure, lear-coloured germen, upon a fleshy base or disk, scarcely broader than itself, ovate, two or three celled. Style about equal to it in length. Stigma capitate, obscurely lobed. Capsule broadly ovate, with a somewhat spongy coat, purplish brown, opening 
by two or three valves, according as the cells are two or three; the margins of the valres entering into the capsules, and thus forming the disseppiments; again each valre is deeply cleft, so that, on looking at the upper half of an open capsule, we find four or six valves or segments, each haring one of its sides inflexed, to form (with the introtlexed side of the neighbouring segment) a disseppiment of a double plate. Seeds fixed to two or three lobes of a central, at length (when the valves open) free column or receptacle, oval, pale brown, dotted."

Habilat.-Dry moory ground; on most of the mountains in the highlands of Scotland.

Shrub; flowering in May and June.

The anthers of this plant, Smith says, consist of two cells, each cell opening by a rather wide pore, with a blunt border; and that he never found them bursting longtitudinally. In our own insestigations we do not find this to be the case, but that they burst longitudinally as above described in the words of Sir W. J. Hooker, whose excellent description of them and the capsules we have quoted, and he further remarks, "A. procumbens abounds in the Arctic Regions of, I believe, the whole northern bemisphere. It is found in America, as far south as the White Mountains of New Hampshire. My friend, Dr. Boott, gathered it on Mount Washington of that range; and it is extremely plentiful on the highest part of the Rocky Mountains."

\title{
GENUS XXII. VERBAS'CUM.-Lins. Mullein.
}

\author{
Nat. Ord. Solan'Ez. Juss.
}

Gen. Char. Calyx five parted. Corolla wheel-shaped, of five unequal segments. Filaments declining, mostly hairy. Capsule ovate or globose, with two cells and two valves.-Name supposed to be from Barbascum (Quasi barbascum), from Barba, a beard, in allusion to the hairy foliage of most of the species.

1. V. Thap sus, Linn. (Fig. 347). Great Mullein, High Taper. Leares decurrent, crenated, ovate-lanceolate, woolly on both sides; stem simple, raceme spiked, very dense, flowers with two stamens longer than the others, and smooth.

English Botany, t. 549.-English Flora, vol. i. p. 309.-Hooker, British Flora, vol. i. p. 111.-Lindley, Synopsis, p. 181.

Root long, tapering. Stem erect, simple, from three to six feet high, sometimes, but rery rarely, branched, round, or slightly angular, densely woolly, like all the rest of the plant, with very soft curiously 
branched pale yellowish hairs. Leaves numerous, alternate, crowding the stem, all decurrent, densely dotted on both sides the margius, more or less distinctly crenated, with a strong mid-rib and lateral branched reins, the lower on footstalks, often a foot long, ovate oblong, tapering at the base, the upper sessile, strongly decurrent at the base, forming wings to the stem, oblong-lanceolate in the lower part of the stem, with an acute point in the upper tapering. Inflorescence a much crowded racemose spike, cylindrical, from one to two feet long. Flowers large, handsome, golden yellow, gradually expanding from the base upwards, and by their continual succession, are a considerable time in flower, some are sessile, others on shurt stalks, each with a narrow ovate-lanceolate Bractea as long as the calyx, woolly on the outside, mostly smooth and pale on the inside. Calyx of five deep lanceolate segments, the one next the stem narrower than the others, pale, smooth, and shiuing, on the inner surface. Corolla wheelshaped, with a short tube, sometimes the tube is longer, and approaches funnel shape. The $\lim b$ spreading, of five unequal rounded lobes, woolly on the outside, smooth and veiny within. Stannens inserted into the tube of the corolla, two of them with long slender filaments, quite smooth, or with a few hairs, the others with much shorter and very bairy filaments. Anthers bright orange, those on the two long filaments much larger than the others. Style nearly as Iong as the corolla, hairy below, swollen upwards. Stigma obtuse, green. Capsule surrounded by the persistent calyx, orate, compressed, furrowed on each side, downy, with two cells, opening with two valves. Seeds very numerous, angular, compressed, beautifully dotted, attached to a placenta formed by the disseppiments.

Habitat.-Fields, banks, and road sides; frequent, especially in a light sandy soil.

Biennial; flowering from June to August.

This large conspicuous plant has, no doubt, obtruded itself on the notice of, and is known by many persons who are mere admirers of flowers: but those who explore with more than with a general eye this vast field of investigation, will find in this plant much that is worthy of minute examination. The hairs with which almost the whole plant is so abundantly clothed, are rery delicate, and of exquisite structure, branched and stellated in a remarkable manner. The unequal stamens with their different filaments, and variously formed anthers: the capsule and the beautiful seeds, are all parts whose use and curious structures will afford much interest in their examination, and the offices they perform in the econoiny of the plant.

The flowers, "when dried in the sun give out a kind of fatty matter, used in Alsace as a cataplasm in hœmorrhoidal complaints." The 
whole plant is said to he emollient and mucilaginous. The flowers are made into an infusion or decoction in some parts of Italy, an ounce and a balf to a pint of water, and is said to be useful for a cough, inflamed bowels, diseases of the kidneys and bladder, and is used as an injection to allay tenesmus. It was also used by the Italian ladies as a cosmetic to remore spots from the skin, and it was quite as useful as many of the now more fashionable and expensive compounds that is sold for the same purpose.

2. "V. thap'siforme, (Fig. 348.) Schrad. Thapsus.like MIullein. Stem simple, leaves lanceolate-orate, decurrent, crenulate, downy, the upper acuminate, raceme spiked, dense; bractea longer than the woolly calyx; segments of the corollia oborate rounded, two anthers oblong."-De Cand.

Lindley, Synopsis, p. 181.-Hooker, British Flora, vol. i. p. 111.

Habitat._-"By-road sides in Kent."

"Biennial; flowering in July and August."

This plant we are unacquainted with as a natice of Britain; it is not unfrequent on the continent, but we are disposed to consider it rather as a rariety of $V$. Thapsus than a distinct species.

3. V. Lich'nitis, Linn. (Fig. 349.) white Mullein. Leares oblong, wedge-shaped abore, the lower owate oblong, on footstalks, nearly smooth on the npper side, woolly beneath, crenated, stem angular and panicled.

English Botany, t. 58.-English Flora, vol. i. p. 310.-Hooker, British Flora, vol. i. p. 111.-Lindley, Synopsis, p. 181.

Root tapering. Stem from two to four feet high, erect, somewhat angular, branched at the top, elothed with short close woolly hairs. Leares numerous, smooth on the upper side, or slightity scattered orer with hairs, beneath thickly clother with short yellowish wool, with a strong mid-rib, and numerous branched reticulated veins, the margins crenated, the lower ones orate-oliong, contracted upwards, and tapering at the base into a footstalk, becoming more lanceolate as they arlvance upwarks, and the fuotstalks shorter, until at length they are sessile, orate-lanceolate, with a more or less acute or tapering puint. Inflorescence a branched paniculated raceme, its branches erect, scarcely spreading, angular and woolly, densely crowled with white flowers, some on a short footstalk, others sessile. Bractea small, lanceolate, smooth within. Calyx of five narrow lanceolate woolly segments, one shorter and rather narrower than the others. Corolla with a short tube, wheel-shaped, the limb of five spreading oblong acute reiny segments, wooly on the outside, smooth within. Stamens with short white woolly inflexed filaments, nearly equal in length, inserated into the tube of the corolla, rather small, orange-coloured. Anthers yellow, all similar in size. Style slender, hairy below, smooth, and swelling uprards, nearly as long as the corolla, with an obtuse

VOL. I.

$2 \mathrm{~N}$ 
stigma. Capsule orate, somewhat compressed, furrowed on each side, woolly, of tro cells, opening with two valves, surrounded with the persistent calyx. Seeds numerous, small, brown, angular, dotted.

Habitat.-Pastures, road sides, and waste places, especially on a chalky soil.

Biennial; flowering in July and August.

4. V. flocco'sum, Waldst et Kit. (pl, rar. hung.) (Fig. 350.) yellow hoary Mullein. Lower leares ovate oblong, on footstalks, the upper ones sessile, ovate-lanceolate.

V. pulcerulentum, Till.-English Botany, t. 487.-English Flora, vol. i. p. 311.-Hooker, British Flora, vol. i. p. 112.-Lindley, Synopsis, p. 181.

Root tapering, sometimes divided and branched. The whole plant clothed with a soft thich powdery woolliness, haring a unctuous feel when rubbed between the fingers, easily rubbed from the plant. Stem from three to six feet high, erect, stout, much branched, round, or sometimes obscurely angular. Leares numerous, more or less distinctly crenated on the margin, with a strong mid-rib, and numerous branched reticulated reins, above sparingly, but beneath densely clothed with woolliness, the lower and radicle leaves orate oblong, attenuated into a footstalk of variable length, large, often a foot long, hecoming gradually smaller up the stem, with a shorter foutstalk, until they are sessile and lanceolate, often with a tapering point. Inflorescence a large branched paniculater raceme, the branches round, erect, and disposed in a prramidal form, from two to three feet long. Flowers very numerous, crowded, rather large, bright yellow, very handsome, some sessile, others on short footsialls, in crowded alternate tufts, rery woolly. Bractea cordate lanceolate, the upper ones very small. Calyw in five lanceolate somewhat uneriual segments. Corvlla in five oblong ovate spreading segments, with a short tube, woolly externally. Stamens nearly equal, the filaments clotlied with pale yellow or white woolliness. Anthers all similar in size, scarlet. Style about as long as the corolla, slender, somewliat hairy below, smooth and thickened upwards. Stigma obtuse. Capsule woolly, orate, slightiy compressed, scarcely furrowed on each side, surrounded by the persistent calyx, of two cells, opening with (wo valves. Seeds small, numerous, brown, angular, dotted.

Habitnt.-Banks, road sides, and the borders of fields, in a gravelly or chalky soil; frequent in Norfolk and Suffulk, Nottinghamshire, Den, near Cullen, and about Stirling, Scotland.

Biennial; flowering in $\mathrm{July}$ and August.

A curious instance of the irritibility of this plant is mentioned by Sinitls; he saya, if the stem lie smartly struck three or four times with a stick, all the flowers then open will in a few minutes throw off their 
corulla, the calyx clusing round the gremen, so that after eight or ten minutes none will remain on the plant.

It is one of the must magnificent of our native plants; its large panicle of golden-colonred fluwers, with their fringed filaments and scarlet anthers, crowding round the stems for a foot or more long, forms a large pyramid of shiuing gems, not surpassed, if equalled, by any of the genus. It is adminibly calculated for ormamental bushy rock work in pleasure grounds, and two or three plants growing together, have a most splendid appearance; it is also very handsome on borders, especially between and amongst low young shrubs, but is not so well standing alone, without other lower plants about it. The hairs on the stems and leares, examined ly the microscope, are seen beatifully and delicately branched in a stellated manner, like slender stars of highly polished silver.

5. V. pulverulen'tum, Vill. poudery-leaved Mullein. Lower leaves orate oblong, on short footstalks, the upper ones sessile, with an acuminated point, slightly powdery above, beneath densely woolly, subcrenated, stem round, branches of the panicle obtusely angular.

V. nigro-pulverulentum.-Fl. Br. Var. B.-English Elora, vol. i. p. 311.

This species has the general aspect of $V$. floccosum; its leaves, however, are more distinctly crenated, the upper ones with a more acuminated point, the lower ones on longer footstalks, and the upper side of the leaf is less clothed with woolliness, but the under side is densely corcred ; the sten is round below, but above and the branches of the panicle are ohtusely angular, patent, and the hairs of the stamens are somewhat purple, or white, in other respects it is the same as V. floccosum.

Habitat.-Road sides and stony places; "near Norwich, and various parts of Norfolk;" about Yarmouth ; not unfrequent.

Biennial ; flowering in July and August.

How far this may be found a distinct species, we are at present unable to determine; it is readily distinguished from the former, and would appear, from its characters, to be an hybrid between $V$. floccosum and $V$. Lychnitis, or an intermediate species. We have found it in Germany and Italy, a circumstance which favours its being a distinct species, independent of hybrids in plants being of very yare occurrence,

6. V. ni'grum, Linn. (Fig. 351.) dark Mullein. Leaves on footstalks, oblong, heart-shaped, crenated, nearly smooth above, slightly downy beneatl.

English Botany, t. 59.-English Flora, rol. i. p. 312.-Hooker, Buitish Flora, rol. i. p. 112.-Lindley, synopsis, p. 181. 
B. ovatum. The lower leaves ovate, or ovate oblong, contracted at cach end, scarcely cordate at the base, petiolated.-Verbascum nigroLychnitis.-Schrad.

A variety sometimes found, especially in a dry situation.

Root tapering. Stem simple, from two to four feet high, slightly angular, purplish, smooth below, above scattered over with a short soft woolliness; leafy. Leaves green above, and smooth or slightly scattered over with down, beneath pale and woolly, the margins sometimes wared, simply or doubly crenated, with a prominent mid-rib beneath, with branched reticulated veins, oblong, heart-shaped, the radical ones large, sometimes a foot long, on long channelled footstalks, the upper ones smaller, cordate lanceolate, with a gradually shorter stalk, the upper ones nearly sessile. Inflorescence a simple rarely branched racemose spike, of numerous crowded flovers, some sessile, others on a short stalk in alternate clusters, of a bright yellow colour. Bractea narrow, linear, long, downy. Calyx of five linear, nearly equal, somerwat downy segments. Corolla rather small, wheel-shaped, with a short tube. The limb of five ovate obtuse spreading segments, downy on the outside, smooth within. Stamens nearly equal, the filaments densely clothed with purple down. Anthers equal, dark orange colour, or purple. Style nearly as long as the corolla, hairy below; smooth and thickened upwards. Stigma obtuse. Capsule ovate, somewhat compressed, downy, surrounded by the persistent calyx, of two cells, opening with two valves. Seeds numerous, angular, small.

Habitat.-Banks, road sides, and waste places, especially in a gravelly or chalky soil, but not common; rare in Scotland; near Boglehill, east of Cockenzie.-Mr. Neill. Links between Seaton and Gosford.-Dr. Yule. Banks of the river Esk, opposite Cual-pits, and at Brothwick Castle.-Mr. Maugham. Not known in Ireland.

Perennial ; flowering in July and August.

This is a striking and beautiful plant, readily distinguished from the other species. It is said to possess narcotic properties, and to be one of the plants used by poachers to intoxicate fisl, for the purpose of capturing them. The whole plant is mildly astringent, said to be useful in a weakened state of the bowels; and Galen says that a decoction of it is useful as a wash for the mouth, in pains of the teeth and gums.

7. V. virga'tum, Wilh. (Fig. 352.) large-flowered Primrose-leaved Mullein. Leaves ovatc-lanceolate, toothed, sessile, partly decurrent, the radical ones downy, somewhit lyrate, stem erect, branched, flowers in long racemes of small alternate clusters, nearly sessile.

English Botany, t. 550.-English Flora, vol. i. p. 312.-Hooker, British Flora, vol. i. p. 112.-Lindley, Synopsis, p. 181.

Root of thick tapering fleshy branches. Stem from five to six feet 


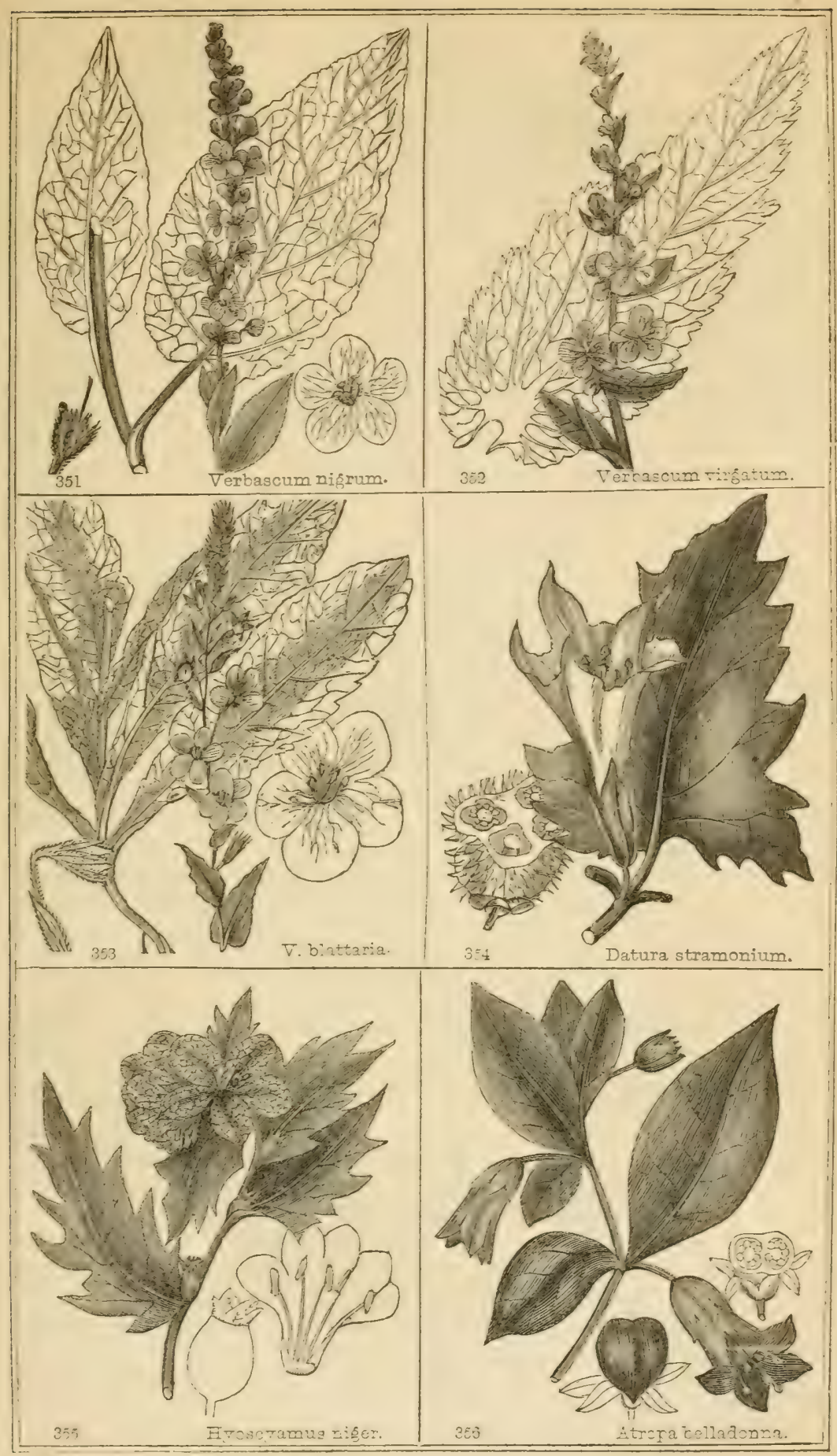



ligh, or more, stout, round, or slightly angular, mostly much brauched from the bottom upwarls, smooth, or somewhat downy, leafy, and partially winged from the more or less decurrent leaves. Leaves variable, the lower nnes large, much resembling those of the Primrose, more or less lyrate, sometimes erosed, doubly toothed or scrrated, those on the lower part of the stem oblong lanceolate, doubly toothed gradnally towards the top of the stem, and at length heart-shaped, taper-pointed, and simply serrated or toothed, clasping the stem, and more or less decurrent, the upper ones are generally smooth, the lower more or less profusely scattered over with stellated, sometimes glandular hairs, all a palish green, with a strong mid-rib, and numerous branched reticulated reins. Inflorescence long, simple or branched racemose spikes terminating the stem and branches. Floucrs large, bright yellow, in lateril clusters, of from one or two on the top of the stem, to about six arising from the axis of a heart-shaped lanceolate, bractea gradually becoming smaller, sume of the flowers nearly sessile, others on a stalk as long as the calfs, hairy and elongating after flowering. Calyx of fire nearly equal lanceolate viscid segments, persistent cnlarging and enveloping the capsule. Corolla wheel-shaperl, rather large, bright yellow, of fire orate spreading nearly equal segments, downy on the outside, smooth and veiny within. Stamens unequal, two with long slender filaments, less thickly clothed with purple down, and bearing larger curved anthers than the others. Style ahout the length of the corolla, slender, somewhat bairy at the base, thickened upwards. Stigma obtuse. Capsule globose, somewhat hairy, and scarcely furrowid on each side, of two cells, opening with two valves. Seeds numerous, small, angular.

Habitat.-Fields and road sides; rare. Fields near Wrexham.Mrs. Nash. Near Plymouth.-MIr. Banks. Near Lincoln.-Mr. Nicholson. On the College grounds, at West Green-lane, near Krenmare, in Ireland.

Biennial ; flowering in July and August.

This is nearly allied to the following species, and we are disposed to think that the Lincoln station given for this plant belongs to the following, which we have collected there: we have receired dry specimens from the same quarter, named $V$. virgalum, which are undoubtedly $V$. Blattaria.

8. T. Blat'taria, Linn. (Fig. 353.) Moth Mfullein. Leaves smooth, oblong, acute, subcordate at the base, embracing the stem, crenate, the radicle ones orate oblong, attenuated at the base, sinuated ; stem erect, hranched; flowers in a long raceme, solitary, on a footstalk half as long again as the bractea.

English Botany, t. 393.-Euglish Flora, vol. i. p. 313.-Hooker, British Flora, vol. i. p. 112,-Lindley, Synopsis, p. 181. 
Root tapering. Stem erect, smooth, roundish, or obtusely angular, three or four feet ligh, branched upwards, leafy. Leaves smooth, variable, those from the root aud lower part of the stem ovate oblong, acute at the point, but tapering at the base, and sometimes with a short footstalk, the margin sinuated and crenated in an irregular manner, often nearly a foot long, lecoming, as they adrance up the stem, smaller, less sinuated until simply crenated, smaller, obloug, with an acute point, the upper ones more or less deeply heart-sbaped at the base, clasping the stem, and sometimes scattered orer with glandular hairs, the whole rather a dark shining green, with a strong mid-rib, and branched lateral veins. Influrescence a simple raceme terminating the stem and slender branches, which are more or less profusely scattered over with glandular hairs. Flowers rather large, solitary, or sometimes in pairs, on a rather long flover stalk, scattered orer like the bractea and calyx with glandular hairs. Bractea orate-lanceolate, shorter than the flower stalk. Calyx of five nearly equal lanceolate segments. Corolla in five orate spreading segments, the margin often wared, a dark yelluwish brown externally, sometimes slightiy hairy, bright yellow within, and more or less marked with purple at the base. Stumens unequal, two longer thau the otbers, with larger recurved anthers, the upper part of the filaments smooth, naked, but the lower part like the whole length of the others, thickly clothed with longish purple hairs. Style nearly as long as the corolla, slender, or slightly hairy at the base, smootb, mostly thickened upwards. Stigma obtuse. Capsule globose, smooth, or tbinly scattered over with glandular hairs, slightly furruwed on each sicle, surrounded by the persistent calyx, Laving two cells, opening with two valves, and containing numerous small angular seeds.

Habitat.-Field̀s and bants, in a rrarelly soil, but rave; at Cołham, and several uther places in Kent; not uncommon in Deronshire and Cornwall; near Plymouth.-Mr. Banks. Found in several places about Linculn. $-R$. $D$.

Annual; flowering from July to September.

This beautiful species is frequently cultivated in gardens, aud is highly ornamental; commences fluwering in June, and coutinues to produce a succession of its flowers the remainder of the summer, and even in the autumm, when grown in a shaded situation. A variety with white flowers is not unfrequently produced hy cultivation, which is remarkably delicate and beautiful.

The leaves and tender branches of this plant are said to be destructive to the Cockroach (Blatu micmalis), and from this circumstance the Romans called it Blattaria, the specific name by which it is now distinguished. If it still relaius thie reputed virtue, its use may be very great to the iuhabitusts of houses infested hy this troublesome insect; and in the stores and warehouses it may be suattered about. 
without danger of any ill effects arising from it, as is often the case in using many of the poisons for that purpose. The Cockroach is well known, by its deep brown colour, flat body, small head, almost concealed by the thorax, haring long slender antennx, and spinous legs, the elytra and wings shorter than the hody; the female is without wings. They hide themselves rluring the day in crevices, \&c. the females secreting a peculiar cellular substance, in which she deposits her eggs. They come out at night, and heing very voracious, are particularly destructive in kitchens, mills, granaries, and ships'stores, especially the $B$. gigantea. They are said to have been originally brought from the Levant, but are now common in all parts of Europe.

\section{GENUS XXIII. DATU'RA.-LINN. Thom-apple.}

Nat. Ord. Solan'Ee. Juss.

Gen. Char. Calyx tubular, with five angles and five teeth, falling away, leaving a broad persistent orluicular base. Corolla funnelshaped, with a long tube, the limb plaited, five angled and five lobed. Stigma of two plates. Capsule spinous or smooth, four celled, frequently with imperfect disseppiments, four valves, and many seeded.-Named, it is supposed, from the Indian word datiro.

1 D. Stramo'nium, Linn. (Fig. 354.) common Thorn-apple. Herbaceous, leaves ovate, angular, and sinuated, smooth; fruit orate, erect, clothed with numerous spines.

English Botany, t. 1288.-English Flora, vol. i. p. 314.-Hooker, British Flora, vol. i. p. 110.-Lindley, Synopsis, p. 180.

Root tapering. The whole plant smooth, from one to three feet high. Stem round, much branched, and spreading leafy. Leaves on footstalks, ovate, variously angular, acutely sinuated and toothed, large, smooth, shining, of a dullish green, with a mid-rib, ard numerous lateral branched veius. Flowers solitary from the axis of the stem or leaves, on a short stalk, elongating, nearly as long again after flowering. Calyx oblong, tnbular, swelling upwards, with five angles and five lanceolate teeth, thickened at the base, where it separates in a circular manner after flowering, which forms a fleshy reflexed persistent rim acound the base of the capsule. Corolla white, funnel-shaped, the tube half as long again as the calyx, cylindrical, the limb spreading, with five folds and five angles, each forming a mid-rib to the five waved pointed lobes. Stamens as long as the tube, and united to it in their lower half. Style as long as the stamens. Stigma of two obtuse plates. Capsule orate, or roundish, thickly clothed with smooth spines, 
four valved and four celled, two of which are generally only divided half way by their disseppiments, hence though four celled in the lower part, it is only two in the npper. Seeds numerous, flattish, kidney shape, and dotted.

Habitat.-Waste ground, especially in the vicinity of gardens.

Annual; flowering in July.

This is a naturalised plant, now found in almost all parts of England, and was probably introduced from America, and ought not to be admitted into the British Flora; but since it is so commonly found, and a plant 'of importance to be known, we have given it a place here.

The whole plant is narcotic and stimulent, with a foetid unpleasant odour, frequently in a very short time producing lead-ache in some people, and has a bitter nauseous taste. The narcotic principle which it contains, according to the analysis of $\mathbf{M}$. Brandes, resides in a peculiar alkaline salt, which he has named Daturine. The effects which the plant of this genus have upon the system are variously stated by authors, and many strange tales have been told of the use made of it by the savages of the Asiatic Islands, and people of more cirilised nations, previous to the committal of various atrocious crimes.

D. Stramonium is called by the Americans the Deril's Apple, or the Jamestown weed, from the circumstance of its being there found so extremely abundant, and producing upon the new settlers, when eaten, such extraordinary effects. Beverly's account of it, in his History of Virginia, is somewhat amusing. He says, "the Jamestown weed, which resembles the thorn apple of Peru, is supposeci to be one of the greatest coolers in the world. This being an early plant, was gathered very young for a boiled salad by some of the soldiers sent thither to quell the rebellion of Bacon, and some of them ate plentifully of it, the effect of which was a very pleasant comedy, for they turned natural fools upon it for several days. One would blow up a feather into the air; another would dart straws at it with much fury; another (stark naked) was seen setting up in a corner like a monkey, grinding and making mouths; a fourth would fonrly kiss and paw his companious, and sueer in their faces, with a countenance more antic than any in a Dutch droll. In this frantic condition they were confined, lest in their folly they should destroy themselses. A thousand simple tricks they played, but after eleren days returned to themselves again, not remembering any thing that had passed."

Numerous cases are on record of the narcotic properties of stramonium, and it is eren said to be used by the Turks instead of opium, and that the Chines infuse the seerls in beer. It has been recommended in cases of mania and epilepsy, but its beneficial effects are very douhtful, from the reported trials that have been made with it. Dr. Barton, of America, regards it as a remedy of great efficacy, and has reported 
sereral cases; he mentions that of a child suddenly seized with idiotcy, without ferer. The pulse, he says, was natural, the tongue clean, and no internal function disturbed, excepting that of the brain. The boy appeared very lappy, talling, laugluing, and in constant motion; yet so weak, he could not stand or walk without tottering. An emetic was administered, some seeds of the Stramonium were rowited up, and the child shortly after recovered. Dr. Fowler also has related the case of a little girl, who took a drachm and a half of the seecis. In less than two hours she was attacked with maniacal delirium, accompanied with spectral illusions, and she remained in this state most of the following night, but had some intervals of lethargic sleep. Text morning, after the operation of a laxatice, she fell fast asleep, and awoke after some hours quite well. The seeds have been sometimes taken in mistake, and at others alministered designedly, sometimes producing death; but the symptoms produced when taken in poisonous doses appear very rariable. Tliere is generally great delirium, dilatation of the pupils, and stupor; sometimes there are spasms, and palsy also occasionally occurs. Blood-letting, emeties, and purgatives, are the remedies found to gire relief, but bleeding seems to be particularly called for, from the symptoms of determination of blood to the head.

The deleterious effects of this plant have also been produced by the application of the leares to the skin, when deprived of its cuticle, as in the cases of burns.

A poultice of the bruised leares has been fomd an useful application to inflammatory tumours, and an vintment made of the leases is said to be useful in homorrloides; and the extract in closes of half a grain, gradually increased to ten, twice a day, is said to have given great relief in severe chronic pains; its use requires, however, great caution. The dried leaves smoked in the manner of tobacco at one time obtained for it great reputation in relieving the paroxysm of spasmodic asthma, a practice introduced into England from Ceylon; it has been, however, found so often to fail in its beneficial effects, as to have lost much of its fame.

As a garden flower it is not much admired; it is too spreading, and but little ornamental. The flowers have a pleasant fragrance, espe. cially at night, but it is not now much cultivated.

\section{GENUS XXIV. HYOSCY'ANITS-LINN. Henbane.}

Nat. Ord. Solan'E

Gex, Char. C'alyx tubular, tire-cleft, persistent, Corolla funnelVOL. I. 
shaped; the limb oblique, somewhat unequal, five lobed. Capsule ovate, furrowed on each side, swelled at the base, contracter abore, and opening with a transrerse aperture. Seeds numerous.

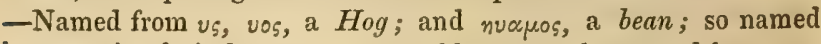
because its fruit bears some resemblance to a bean, and hogs are said to eat it as a medicine.

1. H. ni'ger, Linn. (Fig. 355.) common Henbane. Leaves ovateoblong, sinuated, amplexicaul abore, petiolated below ; flowers nearly sessile.

English Botany, t. 591.-English Flora, vol. i. p. 316.-Hooker, British Flora, vol. i. p. 110.-Lindley, Synopsis, p. 181.

Root tapering. Whole plant more or less profusely clothed with soft viscid hairs, and of a foetid odour. Stem from one to two feet high, round, simple, or branched, very leafy ; the lower leaves on short footstalks, the upper sessile and embracing the stem, large, alternate, ovate-oblong, pinnatifid, or deeply sinuated with a broad mid-rib, and small lateral veins, mostly very hairy. Inflorescence a terminal leafy recurved raceme. Flowers on short stalks from the axis of the floral leaves, numerous, but only a few blown at one time. Calyx tubular, swelling below, reined with dark purplish veins, the limb fire cleft. Corolla funnel-shaped, the tube short, cylindrical, the limb five lobed, deeply divided, one segment broader than the rest, a pale sulphur colour, beautifully peneilled with dark purple veins. Stamens inserted into the tube of the corolla, of unequal lengths. Anthers purpleish. Capsule ovate, somewhat compressed with a longitudinal furrow on each side, closely enreloped with the enlarged tuhe of the calyx, bellying below, contracted into a neck above, which falls off transversely like a lid, and exposes the two cells within. Seeds numerous, obovate, dotted, abounding with oil.

Habitat.-Waste rubbishy places, especially in a chalky or limestone soil; not uncommon.

Annual; flowering in June and July.

Henbane is a narcotic plant, and when it is taken in any considerable quantity is, like opium, quickly poisonous to man and most animals. Swine are said to eat it with impunity; hence it has in sume places the name of $\mathrm{Hog}$-weed, but if they eat it in too great a quantity, it proves also poisonous to them. On a village green, near Worksop, Nottinghamshire, this plant used to grow abundantly, and was called by the villagers Hog-weed, from the pigs cating it when no other animals would; but a number of these pigs occasionally dying from eating too much of this plant, they took the means of further preventing their loss, by destroying every year all the plants they could meet with; now scarcely one is to be met with, and the apothecary is obliged to seek elsewhere for his supply of this medicine. Goats and sheep will eat it, but very sparingly. 
The whole plant is poisonous, with the exception, according to Smith, of the seeds, which abound in oil, and he says he has eaten them with impunity when a youth. This appears, however, from the accounts of some authors, to want confirmation, and that they are poisonous, but in a diminished degree. Dr. Arehibald Hamilton has described (in the Edin. Phys. and Lit. Essays, Fnl. ii. p. 268.) the case of a young medical student, who took about twenty-five grains of the seeds, he was seized in half an hour with lassitude and somnolency, and successively with dryness of the throat, impeding deglutition, convulsive morements of the arms, incoherency, total insensibility of the skin, and loss of recollection. These symptoms continued about twelve hours, and then slowly receded. From which it will seem that the seeds are not to be taken with impunity, but are dangerous, as the rest of the plaut. Other cases of a similar result are on record, and we find in Pyl's Magazine the case of two boys, a few minutes after eating the seeds, were attacked with convulsions and heat in the throat; one of them, who could not be made to romit, died in the course of twelre hours. The seeds and capsules smoked like tobacco, are a favourite remedy with some people for the cure of the tooth-ache; but if relief is to be obtained by this means, the leares will be found better to answer the purpose. The roots are equally as poisonous as the rest of the plant; Orfila, indeed, says they are more so, but vary in their actirity at different seasons of the year. Mr. Wilmer, in his Treatise on the Poisonous Vegetables of Great Britain, has given an account of six persons of one family who were poisoned by eating the cooked roots for dinner of hyoseramus, by mistake for those of parsnips. Some of them were delirious, and danced about the room like manacs; one had the appearance of being drunk, and one woman became profoundly and irrecoveralily comatose. Emetics could not be swallowed, stimulating injections had no effect, the application of various external stimulants failed to rouse her, and she expired the following morning.

The symptoms produced by an over duse of the plant, are giddiness and stupour, insensible eye, and clilated pupil, difficulty of breathing, frequently locked jaw and distorted features, the pulse small and intermittent, with coldness and palsy of the extremities. Emptying the stomach of its contents, either by means of the stomach pump, or by emetics, afterwards administering purgatires, aud laxative injections, and giving the patient rinegar and water, are the means found to give relief, and restoration speedily follows.

Medicinally henbane is used either in the form of extract or tincture, and in doses of from two to six grains of the former, and from twenty to sixty drops of the litter, usually inducing pleasant sleep, and may be administered in all cases where opium is indicated, frequently producing the desired effect, without the unpleasantness which opium 
causes in dreams and disturbed sleep; and at the same time it does not constifate the howels, but ratber acts as a laxatire. Esternally the leares are used in the form of fomentations, to diminish the pain and irritation of inflamed parts in gout and rheumatism, but with much greater adrantage to scrofulous and cancerous ulcerations, and inflamed homorrtoids. The tincture is frequently an useful application to strumous or chronic inflammations of the conjunctira; it has also the effect of contracting the pupil, but is much less powerful than belladonna for that purpose.

The actire principle of the plant resides, according to the inrestigations of M. Brande, in a peculiar alkaline salt, which he has named Hyosciamia, which crystallizes in long prisms, and forms neutral salts with the acids.

The plant by cultiration seems to loose in its actire properties, and the flowers become much paler. Wild specimens are also sometimes found quite pale, with indistinctly coloured reins, and is the rariety B. pallidus.

\section{GENUS XXV. ATRO'PA.LINN. Dwale.}

Nat. Ord. SOLAN'EE. JUSS.

Gev, Char. Calyac bell-shaped, fre cleft. Corolla bell-shaped, with fire equal lobes. Stamens distant. Berry within the calyx, globose, two celled.-Name from Atropa, one of the three fatal sisters who cut the thread of life, in allusion to the fatal effects of the plant upon those who are subjected to its influence.

1. A. Belladon'na, Linn. (Fig. 356). common Duale, or Deadly Night-shade. Stem berbaceous; leares orate, entire; flowers axillary, on short peduncles.

English Botany, t. 592.-English Flora, vol. i. p. 317.-Hooker, British Flora, vol. i. p. 111.-Lindley, Synopsis, p. 182.

Root thick, lleshy, whitish. Whole plant of a dark lurid aspect, and of a foetid unpleasant odonr when bruised. Stcm round, smouth, much branubed, from two to four feet high, lierbaccous, somewhat down alowe. Leaie numerous, mosily opposite, one grenerally smaller than the other, langr, onate, acnte, entire, smoonh, with a mirl-gib, and rumerous latemi reins, on f ststalls. Floners sulitary from the axis

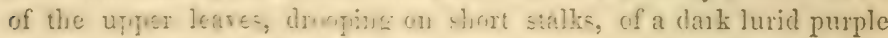
colour. Calyx bell-shaped, fire cleft, sinootl, or corered orer with short close down. Corolla bell-shaped, about three times as long as the calys, sith a short tulie, firc cicf at the extrenity, the segments speading, acute, veiny. Sinmens inserted into the tube of the corolla. 
Filaments thearl-shaped, curred within the corolla, hairy at the base around the mouth of the tube. Anthers heart-shaped, yellow. Style longer than the corolla. Stigma large, capitate. Fruit a shining violet black berry, as large as a cherry, inclosed within the calyx, globular, with a furrow on each sicle, wwo celled, with numerous small kidney-shaped seeds attached to the placenta, in the middle of the disseppiments.

Habitat.-Hedges and waste places, especially amongst ruins in a calcarious district; not very common.

Perennial; flowering in June and July.

Dwale, or Deally Night-shade, is one of the most poisonons of our native plants; it was called by the ancients Solanum lethale, maniacum, or furiosum, all names expressive of the powers which the plant possesses. It present specific name bella-donna (beautiful lady) refers to the use that the Italian ladies made of the berries, as a cosmetic to beautify the appearance of the skin, but we cannot learn that it is used now by them for that purpose.

Numerous cases are on record of the poisonous effects of this plant when taken by mistake for some other, or administered designedly, producing pain in the head, restlessness, dimness of vision, dilitation of the pupils, and subsequent loss of sight, dryness of the throat, delirium, coma, and sometimes conrulsions. The delirium is not always present, and is mostly of the pleasing kind, with constant and immoderate laughter, talking coutinually, but generaily on lively subjects. The muscles of the eyeballs are sometimes spasmorlically contracted, as well as the muscles of deglutition, especially when any thing is attempted to be swallowed. At other times the effect produced resembles somnambulism, as occurred in the instance of a tailor, who was poisoned with an injection of the infusion of hella-donna, and who for fifteen hours, though speechless and insensible to external objects, went through all the usual operations of his trade with much vivacity, and moved his lips as if in conversation. Bloody stools, and aphthous nlcerations of the throut and mouth, are mentioned as being sometimes present, and also violent stranguary, with suppression of urine and bloody micturition.

The most frequent cases of acciclental poisoning of this plant are from children being tempted to eat the black shining cherrv-like fruit, which is sweetish, without any unpleasant odour. It is said that in some cases even half a berry has proved fatal; but an instance is related by M. Gigault, a French physician, of a young man who took a pound of the berries before going to bed, and was not subjected to treatment until the next morning, when he was found in a state of delirum, but soon recovered after the operation of emetics and purgatives; indeed, fatal results now seldom occur from the accidental 
taking of this plant, for as delirium comes on some time before the state of stupor ensues, suspicion is excited, and the stomach may be emptied either by means of the stomach pump, or emetics, before the poisonous quality has been absorbed in sufficient quantity to prove fatal. After this has been done, the bowels ought to be cleared by active purgatives, assisted by laxative injections. The drinking of regetable acids as vinegar, is also said to be useful.

As a poison this plant appears to have been long known, and used for treacherous purposes. Buchanan, the Scottish historian, relates that the Scotch, under the command of Macbeth, owed their victory over the Danes to their having given to the troops of Sweno, during a truce, bread and a drink of ale and wine, in which was mixed the poison of this plant. After very accurately describing the botanical character of the plant, he adds, "vis fructui, radici, ac maxime semini somnifera et quiæ in amentiam, si largius sumantur, agat." This remarkable circumstance appears not to have escaped the observation of Shakspeare, for Banquo in his speech says, "Or have we eaten of the insane root that takes the reason prisoner?" It is supposed to have been known even long before this period, for Plutarch in his account of the Parthian war, when speaking of the want of provisions by the soldiers of Mark Authony, says, "ThGse who sought for herbs obtained few that they had been accustomed to eat, and in tasting unknown herbs they found one that brought on madness and death. He that had eaten of it immediately lost all memory and knowledge, but at the same time would busy himself in turning and moving every stone he met with, as if he was upon some rery important pursuit. The camp was full of unhappy men, bending to the ground, and thus digging up and removing stones, till at last they were carried off by bilious vomiting, when wine, the unly remedy, was not to be found."

Medicinally, bella-donna is used in the form of extract and tincture; it is powerfully narcotic, and is said to have been found of use in obstinate intermittents, chronic rheumatism, gout, paralysis, amaurosis, epilepsy, and pertussis, as well as relieving painful neuralgic affections. Its intermal administration, however, requires much caution; applied externally we have seen it extremely useful in the form of a plaster, combiued with soap cerate, in relieving hooping cough; also applied in the form of ointment to painful, irritated scirhus ulcers. The extract smeared round the eye, or the tincture dropped into it, is well known as shortly producing dilatation of the pupil, and is of the greatest use previous to the performing certain operations on the eye, and in some discases of the iris, upon the radiated fibres of which, observes Mr. Adams, its operation secms to be limited.

Bella-donna appears, from experiments that have been made, to have the power of protecting individuals to whom it is administered from the infection of scarlet fever, during the prevalence of that con- 
tagious disorder. It should at first be administered in small doses, gradually and cautiously increasing it.

\section{GENUS XXVI. SOLA'NUMI.LINN. Night-shade.}

Nat. Ord. Solan'Ex: Juss.

Gen. Char. Calyx five or ten partite. Corolla wheel-shaped. Anthers connivent, oblong, opening with two pores at the extremity, Berry roundish, two or more celled. - Name thought to be derired from solor, to comfort, on account of the medicinal properties of some of the species.

1. S. Dulcam'ara, Linn. (Fig. 357.) Woody Night-shade, or Bittersweet. Stem shrubly, flexuous, climbing, leaves ovate, cordate, upper ones hastate, corymbs drooping, inserted opposite the leaves.

English Botany, t. 565.-English Flora, rol. i. p. 318.-Hooker, British Flora, vol. i. p. 111.-Lindley, Synopsis, p. 182.

Root woody, of numerous long slender branches, and tufts of branched fibres. Stem woody, slender, straggling, branched, several feet long, especially when supported by other plants, roundish and smooth below, downy towards the extremities. Leaves smooth, alternate on footstalks, the lower ones ovate, heart-shaped at the base, the upper ones narrower, and mostly hastate at the base, a palish green, with a mid-rib, and numerous lateral branched reins. Inflorescence a lax branched corymb, on a longish stalk, arising opposite the leares. Flouers numerous, dark purple, on a mostly smooth pedicle, arising from a swollen bractea. Calyx smooth, persistent, of five or ten obtuse segments. Corolla wheel-shaped, with a very short tube, the limb spreading, of from four to six segments, orate-lanceolate, each with two green tubercles at the base, the margins finely ciliated. Stamens from four to six, according to the number of the segments of the corolla, but five is by far the most usual number. Filaments very short around the mouth of the tube of the corolla. Anthers long, yellow, large, united together in a hollow cone-shaped manner, each opening at the extremity by a small pore. Style in the middle, and longer than the stamens. Stiyma rather small, obtuse. Fruit an ovate berry, bright scarlet or yellow, having from two to six cells, and numerous roundish compressed seeds in the midst of the soft pulp.

Habitat.-Hedges and bushes; frequent in England, less so in Scotland and Ireland.

Shrub; flowering in June and July.

B. tomentosum. Stems and leares more or less clothed with a soft down. 
A rariety occasionally found in dry places, as on old walls, \&c.

The Bitter-sweet or felon-wood has been usually considcred a rery poisonous plant, but from the experiments of Orfila and others, it does not appear to possess by any means active poisonous properties; it has the same effect as Hyoscyamus, but in a much feebler degree. M. Dumal has given to a $\operatorname{dog} 180$. berries, or four ounces of the extract, without producing any ill effects, and he quotes an experiment on the human subject, where thirty-two dracbms of extract were taken without injury. From which it would appear that it is scarcely entitled to the name of a poisonous plant. The same may be also stated with respect to the following plant, $S$. nigrum, which is, perhaps, the most active of the two species; but Orfila says it is not stronger than lettuce opium. Subjected to chemical analysis, M. Desfosses discorered their active principle to reside in a peculiar alkaloid, which is named solanine, or solania, possessing narcotic properties, but is not an actire poison.

The roots and stems of this plant are the parts used medicinally; when chewed, they have at first a bitter taste, which shortly clanges to a considerable degree of sweetness; and lience it is that the plant has obtained the name of Bitter-sucet. It is narcotic, and has been found useful in humoral asthma, dropsy, and chronic rheumatism, but more especially in cutaneous diseases; and we have known it used to a considerable extent in syphilitic affections in place of sarsaparilla, and apparently with equal benefit as that fur more expensive medicine. It is generally used in the form of infusion or decoction, but requires cautious watching in its administration, in not giving too large a dose, producing in such cases nausea, vomiting, fainting, and palpitation; if such symptoms occur, the dose must be climinished, and the addition of some aromatic is advisable.

2. S. ni'grum, Linn. (Fig. 358.) common or Garden Night-shade. Stem herbaceous, leares ovate, toothed and wared, umbels simple, lateral, drooping.

English Botany, t. 566.-Euglish Flora, vol. i. p. 319.-Hooher, British Flora, vol. i. p. 111.-Lindley, Synopsis, p. 182.

Koot annual, much branched. Stem erect, much branched and spreading, from one to two feet high, angular, or slightly winged, especially the branches, and scattered over especially towards the extremities, with soft hairs. Leures numerous, alteruate, on footstalks, smooth, or slightly hairy, orate, bluntly toothed or waved, somewhat decurrent at the base, with a mid-rib, and numerous lateral veins. Inflorescence a simple racemose umbel, on a short hairy stalk, arising solitary from the stem, in lise space between the lranches, mostly about an inch below the upper branch. Flowers not very numerous, whitish, with at musky scent, chrooping, each on a slrort hairy pedicle, thickened towards the extremity, Calyx of five obtusely angular 



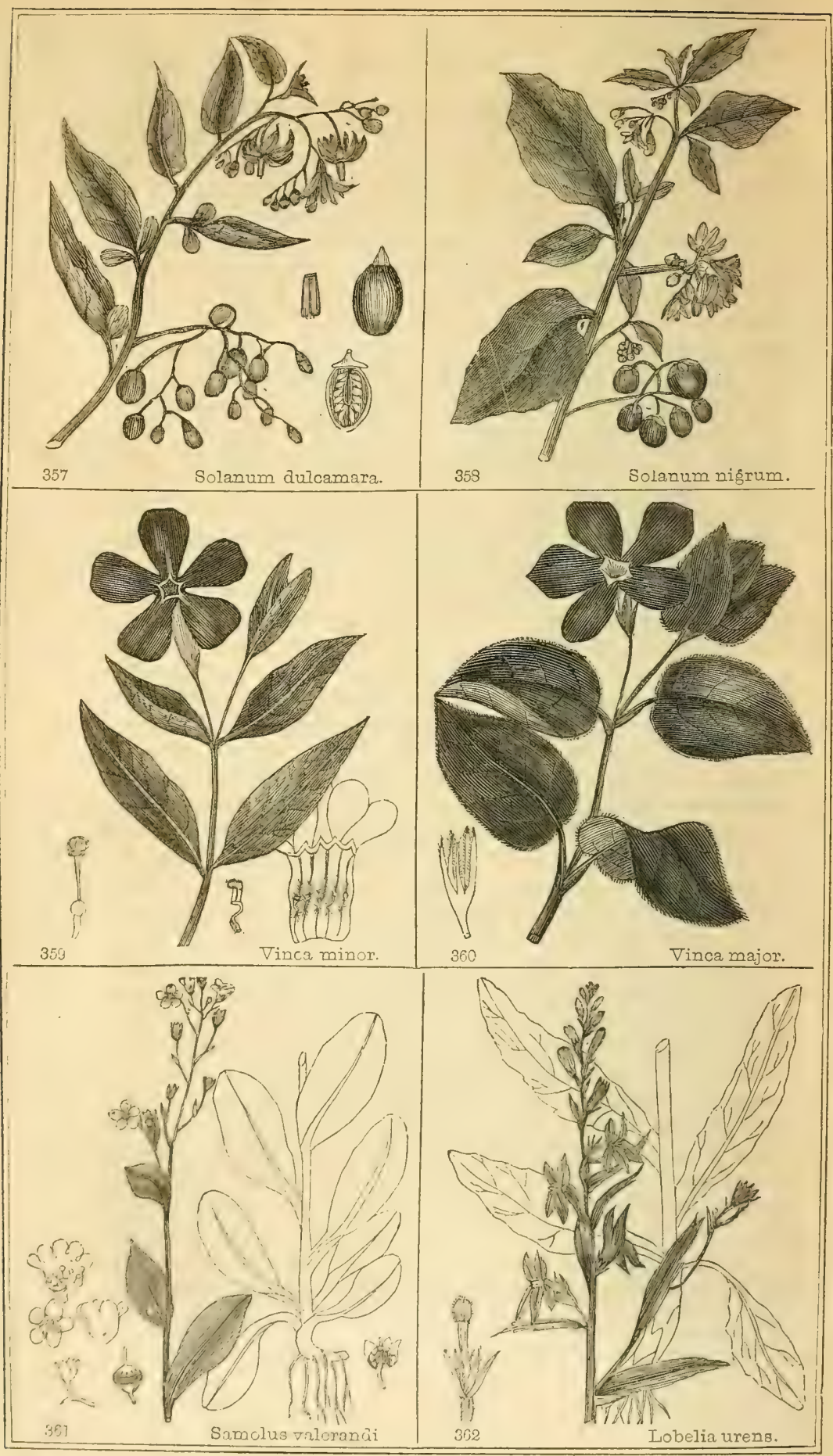


hairy segments. Corolla wheel-shaped, with a short tube, and fire oblong lanceolate spreading segments, finely downy on the outside, and fringed on the margin. Stamens with very short flaments. The anthers yellow, oblung, united together in the form of a tube, opening at the apex with a small pore. Style downy, longer than the stamens, dilated at the base. Stigma obtuse. Fruit a round smooth black berry, with numerous orate compressed seeds.

Habitat. - Waste places, road sides, \&c. ; not uncommon.

Annual ; flowering from June to September.

B. hrmile, a smaller plant, smoother, with the leaves less decurrant, the angles of the stem less distinct, and with yellowish berries.

It is sometimes found growing with the above, and is the S. Jumile of Bernhard, the S. luteo-vireis of Gemel. and the S. nigrum $\delta$ De Cand. By the German Botanists it is considered a distinct species, but we are unahle to satisfy ourselves of its being other than a rariety of S. nigrum.

\section{GENUS XXVIT. VIN'CA.-Linn. Periwinkle.}

Nat. Ord. A POCYNE'正. JusS.

Gen. Char. Calyz five partite. Corolla salver-shaped, the segments oblique, spirally imbricated in the bud. The tube long, its orifice prominent, with tive angles. Anthers closing over the pistil. Stigma crowned with a tuft of hairs. Follicles two erect. Seeds naked, (without seed down).-Name from vincio, to bind, either from its trailing stems binding round those of other plants, or because it is used in some places for wreaths and garlands.

1. V. minor, Linn. (Fig. 359) lesser Periwinkle. Stem procumbent, leaves oblong lanceolate, their margins, as well as the segments of the calyx, smooth.

English Botany, t. 91\%.-English Flora, vol. i. p. 339.-Hooker, British Flora, vol. i. p. 114.-Lindley, Synopsis, p. 176.

Root with long creeping underground stems and branched fibres. Stem trailing, frequently much branched at the base, round, smooth, slender, simple, abrove leafy, the lower parts strong and very tough. Leaves opposite, smooth, shining, ovate lanceolate, on short channelled footstalks, the upper ones more acute at the extremities, mid-rib rather strong, with slender branched veins. Flowers solitary from the axis of the upper leaves, on a smooth, slender, erect stalk, shorter than the leaves. Calyx of five linear lanceolate segments, nearly equal, and

VOL. I. 
not half as long as the tube of the corolla. Corolla salrer.shaped, the tube dilated upwards, and with slender reins running its whole length, the limb riolet purple, about an inch wile, ol five flat spreading obliquely truncated segments, spirally twisted ingether in the bud, the orifice of the tube surrounded with fire prominent angles, paler than the rest. Stamens fire, arising about the sisddle of the tube; above their origin to the orifice of the tube is clothed with short white shining hairs. Filaments short, dilated upwards, smooth above, hairy below, curved, beneath the stigma they are bent with an acute angle, afterwards curving over it, and with the connivent anthers turning over its summit quite enclose it on all sides. The anthers flat, auriculated at the base, curred over the stigma, pale yellow, of two cells opening on the inner side, with longtitudinal fissures near the margins, the upper or convex surface mostly with a few simple hairs scattered over it, especially on the margin. Style short, smooth, swollen upwards. Stigma flat orbicular glandlular, haring from its disk, on a short stalk, a thick tuft of delicate white silky hairs. Fruit an erect two celled follicle, surrounded with the persistent calyx. Seeds without seed down, but seldom perfected in England.

Habitat.-Woods, hedges, groves, and shady places; not unfrequent in various parts of England, not so common in Scotland or Ireland.

Perennial; flowering from May to July.

This, we fear, in various stations descrihed for it, is often the ontcast of gardens; but it is decidedly wild in Devon, according to the Rev J. S. Tozer, both with blue and white flowers. The white flowered variety is very common in gardens, and the leaves also variegated green and yellow; this variegation appears to he owing to the kind of soil in which they are grown. We have repeatedly taken fine healthy green leaved plants with purple flowers from a good soil, and planted them in one of poor rubbishy sand, gravel, \&c., and in the course of one or two years the leaves have become variegated, and the flowers paler and shortly white; if these same plants were again removed to a good soil, they would soon regain their former state of green leaves and purple flowers. Both this and the following species are extremely useful plants to the gardener, growing and ornamenting with a good cover all the year, situations under the shade of trees, the drip of buildings, \&c. where most other plants would perish; and they are not in the least particular as to the atmosphere being free from the smoke of houses: this renders them extremely useful in ornamenting suburban plantations, shrubberies, \&c. afforling a lively green cover all the year by their plentiful leaves, and in some situations they are scarcely ever without flowers.

$V$. minor, the Clematide prima of the old authors, was likened by them to a serpent creeping amongst the grass. The stems and leaves, 
bruised in wine, they used as an astringent in dysentery, and as a gargle in relaxed sore throat; the bark masticated relieved tooth-ache; made into a plaster it cured the bite of serpents ; and bruised in vinegar it relieved the stiug of wasps.

It has long been the custom amongst the peasantry in ltaly to wreath the brow, and, indeed, the whole body of unmarried persons, both men and women, as well as children, with this plant, intermixing with it various other evergreens and flowers of different kinds, forming gay garlands, and placing upon the breast a large bunch of the finest flowers that the season will afford; dressing in fact, the whole body in a vegetable garment, composed of the richest productions of Flora that they can meet with. This practice is still followed, especially amongst the peasantry in the provinces of Tuscany; and we think it most probable that the generic name of Vinca has been given to it from the circumstance of their using it to bind the bodies of their dead.

2. V. ma'jor, Linn. (Fig. 360.) greater Periwinkle. Stem suberect. Leares ovate cordate, their margins, as well as those of the linear subulate segments of the calyx, ciliated.

English Botany, t. 514.-English Flora, vol. i. p. 340.-Hooker, British Flora, vol. i. p. 114.-Lindley, Synopsis, p. 176.

Root with long creeping underground stems, much branched. Stems numerous, branched and procumbent below, erect above, especially whilst fluwering; round, smooth, and shining, not so long, or s) tough and strong as $V$. minor, although the plant is much larger in all its parts. Leaves opposite, on short footstalks, of a dark shining green, smouth, except the margins being fringed with short white hairs, paler beneath, the lower ones ovate at the apex and base, the upper ovate, attenuated at the apex, rounder, or heart-shaperl at the base, the mid-rib rather strong, with numerous slender branched veins. Flowers from the axis of the upper leaves, on round, erect, slender, smooth footstalks, half as long as the leaves, elongating after flowering, and reflected. Calyx of five narruw long subulate segments, nearly as long as the tube of the corolla, with a mid-rib, and the margins fringed with pale hairs. Corolla a fine blue or purple, but varying from a dark to a very pale blue, almost white, as large again as the last species, salver-shaped, the tube suddenly contracted in the lower half, striated with longtitudinal veins, the limb spreading, of five flat obliquely truncated segments, frequently two inches across, the mouth of the tube surrounded with five prominent angular protuberances. Stamens about the middle of the tube, inserted into the top of the contracted part. The filaments short, and acutely angled at their insertion, smooth, but much dilated upwards, with a membraneous margin above, which surrounds and encloses the lower amular part of the stigma. Anther that, pear-shaped, with a 
dilated auriculated margin at the base, smooth on the inner side, where it is concave, and where the longtitudinal fissures of the cells open, the outer or convex surface of the anther is more or less thickly clothed with rigid pale hairs, they close over the upper tessellated part of the stigma, so that, with the dilated filaments below, and the curved spreading anthers above, the stigma is completely enclosed in a kind of globular case. Style smooth, dilated upwards. Stigma a glandular ring, crowned with a thick tuft of white hairs on the top of a short pedicle from its disk. Fruit a follicle, of two cells, surrounded by the persistent calyx. Seeds several, large, whitish.

Habitat.-Woods and groves; naturalized.

Perennial; flowering in May and June.

An examination of the curious structure of this flower will afford the student much gratification. The stamens are very remarkable, but not more so than the stigmas; the tuft which surmounts the glandular ring is formed of simple and branched delicate hairs, and seem to act as a brush, perhaps to stimulate the discharge of the pollen, which they brush away and convey to the gland below it, upon which it will be observed the granules of pollen adhere. This operation is carried on in a closed case, as it were, which prevents our peeping in and observing the process; but we suppose, from having observed the hairs of the ring differently disposed at one time from another, that they have a peculiar function to perform. The structure of the fruit and seeds is also worthy of particular attention.

\section{GENUS XXVIII. SA'MOLUS.-LINN. Brookweed.}

Nat. Ord. (allied to.) Primulace'se. Brown.

Gen. Char. Calyx half superior five cleft. Corolla somewhat bellshaped, with a short tube, its mouth surrounded with five scales, (sterile stamens), alternating with five stamens, and opposite the segment of the limb. Capsule half, superior, two celled, opening with five valves. Seeds numerous, fixed to a large central placenta._"Named, some sty, from the island Samos, where Valerandus, a botanist of the I6th century, is alleged to have gathered our Samolus Valerandi. Others, as Théis, derived it from san, salutary, and mos, a $7 \mathrm{hog}$ in Celtic; because it was used by the ancients for curing diseases in hogs."

1. S. Vale'randi, Linn. (Fig. 361.) Brook-veed, or Water Pimrernel. Leaves oblong, obtuse; racemes many flowered, becoming 
elongated, each pedicle with a small bractea about its middle; capsule sub-globose.

English Botany, t. 703.-English Flora, vol. i. p. 325.-Hooker, British Flora, vol. i. p. 114.-Lindley, Synopsis, p. 185.

Root of numerous white branched fibres. Stem erect, simple or branched, from six to eighteen inches high, round, smooth, and somewhat succulent, like the rest of the plant. Leaves alternate, somewhat fleshy, entire, with a strong mid-rib, and numerous lateral slender branched veins, the root leaves numerous, spreading around on footstalks, of variable length, oblong, ovate, rounded at the extremity, but more or less attenuated at the hase, the upper or leares of the stem sessile, or on short footstalks, orate, with a short acute point. Inflorescence terminating the stem and branches, at first in a close corymbose raceme, at length elongating after fluwering in the lower part. Flowers small, white, each on a simple slender stalk, more or less acutely bent about the middle, from whence arises a small orate-lanceolate bractea. Calyx separating from the germen about half way up, its limb of five angular segments. Corolla rery small, somewhat bell-shaped, with a short tube, the limb of tive oblong obtuse spreading segments, having five small obtuse scales between each, and at the base of each segment around the mouth of the tube are the five stamens, on short broad filaments. The anthers ovate, of two cells, bursting with two lateral longtitudinal fissures. Style erect, very short. Stigma obtuse. Capsule glohose, of one cell, opening at the top with five lanceolate valves, splitting half way down, and curving backwards, closely invested in the lower half by the persistent calyx. Seeds numerous, angular, attached by one end to the central globose loose placenta.

Habitat.-Watery places, especially in a gravelly soil, both inland and near the sea; nut uncommon.

Perennial; flowering in June and July.

Brook-weed appears to be found in almost all parts of the world, but does not seem to have been applied to any particular use, except that formerly it was used in some of the incantations and mystic ceremonies of the Druids, and thought a specific in almost all diseases affecting pigs.

\section{GENUS XXIX. LOBE'LIA.-LINN. Lobelia.}

Nat, Ord. Lobe'LiaCe. J. Juss.

Gen. Char. Calyx five cleft. Corolla irregular, two lipped, five cleft. Stamens united around the pistil. Stigma blunt, mostly two lobed and hairy. Capsule of two or three cells, opening at 
the apex with two or three valves.-Named in honour of Matthias Lobel, a Fleming who settled in England, and published several Botanical Works.

1. L. u'rens, Linn. (Fig. 362.) acrid Lobelia. Stem erect; leaves toothed, the lower obovate, stalked, the upper lanceolate, sessile; flowers bracteated, in terminal racemes; calyx rough.

English Botany, t. 953.-English Flora, vol. i. p. 299.-Hooker, British Flora, vol. i. p. 115.-Lindley, Synopsis, p. 137.

Root fibrous. Stem about a foot high, erect, branched, angular, sometimes channelled, leafy, smooth, ol somewhat rough. Leaves alternate, the lower ones on footstalks of variable lengths, obovate, and deeply toothed in an irregular manner, the upper lanceolate, sessile, with smaller and frequently more distant teeth, nearly smooth, except the margin, which is mostly rough, with minute points. Inflorescence long bracteated racemes, of alternate flowers, with a long pale tube, and beautiful blue limb, each on a short rough stalk, from the axis' of a lanceolate or awl-shaped bractea, rough, with rigid points, simple or toothed. Calyx of five deep awl-shaped rough spreading segments, permanently crowning the capsule. Corolla of one piece, irregular, roughish externally; the tube a palish pink, swelling upwards, and split along its upper side about half way down, between the two upper narrow lanceolated reflexed segments of the limb, forming the upper lip; the lower lip of three lanceolate segments, the middle one the largest. Stamens five, from the middle of the tube of the corvlla, and as long as it. The filaments and unthers united together around the pistil. The anthers purple and roughish, the two upper ones rather longer than the others, and curved orer the pistil. Style as long as the filaments, mostly curved upwards between the two upper segments of the corolla. Stigma obtuse, cleft into two lobes, and hairy beneath. Capsule oblong, angular, roughish, crowned by the persistent calyx, of two or three cells, opening at the apex with two or three teeth. Seeds small, numerous.

Habitat.-Heathy ground; very rare. Near Axminster-Mr. New. berry; and Ottery St. Mary, Deyonshire-Miss Burgess.

Perennial; flowering in August and September.

This rare and beautiful little plant exudes from all parts of it, when broken, a milky acrid fluid, a quality possessed by most plants of the genus; and some of them, as L. longiflora, are highly poisonous to the animals that eat it; and from itsbeing the cause of frequently destroying horses, it is known by the appellation of horse poison. The L. Tupa is said to be still more baneful than this, for Fenillée says that the odour arising from the flowers will cause vomiting; and if applied either externally to the shin, or takeu internally, it produces violent indiammation and pain, and is often followed by death; some other 
species are equally injurious. The $L$. inflata is much recommended as a medicine for the relief of spasmodic asthma, difficulty of breathing, and even croup may be relieverl by it; if taken in too large a dose, it acts as an emetic, but is violent in its operation, producing very frequently giddiness, pain in the head, and faintness. The flowers of many of the species are very beautiful, of brilliant scarlet and purple colours, flourishing well in open warm borders in a light soil; others require the protection of the greenhouse. The milky juice contains a considerable portion of caoutchouc, or Indian rubber, but apparently much more in some than in other species. $L$. caoutchouc is so named from the circumstance of its being one of the plants, from which that very useful and valuable substance is procured. It will be remembered by many persons that Indian rubber was a few years since known only as an article useful in erasing the marks of lead pencils, and was imported into this country in small quantities; but now so extensirely is it applied in the making of many useful articles of wearing apparel, surgical instruments, bandages, \&c. \&c. that the demand for it is not by pounds' weight, but tons; and ships laden only with this substance are sent to this country.

2. L. Dort'manna, Limn. (Fig. 363.) Water Lobelia. Scape nearly naked. Flowers racemed. Leares linear, sub-cylindrical, entire, obtuse, of two parallel tubes.

English Botany, t. 140.-English Flora, vol. i. p. 298.-Hooker, British Flora, vol. j. p. 115.-Lindley, Synopsis, p. 137.

Root of numerous long simple white tibres. Scape rouni, simple, smooth, hollow, from six to twelre inches long, erect, with one or two small obtuse leaves upon it, the radical leaves numerous, tufted, cylindrical, smooth, somewhat recurved, obtuse, from one to three inches long, formed of two cylindrical longtitudinal cells, with thin walls and slight partition. Inflorescence a terminal raceme, reaching a few inches above the water, of a few altermate pale blue drooping flowers, each arising from the axis of a small obtuse bractea, on a slender footstalk. C'alyx of five lanceolate ohtuse spreading segments, quite smooth. Corolla larger than the last, the tube with a longitudinal slit between the two small segments, nearly cylindrical, pale, somewhat bearled in the throat, the limb more irregular, the segments of the upper lip much narrower than the lower. Stamens included within the tube of the corolla, united into a tube round the pistil. The anthers ovate, dark purple, two larger and curved over the stigma, mostly smooth, the three smaller bearded at the apex, with white shining hairs. Stigma obtuse at length, of two lobes, slightly bearded beneath. Capsule oblong, smooth, of five angles, crowned near the summit, with the persistent calyx, opening with five small teeth, erect on its stalk, drooping when in Hower. Seeds small, mostly numerous. 
Habitat.-Shallow parts of lakes, especially in mountainous districts, in the Northern parts of England, Scotland, and 1reland; common.

Perennial ; flowering in July and August.

This plant generally grows much crnuded together, its numerous leaves greatly matted, forming at the botton of the lakes a thick layer, the stems seldom reaching more than a ferv inches above the surface of the water : they have not the power of elongation, as sume plants have, of raising themselves, in case of an increase of the waters; but both the leaves and stem are furnished, as is the case with all water plants, with curious air cells. The corolla, and especially the stamens and pistil of this genus, are of remarkable structure; and the student, after their minute examination, will, we doubt not, be ready to exclaim with Byron,

"true Wisdom's world will be

Within its own creation, or in thine,

Maternal Nature."

\section{GENUS XXX. JASI'ONE.-LINN. Sheep's-bit.}

Nat. Ord. Campandua'cex. Juss.

Gen. Char. Calyx five-cleft. Corolla wheel-shaped, in five deep narrow segments. Anthers united at the base. Stigma clubshaped, bifid. Capsule two celled, opening at the apex. (Flowers collected into a head with a many leaved involucrum).-Name " supposed from cov, a violet, from the blue colour of its flowers, applied by Pliny to some esculent plant."

1. J. monta'na, Linn. (Fig. 364.) Sheep's-bit, or Sheep's Scabious. Leaves linear, waved, hispid. Root annual.

English Botany, t. 882.-English Flora, vol. i. p. 296.-Hooker, British Flora, vol. i. p. 114.-Lindley, Synopsis, p. 137.

Root small, tapering. Stems erect, from one to two feet high, either single, or numerous from the same root, simple, or much branched, roundish, rough, with simple rigid hairs, leafy. Leaves alternate, numerous, sometimes crowded, linear, obtuse, with a strong mid-rib, and scattered over with hairs, the lower ones with a tapering footstalk, the upper sessile, darker green above than beneath, the margins slightly recurved, and mostly waved. Inflorescence capitate, surrounded by an involucre of numerous ovate-lanceolate notched or waved imbricated leaves. Flowers bright blue, densely crowded into an hemispherical head, each flower elevated on a short slender footstalk, and having a calyx of five narrow awl-shaped segments, seldom 


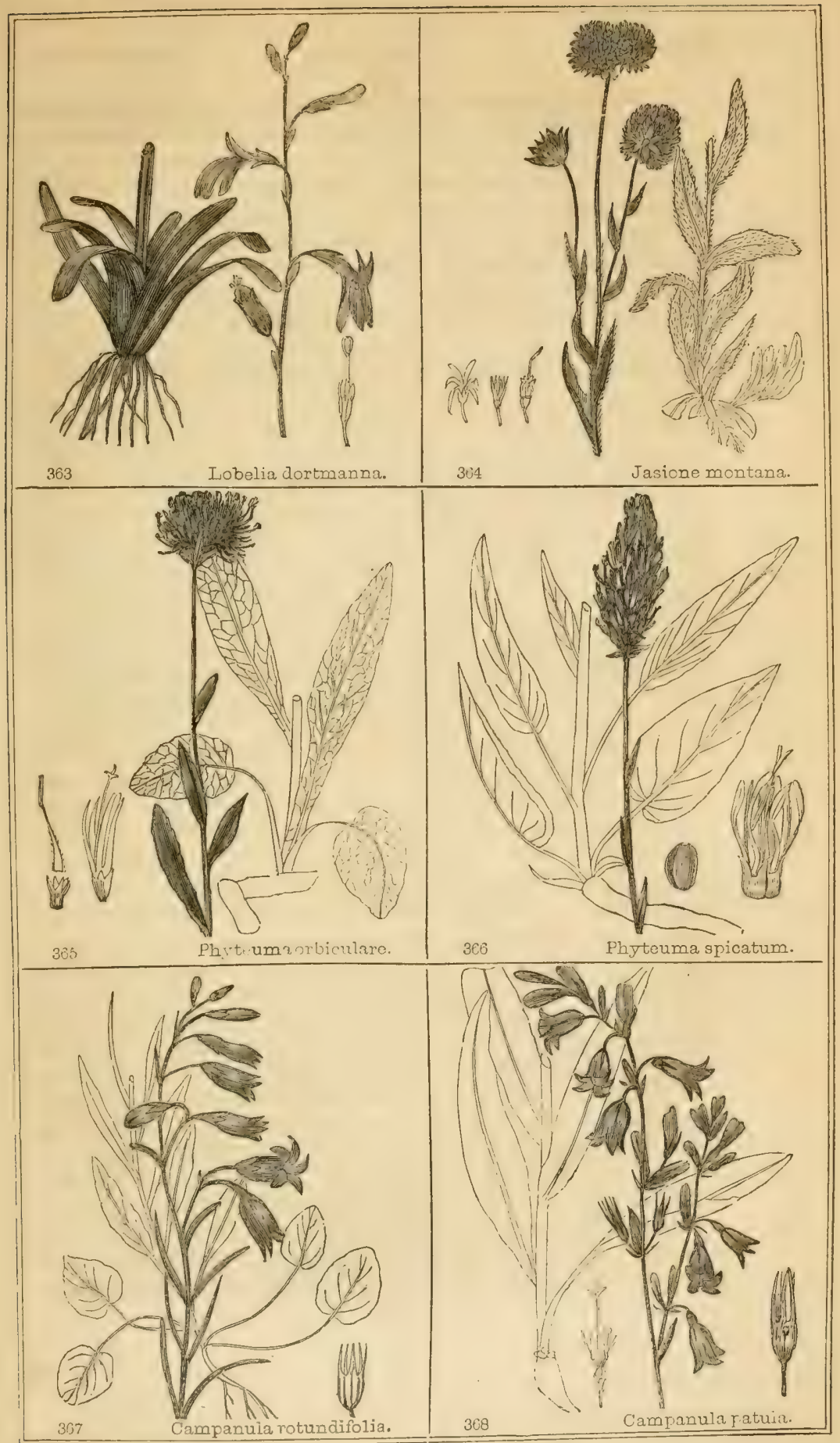



uf equal lengths, somewhat membranous at the hase. Corolla wheelshaped, with a short tulie, the limb of five mostly regular linear obtuse spreading segments. Stumens five, inserted into the orarium, about half the length of the corolla. Filaments awl-shaped, free. Anthers obloug, of two cells, mostly united at the base around the style, which is as long again as the stamens, bearing a club-shaped stigma, notched at the extremity, with a furrow on one side of most of them. Capsule of two imperfect cells, with five angles, opening at the apex with a small pore. Seeds numerous, very small, attached to a central placenta.

Habitat.-Dry heaths, sandy pastures, and tops of old walls; common.

Annual; flowering in June and July.

From the general appearance of this plant, the student might suppose that it belonged to the genus Scabiosa; but, upon examination, he will find them very different. It has also a considerable resemblance to the natural order Compositce (class Syugenesia), amongst which it was placed by Linneus; but this has a distinct calyx to each perfect flower, elevated on a footstalk, which is not the case with compositæ. The flowers, howerer, are collected into a head, within a general iurolucra, and the union of the anthers around the style shows the near affiuity it bears to that order, and it will be seen how nearly allied it is to the following genus Phyteuma.

\section{GENUS XXXI. PHYTEU'MA.-Lrnn. Rampion.}

Nat Ord. Campanula'́ceE. Juss.

Gen. Char. Calyx five-cleft. Corolla wheel-shaped, in five deep narrow segments. Filaments dilated at the base. Anthers free. Stigma three.cleft. Capsule of two or three cells opening at the side. (Flowers collected into a dense bracteated head or spike.)-

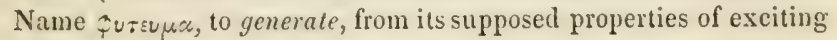
love.

1. P.orbicula've, Linn. (Fig. 365.) round-headed Rampion. Flowers in a roundish head; root leaves ovate cordate crenated on long footstalks, those of the stem latuceolate serrated as well as the bractea.

English Botany, t. 142.-English Flora, vol. i. p 296.-Hooker, British Flora, vol. i. p. 115.-Lindley, Synopsis, p. 135.

Root long, woody, branched, especially near the surface. Stem VOL. I. 
erect, simple, roundish, striated, smooth, or slightly scattered orer with liairs, from one to two feet high, surrounded by a tuft of leares at the root, and with alternate ones abure. Leaves more or less hairy, especially on the margin, paler beneath, with a strong mid-rib, and numerous small branched lateral veins. The root leares on long slender footstalks, channelled above, ovate oblong heart-shaped or rounded at the base, the margin crenated, these leaves often wither and die away, while those on the stem are in perfection, the leares on the lower part of the stem with a short broad footstalk, lanceolate, with serrated margins, alternate, mostly distant, becoming smaller towarls the top of the stem, and generally more fringed on the margin, with fewer or without serratures. Inflorescence a terminal, dense, roundish head of numerous beautiful blue flowers, surrounded at the base with several orate-lanceolate bractea, with a mid-rib, and fringed margins, and each flower has at its base a small orate lanceolate bractea, about as long as the calyx, which is superior, of five broad lasceolate segments, smooth, spreading. Corolla wheel-shaped, long, narrow, linear, of a fine blue colour, with a short tube. Stamens fire, arising from the bottom of the tube, alternating with the segments of the corolla. The flaments slender, awl-shaped, about half as long, or shorter than the corolla. Anthers long, linear, of two cells. Style longer than the corolla, hairy, curred towards the end. Stigma threecleft, spreading. Capsules orate, angular, crowned by the persistent calyx, which spreads its segments out in a star-like manner, three celled, opening laterally. Seeds numerous, somewhat angular, attached to a central placenta.

Habitat.-Pastures, and by road sides, in a chalky soil; rare. On the downs of Sussex and Hampshire; in Surrey and Kent.

Perennial; flowering in August.

2. P. spica'tum, Linn. (Fig. 366.) spiked Rampion. Flowers in an oblong spike; root leares oblong cordate, with somewhat compound serratures, on slender footstalks, those of the stem lanceolate, sessile, as are the bractea.

English Botany, Suppt. t. 2598.-Hooker, British Flora, rol. i. p. 115.-Lindley, Synopsis, p. 135.

Root white, fleshy, spindle-shaped, branched, with a few fibres, and containing a milky juice. Stem roundish, smooth, striated, and often somewhat twisted in the upper part, erect, simple, from one to three feet high, slender. Leares numerous, smooth, with a strong mid-rib, and slender branched reins, those from the root and bottom of the stem on channeled footstalks of variable lengths oblong broad at the base and heart-shaped, the margin more or less doubly serrated, smooth, rarely simple, leaves nn the lower half of the stem lanceolate, sessile, simply scrrated or toothed, those on the upper part, few, small, lincar. Inflorescence a terminal cylindrical spike, from two to four 
inches long, of numerous yellowish green flowers, each having at its base a linear bractea shorter than the flowers, and hid amongst them, except a few at the base of the spike, which are long and spreading. Calyx of five awl-shaped spreading segments. Corolla wheel-shaped, with a very short tube, the limb of five deep narrow linear lung spreading segments, of a yellowish green colour. Stamens five from the bottom of the tube of the curolla, with slender awl-shaped filaments, and long linear two celled anthers. Style much longer than the stamens, somewhat hairy above. Stigma two or three cleft, reflexed. Capsule oblong, angular, crowned by the persistent calyx, of two cells, opening laterally. Seeds small, numerous, angular, attached to a central placenta.

Habitat.-Woods, thickets, hedges and fields, recently cleared of wood in several stations about Maytield and Waldon, Sussex. $-\boldsymbol{M} r$. Borrer. First detected in the former place by the Rev. Ralph Price, in 1825 .

Perennial; fluwering in June and July.

This Phyteuma is mentioned by Parkinson as growing "in divers places of this land." It was formerly grown as an esculent vegetable, and whether a native or not, is somewhat doubtful; it may have escaped from gardens, and now become naturalized. Its growth is limited to a small circuit, but it has probably as great a claim to rauk amongst the plants of our Flora, as some others. It is not uncommon on the continent in woods and mountain pastures.

\section{GENUS XXXII. CAMPAN'ULA.-Linn. Bell-flower.}

Nat. Ord. Campanula'Cex. Juss.

Gen. Char. Calyx five-cleft. C'orolla bell-shaped, or wheel-shaped, with five larger or smaller segments, the mouth of the tube closed with the dilated base of the filaments. Anthers free. Stigma two to five-cleft. Capsule from two to five celled, opening on the side, rarely at the extremity.-Named from the shape of the corolla, Campana, a bell.

* Flowers in panicles, or racemes. Capsule opening by lateral pores.

1. C. rotundifo'lia, Linn. (Fig. 367.) round-leaved Bell-flower, or II are-bell. Smooth root leaves sub-rotundate heart-shaped at the base, crenated petiolated those of the stem lanceolate and crenated in the lower part, linear and entire above; flowers drooping; segments of the calyx subulate, simple. 
English Botany, t. 866.-English Flora, vol. i. p. 288.-Hooker, British Flora, vol. i. p. 116.-Lindley, Synopsis, p. 136.

Foot long, slender, branched, somewhat wiry. Stems mostly numerous, erect, or bent at the base, and sometimes sending out short runners from the bottom, slender, round, smooth, as is the whole plant, either simple or slightly branched, mostly very leafy, from one to two feet high; the root leaves generally very numerous, but soon withering, roundish, or oblong, with a heart-shaped base, the margins crenated and rough, like those of the stem, with a minutely serrated cartilaginous edge, the footstalks long and slender, the leaves of the stem in the lower part on footstalks also, oblong-lanceolate, crenated, becoming lanceolate, above sessile, linear, and entire on the margin, they are very rariable in length and numbers, alternate. Inflorescence a terminal scarcely branched panicle, of a few gracefully drooping sky blue flowers, on slender stalks of variable lengths, each having at its base an awl-shaped bractea, and not unfrequently one or two small ones on the stalk. Calyx in five, awl-shaped, entire spreading segments. Corolla about three times as long, bell-shaped, with a short tube, the limb of five broad acute spreading segments. Stamens half as long as the corolla. The filaments broadly dilated at the base with a fringed margin, the upper part slender, smooth, spreading, while the base forms valves which converge together and completely close up the mouth of the tube. Anthers oblong, of two cells, yellow. Style as long as the corolla. Stigma three-cleft, hairy. Capsule roundish, oblong, with ten ribs, crowned by the persistent calyx, of three valves, opening on the side. Seeds small, numerous.

Habitat.-Dry hills, pastures, banks, walls, \&c.; common.

Perennial; flowering in July and August.

B. hirla, De Cand. Leaves and stem in the lower part of the plant, hairy.

$\gamma$. lancifolia, De Cand. Leaves in the lower part of the stem, two inches long, and three or four lines wide, above narrower and shorter.

These varieties we have occasionally met with. The first on very dry sandy banks, and old walls. It is seldom more than six inches high, while the variety lancifolia grows in a damp shady situation, and is smooth, stout, and mostly two feet high, with but few ovate root leaves, those of the stem very long, and often much crowded.

No one who has made the collecting of plants eitber a part of his amusement or study, will turn over the collection of his lierbarium, without almost erery specimen reminding him of the circumstances under which it was gathered-- nay, even the spot where, perhaps, the

\footnotetext{
"Stranger's, whose steps have reached this solitude, Know that this lonely spot was dear to one Devoted with no unrequited zeal To Nature :-
} 
and who can lrave gathered the beauteous Hare-bell gracefully bending on its slender stem, ringing its chimes to the song of the zephyrs, and saluting them as they pass over the dreary moors, or perhaps along the shady glen or bounding on the green clad mead, without having the place of its abode impressed upon the memory. It is so delicate in the colour of its flowers, so elegant in its form, so slender and graceful in its structure, as to be the favourite theme of many a worthy poet's song. In the garden it is frequently cultivated, and some beautiful delicate varieties obtained, the corolla often becoming pure white.

2. C. pa'tula, Linn (Fig. 368.) spreading Bell-flower. Stem angular, rough; leaves crenated, roughish, those of the root oblonglanceolate, shortly petiolated; those of the stem linear, lanceolate, sessile; flowers erect, paniculated; segments of the calyx subulate, toothed.

Euglish Botany, t. 42.-English Flora, vol. i. p. 289.-Hooker, British Flora, vol i. p. 116.-Lindley, Synopsis, p. 136.

Root white, long, tapering. Stem erect, two feet high, or more, simple, or branched, angular and rough, with rigid deflexed hairs, lcafy. Leaves alternate, crenated, and hairy, the lower and root leaves oblong-ovate or oblong-lanceolate, soon withering, on a short decurrent footstalk, the leaves on the lower part of the stem lanceolate, nearly sessile, while those above are long, linear, lanceolate, sessile, and the margins more serrated or toothed than crenated, and mostly less hairy than the others, and more distant. Inflorescence a terminal, branched, crect panicle, of numerous erect flowers, alternate, on a smoothish nearly naked common stalk, each flower on a short slender erect footstalk from the axis of a narrow subulate bractea. Calyx of five long awl-shaped erect segments, broadish at the base, with one or two teeth on each side, smooth and shining. Corolla larger than the last, erect, wider, and more broadly spreading at the mouth, with deeper more angular spreading segments, of a fine purplish blue, veiny, the tube very short. Stamens about half as long as the corolla, the filaments broadly dilated at the base and hairy, closing over the mouth of the tube, the upper part broad, smooth, bearing a long linear two celled anther, of a yellow colour. Style about the length of the corolla, with a long hairy three-cleft stigma. Capsule oblong, with five prominent angles, and five smaller alternate ones, somewhat downy between the angles, of three cells, opening near the top on the sides with a small oval opening. Seeds small, oval, numerous.

Habitat.-Pastures and hedges; rare. Confined to the middle and south-eastern counties of England, as Nottinghamshire, I.cicestershire, Worcestershire, Staffurdshire, Norfolk, Surrey, and Kent.

Bicnnial; flowering in July and August. 
The whole plant varies more or less in hairiness, by which distinction several varieties are mentioned by Continental Botanists, with whom it is much more frequent than with us. It is readily distinguished from $C$. rolundifolia, by its more branched erect panicle, its larger more spreading not drooping flowers, und its broader crenated leaves. The whole plant, too, is taller, stouter, and more robust. It, like most other of the genus, contains an acrid milky juice, but not so much as to render it disagreeable to cattle.

3. C. Rapun'culus, Linn. (Fig. 369.) Rampion Bell-fower, Stem somewhat angular, rough below; leaves crenate, roughish; those of the root ovate, oblong; petiolated, upper ones narrower, sessile, lanceolate; pauicle erect, racemose; segments of the calyx subulate, simple.

English Botany, t. 283.-English Flora, vol. i. p. 291.-Hooker, British Flora, vol. i. p. 116.-Lindley, Synopsis, p. 136.

Root fleshy, tapering, white, and milky. Stem erect, from two to three feet high, somewhat angular, simple, or sometimes branched, smooth or hairy, especially below, leafy. Leaves smooth, or sometimes hairy, rather paler below than above, the margins crenated, those of the root orate, oblong, tapering into a footstalk of variable length, the upper narrower, linear, lanceolate, and sessile. Inflorescence a terminal, erect, simple, or slightly branched, racemose, panicle of numerous spreading more truly campanulate flowers, of a fine blue colour; the flower stalks and stem round, quite smooth, as are the small lanceolate bractea. Calyx of rather long, narrow, erect, spreading or reflexed, awl-shaped segments, the margins without teeth. Corolla larger than in the last species, of a fine bluish purple colour. Stamens not half as long as the corolla. Filaments dilated at the base into a valve, closing orer the tube of the corolla, hairy, especially on the margins. Style half as long again as the stamens, downy above. Stigma three-cleft, spreading, or rolled back. Capsule oblong, with five prominent angles, and five small alternate ones, smooth, or sometimes slightly downy, opening near the top with the small oval openings. Seeds small, oval, numerous.

Habitat.-A gravelly soil, in the southern and midland counties; not very common.

Perennial ; flowering in July and August.

The roots of this plant have a sweet, somewhat pungent taste, which in a great measure it looses by cultivation. Formerly this plant was much grown in England as a culinary regetable, and was known by the name of Ramps; it is now, however, almost or entirely neglected; but on the continent it is much used, and especially in Italy, where in the mountainous districts it grows abundantly, and is collected and brought to market by the peasantry, with whom it forms a 
considerable article of consumption during its season, boiled into a kind of soup, with a little vermicelli, or eaten raw with bread.

4. C. persiciffolia, Linn. (Fig. 370.) Peach-leaved Bell-flower. Smooth stem, round, few flowered; root leaves obovate stalked; those of the stem sessile, linear, lanceolate, remotely serrated; raceme fow flowered; segments of the calyx lanceolate, entire; corolla large, spreading.

English Flora, vol. i. p. 291.-English Botany, Suppt. t. 2773. Hooker, British Flora, rol. i. p. 116.-Lindley, Synopsis, p. 136.

Root somewhat creeping, slender, knotted, and fibrous above. The whole plant destitute of hairs. Stem erect, generally simple, from one to two feet high, shining, somewhat angular. Leares alternate, mostly distant on the stem, those arising from the base of the stem and root orate-oblong, somewhat decurrent, on a long footstalk, the margins crenated, or bluntly serrated, shortly withering, the leaves of the stem narrow, linear, lanceolate, those on the lower part on footstalks, the upper sessile, all with a strong mid-rib, and numerous minute branched veins, the margins remotely and more or less distinctly serrated. Inflorescence a terminal, few flowered, raceme. Flowers from the axis of a lanceolate bractea on a short footstalk. Calyx of five spreading lanceolate segments. Corolla large, of a fine purplish blue colour, wide spreading, the segments large, broad, acutely pointed. Stamens with a broadly, dilated, obovate, hairy base, closing over the mouth of the short tube of the corolla, slender and smooth above. Anthers long, linear, hairy, of two cells, yellow. Pistil as long as the corolla. Style smooth. Stigma long, hairy, deeply three-cleft, and spreading. Capsule obovate, angular, crowned by the persistent calyx, of three cells, opening near the top of the sides with a circular opening, the valve curling upwards. Seeds numerous, ovate.

Habitat.-Woods, near Cullen, Scotland, apparently indigenous.Mr. G. Don.

Perennial ; flowering in July.

We have not beeu able to obtain wild native specimens of this plant; it is frequent on the continent, and its claim to the rank of one of our indigenous species is very doubtful. It is frequently cultivated as a border flower, and is very ornamental, its flowers mostly becoming double, and often pure white; and from its resemblance to a small rose, it is called in sume parts of the country the "rose without a thorn."

5. C. latifo'lia, Linn. (Fig. 371.) Giant Bell-flower. Stem simple, rounded; leaves ovate-lanceolate, acuminated, coarsely and doubly serrated, hairy, raceme of erect stalked axillary flowers; segments of the calyx smooth, lanceolate, erect. 
English Botany, t. 302.-English Flura, vol. i. p. 291.-Hooker, British Flora, vol. i. p. 117.-Lindley, Synopsis, p. 136.

Root somewhat fleshy, with long branched ibres, exuding when broken an acrid milky fluid like the whole plant. Stem from two to three or four feet high, erect, simple, roundish, or obscurely angular smooth, or scattered over more or less profusely with soft hairs, leafy the leaves alternate, large, lanceolate, with a tapering point, the margins coarsely and doubly or irregularly serrated, the teeth blunt, the lower ones on short footstalks, the upper nearly sessile, roughish, with spreading hairs, especially on the under side along the mid-rib, and lateral branched veins. Inflorescence a long terminal raceme, or occasionally a slight branched panicle of numerous large axillary flowers, arising single, or sometimes the lower ones of the raceme double, on a branched slender erect stalk, which is somewhat angular, roughish generally without, but sometimes there is a small lanceolate scale upon it, the floral leares or bractea in the lower part lanceolate, serrated, becoming narrower upwards, at length linear and entire. Calyx erect, of five lanceolate or somewhat ovate-lanceolate segments, with entire or serrated margins, smooth, or scattered over with hairs, and the margins ciliated. Corolla large, deep blue, erect, or slightly drooping, the segments lanceolate, reflexed. Stamens about one-third the length of the corolla, downy, with a broad dilated valve at the base, closing over the mouth of the short tube of the corolla. Anthers long, linear, very downy. Pistil nearly as long as the corolla, downy, thickening upwards. Stigma deeply three-cleft. Capsule angular, mostly smooth, crowned by the persistent calyx, three celled, opening near the top with oval lateral pores. Seeds numerous.

Habitat.-Moist woods, and shady places; not very common. In Norfolk, Suffolk, Belfordshire, Lincolnshire, and the North of England; more frequent in Nottinghamshire, Derbyshire, and Yorkshire; but in the woods and shady glens of Scotland very frequent; and in woods by the river Barrow, above New Ross, Ireland.

Perennial; flowering in July and August.

The Giant Bell-flower is the largest and most ornamental of our species, having a very stately and noble appearance, raising its gay lead far above its companions in its native abode: in the close shady woods, as well as by cultivation, the flowers become paler, sometimes white, and of a pinkish tinge. It is well calculated to ornament shady walks, plantations, and groves, but does not flourish so well in an open situation.

6. C. rapunculoi'des, Linn. (Fig. 372) creeping Bell-flower. Stem slightly brancled, obtusely angular; leaves cordate-lanceolate, uncqually erenated, hairy; raceme of drooping stalked axillary unilateral fowers; segments of the calyx hairy, lanceolate, spreading. 



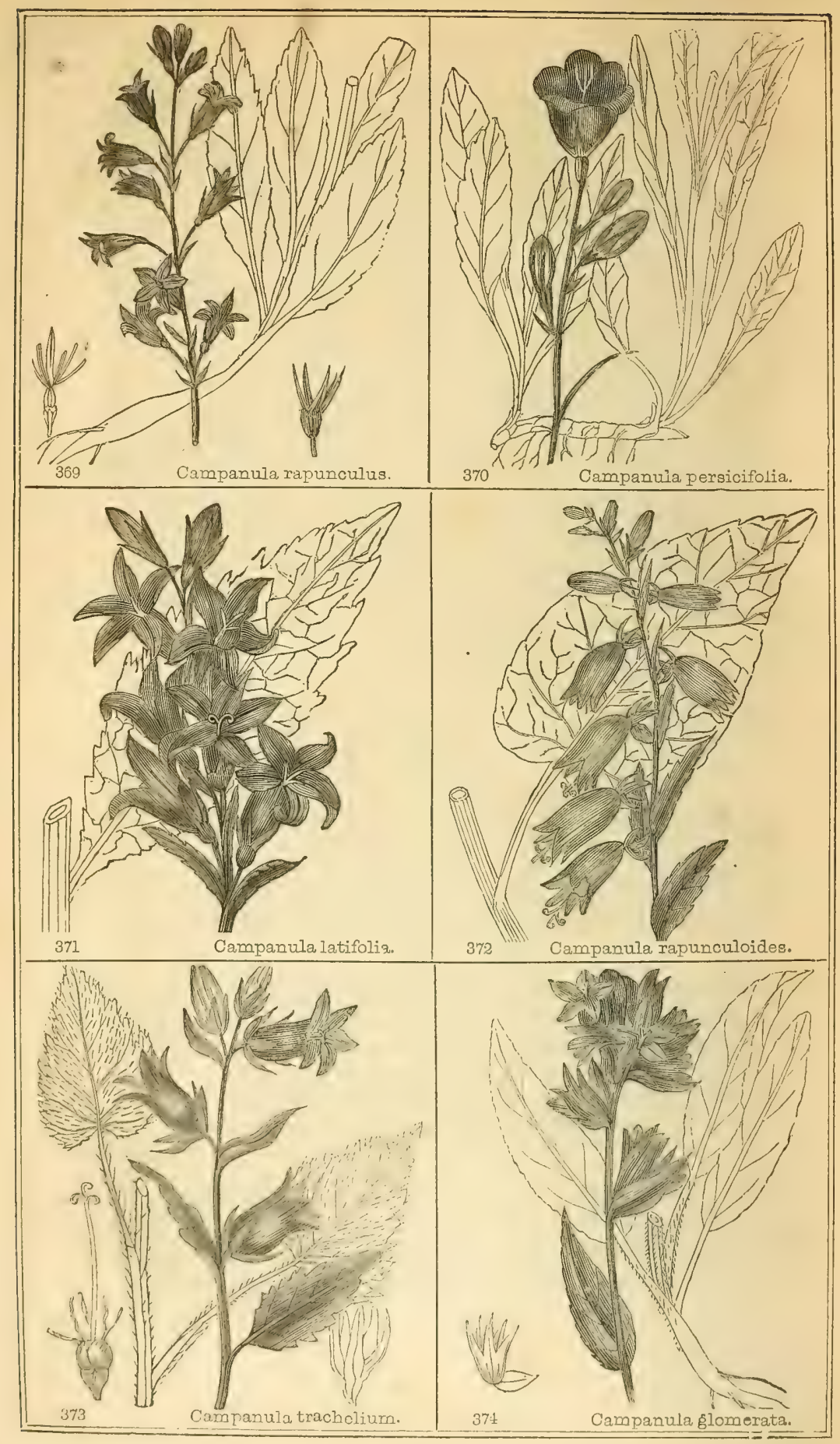


English Botany, t. 1369.-English Flora, vol. i. p. 292.-Hooker, British Flora, vol. i. p. 117.-Lindley, Synopsis, p. 136.

a. major. Whole plant, except the corolla, much larger, and nearly smooth.

$R$ oot with long creeping underground stems. Stem erect, sometimes slightly branched, but mostly simple, from one to two feet high, or more, obtusely angular, scattered over with reflesed hairs, nearly smooth in the lower part, but hairy above. Leaves alternate, rough, with rigid hairs, especially near and on the margins, coarsely and irregularly crenated, or obtusely serrated, the mid-rib strong, and with the branched lateral reins rougher below than above, the lower leares on footstalks, broadly lanceolate, with a heart-shaped base, the upper ones sessile, ovate lanceolate, gradually diminishing to lanceolate and linear bractea. Inflorescence a terminal raceme, of distant une-sided flowers. Flowers large, drooping, on a short angular hairy stalk, solitary from the axis, of linenr or lanceolate bractea, which are crenated below, simple above, rough, and with strongly ciliated margins, Calyx hairy, its segments lanceolate, entire, spreading, or reflexed, Corolla smaller than the last species, of a deep purplish blue, scattered over with long soft hairs, especially on the margin of the spreading acutely lanceolate segments, sonietimes the hairs are absent, but within near the bottom seldom wanting. Stamens half as long as the corolla, dilated into an angular base, ciliated on the margin, and hairy within, closing over the short tube of the corolla. The filaments slender, short. Anthers long, linear, of two cells. Pistil about as long as the corolla. Style hairy, thickened upwards, and scattered over with small warty excrescences. Stigma three-cleft, recurved. Capsule ovate, or roundish, angular, hairy, three celled, opening near the base with three large roundish pores.

Habitat.-Woods and fields; rare. Oxfordshire.-(Buddle's Herb.) On the magnesian limestone between Wentbridge and Darlington, Yorkshire.-Mr.J. Backhouse. Blair in $\Lambda$ thol, Scotland; and found plentifully in corn fields two miles N. W. of Kirkcaldy, (where it is considered a troublesome weed by the farmer).-Alexander Chambers, Esq. Hooker. Castle Hill, on a sandy soil, Worksop, Nottingharnshire; and the variety $\alpha_{0}$ major in clayey woods, in the vicinity of Lincoln. $-R$. $D$.

\section{Perennial; flowering in July and August.}

This species is readily distinguished from $C$. latifolia, by its lower heart-shaped leaves, and its drooping one-sided flowers. The variety o. major rivals in magnitude that of $C$. latifolia. It has, however, otherwise the same marked characteristic difference in its structure. Some of my spesimens of it are a shining green, and almost without any hairs upon them, especially in the lower part of the plant.

VOL. I. 
7. C. Trache'lium, Linn. (Fig. 373.) Netlle-leaved Bell-flower. Stem angular, simple; leaves hispid, coarsely and doubly serrated, cordate lanceolate, petiolated; raceme of a few stalked axillary flowers; segments of the calyx ovate lanceolate, erect.

English Botany, t. 12.-English Flora, vol. i. p. 293.-Hooker, British Flora, vol. i. p. 11\%.-Lindley, Synopsis, p. 136.

Root somewhat woody. Stem erect, simple, acutely angular, from two to three feet high, leafy, of a reddish purple colour, rough, with coarse spreading hairs. Leares alternate, somewhat rugose and rough, with rigid hairs, especially on the mid-rib, and brancled reins on the under side, the margins coarsely and irregularly crenated, the lower leaves on footstalks of variable lengths, ovate lanceolate, heart-shaped at the base, and tapering at the point, the upper leares on short footstalks, or sessile, ovate lanceolate. Inflorescence a terminal leafy raceme, of a few large blue flowers, arising from the axis of the ovate lanceolate crenated bractea, the flower stalk simple, sometimes branched, and hearing two or three flowers, short, angular, rough. Calyx large, of five ovate lanceolate erect veiny segments, rough, especially towards the base. Corolla large, spreading, scattered orer hoth on the external and internal surface, with long spreading hairs, the segments lanceolate, spreading, fringed with slender hairs. Stamens short, hairy. Filaments dilated into angular valves at the base, closing orer the short tube of the corolla, slender above. Anthers short, oblong. Pistil nearly as long as the corolla, thickened upwards. Stigma three-cleft, recurved. Capsule ovate, three celled, many seeded.

Habitat.-Woods, not unfrequent in England; old walls. Mugdoch Castle, near Glasgow, Scotland.-Mr. Hopkirk. Between Glasnevin and Finglass.-Di. Brinkley. River side below Innistrogue, County of Kilkenny, Ireland.-Mr. Templeton.

Perennial; flowering in $J u l y$ and August.

The English name of this plant is from the resemblance of the leares to those of a nettle; its hairs are also almost as pungent, but they are not venomous. Formerly a decnction of its leares was thought useful in inflammatory affections of the throat and mouth; hence its specific name of Trachelium. It is, howerer, we believe, not now used for that purpose; it contains an acrid milky juice, and may lave been useful as a stimulating gargle. It is cultivated as a border flower, and is very ormamental, the flowers often becoming rery double, and sometimes quite white.

** Flower's sessile, spiked, or collected into a terminal head. Capsule opening by lateral pores.

8. C. glomera'la, Linn. (Fig. 374.) clustcred Bell-flower. Stem angular, simple, lairy, or smooth; leares oljlong lanceolate, rough, 
finely crenated, the lower ones petiolated, the upyer sessile; flowers sessile, in axillary and terminal clusters.

English Botany, t. 90.-English Flora, vol. i. p. 293.-Hooker, British Flora, vol. i. p. 117.-Lindley, Synopsis, p. 136.

B. farinosa. Stem and under-side of the leaves thickly clothed with white woolly hairs.-C. glomerata, $\beta$. salvia folia, Wahl. Sched. C. farinosa, Andrez. C. petrea, Schmidt and De Cand. Fl. Franc. C. aggregata, a. farinosa, Reicheub 1. c. f. 757-759.

$\gamma$. aggregata. Green leares of the stem with a broad petiole, flowers large.-C. aggregata, Willd. supplt. Reicheub. ic, 6. f. 760, 761 .

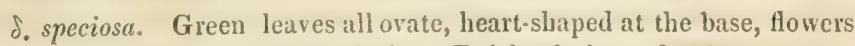
large.-C. speciosa. Hornan. hafer. Reicheub. ic. 6.f. 762.

E. elliptica. Leaves all rounded at the base, or attenuated into a footstalk, accuminated at the apex.-C. clliptica. Reicheub, ic. 6. f. 763,764 .

ל. lancifolia. Leaves all lanceolate, the lower ones petiolated, the margins waved and irregularly crenated, slightly downy.

n. attenuata. Leaves all lanceolate, with a long attenuated point, minutely downy, the lower ones on a short broad petiole.

Root of strong woody fibres. Stem erect, from six to twenty inches high, angular, simple sometimes, but rarely branched, of a purplish colour, an! more or less cluthed with hairs, sometimes smooth, at others woolly, leafy. The leaves alternate, those arising from the root on long footstalks of variable shapes, usually oblong lanceolate, with a heart-shaped base, the upper ones mostly sessile, or with short footstalks, oblong lanceolate, partly embricing the stem at the base, paler beneath, and generally more hairy than the upper side, the margins finely crenated, the upper ones sometimes entire, the hairiness is extremely variable, the upper sille is sometimes quite or nearly smooth, as well as the under, at others the under side alone clothed with hairiness, and not unfrequent, both soft, with spreading hairs. Inflorescence a terminal spike, with axillary clusters of sessile flowers from the bottom of the upper leaves, large, erect, of a fine blue colour, each flower having at its base a bractec of greater or less size, mostly broadly ovate, acute. Calyx of five narrow lanceolate segments, crect and downy. Corolla large, erect, with five acute segments, quite smooth, or scattered over with simple palc hairs, longer, and often more numerous on the inside than out. Stamens short, dilated into an ovate valve at the base, hairy, especially within and on the margins, closing over the base of the erect simple downy style, which is not so long as the corulla. Stigma two or three cleft, downy, recurved. Capsule ovate, angular, hairy.

Habitat.-Dry pastures, especially of a clayey or chalky soil; not 
unfrequent in England. "Hilly pastures in Scotland; but confined, we believe, to the east side between the Firth of Forth and Montrose."

Perennial; flowering in July and August.

Few, if any of our native plants, vary so greatly as this. We have enumerated the principal varieties that we have met with; the leaves vary in their size as to length and breadth, and are either smooth, hairy, downy, or woolly, the flowers are either large or small, only terminating the stem with a simple cluster, or with axillary ones also for some distance down the stem. Of those varieties which we have enumerated, the lancifolia appears to us the most like a distinct species, the leaves are all truly lanceolate, the margins wared, irregularly crenated, a fine green above and scarcely hairy, beneath pale and much more hairy, the flowers small, stigma three-cleft, the lower leares have long winged footstalks, the upper with a broad one, but not embracing the stem. The $\varepsilon_{0}$ elliptica has rather small elliptic leaves, elevated on a footstalk, the upper or floral leaves alone sessile, all thickly clothed with short soft down, the flowers small, downy. n. attenuata has nearly all its leaves sessile, or with a broad footstalk, ovate lanceolate, with a long tapering point, green above and finely downy, pale beneath, and soft, with spreading hairs. It is probable that many of these varieties are, owing to the circumstances of their growth with regard to the soil, and to their being more or less frequently eaten down by cattle grazing in the pastures. It is frequently cultivated for the beauty of its flowers, when their colour often becomes paler, sometimes white, and their foliage larger and more luxuriant. Prof. Henslow has observed the petals sometimes turn to a bunch of leaves.

*** Flower's solitary. Capsule opening at the extremity with three or five valves, within the caly cine segments.-(Wahlenbergia, Schrad).

9. C. hedera'cea, Linn. (Fig. 375.) Ivy-leaved Bell-flower. Stem weak, thread-like, branched; leaves smooth, stalked, sub-rotundate, cordate, with angular toothed lobes.

English Botany, t. 73.-English Flora, vol. i. p. 293.-Hooker, British Flora, vol. i. p. 117.-Lindley, Synopsis, p. 136.

Root small, branched, fibrous. Stem trailing, slender, thread-like, much branched, angular, entangled together, and extending itself some distance. Leaves numerous, opposite, or alternate, smooth, shining pale green, on long s!ender angular footstalks, somewhat rounded, with a heart-shaped base, angularly lobed in a tooth-like manner, acute, having three principal ribs, with numerous fine branched lateral veins. Flowers from the axis of the branched stem and leaves, and terminal on long slender angular stalks, at first drooping, becoming erect, solitary. Calyx of five slender awl-shaped segments. Corolla a delicate pale blue, bell-shaped, in fire acute spreading lobes. Stamens 


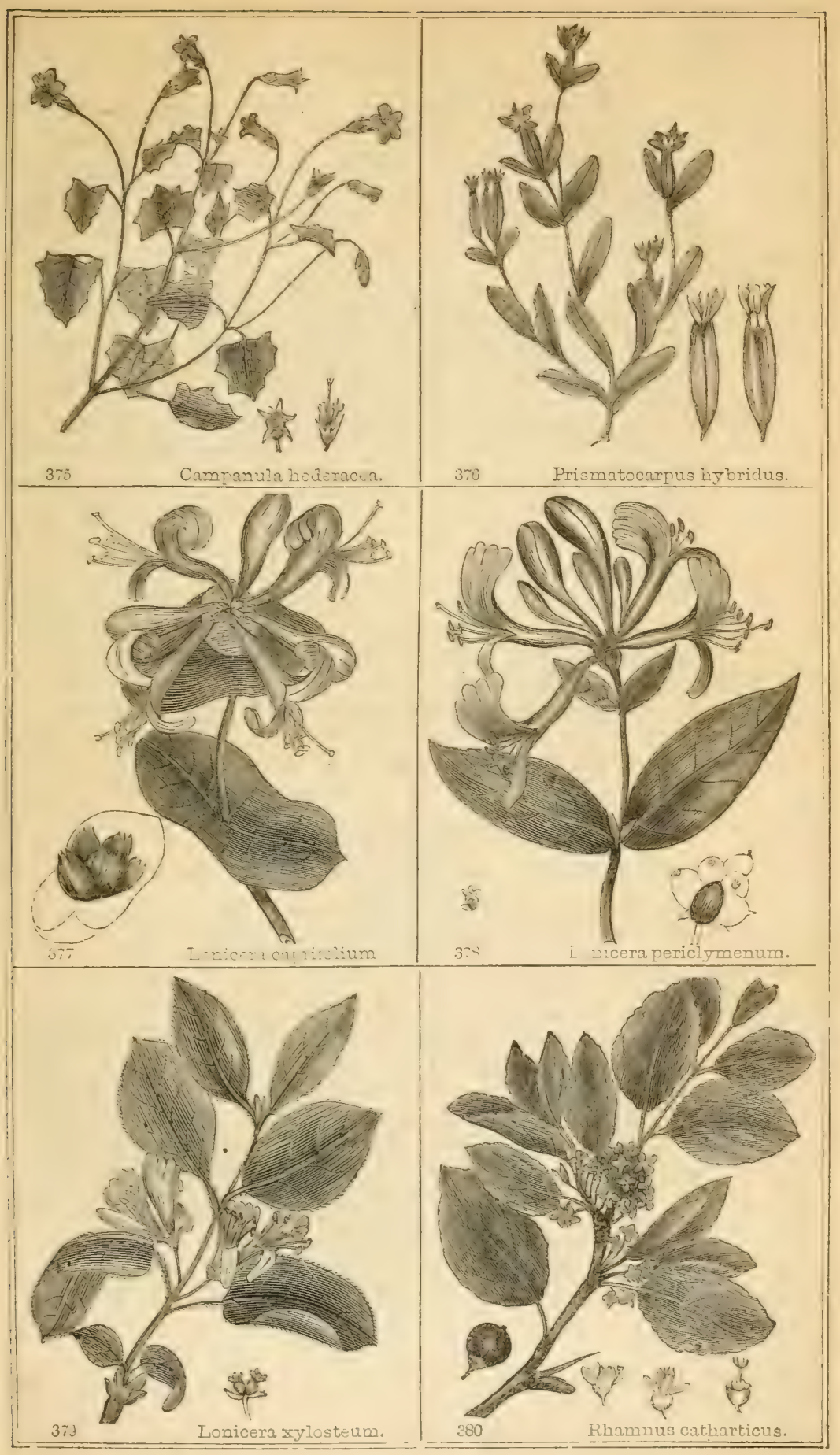



about half as long as the corolla. Filaments dilated and hairy at the base, slender, and smooth above. Anthers oblong, of two valves. Pistil nearly as long as the corolla, smooth below, hairy above. Stigma two-cleft, rolled back. Capsule almost globose, smooth, the calys attached about one-third from the top, opening at the apex between the calyx with either three or five angular teeth. Seeds numerous, small, ovate.

Habitat.-Moist shady hanks and woods. Abundant in Deronshire, Cornwall, the Scilly Isles, and Wales; in Sussex, (plentiful), Hampshire, Oxfordshire, Worcestershire, Essex, Epping Forest, near Theydon Bois.-3r. H. Cole. Near Derwent Hall, Ashopton, Derbyshire.$R$. D. In Scotland, on the south banks of the Clyde.-Dr. Brown. In Ireland, on the Sugar-loaf Mountain County of Wicklow.-Dr. Stokes and Mr. John Nuttall. Near Bandon, Couniy of Cork, and in Glencree, between Euniskerry and Lough Bray, near the Copsewood, abundant.-Mr. J. T. Mackay.

Perennial; Howering from June to August.

This is included by Schrad in his genus Wahlenbergia, which is distinguished by the capsule being half superior, and opening at the apex, and not on the side, as in the genus Campanula; in this particular it agrees, and has a claim to be in that genus, instead of Campanula, but its habit is quite different; and on this account it is retained in the present genus, but doubtingly as to its being its proper place.

The Iry-leaved Bell-flower is extremely elegant and delicate in its structure and habit, when

\section{"Over the font's damp, mossy stones they grew Luxuriantly. \\ These little bells of faint and tender blue, Which gracefully \\ Bent their small heads in every breeze which strayed, From lawny sunshine to the woodland's shade."-}

Romance of Nature.

We hare seen it spread its delicate and tender form over ornamental mossy rock work, and damp banks, in most elegant tufts of greater beauty than we remember to hare seen any plant, having the same labit ; it far surpasses in elegance and gracefulness of form and flower. the Iry-leaved snap dragon: but they may be grown together with great adrantage, and clothe those places, which otherwise would be naked and barren, with a raried green tapestry, constantly scattered orer with beautiful flowers during the summer months. 


\section{GENUS XXXIII. PRISMATO'CARPUS.-L'HERITIEl.}

\section{Corn Bell-flower.}

Nat Ord. Campanolace'死. Juss.

Gen. Char. Calyx five-cleft. Corolla wheel-shaped, with a flat limb. Capsule oblong, prismatic, two or three celled, opening near the top.-Name from the shape of the capsule.

1. P. hy'bridus, L'Heritier, (Fig. 376.) Corn Bell-flower. Stem erect, simple, or branched; leaves oblong, waved, and crenated ; flowers solitary; corolla spreading, shorter than the lanceolate segments of the calyx.

Lindley, Synopsis, p. 135.-Campanula hybrida. Linn.-English Botany, t. 375.-English Flora, vol. i. p. 294.-Honker, British Flora, vol.i. p. 118.

Root tapering, with long slender branched fibres. Stem erect, from six to twelve inches high, angular and rough, with short rigid hairs, simple, or more or less branched, especially from the base, which are frequently long, spreading, ascending towards the extremity, leafy. Leaves alternate, sessile, the margins waved, and somewhat crenated, rough, especially near the margin, with short rigid hairs, the lower ones oborate, the upper oblong. Flouers terminal, solitary, or sometimes three or four terminate the stem and lateral branches. Calyx of five narrow lanceolate spreading rough segments. Corolla wheel. shaped, much shorter than the calys, of five ovate spreading segments, of a deep blue, paler outside and within at the base. Stamens fire, with slender filaments, not dilated at the base; smooth. Anthers oblong, pale yellow. Pistil shorter than the corulla. Style slender, and with the two or three cleft. Stigma somewhat hairy. Capsule oblong, triangular, rough, with minute points, formed of three obtusely angular columns, crowned by the persistent calyx, and opening near the top with oblong falves, which separate beweath, and curl upwards. Seeds numerous, pale, shining, brown, ovate, attached by the extremity to the central placenta.

Habitat.-Corn fields, on a chalky or clay soil; not yery common, and chiefly in the middle and southern parts of England.

Annual; flowering in July and August.

This species is nearly allied to the $P$. Speculum, or Venus's Lookingglass, a plant very common on the continent, though not found with us. It has linear calyx segments, shorter than the orate acute segments of the corolla, more hairy, and mostly a lirger stouter plant.

The capsule of this genus is remarkable, it is formed of threc cylin- 
drical cells, with the margins united to a central thead-like placentar, common to all three, to which is attached by their pointerl base the numerous pendent seeds. The cells are opened for the escape of the scels by three valves, of an obovate or rather ligulate form, attached to the base of the calyx; between the cells these closely cover over the openings into the cells, until the seeds are ripe, when the central broadish rib with which each valve is furnished contracts and curls up the valve, leaving the opening free for the escape of the seeds; the capsule has then a very singular appearance, the calyx and recurved valves supported on three lateral and one central column: the openings in the cells are formed by a portion taken out as it were on each side, leaving the rib of each as a support for the calyx and valves, which form a protecting cover to prevent rain, Ec. getting to the seeds in the cells; and the central column is the placenta attached to the base of the pistil. Here may we truly say that

"Dame Nature is the kindest mother still, Though always changing."

\section{GENUS XXXIV. LONICE'RA.-Lins. Honcy-suckle.}

Nat. Ord. Caprifoltace'A. Juss.

Gen. Char. Calyx of five small teeth. Corolla tubular, with an irregular five-cleft limb. Stigma capitate. Berry from une to three celled, one or many seeded.-Named in honour of Adam Lonicer, a German Botanist.

* Flowers in whorled heads. Berry crowned by the persistent calyx. Stem climbing. (Caprifolium, Juss).

1. L. Caprifo'lium, Linn. (Fig. 377.) pale perfoliate Honey-suckle. Whorls of flowers, in sessile, terminal, and axillary clusters; leaves deciduous, the upper ones united at the base, perfoliate.

English Botany, t. 799.-English Flora, vol. i. p. 326.-Hooker, British Flora, vol. i. p. 118.-Caprifolium perfoliatum.-Lindley, Synopsis, p. 131.

Stem woody, climbing, several feet high, by twisting itself round the stems of other plants, taking a course from right to left, it is round, smooth, and generally a little branched. Leaves obovate, or roundish, sometimes waved on the margin, quite smooth, bright green, and shining above, bencath of a dull pale glatucous hue, with a prominent midrib, and numerous branched slender netted veins, the lower ones mostly opposite, on short footstalks, the upper ones united at the base, 
those terminating the branches cupped at the base. Inflorescence terminal and axillary whorls, of about six sessile flowers in each. Flowers highly fragrant, about two inches long, of a yellowish colour, with a pale pink tube, sometimes almost white. Calyx cup-shaped, the limb of five angular teeth. Corolla irregular, with a long tube dilating upwards, swelling more on one side than the other, the limb of five deep linear obtuse segments, one cut deeper than the others, recurved, two of the segments forming as it were one lip, and three another. Stamens of irregular lengths, the filaments about the top of the tube. Anthers oblong, yellow. Style about as long as the corolla, slender. Stigma capitate. Berry ovate, of a tawny yellowish hue, quite smooth, crowned by the peristent calyx.

Habitat.-Woods and thickets; rare. Oxfordshire and Cambridgeshire, in England; Collinton Woods, and Corstorphine Hill, near Edinburgh, and in hedges at Dalmeny, Linlithgowshire, Scotland.

Shrub; flowering in June and July.

The pale flowered Honey-suckle is frequent in almost all the woods and shady places in Italy, and is not unfrequent in many other parts of the Continent. It was formerly thought to possess wonderful power in the cure of ulcerated legs of aged persons, but it is not now thought to be any remedy for the cure of old age. 'The specific name of Caprifolium is from the leaves being the farourite food of goats (Capra regagrus.)

2. L. Pericly'menum, Linn. (Fig. 378.) common Honey-suckle, or Woodbine. Whorls of flowers in terminal stalked heads; leaves deciduous, all distinct, petiolated.

English Botany, t. 800.-English Flora, vol. i. p, 327.-Hooker, British Flora, vol. i. p. 118.-Caprifolium Periclymenum.-Lindley, Synopsis, p. 131.

Stem woody, climbing, smooth, twisting itself from right to left around the stem and branches of trees, \&c. to a considerable lengtl, having numerous opposite branches and leaves. Leaves ovate lanceolate, on short footstalks, a shining green above, glaucous beneath, with a prominent mid-rib, and five branched lateral veins; sometimes the leares, especially on the under side and the extremity of the branches, are more or less scattered over with simple hairs, and on plants grown by the sea they are mostly more glaucous, and become somew hat succulent; and a rariety is mentioned having the leaves sinuated like those of the oak, and rariegated. Inflorescence in terminal stalked heads, of numerous whorled flowers. Flowers about an inch and half long, irregular, very fragrant in the evenings, or after a shower. Calyx small, each having at its base a small bractea, and, like the calyx, scattered over with glandular hairs, the limb of five obtuse segments. Corolla with a long tube, dilating upwards, swelling on one side, 
externally of a darkish red or yellowish, but varying greatly in its colour, sometimes a pale straw colour, more or less clothed with glandular hairs, the limb very unequally divided into two segments, the upper one reflexed upwards, broad and notched at the extremity, in three rounded shallow lobes, the lower segment narrow, linear, obtuse, reflexed downwards, the tube scattered over on the inside with simple hairs, and on the lower part of it with a considerable number of small glands, which secrete the fragrant perfume. Stamens of irregular lengths, rising from the top of the tube, nearly as long as the corolla. Filaments slender, smooth. Style as long as the corolla, slender, smooth. Stiyma capitate, notched. Berry globular, of a bright shining red, sometimes roughish, of a bitter nauseous taste.

Habitat.-Woods and hedges; frequent.

Shrub; flowering from June to October.

The Honey-suckle raries considerably in the size of its plants, and in the smoothness and the colour of its flowers; these circumstances depending upon the more or less open or close situation, and the kind of soil in which it grows. The fragrance of its flowers is most grateful, especially in the morning or evening, or after a refreshing shower; and this is owing to the volatile oil secreted by the glands mentioned above, being rapidly dissipated by the heat of the sun, and scarcely sensible; but when it is less rapidly evaporated either in the cool of the day, or after a shower, it is then perceived, and its balmy fragrance adds no little to the pleasures of a ramble at such a season-for

"Look where'er you may, a tranquillising soul

Breathes forth a life-like pleasure o'er the whole;

The shadows settling on the mountain's breast,

Recline, as conscious of the hour of rest;

Stedfast as objects in a peaceful dream,

The sleepy trees are bending o'er the stream;

The stream half veiled in snowy vapour flows

With sound like silence, motion like repose."

The Honey-suckle is cultivated for a variety of useful as well as ornamental purposes; but never to our minds is it more beantiful or ornamental than when its branches are nicely arranged on the face of a little white-washed cottage, overhung by its thick thatched roof, or the pliant branches interwoven in the lattice work around the lahourer's door: the sweet fragrance of its fresh blown flowers is wafted in gentle puffs around the frugal board, and repays in two fold pleasures the care bestawed upon its growth and training.

** Flowers in pairs. Calyx deciduous, not crowning the Berry. Stem erect.

3. L. Xylos'teum, Linn. (Fig. 379.) upright Fly Honey-suckle. VOL. I. 
Peduncles bearing two downy lowers; berries distinct; Jeares ovate accuminate, downy.

English Botany, t. 916.-English Flora, p. 329.-Hooker, British Flora, vol. i. p. 119.-Lindley, Synopsis, p. 132.

An erect, bushr, much branched shrub, four or fire feet high, the bark pale, branches opposite, their extremities downy. Leaves numerous, opposite on short footstalks, orate, with an accuminated point, the lower ones obtuse, and the younger ones at the extremity of the branches lanceolate, clothed with a close soft down, especially beneath, where it is of a pale colour, mid-rib distinct, with slender lateral reins. Flowers axillare, in pairs, elevated on a short downy stalk. Bracteu two or four small scales, united together, and forming a small cup around the base of the flowers. Calyx small, in fire obtuse short segments. Comlla short, the limb of two lips, the upper one of four short ubtuse lobes, the lower one narrow, ligulate, cream coloured, sometimes pinkish outside, without fragrance, the tube somewhat funnel-shaped, with the lower part swollen on one side, clothed on the outside with short soft down, nearly smooth within, except in the tube: it is very downy. Stamens shorter than the corolla, its filaments downy, inserted into the top of the tube. Anthers oblong. Pistil as long as the stamens. Style downy. Stigma capitate. Berry bright scarlet, oral.

Habitat.-Thickets; near Sewenshele, Northumberland.-Wallis. Certainly wild near Houghton Bridge, four miles from Arundel, Sussex.-Mr. Borrer.

Shrub; flowering in July.

This small shrub, not distinguished for its beauty, is called Fly Honey-suckle, from the distant resemblance of its flowers to the figure of a Fly. It is frequently planted in shrubberies and plantations, and it is probable that it has escaped and established itself in the stations above mentioned as a wild plant. It is frequent on most parts of the Continent, especially in the mountain woods of Italy.

\section{GENUS XXXV. RHAMNUS.-LiNs. Buckthorn.}

Nat. Ord. Rhasine五, Juss.

Gev. Char. Calyx urceolate, the limb four or five-cleft. Corolla of four or tire petals, or wanting. Stamens oppusite the petals, and with them inserted into the tuhe of the calyx. Styles from two to four, united or distinct. Fruit fleshy, of two to four cells, each cell containing a single seed.-Name from the Greek word gausos, a branch, from being numerously branched. 
1. R. cathar'ticus, Linn. (Fig. 380.) common Buchthorn. Spines terminal; leaves ovate, sharply serrated, sub-cordate at the base; flowers four-cleft, diœcious.

English Botany, t. 1629.-English Flora, rol. i. p. 32..-Hooker, British Flora, vol. i. p. 119.-Lindley, Synopsis, p. 73.

A sprearling shrub, with nearly opposite or altemate rigid hranches, terminating in a strong spine, the branches round, with a smooth bark. Leaves numerous, opposite, sometimes alternate, on downy channelled footstalks, ovate, or orate-lanceolate, with a more or less heart-shaped base, strongly marked with its mid-rib and four or six lateral parallel veins, pale on the under side, a brightish green ahore, the margins sharply and finely serwated, more or less thickly scattered over with simple hairs, the younger leares bave each at the base of the footstalk a pair of small lanceolate bractea, which soon fall away. Flowers in numerous crowded fascicles on the last year's branches, of a yellowish green colour, diocious, each elevated on a sleuder footstalk. Burren flowers bearing stamens only, have the calyx tube somewhat bellshaped, the segments four, ovate-lanceolate, with a mid-rib and tun marginal ones. Petals ovate oblong, shorter than the calyx segments, and alteruating with them, inserted at the top of the tube of the calyx, with the stamens before them, rising on four awl-shaped filaments, bearing orate two celled anthers; at the bottom of the tube of the calyx is a small abortive germen, with its short style and stigma. Fertile flower, with a bell-shape tube contracted at the mouth, its four pale ovate-lanceolate three ribbed segments erect. Petals small, linear, incurved above, inserted with the short abortive stamens before them into the mouth of the calyx tube. Style short, deeply four-cleft. Stirmas small, spreading. Berrie, bluish black, surrounded at the base with the persistent calyx, somewhat fleshy, of four (or less by abortion) cartilaginous cells, each containing a single erect seed, ovate, marked with a deep longitudiual suture in front, rounded at the back, and terminating in an acute curved cartilaginous point orer the foramen, emliryo nearly as long as the seed, with that hilney-shaped cotyledons, with an inferior radicle, surrounded by the albumen.

Inabitat.-Hedges, woods, and thickets; common in England; ahout Dumfries, Scotland; Islands in Lough Erne, near Enuiskillen; on a limestone rock east side of the Lee, two miles abore Cork, Ireland.Mr. J. Drummond.

Shrub; flowering in May and June.

Buckthorn berries were formerly much used as a cathartic medicine, hut their operation is so violeut, and produces so much griping pain, that they are now onily used to make a syrup to add as anxiliary to furgative enemas; when, however, taken internally in any form, they are productive of considerable dryness of the mouth and throat, causing great thirst, which unpleasant effects are not relicred eren with copious 
diluents. The juice expressed from the unripe berries has a faint unpleasant odour, a bitterish acrid nauseous taste, and is of a yellowish saffron colour ; it is used as a pigment, and a dye for staining paper, \&c. ; the juice of the riper berries is of a deep green, from it, by the addition of a little alum or lime water, and a portion of gum arabic, is formed by evaporation the sap green, used by painters. If the berries are gathered when quite ripe, the juice is purple instead of green, containing a portion of saccharine matter; it soon ferments, forming acetic acid, and the juice becomes of a reddish colour. The dried berries sold in the shops under the name of Freuch berries, are the unripe fruit of this plant, which is frequently mixed with the useless fruits of other plants, which do not possess the same property; but they are readily known by not having four cells, as the fruit of this plant has. The bark also affords a good yellow dye.

2. R. Fran'gula, Linn. (Fig. 381.) Berry-bearing Alder, or Alder Buckthorn. Without spines; leaves ovate, acute, entire; flowers all perfect.

English Botany, t. 250.-English Flora, vol. i. p. 329.-Hooker, British Flora, vol. i. p. 119.-Lindley, Synopsis, p. 73.

An erect shrub, with round, smooth, alternate, unarmed branches, mostly long, slender, leafy, and clothed with a soft down at the extremities, the bark a smooth shining purplish brown. Leaves alternate, ovate, or roundish, with an acute or accuminated point, round at the base, the margin entire, of a smooth shining deep green, paler beneath, with a strong mostly hairy mid-rib, and numerous straight parallel veins, smooth or hairy, footstalk channelled above, downy, each having at the base a pair of awl-shaped downy bractea, which shortly fall away. Flowers perfect, (containing both stamens and pistil), mostly numerous in fascicles from the axis of the leaves, each elevated on a slender, smooth, or downy stalk, with a minute stipule about mid-way. Calyx of five obovate downy erect segments, larger than the five altermating petals, which have a waved margin attached into the contracted throat of the calyx, with the short stamens before them, and partly enveloping them. Anthers ovate, of two cells. Stigma nearly sessile, capitate, cloven. Fruit a dark purple, somewhat fleshy berry of two or three single seeded cells, surrounded at its base with the persistent calyx, contracted into a shield-like plate.

Habitat.-Woods and shady places; frequent in England. Near Anchincruive, Ayrshire, Scotland.- $M I r$. Smith. On a small island, called the Creagh Bog, in Lough Beg, County of Derry, Ireland.Mr. D. Moore.

Shrub; flowering in May and June.

The Black Alder contains in all its parts, but particularly in the bark, a bitter astringent principle, which las been used in the form of 



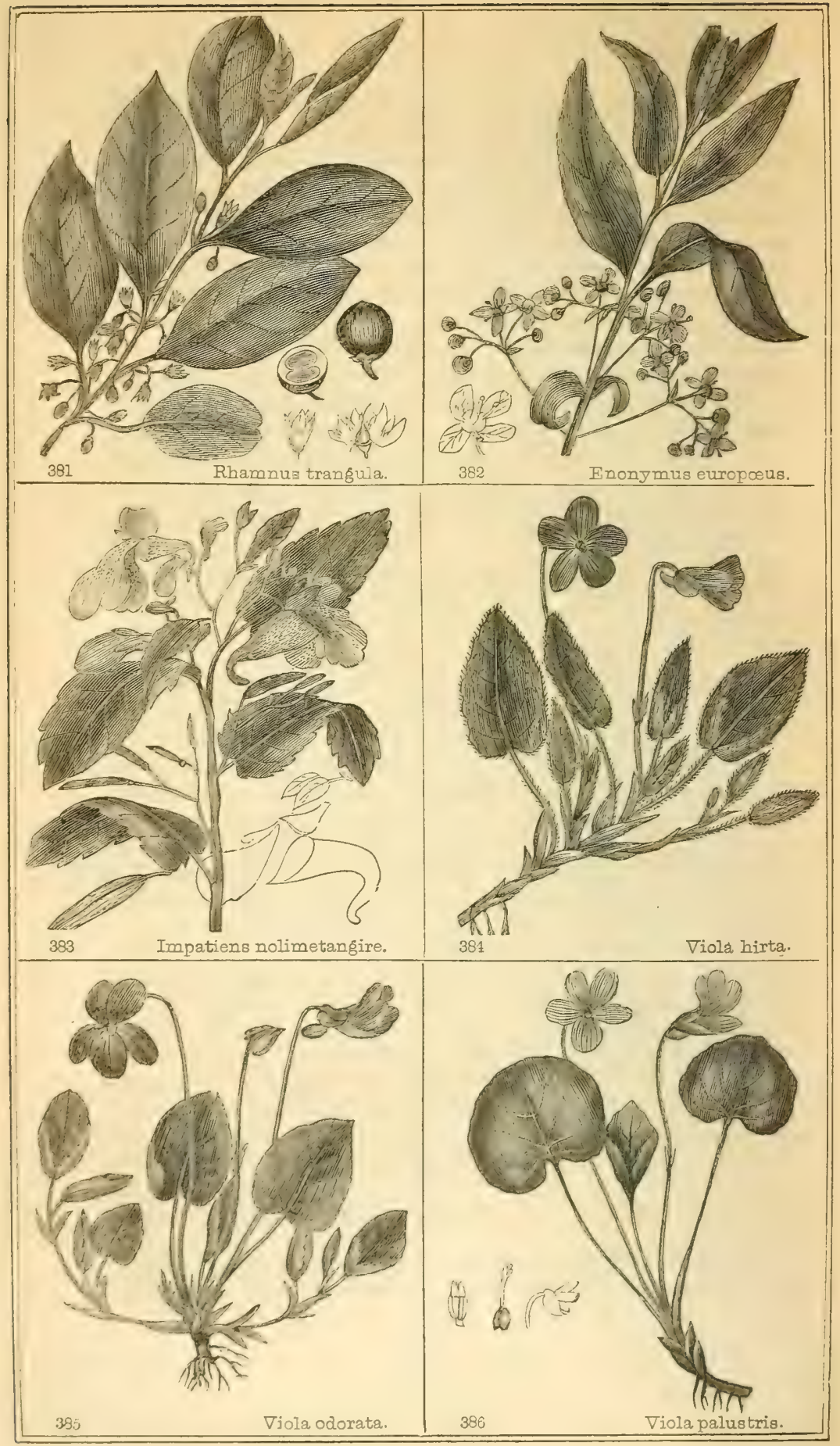


infusion and decoction for the cure of ague and dropsy, it is also used as a gargle in inflammatory affections of the throat. If taken in too large a dose it excites romiting, purges violently, and causes much griping. It is not now used, except by the country people and herbalists, and requires cautious administration. The berries, so far as their medicinal properties are concerned, are similar to the last, hut do not give the same useful colour, and are often mixed with them; a fraud which may be easily detected, from the difference in their shape and number of cells, this having but two, while the former has four.

It is remarked by Dr. Murry, of Gottingen, that he has found the chopped leaves of this plant, heated over the fire, the best remedy with which he is acquainted to disperse milk in the breasts; at all events it is a harmless remedy, how useful it may be we cannot say.

The berries and bark, both of this and those of $R$. cathaticus, are esteemed as purgatices in veterinary practice. Half an ounce of the bark boiled in some alle is frequently giren to cattle, and acts as a brisk cathartic, or a few seeds answer the same purpose. Both the bark and berries are used by dyer's for giving a yellow colour to woollen goods, and by the addition of preparations of iron a black colour is obtained. The wood is esteemed for burning into charcoal, particularly by the manufacturers of gunpowder; and the flowers, like several other species of this genus, are great favourites with the bees: for Evelyn says that the "honey-breathing blossoms affurd a marvellous relief to bees."

\section{GENUS XXXVI. EUO'NYMUS.-Linn. Spindle tree.}

\section{Nat. Ord. Celastri'nex. R. Brown.}

Gen, Char. Calyz flat, four or five-cleft, with a peltate disk at tha bottom. Petals four or five, inserted into the margin of the disk. Stamens four or five, alternating with the petals, and inserted into the disk. Capsules with three or live angles, and as many cells. Seeds one in each cell, with a coloured fleshy arillus, partly or entirely covering it.-Name from "Euonyme, mother to the Furies, in allusion to the injurious effects produced by the fruit of this plant."

E. Europ'œus, Linn. (Fig. 382.) common Spindle tree or Prickuood. Flowers mostly four-cleft; petals acute; branches smooth; leaves ovate-lanceolate, smooth, finely serrated; capsule obtusely angular, smooth.

English Botany, t. 362.-English Flora, rol. i. p. 330.-Hooker, British Flora, vol, i. p. 119.-Lindley, Synopsis, p. 74. 
An crect shrub, from four to eight feet high, with green smooth bark, and numerous straight branches opposite, divaricating, of four obtuse angles when young, afterwards becoming round. Leaves opposite, ovate-lanceolate, quite smooth, shining, the margins finely serrated, on a short footstalk, with a strong mid-rib and slenrler branched veins. Stipules awl-shaped, very small, and soon falling away. Inflorescence a small cyme of few flowers, on a naked peduncle from the axis of the leaves. Flowers small, greenish white, on short slender footstalks, having a fœtid odour; around the base of each footstalk is a thickened glandular ring. Calyx of four or five flat obtuse short segments, having at the bottom a flattish shield-like glandular disk. Petals four or five, alternating with, and much larger than the calyx, ovate oblong, whiteish green, waved and veiny, inserted under the margin of the disk. Stamens four or five, from the middle of the disk, filaments short, bearing rather large yellowish anthers, formed of two cells, and attached by their base to the filament. Style short. Stigma obtuse, emarginate. Capsule of a fiue rose colour, from three to five cells, but mostly four, smooth, obtusely anguler, surrounded at the base by the persistent calyx and glandular disk, and crowned by the persistent pistil, each cell bursting at the outer angle, and containing a single ovate ascending seed, surrounded either entirely or only in part with a succulent orange-coloured arillus, the albumen fleshy, surrounding a straight embryo, cotyledons flat, large, veiny, having a short inferior radicle.

Habitat.-Woods and hedges; not unfrequent in England, and the South of Ireland; King's Park, near St. Anthony's Well, and near Craigmillar Castle, near Edinburgh, Scotland.

Shrub; flowering in May.

The wood of the Spindle tree was formerly in great request for making spindles and distaffs; it is now chiefly used for skewers, tooth-picks, and other small articles, as well as by the musical instrument makers, \&c. All parts of the plant have a disagreeable smell, and are said to be poisonous to animals that feed upon it, except the goat; and when taken by man it acts as a strong purgative, and if in a large dose as an emetic. The seeds, when powdered and sprinkled amongst the hair, have been used and found an effectual remedy for cleansing it of all troublesome intruders, and may be employed with equal advantage in the destruction of other vermin.

It is an ornamental shrub in plantations mixed with other trees. Its rather large capsules, which are generally of a fine rose colour, sometimes almost white, look very handsome amongst its shining leares, and continue for a long time upon the trees. 


\title{
GENUS XXXVII. IMPA'TIENS,-LINy, Balsam.
}

\author{
Nat, Ord. Balsamínex, A. Richard.
}

Gen. Cuar. Calyx of two deciduous segments. Petals four, very unequal, the lower one elongated at the base into a spur. Anther's united, three of which are two celled, and two one celled. Stigma fire, united. Capsule long, tapering, of five elastic ralves, bursting sudilenly at the base, and rolling spirally.-Name (impatient) from the circumstance of the valves sudlenly flying open when touched.

1. I. Noli-me-tan'gere, Linn. (Fig. 383.) yellow Balsam, or Touchme-not. Peduncles solitary, axillary, many flowered, shorter than the leares, and spreading beneath them; spur of the flower recurred at the apex; leaves orate, petiolated, coarsely serrated; stem swelling at the joint.

English Botany, t. 93\%.-English Flora, vol. i. p. 299.-Hooker, British Flora, vol. i. p. 120.-Lindley, Synopsis, p. 60.

Root tleshy, with numerous spreading filores from the joints. Stem erect, from one to three feet high, round, smooth, pellucid, very strcculent, swollen at the joints, quite smooth, like all the rest of the plant, of a pale yellowish green, except about the joints, where it is pinkish, branched, opposite, or mostly alternate. Leares opposite or alternate, on footstalks of rariahle lengths, ovate or ovate oblong, sometimes tapering at the base, of a bright green, glaucous, and paler beneath, the margin coarsely serrated, some of the lower ones mostly lengthened into cilix, mid-rib strong, lateral ones rery slender. Peduncles slender from the axis of the leares, solitary, branched, shorter than the leaves, bearing from three to six pendulous flowers, each partial flower stalk with one or two small awl-shaped bractea, Flowers large, pale yellow, spotted with scarlet, very handsome. Caly.x of two ovate-lanceolate pellucid segments, haring a mid-rib, soon falling away after the flower has expanded. Corolla very irregular, of four petals, the upper one erect, flat, somewhat three-cleft, with a point in the midlde, forming the upper lip, the lnwer a long tubular spur or nectary, recurred about one-third from the apex, the mouth obliquely cut, terminating beneath in a point, the upper edge attached to the receptacle, the lateral petals much larger than the others, lobed, each accompanied at its base with a small entire oblong petal, all finely reined. Stamens five, on short curred filaments, thickened and somewhat hairy above. Anthers large, united together when ripe, the three lower ones with two perfect cells, the two upper with one cell ouly, the valres opening lengthwise. Pollen very 
abundant. Stigma five, sessile, united together into a cone-shape. Fruit a long pointed capsule, of five cells, with thin membranous divisions around the central placenta, having five valves, separating from the base to the apex, curling themselves suddenly when ripe by the least agitation, and throwing the seeds for some distance. Seeds numerous, ovate, suspended in the capsule, without albumen, having a straight embryo, with a superior radicle.

Habitat.-Moist shady woods; rare. Fountain's Abbey, and other places in Yorkshire; Westmoreland; Guildford, Surrey.-Rev. J. Jenyns. Abundant in a wet glen at Castlemilk, near Glasgow.Mr. Hoplirk.

Annual; flowering in July and August.

The whole plant possesses a degree of acridity, from which circumstance it is by no means a food palatable to most cattle. The structure of its flowers, and particularly its capsules, are worthy of minute examination; for when they are quite ripe, the least motion of the plant, more especially when the sun is upon them, causes the elastic power which they possess to separate the valves at the base, and suddenly rolling or rather curling up throw the seeds some distance from them, a circumstance which is thus noticed by Darwin in his Botanical Garden, and this is the reason that it bears the common name of Touch-me-not, by which it is known.

"With fierce distracted eye Impatiens stands,

Swells her pale cheeks and brandishes her hands;

With rage and hate the astonished groves alarms,

And hurls her infants from her frantic arms."

\section{GENUS XXXVIII. VIO'LA.-Linn. Violel.}

Nat. Ord. VIOLA'CEe: DE CAND.

Gen. Char. Calyx of five sepals, unequal and apendiculated at the base. Petals unequal, the lower one spurred at the base. Stamens with dilated flaments. The anthers united around the pistil, the two lower ones with processes at the base. Capsule of one cell, opening with three elastic valves.-The derivation of this name is variously stated; the most probable one appears to be from 6oy, as it is said to have been first noticed at Ionia.

* Stemless, or nearly so.

1. V. hir'la, Linn. (Fig. 384.) hairy Violet. Leares heart-shaped, downy above, beneath and the petioles hairy. Calyx sepals obtuse, lateral petals with a hairy central line. Capsule hairy, upon a prostrate peduncle without runners. 
English Botany, t. 894.-Euglish Flora, vol. i. p. 302.-Hooker, British Flora, yol. i. p. 120.-Lindley, Synopsis, p. 36.

Root strong, round. Runners rery short, or wanting, but not taking root. Leaves numerous, from the axis of a lanceolate, simple, or toothed stipule, on a long channeled hairy footstalk, oblong, heartshaped, more or less decply cut at the base, the margin crenated, downy above, heneath hairy, with a strong mid-rib and lateral branched veins. Flover stalk longer than the leaves, angular, simple, smooth, bearing below its middle a pair of lanceolate smooth bractea. Floner solitary, drooping. The calyx of live obtuse smooth pieces. Corolla palish blue, with darker veins, of five irregular petals, secntless, the two upper ones narrowest, and mostly entire, as are the two lateral ones, each of which has a central line of short white hairs, the lower petal larger and notched. Anthers surrounding the style, but not united, each tipped with an orange-coloured thin membrane. Style short. Stigma an oblique point. Capsule roundish, hairy, of three cells, and numerous seeds; its fuotstalk elongates after flowering, becomes prostrate on the earth, and mostly buries the capsules beneath the soil.

Habitat.-IVoods, pastures, and banks; not uncommon in England, especially in a calcareous soil. Rare in Scotland, fand apparently only about Edinburgh. Sand fields in Ireland, on banks by the sea between Clontarf and Kilbarrick Church, near Portmarnock, and elsewhere about Dublin, and wouds at Blarney, near Cork.

Pereunial; flowering in April and May.

It is probable this species is frequently orerlooked as $V$.odorata, from which, upon examination, it will be found to differ, especially in the want of rumers, in its hairiness, and its being spreading, the want of odour in the flowers, the situation of the bracteas, and the shape and hairs upon the capsules.

2. V. odor'ata, Linn. (Fig. 385.) sweet Violet. Leares broadily heart-shaped, nearly smooth, as well as the petioles. Calyx sepals obtuse, lateral petals with an hairy line. Capsule smooth, on a prostrate peduncle. Runners long, creeping.

English Botany, t. 619.-Euglish Flora, vol. i. p. 302.-Hooker, British Flora, vol. i. p. 120.-Lindley, Synopsis, p. 35.

Root with long branched fibres, sending out numerous long runners, and putting out at intervals long fibrous roots, where leaves and fluwers spring, and a new plant is established, the whole plant smooth, or scattered orer with a few short hairs, which are deflexed. Leaves arising from the axis of simple lanceolate or ovate-lanceolate toother stipules, on long channeled footstalks, broadly heart-shaped, with a mid-rib, and lateral reins nearly of the same size, the margin more or less deeply crenated. Flowers single, on a round or somewhat angular 
footstalk, having a pair of simple lanceolate or awl-shaped bractea about the middle, segrments of the calyx obtuse, slightly extended behint the insertion. Corolla a fine blue, white at the base, and the lower and two lateral petals penciled with dark purple veins, sometimes white, with purple reins, as well as the spur; of a rich fragrance, the lower petal largest, with a dark obtuse spur at the base, and notched at the apex, the lateral petals sometimes notched, and having at their base a few short white hairs, either in a line or a tuft, the two upper smallest, entire, ovate, oblong. Stamens nearly sessile, of two longtitudinal cells, bursting half way down from the apex, and extending besond them is a thin membranous lanceolate appendage, tipped with orange, and extending to the end of the style, the two lower ones having at their base a broad curved green appendage extending into the spur. Style as long as the stamens, recurved at the top and pointed, tipped with the stigma. Capsule ovate oblong, triangular, of three valves, smooth, bursting elasticly, and containing numerous pale seeds, its footstalk elongating after flowering, and lying prostrate on the ground when ripe.

Habitat.-Woods, banks, pastures, and shady lanes; frequent in England; rare in Scotland; banks near Slateford Aqueduct, and Colmton WVods, near Edinburgh ; not unfrequent in Ireland.

Perennial; flowering in March and April.

The Violet is a well known garden plant, producing its rich dark purple fragrant flowers early in the Spring.

"Ye Violets that first appear,

By your pure purple mantles known,

Like the proud virgins of the year,

As if the Spring were all your own;

What are ye when the Rose is blown?"-

Sir H. Wotton.

Many beanliful varieties are produced as the white and light blue, and these by cultivation become very double, but we think the deep blue by far the most beautiful ; for, as Byron says,

"The sweetness of the Violet's deep blue eyes,

Kiss'd by the breath of heaven, seems colour'd by its skies."

The petals have a somewhat laxative property and bitterish taste, and enter into the formation of a syrup, which, in combination with oil of almonds, is considered useful in relieving coughs in young children; and the syrup is also used as a delicate test in chemical investigations, to detect the presence of alkalies or acids: by the former it is changed into green, and hy the latter red. The petals of this, and sometimes of other species, are occasionally found wanting, but the capsules and seeds are perfected. 
We never meet with the beautiful Violet without admiring the construction of its flowers, and the admirable adiptation of its various parts to the fulfilment of the offices assigned to them by the wisdom of the Great Parent of all things. In taking the flower in the hand, we are first struck with the lateral petals having at the base a number of white hairs, which reach over the mouth, and seem to protect it from the intrusion of insects that might disturb the process of the works below, we mean in the stamens and pistils. We next see that the lower petal has at its base an elongated spur. like sack, cuntaining a quautity of fluid, and immersed in this are two curved clungated appendages, which are from the base of two of the stamens; these will be found to terminate in a naked glandular substance, orer which the cuticle does not extend, but is the prolongation of the inner substance, composed of a number of tubes, sc., and which aprear to absorb the fluid secreted in the spur, and apply it to the increased demand of nutriment to the stamens, and probally also the ovules in the germen during the period of fecundation; this supposition is strengthened from the fact, that after the discharge of the pollen no more fluid is secreted in the spur. If we next examine the stamens, we find that they surround the germen and pistil, and that each is surmounted by a pointed membrane, which unfolds the upper part of the style, and forms a kint of tube. We find also that the stamen is formed of two long cells, which burst longtitudinally at the top, and that each cell has at its apex a broadish bristle. Now this very almirable contrivance appears to be formed for the purpose of conreying the minute grains of the discharged pollen to the stigma, to prevent its dispersion around, and for the greater certainty of securing its application to the stigma, which is curved for its more easy accomplishment; for upon examination of the pistil, we find it also of a rery curious construction. As already stated it is thickened upwards, and curved at the extremity, and at the apex there is a small round orifice, which opens into a short hollow space, which contains a fluid, keeping moist the surface of the stigma, which is thus surrounded with a lind of hoorl; the upper or swollen part of the stigma is filled with the peculiar cellular structure proper to the stigma, but is again hollow in the lower contracted part. Frum the peculiar formation of the corered stigma, it will be seen what use there is in the peculiar formation of the stamens for the directing of the pollen to come in contact with the surface of the stigma; and what at first appears a useless appendage, will be seen to be a very curious and admirable structure, to accomplish an important purpose in the economy of the plant: but this is only oue instance of the beautiful adaptation of one part to another, the same more or less unvaried contrivance for the accomplishment of the same purpose will be found in the whole of the species of this interesting genus. But were we to examine the different parts of any 
plant, we should find the same display of wisdom and admirable design, cren in the minutest of the varied vegetable forms. There is another curious circumstance connected with the plants of this genus, we mean the capsules, and the bursting open of their valves with a sudden elasticity. If a transverse section of the more or less angular capsule is made, it will be seen to consist of one cell with three valves, and that each valve has at the angle a stout column of cellular matter, thicker in the lower part than above, and its two sides of a thin membranous substance, which are united to those of the other valve by a very thin transparent membrane. The inner edge of the contral column is the placenta, on which the seeds are attached by a very short slender cord, by which they are nourished until they are matured, at which time, when there is no further demand for the continued flow of fluid in the cellular substance or vther parts of the capsule, it gradually dries up; but as the cellular column contracts much more than the membranous sides of the valves by drying, it is constantly exerting a power to pull back the valves, which is resisted so lung as the thin membrane which unites the edges of the valves has power, which, however, at length gives way; and mostly by a sudden tear, by which motion the seeds now loosely attached are thrown to a considerable distance from the plant. This operation is generally performed during the day, while the sun is shining upon them and drying them, when their elastic power is greatest; for when the humid dew falls upon them a portion of it is absorbed, and consequently the valves become relaxed. We bave here endeavoured to describe the structure and use of the parts of a flower of remarkable formation, in the lope that the student of nature will be induced to examine it himself, and not rest satisfied with reading an imperfect account; and he will then find how difficult it is to read with satisfaction the real book of nature, and as difficult to describe even that which we think we know. But let lim not rest satisfied with the examination of this plant only, for he will find many others equally familiar to him as the sweet smelling Violet, that will fully compensate him for the trouble bestowed upon its investigation.

3. V. palus'tris, Linn. (Fig. 386.) Marsh Violet. Leares heart or lidney-shaped, quite smooth; calyx segments obtuse; spur very short; lateral petals nearly smooth; capsule smooth, without runners.

English Botany, t. 444.-English Flora, vol. i. p. 303.-Hooker, British Flora, vol. i. p. 121.-Lindley, Synopsis, p. 35.

Root small, branched, and fibrous, without or with very short xunners. Leaves mostly few in number, quite smooth, on longish footstalks, from the bosom of small thin membranous stipules, the footstalk is chamneled, and frequently slightly winged near the top, the leaf kiduey-shaped, with a licart-shaped base, the margin crenated more or less deeply, palcr on the under side and veiny; the reins all 
atrising from the base, and scarcely branched, sometimes the leaves are longer than broad, with an acute point, which is the variety $\beta$. uliginosa of Fries. Flowers on somewhat angular footstalks, with a pair of lanceolate bractea embracing the stem mostly more than half way up, generally toothed, or with glandular hairs. Calyx of five obtuse segments, slightly extending beyond the insertion. Corolla with a short obtuse spur at the base, inodorous, of a pale blue colour, with purple penciled lines, especially the lower one, and quite smooth, or slightly hairy at the base, but the lateral ones have not a distinct line of bairs, the upper petals rounded, the lower one with an acute point. Stamens nearly sessile, of two longtitudiual cells, opening towards the apex, and with a thin lanceolate membrane extended beyond them, having an orange-coloured point. Stigma obliquely truncated, not pointed and curved, as in the abore species. Capsule smooth, bluntly angular. Seeds numerous.

Habitat.-Bogs and marshy places; frequent in the North of England and Scotland, less common in the South; and in Ireland not unfrequent.

Perennial; flowering from April to July.

$$
\text { ** Furnished with a Stem. }
$$

4. V. Cani'na, Linn. (Fig. 387.) Dog's Violet. Stem procumbent, at length ascending, channeled, smooth, or slightly laairy; leares oblong, heart-shaped, acute; calyx segments lanceulate, accuminate; stipules lanceolate, with long ciliated teeth at the base; bractea awlshaped, entire.

English Botany, t. 620.-English Flora, vol. i. p. 304.-Hooker, British Flora, vol. i. p. 121.-Lindley, Synopsis, p. 35.

B. minor, (Fig. 388 ) V. flavicornis, Smith.-English Flora, vol. i. p. 305.-Forester in English Bot. Supplement. t. 2736.

$\%$ lactea. Stem ascending; leaves ovate-lanceolate, smooth; stipules toothed. I. lactea, Smith. English Botany, t. 445.-English Flora, rol. i. p. 306.-Hooker, British Flora, rol. i. p. 121.-Lindley, Synopsis, p. 35. V. lancifolia, Thore. and De Candolle makes it a variety of $V$. montana of Linn. It appears to be the $V$. lactea of Reichenb. V.persicifolia, Hartm. V. stagnina, Kilaibel in Schult.

Root somewhat woody, with long branched fibres. Stems mostly numerous from the same root, and spreading around it, the first flowers mostly blow without any stem, but then shortly appear, and are prostrate at the base, and gradually curving round, until erect at the extremities, smooth, or scattered with hairs, angular, extending from two to six or eight inches long, branched in the lower part, leafy. Leaves alternate, quite smooth, or scattered over with hairs, the margins crenated, the unler side paler than the upper, and somewhat glancous, with a midl-rib and branched slender veins, the lower or radical leares kidney-shaped, or broadly heart-shaped, hecoming 
oblong, with a broadish point and scarcely heart-shaped base, each on a long channeled footstalk, arising from between a pair of lanceolate stipules, each having a mid-rib, and the margins with long hair-like teeth. Flowers solitary, axillary, on long angular stalks. Bractea awl-shaped, entire above the middle of the stalk. Caly $x$ of five linear lanceolate acutely pointed segments, scarcely extended at the base beyoud the insertion, each with a mill-rib and two more or less listinct lateral ones. Corolla mostly large, of a pale blue, white at the base, and with dark purple simple and branched lines, spur obtuse, and mostly of a greenish white, the upper petals mostly entire, with a few hairs at the base, either in a tuft or in lines, the lower one smooth, and generally notched. Anthers nearly sessile, surrounding the pistil, the two lower with curvea appendages at their base behind, which extend into the spur, and are scattered orer with glands, the cells long, linear, having a thin membranous lanceolate appendage, coloured with orange, cxtending beyond them, which seems for the purpose of forming a clannel to direct the discharged pollen to the stigma at their extremity. Style curved at the base, thickening upwards. Stigma recurred of two plates, surrounded at the base with a few short white hairs. Capsule oblong, of three obtuse angular valves. Seeds numerous, ovate, of a white shining satin appearance, attached by their extremity to the inner angle of the valves, and thrown some distance from the plant when ripe, by the sudden separation of the valves.

Habitat.-Woods, banks, thickets, and dry places; frequent.

Perennial; flowering from April to August.

The Dog's Violet is readily distinguished from the sweet one, by the absence of that fragrance which renders the other so great a favourite, and by this having also stems, which are wanting in $V$. odorata. These are the two most obvious characters, and at once distinguish them from each other; but there are numerous states of this plant which appear to depend on their situation of growth, that differ in several respects from each other, as being larger or smaller jlants, smooth, or hairy; and the flowers also differ greatly in their size and the intensity of their colour. The most marked of these varieties is the $V$. favicornis, which has a small yellowish spur; in other respects, except its smaller size and more rigid habit, it is the same as above described.

5. V. tri'color, Lirn. (Fig. 389.) Pansey Violet, or Heart's Ease. Stem ascending, angular, branched; leaves deeply crenated, the lower ovate, heart-shaperl, the upper oblong; stipules lyrate, pinnatifid; calyx segments shorter than the corolla.

English Botany, t. 1287.-English Flura, vol. i. p. 306.-Hooker, British Flora, vol. i. p. 121.-Lindley, Synopsis, p. 36.

$\alpha$, vulgaris. Corolla longer than the calyx of a violet, blue, purple, 
yellow, or white, colour either simple or mixed, the upper petals mostly coloured.

B. arvensis, (Fig. 390.) Corolla shorter than the calyx, yellow, or white, the upper petals seldom colourcd. V. arvensis, Sibth. Forst. in English Butany Suppt. t. 2712.

$\gamma$. saxatilis, (Fig. 391.) Corolla yellow, longer than the calyx, the plant small. V. saxatilis, Schm. V. Curtisii, Forst. in English Botany, Suppt. t. 2693.

An extremely variable plant, both as to the size and coluur of the flowers. Root small, and fibrous. Stem erect, or ascending from two to twelve or more inches hirh, smooth or hairy, especially in the lower part, branched and leafy, straight or zig-zag, angular, and frequently furrowed. Leaves on long flit footstalks, smooth, or hairy, the margins deeply crenated, the lower ones ovate, with a heart-shaped base, the upper ovate, or oblong lancelate, and somewhat decurrent at the base. Stipules large, in pairs at the base of each footstalk, lyrato pinnatifid, the segments uarrow, tongue-shaped, hairy and ciliated, generally most numerous on the outer side, the terminal segment large, ovate, entire, or crenated. Flowers solitary, on long axillary angular stalks, bearing a pitir of small lanceolate bractea, which are simple, or with one or two slender tecth at the base. Caly.x of five linear lanceolate acute segments extended at the base from the insertion, in an oblong, rounded, or notched, sometimes waved or lanceolate prolongation, smooth, hairy or ciliated on the margin, and more or less distinctly three ribbed. Corolla longer or shorter than the calyx, ' and of various colours, the four upper ones entire, the lower one broadest, heartstaped, and marked from the base with simple or slightly branched purple lines, the lateral nnes having at their base a tuft of obtusc inflated hairs. Stamens somewhat united in their upper part around the style, of two valves, the margins mostly lairy. Stigma surrounded by an inflated hood, opening on one side near the apex with a circular apperture, surrounded with a few short white hairs. Style curred at the base, and marked on the under side from the top with a dark line. Capsule obtusely triangular, of three valves, opening clasticly. Seerls numerous, ovate, attached by one end to the placenta.

Habitat.-Banks and cultivated lields; frequent. $\beta$. corn fields, common. $\gamma$. South of England and Ireland.

Annual; flowering during the Summer months.

This is an extremely rariable plant as to its size, hairiness, and the colour of its flowers. It is said to he annual, bicnnial, or perennial, according to the circumstances of its grow th and cultivation; for it is from this species that the many rery beautiful and various coloured sorts are obtained by cultivation that adorn our garden borders : and the successful triumphs of the cultivator, in the production of large 
and splendid various coloured sorts are seen at almost every floricultural exhibition in the country. As a low border flower, perhaps few surpass it either in the beauty or variety of its colours, and it continues putting out its blooms during the whole of the Summer montlis. And may we not in the contemplation of these floral gems, with the poet Smart, exclaim-

"Immense Creator! whose all powerful hand

Framed universal being, and whose eye

Saw, like thyself, that all things form'd were good;

Where shall the timorous bard thy praise begin,

Where end the purest sacrifice of song

And just thanksgiving?-

O thrice illustrious! were it not for thee,

Those pansies that, reclining from the bank,

View through the immaculate pellucid stream

Their portraiture in the inverted heaven,

Might as well change their triple boast, the white,

The purple and the gold, that far outvie

The Eastern monarch's garb, e'en with the dock,

E'en with the baneful hemlock's irksome green."

It has been recommended either in the form of an extract, or boiled in milk, for the cure of epilepsy, asthma, and in various cutaneous diseases; and stated by some authors to have been used with success when all other remedies have failed, especially in that kind of diseased skin called crusta lactea, but in the hands of modern practitioners it has failed: formerly too, its decoction was thought to possess the property of removing from the eye specks and scars, caused by ulcerations, and also to be an excellent remerly for coughs, and a good diuretic. How it obtained the name of Heart's-ease I know not. Herrick says-

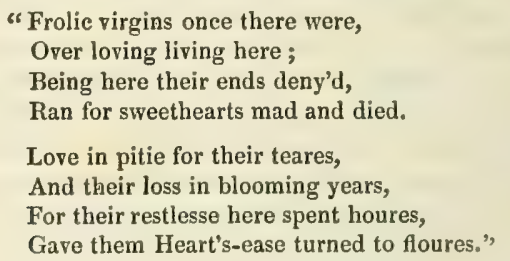

These are not, however, the only virtues that they are said to possess; for the poets say-

"Are not Pansies emblems meet for thought?

The pure, the chequer'd-gay and deep by turns;

A line for every mood the bright things wear

In their soft velvet coats."

6. V. Iu'tea, Huds. (Fig. 392.) yellow Mountain Violet, or yellow Pansy. Stem ascending, much branched at the base; leaves crenated, 


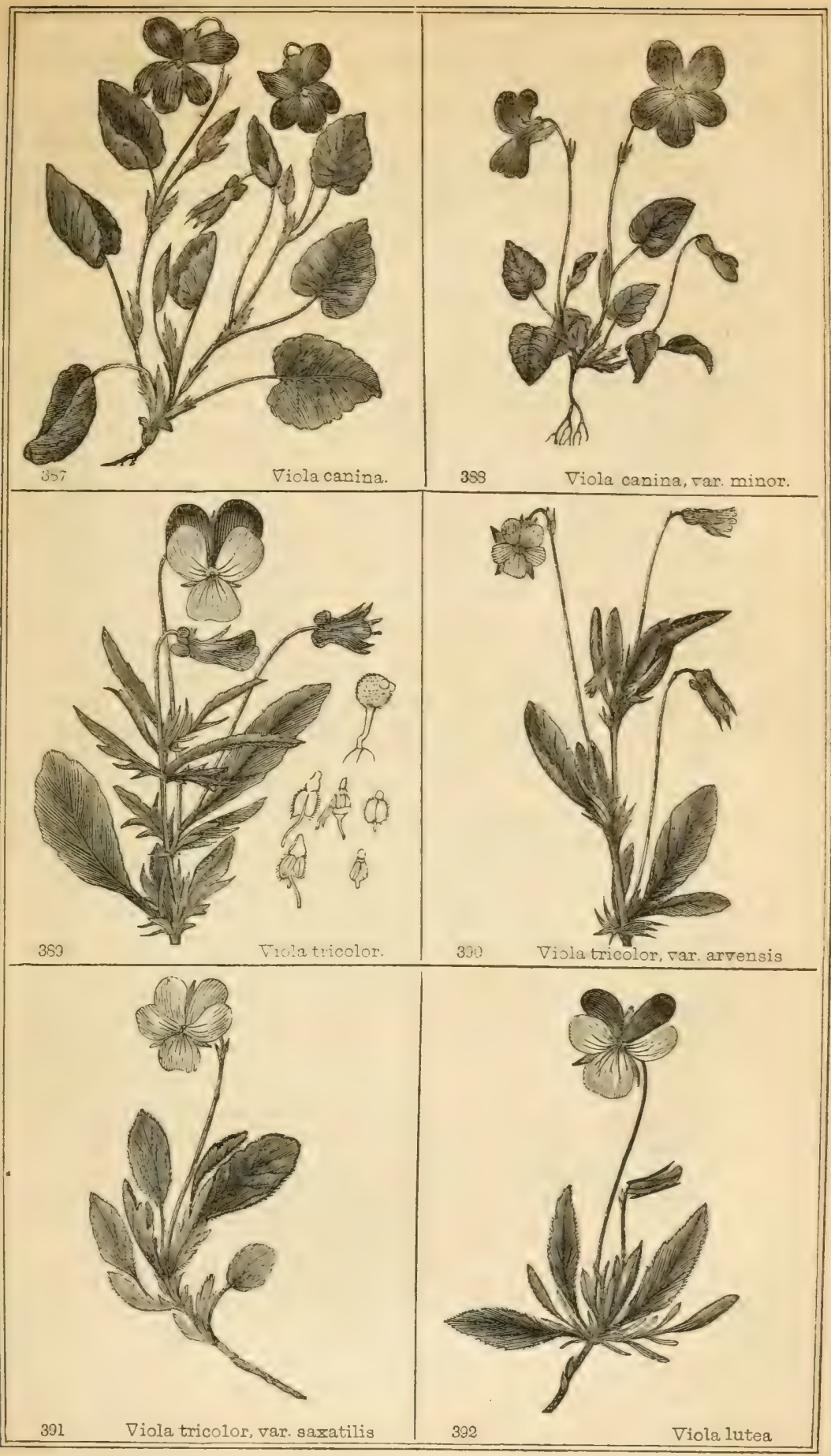



the lower orate, the upper oblong; stipules lyxate, pinnatified, much divided.

English Botany, t. 721.-English Flora, vol. i. 1. 307.-Hooker, British Flora, vol. i. p. 122.-Lindley, Synopsis, p. 36. I. grandiflora, Hudson, not Linn.

Vill. Cat.
x. grandiflora.
Flowers large, the plant small.
V. grandiflora,

B. sudetica. Hlowers large, petals often deeply crenated. $V$. sudetica, Willd.

$\gamma$. majus. Leaves broadly orate, subcoriaceous, flowers deep yellow. Root small, fibrous. Stem from three to six inches high, much branched and curved at the base, sometimes simple, weak and slenter, angular, hairy or smooth. Leaves numerous, alternate, on flat footstalks, slightly crenated, and more or less hairy, with a mid-rib and slender lateral reins, the lower ones orate, somewhat heart-shaped at the base, the upper ovate oblong. Stipules large, lyrate, with numerous narrow linear segments, the terminal one lanceolate, ovate, simple, or crenated. Flowers large, solitary, on a long slender angular footstalk, quite smooth, and near the top is a pair of lanceolate, simple, or more generally toother at the base bracteas, sometimes they are oblong, obtuse. Caly $x$ of fire lanceolate mostly acute segments, having at its base from the point of insertion an obtuse simple or notched prolongation, smooth, or sumetimes slightly hairy, and the margins are often membranous, and each segment has three longitudinal ribs. Corolla large or small, but always longer than the calyx, and is of variable colours, sometimes entire, deep purple or yellow, or these colours more or less blended together, or the two upper petals are purple, and the others yellow, or the four upper ones purple, and the lower yellow, the lower one and almost always the two lateral ones marked with dark simple or slightly branched lines, spur obtuse, scarcely extending beyond the calyx, the lateral petals with a tuft of lairs at their base. Stamens and pistil similar to the last, as well as the capsule and seeds.

Habitat.-Frequent in mountain pastures in the North of England, Wales, and Scotland; and mountains near Castletown, County of Cork, Ireland.

Perennial; flowering during the Summer months.

The rariety $\gamma$. majus, Sic W. J. Hooker observes, is a rery singular one, discovered by Mr. Murry, in Arran, and cultivated for many years in the Glasgow Botanical Garden. It forms a large dense tuft, and with its very numerous broad dark green leares and bright yellow fiowers, makes a bandsome appearance. 
GENUS XXXIX. RI'BES.-Lins. Currant and Gooseberry.

Nat. Ord. Grossulari'ex, DE Cand.

GEN. Char. Calyx of four or five segments, regular, and bearing the petals and stamens. Style from two to four-cleft. Fruit a single celled, many seeded herry.-Name: "Pibes was a word applied by the Arabic physicians to a species of Rhuturb, Rheum Ribes. Our older Botanists believed that it was our Gooseberry; and hence Bauhin called that plant Ribes acidum." - Hooker.

* Without Thorns. Flowers racemose. Currants.

1. R. ru'brum, Linn. (Fig. 393 ) common red Currant. Racemes smooth, pendulous both in flower and fruit; calyz cup-shaped, almost flat; petals small, spatulate, or notched.

English Botany, t. 1289.-English Flora, vol, i. p. 331.-Houker, British Flora, vol. i. p. 122.-Lindley, Synopsis, p. 106.

A bushy erect shrub, with a smooth cuticle that cracks and curls up as the plant increases. Leaves alternate, on longish smooth or fringed footstalks, five lobed, and doubly serrated, paler beneath, and with prominent ribs and reins, smootb, or slightly hairy, especially beneath. Inflorescence racemes of numerous flowers, pendent from the axis of the leares. Flowers small, pale green, each on a short partial footstalk, arising from the axis of a small orate bractea, which soon falls away, and frequently beneath the flower there are one or two small ones. Calyx somewhat cup-shaped, but almost flat, the limb of five acute segments. Petals small, alternating with the segments of the calyx, and fixed into its tube, spatulate, obtuse, or slightly notched. Stamens on short filaments, opposite the segments of the calyx. Anthers of two separate lobes, two celled, bursting longtitudinally. Style short. Stigmas two, spreading. Berry globular, smooth, red, and shining, crowned by the withered persistent flower, of one cell. Seeds numerous, attached by one end to the parietal placenta by a slender cord, and suspended amongst the pulp; the external integument of the seed is gelatinous, the internal membranous. Embryo minute.

Habitat.-Alpine woods in the North of England and Scotland; and not unfrequent in hedges in rarious parts of the country, and Ireland, but not wild in such situations.

Shrub; flowering in May.

The red currant is a well known cultivated garden shrub, producing red, pink, and white berries, the two latter being only varieties of the former, and are esteemed more as a dessert fruit than as applied to so many domestic puryoses as the red currants, which contain more abun- 
dantly the grateful acidity than the others. They are boiled with nearly an equal weight of sugar, and make an excellent preserve useful for a rariety of culinary purposes; and the juice, boiled with an equal weight of lump sugar into a jelly, is esteemed as a delicious addition to the sauce of roast hare, renison, and a long kept leg ut mutton, and also for various kinds of confectionery. The agreeableness of the red currant depends upon its peculiar aroma in combination with malic acid and saccharine matter, and it imparts these qualities to wine made from its fermented juice, with the addition of a quantity of water and sugar; a wine which is superior, in the opinion of many persons, to several grape wines, which are procured at great expense, a circumstance that tends in no inconsiderable number of cases to the increase of their estimation. When the fruit is fresh it is cooling, and mustly very agreeable to the palate of those suffering from fever, and a small quantity of its jelly added to boiling water, and allowed to cool, is a useful drink agreeable for a time to many persons in a feverish state; and is said to lessen an increased secretion of bile, and act as a laxative upon the bowels, but in some cases it occasions considerable flatulency and uneasiness.

The currant, like the guoseberry, is a plant flourishing only in a cool climate, and seems there to supply the place of the grape in warmer countries, requiring a longer time for the perfection of its fruit than seems allowed it when planted in a warmer climate. We have repeatedly seen the attempt made to grow them in the South of Italy and Portugal; but the plants become tall and straggling, quite losing the compact character of the bush in its natire country, and the fruit is small, bitterish, and far from being pleasant, and very little is produced: so that the Englishman far from his natire land, who still retains in memory the delights of this fruit, and the grateful taste of his mother's preserve, must procure them in perfection from his parent land.

"On foreign mountains may the sun refine

The grape's soft juice, and mellow it to wine,

With citron groves adorn a distant soil, And the fat olive swell with floods of oil: We envy not the warmer clime, that lies In ten degrees of more indulgent skies, Nor at the coarseness of our heaven repine Though o'er our heads the frozen Pleiads shine."

Addison.

2. R. petre'um, Wulf. (Fig. 394.) Rock Currant. Racemes with glandular hairs, erect in flower, pendulous in fruit; calyx smooth, cunshaped; its segments beneath bluntish, flat; petals small, spatulate; leares pale and dull.

English Botany, t. 705.-English Flora, rol. i. p. 332.-Hooker, British Flora, vol, i. p. 122.-Lindley, Synopsis, p. 106. 
A low much branched shrub, with a smooth cuticle cracking and curling up, as in the last species. Leaves alternate, on chamneled hairy footstalks, three or five lobed, smooth, or somewhat scattered over with hairs, a pale glaucous green beneath, with three or tive mid-ribs and numerous small lateral veins, the margins doubly serrated. Inflorescence erect axillary racemes, which are recurved and pendant when in fruit, the stalks more or less scattered over with short glandular hairs, partial stalks short, arising from a small ovate membranous edged bractea, which soon falls away, and frequently there are one or two small scales beneath the flowers. Calyx cup-shaped, with five spreading flat obtuse or acute segments, smooth, or sometimes with a slightly ciliated margin, green, or with a pinkish tinge. Corolla of five small spatulate segments fixed into the tube of the calyx hetween the segments. Stamens five, alternating with the petals on short filaments. The anthers of two oblong cells, bursting longitudinally. Style short. Stigma of two spreading lobes. Berry small, smooth, with several obscure ribs, globose, bright red, acid, crowned by the persistent withered flower. Seeds numerous, similar to the above species.

Habitat.-Woods in the North of England and Scotland; rare. Eggelston, and near Conscliffe, Durham; Scots Wood Dean, Northumberland; near Airy Castle, and by the Spey side, at Aviemore, Scotland.

Shrub; flowering in May and June.

3. R. spica'tum, Robson.- (Fig. 395.) acid Mountain Currant. "Spikes upright in flower and in fruit; flowers nearly sessile; petals oblong; bracteas shorter than the flowers."

English Botany, t. 1290.-English Flora, vol. i. p. 332.-Hooker, British Flora, vol. i. p. 122.-Lindley, Synopsis, p. 106.

"This has the bahit of the two foregoing species, but differs from both in the extreme shortness of the partial flower stalks, rendering the inflorescence a spike rather than a cluster, which, moreover, is erect both in flower and fruit. If these characters be not constant, the present species probably belongs to $R$. petroum, which seems scarcely credible."

Habitat.-Woods near Richmond, Yorkshire; and formerly near Gainsford, Durham.-Mr. G. Robson.

Shrub; flowering in May.

This plant we are not acquainted with, except from the works above quoted; the description and remarks are from Smitb.

4. R. alpi'num, Linn. (Fig. 396.) tasteless Mountain Currant. Racemes with glandular hairs, ereet both in flower and fruit; flowers flain, smooth, shorter than the lanceolate bractea; leaves beueatl pale and shining. 



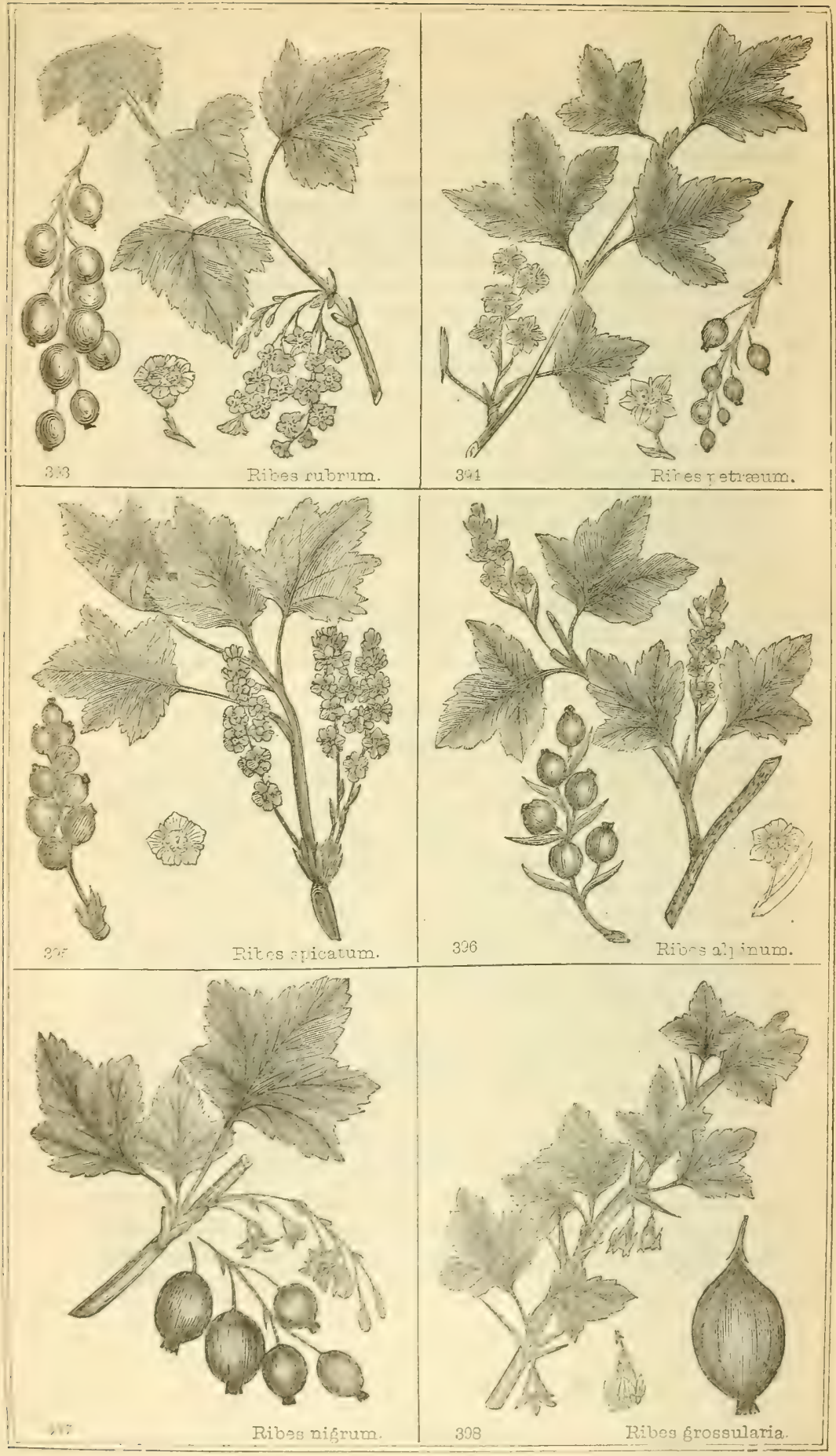


English Botany, t. 704.-English Flora, vol. i. p. 333.-Hooker, Britisl Flora, vol. i. p. 121.-Lindley, Synopsis, p. 106.

A small branched shrub, from two to three feet high, with a pale smooth shining loose cuticle cracking and curling up, much branched and leafy. Leares alternate, scattered over with hairs, on" channeled hairy footstalks, of three or five lobes, green above, pale and shining beneath, with three or five ribs and a few slender lateral veins, the margins ciliated, coarsely and doubly serrated. Inflorescence axillary. Racemes erect both in flower and in fruit, more or less profusely scattered over with short hairs, terminating in a rather large round lark gland, some of the racemes large, with numerous flowers bearing stamens only in a perfect state, others with a few flowers that are perfect, partial fontstalks, short from the axis, of a lanceolate membranous bractea, longer than the flower, having a mid-rib, and the margin fringed with glandular hairs. Calyx plain, of tive broad obtuse or acute segments, three ribbed petals very short, obtuse, fixed into the tube of the calyx between the segments of the calyx. Stamens with short filaments, and two oblong anthers. Style short, with an obtuse notched stigma. Berry small, red, globose, smooth, crowned by the withered flower, having an insipid taste.

Habitat.-Woods and fissures of shady rocks; in the North of England and Scotland; about Bradford and Ripon, Yorkshire; Buxton, Derbyshire; Cadzow Castle, near Hamilton, and Bothwell Castle, Scotland.

Shrub; flowering in May.

This is readily distinguished by its shining leaves and long lanceolate bracteas. Upon the cuticle of this, as may also be observed upon other species of Ribes, are minute black spots, which, upon-examination with a strong lens, will be found to be a kind of Fungus, the Dothidea ribesia, Pers.

5. R. ni'grum, Linn. (Fig. 397.) black Currant. Racemes downy, pendulous, of few flowers, with a separate one at the base; fluwers bell-shaped; calyx scattered over with glands; the segments obtuse, recurred; leaves doited with glands on the under side.

English Botany, t. 1291.-English Flora, vol. i. p.333-Hooker, British Flora, vol. i. p. 123.-Lindley, Synopsis, p. 107.

A shrub about three feet high, more spreading, and less branched than $R$. rubrum. Leaves alternate, large, on channeled footstalks, three or five lobed, coarsely and sometimes doubly serrated, smooth above, paler beneath, and scattered over with glandular dots, which exhale a peculiar odour, the ribs and reins strong and promiuent beneath. Inflorescence a pendulous raceme, of few green flowers, having an odd one at the base, the stalk downy, the partial footstalks long, from the axis of a small lanceolate bractea. Calyx bell-shaped, the 
segments oblong, recurved, scattered over with glardular hairs. Petals oblong, acute, fixed into the tube, and alternating with the segments of the calyx. Stamens on slender filaments, bearing roundish oblong anthers. Style short. Stigma obtuse, notched. Berry large, black, globose, crowned by the withered flower, of a pleasant sub-acid taste, with somewhat of the flavour of the leaves.

Habitat.-Damp woods, and the banks of rivers in various parts of the country; not unfrequent.

Shrub; flowering in May.

The fruit of the black currant is esteemed by many persons much more than the red; but to others its peculiar fragrance is very objectionable. Made into jelly or jam, with sugar, the fruit is highly approved of as a remedy for the relief of sore throats and ulcerated mouths, either taken alone, made into lozenges, or boiling water poured upon it, and drinking the infusion. This, as well as an infusion made of the leaves, is said to act powerfully as a diuretic; and a good draught of it taken hot before getting into bed promotes perspiration; and the wine made from the fermented juice of the berries is thought to have the same medicinal properties. In Siberia the leares are dried and mixed with souchong, $t n$ give it the flavour of green tea; and infused in spirits they give it a colour resembling common brandy. The young wood seems also to possess the same properties as the leares.

* With Thorns. Flowers pedunculated one to three. Gooseberries.

1. R. Grossula'ria, Linn. (Fig 398.) common Gooseberry. Peduncles from one to three flowered, hairy, each flower-stalk bearing one, two, or three bracteas; fruit more or less hairy; calyz campanulate; its segments reflexed.

English Botany, t. 1292.-English Flora, vol.i.p. 334.-Hooker, British Flora, vol. i. p. 123.-Lindley, Synopsis, p. 107.

$\beta$ pubescens. Orarium hairy, becoming smooth as the fruit advances to maturity. R. Uva crispa, Linn. English Botany, t. 2057.

$\%$ glabrum. Smooth, except the margins of the leaves, petioles, bractea, and calyx, being ciliated. IR. reclinatum, Linn.

A low much branched bush, with a smooth pale cuticle cracking and rolling off, armed with sharp thorns, one, two, or three together immediately beneath the buds, which put out a fascicule of leaves and the flowers. Leaves numerous, on footstalks, channeled above, either smooth or hairy, three or five lobed, cut and serrated, paler beneath, with strong ribs and branched reins, generally hairy on both sides, but sometimes quite smooth and shining above, while beneath it is thickly clothed with soft hairs. Flouers solitary, or on a branched peduncle of two or three flowers from the axis of the leares, smooth $\mathrm{ol}$ hairy, as are the minute bractens heneath them. Caly $x$ bell-shaped, 
surmounting the ovarium, which is smooth or hairy, having also sometimes a number of beautiful pink glandular hairs interspersed amongst them, the $\lim b$ of the calyx of five oblong obtuse reflexed reiny segments. Petals alternating with the segments of the calyx, and fixed into the mouth of the tube, oblong, obtuse, smooth or hairy. Stamens alternating with the petals, on smooth or hairy slender filaments. Anthers two, oblong, bursting longtitudinally. Style nearly as long as the stamens, simple or hairy. Stigma obtuse, notched, or entire. Berry roundish, oblong, smooth or hairy, red, green, or yellow, and very variable in size.

Habitat.-Woods, hedges, and thickets; not unfrequent. Thought by some persons not to be an indigenous plant, but naturalized. In the North of England, howerer, as well as Hamilton woods in Scotland, it has the appearance of being wild.

Shrub; flowering in April and May.

The fruit of the Gooseberry is so well known as a farourite dessert, and applied to so many domestic purposes, as not to need specifying here. The wine made from its green fruit forms an excellent and very farourite beverage, and the making it of a superior quality and favour is a triumph of considerable importance in the annals of the domestic management of our country dames, and when well made and managed it is little inferior to champagne; in fact, it is frequently sold in the shops under that name at a most extravagant charge, and is a fraud upon the pockets of the ignorant, whose palate, untutored in such luxuries, is unable to detect the cheat.

There are a considerable number of rarieties of gooseberries both as to size, colour, and acidity; the size depending mainly upon the mode of cultivation. In sume parts of the country, especially in Lancasbire, Nottinghamshire, and other neighbouring counties, this is a very farourite fruit with amateur gardeners, and the success of the cultivation is judged of not by the quantity produced by any plant, but the magnitude of the fruit, and these sometimes are grown to a size weighing an ounce and a half or more. To produce these, however, the tree is sometimes not allowed to bear more than one ur two berries, and requires the greatest care in pruning, keeping cool and dry the fruit, \&c. \&c. The acidity of the fruit seens in some way connected with the colour, for those of the darkest colour contain the greatest proportion of acid, which is the malic in combination when the fruit is ripe with sugar, and it is from this that the rarious kinds of berries are better suited to different purposes, as preserving, kitchen use, wine, \&c.

The gooseberry is, like the currant, found wild in the mountainous districts of the continent; but it is seldom cultivated in the gardens, frum its not producing either much or good flavoured fruit. In 
Portugal gooseberries are called Uva de Nord, (grapes of the North); in Italy Uva spinosa, (spiny grapes); and in French groseilles.

\section{GENUS XL. HE'DERA.-LINN. Ivy.}

Nat. Ord. Aralia'ceer, Juss.

Gen. Char. Calyx of five teeth. Petals broadest at the base. Style simple, or divided. Fruit a succulent berry, crowned by the calyx, of from three to five cells, and as many seeds.-Name said to be from hareo, to stick, because it attaches itself to trees and old walls.

1. H. He'lix, Linn. (Fig. 399.) common Ivy. Stem climbing; flowers in erect umbels; leaves coriaceous, smooth and shining, ovate or heart-shaped, or of from three to five angular lobes.

English Botany, t. 1267.-English Flora, vol. i. p. 335.-Hooker, British Flora, vol. i. p. 123.-Lindley, Synopsis, p. 133.

Stem very long and creeping, and attaching itself to objects that are near it, as walls or trees, by means of numerous root-like processes, branched, and very leafy. Leaves evergreen, of dark hue, smooth and shining, paler beneath, with a mid-rib and long lateral veins, alternate on footstalks of variable shapes, sometimes the whole are orate-lanceolate, with a more or less wared border, in others the upper leaves are only of this shape, while the lower are of three or five angular lobes, and in other instances the whole are of this shape. Inflorescence a simple umbel, of numerous flowers, terminating the branches either with one or a number of umbels, disposed in a corymbose manner. Flowers small, green, on stalks, clothed with close minute star-like down, surrounded at the base with sereral small ovatelanceolate bracteas, limb of the calyx of five minute tecth. Petals green, reflexed, oblong from a broad base, pointed, with a mid-rib. Stamens alternating with the petals. Filaments as long as the petals. Anthers of two longtitudinal cells, cloven at the base. Style simple and furrowed, or several. Stigma simple, obtuse. Fruit a smouth globular berry, black, somewhat glaucous, of from three to five cells, surrounded by a mealy substance. Seeds single in each cell, oblong.

Habitat.-Hedges, woods, rocks, and ruined buildings ; frequent.

Shrub ; flowering in October.

Iry by the ancients was much esteemed. Of it they wove the fillets of their Bacchanalian merry makings, and wreathed into a crown they placed it on the brows, to mark the poet's fame; not only, how- 



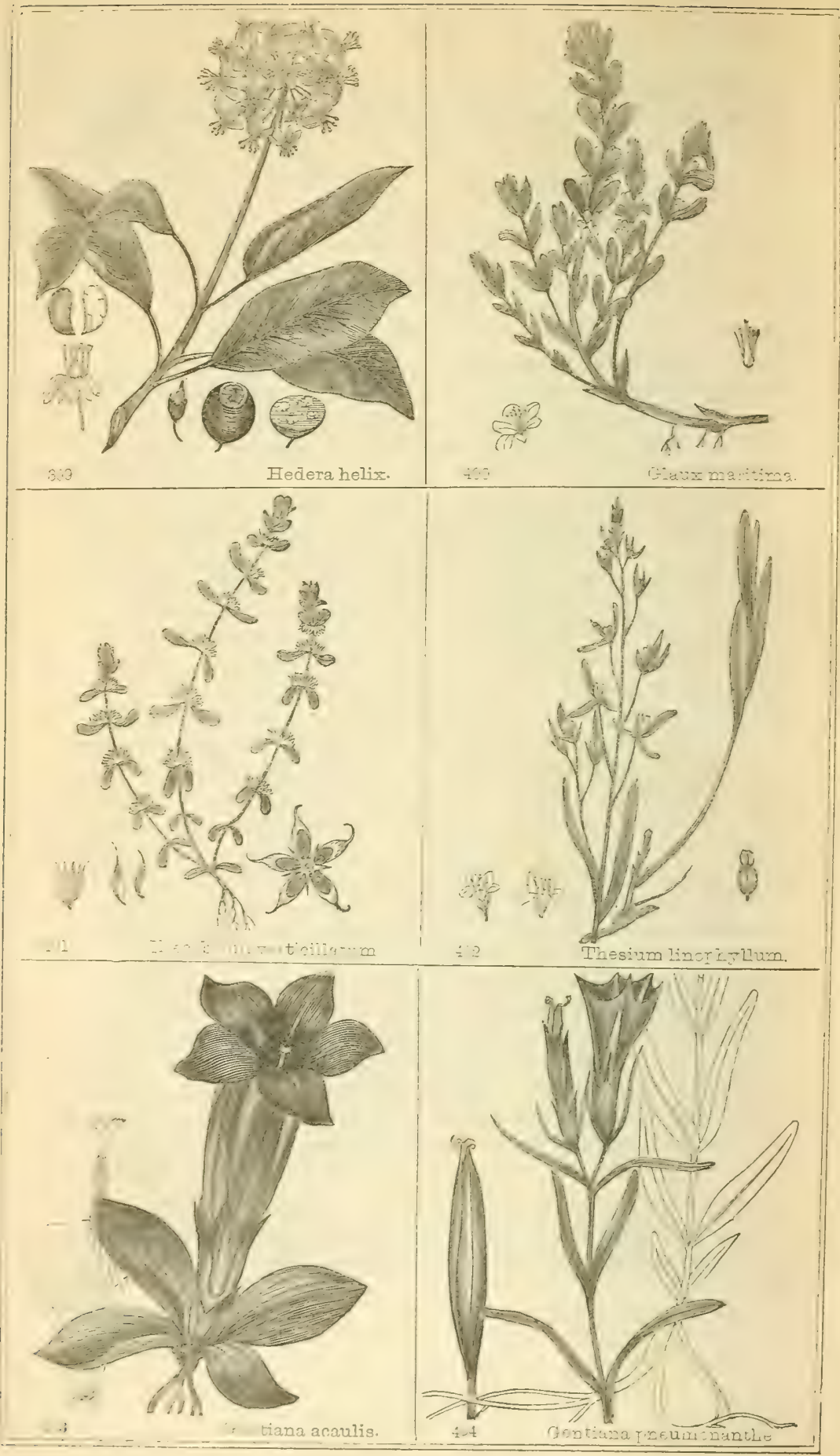


ever, did they use it as an extemal decoration, lut its juice, they say, dissipated the effects of too great potations of their generous wine. We do not, howerer, find that it has this property. The leaves have little or no smell, but a rery nauseous taste, possessing stimulating properties, with a somewhat purgative effect; they were formerly applied to ulcers, and are at the present time, by the country people, as well as it was formerly used to increase the discharge of issues. The berries are bitter, purgative, and also emetic; they are not now used, but are the favourite food of some kinds of birls during the winter season.

Iry is now chiefly valued as an ornamental evergreen, of which there are numerous varieties; some with variegated leaves, others with very large green lobed ones: and no plant is more useful than it is for covering old walls, mouldering ruins, or rugged rock work, since it will flourish well in the poorest snil, in shady situations, or twisting its pliant arms around the withered limbs of the patriarchal oak, holds fast its mouldering fragments, with seeming filial solicitude, and rejoices in making gay with its erer-shining leaves the tottering head of the grey grown monarch of the forest; and o'ten, too, do we see it mounting orer the shattered ruins of battlements and towers, clinging to and holding in its grasp the very fragments. Byron in lis Childe Harold, speaking of the tomb of Cecilia Metella, says,

"There is a stern round tower of other days,

Firm as a fortress, with its fence of stone,

Such as an army's baffled strength delays,

Standing with half its battlements alone,

And with two thousand years of ivy grown,

The garlaud of eternity, where wave

The green leaves over all by time o'erthrown ;-

What was this tower of strength? within its cave,

What treasures lay so lock'd, so hid? - A woman's grave."

From the stem of the iry there exudes a juice of a resinous character, called Gummi hederce. It may be obtained in small quantities in this country, but is imported from warmer climates, particularly the East Indies. It is brought orer in hard compact masses, of a brownish colour, reddish outside, paler within; it has an agreeable smell, and astringent taste. It is seldom or nerer used in the practice of the present day; it possesses astringent and slight anti-spasmodic virtues.

The root-like processes, which are abundantly sent out from the stems, and by which the plant clings to oljects, and supports its long slender branches, is one of the many iustances of the admirable manner in which this is accomplisher in climbing plants; and the olsserver of nature will find that even in these appendages to plants, there is mucl that is curious in their structure. They are very variously formed, but all equally perfect in accomplishing the purpose for which they were

VoL. I. 
made, namely, the support of the climbing branches, but not as means of absorbing sustenance for the maintenance of its ritality.

\section{GENUS XLI. GLA'UX.-LrNN. Sea Milkwort.}

Nat. Ord. Primula'cex, Vent.

Gen. Char. Perianth single, inferior bell-shaped, five-cleft, coloured.

Slamens inserted at the bottom of the perianth. Stigma capitate. Capsule globose, of one cell and five valves. Seeds about tive, attached to a central placenta,-Name from $\gamma^{\lambda a u r b r, ~ o n ~ a c c o u n t ~}$ of its sea green colour, or because it grows near the sea.

1. G. Mari'tima, Linn. (Fig. 400.) common Sea Milkwort, or Black Saltwort.

English Botany, t. 13.-English Flora, vol. i. p. 337.-Hooker, British Flora, vol. i. p. 124.-Lindley, Synopsis, p. 183.

Root with long branched fibres. Stem bent at the base, or nearly erect, and sending out roots from the lower juints, from two to fire inches high, branched, especially below, round, smooth, and very leafy. Leaves in alternate pairs, ovate or orate oblong, quite smooth, entire, fleshy, of a glaucous green, paler beneath, with a mid-rib, saltish to the taste. Flowers numerous, solitary, nearly sessile in the axis of the leares, of a pinkish colour, the perianth single, bell-shaped, deeply cleft into fire obtuse segments. Stamens inserted into the bottom of the perianth. Filaments awl-shaped, and as long as the perianth. Anthers oblong, of two longtitudinal cells. Style as long as the stamens, tapering upwards with a capitate stigma. Capsule glolose, pointed with the base of the style, of one cell, bursting with five ralves. Seeds mostly five, roundish, attached to a central globose placenta. Embryo central, straight.

Habitat.-Sea shore, and muddy marshes near the sea; frequent. Perennial; flowering in June and July.

\section{GENUŚ XLII. ILLE'CEBRUMí.-Linn. Knotgrass.}

Nat. Ord. Paronychi'ex. St. Hiz.

Gen. Cran. Calyx in five nearly separate segments, thickened and laterally compressed, cartilaginous, terminating in a slender awlshaped point. Petals wanting, or reduced to five alternate awlshaped scales. Style short. Stiqmas two, obtuse. Capsule 
surrounded by the calyx, of one cell, markerl with five loigtitudinal stria. Seed single, attached to the side of the cavi:y.-Name illecebra, an enticement, or attraction, anciently given to a showy tribe of plants.

1. I. verticilla'tum, Linn. (Fig. 401.) whirled Knotgrass. Stem procumbent, thread-like; leaves broadly ovate; flowers in cruwded axillary whirls.

English Botany, t. 895.-English Flora, vol. i. p. 336.-Hooker, Britislı Flora, vol. i. p. 124.-Lindley, Synopsis, p. 61.

Root small, fibrous, with creeping stems, putting out roots from the joints. The whole plant quite smooth. Stems slender, thread-like, much branched, or simple, spreading upon the surface of the ground, green, or of a pinkish colour, rouud, or somewhat angular at the whirls. Leares numerous, in alternate pairs, roundish, oblong, or spatulate, sessile, or on short footstalks, somewhat fleshy, having at their base thin pale membranous lacinated stipules. Flowers numerous, crowded in axillary whorls, small, white, or pinkish. Calyx of five white segments, scarcely united at the base, oblong, fleshy, pointed, and terminating in a curved slender aw!-shaped bristle, compressed on the sides, hollowed out in the inside into a kind of hood, where it is of a green colour. Petals either wanting or reduced into thin awl-shaped pinkish scales, alternating with the segments of the calyx. Stamens opposite the segments of the calyx, and inserted into their base. Anthers ovate, of two cells. Style very short. Stigmas two, obtuse. Capsule surrounded by the persistent calyx, oblong, pointed, marked with firc longtitudinal lines, along which it separates. Sieed solitary, uvate, pointed, attached to one side of the capsule.

Habitat.-Damp marshy places in Devonshire and Cornwall; not uncommon.

Perennial; flowering in July.

A small interestiug plant, from the singular construction of its flowers; and though not obtruded upon the notice from any gay charms that it has, the Botanist will find, on its examination, much that is worthy of notice, especially in the calyx, and its curious formation hollowed out in its inside, forming a cavity, which is closed around, and protecting the important parts of fructification from intrusion or injury by external causes; and at the same time their fleshy substance supplies those parts with nutriment, and form reservoirs in case of need, a circumstance not unlikely to occur during the Summer months, from the moisture of the situation in which the plant grows becoming dried up. These, it will appear, are thus formed, and supply the want of a glandular disk, which we see in many other plants; and thus we observe in this unobtrusive plant another instance of admirable and beatiful arrangement of its parts, adapted to the circumstances and situation of its growth, and that all things are made, thongh so 
very variable, for some useful end; and that every weed, however insignificant in its appearance, will point out the perfection given to his works by the all-wise Author of creation.

\section{GENUS XLIII. THE'SIULI.-Linn. Bastard Toadflax.}

Nat. Ord. Santalácex, R. Brown.

GeN. Char. Perianth four or five-cleft. Petals wanting. Stamens npposite the segments of the calyx, surrounded with a small fascicle of hairs. Style long. S'tigma simple, obtuse. Fruit a single seeded dry or fleshy drupe, crowned by the persistent calyx.Name of doubtful urigin.

1. T. linophyl'lum, Linn. (Fig. 402.) Lint-leaved Bastard Toadflax. Stem and branches paniculated; leaves linear, lanceolate, three nerved; bracteas ternate; fruit nearly globose.

English Botany, t. 247.-English Flora, vol. i. p. 338.-Hooker, British Flora, rul. i. p. 124.-Lindley, Synopsis, p. 208.-T. pratense, Ehrh.

Root woody, yellow, branched, bearing several stems. Stem erect, or spreading, smooth, striated, or angular, branched and leafy, from twelve to eighteen inches high. Leares numerous, alternate, linear, lanceolate, obtusely pointed, three ribbed, the margins smooth, or roughish towards the point, about an inch long, of a pale green colour. Inforescence terminal, paniculated, racemes of numerous flowers, mostly turned to one side, erect, sprearling when in fruit, each partial footstalk laring at its base a bractea of three irregular sized leares, one mostly much larger than the two others, obscurely, three ribbed. Flowers pale, jellowish, or white, the perianth with a short tube, the segments four or fire oblong obtuse or acute ones, margins entire, or irregularly toothed. Stamens inserted into the base of each segment, surrounded with a few short hairs. Style simple, as long as the perianth. Stigma obtuse, capitate. Fruit somewhat globose, strongly ribbed, a single seeded drupe, crowned by the persistent perianth. Seed roundish.

Habitat.-Elevated chalky pastures; not unfrequent in Cambridgeshire, Norfolk, Suffolk, and Dorsetshire; Ramar Hills, near Dorking, Surrey.-J. S. Mill, Esq.

Perennial; flowering in July. 


\section{ORDER II.}

\section{DIGYN'IA. 2 Pistils.}

\section{GENUS XLIV.† GENTIA'NA.-Linn. Gentian.}

Nat. Ord. Gextian'ex. Juss.

Gen. Char. Calyx four or five-cleft. Corolla funnel or salvershaped, with a tubular base, the limb five-cleft. Stamens inserted into the tube of the corolla. Styles sometimes united into one. Stigmas two. Capsule of one cell, with two valves, and margiual placenta.- Named from Gentius, King of Illyria, who is said to have brought it into use as a medicine.

* Flouers terminal or axillary, solitary, or in pairs, the mouth naked.

1. G. acau'lis, Linn. (Fig. 403.) dwarf Gentian. Flower solitary, terminal, about as long as the square stem; leaves oblong lanceolate; stigmas semi-orbicular toothed.

English Botany, t. 1594.-English Flora, vol. ii. p. 28.-Hooker, British Flora, vol. i. p. 124.-Lindley, Synopsis, p. 178.

Root fleshy, branched fibres. Stem solitary, square, smooth, from one to two inches long, arising from the middle of a tuft of radical leares, and one or two pairs on the stem. Leares oblong lanceolate, acutely pointed, from one to five ribbed, quite smooth, shining. Flower terminating the stem, and about the same length. Calyx mostly with a pair of leares at the base, of one piece, tubular, dirided into tive broadly lanceolate acute segments, closely pressed to the tube of the corolla, each with a single and two lateral obscure ribs. Corolla bell-shaped, with a somewhat inflated tube, ribbed, of a pale blue, spotted within with dark purple spots, and quite naked, the limb plaited, of fire broadly lanceolate icute spreading segments, of a very deep rich blue, entire, or occasionally notched at the base.

† Suertia perennis, Linn. (Marsh Felwort, or Suertia.) Corolla of five lanceolate acute segments; stem simple; peduncles corymbose; leaves nerved, ovate, pointed at each extremity.

English Botany, t. 1441.-English Flora, vol. i. p. 26.-Hooker, British Flora, vol. i. p. 124.-Lindley, Synopsis, p. 179.

According to Hudson, this plant was found by Dr. Richardson in Wales; but as it has not since been found there, and as there are soine reasons to suppose there is a mistake as to its being a native plant, we think it ought not to be admitted into our Flora. 
Stamens arising from about the midule of the tube, and about the same length. Filaments awl-shaped. Anthers of two long narrow cells, united round the style. Styles uuited, as long as the stamens. Stigmas semi-orbicular toothed.

Habitat.-Mountainous districts; near Haverfordwest, South Wales.-M. de St. Amans.

Perennial; flowering in June and $\mathrm{July}$.

We hare some doubt as to the claim this has to be admitted as a native plant, it having most probably escaped from the garden, where it is much cultivated for the beauty of its rich flowers, either in small beds or along the borders, and certainly few flowers surpass it in the richness and splendour of its colours. It is frequent on the mountain pastures of the Continent, and is sometimes used as a tonic, a principle possessed by all the plants of this order. Several varieties are mentioned of this plant, depending upon the length of the stem and the size and wilth of the leares, as growing upon the Appenine mountains, in Italy.

2. G. Pneumonan'the, Linn. (Fig. 404.) Marsh Gentian. Flowers solitary, or numerous, terminal and axillary; stigmas linear, oblong; leaves linear.

English Botany, t. 20.-English Flora, vol. ii. p. 27.-Hooker, British Flora, vol. i. p. 125.-Lindley, Synopsis, p. 178.

Root of numerous long stout simple brown branches. Stem simple, solitary, or several from the same root, square, erect or bent at the base, smooth and leafy, from four to twelve inches high. Leares opposite, linear, or linear lanceolate, obtuse or acute at the point, the margin fine serrated towards the point, smooth, paler beneath, single ribberl, sessile, and united at the base into a short tube round the stem. Flowers terminal and axillary, solitary, or mostly numerous, the axillary ones on short footstalks. Calyx tubular, membranous, with five broad ribs, terminating in linear lanceolate segments, with minutely serrated margins at the base of the calyx; there is mostly a pair of linear bractea, and sometimes sereral. Corolla somewhat bellshaped or funnel-shaped, the tube yellow at the base, blue above, the limb plaited in five broadly lanceolate acute segments, of a rich deep blue, mostly notched between, and marked with five greenish streaks outside. Stamens arising from about the middle of the tube on awlshaped filaments. Anthers of two linear cells, united around the style, heneath the linear oblong stigmas, which are minutely granulated. Capsule of one cell, surrounded by the withered flower, oblong, cylindrical, on a contracted footstalk, pointed at the extremity by the styles, which roll back, and separate the two valves at the apex for the escape of the seed, smooth, with two simple dorsal and the two lateral ribs, where the valves separate. Seeds very numerous, minute, ovate, attenuated, and heautifully markerl with sunk ints, attached hy their 
pointed base to the placenta, formed by the incurved margin of the valves.

Habitat.-Moist heaths and damp places, in rarious parts of England.

Perennial ; flowering from July to September.

This species is used in Russia for the same purposes that the Gentiana lutea is with us, and possesses similar tonic properties, useful in many debilitated states of the system, its infusion forming one of our most elegant bitters. Specimens are not unfrequently found with the leaves two or three times wider than in the normal state of the plant, and having a mid-rib and two lateral ones, a circumstance which has induced the belief in some persons of their being different species, and not a variety only.

** Flowers terminal, solitary, with five large and five small segments, the mouth naked.

3. G. ver'na, Linn. (Fig. 405.) Spring Gentian. Stem single flowered; calyx of five narrow winged angles; the larger segments of the corolla obtuse and crenated; style undivided; stigmas semiorbicular; leaves ovate, crowded.

English Botany, t. 493.-English Flora, vol. ii. p. 29.-Hooker, British Flora, vol. i. p. 125.-Lindley, Synopsis, p. 178.

Roots slender, with creeping branches putting out fibrous roots and tufts of leares, from amidst which arise the flowering stems. Leares numerous, ovate, acute, sessile, the lower ones crowded in a rosette manner, those of the stem opposite, slightly sheathing at the base, each with a single rib, somewhat fleshy, quite smooth. Stem rery short, square, bearing a solitary terminal flower. Caly $x$ tubular, of fire acute more or less broadly winged angles, each terminating in the mid-rib of five lanceolate segments, shorter than the tube of the corolla; at the base of the calyx are sereral small leares or bracteas. Flower salver-shaped, the tube of the corolla cylindrical, yellowish above, green below, plaited and reiny, twice as long as the calyx, the limb of five ovate, obtuse, or acute spreading more or less crenated segments, and between these are five small deeply cloven ones, the limb is about half an inch across, of a dark brilliant blue, the mouth naked. Stamens on short filaments from the middle of the tube. Anthers oblong, of two cells, uniterl around the upper part of the style, which is single. Stigmas of two semi-orbicular crenated lobes. Capsule oblong, of two valves. Seeds numerous.

Habitat.-Mountainous and alpine pastures; rare. Middleton in Teesdale, Durham, plentiful. Burrow Mountains, near Gort, and between Gort and Galway, Ireland.

Perennial ; flowering in April.

This beatiful little flower is far more frequent in the alpine districts 
of the Continent than with us. It is frequently cultivated as a border flower, but requires much more care than $G$. acaulis, and is a most beatiful addition to the collection of our early Spring flowers, blooming as when in its native fields, or along the mountain's side, while the white snowy mantle yet lingers on the ground.

4. G. niva'lis, Linn. (Fig. 406.) small alpine Gentian. Stem single flowered; calyx of five acute angles; the larger segments of the corolla acute, entire; style short, bifid; stigmas semi-orbicular; leaves small, ovate oblong, acute.

English Botany, t. 896.-English Flora, vol. ii. p. 29.-Hooker, British Flora, vol. i. p. 125.-Lindley, Synopsis, p. 178.

Root tapering, fibrous, simple. Stem erect, simple or branched, smooth, square, slender, from one to six inches high, leafy, the lower leaves surrounding the root, numerous, ovate oblong, the upper opposite, ovate, acute, united at the base, and forming a short sheath around the stem, smooth, shining, entire, single ribbed. Flowers terminating the stem and branches, sulitary, about half an inch long. Calyx tubular, of five acute angles, terminating in the mid-rib of the lanceolate segments, nearly as long as the tube of the corolla, which is yellowish below, striated, plaited above, the mouth naked, the limb of five spreading oblong acute entire veiny lobes, having small cloven segments between them, all of a dark brilliant blue colour. Stamens on short slender filaments, from about the middle of the tube. Anthers small, ovate, scarcely united. Styles rery short, spreading. Stigmas semi-orbicular, downy. Capsule oblong, of two valves, surrounded by the withered flower, as in the other species, bursting at the top. Seeds numerous, ovate, dark brown, closely pitted with small ovate pits.

Habitat.-Mountains, near the line of perpetual snow; exceedingly rare, and found only on the mountains of Scotland, Ben Lawers; and abundantly on rocks on both sides of Glen Isla, Clova:

Annual; flowering in August.

No plants exceed in the richness of their colours these minute gems of alpine districts, and none are more splendid than the flowers of this plant. It would seem that the more elevated a situation in which plants grow, the richer and deeper are the colour of their flowers, and these are mostly blue or purple, or white, and generally far surpass in the depth and richness of colour those species of the same genus growing in less elevated situations, as will be seen in the present; and as other familiar examples, we may mention those of Myosotis and Veronica.

*** Flovers racemose or paniculated, four or five-cleft, the mouth fringed.

5. G. Amarel'tn, Linn. (Fig. 407.) Autumnal Gentian. Stem much 



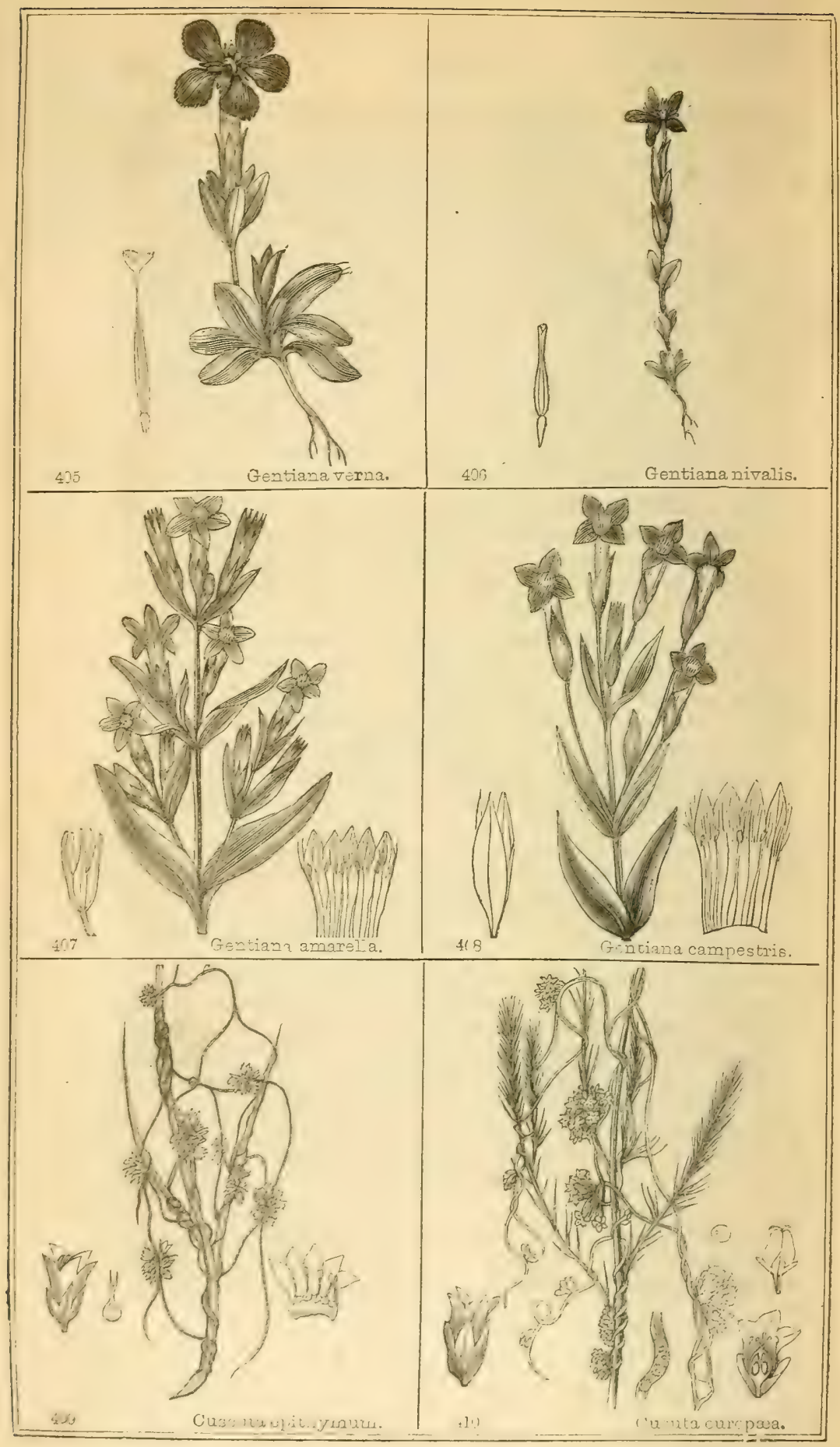


iranched, many flowered; calyx of five nearly equal linear lanceulate. teeth; corolla five cleft, bearded.

English Botany, t. 236.-English Flora, vol. ii. p. 30.-Hooker, British Flora, vol. i. p. 125.-Lindley, Synopsis, p. 178.

$R o n t$ tapering, twisted and branched below, yellowish. Stem square, erect, smooth, leafy, from four to twelve inches high, mostly purplish, very much branched, with short many flowered branches, forming a leafy panicle. Leaves lanceolate, or ovate-lanceolate, opposite, sessile dark green, paler beneath, three ribbed, and often five, the lower leares frequently on short foutstalks, broad at the base, the upper ones narrow, lanceclate, with an acute point. Flouers numerous, on short footstalks, hearing one or two lanceolate bractea, frequently the whole plant from the axis of the lower leaves upwards bears flowers. Calyx tubular, about half as long as the tube of the corolla, pale green, of five angles and ten ribs, the limb of five lanceolate nearly equal green segments, about as long as the tube. Corolla salver-shaped, the tube pale, striated, the limb pale dull purple, of five, sometimes four, or even three short broadly lanceolate segments, expanding in the sun, the mouth of the tube surrounded with waved hairs. Stamens inserted below the middle of the tube. The filaments slender, awl-shaped, longer than the tube of the corolla. Anthers oblong, of two nearly separate cells, bursting longtitudinally. Style very short. Stigmas oblong, flat, spreading. Capsule long, cylindrical, pointed, opening at the apes, two ralied, many seeded. Seed roundish, flat, dark brown, minutely dotted.

Habitat.-Pastures and meadows frequent, especially in a lime. stone district in a subalpine country.

Annual; flowering from April to July.

This and the following species are nearly allied to each other, but are readily distinguished by the calyx, that of $G$. Amarella being tubular, with a nearly regular limb of fire narrow segments; while that of $G$.campestris is four-cleft, the two outer segments very large, enveloping the others. They are both possessed of the same bitter tonic principle, and are used indiscriminately by the country people as a stomachic, in combination with centaury, Erythroca centaurium, making a tea of them, and taking one or two wine glasses of it during the day, and is often useful in debilitated state of the digestive organs.

6. G. campes'tris, Linn. (Fig. 408) Field Gentiant. Stem mucls branched, many flowered; calyx four-cleft; the two outer segments very large, ovate-lanceolate; corolla four-cleft; bearded.

English Botany, t. 237.-English Flora, vol. ii. p. 31.-Hooker, British Flora, vol. i. p. 125.-Lindley, Synopsis, p. 178.

Root tapering, twisted and branched below, yellowish. Stem square, erect, smooth, leafy, from four to twelve inches ligh, much braucherl, frequently from the base, somewhat corymbose abore, green or pinkish. 
Leaves in pairs, orate-lanceolate, acute, three ribbed, smooth, dark green, paler beneath, the lower leaves orate, or ovate-lanceolate, on short footstalks. Flowers rery numerous, on rather long naked footstalks, thickened upwards. Caly $x$ of four very unequal segments, with a short tube, the two outer ones rery large, orate-lanceolate, three ribbed, nearly as long as the tube of the corolla, enreloping the two smaller lanceolate ones, also three ribbed. Corolla salver-shaped, the tube crlindrical, striated, pale, yellowish, the limb of four, sometimes the terminal flower with fire lanceolate segments, more or less bearded round the mouth, of a pale dull purplish colour. Stamens inserted about the middle of the tube, and ahout the same Jength, on awlshaped filaments. Anthers oblong, of two longtitudinal cells. Style short. Stigmas flat, spreading. Capsule linear, cylindrical, or slightly compressed, four ribbed, pointed, bursting at the apex, two valred, many seeded. Seeds rery small, roundisb, flat, brown, minutely dotted.

Habitat.-Fields, meadows, and elerated pastures, especially in a limestone district; fiequent.

Annual; flowering from July to September.

\section{GENUS XLV. CUS'CUTA.-Lins. Dodder.}

Nat. Ord. Coxrolrola'ceEs. Juss.

Gex. Char. Calyx four or five-cleft. Corolla roundish, bell-shaped, the limb of four or five lobes, and sometimes with as many scales at the base below the stamens. Capsule two celled, two seeded, bursting at the base transversely. Parasitical twining leafless plants, with long thread-like stems. - Name the same as norfutc, probably from the Arabic Keshout. (Theis).

1. C. Epithymum, Linn. (Fig. 409.) lesser Dodder. Stem very slender, branched; flowers sessile, in cruwded heads; limb of the corolla in four or fire orate-lanceolate segments, about as long as the tube; stamens with a fringed couverging scale at the base; stigmas filiform.

English Botany, t. 55.-(C. Europaa).-English Flora, rol. ii. p. 25.-Hooker, British Flora, rol. i.p. I27.-Lindler, Synopsis, p. 168.

Root small, fibrous, soon withering away. Stem thread-shaped, much branclued, twisted, and entangled, of a dark red colour, sometimes pale yellow, attaching itself to the stem and branches of other plants by small orate suchers, with a fringed margin. Leares none. Inforesecter of from six to twelve sessile flowers, in a close roundish 
head. Flowers small, white, or slightly tinged with pink. Calyx of une piece, persistent, deeply five-cleft in Lutr or five lanceolate segments, somewhat fleshy at the hase. Corolla bell-shaped, the limb of four or fire ovate-lanceolate segments, about as long as the tube, the point more or less elongated. Stamens four or five, with aw l-shaped filaments arising from the top of the tube between the segments of the limb, each having at its base an orate scale, with a fringed margin closing over the germen. Anther small, yellow, orate, cleft at the base. Germen roundish, superior, crowned by the two erect simple styles, with red stigmas. Capsule small, roundish, surrounded by the withered calyx and corolla, two celled, each cell single seeded, bursting transversely at the hase. Seed small, roundish, flat, pale hrown.

Habitat.-On furze, heath, broom, nettles, clover, thyme, \&c. In various parts of England and Scotland.

Annual; flowering from July to August.

This is readily distinguished from the following, by its much more slender darker red stems, smaller clusters of flowers, the narrower segments of the calyx and corolla, and especially the fringed scale at the base of the stamens. We have found it on a great variety of plants, but more especially the heath, broom, and furze, in dry heathy situations, orer which it spreads its slender arms, and seems indiscriminate in its selection of the species of plants which it converts to its use; for it may not unfrequently be found deriving support from fire or six different plants at the same time, spreading over a surface of three or four feet, twisting and entangling in a confused looking manner. It is much more frequent on the Continent than with us, and especially in Purtugal ; We hare seen it almost corering the herbage on the side of banks near the sea for a considerable distance.

2. C. Europaa, Linn. (Fig. 410.) greater Dodder. Stem slender, branched; flowers sessile, in crowded lieads; limb of the corolla in four or fire orate acute segments, about as long as the tube, without scales at the base of the stamens; stigmas filiform.

English Botany, t. 378.-English Flura, p. 24.-Hooker in Flora Lond. t. 67.- British Flora, vol, i. p. 126.-Lindley, Synopsis, p. 168.

Root small, fibrous. Stem much stouter than the last, pale green, or pink, much branched and entangled, twisting itself about the other plant, three or four feet high, round and smooth, putting out indiscriminately at any part of the stem papillæ, round or orate at the extremity, with a narrow fringed border around a central radical, by which it attaches itself to other plants, and derives its nourishment. Leares none. Inflorescence round sessile heads, the size of a hazel nut, of numerous white flowers. Calyx of one piece, persistent, sessile, the base fleshy, having in the centre a green pedicle, which supports the germen and corolla, the limb of four or five orate acute segments. 
Corolla white, of one piece, the tube cylindrical, the limb of four or fire orate acute segments, as long as the tube. Stamens on slender filaments, with small orate jellow anther:. Germen roundish, superior, crowned with the two short erect simple styles and pinkish stigmas. Capsule roundish, ovate, on a stalk about its oirn length, surrounded by the withered corolla and calyx, the stalk on which it stands is the pedicle, which was surrounded by the fleshy base of the calyx, which is absorbed after germination has taken place, during the perfection of the orules. The capsule of two cells bursts transrersely near the base for the escape of the four roundish seeds, which are minutely punctured, the hilum with a depressed opening, the embryo spiral, round, the central flesh albumen.

Habitat.Parisitical on nettles, flax, hemp, hop, box, \&c; rare. Chiefly in the Midland Connties of England; ahout Edinburgh, Aberdeen, the Isle of Arran, Scotland; and in Ireland.

Anpual; flowering from July to September.

C. Epili'num, Weike, Flax Doddcr. Stem simple, heads of ahout five flowers; corolla with a fleshy globose tube, longer than the somewhat spreading campanulate calyx.

Reich. Ic. Bot. t. 500.-Hooker, British Flora, Ed. 4. rol. i. p. 109. C. major.-Koch. et. Tiz. cat. pl. palat. p. 5.

"Stem simple, yellowish green. Flowers fewer in a head, and much more succulent than in the preceding species, and cellular when seen under a lens. Tube of corolla alwass globose. Filaments very short. Caly $x$ broad and spreading, with five brnad acute teeth."

Habitat.-On flax, Ellesmere-J.E. Rowman, Esq.

Annual; flowering in August and September.

"This," Sir W. J. Hooker observes, "I believe to be quite a distinct species;" and that "it is abundant in Germany, (whence it was probably introduced with flax seed to us), and is rery injurious to the crops of this plant, upon which it is a parasite."

Of the two species of Cuscula first above mentioned, the grealer Dodder is easily distinguished from the lesser, by its more robust growth and larger size. It is on the Continent as with us far less common than the lesser Dodder, and like it seems indiscriminate in the plants from which it derises its suppport.

The Dolders, though less attractive in their appearance than many other of our native plants, are, nerertheless, perhaps amongst the most interesting to the student of nature, who delights to search out the wisdom, the ways, and perfection of all things made by the Father of the Universe.

The seeds of the Dodder, as we have alrearly described, are contained in a two celled capsule, which bursts trancversely near the hase for the perape of the seeds: these falling to the ground remain in a dormant 
state until the following Spring, when they put forth their slender stem and fibrous roots. 'The roots, howerer, are not able to supply the plant for any length of time with uutriment, and shortly die away; as does the stem also, if it is made to attach itself to some plaut growing near it, around which it entwines its slender brancles, and at various intervals puts out small wart-like protuberances, laving a glandular apex, by which it attaches itself to other plants, at first adhering by the peculiar secretion from the gland, and shortly after this a minute fringed border is formed around it, and from the centre is protruded a slender radical, which pierces the bark and absorbs the fluids, circulating in the ressels of the plant upon which it attaches itself, and applies them to its own use-thus being able to support itself at the expense of the proper juice of another plant, its own root dies, and it becomes a true "parasite," widely extending its branches, and deriving support from all the plants around, producing its numerous compact heads of crowded flowers, whose structure is equally curious as that of the stem. The calyx is large for the size of the flower, (more especially that of C. Europiea), but very fleshy in the appareut tubular part, which has a pedicle in the centre, supporting the corolla. After the stamens and pistils have performed their office, and the ovules are in need of a large and constant supply of nutriment, the fleshy base of the calyx, which appears to act as a reservoir in case of exigence, becomes, as they arrive at maturity, absorbed, leaving the capsule supported upon the central pedicle, and then it appears as though each flower was elerated upon its own footstalk, instead of sessile, as in reality it is. Thus we see a beautiful provision for the perfecting of the seeds to perpetuate the species, in a plant which derives its support through the medium of others, a supply of which is so apt to be checkel or stopped from rarious contingent circumstances. The corolla is tubular in its lower part, and surrounds at its base the globular germen, orer which is stretched a thin membrane from the sides of the corolla; and as the germen increases in size, this membranc is ruptured, forming scales at the base of the stamens, in a more or less regular manner. In our species, $C$. Exithymum, they form a cnustant and beautiful character; but in $C$. Europac they are much smaller, lanceolate, of a rery delicate texture, irregular in number, and shortly disappear. Their size, as well as number, is very variable, scarcely erer the same in two flowers on the same plant; and it is probable, from the circumstance of their extreme delicacy and rariation in this species, that contradictory opinions are entertained as to their being ever found or not: for after the corolla expands, and the germen enlarges, we do not find scarcely a rudiment of them. The seeds are remarkable from their want of cotyledons and the embryo being spiral round the central albumen. It is also a curious fact, that the same plant extends its varinus ramifications over different plants, and ab- 
sorbs their fluids impregnated with different qualities, and applies them to their own support; for we hare remarked it attached to the box, hop, nettle, clover, and various grasses, at the same time; also on broom, heath, cistus, galiums, and sedums, the fluids of which are absorbed into one plant, and converted in the system of their cells and ressels into a nutriment, on which it flourishes and attains perfection!

\section{NAT. ORD. UMBELLIFER死.}

The natural order Umbelliferæ is an extensive and important group of herbaceous plants, for the most part, readily distinguished by the umbellate form of their inflorescence; but the student, to obtain a knowledge of their distribution into tribes and genera, and the distinguishing of the species, must be well acquainted with the different parts of the plant, especially the parts of the flower and fruit; and in the hope of rendering this more easy of attainment, the following remarks are made :-

The roots are rariable, frequently fusiform, and often cultivated for culinary purposes, as the Carrot, (Daucus Carota); Parsnip, (Pastinica Sativa), \&c.

The stem is round, angled or furrowed, simple or branched, hollow, or sometimes full of pith, but generally with a thin lining of pithy matter, divided at intervals with a partition of the same substance, forming a knot or joint where the branches and leaves are given off. The cortical or external part of the stem is furnished with receptacles of secretion, frequently abounding with aromatic juices, holding in solution gum or resinous matter, which on exposure to the air concretes into solid masses, and possesses various medicinal properties, as assafœtida, from the stem of the (Fercela assafcetida), \&c.

The leaves are alternate, rarely opposite, sheathing at the base, which is sometimes very much dilated, as in Angelica sylvestris, com. pound, more or less divided, sometimes simple.

The inflorescence is an umbel, either simple or more generally compound. An umbel is formed when a number of pedicles proceed from the same point, and are of equal lengths; and if each pedicle bears a single flower, it is called a simple umbel, as in Eringium; but if these pedicles divide at the top and bear other umbels, it is called a compound umbel; and in this case the peduncles, which support the partial umbels, are called radii, and form the umbella universalis, or general umbel: while the secondary umbels, or umbellules, which they bear, are called umbella partialis, or partial umbel. The umbels are mostly furnished with bractea, in whorls around their base, and are called when they surround 
the universal umbel involucra, or involucra universalis, or general involucra; and when they surround the partial umbels involucella, or partial involucra. Both of these may be present, or one or both of them absent.

The flowers are generally white, rarely pink, yellow, buff, or blue.

The caly $x$ superior, attacher: to the germen, the limb of live lobes, entire, deciduous, or persistent, or truncated, or obsolete.

The petals five, equal or unequal, (rarely absent), inserted on the outer edge, of a fleshy nectariferous disk, alternating with the segments of the calyx, the claw (ungues) is narrow, and the limb either entire, notched, or with an inflexed point, in restivation involute, imbricated, or rarely valvate, the outer petals of the flowers on the outer rays of the umbels sometimes the largest.

The stamens five, alternating with the petals. The filaments free, incurved in astivation. Anthers of two cells, bursting by longtitudinal clefts.

The styles two, simple, united at the base, where they are more or less thickenerl, forming the fleshy disk on the top of the germen, persistent spreading. Stigmas simple.

The germen inferior, formed of two adhering carpels, consequently two celled, each with a solitary pendulous ovula.

The fruit consists of two carpels, at length separating from the common axis, to which they adhere by their fices forming the commisure, each being crowned by its style, and they are suspended for a time from the extremity of the central filiform, mostly bifid, (at least at the top), columella. The carpels are of various shapes, covered externally by the lobes of the calyx, and variously marked with longtitudinal elevated ridges, which are variable, being simply winged, filiform or obtuse, or crenated or waved, and in some nearly obliterated. Each carpel is marked with five, which are called primary ridges, from their being always present more or less distinctly, and alternating with these primary ridges are sometimes four others, which are called secondary. The channels between the ridges are called vallecules, and beneath them, covered by the coat of the pericarp, and sunk in the substance of the testa, are linear receptacles or bands, called vitta; these vittæ, solitary, or several together, simple or elevate, contain an essential, oily, or resinous matter, in which resides their medicinal property, which is mostly aromatic and wholesome.

The seed is solitary, pendulous, usually adhering inseparably from the pericarp, rarely loose, as in Crithmum and Archangelica. The albumen is large, fleshy or horny, more or less, convex externally, but internally flat and smooth, as Angelica, Daucus, \&c., or the sides rolled inwards, or deeply channeled in front, as Torilis, Myrrhis, \&c., but rarely concave in front, as in Coriandrum. The 
embryo is smill, at the base of the albumen. Cotyledons oblong, sornewhat unequal.

The distribution of this order which we have followed is nearly that of Dr. Koch, as giren in his Flora Germanicæ et Helveticæ. He divides it into three sub-arders.

1. Orthosperme. Albumen in front, flat, or nearly so.

2. CAMPYlosperme. Albumen with its sides cursed inwards, forming a longtitudinal furrow in front.

3. Codosperme: Albumen hemispherical, concare in front.

The Tribes are founded upon the diversities of forms in the umbels, the presence or absence of the vittæ, and the number of ridges on the carpels. The genera upon the presence or absence of the calyx, the furm of the petals and the position and outline of the ridges upon the carpels.

It will be seen by the details of this important order of plants how very much they differ in their properties, some being mild, and useful as articles of foods, affording an abundance of nutritive matter; others are agreeable, or powerfully aromatic, from the abundance of essential oil which they contain, being grateful stimulants and useful; condiments, while others possess powerful medicinal properties, or are in a high degree poisonous; and those plants growing in watery places may in general be regarded with suspicion as possessing poisonous or dileterious properties; while those plants growing in a dry soil are for the most part esculent and aromatic; but although the stem and leaves may be poisonous, of some plants, the seeds do not in any case seem to possess the same property.

They are natives chiefly of the northern parts of the northern hemisphere; and according to the investigations of M. De Candolle, the proportions in which they are found in different parts of the world is as follows:-

$\left.\begin{array}{l}\text { In the Old World............... } 663 \\ \text { In America. .................... } 159 \\ \text { In Australia .................. } 54 \\ \text { In Scattered Islands............. } 14\end{array}\right\}$ or $\left\{\begin{array}{l}\text { In the Forthern Hemisphere. } 679 \\ \text { In the Southern Ditto ....... } 205\end{array}\right.$

Suborder 1. Orthosperme. Albumen in front, flat; or nearly so.

Tribe 1. Hydrocotylex. Fruit with the sides very much flattened, the back convex or acute. Albumen flat in front. Petals spreading, entire, acute, with a straight or slightly inflexed point. Umbels simple, or imperfect. 


\section{GENUS YLVI. HYDROCO'TYLE.-LINN. Whiterot.}

Girn. Char. Calyx margin obsulete. Petals ovate, entire, acute, with a straight point. Fruit compressed at the sides, so as to form two flat nearly orbicular lobes. C'arpels with five filiform ridges, those of the sides and back nearly obsolete, and the two intermediate ones arched. Seeds carinated, compressed.-Name from vdwę, water; and xozv $\lambda n$, the cotuli, or cup, from the shape of the leaves being depressed on the centre stalk, and somewhat resembling a cup.

1. H. vul'garis, Linn. (Fig. 411.) common Whiterot, Marsh Pennyworl. Leaves peltate, orbicular, somewhat lobed and crenated ; umbel of about five nearly sessile flowers.

English Botany, t. 751.-English Flora, vol. ii. p. 96.-Hooker, British Flora, vol. i. p. 126.-Lindley, Synopsis, p. 128.

Stem very long, filiform, creeping on the surface, and putting out from the joints numerous librous roots, and from the same point one, but mostly numerous leaves and flowering stems, quite smooth, succulent, pale green, or pinkish, simple or branched. Leaves on long slender simple upright footstalks, from two to three inches long, smooth, or scattered over with a few fine hairs, orbicular, shield-like, with the footstalk from the centre, from whence radiate around the branched veins more or less prominent on the under side, the margin more or less lobed and crenated, quite smooth, light grecn, horizontal. Flowes stalks simple, slender, seldom more than an inch long, arising from the axis of the leares, with a pair of small bractea at the base, bearing at its extremity one, sometimes two, onc above the other small umbels, of about five flowers; on very short footstalks, with an involucra of four or five segments at the base. Flowers small. Calyx without limb. Petals broadly lanccolate, white, or frequently with a pinkish tinge, entire, spreading.

Habitat.-Bogs and low wet meadows; frequent.

Perennial; flowering in May and June.

Hydrocotyle, common water cup, marsh pennywort, whiterot, flowkwort, or sheep killing pennygrass, is very common in wet marshy places, growing amongst the grass; and it has received its last name from the popular belief that it is the cause of that destructive disease of the liver in sheep, known by the name of rot. Why such an opinion should have become general we are at a loss to imagine, for if the promulgators of this idea had observed the sheep with greater attention, it would have been found that they will not eat this plant. It is true that in sheep kept in wet meadows where this plant grows, the disease is developed; but if the occupiers of these 
lands would take warning, they wocild, especially in a warm moist season, take their sheep out of the meadows where the pennywort grows, and put them into dryer and more elevated pastures where it will not grow, it will then be found that no disease of this kind will appear amongst the sheep. Indeed the cause of the disease will be found a general one, and not depending upon the presence of any one plant or a combination of plants, which have been accused of being alike destructive to sheep, for the Sun-deros (Drosera longifolia and rotundifolia) are in the same predicament as this plant. But from repeated observations and trials made with sheep, we are convinced that it is the general nature of the food and the wet season, together with the humid soil saturated with stagnant moisture, that are the means of the disease being dereloped; and if the sheep are removed from these to dryer pastures and dryer and more substantial food, it will be found sufficient to prerent the appearance of the disease amongst them, and a great means of mitigating its violence when it has made its appearance.

The Fluke, or flounder insect, (Fasciola hepatica), found in the biliary ducts of the liver of sheep and other animals, is a very remarkable animal, (Fig. 524), flat, ovate, pointed at one end, and numerously branched over with reins, having very much the appearance of a leaf; at the broad extremity there is a narrow prolongation, on which are two suckers, by these they attach themselres to the sides of the ducts of the liver, and appear to live upon the secreted biliary matter, and when there are only a few present they do not seem to cause any injury to the animal; but as they become more numerous, the sheep, from the want of the proper supply of stimulus to the digestive organs, become unhealthy, the liver disorganised, and at length destroyed, from the disease produced.

Pennywort was formerly admitted into the list of some of the pharmacopxias, from the acrid properties that it is said to possess; but we are not aware that it is now used for any particular purpose. $H$. Asiatica is, we are told, used in India as a culinary regetable, and also as a diuretic; and some other species are said to possess like properties, but none are very active, or of much value.

Tribe 2. Saniculex. Fruit nearly round. Carpel with five equal primary ridges, the secondary wanting, or all the ridges are obliterated by scales or prickles. Albumen on a transverse section, nearly round, plain in front. Petals erect, a little broken on the margin in the middle. Umbel simple, or irregularly sub. compound, or in a head. 


\section{GENUS XLVII. SANI'CULA.-LInN. Sanicle.}

Gen. Char. Calyx with a five toothed leafy margin. Petals erect, obovate, notched, with a slender inflexed point, as long as the petal. Fruit sub-glubose, densely clothed with hooked prickles, without ridges, but with many vitte. General involucra lobed, partial, of many lanceolate segments.-Name from sano, to heal; from its supposed virtues "to make whole and sound all inward wounds and outward hurts."

1. S. Europa'a, Linn. (Fig. 412.) Wood Sanicle. Lower leaves palmated with the lobes trifid, cut or serrated, perfect; flowers sessile, those with stamens only on short footstalks.

English Botany, t. 98.-English Flora, vol. ii. p. 36.-Hooker, British Flora, vol. i. p. 126,-Lindley, Synopsis, p. 127.

Root of numerous strong branched somewhat fleshy fibres. Stem erect, simple, or slightly branched, from ten to eighteen inclies high, round, smooth, channeled, almost naked. Leaves almost all radical, on long smooth channeled footstalks, dilated and sheathing at the base, a bright shining green, paler on the under side, divided into five or seven almost separate segments, each of which is mostly three-cleft, irregularly cut, and sharply serrated, each serrature pointed with a sharp bristle, and sometimes the margins arc ciliated, leaves of the stem alternate, frequently absent. General umbel of numerous unequal radii, partial umbels small, those on the shorter pedicles bearing fluwers on short footstalks containing stamens only, while those on the longer pedicles bear flowers, nearly sessile and perfect, containing stamens and pistils. General involucre of several lobed leafy segments, the partial of numerous lanceolate ones. Flowers very small, white or pinkish, numerous, crowded in small round umbels. Calyx of five lanccolate leafy segments, bristle pointed. Petals rather longer than the calyx, obovate, erect, with a crenated margin, apparently caused by the mid-rib, which is lengthened out into a long bristle-like point, and then closely curved inwards, giving the petal the appearance of being notched at the extremity. Stamens on long slender filaments, curved inwards before the bursting of the ovate two celled anthers. Style recurved, about as long as the petals. Stigma small, obtuse. Fruit sub-globose, densely clothed with hooked rigid bristles.

Habitat.-Shady woods and humid situations; frequent.

Perennial; flowering in May and June.

Sanicle, formerly much extolled for its samative properties, is slightly astringent, with a bitterish acrid taste; but its virtues are so limited, that it is not now thought worthy of a place even in the catalogue of the remedial plants of our country tames. 


\section{GENUS XLVIII. ERYN'GIUM.-LINN Eryngo.}

Gen. Char. Caly $x$ with a five toothed leafy margin. Petals erect, oblong, notched, with a slender abruptly inflexed point, the length of the petal. Fruit obovate, densely clothed with pointed scales, without ridges or vittæ. Involucre of sereral leaves. Flowers blue, upon a scaly receptacle, collected into an oblong compact head.-Name from ęryror, to eructate.

1. E. mariti'mum, Linn. (Fig. 413.) Sea Eryngo, Sea Holly. Leaves glaucous, white, the radical ones roundish, heart-shaped, undivided, plaited spinous, on footstalks, the upper ones embracing tho stem, sub-palmate, lobed, rigid, spiny ; involucre of lobed spiny segments, longer than the sub-rotundate heads of flowers, scales of the receptacle three lobed.

English Botany, t. 718.-English Flora, vol. ii. p. 35.-Hooker, British Flora, yol. i. p. 126 - Lindley, Synopsis, p. 127.

Root very long, round, stout, white, fleshy, of a warm aromatic flavour. The whole plant quite smooth, rigid, of a glaucous pale blueish green colour. Stem roundish, striated, branched, leafy, about a foot high. Leaves beatifully variegated with whitish veins and ribs, and a broadish obtuse margin, the radical ones on footstalks, with a dilated base, roundish, heart or kidney-shaped, undivided, plaited or lobed with deep wide spreading rigid spiny teeth, the stem leares sussile, embracing the stem, roundish, oblong, simple or divided, with deeply lobed spiny spreading teeth. Involucre of numerous large leafy segments, similar to the leaves, longer than the roundish heads of crowded blue flovers. Common receptacle conical, scattered over with simple scales, terminating in sharp spines, or mostly three lobed, one scale at the base of each sessile flower. Calyx with a limb of tive lanceolate single ribbed segments, longer than the corolla. Petals erect, altemating. with the segments of the calyx, oblong, deeply cleft at the apex, from its long narrow point being abruptly curved inwards. Stamens alternatiug with the petals. Filaments long, slender, curved inwards, until the orate yellow anther bursts. Styles as long as the corolla, simple. Stigmas simple, obtuse. Fruit obovate, nearly round, on a transwerse section, closed with pointed scales, without ridges or vitto.

Habitat.-Sandy sea shores; frequent.

Perennial; flowering from July to August.

The compact ovate heads of sessile flowers of this geuns has much the resemblance to those of the compound flowers in class Syngenesia. Upon examination, howeres, they will be found very different, but resemble those of the genus Dipsacus (page 173). The root of this plant has a warm aromatic flarour, and was once fumed as a stimu- 


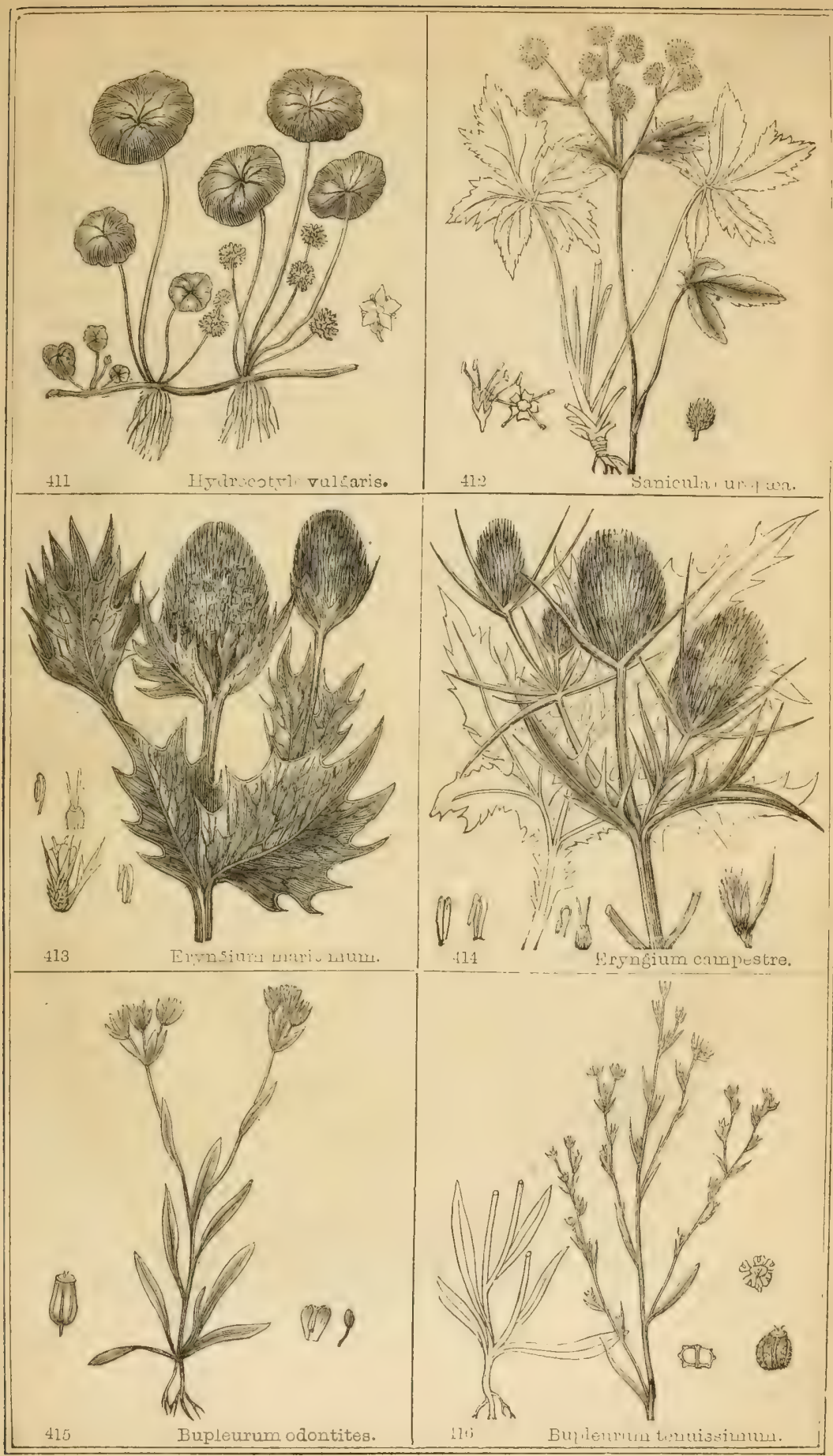



lant and restorative when candied with sugar; and from Shakspeare's account by Falstaf, was much esteemed when made into " kissing comfits;" it has also been used in medicine as a stimulating tonic, but its power is so slight as now to be discarded. The young tops are said to be used in Sweden and Crete in the same way as asparagus.

2. E. campes'trie, Linn. (Fig. 414.) Field Eryngo. Leares reticulated with veins, teeth spinous, the radical ones on footstalks, subternate, the lobes pinnatifid, the upper ones embracing the stem, with deep narrow rigid spinous teeth; inrolucre of numerous lanceolate spinous segments, longer than the small sub-rotuudate heads of flowers, scales of the receptacle entire.

English Botany, t. 57.-English Flora, vol. ii. p. 35.-Hooker, British Flora, vol. i. p. 127.-Lindley, Synopsis, p. 127.

Root long, round, stout, flesh. Stem round, smooth, striated, very much branched above in a corgmbose manner, and leafy, of a pale glaucous green. Leares numerously netted with pale veius and an obtuse margin, the radical ones large, on long stout footstalks, finely striated, divided into three, the midlle one largest, deeply divided in a pinnatifid mauner, Jobed, and the margin with teeth, pointed with long sharp spines, the stem leaves sessile, opposite, embracing the stem with a spinous auricular appendage on each side, deeply divided into three lobes, in a pinnatifid manner, with long narrow spinous teeth. Involucre of numerous narrow lanceolate spinous segments of variable lengths, some longer than the heads of flowers, some shorter. Flowers numerous, white or purplish, on a conical receptacle, each flower having at its base a long narrow simple spinous scale. Calyx with a limb of five lanceolate single ribbed spinous segments, longer than the corolla. Petals erect, alteruating with the segments of the calyx, oblong, notched at the apex, between which is abruptly inflesed a long narrow point, as long as the petal. Stamens alternating with tho petals. Filaments long, slender, curved inwards, until the oblong purplish anther bursts. Styles long, slender, spreading. Stigmas simple, obtuse. Fruit oblong, ovate, nearly round, on a transverse section closely covered with pale thin membranous pointed scales, without ridges or vittæ.

Habitat.-Waste sterrile ground, especially near the sea; very rare. Near Plymouth; Newcastle-upon-'Iyne, and St. Peter's Quay, Northumberland; near Daventry; and in Ireland, near Lismore, Waterford.

\section{- Mr. Drummond.}

Perennial; flowering in July and August.

This species, very frequent on the Continent, possesses similar properties to the above, and appears to have been used for the same purposes; but, like it, is now out of use. 
Tribe 3. Amminex. Fruit evidently compressed at the sides, and mostly double. Carpel with five primary ridges, filiform, rarely slightly winged, the lateral ones forming the margin of the same size as the others. Albumen rounded, or slightly gibbous at the back, in front plain or rounded. Umbel perfect, compound.

\section{GENUS XLIX. 'BUPLEU'RUM.-LinN. Hare's Ear.}

Gen. Char. Calyx limb obsolete. Petals roundish, entire, broad, closely rolled inwards, the sides depressed. Fruit laterally, compressed, crowned by the recurved styles and depressed disk. Carpels with five equal winged acute filiform or obsolete ridges, the lateral ones forming the margin. Channels with or without vitte. Albumen plain in front. Involucre various. Flowers yellow. Leaves undivided.-Named from Bovs, an $0 x$; and $\pi \lambda \lambda_{\text {ve }}$,, $\mathrm{rib}$; in allusion to the remarkably ribbed leaves of some of the species.

\section{* Annual.}

1. B. Odonti'tes, Linn. (Fig. 415.) narrow leaved Hare's Ear. Stem branched, widely spreading; leaves linear, lanceolate, three ribbed; general and partial involucre of four or five lanceolate segments, with rigid points, each three ribbed, and longer than the umbels.

English Botany, t. 2468.-English Flora, vol. ii. p. 93.-Hooker, British Flora, vol. i. p. 130.-Lindley, Synopsis, p. 120.-B. aristatum, Bartling.-Odontites lutea, Spreng.

Root small tapering. Stem from one to tive inches high, smooth, somewhat angular, leafy, branched, and spreading. Leaves linear, lanceolate, sessile, with an acuminated point, and three nerved, from one to two inches long, the lower ones tapering into a footstalk, pale, yellowish, green. Umbels small, lateral and terminal, erect, or spreading, enveloped in the lanceolate leaves of the involucre, those of the general one three or five ribbed, the partial ones mostly three, longer than the umbels, the peduncles very short. Calyx without any limb. Petals small, yellow. Stamens with slender filaments, bearing rather large yellow anthers. Styles very short, from a depressed base. Fruit ovate, compressed on the sides with five indistinctly elevated vidlges, the two marginal ones of cach carpel united, appearing until separated as one.

Inabitat.-Rocks in the neighbourhood of Torquay, Deronshire; ritre.

Aunual ; flowering in July.

This little plant is frequent on the Continent, especially in the 
southern countries, growing in dry open sunny situations. It has a slight degree of bitterness and astringency, but is not, we believe, applied to any use.

2. B. tenuiss'imum, Linn. (Fig. 416.) slender Hare's Ear. Stem erect, much branched, slender; leaves linear, lanceolate; umbels terminal and lateral, small, of three rays, mostly shorter than the setaceous involucres; carpels granulated, its five ridges waved and granulated.

English Botany, t. 478.-English Flora, vol. ii. p. 94.-Hooker, British Flora, rol. i. p. 131.-Lindley, Synopsis, p. 120.

Root small, tapering, zig-zag, branched. Stem erect, very much branched from the base upwards, round, smooth, slender, wiry, from six to eighteen inches high. Leaves few, distant, linear, lanceolate, with a sharp point, three ribbed, alternate, the lower ones tapering into a footstalk of variable length, quite smooth, of a glancous green. Umbels very small, sessile, axillary, terminal, or on short footstalks, sulitary, or disposed along the branches in a spike-like manner. Involuere mostly of five setacenus pungent segments, longer than the umbels. Flowers small, yellow, from three to five, in an umbel or unequal peduncles. Calyx with an obtuse rim, the obsolete limb. Petals very sinall. Style very short, from a depressed fleshy base. Fruit oblong, ovate, with compressed sides, finely granulated, its five ridges three at the back, and two forming the margins, uniting the carpels together, obtuse, waved and granulated. Albumen nearly cylindrical, slightly flattened in front.

Habitat.-Salt marshes on the south and east coasts of England; not common.

Annual; flowering in August and September.

3. B. rotundifo'lium, Linn. (Fig. 417.) common Hare's Ear, Thorow-wax. Stem branched; leaves roundish, oval, perforated, the lower ones narrow at the base, embracing the stem; general involucre wanting, partial ovate, with bristle points ; ridges of the fruit filiform; channels striated.

English Botany, t. 99.-English Flora, vol. ii. p. 93.-Hooker, British Flora, vol. i. p. 130.-Lindley, Synopsis, p. 120.

Root tapering, branched, white. Stem erect, about a foot high, round, smooth, finely striated, branched and spreading, somewhat corymbose above, often of a purplish colour. Leaves numerous, of a pale glaucous green, each with a mid-rib, terminating in a bristle point, and with numerous fine branched veins, the lower leaves oblong, narrowing at the base, sessile, and embracing the stem, the upper ones roundish, oblong, perforated, alternate. Umbels terminal, compound, of about six rays. General involucre wanting, partial of about four mostly unequal ovate acute bristle pointed reiny segments, of a pale 
yellowish green colvur, spreading when in flower, becoming erect in fruit, and meeting closely orer the partial umbels, than which they are much longer, partial umbels of numerous yellow flowers, on short peduncles. Calyx limb obsolete. Petals small, closely rulled inwards, the margin waved, veiny. Stamens alternating with the petals, on short filaments, hearing yellow ovate anthers of two cells, disk large, depressed, fleshy. Styles very short. Stigmas simple, obtuse. Fruit oblong, with five slender filiform primary ridges, the channels striated, and without vittæ.

Habitat.-Corn fields in England, especially on a chalky ${ }^{-o r}$ limestone soil.

Annual; flowering in July.

A plant formerly numbered amongst those that were thought to have a healing effect, and this was especially supposed to liave the power of curing ruptures. It is, we hope, needless to add that to such virtues wholly unfounded in reason, no one is now so foolish as to trust in such dangerous cases as ruptures.

B. rotundifolium is nearly allied to $B$. protractum, a species not unfrequent on the Continent, distinguished by its stem being branched from the base, and the leaves more oblong and larger than in $B$. rotundifolium. The fruit is about the same size with filiform ridges, but the channels between are granulated, and not striated, as in $B$. rotundifolium; and the involucre is always spreading, which in $\boldsymbol{B}$. rotundifolium become erect after flowering, and close orer the fruit. The general appearance of the two plants are so 'similar, that we think it probable they may have been overlooked as the same species; and we hope this notice will direct the attention of the Botanist to the more minute investigation of the plants found in different parts of England, and especially in the Southern Counties.

\section{* Perennial.}

4. B. falca'tum, Linn. (Fig. 418.) falcate-leaved Hare's Ear. Stem erect, branched; leaves from five to seven, nerved, the radical ones ovate oblong, on long footstalks, the upper sessile, linear, lanceolate; general involucre of about five unequal segments, the partial of five, broadly lanceolate, as long as the umbels; fruit with narrow winged ridges; channels plane, with three vittæ.

Corder in English Botany Suppt. t. 2763.-Hooker, British Flora, rol. i. p. 131.-Lindley, Synopsis; Suppt. p. 324.

Root woody, twisted and branched. Stem erect, from one fo four feet high, round, smooth, striated, much branched above with alternatc branches in a paniculated manner, often zig-zag. Leaves altcrnate, from tive to seven, the lower ones sometimes nine, ribbed, of a dark somewhat glaucous green, paler beneath, quite smooth, the lower leaves orate or ovate oblong, attenuated at the base into a long slender 



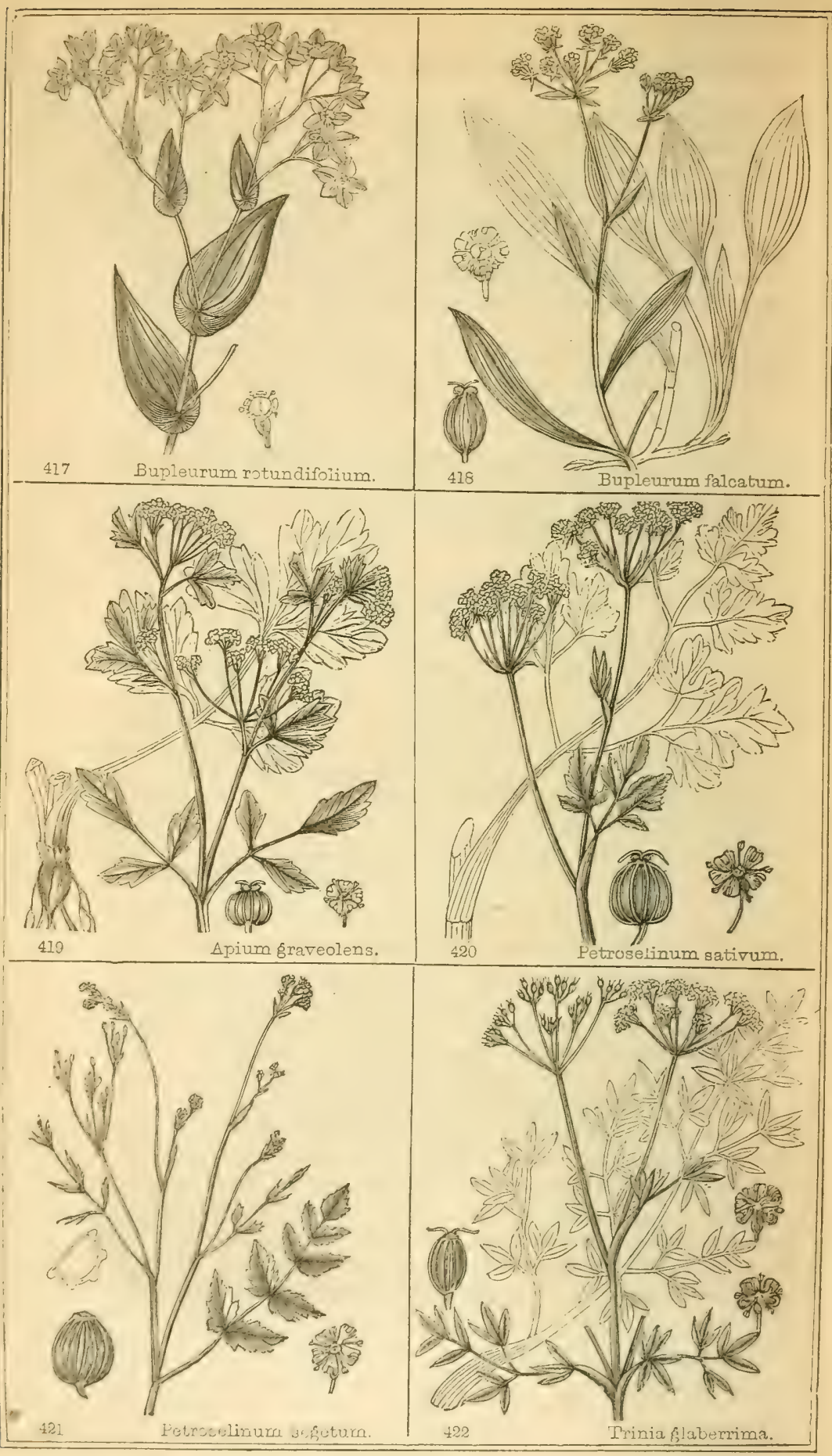


footstalk, chandeled above, the upper ones linear, lanceolate, sessile, with an acute point, curved in a falcate manner. Umbels terminal, compound, of from four to ten slender mostly unequal rays. General involucre of from one to five unequal lanceolate or orate segments, and sometimes they are wanting, partial of five equal broadly lanceolate fine pointed three ribbed segments, as long as the partial umbels, of numerous yellow flowers, on short pedicles. Petals small, with a single rib and incurred point. Anthers small, ovate, on incurved filaments. Styles short, spreading. Stiyma simple, somewhat capitate, disk large, flat, depressed, yellow, fleshy. Fruit ovate oblong, with compressed sides, and five narrow somewhat winged and slightly waved primary ridges, the channels between plain, smooth, with three small vitta.

Habitat.-Borders of fields between High Ongar and Chelmsford, Essex, growing by the road side within the field for nearly a mile.Mr. T. Corder, jun.

Perennial; flowering in June.

GENUS L. A'PIUM.-Linn. Celery.

Gen. Char. Calyx limb obsolete. Petals roundish, entire, with an involute point. Fruit roundish, laterally contracted, double. Carpels with fire filiform equal ridges, the two lateral ones forming the margin. Channels with single vitta, the outer ones sometimes having two or three. Albumen very convex at the hack, plain in front. Involucre wanting. Flovers white-Name from "apon, water, in Celtic; from the place where the plant grows."

1. A. grave'olens, Linn. (Fig. 419.) Smallage or wild Celery. Smooth; leaves pinnate; leaflets wedge-shaped, lobed and toothed at the apex.

English Botany, t. 1210.-English Flora, vol. ii. p. 76.-Hooker, British Flora, vol. i. p. 127.-Lindley, Synopsis, p. 123.

Root somewhat tapering and branclied. The whole plant smooth and shining, of a dark green. Stem erect, much branched and spreading, furrowed, from one to two feet high, leafy. Leaves alternate, pinnate, the lower on long channeled tootstalks, the leaftets large, werlge-shaped, three lobed, and irregularly toothed, with slender branched veins, the upper leares on short stalks, ternate, lobed and toothed, or sometimes lanceolate toothed. Umbels terminal and lateral, on footstalks, or sessile, of from four to ten unequal rays, the partial umbels of numerous small white flowers, on short slender pedicles. General and partial involucre wanting. Calyx limb vol. I. 
obsolete. Petals entire, roundish, with a small abruptly inflexed point, and a greenish mid-rib. Stamens about as long as the petals, with incursed filaments, and bearing roundish anthers of two cells. Fruit rather small, roundish, oblong, quite smooth. Carpels closely united, the thread-like ridges equal, the two lateral ones forming the margins, the channels have one, or the outer ones have three vitta. Albumen very convex, almost gibbous at the back, plain in front.

Habitat.-Moist marshy places, and on the banks of rivers, especially near the sea; not unfrequent, in England; Musselburgh, in Scotland. Plentiful near Irishtown and Baldoyle, and various places on the Dublin coast, Ireland.

Biennial; flowering in August.

This, the well known culinary plant of our gardens, appears to have been grown for domestic use in the time of Pliny, and probably before. It is one of the many remarkable instances we have of the conquest of cultivation, and the power which it possesses in changing that which is dangerous into a bland and grateful vegetable, subservient to our use; for Celery, in its wild state, is very acrid, with a strong disagreeable smell, and is said to be poisonous; but when it is cultirated it looses all its noxious properties, and becomes one of our most mild and pleasant garden regetables: and to see, as sometimes is the case, a single plant with the footstalks of the leares three feet long, blanched a beautiful white, with a mild agreeable flavour, and the plaut weighing six pounds, it scarcely appears credible that it should have been produced from a noxious weed, which, when the stem is full grown, rarely exceeds two feet high, and does not weigh more than an ounce or two.

\section{GENUS LI. PETROSELI'NUM.-Hoffm. Parsley.}

Gex. Char. Calyx limb obsolete. Petals roundish, entire, slightly emarginate, with a narrow incurved point. Fruit ovate, Jaterally, contracted, nearly double. Carpels with fire filiform equal ridges, the two lateral ones forming the margin. Channels with single vittœ. Albumen very convex at the back, plain in front. General involucre of few, partial of many, segments. - Name from $\pi \varepsilon r \rho o s$, a stone; from the circumstance of the plants of this genus growing in rocky or stony places.

1. P. sati'vum, Hoff. (Fig. 420.) common Parsley. Stem erect, striated; leaves doubly compound, shining; leaflets of the lower leaves ovate, wedge-shaped, three-cleft, and toothed; upper leaflets lanceolate, entire, threc-cleft; partial involucre of awl-shaped segments. 
Borrer, in English Botany Suppt. 2793.-Huoker, British Flora, vol. i. p. 127.-A pium Petroselinum, Linn.

Root long, fusiform, white. The whole plant a smooth shining green. Stem erect, from one to two feet high, round or angular, striated, alternately branched below, opposite abore, spreading. Leares numerous at the base of its stem, footstalks channeled, dilated at the base with a thin nembranous margin, partly embracing the stem, lower leaves doubly compound, the leaflets orate, wedge-shaped, mostly deeply dirided into three segments, acute, and deeply toothed, leaflets of the upper leares with simply three-cleft lanceolate mostly entire segments. Umbels terminal, compound, the general of numerous somewhat unequal rays, the partial numerous, short, unequal. General involucre of a few narrow lanceolate entire or occasionally toothed unequal segments, mostly with membranous margins, sometimes altogether wanting, the partial of numerous awl-shaped segments, with membranous margins. Flowers numerous, yellowish white. Calyx limb obsolete. Petals roundish, notched at the apex, with an elongated incurved point, mid-rib broadish green. Stamens with incurred filaments, as long as the petals. Anthers roundish, oblong, of two cells. Styles short, curved, with a thickened glandular base. Stigma simple. Fruit urate.

Habitat.-Old walls and dry waste places; frequent in the Southwest of England; Woollaton, near Nottingham.-R. D: Blarney Castle, near Cork, 1reland.-Mr. Wilson.

Biennial; flowering in June and July.

Parsley is a well known pot herb, used for a rariety of culinary purposes. Its leares, and the greenish aspect of the plant, are similar to those of some other umbellate plants, and especially the Ethusa Cynapium, fool's parsley, which is a common weed in gardens, and is considered rery unwholesome. It is readily distinguished from the real parsley by the three long pendent segments of the partial involucre, and the unpleasint odour emitted by its leaves when bruised. The roots and seed of the common parsley were formerly directed for medical use, the former haring a sweet taste, somewhat resembling that of carrots : they are slightly aperient and diuretic, and used in the form of an infusion, are of benefit in obstructions of the kidneys, and other of the urinary passages. They are warm, aromatic, and more bitter than any other part of the plant; but we are not aware of their being much used for their carminative properties. A variety, crispum, is much cultivated in gardens, haring the leares very much curled aud larger, remarkably beautiful, especially for the garnishing and ornamenting of culd meats, \&c. \&c.

2. P. sege'tum, Koch. (Fig. 421.) Corn Parsley. Stem erect, almost aaked; leaves pinnated; leaflets of the lower ones orate, nearly sessile, 
cut, and irregularly serrated, the upper with linear segments; involucre of two or three linear segments; general and partial umbel of a few very irregular rays.

English Botany, 1. 228.-English Flora, vol. ii. p. 60.-Hooker, British Flora, vol. i. p. 127.-Lindley, Synopsis, p. 123.-Sison segetum, Linn.

Root small, tapering. Stem erect, round, smooth, striated, from one to two feet high, much branched, and spreading on all sides, tough and wiry. Leaves mostly on the lower part of the stem, on lung narrow channeled footstalks, pinnated, leaflets nearly sessile, in opposite pairs, orate, or roundish oblong, lobed, cut and toothed, or serrated, sometimes they are large, ovate-lanceolate, with two distinct ovate lobes at the base, the upper leaves with mostly three linear segments. Umbels terminal, compound, the general of from three to six rays, of irregular lengths, partial of three to six short very irregular pedicles. General involucre of about three linear segments, partial of three or four small lanceolate segments, of unequal sizes. Flowers white or pinkish. Calyx limb obsolete. Petals roundish, notched at the apex with an elongated shortly incurved point. Stamens on short filaments. Anthers roundish, ovate. Styles very short, with a thickened fleshy at length depressed base, crowning the fruit. Stigmas simple, obtuse. Fruit ovate, the sides slightly compressed. Carpels with five pale obtuse filiform ridges, the lateral ones forming the margins, nearly united. Channels with single slender vitta. Albumen very convex, almost conical at the back, flat in front.

Habitat.-Moist fields and meadows, especially on a calcareous soil; in the middle and southern parts of England. "Said to have been found in one of the Hebrides by the late Dr. Walker."

Annual; flowering in August.

\section{GENUS LII. TRI'NIA.-Hoffr. Honewort.}

Gen. Char. Calyx limb an obsolete margin. Petals of the barren plant lanceolate, with a narrow inflexed point, those of the fertile ovate, with a short inflexed point. Fruit ovate, laterally compressed. Carpels with five prominent filiform equal ridges, the two lateral ones forming the margins. Channels with obscure vitte, but with a distinct channel under each ridge. Albumen very convex at the back, plain in front. Involucre various.Named in honour of Dr. C.B. Trinius, a learned Botanist of St. Petersburgh, author of a Species Graminum, $\& c$.

1. T.glaberi'ma, Hoffm. (Fig. 422.) glabrous Honewort. Smooth 
leaves, tripinnate, with linear segments; umbels numerous, simple, and compound; involucre of a single segment, or wanting.

Hooker, British Flora, rol. i. p. 128.-Lindley, Synopsis, p. 123.Pimpinella divica, Linu.-English Botany, t. 1209.-English Flora, vol. ii. p. 90 .

Root tapering, fleshy. The whole plant smooth, or nearly so, of a pale glaucous green. Barren plants smaller and less spreading than the fertile ones. Stem erect, angular, furrowed, frequently purplish, branched from the base, and leafy, branches alternate, sometimes opposite above. Leaves numerous, on channeled footstalks, dilated at the base, and partly embracing the stem, tripinnate, leaflets linear, lanceolate, simple, entire, the terminal ones mostly united in threes. Umbels mostly numerous, simple, and compound, the general of about eight slender channeled rays, mostly of unequal lengths, partial of from four to ten irregular short pedicles. Flowers white or pinkish. Calyx limb an obsolete margin, barren flowers without. Involucre both general and partial mostly absent, or only of one segment, germen and the fertile bearing imperfect anthers. Styles spreading. S'tigmas almost globular. Fruit ovate, slightly compressed on the sides.

Habitat.-Dry barren places in limestone districts; rare. On St. Vincent's rock, near Bristol; at Uphill, Somersetshire; Whorlhill, Sumerset; stid to have been found by $D r$. Wade, at Athboy, Ireland.

Perenuial; flowering in May and June.

\section{GENUS LIII. HOLOSCIA'DIUM.-KocH. Marsh-wort.}

Gen. Char. Calyx limb of fire teeth, or obsolete. Petals ovate, entire, with a straight or inflexed point. Fruit orate or oblong. laterally compressed. Carpels with five filiform prominent equal ridges, the lateral ones forming the margins. Channels with single vitto. Albumen convex at the back, plain in front. Involucre various.-Name from $\varepsilon \lambda_{\circ}$, a marsh; and $\sigma \times \iota \alpha d_{\llcorner o v}$, an umbel.

1. H. nodiflorum, Koch. (Fig. 423.) procumbent Marsh-wort. Stem procumbent, and rooting at the base; leaves pinnate; leaflets sessile, ovate-lanceolate, obtusely serrated; umbels opposite the leaves, sessile, or on short peduncles.

Hooker, British Flora, rol. i. p. 128.-Lindley, Synopsis, p. 122.Sium nodiflorum, Linn.-English Botany, t. 639.-English Flora, vol. ii. p. 57.

Stem long, procumbent at the base, putting out at the joints tufts of long slender branched fibrous roots, the stem is erect above, round, smouth, finely striated, branched and leafy. Leares alternate, pinnated, 
common stalk long channeled, dilated at the base, and sheathing, bearing about three pairs of ovate-lanceolate leaves, and an odd one at the end, having a slender mid-rib, and numerous finely branched reins, the margins blunt, and somenhat irregularly serrated, of a shining green, paler beneath, the terminal leaf is sometimes united to the two upper ones, and the margins cut, as well as serrated. Umbels lateral, opposite the leaves, and either sessile or on a short stalk; the general of about six slender angular mostly unequal rays; the partial of numerous short nearly equal pedicles. Flouers white. General involucre of one segment, or mostly wanting; the partial of five or six lanceolate segments, about the length of the umbel, pale green, with three to six ribs, and a narrow membranous margin. Calyx limb an obtuse margin. Petals ovate, somewhat incurved, with a lanceolate point. Stamens on slender awl-shaped filaments. Arthers roundish, of two cells. Styles very short. Disk large, fleshy, depressed. Fruit with the sides compressed, ovate, the vidges prominent, obtuse, pale, channels with slender vitta. Albumen rounded at the back, plain in front.

Habitat.-Sides of lakes, rivers, and in drains; frequent.

Perennial; flowering in July and August.

The juice of this plant has been recommended for the cure of some diseases of the skin; two table spoons full, mixed with a little milk. It has not any unpleasant taste, and may be administered without difficulty to children, and in some cases it has been found beneficial; but it is not now in much use, except amongst the country people, and they not unfrequently eat it as a salad, mixed with the leaves of the common water cress, for which it is indiscriminately gathered, a mistake of no consequence to the consumer, if his palate does not detect it.

2. H. re'pens, Koch. (Fig. 424.) creeping Marsh-wort. Stem creeping and rooting at the joints; leares pinnate, roundish, ovate, lobed, unequally toothed and serrated; umbels on short peduncles, opposite the leaves.

Hooker, British Flora, rol. i. p. 128.-Lindley, Synopsis, p. 122.Sium, repens, Linn.-English Botany, t. 1431.-English Flora, vol. ii. p. 58.

Root of long slender much branched fibres. Stems several, round, smooth, finely striated, creeping, putting out roots from the axis of the branches, which are distant, alternate, and bearing but few leaves, from six to ten inches long. Leaves on long channeled footstalks, dilated and sheathing at the base, with thin membranous edges, leaflets from three to five pairs, and an odd one at the end, roundish, ovate, sometimes lobed, unequally toothed anci serrated, the terminal one mostly threc lobed, finely reincd. Umbels opposite the leaves, on 
short peduncles; the yeneral of from three to six rays, of unequal lengths; partial numerous, short, unequal. Flouers white, small. General involucre of about six lanceolate segments, frequently wanting; partial of about six, as long as the umbels. Calyx limb an obtuse margin. Petals roundish, ovate, with a short point, rolled inwards. Stamens about as long as the petals, with slender filaments and roundish anthers. Styles very short, curved. Stigmas obtuse. Fruit small, roundish oblong, similar to the last species.

Habitat - Boggy meadows and watery places. In Oxfordshire, Cambridgeshire, Bedfordshire, and Nottingham meadows. Side of the river Fergus, a little above the bridge Ennis, Ireland. Near Edinburgh, and banks of a pond at Fisharrow, and at Guillon Links, Seotland.

Perennial; flowering in July and August.

It is very doubtful if this is any more than a variety of the above species. The whole plant is smaller, its branches less numerous and creeping, and the umbels are stalked, not sessile; the leaves are rounder, and generally more lobed and irregularly toothed.

3. H. inunda'tum, Koch. (Fig. 425.) least Marsh-wort. Stem creeping at the base, and rooting; leaves pinnate the submersed ones, with capillary much divided leaflets, the upper wedge-shaped, cut and toothed; umbels on short peduncles, of two rays opposite the leaves.

Hooker, British Flora, vol. i. p. 128.-Lindley, Synopsis, p. 122.Sison inundatum, Linn.-English Botany, 1. 227.-Sium inundatum, Roth.-English Flora, vol. ii. p. 58,-Hydrocotyle inundatum, Smith. -Flora. Brit. p. 290.

Root of long slender branched fibres from the axis of the lower branches. Stem slender, round, smooth, succulent, somewhat striated, varying considerably in length, from a few inches to two feet, branched and leafy. Leares alternate, on somewhat channeled footstalks, dilated and sheathing at the base, where it is striated, and with a thin pale membranous margin; the lower leaves, when submerged in water, are repeatedly divided into long slender hair-like segments, becoming in the upper part of the stem broader, at length in four or five pairs of wedge-shaped leaflets, deeply cleft into narrow lanceolate segments, the upper leares with ovate leaflets, toothed and lobed, the terminal one three-cleft. Umbels on short stalks, opposite the leaves; the general of two rays; the partial of about six short ones. Flowers small, white. General involucre wanting, partial of four or five unequal lanceolate segments. Calyx limb an obtuse margin. Petals uvate, with a somewhat incurved point. Stamens on short filaments, with small round anthers. Style short, curved. Stigma obtuse. Fruit oblong. Carpels with five prominent obtuse pale ridges. Channels with slender simple vitta. Albumen nearly round, on a transverse section, but slightly flattened in front. 
Habitat. $\rightarrow$ Pools, lakes, and inundated places that are dried up in the Summer; not unfrequent.

Perennial; flowering from May to July.

This plant is readily known from all other of our umbellate plants by its slender creeping stems, its variable leaves, and small umbels of few flowers.

\section{GENUS LIV. SI'SON.-Linn. Bastard Stone Parsley.}

Gen. Char. Calyx margin obsolete. Petals roundish, deeply notched and curved with an inflexed point. Fruit ovate, laterally compressed. Carpels with five filiform equal ridges, the lateral ones forming the margins. Channels with short single clubshaped vittc. Albumen convex at the back, plain in front. General and partial involucre of few segments.-Name, according to Thèis, originating in the Celtic sizun, a running brook; some of the plants formerly placed in this genus delighting in such situations.

1. S. Amo'mum, Linn. (Fig. 426.) Hedge Bastard Stone Parsley.

English Botany, t. 954.-English Flora, vol. ii. p. 60.-Hooker, British Flora, vol. i. p. 129.-Lindley, Synopsis, p. 122.

Root tapering, fleshy. Stem erect, from three to four feet high, with numerous alternate slender wiry branches, smooth, striated. Leaves pinnate, of a dark green, smooth, leaflets ovate, deeply cut and serrated, the terminal one mostly three lobed, the upper leaves cut into narrow unequally serrated segments, footstalks with a dilated memhranous edge, the base half embracing the stem. Umbels mostly numerous; general of about four unequal rays; partial of numerous short unequal ones. Involucre irregular; general of about four lanceolate segments; partial of about four smaller ones. Flowers white, or straw colour. Calyx an obtuse margin. Petals roundish, or inversely heart-shaped, from being deeply notched at the extremity by the inflexion of the small point. Stamens alternating with the petals. Filaments slender. Anthers yellow, small, roundish. Styles very short. Stigma obtuse, small. Disk large, swollen fleshy. Fruit small, ovate. Carpel sides somewhat compressed, with obtuse ridges, three at the back, the two lateral ones forming the margin. Vitto small, club-shaped. Albumen on a transverse section, very convex at the back, compressed, or slightly plain in front.

Habitat.-Chalky and limestone districts, in a moist soil in shady situations; not very frequent in England. Near Coldstream, Scotland.- Miss E. Bell.

Biennial ; flowering in August. 


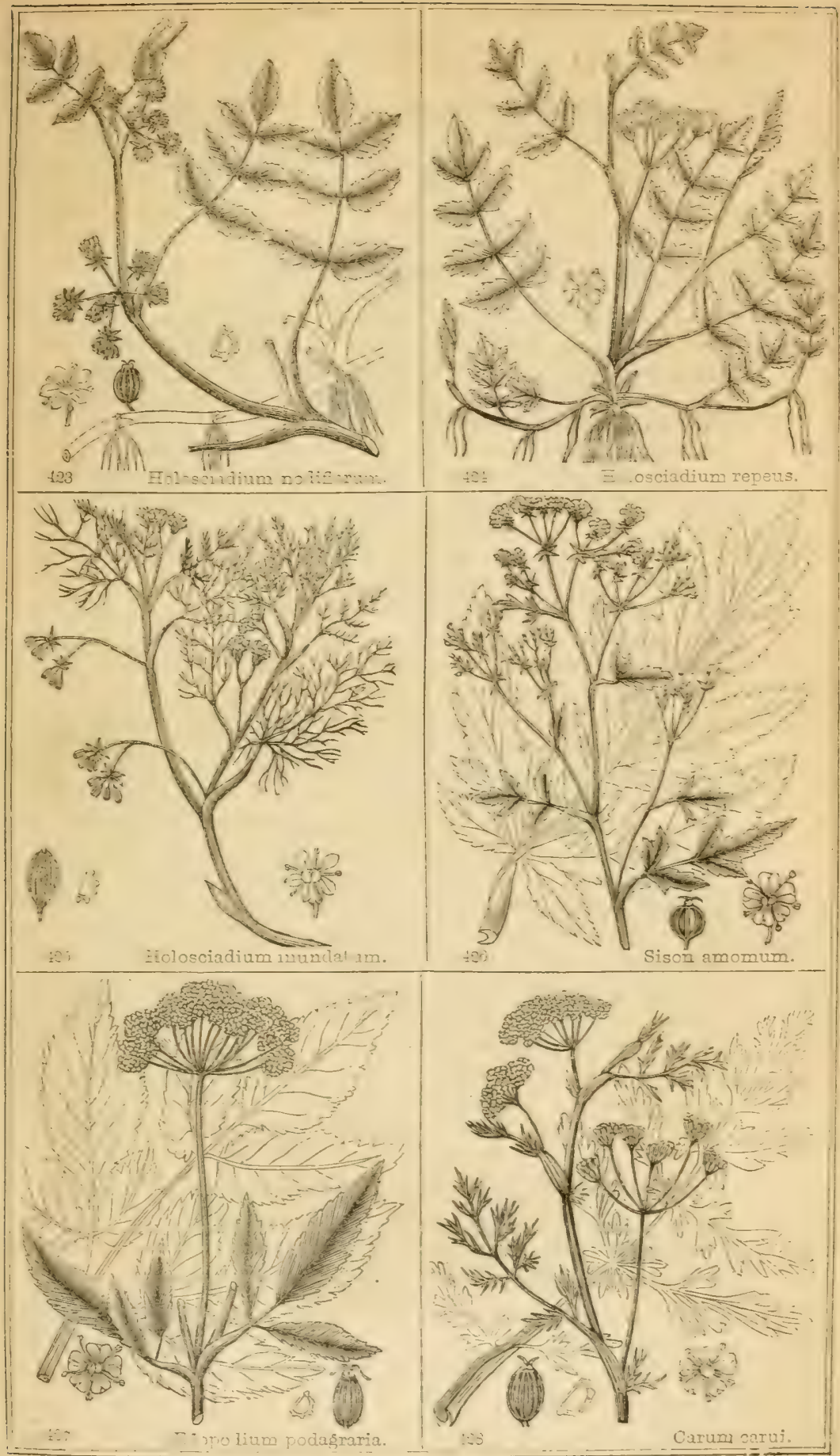



The seeds, when hruised, have a pungent aromatic smell; but when young, they, like the rest of the plant, have a disagreeable odour, resembling, according to Smith, that of Bugs.

\section{GENUS LV. AEGOPO'DIUM.LINN. Goufweed.}

Gen. Char. Caly $x$ margin obsolete. Petals oborate, notehed and curved with an inflexed point. Fruit oblong, laterally compressed. Carpels with five filiform ridges, the lateral ones forming the margin. Channels without vitte. Albumen roundish, conrex, somewhat plain in front. General and partial involucre wanting.-Name from $\alpha_{b} \xi$, aryos, a goat; and rous, a foot, from the supposed resemblauce of the leaves to a goat's foot.

1. IE. Podagra'ria, Linn. (Fig. 427.) Goutweed, or Herb Gerarde. English Botany, t. 941.-English Flora, vol. ii. p. 77.-Houker, British Flora, vol. i. p. 129.-Lindley, Synopsis, p. 123.

Root long, creepiug, putting up stems at various distances. Stem erect, from one to two feet high, round, smooth, furrowed, branched above, and leafy. Leaves smooth, with a strong mid-rib and numerous lateral branched veins, pale and somewhat glaucous beneath, the radical ones on long footstalks, twice ternate, the leaflets ovatelanceolate, with an acute point, the litteral ones mostly obliquely cut on the upper side, and the terminal one larger and broader, the upper ones mostly opposite, ternate, narrower, lanceolate, more unequally and acutely serrated than the lower ones, and the footstalks of the leaf broadly dilated and sheathing the stem. Umbels terminal, the gencral of numerous unequal angular rays, smootb, or sometimes downy, as are the more numerous short unequal rays of the partial umbels. Involucre both general and partial wanting. Flowers white. Calyx an obtuse margin. Pctals oborate, slightly notched at the extremity from the inflexed point, which is slender, and about half as long as the petal. Stamens with slender filaments, and small round anthers. Styles long, slender. Stigmas somewhat globose, obtuse. Carpels with five slender filiform ridges, three on the back, and two lateral ones forming the margins, the channels without vitta. Albumen on a transrerse section, convex at the back, plain in front.

Habitat.-Gardens, under hedges, and wet places; frequent.

Perennial; flowering in May and June.

Gout-weed by the ancients was supposed to possess active properties that were of considerable use in the relief of gout, (hence its English name), used in the form of poultice; but whatever arthritic virtues it may have possessed, appear now to have degenerated, and it has fallen into disuse.

VOL. I. 


\section{GENUS LVI. CARUM.-Linn. Caraway.}

Ges. Char. Calyx margin obsolete. Petals obovate, notched and curved with an inflexed point. Fruit oblong, laterally compressed. Carpels with five filiform ridges, the lateral ones forming the margin. Channels with single vitte. Albumen roundish, convex, plain in front. General and partial involucre various.-Name derived, according to Pliny, from that of the conutry Caria.

1. C. Ca'rui, Lirn. (Fig. 428.) common Caraway. Leaves doubly pinnate; leaflets cut into linear segments, the lower ones decussate; stem angular, branched; general involucre scarcely any; partial none.

English Botany, t. 1503.-English Flora, rol. ii. p. 86.-Hooker, British Flora, vol. i. p. 129.-Lindley, Synopsis, p. 122.

Root tapering. Stem from one to two feet ligh, erect, angular, smooth, furrowed, branched, and leafy. Leaves doubly pinnated, footstalk much dilated at the base into a thin ribbed membranous sheath, enveloping the stem, the lower ones alternate, the upper ones have each opposite the insertion of the footstalk a small sessile leaf of numerous linear segments. Leaflets in pairs, cut into narrow linear, simple or eleft segments; the lower leaflets cross each other (decussate) in their insertion, the upper ones opposite. Umbels numerous, terminal and lateral. General of numerous angular somewhat unequal rays, the partial dense, unequal. General involucre wanting, or of few narrow segments, the partial always wanting. Flowers white. Calyx an obsolete margin. Petals five, sometimes six, obovate, notched at the extremity with a slender obtuse inflexed point. Stamens on slender filaments, longer than the petals. Anthers small, roundish. Styles short. Stigmas small, globose. Fruit oblong, compressed on the sides. Carpels with five filiform ridges, three on the back, and two forming the margin. Channels smooth, each with a single simple vittce. Albumen roundish at the back, somewhat flattened in front.

Habitat.-Meadows and pastures, in damp situations in various parts of England and Scotland.

Biennial; flowering in June.

The Caraway is a naturalised plant, probably at first escaped from gardens; now estahlished in various parts of the country. Its seeds are well known as possessed of an agreeable aromatic quality, residing in the essential oil secreted in the vitto; they are much used in domestic cookery, confectionery, and as a warm aromatic are admitted into our Pharmacopæias.

2. C.vericilla'tum, Koch. (Fig. 429.) whorled Caraway. Leaflets in short capillary whorled segments. 
Hooker, British Flora, vol. i. p. 129.-Lindley, Syuopsis, p. 122.Sison verticillatum, Linn.-English Botany, t. 295.-Sium verticillatum.-English Flora, vol, ii. p. 59.

Root tapering. Stem crect, from one to two feet high, slender, round, smooth, finely striated, slightly branched, and almost naked. Leaves almost all from the base of the stem, footstalk long, round, fiuely striated, tapering, dilated and sheathing at the hase. Leaftets opposite, divided nearly to the base into numerous narrow hair-like segments, which spread, and have the appearance of heing whorled. Umbels terminal, general of numerous long slender unequal rays, partial of numerous short unequal ones. General involucre of about six narrow lanceolate segments, parlial of about eight, ovate-lanceolate. Flowers white, numerous, crowded. Calyx an obtuse narrow margin. Petals five or six, obovate, slightly notched at the extremity with an inflexed obtuse point. Stamens five, as long as the petals. Anthers small, roundish. Styles as long as the stamens. Stigmas small, globose. Fruit oblong, with compressed sides. Carpels with five filiform obtuse ridges, three on the back, and two lateral ones forming the margins. Channels with single simple ville. Albumen round at the back, flattish in front.

Habitat.-Unknown to England; in the flat part of Wales; in Ireland, in a marsh near Lane Bridge, Killarney, and other places in Kerry, marshes in the district called Cranmore, near Belfast.- $M r$. Templeton. Salt marshes below Coleraine, county of Derry. $-M r . D$. Minore. Very abundant in moist pastures in the West of Scotland, especially near the sea.

Perennial; flowering in July and August.

\section{GENUS LVII. BUNIUM-Kocr, Earth-nut.}

Gen. Char. - Calyx margin obsolete. Petals obovate, slightly notched with an inflexed point. Fruit linear, oblong, laterally compressed, crowned by the conical disk and straight styles. Carpels with five equal obtuse filiform ridges, the lateral ones forming the margins. Channels with many vitta. Albumen convex at the back, flat in front. General involucre none; partial of a fow segments. - Named from _ Bovros, a hill, the situation in which tho plants delight to grow.

1. B. Alex'uosum, With. (Fig. 330). common Earth-nut.

English Botany, t. 988.-English Flora, vol. ii. p. 54.-Conopodium Jenudatum, Koch.-Lindley, Synopsis, p. 121.-Bunium denudatum, De Cand.-B, Bulbocasianum, II udson. 
Root a solitiry tuber, about the size of a uut. S'tem erect, from one to two feet high, round, smooth, finely striated, slender, branched above, and bearing but few leares, that part of the stem beneath the ground is very slender, tough, and wiry, waved. Leaves very few, pinnated, leaflets much divided into linear segments, quite smooth, dark green, the radical ones on long slender waved striated footstallis, the upper ones with rery short dilated sheathing footstalks, and the leaflets with longer narrower segments. Umbels three or four, terminal, the general of numerous long slender angular, nearly equal rays, the partial of very numerous short crowded rays, mostly unequal in flower. General involucre wanting, or sometimes there are one or two narrow segments, partial either wanting or of a few narrow lanceolate segments. Flover's numerous, white. Calyx an obtuse slightly notched margin. Petals obovate, notched at the extremity with an obtuse inflexed point, about half as long as the petal. - Slamens on slender filaments, longer than the petals. Anthers small, round. Styles short, straight, or spreading, with a conical disk, and small obtuse stigma. Fruit long, narrow, smooth, and shining, somewhat tapering above, and crowned by the conical disks, the sides slightly compressed. Carpels each with five slender ridges, the lateral ones forming the margins. Channels with numerous slender simple ritla. Albumen rounded at the back, somewbat flattened in front.

Habitat.-Woods and pastures; frequent.

Perennial; flowering in May and June.

The sweet and esculent tuberous roots of the Earth-nut, containing a considerable portion of farinaceous matter, are very nutritive, and are much sought after by pigs; and it is an amusement for children to trace them to their deep situation in the ground by the slender stem which guides them to it, and in times when there is a scarcity of provisions they have been sought after as human food; when dried, they are readily powdered into flour, which has much the taste and appearance of arrow root, for which it might be substituted.

\section{GENUS LVIII. PIMPIN'ELLA.LINN. Burnet Sixifrage.}

Gen. Char. Calyx margin obsolete. Pelals oborate, notched, with an inflexed point. Fruit ovate, laterally compressed, crowned by the convex disk and long slender style. Carpels with five filiform ridges, the lateral ones forming the margins. Channels with many vitta. Albumen roundish at the back, plan in front. Involucre wanting. Flowers white- - Name altered, according to Linnaus, from Bipennula, twice pinnaled. 



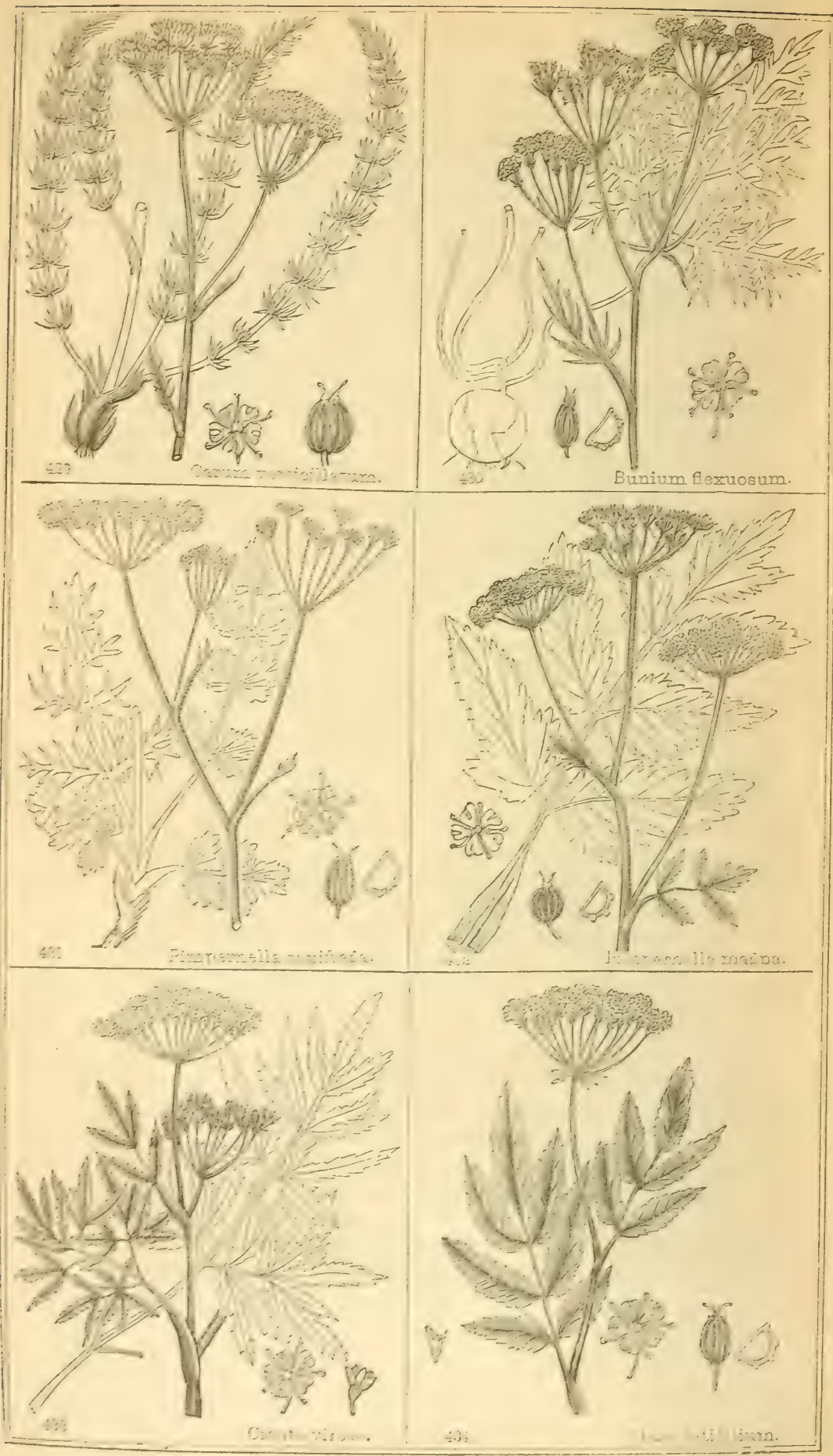


1. P. Saxifraga, Linn. (Fig. 431.) common Burnet Saxifrage. Leares pinnate; leaflets of the radical ones roundish orate, lohed, toothed or serrated, those of the upper ones in liuear segments; stem round, slender, striated, nearly naked abore; fruit orate smooth.

English Botany, t. 407.-English Flora, rol. ii. p. 89.-Hooker, British Flora, rol. ii. p. 130.-Lindley, Synopsis, p. 121.

B. dissectifolia. Leaflets of all the leaves cut into linear segments. P. Saxifraga dissectifolia-Wallr. P. hircina.-Leers.

Root tapering, somewhat woody, having a pungent aromatic smell. Stem erect, from a few inches to two feet high, ronnd, slender, finely striated, smooth ol' clothed like the rest of the plant, with a close soft down, simple or branched, leafy below, almost naked above. Leaves almost, all radical, on long slender channeled footstalks, dilated at the base intu a broad short membranous sheath. Leaflets opposite, sessile, or on short footstalks, roundish oblong, or ovate, the terminal one mostly three-cleft, the margins more or less deeply cut and coarsely toothed or crenated, the upper leaves or the whole of them as in the rariety $\beta$. dissectifolia. They are twice pinnate, and the leaflets cut into narrow linear simple or cleft decurrent segments, green abore, paler and somewhat glaucous beneath, with a prominent mid-rib and branched lateral reins, and the under side is mostly thicker clothed with a softer down than the upper. Lmbels terminal and lateral, the general of numerous slender angular somewbat unequal rays, partial of numerous short unequal ones. General and partial involucre wanting. Flowers white, nearly regular. Calyx a scarcely distinguishable obtuse somenhat wared margin. Petals oborate, slightly notched, with an obtuse inflexed point, about half as long as the petal. Stamens with long slender filaments and small round anthers. Styles long, slender, somewhat recurved. Stigma small, round, obtuse. Disk laige, convex, fleshy erowning the fruit, which is ovate, the sides compressed. Carpels with fire ridges, the lateral ones forming the margins, two lateral towards the back, and one forming a ridge on the back. Channels with numerous slender simple vittc. Albumen roundish gibbous at the back, plain in front.

Habitat.-Dry places and pastures; frequent.

Perennial; flowering in July and August.

The rarieties of this species are very puzzling to the young stulent, from the varied forms which the leares assume. It is not unfrequent that on one plant the leaves are both with orate leaflets more or less cut and coothed, and with leares having the leaflets much dirided into linear segments, and it is not unfrequent to find the variety $\beta$. dissectifolia with all the leares cut in the same manner. The student will also frequently meet with the plant of different sizes, and with the leaftets more or less deeply cut, and also variously clothed with pubescence, owing to the greater or less humidity of the situation of 
its growth. These are made by some of the Continental Botanists separate varieties; but as they are probably only varied owing to the local circumstances of their growth, we do not think it necessary.

Buruet Saxifrage was formerly placed in the Materia Medica of the Edinburgh Pharmacopæia. The roots, which have a hot, pungent, bitterish taste, were recommended as a stumachic, and a decoction was thought useful as a stimulating gargle in affections of the throat, and to remore freckles from the face; the root masticated for a time, is said to relieve the tooth-ache from its stimulating the salivary secretions.

2. P. mag'na, Linn. (Fig. 432.) greater Burnet Saxifraye. Leaves pinnated; leaflets orate, serrated, somewhat cut; stem angular, furrowed, leafy; fruit oblong, ovate, smooth.

English Botany, t. 408.-Englisb Flora, vol. ii. p. 90.-Hooker, British Flora, rol. i. p. 130.-Lindley, Synopsis, p. 121.

Root tapering, stout, somewhat woody. Stem erect, stout, angular, and deeply furrowed, from one and a half to three feet high, smooth and much branched above, leafy. Leares a lively green, smooth above, heneath somewhat shining, strongly ribbed, and clothed more or less thickly with a short close soft pubescence, the lower leares on long slende furrowed and channeled footstalks. Leaflets about fuur pairs, and a terminal one, the lower ones on short footstalks, the upper sessile, ovate oblong, somewhat irregularly coarsely serrated, and the lower ones variously cut and lobed, the terminal leaflet mostly three-cleft and cut irregularly; the upper leaves of the stem with short dilated sheathing footstalks, and narrow lanceolate coarsely serrated leaves. Umbels numerous, terminal and lateral, the general of numerous slender angular unequal rays, partial crowded with short rery slender unequal angular ones. General and partial involucre wanting. Flowers crowded, small, white, nearly regular, sometimes rose colour. Caly $x$ a very narrow scarcely distinguishable margin. Petals five, small, obovate, notched with an obtuse incurved point, about half as long as the petal. Stamen with long sleuder filaments and roundish anthers. Styles long, slender, with small globose stigmas, the disk large, flesh convex, crowning the oblong orate fruit, which is smooth. Carpels with five slender ridges, the lateral ones forming the margins, the sides cornpressed. Channels with three or more simple slender vitta. Albumen rounded at the back, flat in front.

IIabitat.-Under hedges and in shady places; not unfrequent in various parts of England. Friar's Walk, near Cork; MIucruss Woods, near the Abbey and Church-yard, at Youghall, Ireland.

Perennial; flowering in July and August.

This species, rearlily distinguisbed from the last, is less frequent, and is not, though possessed of similar properties, so strong. 


\section{GENUS LIX. CICU'TA.-Liss, Cowbane.}

Gen. Char. Calyx margin of five teeth, leafs. Petals obcordale, with an inflexed point. Fruit roundish, laterally compressed. Carpels with fire nearly plain ridges, the lateral ones forming the margins. Channels with single vitta, which are more prominent in the ripe fruit than the ridges. Albumen roundish. General involucre none, or of few segments; partial of numerous linear segments.-Name Quasi cacuta, blind; because it destroys the sight of those who use it. Cicuta was a term used by the Latins for the internode or the space between two joints of a reed; or the hollow stem of any plant which was used by their shepherds for making their rural pipes, and the stem of this plant has the hollow internode. Virgil says, "Est mihi disparibus septem conjuncta fistula."

1. C.viro'sa, Linn. (Fig. 483.) Water Hemlock, or Coubane. Root with thread-like fibres; leaves tri-pinnate; leaflets lanceolate, acutely serrated, decurrent.

English Botany, t. 479.-English Flora, vol. ii. p. 62.-Hooker, British Flora, vol. i. p. 127.-Lindley, Synopsis, p. 125.

Root of numerous long branched thread-like fibres, from the large swollen base of the hollow stem, which is stout, round, smooth, furrowed, hollow, and divided by transverse partitions at the axis of the hranches into large long cells, much branched above and leafy. Leaves bi- or tri-pinnate, smooth, of a bright green, on long stout hollow striated footstalks, with a long dilated sheathing base, secondary footstalks opposite, in about four pairs of the lower leaves, and a terminal one, the upper ones less numerous; tertiary footstalks very short, and bearing two or three leaflets, which are lanceolate, with deep acute irregular serratures, margins decurrent at the base, and the two or three leaflets frequently appear as one by the union of the bases, the leaflets of the upper leaves very narrow, almost linear. Umbels numerous, terminal and lateral, the general of numerous long slender angular somewhat irregular rays, partial of numerous crowded short jrregular ones. General involucre wanting, or of a few narrow segments, partial of numerous linear spreading segments of irregular lengths. Flowers white, crowded, nearly regular. Calyx margin of five broadish spreading leafy teeth. Petals inversely heart-sinapel, rolled inwards, haring a mid-rib and an obtuse inflexed point, about half as long as the petal. Stamens on slender fiaments, longer than the petals, with ovate anthers of two swollen cells, frequently purplish. Styles as long as the fruit, recurved. Stigmas small, globose. Disk small, somewhat conical. Fruit small, roundish, the sides somewhat 
compressed. Carpels with fire flattish equal ridges. Channels with single sinple vitla, more prominent in the ripe fruit than the ridges.

Habitat.-Ditches, margins of rivers and lakes, and in low damp meadows in various parts of England, and the lowlands of Scotland; but not vers frequent. Plentiful at Farnham, and other places on the banks of Lough Erne, Ireland.

Perennial; flowering in July and August.

Water Hemlock, or Cowbane, has a disagreealble fotid odour and pungent taste, possessing poisonous qualities, eren of greater energy than the common Hemluck, and producing effects similar to hydrocyanic acid. The symptoms related of those cases where the plant has accidentally been taken, are first swelling at the stomach, with vomiting, succeeded by total insensibility, finally with severe convulsions, during which there is generally locked jaw, rolling of the eses, and distortion of the spine; death terminating the sufferings generally within half an hour after taking the plant. When the plant is unfortunately taken into the stomach, the best means appears to be to hare recourse as soon as possible to an emetic, followed up with a brisk purgatire of repeated doses of oil, assisted by cathartic injections.

It is a singular circumstance in the history of many plants that while so strongly poisonous to some animals, they may be eaten with impunity by others. Such we find is the case with the Coubane; for when taken by most animals it is highly poisonous, but is eaten without injury by others, as by horses, sheep, and goats. It is related by Linnæus that in the moist pastures of Sweden this plant used to cause a consiclerable yearly loss amongst the horned cattle, until the cause was shown by him to arise from their feeding upon the Cowbane, and the means of preventing its recurrence pointed out. When full grown, Cowbane has a strong disagreeable odour, and is aroided by cattle; but when it is young, and growing luxuriantly amongst other luerbage, it has a rery faint smell, and is not discriminated, though almost as poisonous as the older plants. Linnæus, therefore, as a remedy against this yearly loss, pointed out to the owners of the cattle, that if they kept them out of these low pastures until the Cowhane was well grown, they might then be turned into them without fear of loss, for the instinct of the animals would prevent them from eating the plant by its disagreeable odour. They took his advice, and adopted this simple remedy; and from that time these animal losses have ceased. In some parts of Derbyshire this plant is very frequent; and we remember on one occasion conversing with a farmer who complained of having lost some of his young stock of cattle, and that he was equally unfortunate every year. TWe walked with him to his meadow where his cattle had been grazing, and found amongst the herbage a considerable number of ycung plants of the Cowbane; and remembering the circumstance above related of this plant by Linnaus, wc 
recommended the same plan of obviating the evil, and the careful removal of all the plants of the Cowbane from his meadows, which was followed, and produced the same happy results.

\section{GENUS LX. BERU'LA.-Косн. Berula.}

Gev. Char. Calyx margin of fire teeth. Petals obcordate, with an inflexed point. Fruit ovate, laterally contracted. Disk shortly conical, with a narrow margin. Styles reflexed. Carpels with five equal filiform ridges, the lateral ones before the margin. Channels with many vittc. Albumen roundish. General and partial involucre of several reflexed lanceolate or pinnate segments.

1. B. angustiffolium, Koch. (Fig. 435.) narrow-leaved Berula, or Water Parsnip. Stem erect; leares pinnate; leaflets unequally cut and serrated; umbels pedunculated opposite the leaves; involucre frequently pinnatifid.

Sium angustifolium.-English Botany, t. 139.-English Flora, vol. ii. p. 56.-Hooker, British Flora, vol. i. p. 130.-Lindley, Synopsis, p. 121.

Roots slender, fibrous, branched, in numerous whorls from the joints of the long creeping underground stems. Flowering stems erect, round, or somewhat angular, striated, smooth, much branched and leafy ahove, from one to two feet high. Leaves alternate, simply pinnate, quite smooth, footstalks striated, with a much dilated thin membranous margin sheathing the stem. Leaflets opposite, in about eight pairs, and a terminal three-cleft one, ovate or ovate-lanceolate, those on the lower leaves more distant, with the margins deep and irregularly cut or lobed, and unequally serrated, those of the upper leaves narrower, more crowded, finer, and more regularly serrated. Umbels on short footstalks opposite the leares, the general of numerous unequal angular slender rays, and the partial of short mostly crowded ones. General involucre of about six segments, which are simply lanceolate, or cut and not unfrequently pinnated, the partial of about six lanceolate spreading segments, seldom cut or pinnated. Flowers white. Calyx margin of five small teeth, shortly withering after flowering, and falling away. Petals inversely heart.shaped, or somewhat oborate, with a mid-rib and small inflexed point. Stamens with long slender filaments and small round anthers. Fruit crowned with the conical disk, and the short reflexed styles with small dark obtuse stigmas, orate, the sides contracted, smooth. Carpels with five equal filiform ridges, the lateral ones placed before the margins. Channels with many vittc, the vitta corered with a thick leathery pericarp. Albumen on a transverse section, roundish.

VOL. I. 
Habitat.-Ditches and rivulets ; frequent in England and Ireland; but not common in Scotland.

Perennial; flowering in July and August.

\section{GENUS LXI. SI'UM.-LINN. Water Parsnip.}

Gen. Char. Calyx margin of fire teeth. Petals obcordate, with an inflexed point. Fruit laterally compressed or contracted. Disk flattish, with a depressed margin. Styles reflexed. Carpels with five equal obtuse filiform ridges, the lateral ones forming the margins. Channels with three superficial vitta. Albumen rounded at the back, flat in front. General involucre mostly of several linear segments, partial of numerous ones.-Name from o\&w, to move; from the plant being almost constantly agitated by the water: or, according to Théis, from the Celtic word siw, water.

1. S. latifolium, Linn. (Fig. 434.) broad-leaved Water Parsnip. Stem erect; leares pinnated; leaflets lanceolate, equally and acutely serrated; umbels terminal ; involucre of numerous linear segments.

English Botany, t. 204.-English Flora, vol. ii. p. 56.-Hooker, British Flora, vol. i. p. 130.-Lindley, Synopsis, p. 121.

Root of slender long branched fibres, from the creeping underground stem. Flowering stems erect, angular, smooth, deeply furrowed, from two to six feet high, smooth, hollow, branched, and leafy. Leares alternate, pinnate, on long striated footstalks, with a dilated base, with membranous edges sheathing the stem, the lower unes or those under the water sometimes bi-pinnate, with the margin of the leaflets irregularly cut and serrated, the upper ones with about fire pairs, and an odd one of lanceolate smooth leaflets, of a lively green above; beneath paler, somewhat glaucous, with a mid-rib and numerous fine netted veins, the margin fine, and acutely serrated. Umbels teiminal, large, of numerous long angular rays, of nearly equal lengths, partial of numerous short slender nearly equal ones. General involucre mostly of sereral linear reflexed segments, sometimes one or two of them pinnated, partial of several lanceolate mostly unequal ones. Flowers white, crowded. Calyx of five teeth, sometimes very small. Petals inversely heart-shaped, or obcordate, with an inflexed small point. Stamens with slender filaments, and rather large inversely heartshaped anthers, of a purplish colour. Styles short, reflexed, or spreading. Stigmas small, obtuse. Disk flattish, with a depressed margin, fleshy, yellowish, crowning the ovate fruit, with the sides much compressed or contracted, smooth. Carpels with five filifurm obtuse palish equal ridges, the lateral ones forming the margins. Channels 
with three simple superficial vitto, pericarp of two coverings. Albumen rounded at the back, flat in front.

Habitat.-Ditches, rivulets, the margins of streams and watery places. Frequent in England and Ireland, but rather rare in Scotland.

Perennial; flowering in July and August.

Tribe 4. Seselinex.-Koch. Fruit in a trausferse section, round, or roundish. Carpels with five filiform or winged vidges, the lateral ones forming the margin, which are equal or a little wider than the others. Albumen convex at the back, flat in front, or roundish. Umbels perfect.

\section{GENUS LXII. CENAN'THE.-Linn. Water Drop-wort.}

Gen. Char. Calyx margin of five teeth. Pelals obcordate, with an inflexed point. Fruit cylindrical, or oblong, crowned by the erect styles. Carpels with fire somewhat convex obtuse ridges, the lateral ones rather wider than the others forming the margin. Channels with single vitta. Albumen convex, or roundish. General involucre various, partial of numerous segments.Named from oเvn, a vine; and avots, a flower; alluding to the vinous smell of the blossoms.

1. OE. fistu'losa, Linn. (Fig. 436.) common Water Drop-wort. Root with runners; stem cylindrical, hollow; upper leaves pinnate, with hollow petioles; leatlets linear, simple, or trifid; the first umbels of three rays, fertile, the remainder of from three to seren, abortive.

English Botany, t. 363.-English Flora, vol. ii. p. 68.-Hooker, British Flora, rol. i. p. 13l.-Lindley, Synopsis, p. 119.

Root fasciculated with long branched whorls of fibres, putting out underground stems, by which the plant spreads and propagates itself. Stem erect, bent at the base, from two to three feet high, round, smooth, hollow, striated, branched, of a glaucous green, frequently swelled in the upper part of the spaces between the joints, as if inflated. Leaves alternate, dilated and sheathing at the base of the long hollow footstalks, quite smooth, pinnate, with narrow linear simple or cleft segments, the root leares bi- or tri-pinnate, with broader segments than those of the stem, which are simply pinnate, distant, and very small, with a few leaflets at the top of the footstalks only. Umbels lateral and terminal, rarious, the lower ones only are fertile, and of two or three rays, stout, short; the upper ones of about five slender rays, bearing flowers with stamens only; partial umbels of the fertile flowers with short crowded rays, those of the barren longer and more slender. General involucre almost always wanting, sometimes the barren umbels 
have a few narrow linear segments, partial involucre either wanting or of a number of linear lanceolate segments. Flowers white or pinisish, irregular, the outer ones barren, bearing only the rudiments of styles, haring also narrower longer more pungent segments to the calyx. Calyx of fire nearly equal narrow lanceolate segments. Petals inrersely heart-shaped, or obovate, notched, with a small inflexed point, unequal, especially the outer ones. Stamens on long slender filaments, with small purplish anthers. Styles long, with small obtuse stigmas. Dish small, conical, crowning the somewhat pear-shaped fruit, which are crowded together with a roundish rough looking head. Carpels with five ridgcs, the two lateral ones forming the margins rather wider than the rest, which are pale and obtuse. Albumen on a transverse section, convex, or roundish.

Habitat.-Ditches, rivulets, and watery places; frequent.

Perennial; flowering in July and August.

2. OE. pimpinel'loides, Linn. (Fig. 437.) Parsley Water Drop-wort. Root with fleshy tubercles, mised with fibres; leaves tri-pinnate, the radical ones wedge-shaped and cut, the upper ones long, linear, undirided; general inrolucre of several linear segments.

English Botany, t. 347.-Englisb Flora, vol. ii. p. 69.-Hooker, British Flora, rol. i. p. 131.-Lindley, Synopsis, p. 119.

Koot with sereral flesby tapering tubercles, intermixed with branched filiform fibres. Stem erect, round, smooth, striated, from one to three feet high, slightly hranched and leafy. Leares smooth, bi-pinnate, alternate, on long striated footstalks, dilated at the base and sheathing, the root leaves with wedge-shaped cut leaflets, mostly trifid, the upper ones are long, linear, simple, while the intermediate ones are orate oblong, and sometimes with a crenated margin. Umbels lateral and terminal, the general of numerous angular striated equal rays, the partial of numerous crowded short somewhat unequal ones. General involucre of sereral narrow linear unequal spreading segments, and the partial ones generally more numerous than these. Flowers white or pinkish, somewhat irregular. Caly $x$ of fire nearly equal lanceolate teeth. Petals five, unequal, especially on the outer flowers, inversely heart-shaped, or urate and notched with a small intlexed point. Stamens with long slender filaments and small roundish anthers. Styles at first short, hecoming longer, straight, rigid, with an obtuse small stigma and cunical base. Fruit crowded into roundish heads, cylindrical, narrower at the base, and somewhat contracted beneath the calyx. Carpels smooth, with five prominent obtuse ridges, the litteral ones forming the margins somewhat wider than the others. Channels with single rather large rilta. Albumen roundish, somewhat flat in front.

Habilat.-Salt marshes not unfrequent, and sometimes in wet incadows. 


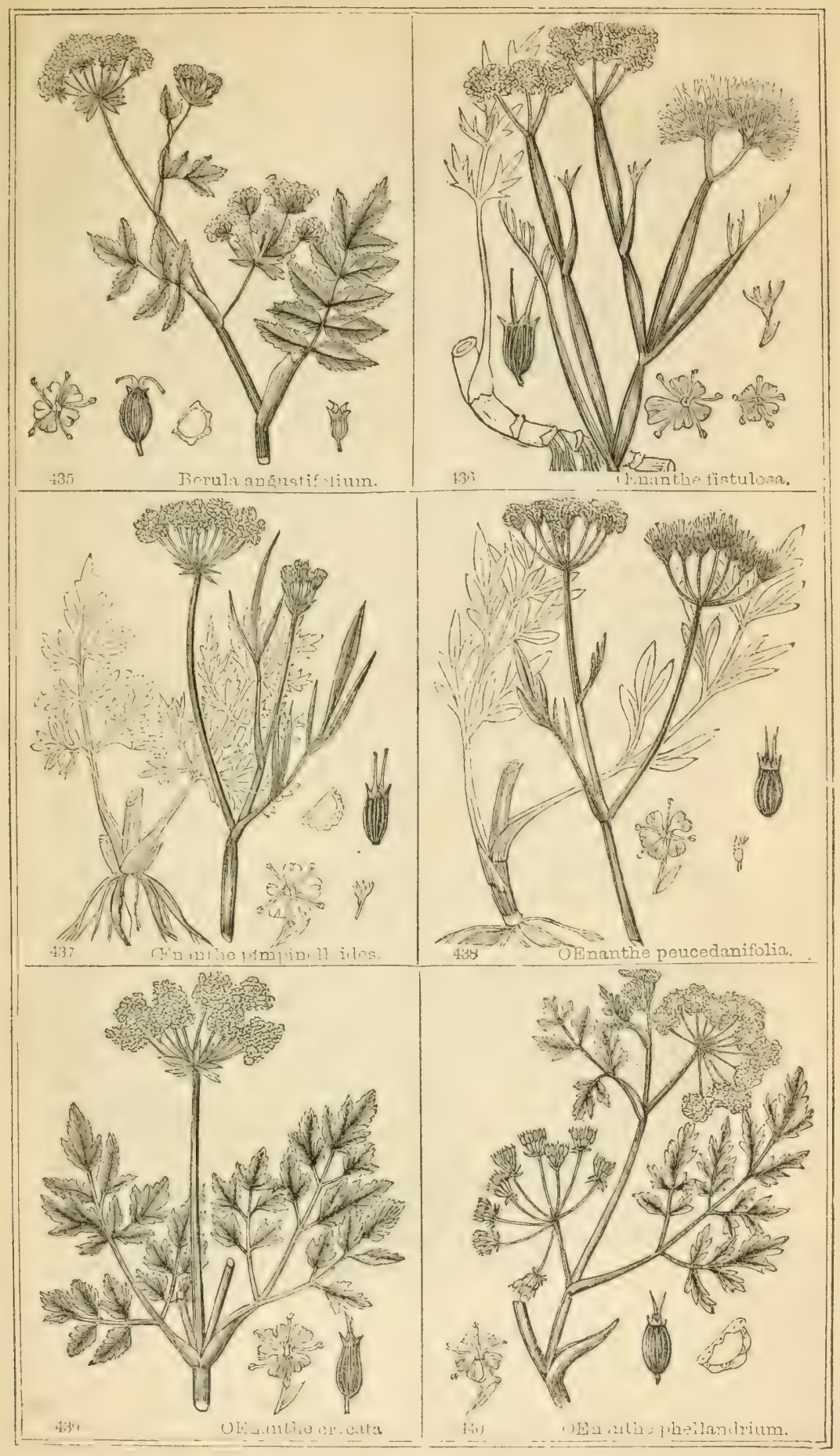



Perennial; flowering in July.

3. OE. peucedaniffolia, Poll. (Fig. 438.) Sulphur-veed Water Drop-urort. Root with fleshy sessile tubercles, mixed with branched tibres; radical leaves bi-pinnate, the upper pinnate, all with narrow linear leaflets; general inrolucre wanting.

English Botany, t. 348.-English Flora, rol. ii. p. 70.-Hooker, British Flora, vol. i. p. 131.-Lindley, Synopsis, p. 120.

Root with several fleshy sessile elliptical tubers, intermixed with long slender branched fibres. Stem erect, smootl, striated, or angular, branched and leafy, from one to three feet high. Leares smooth, alternate, on long striated footstalks, with a sheathing dilated base, the root leaves bi-pinuate, with linear leaflets, the upper ones simply pinnate, with longer narrower leaflets, acute, and with a slender midrib. Umbels lateral and terminal, of about eight angular unequal rays, the parlial of numerous short irregular ones. General involucre wanting, or of two or three short narrow linear segments, the partial of numerous narrow irregular lanceolate ones. Flouers numerous, crowded, white or pinkish, the outer ones barren. Calyx of five short lanceolate irregular teeth, especially on the outer flowers. Petals fire, unequal, especially on the outer flowers, inversely heart-shaped, the outer ones largest, with the sides of the base curved inwards, and forming a kind of canal. Stamens with long slender filaments and small roundish purplish anthers. Fruit when ripe crowded into small roundish heads, crowned with the elongated rigid styles and small conical base, oblong, contracted at the base and slightly beneath the calyx. Carpels with five prominent obtuse rilges, the lateral ones slightly broader than the others, and forming the margin. Channels with single rather large vittce. Albumen roundish, somewhat flat in front.

Habitat.-Fresh water, ditches and marshes. Oxfordshire, Bedfordshire, Suffolk, Sussex. $-M r$. Borrer. Lincolnshire.-R. $D$.

Perennial; flowering in June and July.

The tubers of this and the above species, $Q$. pimpinelloides, contain a farinaceous matter, with a pleasant nutty flarour, and in some parts of the Continent they are cultirated and much esteemed as a regetable; but though mild and wholesome when cultivated, they are in the wild state dangerous, and cannot be used with impunity. This is another example of the advantages derived from careful cultivation, in rendering that which is unwholesome and deleterious in the wild state, bland, and nutritious, and subservient to our wants.

The two species, $E$. pimpinelloides and peucedanifolia, are nearly allied to each other; the principal difference appears to be in the leaves and the shape of the fruit, to which characters the student must give much attention in distinguishing the species of this order. 
4. E. cro'cata,Linn. (Fig. 439.) Hemlock Water Drop-wort. Root with many fleshy tubers; leares bi- or tri-pinnate; leaflets ovate, wedge-shaped, cut or serrated, those of the upper leares narrower; general involucre of a few segments, or sometimes wanting.

English Botany, t. 2313.-English Flora, vol. ii. p. 70.-Hooker, British Flora, vol. i. p. 131.-Lindley, Synopsis, p. 120.

Root with numerous fleshy elliptical tubers, mixed with branched fibres. Stem erect, large, stout, smooth, furrowed, hollow, much branched and leafy, from three to five feet bigh. Leaves alternate, large, smooth, dark green, on short furrowed footstalks, with a broadly dilated sheathing base, bi- or tri-pinnate, leaflets all wedge-shaped, or orate wedge-shaped, opposite, more or less deeply cut and serrated, with numerous branched veins on the under side, which is rather paler than the upper, the leaflets of the upper leaves narrower. Umbels terminal and lateral, the general of numerous stout angular nearly equal rays, the partial of numerous short unequal crowded ones, the outer longest. General involucre either wanting, or of a few linear segments, partial of numerous linear unequal ones. Flowers white, crowded, irregular. Calyx of five short lanceolate teeth, somewhat imegular. Petals obcordate, or obovate, notched with an inflexed point, the outer ones largest. Stamens with long slender filaments and small roundish purple anthers. Styles long, straight, increasing after flowering. Stigma small, obtuse. Disk small, somewhat conical. Fruit elliptical, cylindrical, narrower at the lower part, smooth. Carpels with five obtuse pale ridges, the lateral ones rather broader than the others forming the margin. Channels with rather large single vitte. Albumen roundish, somewhat flattened in front.

Habitat.-Ditches, river sides, and watery places; frequent.

Perennial; flowering in July.

Hemlock Water Drop-wort is one of our most poisonous umbellate plants, and has caused many fatal disasters, by being eaten in mistake instead of Water Parnsnip and other plants. The fleshy roots have not an unpleasant taste, but are most deleterious. It is related by Mr. Howel, surgeon, at Haverfordwest, that "eleven French prisoners had the liberty of walking in and about the town of Pembroke. Three of them being in the fields a little before noon, dug up a large quantity of this plant, which they took to be wild Celery, to eat with their bread and butter for dinner. After washing it, they all three ate, or rather tasted of the roots. As they were entering the town, without any previous notice of the sickness at the stomach, or disorder in the head, one of them was seized with convulsions; the other two ran home, and sent a surgeon to him. The surgeon endeavoured first to bleed, and then to vomit him; but those endeavours were fruitless, and he died presently. Ignorant of the cause of their comrade's death, and of their own danger, they gave of these roots to the other eight prisoners, 
who ate of them with their dinner. A few minutes afterwards, the remaining two who gathered the plants were seized in the same manner as the first, of which one died; the other was bled, and a romit with great difficulty forced down, on account of his jaws heing, as it were, locked together. This operated, and he recorered; but was some time affected with dizziness in his head, though not sick, or the least disordered in the stomach." Numerous cases are on record of the poisonous effects of this plant, and accidents are of frequent occurrence in its being mistaken for other plants. The symptoms which it generally produces are heat in the throat and stomach, delirium, followed by stupor, and, more or less general convulsions.

It appears to contain the most energetic poison of all our umbelliferous plants, producing the riolent symptoms above stated almost immediately after being taken, and terminating the existence of the unfortunate individuals sometimes within an hour; but it is seldom they live more than four hours, unless some remedial means have been taken, by prolucing immediate sickness. Frequently bleeding is necessary, and drinking large quantities of warm diluents, followed up with some active aperient medicine.

The violent action of this plant upon the system has not, howerer, prevented its being used medicinally in the treatment of obstinate affections of the skin, in which it is said to have been found serviceable. The juice is of a yellow colour, and its odour resembles in some degree that of the vine blossom. It was taken in the dose of a table spoonful, in a case related by Dr. Bulteny, affecting the head in two hours after, in a very extraordinary manner, followed with violent sickness and romiting, succeeded by cold sweats and rigors. These severe symptoms appears not, however, to have deterred the patient from continuing the medicine, but in smaller doses, until it effected a cure. The roots have also been used in the form of poultices to felons, whitlows, and foul ulcers; and it is said to be sometimes used as a bait to poison rats and moles.

The noxious effects of this plant do not appear limited to the human subject, but are equally poisonous to some animals, while others eat it with impunity.

This species is nearly allied to the $E$. apiifolia, of Brotero, difering, according to Sir W. H. Hooker, only in the colour of the secretions in the plant; but these secretions are rariable, owing to the season and situation of growth of the plant. $O E$. apiifolia is said to grow about Plymouth. The distinctire characters of the two plants would be best inrestigated in their native situation, and we hope some one will examine them more minutely.

5. E. Phellan'drium, Spreng. (Fig. 440.) fine leaved Water Drop. wort. Root fusiform; stem much branched; leares bi-tripinnate; leaflets ovate, wedge-shaped, cut, and spreading the submerged ones, 
much divided; umbels opposite the leares; general involucre wanting, or of few segments; fruit ovate, oblong.

English Flora, vol. ii. p. 71.-Hooker, British Flora, vol. i. p. 132.Lindley, Synopsis, p. 119.-Phellandrum aquaticum.-English Botany, t. 684 .

Root spindle-shaped, fleshy, with many whorled branched filiform fibres. Stem from two to three feet high, hollow, very thick at the base, very much branched abore, spreading in a diraricating manner, smooth, striated, leafy. Leaves alternate, spreading, bi- or tri-pinnate, smooth, of a dark shining green, footstalks rather slender, striated, dilated at the base, and embracing the stem, leaflets opposite, somewhat decurrent at the hase, ovate oblong, with a wedge-shaped hase, deeply cut into acute narrow segments. Umbels opposite the leaves, on short somewhat tumid stalks, the general of about twelve unequal striated rays, the partial of numerous short irregular ones. General involucre wanting, or of a few small segments, partial of numerous unequal narrow ones. Flowers numerous, white or pinkish, the outer ones largest, mostly all fertile. Calyx limb of five spreading narrow lanceolate segments. Petals unequal, inversely heart-shaped, with an inflexed point. Stamens on long slender filaments. Anthers ovate, mostly purplish. Styles long, slender, straight. Stigma small, globose. Disk small, conical, crowning the fruit, which is ovate oblong, smooth, the sides compressed. Carpels with five broad obtuse ridges, the lateral ones forming the margins wider than the others. Channels narrow, with small single vittce, containing a strong disagreeable secretion. Albumen roundish, oval.

Habitat. -Rivers and drains; not unfrequent.

Perennial ; flowering in June and July.

The root is sometimes found to put out creeping runners when the plant is growing on the banks of running streams, and the leaves which are under the surface of the water become much divided into almost hair-like segments. Varieties are sometimes found growing in the dried up bed of ponds with short very thick stems, and much divided branches entangled together, very bushy, but not otherwise different.

\section{GENUS LXIII. RETHU'SA.-Linn. Fool's Parsley.}

Gen. Char. Calyx margin obsolete. Petals obcordate, notched with an inflexed point. Fruit roundish, ovate. Carpels with five elevated acutely carinated ridges, of which the lateral oues are rather wider than the others, and surmounted by a somewhat winged keel. Channels with single vittc. Albumen convex or 



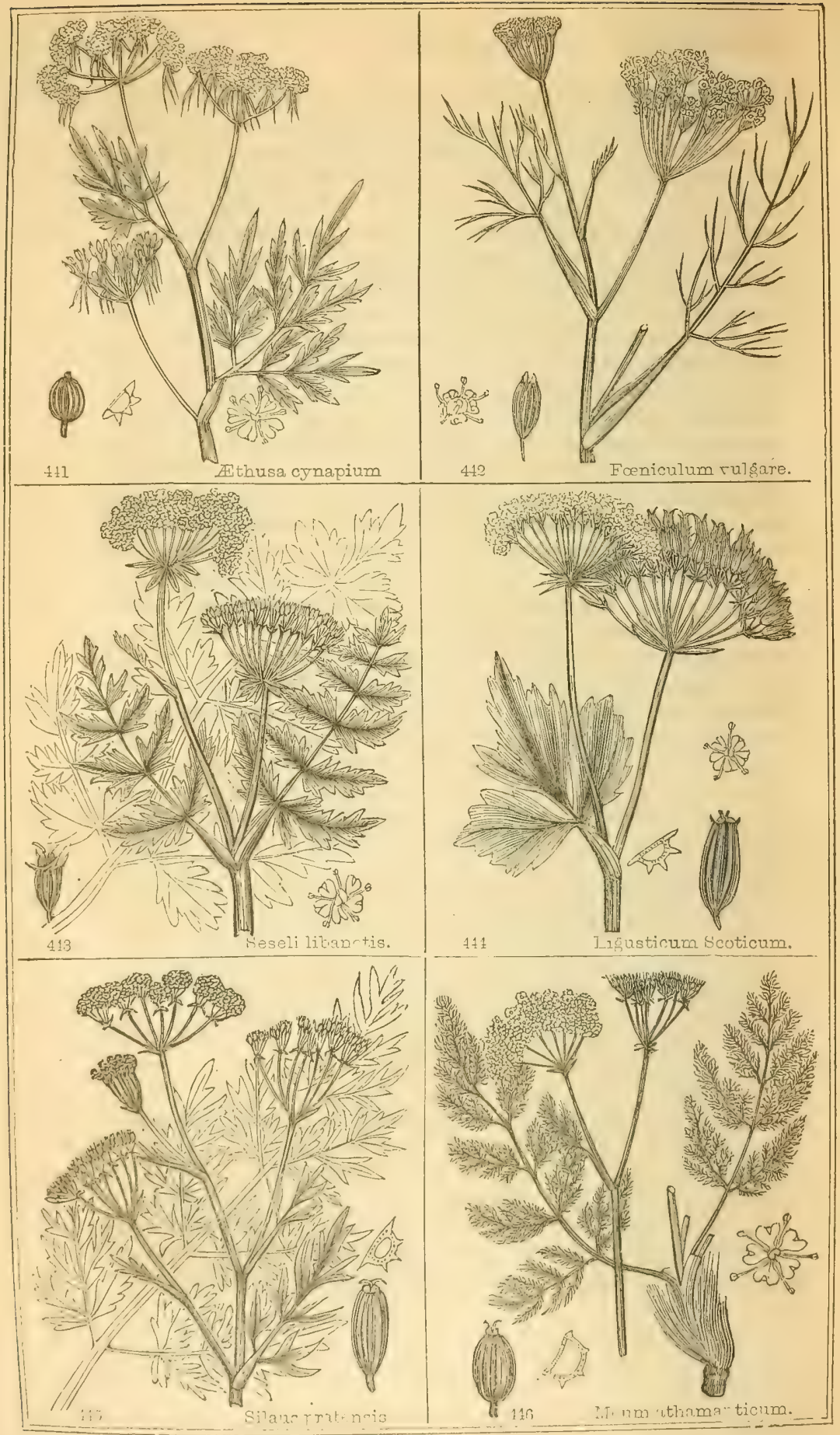


roundish. General involucre various, parlial of three pendent segments.-Name from $\alpha_{6} v_{w}$, to burn; on account of its acrid quality.

1. E. Cyna'pium, Linn. (Fig. 441.) common Fool's Parsley, or lesser Hemlock. Leares unifurm; leaflets wedge-shaped, decurrent, with lanceolate segments; partial involucre of three segments, longer than the rays.

English Botany, t. 1192.-English Flora, vol. ii. p. 64.-Hooker, British Flora, vol. i. p. 132.-Lindley, Synopsis, p. 119.

Root tapering, and with long slender fibres. Stem erect, from iwelve to eighteen inches high, erect, round, smooth, striated, branched above and leafy, frequently purplish. Leares alternate, on short footstalks, much dilated at the base, with a pale thin membranous edge, two or three times pinnate, the leatlets orate lanceolate, variously cut and serrated in narrow segments, quite smooth, of a dark green, somewhat paler beneath and finely veined, slightly decurrent at the base. Cimbels terminal and lateral, the general of numerous striated rays of unequal leugths, spreading, nearly flat, partial of numerous short ones. General involucre none, partial of three narrow long linear segments, hanging pendent on the outer side of the umbel. Flowers numerous, white. Calyx with a narrow obsolete margin. Peluls five, irregular, inversely heart-shaped, with a small intlexed point between the lobes at the end. Stamens with longish slender filaments, bearing small whitish heart-shaped anther's. Styles short, spreading, with small obtuse stiymas. Fruit roundish, orate, small, pale, greenish brown. Carpels with five thick, elevated, acutely keeled ridges, the lateral ones forming the margins rather wider than the others, and with the keel somewhat winged. Channels narrow, with single slender ritte. Albumen consex at the back, plain or concare in front.

Habitat.-Fields, waste places, and gardens.

Annual ; flowering in July and August.

Fool's Parsley is another plant possessing deleterious properties, and is so called from its haring heen mistaken for the real Parsley, and in many instances having produced fatal results. It is readily distinguished from all other genera of this order, by its three long pencient segments of the partial involucre; it has, moreorer, smooth shining leaves, having a very disagreeable nauseous smell when rubbed, which is the reverse with the Garden Parsley. The juice is sail to contain a peculiar alkaloid, which crystallizes in rhombic prisms, aud is soluble in water and alcobol, but not in ether. The deleterious properties are said to reside in this salt, which has been named Cynapia.

The symptoms which are said to be produced by this plant when taken into the stomach are, nausea, romiting, head-ache, gicldiness, somnolence, burning heat in the mouth, throat, and stumach, diffi-

VOL. I.

3 D 
culty in swallowing, and numbness in the limbs. Sometimes there are spasmodic pains and swelling in the stomach, lividity of the skin, and difficulty in breathing.

\section{GENUS LXIV. FEeni'CULUM.-Hofrm. Fennel.}

Gen. Char. Calyx margin obtuse, obsolete. Petals roundish, entire, rolled inwards with a squarish incurved point. Fruit nearly round, on a transrerse section. Carpels with five obtuse prominent carinated ridges. Channels with single vitta. Albumen half round. General and partial involucre wanting.-Name from fcenum, hay; its smell being something like that of hay.

1. F. vul'gare, Gcertn. (Fig. 442.) common Fennel. Stem round; leaves bi-ternate; leaflets cut into long, linear, filiform segments.

Hooker, British Flora, vol. i. p. 132.-Lindley, Synopsis, p. 119.Anethum Foniculum, Linn.-English Botany, t. 1208.-Meum Fæniculum, Spreng.-English Flora, vol. ii. p. 85.

Root tapering. The whole plant of a deep glaucous green, smooth. Stem erect, from three to four feet higb, round, solid, striated, much branched and leafy. Leaves alternate, very much divided, with long narrow linear awl-shaped segments, more or less drooping, the footstalk much dilated and sheathing at the base. Umbels lateral and terminal, the general of numerous unequal striated spreading rays, the partial of numerous short unequal ones, bearing crowded yellow flowers. Involucre both general and partial wanting. Calyx an obtuse obsolete margin. Petals roundish, rolled inwards, somewhat notched at the top from the small squareish inflexed point. Stamens on awl-shaped flaments, with ovate yellow anthers. Styles short, with a flattish fleshy glutinous disk. Stigmas small, obtuse. Fruit oblong, nearly round, on a transverse section. Carpels with five jrominent obtusely keeled ridges. Channels with slender single vitto. Albumen half round.

Habitat. - Plentiful on the chalky cliffs of England, and the banks of rivers near the sea in Norfolk and Suffolk; in the crevices of the rock of Nottingham Castle; and not unfrequent in the neighbourhood of towns and villages, where it has probably escaped from gardens.

Perennial; flowering in July and August.

The boiled leaves of the Fennel is in many parts of the country used, when finely minced and mixed with melted butter, as a sauce to salmon and mackarel; and the warm aromatic seeds are made into tea, and used as a carminative for children, and sometimes as a substitute for caraway seeds. 


\section{GENUS LXV. SE'SELI.-LrNn. Meadow Saxifrage.}

Gex. Char. Calyx margin of five tecth. Petals obcordate, with an inflexed point, or nearly entire. Fruit orate or oblong, roundish, on a transverse section, crowwed with the reflexed styles. Carpels with five prominent or elevated filiform ridges, the lateral ones mostly rather wider than the others, and forming the margin. Channels with single vitla, rarely with two or three. Albumen half round. General involucre various, partial of numerous segments. - Name from $\sigma \varepsilon \sigma \varepsilon \lambda_{b}$, Seseli; originally applied to some plants of this kind.

1. S. Liban'olis, Koch. (Fig. 443.) Mountain Meadow Saxifrage. Stem angular, furrowed; leaves bi-pinnatifid or tri-pinnatifid; leaflets cut into lanceolate very acute mucronated segments; general involucre of many narrow segments.

Hooker, Britisls Flora, vol. i. p. 132.-Lindley, Synopsis, p. 119.Athamanta Libanotis, Linn.-English Botany, t. 138.-English Flora, vol. ii. p. 88.-Libanotis vulgaris, De Cand.

Root tapering, crowned with the withered bases of the old leaves. Stem erect, from one to three feet high, angular, smooth, furrowed, and striated, more or less solid within, branched and leafy, the leaves most numerous below, alternate, sometimes opposite above, the lower ones on longish footstalks, the upper with short, and all with dilated hases, with membranous margins embracing or sheathing the stem, the lower leaves frequently tri-pinnated, with the leaflets broadly wedge-shaped, cut into lanceolate very acute segments, tipped with a bristle point, the lower leaflets on short footstalks, the upper sessile, and frequently united at the base, the upper leares much smaller than the lower, bi- rarely tri-pinnated, the leaflets deeply cut into lanceolate segments, all of them are veiny beneath, and paler than above, frequently somewhat glaucous. Umbels lateral and terminal, hemispherical, the general of nnmerous angular more or less hairy rays, the partial of numerous crowled short ones. General involucre of numerous narrow linear hairy reflexed segments, partial of numerous hairy linear erect ones. Flowers numerous, crowded, white or pinkish. Calyx of five narrow awl-shaped elongated hairy teeth, which soon full away. Petals inversely heart-shaped, with a strong mid-rib and two narrow lateral ones, and inflexed point. Filaments awl-shaped, with ovate anthers. Styles short. Stigmas small, obtuse. Disk fleshy, somewhat convex, becoming purplish after flowering. Fruit ovate, hairy, roundish on a transverse section. Carpels with five elevated ridyes, the lateral ones somewhat wider that the others, and forming the margin. Channels hairy, with single ville. Albumen half round. 
Habilat.-Chally pastures; very rare. Gogmagog hill, Cambridgeshire; between St. Albans and Stony Stratford.-Hudson.

Perennial; flowering in August.

The whole plant has a bitter pungent taste, but is not applied to any particular purpose. It is found of very variable sizes, and with the leares more or less deeply cut and divided. A variety is mentioned by De Candole not more than a foot high, with the stem clotherl with hair, and small and more divided.

\section{GENUS LXVI. LIG'USTICUM.-LINN. Lovage.}

Gin. Criar. Calyx margin of five teeth, or obsolete. Petals obovate, notched, with an inflexed point and rery short claw. Fruit roundish, or the sides slightly compressed. Carpels with five sharp equal winged ridges, the lateral ones forming the margins. Channels with many vittce. Albumen half round. General involucre various, partial of many segments.-Named from Liguria, in Italy, the native country of the old Ligusticum Levisticum.

1. L. Sco'ticum, Linn. (Fig. 444.) Scottish Lovage. Stem round, striated, slightly branched; leaves twice ternate; leaflets subrhomboid toothed, smooth; general involucre of about six linear segments.

Euglish Botany, t. 1\%07.-English Flora, vol. ii. p. 82.-Hooker, British Flora, vol. i. p. 133.-Lindley, Synopsis, p. 118.

Root tapering. Stem round, smooth, finely striated, slightly branched above, solid. Leaves mostly radical, alternate, large, on footstalks, with a dilated base, with purplish membranous edges somewhat sheathing the stem, thrice ternate, lcaftets large, somewhat fleshy, of darkish green, smooth, not glossy, of a somewhat rhomboid shape, cut deep and somewhat irregularly serrated or toothed, finely netted with veins on the under side, the terminal leaflet mostly three cleft, and sometimes the latcral ones also. Umbels terminal, large, the gencral of numerous nearly eyual angular rays, the partial also numerous, angular, as long as the fruit. General involucre of about six narrow linear ribbed spreading segments, the partial of numerous linear ones. Flowers numerous, white or greenish, sometimes pink. Calyx margin of five lanceolate tecth. Pctals equal, obovate, notched with a small inflexed point, narrowed at the base into a short claw, and slightly rolled inwards. Stamens on slender incurved filaments, with ovate reddish anthers. Styles short. Stigmas small, obtuse. Disk fleshy, conrex. Fruil large, elliptical, roundish on a transverse section, or the sides slightly compressed. Carpels with five equal sharp winged ridges. Chamels smooth, with atrout six slender simple ville. Albumen half round. 
Habitat.-Rocky sea coasts; not unfrequent in the North of England and Scotland.

Perennial; flowering in July.

The root, as well as the whole plant, has an acril aromatic flavour, with a somewhat nauscous taste. In the island of Skye it is called Shunis, and is said to be eaten both in a crude fand hoiled state; but though probably wholesome, it is not palatable to most strangers.

\section{GENUS LXVII. SILA'US.-Besser. Pepper Saxifrage.}

Gen. Char. Calyx margin obsolete. Pelals obovate, oblong, entire, or somewhat notched with an inflexed point, at the base either sessile or with an appendage. Fruit roundish. Carpels with five sharp equal somewhat winged ridges, the lateral ones forming the margins. Channels with many vitte. Albumen nearly round. General involucre of few segments, or wanting, partial numerous.-Name of doubtful origin.

1. S. pra'tensis, Besser. (Fig. 445.) Meadow Pepper Saxifrage. Stem angular; leares tri-pinnate; leaflets entire, linear, lanceolate, with a bristle point, or bi-partite, the terminal one tri-partite; general involucre of one or two segments.

Hooker, British Flora, vol. i. p. 133.-Lindley, Synopsis, p. 118.Pcucedanum Silaus.-English Botany, t. 2142.-Cnidium Silaus.Euglish Flora, vol. ii. p. 91.

Root tapering, fleshy, crowned by the withered remains of the old leaves. Stem erect, branched, frequently from the base, angular, somewhat furrowed and striaterl, smooth, purplish, especially near the joints and lower part, solid, from one to two feet high. Leaves mostly radical, on longish striated footstalks, dilated at the base, the lower ones three or four times pinmated, paler on the under side, the midrib and somewhat obtuse margin rough, with minute hairs, leaflets opposite, simple, linear, lanceolate, cntire, with a fine bristle point, or once or twice deeply cleft, separate at the base, or united, the upper leaves much smaller than the lower. Umbels terminal and lateral, the general of about eight irregular angular rays, the partial much more numerous. General involucre of one or two linear segments, sometimes wanting, partial of numerous narrow linear ones. Flowers numerous, white, or pale yellow. Calyx an obsolete margiu. Petals oblong, slightly notched, rolled inwards with an obtuse inflexed point, tapering at the base into a short claw, and with a mid-rib and two slender lateral ones. Stamens with long slender filaments and rathen largc ovate anthers, Styles straight, spreading. Stigmas obtuse. 
Disk large, flatlish, purple. Fruit rather large, elliptical, roundish on a transverse scction, the sides somewhat compressed. Carpels with live sharp winged ridges, the lateral ones forming the margins slightly wider than the others. Channels smooth, with numerous simple slender vittce. Albumen half round, somewhat waved at the back.

Habitat.-Pastures and meadows, not unfrequent in England. Near Oxenford Castle and Kelso, Scotland. Rare in Ireland; by the side of the Foyle river, county of Derry.-Mr. D. Moore.

Perennial; flowering in July.

The whole plant when bruised gives an unpleasant fotid smell, and does not appear to be generally eaten by cattle. It is nearly allied in generic character to Ligusticum, but is readily distinguished by the obsolete calyx and the shape of the petals.

\section{GENUS LXVIII. ME'UM.-TourNF. Spignel.}

Gen. Char. Calyx margin obsolete. Petals entire, elliptical, acute at each end. Fruit nearly round. Carpels with five equal somewhat winged ridges, the lateral ones forming the margins. Channels with many viltce. Albumen about half round. General involucre of few segments, or wanting, partial of numerous ones. -Name, according to Minshew, from $\mu \varepsilon \omega v$, less; from its diminutive size.

I. M. athaman'ticum, Jacq. (Fig. 446.) Spignel, Meu, or Baldmoney. Leaves bi-pinnate; Jeaflets opposite, numerously divided into bristle-like segments, with an acute point.

English Botany, t. 2249.-English Flora, vol. ii. p. 84.-Hooker, British Flora, vol. i. p. 133.-Lindley, Synopsis, p. 118.-Athamanta Meum, Linn.-Ligusticum Meum, Crantz.

Root tapering, fleshy, or somewhat woody, surrounded at the top with the fibrous remains of the leaves of former years. Stem erect, from one to eighteen inches ligh, round, smooth, striated, slightly branched above, and almost naked. Leaves mostly radical, of a dark green, on long purplish striated footstalks, with a dilated sheathing membranous base, doubly pinnated with crowded opposite leaflets, divided to the base into numerous hair-like segments, with an acute point, and from the segments spreading the leaflets appear whorled. Umbels terminal and lateral, the general of numerous unequal angular rays, the previal of more numerous short crowded ones. General involucre of a few lanceolate segments, or, mostly wanting, partial of numcrous nimw lincar ones. Flowers numerous, crowded, yellowish, the entral unes scldom perfect. Calyx margin 
obsolete. Petals elliptical, with an acute point and base, and a slender mid-rib. Fruit rather large, elliptical, somewhat curved, roundish, on a trausverse section, the side slightly compressed. Carpels with fire slightly winged equal ridyes, the lateral ones forming the margins scarcely wider than the others. Channels smooth, with numerous slender simple vilte. Albumen half round, on a transverse section.

Habitat.--Dry alpine pastures; not unfrequent in the North of England and Scotland, especially the Highlands.

Perennial; flowering in June and $\mathrm{July}$.

This plant, called Bald or Bald-money, is, Sir W. J. Hooker ob. serves, a corruption of Balder, the Apolls of the northern nations, to whom this plant was dedicated. The whole plant has a powerful aromatic smell, with a warm or somewhat acrid bitterish taste, and has been recommended as a carminative and stomachic in the form of tea. The peculiar flavour of the plant is said to be communicated to the milk and butter of the cattle feeding upon it, which, according to the taste of some persons, is very agreeable.

\section{GENUS LXIX. CRITH'MUM.-LINN. Samplire.}

Gen. Crar. Calyx margin obsolete. Petals roundish, entire, rolled inwards with an obovate point. Fruit roundish on a transverse section. Carpels with five elevated sharp somewhat winged ridges, the lateral ones forming the margins a little wider than the others. Albumen free in the pericarp, with numerous vitte. General and partial involucre of numerous segments.-Name from xptrw, to secrete; so named from its supposed power in promoting the secretion of urine, \&c.

1. C. mariti'mum, Linn. (Fig. 447.) Sea Samphire. Leaflets lanceolate, fleshy; segments of the involucre ovate.

English Botany, t. 819.-English Flora, vol. ii. p. 73.-Hooker, British Flora, vol. i. p. 133.-Lindley, Synopsis, p. 118.

Root long, branched, and tortuous, extending for a considerable distunce among stones and the fissures of rocks. The whole plant smooth, glaucous, fleshy. Stem erect, or ascending, from six to twelre inches high, round, smooth, branched, and leafy. Leaves twice or thrice ternate, on roundish footstalks, dilated into a sheathing base, leaflets lanceolate, acute, tapering at the hase, about an inch long. Umbels lateral and terminal, general of numerous somewhat unçual rays, parlial of numerous short ones. General involucre of numerous orate lanceolate spreading segments, as well as the partial. Flowers nu- 
merous, crowded, white. Calyx margin obsolete. Petals rolled inwards, roundish, entire, with an obovate incurved point. Stamens with slender filaments and yellow anther's. Styles very short. Stigmas obtuse. Disk large, slightly convex, white, fleshy, becoming more tumid, crowning the elliptic fruit, which is almost round, on a transverse section. Carpels with five raised sharp slightly winged ridges, the two marginal ones scarcely wider than the others. Albumen nearly half round, forming a loose kernel, with numerous vitta, surrounded by a loose covering.

Habitat.-Rocks by the sea side; frequent in England and Ireland; rare in Scotland, on the coast of Galloway, and at Aberlady, Haddingtonshire.

Perennial; flowering in August.

Samphire has a warm aromatic flavour, and is used by the country people in some parts of the country as a pot herb, and mixed with salads; but it is much more frequently used when pickled, for which purpose it is sold in the markets, and is much esteemed, making a warm agreeable aromatic and wholesome condiment, far superior to the Salicornia herbacea, (page 2), although some persons prefer it to the Samphire, and is sold in the market for the same purpose.

Tribe 5. Angenicee.-Koch. Fruit compressed at the back, with dilated winged margins, which (on account of the commissure being almost central) is double. Carpels with five primary ridges, winged, or the three dorsal ones are tiliform, the lateral ones always winged, and almost as wide again as the others. Albumen plane in front, convex behind. Umbels perfect.

\section{GENUS LXX. ARCHANGEL'ICA.-HoFF. Garden Angelica.}

Gen. Char. Calyx margin of five teeth. Petals elliptical, entixe, with an incurved acuminated point. Fruit somewhat compressed at the back, with two wings on each side. Carpels with thick carinated ridges, the three dorsal ones elevated, the two lateral ones dilated into wings, twice as broad as the rest. Albumen free in the pericarp, with numerous vitta. General involucre of a few segments, or wanting, partial of numerous ones.-So named from its supposed superior virtues to the following genus.

1. A. officina'lis, Hoffm. (Fig. 448.) Garden Angelica. Stem round, smooth, striated; leaves bi-pinnate; leaflets ovate, deeply serrated, the terminal one lobed. 


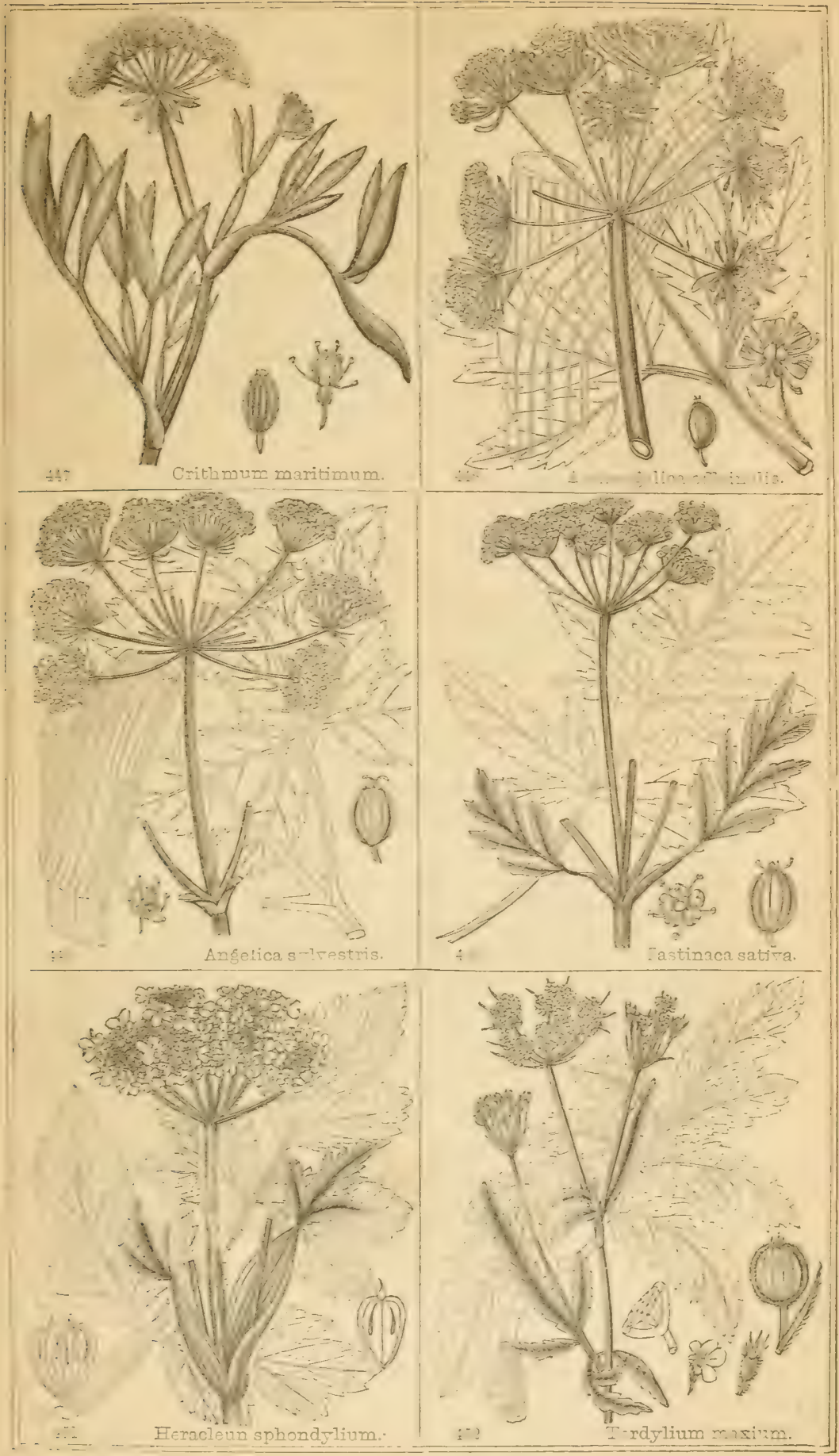



Lindley, Synopsis, p. 11\%.-Angelien drchangelica, Lim.-English Butany, t. 2561.-English Flora, vol. ii. p. 80.-I Iooker, British Flora, vol. i. p. 134.

Root large, fleshy, branched. Stem erect, very stout, four or fire feet high, round, striated, smooth, except near the umbels it is thickly clothed with short soft down, branched and leafy. Leaves alternate, hi-pinnate or tri-pinnate, large, spreading, quite smooth, leaflets ovate lanceolate, sometimes heart-shaped at the base, the apex acute, unequally serrated, occasionally cut and lobed, the terminal one always decply lobed, footstalks much dilated at the base in a saccate manner with thin membranous sides, smooth, striated, embracing the stem. Umbels lateral and terminal, the general of lirge sprealing numerous striated downy rays, the partial globose, of numerous slender unequal downy rays. General involucre mostly wanting, sometimes there are a few linear segments, partial of numerous unequal linear smooth or somewhat downy spreading segments, as long and frequently longer than the rays. Flowers numerous, crowded, greenish white. Calyx margin of five teeth. Petals nearly equal. Stamens on slender filaments, with ovate anthers. Styles short, spreading. Stigmas obtuse, Disk consex, fleshy. Fruit oblung, ovate, compressed at the back, and the sides with two wings. Carpels with thick elevited keeled ridges, the two lateral ones about twice as broad as the others, dilated into thin membranous wings. Albumen free in the pericarp, covered over with numerous vittce.

Habitat.-Watery places; rare. Near Birmingham, Durham, and on the banks of the Thames, near Dorking.

Biennial; flowering from June to September.

It is probable this is not a native plant, but introduced from the garden, where it is cultivated for the sake of the stalks, which contain a warm aromatic flavour, with a degree of puugency; and when candied with sugar, form a pleasant sweetmeat agreeable to most persons ; it is used as a carminative, and is thought to be little inferior to ginger as a grateful stimulant and stomachic. The root possesses the same properties, but in a stronger degree, and is used for the same purposes as the stem, and also in the preparation of some of the most esteemed liqueurs. It was formerly used as a medicine, and admitted into the pharmacopæias; but in Iceland, Norway, Lapland, and Siberia, it is more esteemed than with us; the natives prepare it as an article of diet, and to flavour other food. The young shoots are either eaten candied or raw, with bread and butter, and at one time it was snpposed to be possessed of anti-pestilential powers, and tended greatly to lengthen the span of life, for which purpose the Laplanders and Norwegians are said to masticate it in the manner of tobacco. 


\section{GENUS LXXI. ANGEL'ICA.-Linn, Angelica.}

Gen. Char. Calya margin obsolete. Petals entire, lanceolate, acuminate, with a straight or incurved point. Fruit compressed at the back, with two wings on each side. Carpels with three dorsal filiform ridges, the two lateral ones dilated into broad membranous wings. Channels with single vilta. Albumen roundish, adhering to the pericarp. General involucre scarcely any, partial of many segments.-Named from its supposed angelic rirtues.

1. A. sylves'tris, Linn. (Fig. 449.) Wild Angelica. Leaves bipinnate; leaflets orate, acutely serrated, terminal one cntire or trifid, the lateral ones nearly sessile.

English Botany, t. 1128.-English Flora, vol. ii. p. 81.-Hooker, British Flora, vol. i. p. 134.-Lindley, Synopsis, p. 117.

Root large, of fleshy spreading branches. Stem erect, round, smooth, polished, sometimes finely downy at the base aud extremity of the branches, a pale glaucous green, or purplish, with wide spreading branches, leafy, generally about three feet high, but sometimes we have measured plants ten feet, and stout in proportion. Leaves alternate, on long striated footstalks, much dilated at the base into a thin striated membranous pouch, embracing the stem, two or three times pinnated, the leaflets ovate, acutely serrated, and somewhat irregularly, the terminal leaf frequently divided into three deep lobes, and the lateral ones almost sessile, somewhat lohed at the base, of a pale glaucous green beneath, quite smooth, except the ribs being slightly hairy, finely reticulated with veins, the upper leaves very small, with very large dilated smooth or downy sheaths to the footstalks. Umbels numerous, terminal and lateral, large, or numerous, somewhat unequal striated downy rays, the partial hemispherical, of numerous short slender rays, unequal. General involucre mostly wanting, partial of numerous slender linear downy spreading segments, about as long or shorter than the rays. Flower's numerous, crowded, white or pinkish. Calyx an obsolete waved border. Petals nearly equal, lanceolate, entire, acuminated at the point, straight, or curved inwards, with a mid-rib. Stamens on long slender filaments, with ovate anthers. Styles long, recurved, with capitate stigmas, the disk convex, fleshy. Fruit rather small, ovate oblong, compressed at the back, smooth, crowned with the elongated styles. Carpels with three elevated filiform ridges at the back, and the two lateral ones dilated into broad membranous wings. Channels with single villa, pericarp separated from the albumen, which is half round.

Habitat.-River sides, drains, and damp shady places; frequent.

Perennial; flowcring in July and August. 
This possesses properties similar to the last, but in a very inferior degree.

T'une 6. Peucedanex.-De Cand. Fruit much compressed at the back, with a smooth, thin, dilated, winged, flat, or conrex margin. Carpels with five primary, filiform, sometimes very fine vidges, the lateral ones contiguous to part of it; secondary ridges wanting. Albumen flattened, or somewhat conrex at the back. Umbels perfect.

\section{GENUS LXXII. PASTINA'CA.-Lix. Parsnip.}

Gen. Char. Calyx margin obsolete, or minutely toothed. Petals roundish, entire, rolled inwards with a broad obtuse inflexed point. Fruit flattened at the back, with a dilated flat margin. Carpels with tive rery slender filiform ridges, the three dorsal ones equi-distant, the lateral ones remote, near to the dilated margin. Channels with single ville. Albumen tlat in front. General and partial involucre of few segments, or wanting.Name from pastus, food.

1. P. sati'ra, Linn. (Fig. 450.) common Wild Parsnip. Leaves piunate; leaflets orate ollong, cut, oltusely serrated, the lateral uncs lobed at the base, the terminal one of three lobes, downy beneath.

English Botany, t. 556.-English Flora, rol. ii. p. 101.-Hooker, British Flora, vol。 i. p. 135.-Lindley, Synopsis, p. 116.

Root taperiug, fleshy, white, sweet and aromatic, with a degree of acrimony. Stem ereet, abunt three feet high, lranclied, leafy, angular. and deeply furrowed, more or less rough, with hairiness. Leaves large, with stout striated downy footstalks, channeled abore, with a broad diluted somewhat sleatling base, lectets numeroun, opposite, ovate oblong, obtuse, variously cut and lohed with an acutely semated or crenated margin, nearly smooth above, beneath pale, with a strong mid-rib, and downy, sometimes the lateral leaflets are three luted, as is always the terminal one. Umbels numerous, termiual and lateral. General of numerous umequal striated rays, numerous, also mnequal. General and partial involucre wanting, or of one or two narrow segments. Calyx margiu obsolete. Petals small, roundish, entire, with a broad small obtuse inflexed point. Stamens on slender filaments, with roundish anthers, of two tumid cells. Styles at first very short, becoming elongated and spreading. Stigmas small, capitate. Disk yellow, flesly, conves. Flowers yellow. Fruit ovate, compressed, with a flat dilater ohtusc margin roumel it. Carpels much compressed 
at the back, with three very slender equi-distant ridges at the back, the two lateral ones remote, close to the dilated margin. Channels shallow, each with a single slender vitla the length of the channel. Albumen thin, much pressed, flat in front, somewhat convex at the back.

Habitat.-Road sides, borders of fields and pastures; not unfrequent. In grarelly or sandy soil in Nottinghamshire, Leicestershire, Lincolnshire, Essex, and the South-east of England; Croshy, near Liverpou? in chalky pastures; not unfrequent in Ireland.

Biennial ; flowering in July.

The Parsnip is a well known garden plant, cultivated for its roots, which are large, white, and fleshy, abounding in farmaceous matter, with mucilage and sugar. They are wholesome and nutritious, but much too sweet to be agreeable to many persons. One variety, the Coquaine, has very large roots, and in some parts of the country is much cultivated for cattle, especially in Jersey and Guernsey, and is said to be one canse of the superiority of the milk, both in richness and flavour; and in the North of Ireland the roots are prepared and used with hops to brew a kind of beer in the place of malt. An excellent and wholesome wine is made from the parsuip root, approaching in flavour to the malmsey of Madeira and the Canaries; it is made with but little trouble or expence. The following are the directions given :-To every four of parsnip roots, cleared and quartered, put one gallon of water; boil them till they are quite tender; drain them through a sieve, but do not bruise them, as no remedy could afterwards clear the liquid; pour the liquor into a tub, and to each gallon add three pounds of loaf sugar, and half an ounce of crude tartar; when cooled to the temperature of 75 degrees, put in a little yeast; let it stand four days in a warm room, then tun it. The mixture should, if possible, be fermented in a temperature of 60 degrees. September and March are the proper months for making the wine. When the fermentation has suhsided, bung down the cask and let the wine stand at least twelve months before bottling. The boiled roots, especially of the wild plants, are esteemed for their diuretic and mucilaginous properties in calcarious affections of the bladder.

\section{GENUS LXXIII. HERA'CLEUM.-LINN. Cow Parsnip.}

Gev. C'siar. C'alyz margin of fire tecth. Pelals obovate, emarginate, with an inflexed point, the outer ones often radiant, bifid. Fruit flattened at the back with a broad plane margin. Carpels with very slender ridges, the three dorsal oncs equi-distant, the two Iateral ones remote, contiguous to the dilated margin. Channels 
with single clavate vitte. Albumen flattencd. Gencral involueve falling away, partial of numerous segments.- Named from Hercules, who is said to have brought this or some other allied plant into use, and was sacred to him.

1. H. Sphondy'lium, Linn. (Fig. 451.) common Cow Parsnip, or Hog Weel. Leaves rough, hairy, pimnate, or deeply pinnatifid ; leaflets lobed, cut, sinuated, the terminal one somewhat palmated; fruit orate, obtuse, notched, at length smooth.

English Botany, t. 939.-English Flora, rol. ji. p. 102.-Hooker, British Flora, vol. i. p. 135.--Lindley, Synopsis, p. 1 i6.

$\beta$. angustifolium. Leares more deeply cut, with narrow lobes.H. angustifolium. Sm. Flora. Brit. p. 307. Jacquinii Austr. vol. ij. t. 173 .

Root tapering, whitish, and somewhat sweet. Stem erect, about four feet high, branched, leafy, angular, deeply furrowed aud rough, with white spreading hairs. Leaves large, with stiated footstalks, very much dilated into a thin membranous striated saccate sheath, more or Iess hairy, with three leaflets, or pinnated, rough, with hairs, pale on the under side, lobed, deeply cut or sinwated, irregularly serrated, the terminal leaflet three lobed, or sometimes cut in a palmate manuer; occasionally the leaflets are all deeply cut into narrow lobes, as in the variety $\beta$. Umbels terminal and lateral, large, the general one of numerous striated irregular downy rays, the partial slender, numerous, unequal, the outer ones bearing radiant fertile flowers. Inxolucre various, the general of a few lanceolate membranous finely fringed segments, soon falling away, or wanting, the partial similar, more numerous. Flowers numerous, the outer oncs larger than the others, radiant, white or pink. Calyx of five small teeth. Pelals inversely heart-shaped, with an inflexed point, the petals of the outer flowers much larger than the others, and deeply divided. Stamens on long slender filaments, with orate anthers. Styles short, with a conate disk. Fruit ovate, very thin, compressed at the back, obtuse at the extremity, and notched with a broad plane margin, at first somewhat downy, becoming smooth. Carpels with very slender filiform ridges, the three at the back equi-distant, the two lateral ones near the dilated margin. Chamels rery shallow, with conspicuous club-shaped vitla, about half the length from the top. Albumen very thiv, much compressed.

Habitat.-Hedges, road sides, pastures, and hushy places; frequent. Biennial; flowering in July.

A coarse rank plant, wholesome and nutritire for cattle, and is eaten by most of them; hogs are said to be particularly fond of it, hence its name of Hog-weed. The dried hollow stems are gatlered in many parts of the country, tied up in small bundles of a conrenient length, dried and used for spells, \&c, ; and on the Continent they are made into matches, with brimstone. 


\section{GENUS LXXIY. TORDY'LIUM.-LINN, Hart-wort.}

Gen. Char. Calyx margin of five teeth. Petals ohovate, emarginate, with an inflexed point, the outer ones radiant, bifid. Fruit flattened at the back, surrounded by a thickened of ten urenated accessory margin. Carpels with five very slender ridges, the dorsal ones equi-distant, the lateral ones remote, contiguous to the thickened margin, or sometimes covered over by it. Channels with one to three vitte. Albumen flattened. General and partial involucre of numerous segments.--Name, according to Linnaus, derived from rogvos, a turning lathe; and $\varepsilon \lambda \lambda \omega$, to turn; from the

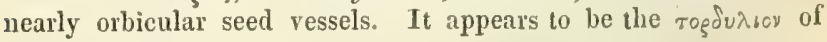
the Greeks.

1. T. max'imum, Linn. Fig. 452.) Great Hart-2vort. Stem rough, with reversed hairs; leaves pinnate; leaflets obtusely crenated, the lower ones ovate, the upper lanceolate; involucre shorter than the umbel; fruit with a rough bairy disk, and scarcely notched hairy border.

English Botany, t. 1173.-English Flora, vol. ii. p. 105.-Hooker, British Flora, vol. i. p. 136.-Lindley, Synopsis, p. 115.

Root tapering. Stem erect, from three to four feet high, angular, furrowed, clothed with rigid hairs pointed downwards, hollow, branched and leafy, its branches slender, bearing uumerous umbcls, terminal and lateral. Leaves pinnate, clother with close pressed hairs, directed towards the point of the leaf, footstalks longish, channeled above, the base dilated intoa membranous striated sheath, leaflets of the lower leaves ovate, cut and obtusely serrated or crenated, those of the upper narrow lanceolate, less deeply cut and more regularly serrated, the lower pair of leaflets reflexed, the upper spreading. Umbels mostly numerous, of a few hairy striated more or less unequal rays, the partial of numerous short ones. General involucre of numerous narrow linear hairy segments, shorter than the rays, the partial about as long as the umbellules, sometimes longer. Calyx margin of five linear teeth, the two outer ones longer than the others. Petals obovate and notched, or .obcordate, with a small inflexed point, the outer flowers radiant, with one or two outer petals larger than the others, and deeply bifid. Flowers white, or more or less deeply tinged, of a rose colour, small. Stamens on short slender filaments, with small roundish anthers. Styles short, with a small conical disk. Fruit nearly orbicular, very neat, flattened, surroumded with a thickened accessory pale border, searcely notehed, more or less clothed with hairs, as well as the disk. Carpels with five very slender filiform equi-distant ridges at the back, the two lateral ones distant from the others, close to the margin. 
Channels rery shallow, with from one to three slender ville. Albumen very flat.

Habitat.-Banks and waste ground; rare. About London, Oxford, and Eton.

Annual; flowering in June and July.

This is a larger and taller plant than the following, with more numenus and more lanccolate leaflets. Scarcely a native plant, though common on the Continent, especially in Italy.

2. T. officinale, Linn. (Fig. 453.) Small Hart-wort. Stem clothed with soft reversed hairs; leaves pinnate; leaflets crenated, cut, ovate; involucre as long as the umbel; fruit with a smooth crenated border and hairy disk, the two outer petals of the flowers of the ray cach with one very large lobe.

English Botany, t. 2440.-English Flora, vol. ii. p. 104.-Hooker, British Flora, rol. i. p. 135.-Condylocarpus, Hoff.-Lindley, Synopsis, p. 115.

Root small, tapering. Stem erect, branched, and spreading, from ten to eighteen inches high, round, furrowed, clothed with soft deflexed hairs, leafy. Leares roughish, hairy, simply pinnate, leaflets few, ovate, roundish, variously lobed and notched, and irregularly crenated or obtusely scrrated, the terminal one largest, footstalks channeled above, the base dilated into a thin striated membrane. Umbels lateral and terminal, the general of numerous unequal rays, the partial of numerous short ones. Flowers numerous, unequal, white, those of the disk small, and nearly equal, but those of the circumference very unequal, the two outer petals very much larger than the others, each with one very large obovate lobe, and one very small one. Involucre both general and partial of numerous narrow linear segments, as long as the umibels, and downy. Calyx of five small teeth. Petals, except the two outer ones of the flowers of the circumference, small, iuversely lieart-shaped, with a small inflexed point. Stamens on slender filaments, with small orate anthers. Styles slender, with obtuse stigmas, and the disk convex. Fruit very beautiful, orbicular, with a thick pale deeply notched or crenated smooth border around the hairy disk. Curpels very much flattened, with five very slender filifurm ridges, three at the back an equal distance from each other, the two lateral ones more distant, near the thickened margin. Channels very shallow, with three vitte, each of which is separated by a furrow. Albumen flat.

Habitat.-Cultivated fields, near London.

Annual ; llowering in June and July.

This species, which is made a separate genus of by Hoffmann, on account of the three vilta in each chamel heing separated by a furrow, is a very doubtful native. It was formerly called Seseli creticum, and 
was esteemed for its supposed medical virtues. The seeds are said to possess diuretic properties, but it is not now used as a medicine.

\section{GENUS LXXV. PEUCE'DANUM.-Linn. Hog's Fennel.}

Gen. Cinar. Calyx margin of five teeth, sometimes obsolete. Petals obovate, emarginate, or entire, with an inflexed point. Fruit flattened at the back with a broad thin margin. Carpels with five nearly equi-distant ridges, the three dorsal ones filiform, the lateral ones more obsolete, near to, or confounded with, the dilated margin. Channels with one to three vitta. Albumen flat in front. Pericarp double. General involucre various, partial of numerous segments. -Name from $\pi$ Evxn, a Pine tree; and davos dwarf; on account of the narrow leaves of some of the species resembling a Pine tree, or from some species giving a resinous extract.

1. P. officinale, Linn. (Fig. 454.) Hog's Fennel, or Sea Sulphur Weed. Stem round, striated; leaves five times tri-partite; leaflets linear, flaccid, tapering at the extremities; inrolucre of few linear deciduous segments; pedicles two or three times longer than the fruit.

English Botany, t. 1767.-English Flora, rol. ii. p. 99.-Hooker, British Flora, vol. i. p. 134.-Lindley, Synopsis, p. $11 \%$.

Root tapering, large, stout, fleshy, containing a resinous juice of a sulphureous smell. Stem crect, round, smooth, numerously striated, slender, smooth, branched and leafy. Leaves on round striated footstalks, large, divided, five times tri-partite, leaflets simple, linear, flat, about an inch and balf long, tapering at each end, three ribbed, the terminal leaflet of three segments. Umbels terminal and lateral, large, of numerous long slender unequal striated rays, the partial of numerous very slender nearly equal rays, both general and partial involucre of numerous narrow linear segments, soon falling away, sometimes one or two remaining. Flowers numerous, yellow. Calyx of five small acute teeth. Petals inversely heart-shaped, nearly entire, with a small inflexed point. Stamens on lung slender filaments, with small roundish anthers. Styles short, elongating, and reflexed, the stigmas small, notched. Disk somewhat convex. Fruit ovate, flattened at the back, with a narrow flat dilated margin. Carpels with slender filiform nearly equal ridges, the two near the dilated margin scarcely distinguished. Channels with from one to three vittce. Albumen flat in front, convex at the back.

IIabitat.- Salt marshes and meadows; very rare. In Kent, Sussex, and Essex.

Perennial; flowering from July to September. 



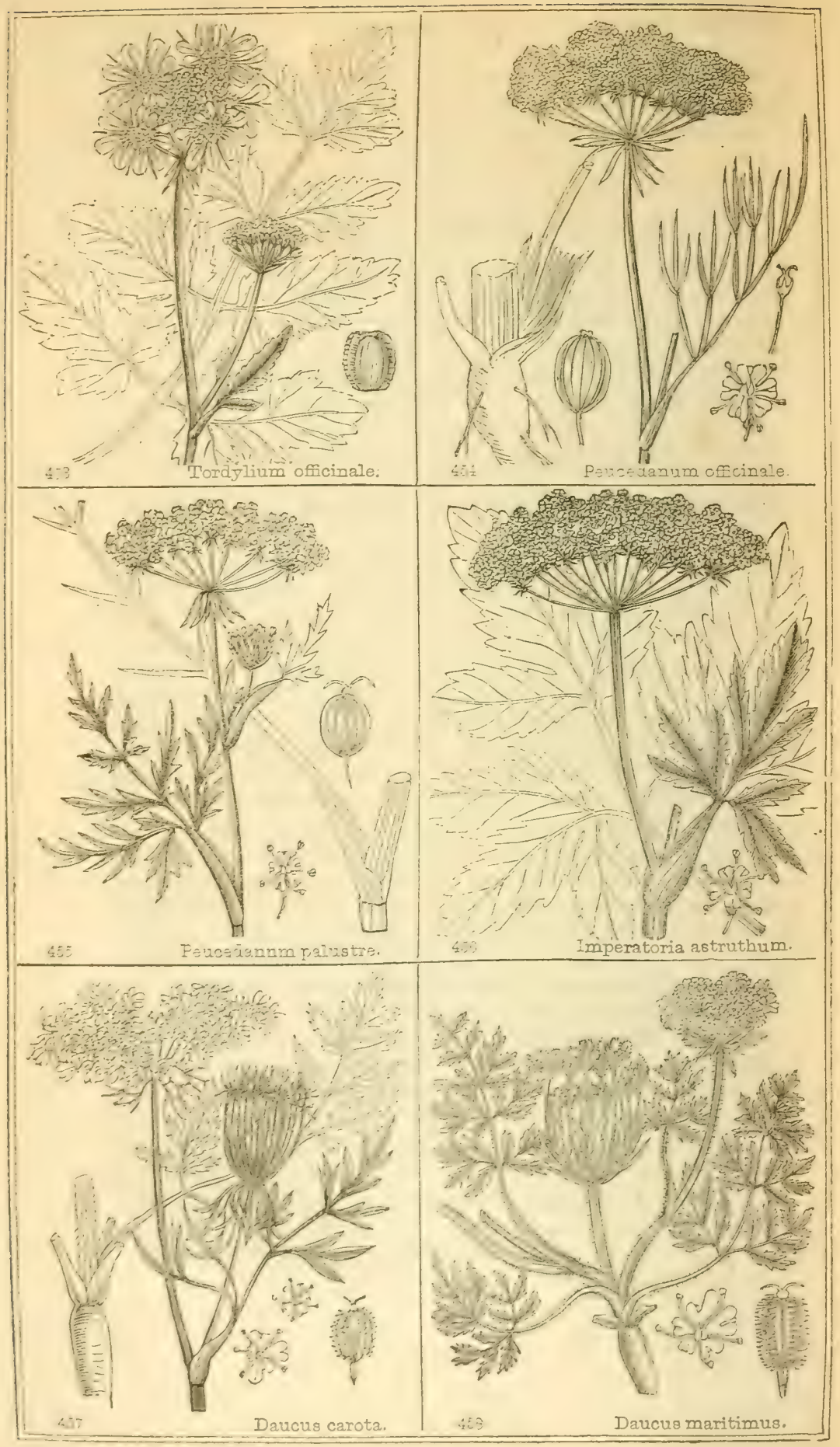


The whole plant, when bruised, has a strong disagreeable sulphurenus smell, and an acrid, unctuous, bitterish taste. The root, when wounded, especially during the Spring and Autumn months, yields a considerable quantity of yellow juice, which soon dries into a solid gum or resinous mass, which retains the taste and smell of the fresh plant. It was formerly used as a medicine in nervous affections, and esteemed useful in hypochondriasis; but the plants grown with us do not yield any quantity of the resinous matter, the juice nearly all evaporating away: this perhaps is owing either to the soil or climate. It grows much more luxuriantly, and is stronger in warmer climates than with us; but its use as a medicine is now abandoned.

2. P. palus'tre, Manch. (Fig. 455.) Marsh Hog's Fennel, or Milk Parsley. Stem furrowed; leaves ternate; leaflets pinnatifid, with linear lanceolate segments, tipped with a hard point; incolucres of numerous lanceolate segments; rays of the umbels rough.

Hooker, British Flora, vol. i. p. 134.-Lindley, Synopsis, p. 116.Selinum palustre, Linn.-English Botany, t. 229.-English Flora, vol. ii. p. 97 .

Root tapering, with numerous long fibres. Stem erect, roundish, deeply furrowed, smooth, about five feet high, simple or branched above, green or purplish at the lower part. Leares distant, the upper ones small, the lower on long furrowed or striated footstalks, with a thin membranous dilated somewhat sheathing base, ternate, with opposite leaflets much divided, the segments linear lanceolate, smooth, veiny, somewhat paler beneath, tipped with a hard sharp point. Umbels terminal and lateral, the general of numerous long unequal striated rays, rough, with short rigid hairs, as well as the partial short slender ones. Involucre both general and partial of numerous lanceolate taper pointed segments, veiny and rough, with hairs. Flowers white, equal, numerous. Calyx of fire small obtuse teeth. Petals ovate, notched, with an inflexed point. Stamens on long slender filaments, with small ovate anthers. Styles short, elongating after flowering. Stigmas small, obtuse. Disk conrex. Fruit elliptical, flattened at the back with a broad dilated, smooth, even, entire border. Carpels with fire equi-distant slender ridges, three at the back, the two lateral ones close to the margin scarcely distinguishable. Channels with three vitte, not so superficial as those of the last species. Albumen flattened.

Habitat.-Marsh and damp boggy situations, by the side of rivers but not common. Yorkshire, Lancashire, about Norwich and the Isle of Ely, Ardincaple, on the Clyde in Scotland.-Mr. Hopkirk.

Biennial; flowering in July.

The whole plant abounds with a white, thick, fetid juice, hitter; which, upon drying, leaves a brownish gum-resin, possessing the same qualities as the last. It is said the roots are used in Russia in the place of ginger. 


\section{GENTLS LXXTI. IMPE'RATORIA,-LINN. Master-wort.}

Gen. Char. C'alyx margin obsolete, (the rest as in Peucedanum).-

Name from impero, to overcome; so named because its leaves extend over smaller plants and smother them.

1. I. Ostruth'ium, Linn. (Fig. 456.) Great Masterwort. Leares bi-ternate; leaflets hroadly orate, cut and serrated, unequal at the base; sheath of the footstalks very large; general involucre wanting.

English Botany, t. 1380.-English Flora, rol. ii.p. 78.-Peucedanum Ostruthium, Koch.-Hooker, British Flora, vol. i. p. 135.-Lindley, Synopsis, p. 116.

Root tuberous, with long spreading fibres, fleshy, acrid and aromatic. Stem erect, from one to two feet high, round, smooth, finely striated, leafy, scarcely brauched above. Leares on long footstalks, with large dilated striated membranous sheaths, mostly purple on the margin, ternate, with large broadly ovate lanceolate leaflets, unequal at the base, the lower edge shortest, irregularly cut and serrated, the lateral ones witb a large lobe on the lower side, sometimes of three lobes, as is always the terminal leaflet, somewhat paler beneath, with prominent ribs and vetted slender veins, the upper leares much smaller than the lower. Umbets terminal, and sometimes lateral, large, the general of numerous long unequal striated rays, and the partial of numerous unequal slender ones. General involucre wanting, partial of a few linear segments. Flowcrs numerous, white, crowded, nearly equal. Calyx an obsolete margin. Petals inversely heart-shaped, with a sinall inflexed point. Stamens on long slender filaments, with small roundish ovate anthers. Styles short, spreading, with obtuse stigmas. Disk sellow, fleshy, somewhat conical. Fruit oblong, flat, with a broad dilated flat margin, notched at the base and apex. Carpels with five slender filiform equi-distant vidges, three at the back, the two lateral ones scarcely distinguishable, close to the margin. Albumen flat.

Habitat.-Moist pastures in rarious parts of Scotland, but a doubtful native.

Perennial; flowering in June.

This plant was formerly considered an infallible remedy for almost all wounds and disorders of the body, hence some say it derived the common name of Master-wort. Its root is acrid, bitter, with an aromatic favour, and is recommended as a masticatory to relieve toothache; but althongh so much extolled formerly as to obtain for it the distinguished appellation of dirinum remedium, it is now almost out of use, being superseded by other more powerful medicines. 
Tribe \%. Dauciner.-Koch. Fruit compressed at the back, or roundish, on a transverse section. Channels with five primary filiform bristly ridges, the lateral ones being placed on the commissure, and with four secondary ridges, bristly, and more prominent than the others, the bristles free, or united with a kind of wing. Albumen flattish in front, or roundish.

\section{GENUS LXXVII. DAU'CUS.-Lrns. Carrot.}

Gien. Char. Calyx of five tecth. Petals ubcordate, with an inflexel point, the outer ones radiant, bifid. Fruit compressed at the back. Carpels with tive primary filiform bristly ridges, three at the back, the two lateral ones on the plane of the commissure, the four secondary ones more prominent than the rest, and with a single row of prickles. Channels under the secondary ridges, with single vitte. Albumen flat in front. General and partial involucre of numerous segments, the former often wanting.-Name from Suvхos, daucus.

1. D. Caro'ta, Linn. (Fig. 457.) Wild Carrot. Bristles of the fruit slender; leaves two or three pinuate; leafiets pinnatifid, with linear lanceolate acute segments; involucre of pinnatifid segments; umbels with a solitary abortive coloured flower, in the centre, when in seed, concave.

English Botany, t. 1174.-English Flora, rol. ii. p. 39.-Hooker, British Flora, rol. i. p. 136.-Lindley, Synopsis, p. 113.

Root tapering, slender, yellowish, sweetish, with a pleasant aromatic smell. Stem erect, from one to three fect high, roundish, coarsely striated, and more or less rough, with deflexed hairs or bristles. Leates small above, larger below, footstalks striated, with a dilated sheathiug base, two or three tines pinnate, with sarrow lanceolate more or less linear acute segments, with a bristly point, smooth, or clothed more or less with white soft or rigid hairs, especially on the under side. Umbcts terminat ant lateral, the general of numerous unequal striated downy or smouth roys, spreading when in fluwer, concave when in seed, from the lunger outer rays bending orer and cuclosing the shorter inner ones, and in the centre of the umbel is a short ray, with two or three ahortive mostly coloured flowers, the partial of numerous short slender unequal ones. General involucre of numerous spreading pinnated segmeuts, smooth, or somewhat rough, partial numerous, narrow, lanceolate, with a pale thin membranous margin. Floucrs white or pinkish. Calyx of five small acutc tecth. Petals nearly equal, except 
the outer ones of the radiant flowers being bifid, the rest inversely heart-shaped, with a small inflexed point. Stamens with long slender filaments, with ovate anthers. Styles spreading, with small obtuse stigmas. Fruit oblong ovate, compressed at the back. Carpels clothed with rigid bristles, which have a small hook at the extremity, the vitta beneath the secondary ridges yellowish, abounding in an aromatic oil. Albumen flat in front, somewhat conrex at the back.

Habitut.-Pastures and road sides, especially in a gravelly soil; frequent.

Biennial; flowering in June and July.

An extremely variable plant with regard to its hairiness and the size, and the more or less divided lanceolate segments of the leaves. We have specimens quite smooth, with broadly linear segments to the leaves, having quite a different appearance to the common state of the plant, but it is not otherwise different, and was found in a damp situation, which is probably the cause, as we find the contrary to be the case with plants grown in a dry sandy soil; they are then more rigid in their foliage, and profusely clothed with hairs, and between these two extremes all varieties may be met with.

The root is well known when cultivated, and by cultivation attains to a very large size. It is used for a variety of domestic purposes, is nutritive and wholesome, and is found to be profitably grown as food for cattle in a deep rich soil. The whole plant, especially the seeds, are diuretic, and are considered useful in gravelly and calculous affections.

2. D. marit'imus, With. (Fig. 458.) Sea side Carrot. Bristles of the fruit flattened; leaves tri-pinnate; leaflets pinnatifid, with short lanceulate acute segments, fleshy; umbels without abortive flowers in the centre, convex when in seed.

English Botany, t. 2560.-English Flora, vol. ii. p. 40.-Hooker, British Flora, vol. i. p. 136.-Lindley, Synopsis, p. 113.

Root slender, tapering, whitish. Stem erect or spreading, branched from the base, roundish, coarsely striated, thickly clothed with white hairs pointed downwards, from ten to eighteen inches high, leafy. Leaves on rough channeled footstalks, dilated and striated at the base, two or three times pinnated, with short broad acute or rounded segments, somewhat fleshy, and more or less profusely scattered over with hairs on the under side, somewhat shining. Umbels terminal, and on short lateral pedicles, the general of stout striated unequal spreading rays, without any abortive flowers in the centre, the partial of numerous short unequal ones. General involucre of numerous roughish pinnated segments, spreading, closing round the umbel when in seed, partial of numerous linear or pinnated roughish segments, also closing round the umbellules when in sect. Flowers white, or pale rose 
culour, regular, except the outer petals of the radiating flowers. Calyx of five small acute teeth. Petals inversely heart-shaped, with an inflexed point. Stamens on long slender filaments, with pink ovate anthers. Styles elongating after flowering, with small obtuse stigmas and conical disk. Fruit larger than the last species, oblong, compressed at the back, clothed with bristles, thin, dilated, membranous, and pale at the base, with a long point, obtuse, with several small sharp reflexed teeth, the vitte beneath the secondary ridges rather large. Albumen flat in front, somewhat convex at the back.

Habilat.-Sea Coast in Kent and Cornwall, Anglesea.-Mr. W. Wilson. Island of Lismore, Scotland.-Rev. C. Smith. Near Baldoyle and Portmarnock, Ireland.-Mr. Mackay.

Biennial; flowering in July and August.

The habit of this plant is quite different to the last, growing near the sea. It is branched from the base, spreading, with mostly an umbel on a short pedicle from near the base. Its different shaped leaflets, and especially the fruit, will readily distinguish it from the last species.

We have frequently found specimens of it on the north coast of Portugal, which were not different from those grown on our own coast.

Sub.order 2. Campylosperme. Albumen with the margins inflexed, or entire rolled inwards, or with a wide deep furrow in front.

Tribe 8. Caucalines.-Koch. Fruit contracted on the sides, or nearly round. Carpels with five primary ridges, filiform, bristly or prickly, three on the back, the two lateral ones placed on the plane of the commissure, the four secondary ridges more prominent than the others, prickly, or altogether obliterated by the abundance of the prickles, which fill up the channels. Albumen involute, or with the margins rolled inwards.

\section{GENUS LXXVIII. CAU'CALIS.-Linn. Bur Parsley.}

Gen. Char. Calyx of five teeth. Pelals obcordate, with an inflexed point, the outer ones radiant and deeply bifid. Fruit slightly compressed on the sides. Carpels with fire primary filiform bristly or prickly ridges, three at the back, the two lateral ones on the plane of the commissure, the four secondary ridges more prominent, with one or two rows of prickles. Channels under the secondary ridges with single vittc. Albumen deeply channeled in 
front. General and partial involucre various.-Name from $\delta x u x \times \lambda b s$, the daucus; from possessing similar properties to the carrot.

1. C. daucoi'des, Linn. (Fig. 459.) Small Buv Parsley. Leaves bi-pinnatifid or tri-pinnatifid; segments linear, acute, short; umbels of few rays; general involucre nowe; partial umbels of few flowers, with an involucre of three segments; prickles of the fruit hooked at the apex.

English Botany, t. 197.-English Flora, rol. ii. p. 41.-Hooker British Flora, vol. i. p. 137:--Lindley, Synopsis, p. 114.

Root tapering, fibrous, whitish, somewhat woody. Stem much branched from the base, bushy, roundish or angular, deeply striated or furrowed, smooth or hairy, especially at the joints, leafy. Leaves on channeled footstalks, with a dilated membranous edged base, smooth, or slightly hairy, two or three times pinnated, with numerous shert narrow linear acute segments. Umbels terminal, the general of three or four stout angular striated rays, somewhat downy, the partial of about the same number of short ones. General involucre none, or of two or three small narrow linear segments, the partial of three or four lanceolate ones. Flower's white or pinkish, seldom all perfect. Calyx of fire lanceolate short tecth. Petals inversely heart-shaped, with a small inflexed point, the outer ones somewhat larger than the others, and bifid. Stamens on short filaments, with small ovate anthers. Styles short, stout, with obtuse stigmaz and a conical disk at the base. Fruit large, ovate oblong, its prickles dilated at the base, tapering upwarls with a small hooked extremity, vitta under the secondary ridges rather large, simple. Channels obliterated by the prickles. Albumen conrex at the back, deeply channeled in front.

Habitat.-Corn fields, in a chalky or clay soil. In Norfolk, Oxfordshire, Cambridgeshire, Nottinghamshire, Lincolnshire, and Yorkshire; but not very frequent. Not known in Scotland or Ireland.

Annual ; flowering in June.

2. C. latifolia, Linn. (Fig. 460.) Great Bur Parsley. Hispid, leaves pinnate; leaflets decurrent, cut and serrated; umbels of two or three rays; inrolucres with ovate membranous segments.

English Botany, t. 198.-English Flora, rol. ii. p. 41.-Hooler, British Flora, vol. i. p. 136.-Lindley, Synopsis, p. 114.-Turgenit latifolia, Hoffm.

Root tapering. Stem about three feet high, roundish, striated, or furrowed, branched, and somewhat spreading, rough, with minute rigid prickles pointed upwards. Learcs from three to sir inches long, simply pinvate, with channeled footstalks, dilated at the base into a sheath, with palc membrunous edges, leaflets pinnatifid, or cut or deeply serrated, lanceolate, a somewhat glaucous grcen, as is the whole plant, reiny bencath, the upper ones decurrent at the base in the lower 
margin. Umbels lateral and terminal, the general of three or four long, stout, rough, furrowed rays, the parlial of numerous short unequal ones, the central ones mostly with abortive flowers. Flowers rose colour, the central ones nearly regular, the outer ones radiant, with one or two petals, larger than the rest, and bifid. Petals inversely heartshaperl, with a small inflexed bifid point. Stamens with short filaments and small ovate anthers. Styles short, stout, with small obtuse stigmas. Calyx broadly lanceolate acute segments. Fruit oblong, laterally contracted, almost divided. Carpels with two ridges placed upon the margin of the commissure, the remaining seren with two or three rows of equal prickles. Channels obliterated, vilta beneath the secondary rilges simple, rough. Albumen convex at the back, deeply channeled in front.

Habitat.-Fields in a chalky soil, rare; frequent in Cambridgeshire. Annual; flowering in July.

This, the most beautiful of the tribe, is made a separate genus by Hoffmann, on account of its laterally contracted nearly double fruit, two of the ridges being placed on the margin of the commissure, and the others having two or three rows of prickles; in other respects it is not different, either in character or habit, and these we do not think of sufficient constancy to constitute it a distinct genus.

\section{GENUS LXXIX. TORILUS.-ADauson. Hedige Parsley.}

Gen. Char. Calyx of five tecth. Petals obcordate, with an inflexed point, the outer ones radiant, and deeply bifid. Fruit with the sides compressed. Carpels with five primary ridlyes, bristly, three at the back, the two lateral ones on the plane of the commissure, the secondary ridges obliterated by the numerous prickles which occupy the whole of the channcls, under which are the single vittc. Albumen deeply channeled in front. General and partial involucre of numerous segments. - Name of doubtful derivation.

1. T. Anthris'cus, Gcrtn. (Fig. 461.) upright Hedlye Parsley. Stem erect, hranched; leaves bi-pinnate; leaflets lanceolate, cut and serrated; umbels terminal; inrolucre of several awl-shaped segments; fruit with simple hooked incurved prickles.

English Botany, t. 987. - English Flora, rol. ii. p. 43.-Hooker, British Flora, vol. i. p. 137.-Lindley, Synopsis, p. 114.

Root small, tapering, branched. Stem erect, from one to three fect high, much branched from the base, roundish, furrowed or striated, rough, with reflexed rigid hairs, leafy, hard and wiry. Leaves alternate, bi-pimate, on rather long slender footstalks, with a thin dilated scarcely sheathing base, rough and channcled above, leaflets lanceo. 
late, cut and sharply serrated, hairy, veiny, and somewhat paler beneath, occasionally almost smooth. Umbels terminal and lateral, on long slender peduncles, the general of about eight almost equal slender striated rays, the partial of about the same number of short ones. General involucre of from four to six awl-shaped segments, the partial smaller. Flowers white or pinkish. Calyx teeth small. Pelals inversely heart-shaped, with an inflexed point, the outer ones radiant, larger than the others, and bifid. Stamens on short awl-shaped filaments, with small roundish anthers. Fruit small, obovate, cluthed with incurved bristles, with a small point at the apex, and crowned by the elongated recurved styles, and somewhat conical base of the disk. Albumen deeply channeled in front, roundish at the back.

Habitat.-Hedges and waste places; not uncommon.

Annual; flowering in July.

2. T. infes'ta, Spreng. (Fig. 462.) Spreading Hedge Parsley. Stem with spreading branches; leaves bi-pinnate; leaflets ovate-lanceolate, pinnated, serrated, the terminal leaflet often elongated; general inrolucre of one segment, or wanting; the partial of several awl-shaped ones; prickles of the fruit with several hooks at the back.

English Botany, t. 13I4.-English Flora, vol. ii. p. 43.-Hooker, British Flora, vol. i. p. 137.-Lindley, Synopsis, p. 114.-Scandex infesta, Linn.-Caucalis infesta, Hudson.-Torilis Helvetica, Gmel.

Root small, tapering, branched. Stem from six to eighteen inches high, branched from the base, spreading, roundish, furrowed or striated, rough, with short reflexed rigid hairs, leafy. Leaves alternate, bipinnate, on shortish channeled footstalks, dilated at the base, and somewhat sheathing, roughish, leaflets ovate-lanceolate, deeply cut in a pinnate manner, serrated, the terminal leaflet of the upper leaves especially elongated into lanceolate rough, especially on the under side, and veiny. Umbels terminal and lateral, on slender long peduncles, the general of about six rough equal rays, the partial of numerous short ones. General involucre of one awl-shaped segment, or frequently wanting, the partial of numerous uarrow rough ones. Flouers whitish or pink. Calyx of five small white hoary teeth. Petals inversely heart-shaped, with an inflexed point, the outer ones of the radiant flower larger than the others, and bifid. Stamens on slender filaments, with ovate notched anthers, of a yellowish or purple colour. Style ahout as long again as the convex fleshy disk. Stigmas small, obtuse. Fruit ovate, crowded with roughish prickles, having at the apex several reflexed small hooks, and three rows at the back of each carpel, with small slender close presseil ones pointed upwards. Albumen rounded at the back, deeply channeled in front, or with the sides rolled inwards.

Habitat.-Fields and road sides; common.

Annual; flowering in June and July. 


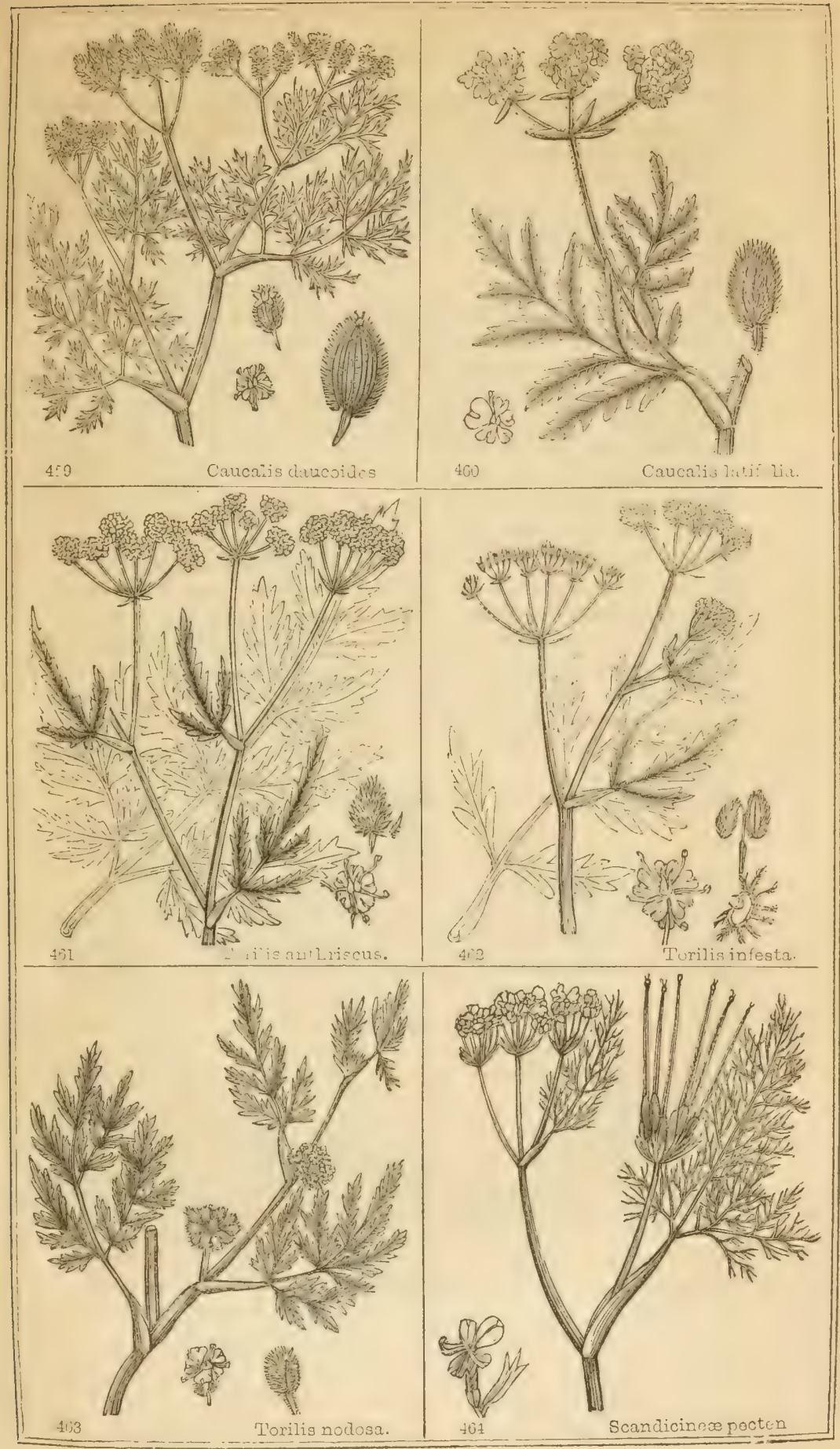



3. T. nodo'sa, Giirtn. (Fig. 463.) Knotted Hedge Parsley. Stem prostrate; branches spreading; leaves bi-pinnate; leaflets pinnatifid and cut; umbels opposite, sessile, globose; fruit on the outer side with prickles, on the inner, rough, with granules.

English Flora, vol. ii. p. 44.-Hooker, British Flora, vol. i. p. 137.Lindley, Synopsis, p. 114.-Caucalis nodosa.-English Botany, t. 199. -Tordylium nodosum, Linn.

Root slender, branched. Stem prostrate, with spreading leafy branches, about a foot lung, round, striated, rough, with reflexed bristles, sometimes almost smooth. Leares bi-pinnate, on striated footstalks, channeled above, rough, with bristles, leaflets ovate-lanceolate opposite, pinnatifid, with simple lanceolate, linear, acute, short or cut segments, rough, with bristles, especially on the under side, the terminal leaflet mostly elongated. Umbels small opposite the base of a leaf, crowded into a globose form, sessile, or on a very short pedicle, with about three short rays. General involucre mostly wanting, or of one segment, the partial of several awl-shaped bristly ones. Flouer's very small, white, or pinkish. Calyx small. Petals very small, nearly regular, inversely heart-shaped, with a small inflexed point, the outer ones rather larger. Stamens on short filaments, with small roundish ovate pinkish or white anthers. Styles very short, with a flattish disk. Fruit ovate, those on the outer side of the umbels clothed with rough prickles, with several small reflexed teeth at the apex, but those carpels on the inner side and the centre of the umbels rough, with hoary granulations, without prickles. Albumen rounded at the back, chanueled in front.

Habitat.-Road sides and waste places; frequent, especially in a dry gravelly or chalky soil.

Annual; flowering in May and June.

The plants of this genus are in many parts of the country troublesome weeds; the seeds are conveyed about by birds, animals, \&c., sticking to them by their small hooked prickles, which are very curiously constructed, and very beautiful objects beneath the microscope.

Tribe 8. Scandicinex.-Koch. Fruit with the sides compressed or contracted, often beaked. Carpels with five primary equal filiform sometimes winged ridges, the lateral ones forming the margins. Secondary ridges none, and sometimes the whole are obliterate, except in the beak. Albumen convex at the back, deeply channeled in front, or the margins rolled inwards. 
GENUS LXXX. SCAN'DIX.-LIN. Shepherd's Needle.

Gen. Char. Calyx an obsolete margin. Petals obovate, with an inflexed point. Fruit with the sides compressed, and with a very long beak. Carpels with five obtuse equal ridges, the lateral ones forming the margin. Channels without or with scarcely any vittc. Albumen roundish, with a deep furrow in front. General involucre wanting, or of few segments, partial of from five to seven.-Name from $\sigma x \varepsilon \omega$, to prick, from the shape of the seeds.

1. S. Pec'ten, Linn. (Fig. 464.) Needle Chervil, Venus' Comb, or Shepherd's Needle. Involucre with the segments two or three times cut, or entire; fruit compressed at the back, rough, with a bristly edged beak; leaves cut into numerous short linear segments.

English Botany, t. 1397. - English Flora, rol. ii. p. 46.-Hooker, British Flora, vol, i. p. 137.-Lindley, Synopsis, p. 125.

Root tapering, somewhat woody. Stems mostly numerous, sometimes simple, branched, leafy, spreading, about a foot high, roundish, furrowed, smooth, or scattered over with spreading hairs. Leaves on slender footstalks, dilated and sheathing at the base, with a pale membranous mostly fringed margin, tri-pinnate, smooth, pale green, with short linear acute numerous segments. Umbels terminal and lateral, numerous, mostly in pairs, the general of seldom more than two rays. General involucre none, partial of numerous segments, simple, or more or less numerously cut in a pinnate manner, roughish on the margins. Flowers white, not very numerous, on short footstalks. Calyx an ubsolete margin. Petals unequal, the outer ones larger than the others, obovate, with a mid-rib, notched at the extremity with a small inflexed point. Stamens with awl-shaped filaments and small dark anthers. Styles straight, with small obtuse stigmas. Disk concave, dark coloured. Fruit ovate oblong, with a very long stout beak, as broad at the base as the fruit, tapering upwards to a point, smooth, somewhat striated, with a pale margin, rough, with sharp rigid bristles on the margin pointed upwards, and crowned by the straight styles, ridges of the fruit pale, obtuse, rough, with minute sharp points. Channels shallow, withont or with a simple lark coloured vitta, running the whole length of the channels. $A l$ bumen roundish at the back, deeply furrowed in front.

Habitat.-Corn fields abundant.

Annual; flowering in June and July.

This plant does not appear to he applicd to any particular purpose; in some parts of the country it is so abundant as to be a troublesome weed; it is very variable in size and appearance: we have perfect full grown plants in seed not more than an inch and half high, and others 
sixten. The fruit is very remarkable with its long rough edged beak, with the spines pointed upwards, which seems to be a provision to allow the seed to pass with ease only in one direction, for the spines offer considerable resistance to its passing, but in a downward direction. This may be to secure the germination of the seed, for otherwise the long beak would appear greatly to prevent its passage into the soil.

GENUS LXXXI. ANTHRIS'CUS.-PERs. Beaked Pursley.

Gen. Char. Calyx an obsolete margin. Petals obcordate, with an inflexed often very short point. Fruit contracted at the sides, beaked. Carpels nearly round, without ridges, except five on the beak. Albumen nearly round, deeply furrowed in front. General involuere none, partial of numerous segments.-Name of doubtful origin.

\section{* Carpels smooth.}

1. A. sylves'tris, Hoffm. (Fig. 465.) Wild Beaked Parsley. Stem hairy below, smooth above, slightly swollen below the joints; fruit oblong, smooth, slightly tubereulated; channels on the beak about one-fifth the length of the fruit; involucre with numerous fringed segments.

Hooker, British Flora, vol. i. p. 137.--Lindley, Synopsis, p. 124.Chcrophyllum sylvestris, Linn.-English Butauy, t. 752.-English Flora, vol. ii. p. 48.

Root tapering. Stem from three to four feet high, angular and furrowed, hairy and purplish in the lower part, green and smooth above, somewhat swollen bencath its joint, branched and leafy. Lenves large, with slender long striated hairy footstalks, the base dilated, long, sheathing, striated, mostly clothed in short puliescence, the margins thin and membranous, thrice pinnated, the leaflets ovate or ovatelanceolate, deeply cut and serrated, the upper ones nearly smooth, the lower hairy, especially beneath and on the mid-ribs, and somewhat paler. Umbels lateral and terminal, at first drooping, becoming erect and spreading, the general of numerous slender rays, the partial of short ones. General involucre none, partial of numerous lancelate ribbed membranous reflexed segments, with a fringed border of very slender silky hairs. Flouers numerous, white, the outer ones with some of the petals larger than the others. Petals inversely heartshaped, with a small inflexed point. Stamens on slender filtements, with roundish anthers. Styles at first very short, becoming clongated. Disk convex, spreading. Fruil oblong, smootb, with a beak about 
one-fifth its length, with five equal obtuse ridges. Albumen roundish at the back, deeply furrowed in front.

Habitat.-Fields and sbady places; frequent.

Perennial ; flowering in June and July.

This plant has not an unpleasant smell, something like carrots; and as it grows only in the greatest luxuriance in a good rich soil, that circumstance is said to be a guide as to the fertility of the land. It is occasionally used as pot-herb, and is a favourite food of cattle and rabbits. The leaves give a good green dye, and the umbels a yellow. The flowers are the resort of numerous insects, who appear to be attracted by its sweets.

2. A. Cerefo'lium, Hoffm. (Fig. 466.) Garden Beaked Parsley. Stem swollen beneath the joints; the lateral umbels sessile; leares tri-pinnate, smooth, except on the nerres on the under side; leaflets ovate, pinnate, with obtuse segments; fruit linear, smooth, with a long beak, and channels half as long as the fruit.

Hooker, British Flora, vol. i. p. 138.-Lindley, Synopsis, p. 124.Scandix Cerefolium, Linn.-English Botany, t. 1268.-Cherophyllum sativum, Bauh.-English Flora, vol. ii. p. 48.

Root small, tapering, annual. Stem slender, erect, round, smooth, finely striated, slightly swollen beneath the joints, and somewhat hairy above them, from one to two feet high, branched and leafy. Leaves thrice pinnate, delicate pale green, with slender footstalks, hairy, and somewhat dilated at the base, leaflets ovate, pinnated, smooth, except the veins on the under side being somewhat hairy. Umbels terminal and lateral, the lateral ones sessile at the axis of the upper leares, the general of about four long slender rays, the partial of numerous short stout ones. General involucre none, the partial of about three linear segments on one side. Flowers numerous, white, the outer ones with three of the petals larger than the others. Calyx an obsolete margin. Petals inversely heart-shaped, with a small inflexed point. Stamens on slender filaments, with small roundish anthers. Styles very short, with small obtuse stigmas, and rery small fleshy disk. Fruit linear", oblong, smooth and shining, minutely dotted, and frequently tuberculated, the beak about one-third the length of the fruit, with obtuse ridges. Albumen roundish, with a deep furrow in front.

Habitat.-Hedges and about gardens; not unfrequent.

Annual ; flowering in July.

Under the name of Garden Chervil this plant is frequently cultivated on the Continent, where it is much used as a sallad, with other regetables, and as a pot-herb; but in England it is not much used.

** Carpels clothed with spines.

3. A. vulga'ris, Pers. (Fig. 467.) Common Beaked Parsley. Stem smooth; leares tri-pinnate, smooth, or scattered over with hairs; 


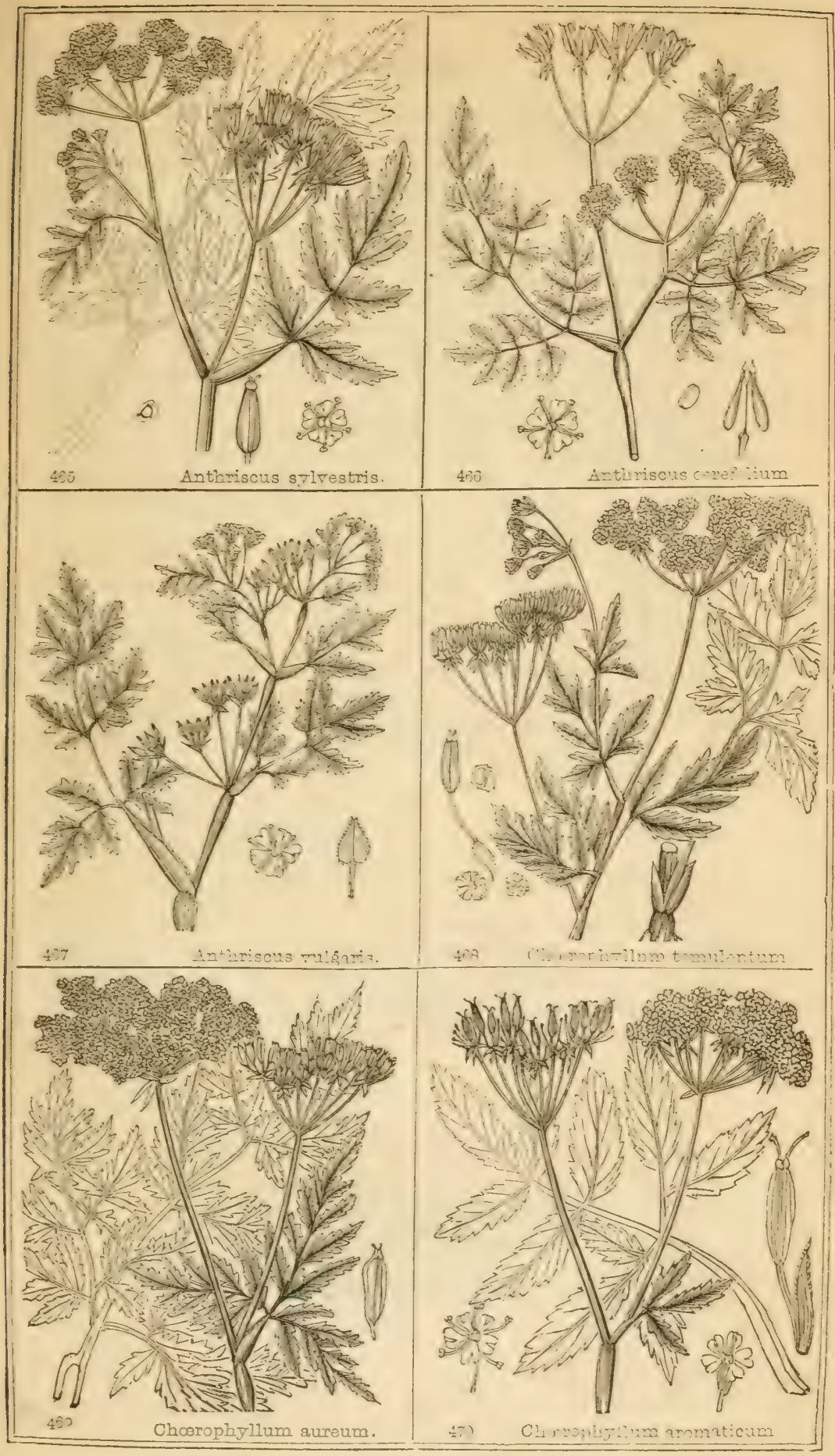



lcaflets pinnate, with obtuse segments; umbels opposite the leaves; fruit orate, clothed with incurved prickles, the beak one-third its length; stigmas nearly sessile.

English Flora, rol. ii. p. 45.-Hooker, British Flora, vol. i. p. 138. -Lindley, Synopsis, p. 124.-Scandix Anthriscus, Linn.-English Botany, t. 818.

Root tapering, with numerous branched fibres. Stem erect, about two feet high, round, smooth, striated, somewhat swollen beneath each joint, branched and leafy. Leaves alternate, thrice pinnated, with long channeled footstalks, finely striated, smooth, except abrut the joints and the smaller branches, much dilated at the base, and sheatling, with a thin white membranous margin, much fringed with fine silky hairs; leaflets a beautiful pale green, ovate oblong, pinnated, with narrow obtuse or acute segments, smooth, except being scattered over sometimes with white hairs, especially on the under side. Umbels on short pedicles from the axis of the upper leaves, the general of about six slender mostly equal rays, and the partial of about six short unequal ones. General involucre none, partial of about six lanceolate ones, with a membranous fringed margin. Floxers small, white, nearly equal. Calyx a slender obsolete margin. Petals inversely heart-shaped, with a small inflexed point. Stamens on short filaments, with small roundish anthers. Styles very short, scarcely observable. Stigmas small, obtuse. Fruit orate, clothed with short rigid prickles, with a small incurved point, the beak contracted, furrowed, about onethird the length, and frequently there are three dorsal very slender ridges the whole length of the fruit. Albumen rounded at the back, furrowed in front.

Habitat.-Waste places, hedges and road sides; frequent, especially near towns and rillages.

Annual; flowering in May and June.

Common Beaked Parsley, or Cherril, has some resemblance in its foliage to the Garden Chervil, for which it has been sometimes gathered in mistake, and it has like it a sweetish aromatic flavour; but its spinous fruit, much more branched stouter stem, and lateral pedunculated umbels, will readily distinguish it from other species.

\section{GENUS LXXXII. CHAROPHY'LLUM.-LINN. Cheril.}

Gen. Crar. Calyx an obsolete margin. Petals obcordate, with an inflexed point. Fruit contracted at the sides, beaked. Carpels with five very obtuse equal ridyes, the lateral ones forming the margins, the commissure with a deep furrow. Channels with single vilte. Albumen roundish, deeply furrowed in front 
General involucre wanting, or of a few segments partial, of

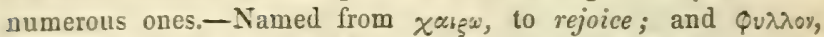
a leaf; said to be so called from the abundance of the leares.

1. C. temulen'tum, Linn. (Fig. 468.) Jough Chervil. Stem rough, swollen below the joints, spotted; leares bi-pinnate; leaflets orate oblong, lobed; partial involucre with reflexed orate-lancerlate ciliated segments.

English Botany, t. 1521.-Hooker, British Flora, rol. i. p. 138.Lindley, Synopsis, p. 125.-Myrrhis temula, Spreng.-Englisb Flora, rol. ii. p. 51.

Root tapering, with branched fibres. Stem erect, branched, from two to three feet high, round, rough, with hairs pointed downwards, swollen beneath each joint, solid, a dark green, with purple spots, and the lower part mostly altogether purple, striated, and leafy. Leares alternate, the lower ones on long channeled footstalks, with a dilated sheathing base, clothed with rough hairs, twice pinnate, with lobed pinnated leaflets, serrated, or crenated on the margin, rough, with hairs, somerhat paler and reiny beneath. Umbels lateral and terminal, numerous, the general of numerous long slender unequal rays, more or less hairy, the partial smooth, or nearly so, numerous, unequal. General inwolucre either wanting, or of from one to fire short lanceolate erect hairy segments, the partial of numerous lanceolate orate nearly smooth reflexed ones, with membranous ciliated margins, and a mid-rib. Flowers white or yellowish, nearly regular, those in the centre of the umbels mostly barren, the outer ones somewhat rased. Calyx a rery narrow margin. Petals inrersely heart-shaped, with a small inflexed point, and mid-rib. Stamens with rather lung slender filaments, and small round anthers. Styles short, recurred, with small obtuse stigmas, and a small concare disk. Fruit linear, oblong, with the sides compressed, smooth. Carpels round at the back, flat in front, with fire equal rery obtuse ridges, the lateral ones forming the margins. Channels each with a single slender vitta. Albumen round at the back, deeply channeled in front.

Habitat. - Road sides, hedges, and shady places; frequent.

Perennial; flowering in June and July.

2. C. aure'um, Linn. (Fig. 469.) Tauny-seeded Chervil. Stem swollen, and hairy beneath the joints; leaves tri-pinnate; leaflets pinnated, lanceolate, acuminate, cut and serrated; partial involucre of spreading broadly lanceolate segments, with long slender points and ciliated margins.

English Botany, t. 2103.-Hooher, British Flora, rol. i. p. 138.Lindley, Synopsis, p. 125.-Myrrhis aurca, Spreng.-English Flora, rol. ii. p. 52.

Ront tapering, with brancherl fibres. Stem crect, three feet high, much branched upwarls, angular, furtawerl, and rowny, especially 
about the somewhat swollen joints, leafy. Leaves large, thrice pinnate, footstalks striated, channeled, downy at the base, dilated into a long thin striated sheath, the lower cones long, leaflets ovate at the base, lanceolate upwards, with a remarkable long attenuated point, pinnated or cut at the base with serrated segments, but towards the point simply serrated, the serratures fine, sharp, somewhat curved upwards, downy, especially on the ribs on the under side, which is rather paler than the upper. Umbels numerous, lateral and terminal, the general of numerous long slender angular rays, unequal, the partial of numerous short unequal ones. General involucre none, or of one or several linear lanceolate downy segments, the partial of numerous ovate-lanccolate reflexed segments, with very downy margins, and a very slender point of variable length. Flouers numerous, white, or cream coloured, nearly equal, the outer ones somewhat radiant, the central ones mostly barren. Calyx a narrow margin. Petals inversely heart-shaped, with an inflexed point. Stamens with slender filaments, and small roundish anthers. Styles short, becoming elongated and recurved, the stigmas small, obtuse, the disk dilated, convex, fleshy. Fruit linear, somewhat thickened upwards, smooth, or slightly hairy, of a tawny colour, and short beak. C'arpels with the sides compressed, having five very obtuse equal ridges, the lateral ones forming the margins. Channels with single slender vitte. Albumen rounded at the back, furrowed in front.

Habitat.-Fields between Arbroath and Montrose. Near Corstorphine, Edinburgh.-Mr.G. Don.

Perennial ; flowering in June.

3. C. aromat'icum, Linn. (Fig. 470.) Broad Leaved Chervil. Stem swollen beneath the joints; leaves sub-ternate; leaflets ovate oblong, acuminate, serrated, undivided; partial involucre of broadly lanceolate segments, with long slender points and ciliated margins.

English Botany, t. 2636.-Hooker, British Flora, vol. i. p. 139.Lindley, Synopsis, p. 125 - Myrrhis aromatica, Spreng.-English Flora, vol. ii. p. 52.

Root tapering, branched. Stem erect, branched, from two to three feet high, rough, with hairs pointing downwards, angular and furrowed, somewhat swollen beneath the joints, and marked with purple spots. Leaves two or three times pinnated, footstalks striated, channeled, and hairy, the base dilated into a long thin striated sheath, with a pale membranous margin, leaftets ovate oblong, acuminate at the point, the base unequal, rounded, or heart-shaped, the terminal one tapering, cither on a short footstalk or sessile, sharply, sometimes doubly serrated, about two inches long, smooth above, paler beneath, and sometimes hairy. Umbels terminal and lateral, the general of numerous long slender angular slightly unequal rays, the partial of numerous short unequal ones. General involucre wanting, or of a short lancen- 
late segment, with a membranous margin and fringed edge, partial of about ten reflexed ones, with a long slender point. Flowers numerous, white, one or two only in the centre fertile. Calyx an obsolete margin. Petals inversely heart-shaped, with a small inflexed point, those of the outer flowers larger than the others. Styles short, spreading. Stigmas small, obtuse. Disk conical. Fruit oblong, smooth, with compressed sides. Carpels roundish at the back, with five obtuse or flattish ridges, the two lateral ones forming the margin. Channels with single slender vitte. Albumen roundish at the back, furrowed in front.

Habitat.-Road side near Guthrie, leading to Arbroath, Scotland.Mr. G. Don.

Perennial; flowering in June.

\section{GENUS LXXXIII. MY'RRHIS.-ScOPOII. Cicely.}

Gen. Char. Calyx an obsolete margin. Petals obcordate, with an inflexed point. Fruit laterally compressed. Carpels with a deep furrow between them, of five equal acutely winged hollow ridges. Channels deep, without vitta. Albumen closely invested with a second covering of the pericarp, the sides rolled inwards. General involucre none, partial of numerous segments.-Name from Myrrha, Myrrh, from the peculiar odour of the leaves.

1. $M$. odor'ata, Scop. (Fig. 471.) Sweet Cicely. Leaves villous; partial involucre numerous, lanceolate, with a long slender point and ciliated margin; fruit large.

English Flora, vol. ii. p. 50.-Hooker, British Flora, vol. i. p. 139.Lindley, Synopsis, p. 125.-Scandix odorata, t. 697.

$R$ oot tapering, fleshy, sweet and aromatic. Stem erect, from two to four feet high, round, finely striated, smooth or downy, especially about the joints, leafy, branched. Leaves large, thrice pinnated, more or less thickly clothed with soft pubescence, paler beneath, above palish green, frequently about the middle of the leaves spotted, with irregular pale almost white hlotches, footstalks long of the lower leaves, shorter above, hollow, striated, and downy, the base much dilated into a large striated sheath, embracing the branches, leaflets ovate-lanceolate, pinnatifid, cut and serrated. Umbels mostly terminal, of numerous long downy nearly equal rays, the partial ones slender, short. General involucre none, partial of numerous lanceolate ones, with a long slender point, and more or less fringed margin, pale, thin, ribbed and membranous, reflexed. Flowers white, nearly equal, the central ones, and frequently whole umbels abortive. Petals inversely heart-shaped, with a small inflexed point. Stamens on long slender filaments, with smąll 



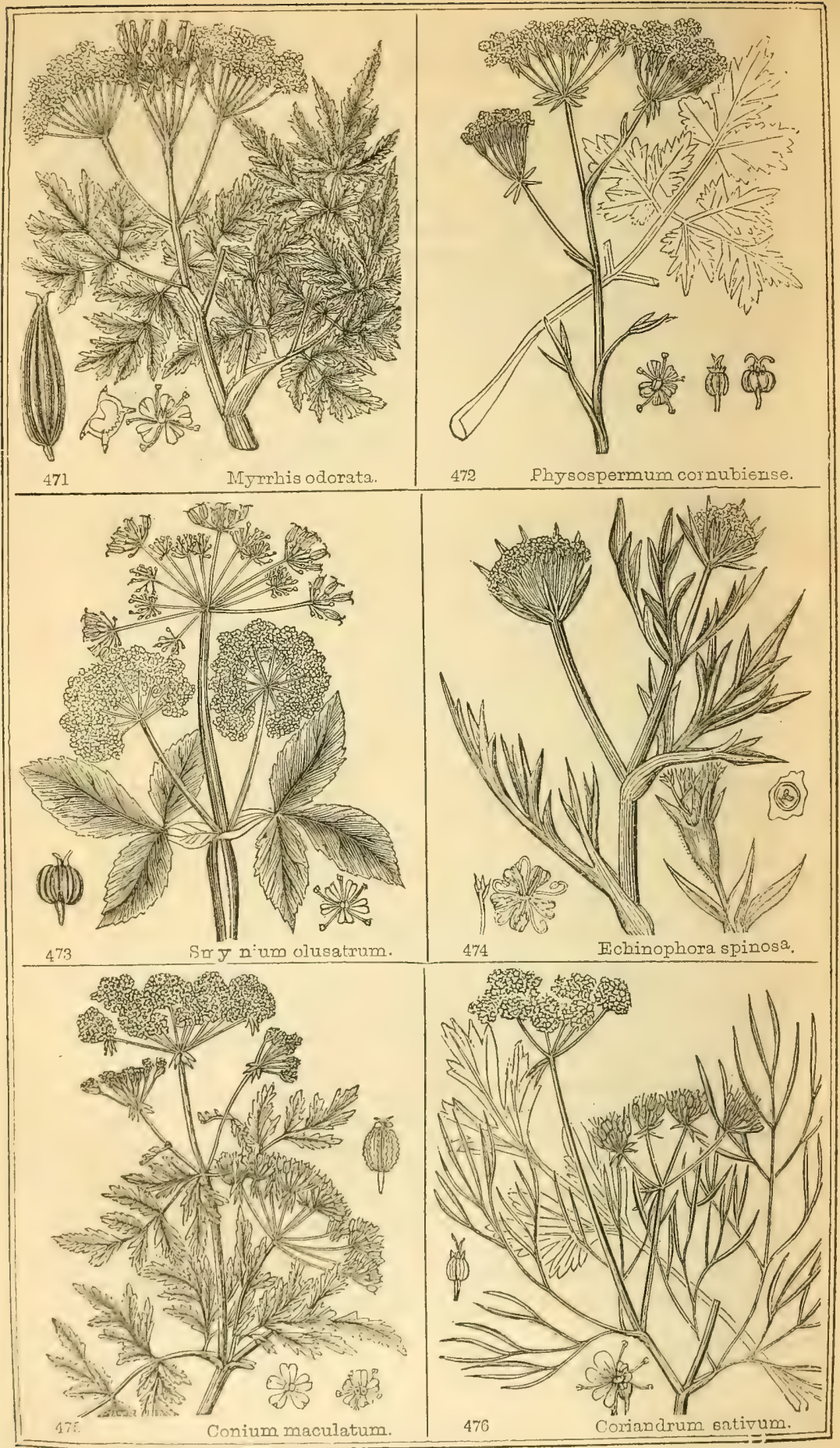


heart-shaped anthers. Styles short, elongating, spreading. Stigmas small, glohose. Disk small, conical. Fruit large, dark brown, smooth, polished, elliptical, acute at the apex, contracted into a short beak, somewhat serrated, the sides compressed. Carpels with five equal prominent vidges, acute, with two shallow fine furrows near the edge, formed by an internal white fibrous thread, rumning the whole length of the outer angle of the hollow cavity in the ridges. Channels deep, quite smooth, without vitte. Albumen rounded at the back, the sides rolled inwards, or deeply furrowed in front, closely invested with a secondary covering of the pericarp.

Habitat.-Pasiures, river sides, and shady places; in the middle and north of England, and lowlands of Scotland, but not very common. Perennial; flowering in May and June.

The seeds, as well as the whole plant, have a pleasant aromatic odour. It has long been cultivated, though now much neglected; it was estcemed a culinary herb, grateful both to the palate and stomach, being gently aperient and diuretic. The leaves were used in salads, and the roots and stems eaten boiled or candied with sugar into a sweetmeat; and in Germany the seeds are used to flavour some kinds of soups: while in the North of England they are used to perfume and polish oaken floors and furniture.

Trabe 9. Smyrnez.-Koch. Fruit turgid, with the sides compressed or contracted. Carpels with five primary ridges, the lateral ones forming the margin, or placed before it, sometimes the ridges are nearly obliterated. Albumen with the sides rolled inwards, or furrowed in front.

\section{GENUS LXXXIV. PHYSOSPER'MUM.-CUsSON,}

\section{Bladder Seed.}

Gen. Char. Calyx margin of five teeth. Petals obcordate, with an inflexed point. Fruit laterally compressed. Carpels roundish, with five equal ridges, of which the lateral ones are placed within the margin. Channels with single vitta. Albumen with the sides rolled inwards. General and partial involucres of numerous

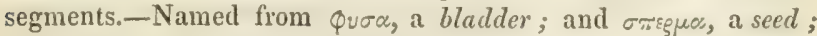
from the shape of the seed.

1. P. Cornu'biense, Hook. (Fig. 472.) Cornish Bladder Seed. Stem erect, rough below, smooth above; root leares bi-ternate or tri-ternate;

VOL. I.

$3 \mathrm{H}$ 
leaflets wedge-shaped, lobed, and cut, the margins rough; those of the stem linear, lanceolate, entire.

Hooker, British Flora, vol. i. p. 140̂.-Physospermum commutatum, Sprengel.-Lindley, Synopsis, p. 126.-P. aguilegifolium, Koch.Ligusticum aquilegifolium, Willd.-L. Cornubiense, Linn.-English Botany, t. 683.-English Flora, vol. ii. p. 82.

Root tapering, branched, somewhat fibrous, Stem erect, from one and half to two feet high, with short branches in a paniculated manner towards the top of the stem, yound, slender, striated, purplish in the lower part, and roughish, with close short woolliness, quite smooth above. Leaves from the root and base of the stem seldom more than two or three times ternate, on long striated purplish footstalks, channeled on the upper side, dilated, and somewhat sheathing in the lower part, mostly smooth, but sometimes roughish, with close woolliness in the lower part, leaflets wedge-shaped, lobed, and cut, pale beneath, with darker branched veins, smooth, or scattered over with hairs, and the margins almost always rough, with short hairs; leaves of the stem few, simple, lanceolate, short, or with one or two linear lanceolate segments. Umbels terminating the stem and branches, the general of about ten nearly equal spreading smooth striated rays, the partial of numerous short ones. General and partial involucre of from one to five lanceolate somewhat membranous ribbed spreading segments. Flouers numerous, white or cream coloured, nearly regular. Calyx of five small teeth. Petals inversely heart-shaped, with au inflexed point. Stamens with slender filaments and small yellow anthers. Styles short, elongating, and spreading. Stigmas small, obtuse, somewhat capitate. Disk fleshy, flat, or convex. Fruit almost globose, the sides compressed, and the margins between the carpels contracted, smooth, except at the top somewhat roughish, crowned by the disk and styles. Carpels with five ridges, equal, three at the back, and the two lateral ones forming or within the margin. Channels shallow, each with a broad single vitta. Albumen loose within the thin swollen pericarp, half moon-shaped, on a transverse section.

Habitat._Bushy places about Bodmin, Cornwall, and near Biddeford; Devonshire; very rare.

Perennial; flowering in July.

This very rare British plant is spoken of in English Botany "as never having been found in any other part of the world except in Cornwall." We have specimens which we collected last year in sandy fields near the sea, along the north coast of Portugal, which differ in no respect from those which we have from Cornwall and Devonshire; it is not, however, there hy any means a common plant, and grows in open as well as bushy places; and in shady places in the North of Italy abundant, especially at the Lucca Baths. 


\section{GENUS LXXXV. SMYR'NIUM.-LinN. Alexanders.}

Gen. Char. Calyx an obsolete margin. Petals lanceolate or elliptical, entire, with a long inflexed point. Fruit laterally compressed, double. Carpels roundish, reniform, with three acute prominent ridges at the back, the two lateral ones nearly obliterated. Channels with numerous vitte. Albumen with the sides rolled inwards. Involucres various. - Named from $\sigma \mu v \rho^{y} \alpha$,

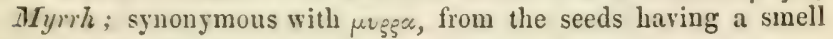
resembling Myrrh.

1. S. Olusa'trum, Linn. (Fig. 473.) common Alexanders. Stem furrowed; its leares ternate, serrated, on footstalks.

English Botany, t. 230.-English Flora, vol. ii. p. 74.-Hooker, British Flora, vol. i. p. 140.-Lindley, Synopsis, p. 126.

Root large, fleshy, branched. Stem stout, erect, about three feet high, smootl, deeply furrowed, branched and leafy, solid. Leares alternate, a bright yellowish green, the upper ones twice, the lower mostly thrice ternate, on smooth slender striated footstalks, with large much dilated pale membranous ribbed sheathing base fringed on the margin, with soft white lowniness, leaflets large, ovate, more or less cut and serrated, paler beneath, and veiny, the terminal one wedgeshaped, often three lobed. Limbels terminal and lateral, large, globose, the general of numerous nearly equal angular rays, the partial of numerous short ones. General and partial involuere wanting. Flowers yellowish green, much crowded, nearly equal. Calyx an obsolete margin. Petals lanceolate, with a long point rolled iuwards, and from one to three ribbed. Stamens with long sleuder filaments and ovate yellow anthers. Styles rery short, elongating after flowering, and spreadiug. Stigmas small, obtuse. Disk large, convex, fleshy. Fruit black, the sides compressed. Carpels alınost globular, hollowed out in front, the back with three acute prominent ridyes, the lateral ones much smaller, almost obliterated. Channels with numerous slender vittc. Albumen rounded at the back, the sides rolled inwards.

Habitat.-Waste ground, amongst ruins, and on rocks and cliffs, especially near the sea; not uncommon.

Biennial ; flowering in May and June.

This plant, commonly known by the name of Alexauders, was much cultivated by the ancients as a pot-herb, on account of its mild qualities and pleasant aromatic flarour, which resides in the root as well as all other parts of the plant. It is still much used on the Continent, though in part, as it is almost entirely with us, superseded by Celery as a vegetable. Its specific name of Olusatrum is from Olus, a pol$h e r b$, in allusion to the use made of the plant; and ater, atrum black, in reference to the remarkable colour of the seed. 


\section{GENUS LXXXVI. ECHINO'PHORA.-LINN. Prickly}

Samphire.

Gen. Char. Calyx margin of five teeth. Petals obcordate, with an inflexed point, the outer ones larger, and bifid. Flowers of the ray on long stalks, sterile, in the centre of a solitary fertile one. Fruit ovate, roundish, inclosed in a hollow receptacle, with a short protruded beak. Carpels with five equal depressed wared striated ridges. Channels with single vitta, covered with an arachnoid membrane. Albumen with the sides rolled inwards. Involucres of numerous segments.-Name from $\varepsilon \chi$ เvos, $a$ hedge$h o g$; and $\phi_{\varepsilon \rho \omega}$, to bear; in reference to the prickly nature of the plant.

1. E. Spino'sa, Linn. (Fig. 474.) Prickly Samphive. Leaves pinnate; leaflets with rigid triangular spinous segments.

English Botany, t. 2413.-English Flora, vol. ii. p. 37.-Hooker, British Flora, vol. i. p. 139.-Lindley, Synopsis, p. 126.

Root tapering, long, fleshy, branched. The whole plant of a pale glaucous green, more or less thickly clothed, especially the stem and branches, with short soft pale hairs. Stem from one to two feet high, rigid, much branched in every direction from the base upwards, leafy, round, striated, solid. Leaves very liard and rigid, opposite and alternate, on striated angular footstalks, channeled abore, dilated at the base with a narrow thin pale membranous margin, pinnate, leaflets rigid, triangular, with a sharp rigid spinous point, the upper leares three-cleft. Umbels terminal and lateral, the general of sereral thick striated rays, swollen upwards, which forms the receptacle to the central solitary fertile flower, the partial of numerous, gradually becoming short towards the centre. General involucre of numerous simply lanceolate spinous segments, sometimes two or three cleft, the partial of numerous short irregular ones. Flowers numerous, white, the outer ones racliant, with some of the outer petals larger than the othcrs, and bifid, the outer ones bearing stamens only, the central one only with pistils, sessile. Calyx of five spinous persistent teeth. Petals inversely heart-shaped, with an inflexed jagged point. Stamens on slender filaments, incurved, and the anthers small, roundish. Disk rather large, almost flat, flesliy. Styles of the central flower long, recurved, spreading. Stigmas very small. Fruit inclosed in the hollow enlarged receptacle at the top of the rays, ovate oblong, with a tapering beak projecting through the opening at the top of the receptacle, crowned by the hardened disk and styles. Carpels with a pale thin pericarp, with five equal wared broadish ridges, depressed and striated, the channels shallow, with single sleuder villa, which have a thin cobweb-like membrane stretcled orer them. Albumen on a 
transverse section, roundish at the back, the sides rolled inwards, and touching each other on their edges, and forming an almost crescentshaped carity in the middle of the albumen. Sometimes there are rudiments of two seeds, but only one of them comes to perfection.

Habitat.-Sandy sea shores. Found formerly on the coast of Lancashire and Kent, but now apparently extinct.

Perennial; flowering in July and August.

This plant, there is reason to fear, is now become extinct in our country. We, however, still retain it, as it may, like some other plants, after having been lost for some years, again make its appearance; and as there cannot be much fear of its ever haring been mistaken for any other plant, we think that it may again be found. It is frequent on the shores of the Mediterranean sea, and from specimens grown on the Italian coast our figure has been drawn and described. The root, as well as the whole plant, has a strong smell, similar to that of larsuips. It is a singularly rigid plant in appearance, and very remarkable in structure, especially the parts of the flower and seed.

\section{GENUS LXXXVII. CONI'UH.-LINN. Hemlock.}

Gen. Char. Calyx an obsolete margin. Petals obcordate, with a very small inflexed point. Fruit laterally compressed, orate. Carpels with fire equal prominent wared or crenated ridges, the lateral ones forming the margin. Channels with numerous streaks, but no vitta. Albumen with the sides rolled inwards. General involucre of few segments, the partial of three on one side.-Name wwyto\%, from *wys, a cone, or top; so called because the juice of the plant produces a giddy or whirling sensation, as that caused by turning round, as does a top.

1. C. macula'tum, Linn. (Fig. 475.) common Hemlock. Stem smooth, spotted, much branched; partial involucre with the short segments on the outer side of the umbel.

English Botany, t. 1191.-English Flora, vol. ii. p. 65.-Hooker, British Flora, vol. i. p. 139.-Lindley, Synopsis, p. 126.

Root tapering, fleshy, mostly branched and fibrous, Stem erect, from three to six feet high, round, hollow, smooth, glaucous green, spotted with purple, striated, sometimes furrowed, much branched upwards, and leafy. Leaves large, thrice pinnate, on a round striated hollow spotted footstalk, with a thin dilated striated sheathing base, and a pale thin membranous margin, elongated at the upper angles into acute appendages, leaflets orate-lanceolate, cut in a pinnatilid manner, and serrated, a deep shining green above, pale beneath, quite smooth. Lmbels lateril and terminal, numerous, the yeneral of nu- 
merous long slender nearly equal striated rays, the partial of numerous short unequal ones. General involucre of several ovate-lanceolate segments, with long slender points, the partial of three similar segments, reflexed on the outer side of the umbels. Flowers numerous, white, nearly regular. Calyx an obsolete margin. Petals obcordate, with a rery small inflexed point, the outer ones of the outer flowers somewhat larger than the others. Stamens with slender filaments and small roundish white anthers. Styles very short, with small capitate stigmas, and the disk oblong, pale yellow, somewhat convex. Fruit orate, the sides compressed, crowned by the waved disk. Carpels with fire equal pale acute prominent crenated ridges, the lateral ones forming the margins. Channels smootb, with several stria, but without vittce. Albumen rounded at the back, the margins rolled inwards.

Habitat. - Waste places, on the banks of rirers, woods and shady places; not unfrequent.

Perennial ; flowering in June and July.

Hemlock, or Cicuta, contains an actire narcotic acrid principle, which, in proper doses, is a valuable and useful medicine, acting as a sedatire and alterative, and has been found of considerable use in the relief of scirrhus and cancerous affections, by reliering the pain and allaying the irritability, and is taken either internally, or applied externally in the form of poultice, made with bread in the common way, and the dried powdered leaves mixed with it; and for internal exhibition, the leaves gathered from good plants just before they come into flower, carefully dried, and kept in a close stopped bottle, is perhaps the best form to secure the preservation of its properties. It is also prepared in the form of an extract, but generally this is so carelessly made as to retain but little of its origiual activity; if, howerer, the expressed juice is eraporated at a rery low heat in the sun, it retains for a considerable period, if kept in close vessels, all its virtues. The leares made into warm fomentations we have also seen of considerable use in promoting the healing process of various irritable ulcers. Fatal accidents have sometimes occurred, from the Hemlock having been mistaken for other plants; as in a short time it produces giddiness, headache, stupor, delirium, coma, convulsions, and death. It is generally beliered to hare been the juice of Hemlock, which was used in former times, and especially among the Greeks, for despatching criminals; we are, howerer, in want of precise information as to this being the only poison used; indeed the accounts of the activity of their poison would lead to the supposition that it was a compound, and contained more powerful ingredients. It was, howerer, the opinion of Linnaus and Lamarck, that the poisonous draught was that of Hemlock.

Hemlock is spoken of in Scripture (Hosea, ch. x., v. 4, and in Amos, ch. vi., v. 12,) as a thing to be feared, something that appears to have been familiar to the people of those times, and what was looked 
upon by no means as pleasant or agreeable; but upon referring to the original Hebrew, we do not find any thing definitely spoken of; the word means something bitter and unpleasant, and authors are rery varied in their opinion as to its signifying Hemlock or not: there appears, indeed, reason to believe that it may have been Wurmwood (Absinthium), and some think it to have been (Lolium temulentum) Darnel, see page 165 .

Sub-order 3. Coelosperma. Albumen hemisplerical, or saccatoconcave.

Tribe 10. Coriandrex.-Koch. Fruit globose or double, being formed of two globose carpels. Carpels with five primary ridges, depressed, wared, or in the form of an obscure furrow, the lateral one placed before the accessory margin; the four secondary ridges more prominent, but not winged. Albumen hemispherical, concare in front.

\section{GENUS LXXXVIII. CORIAN'DRUM.-LrNs. Coriander.}

Gen. Char. Calyx margin of fire teeth. Petals obcordate, with an inflexed point, the outer ones larger, and bifid. Fruit globose. Carpels with fire primary depressed waved ridges, the lateral ones placed before an accessory margin, the four secondary ones more prominent and carinated. Channels without vitta; the commissure with two vitta. Albumen concave in front, covered with a loose membrane. General involuere mostly wanting, the partial on one side.-Name from xogьo\%, or xograyyo\%

1. C. sati'rum, Limn. (Fig. 476.) Common Coriander. Leaflets of the lower leares wedge-shaped, those of the upper linear.

English Botany, t. 67.-English Flora, rol. ii. p. 67.-Hooker, British Flora, rol. i. p. 140.-Lindley, Synopsis, p. 115.

Root small, tapering. Siem erect, from one to two feet high, round, smooth, striated, branched and leafy, the lower leaves on long slender channeled footstalks, bi-pinnated, the leaflets broadly wedge-shaped, mostly deeply three-cleft, cut and deeply serrated or toothed, the upper leaves gradually becoming larger, more compound, with shorter footstalks, and long narrow linear segments, all quite smooth, of a pale shining green. Lmbels lateral and terminal, of from three to fire rays, the lateral ones sessile, or on footstalks, the partial umbels of numerous short unequal rass. Flowers white or pale pink, the outer ones radiant. Calyx of five narrow lanceolate teeth. Petals inversely heart-shaped, 
with a small inflexed point, the outer ones of the radiant flowers much larger than the others, and deeply cleft. Stamens with slender filaments and oblong anthers. Styles elongating after flowering, slender, spreading. Stigmas small, capitate. Disk somewhat conical. Fruit globose, quite smooth.

Habitat-Fields and waste places, especially in the South of England; naturalized.

Annual; flowering in $J$ ane.

This is the only known species of the genus; it is found in rarious places, but not really wild. It is well known as affording warm aromatic seeds, and was formerly cultirated; hence it has escaped, and is now naturalized. The whole plant in a fresh state has a disagreeable odour, but the dried ripe seeds have a grateful smell, are aromatic and carminative, with a degree of pungeney, and are used in compounding some medicines to corer their less agreeable taste and unpleasant effects. They are used in making some kinds of sweet bread, confectionery, ani pastry, and also as a condiment in various ways in the Suth of Europe; while in Peru we are informed by Feuillée, they are used to an unpleasant excess in almost all their dishes.

GENUS LXXXIX. CHENOPO'DIUMI-LINN. Goosefoot.

Nat. Ord. Chenopo'dez. Vent.

Gen. Char, Perianth single, inferior, fire-cleft, persistent, and unaltered, closing orer the fruit. Fruit a thin depressed utricle, containing a single polished seed.-Named from $\chi$ yy, $\chi$ yvos, a Goose; and rous, a foot; from the shape of the leaves, of some species, resembling a goose's foot.

* Leaves semi-cylindrical; flowers with bracteas.

1. C.frut'icosum, Schrad. (Fig. 477.) Shrubby Sea-side Goosefoot. Stem shrubbr; leares semi-crlindrical, acute; flowers in the axis of the leares, of fire fleshy acute segments; seeds smooth.

Hooker, British Flora, rol. i.p. 141.-Lindley, Synopsis, p. 216.Salsola fruticosa, Linn.-English Botany, t. 635.-English Flora, vol. ii. p. 18.

A small bushy slurub, about three feet high, erect, with numerous slender branches, very leafy, the hark pale, striated. Leares arising on all sides, succulent, semi-cylindrical, smooth, with an acute point, a somewhat glaucous green, sessilc. Flowers small, sessile, one, two, or three tngether in the axis of the leares, each having two or three lanceolate pale membranous bractea at the base; the perianth of fire 



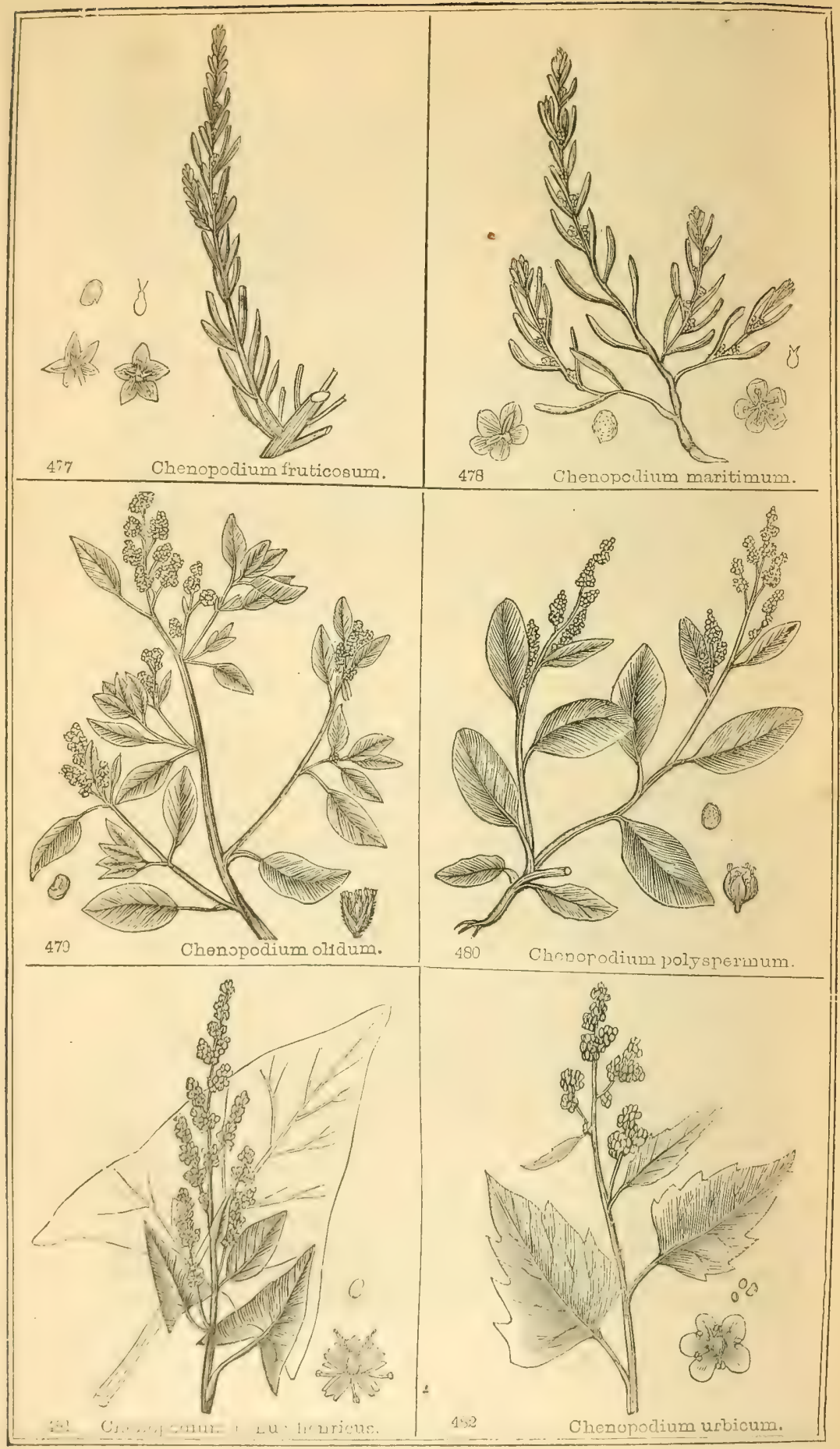


broadly acute somewhat nesly spreading segments, pale on the margin. Stamens on slender filaments, opposite the segments, and as long, or rather longer. Anthers yellow, rather large, of two spreading lobes. Sityls two, sometimes three, combined at the hase. Fruit imbedderl in the unchanged perianth. Sced black, almost kidney-shaped, smooth, with the lobes of the embryo somewhat rolled inwards.

Habitat.--Sea coast, but rare. In Norfulk, Suffulk, Dorsetshire, Deronshire, and Cornwall.

Shrub; flowering in $J u l y$ and August.

2. C. maritimum, Linn. (Fig. 478.) Annual Sea-side Goosefoot. Stem sprealing, herbaceous; leares semi-cylindrical, acute; flowers in the axis of the leares, of fice fleshy acute segments; seeds dotted.

English Botany, t. 633.-English Flora, vol. ii. p. 16.-Hooker, British Flora, vol. i. p. 111.-Lindley, Synopsis, p. 216.-Schoberia maritima, Meyer.

Root small, tapering, branched, and fibrous. Stems herbaceous, mostly several, erect, from four to six or eight inches high, branched; frequently it is much branched from the base, and spreading around, slender, leafy. Leaves numerous, alternate, fleshy, smooth, a glaucous green, semi cylindrical, somewhat tapering upwards with an acute point, about an inch long. Flovers axillary, one, two, or three, small, sessile, each having two small pale membranous orate bractea at the base. Perianth of five ovate acute segments, pale on the margins, fleshy. Stamens opposite the segments, with filaments about the same length, and with smallish yellow anthers. Styles wo. Fruit imbedded in the unchanged periantls. Sceds orbicular, slining black, minutely dotted.

Habilat.- Sea shore in sandy or muddy places; frequent.

Aunual ; flowering in June or July.

The leares have a saline taste, and like most other maritime plants afford, when burnt, an alkaline salt, used for the making of glass, soap, \&c.

* Leaves plane, undivided; flowers without bracteas.

3. C. o'lidum, Curtis, (Fig. 479.) Stinking Goosefoot. Stem spreading; leaves entire, orato-rhomboid; flowers in dense clustered leafless spikes; seeds shining, very finely dotted.

English Botany, t. 1034.-English Flora, vol. ii. p. 14.-Hooker, British Flora, rol. i. p. 141.-Lindley, Synopsis, p. 215.-C. Vulraria, Linn.

Root small, tapering, with branched fibres. Stems sereral, with long spreading straggling branches, or prostrate, roundish, striated, and covered like the rest of the plant with a hoary mealiness, greasy to the touch. Leates numeruus, small, on longish slender footstalks, entire, orate, acute, or more or less rhomboit, paler on the under side,

$$
\text { VOL. I. }
$$


with a mid-rib, and more mealy than the upper. Flowers rery small, in roundish oblong clusters, or small dense spikes, on short stalks, arranger in leafless racemes. Perianth of five lanceolate segments, rough, with mealiness, each with a green mid-rib. Stamens on slender filaments, rather longer than the perianth, with small roundish two Johed yellow anthers. Styles short, spreading. Fruit surrounded by the persistent perianth. Seed shining black, closely invested by a thin pale brown membrane, its testa very finely dotted, hard and crustaceous, roundish, with the sides flattened.

Habitat.-Waste places, especially rubbishy places near the sea.

Annual; flowering in August.

The whole plant when bruised exhales an extremely nauseous odour, something like that of putrid salt fistr: It was much used at one time in nerrous and hysterical complaints, and supplies of it were always to be obtained in Corent Garden Market; but it is now superseded by other and more convenient medicines. Messrs. Chevalier and Las. seigne detected in this plant a quantity of ammonia, which is combined with a portion of oil and resinous matter, on which depends the intolerable odour exhaled by the plant.

4. C. polysper'mum, Linn. (Fig. 480.) many seeded Goosefoot. Leares ovate, entire, quite smooth; racemes elongated, leafless; perianth spreading when in fruit; seeds shining, very finely dotted.

Hooker, British Flora, vol. i. p. 141.

$\alpha_{1}$ cymoso-racemosum. Stems all prostrate; leaves obtuse; flowers in a compound leafless cymose-raceme.

C. polyspermum. English Botany, t. 1480.-English Flora, vol. ii. p. 15.-Lindley, Synopsis, p. 216.

B. spicato-racemosum. Stem erect; leaves acute; flowers leafless, in a spicate raceme.

C. acutifolium, Smith. English Botany, t. 1481.-English Flora, rol. ii. p. 15.-Lindley, Synopsis, p. 216.-C. polyspermum, Curtis.

Root tapering, branched, and fibrous. Stem erect, branched, and spreading, or prostrate on the ground, leafy, roundish, or angular and striated, rarying from six to twenty inches in length, a smooth palish green. Leares alternate, on slender footstalks, smooth, paler beneath than above, with a mid-rib and slender branched veins, ovate, ovateoblnng, acute, almost lanceolate, sometimes obtuse or roundish, but generally with a fine or bristly point. Flowers very small, crowded in small clusters, disposed on slender stalks, in more or less spicate or racemose racemes, leafless, or sometimes with one or two small leaves amongst them, one, two, or three racemes arising from the axis of the leaves, and are citherect or spreading. Perianth of five ovate-oblong or acute short segments, green, with pale membranous edges. Stamens with awl-shaped filaments, as long as the segments, and small yellow 
roundish two lobed anthers. Styles rery short. Fruit closely invested with a pale brown thin membrane in the centre of the spreading segments of the perianth. Seed shining black, its testa hard, crustaceous, very finely dotted, a roundish kidney shape, the sides flattened.

Habitat.-Waste places amongst rubbish; in Cornwall, rare.

Annual; flowering in August and September.

* * Leares plane, toothed, angled, or lobed; flowers without bracteas.

5. C. Bonus Henri'cus, Linn. (Fig. 481.) Mercury Goosefoot, or good King Henry. Leaves triangular, arrow-shaped, mostly entire; spikes compound, terminal and axillary, erect, leafless; perianth of the fruit dry ; seed kidney-shaped, very finely dotted.

English Botany, t. 1033. - Euglish Flora, rol. ii. p. 10.-Hooker, British Flora, rol. i. p. 142.-Lindley, Synopsis, p. 216.-Blitum, Bonus Henricus, Meyer.

Root fleshy, branched. Stem erect, from one to two feet high, roundish, furrowed, smooth, or somewhat mealy, especially towards the end of the branches, and the under side of the leaves simple or slightly branched, leafy. Leaves on channeled footstalks, dilated a little at the base with a membranous margin, large, dark green, pale on the under side, triangular, with latge spreading lubes at the base. Flowers small, numerous, green, densely crowded in oblong clusters into a compound spike, terminating the stem and branches, leafless, or with one or two on the lower part, which are ovate-lanceolate, the terminal spike mostly large, conical. Perianth of fire spreading ovate-oblong segments, green, witb a pale thin membranous margin, terminating near the point abruptly. Stamens on slender awl-shaped filaments, about as long as the perianth. Anther's yellow, ovate, of two lobes. Styles filiform, spreading, elongating after flowering. Fruit closely invested with a very thin pale brown membrane, crowned by the persistent styles, and surrounded at the base with the dried perianth. Seed roundish, kidney-shaped, dark brown, very finely dotted, smooth, shining.

Habitat. -Waste places and road sides; frequent.

Perennial; flowering in July and August.

The whole plant is insipid and inodorous. The young leaves are used in some places instead of Spinach, for which they are a good substitute; formerly it was much more used than it is now. The leaves are considered emollient, and are used to make a decoction for enemas; and the country people account them a good application to flesh wounds and sores, from the idea that they are drawing and healing.

6. C. ur'bicum, Linn. (Fig. 482.) upright Goosefoot. Leaves shining, triangular at the base, slightly lengthened on the petiole, toothed or sinuated; spikes long, erect, almost simple, nearly leafless; seeds smooth, roundish. 
๙. Leares with short triangular acute tecth.

C. urbicum, De Cand.-C. melanospermum, Wallr.

B. intermedium, (Fig. 483.) Leaves sinuato-deantatis; teeth triangular, lanceolate, acuminate.

C. intermedium, De Cand.-C. urbicum.-English Botany, t. 717.English Flora, vol. ii. p. 10.-Hooker, British Flora, vol. i. p. 142.Lindley, Synupsis, p. 215.

Root fibrous. Stem erect, scarcely branched, angular, furrowed, smooth, or somewhat mealy, from one to one and half feet high, green, or often of a reddish hue, leafy. Leaves on channeled footstalks, slightly dilated at the base, triangular, acute, more or less wedgeshaped at the base, and the margins more or less deeply sinuated and toothed in an irregular manner, of a light almost glaucous green, paler beneath, with a mid-rib and lateral veins. Flowers small, in crowded globular clusters, more or less distant, on a common stalk, in a spikate manner. Spikes terminal and axillary, erect, straight, shorter than the leaves, approaching nearer the stem as they advance to maturity, almost leafless, the terminal spike more branched than the others. Ferianth of five roundish ovate obtuse or slightly acute segments, pale green, with lighter coloured margins. Stamens with stout filaments, scarcely the length of the perianth and yellow two celled anthers. Styles short, two or three sometimes wanting. Fruit roundish, closely invested with a pale thin membrane, and crowned by the persistent styles. Sects dark brown, smooth, or with the appearance of being very finely dotted, shining, almost as big as rape sced, much larger than the following species.

Habitat.-Waste rubbishy places under walls, \&c., about towns and villages.

Annual; flowering in August and September.

7. C. ru'brum, Linn. (Fig. 484.) Red Goosefoot. Leaves rhombotriangular, toothed and sinuated; spikes erect, compound, and leafy; seeds very small, smooth, roundish.

English Botany, t. 1721.-English Flora, vol. ii. p. 11.-Hooker, British Flora, vol. ii. p. 142.-Lindley, Synopsis, p. 215.-Blitum rubrum, Reich.

Root fibrous. Stem erect, round, smooth, branched, and leafy, from one to two feet high, mostly of a reddish colour, sometimes green, and more or less striated or furrowed. Leaves on longish channeled footstalks, scarcely dilated at the hase, of a shining green, paler beneath, with a stout mid-rib and lateral branched veins, the upper ones occasionally slightly mealy, triangular, with a wedge-shaped base and acute point, the margins coarsely toothed and sinuated, generally with one larger tooth than the rest on the lower part on cach side, hence sometimes hastate or tri-lobatc. Floner's small, grecnish yellow, in densely crowded oblong clusters, in long leafy very compound termiual and 


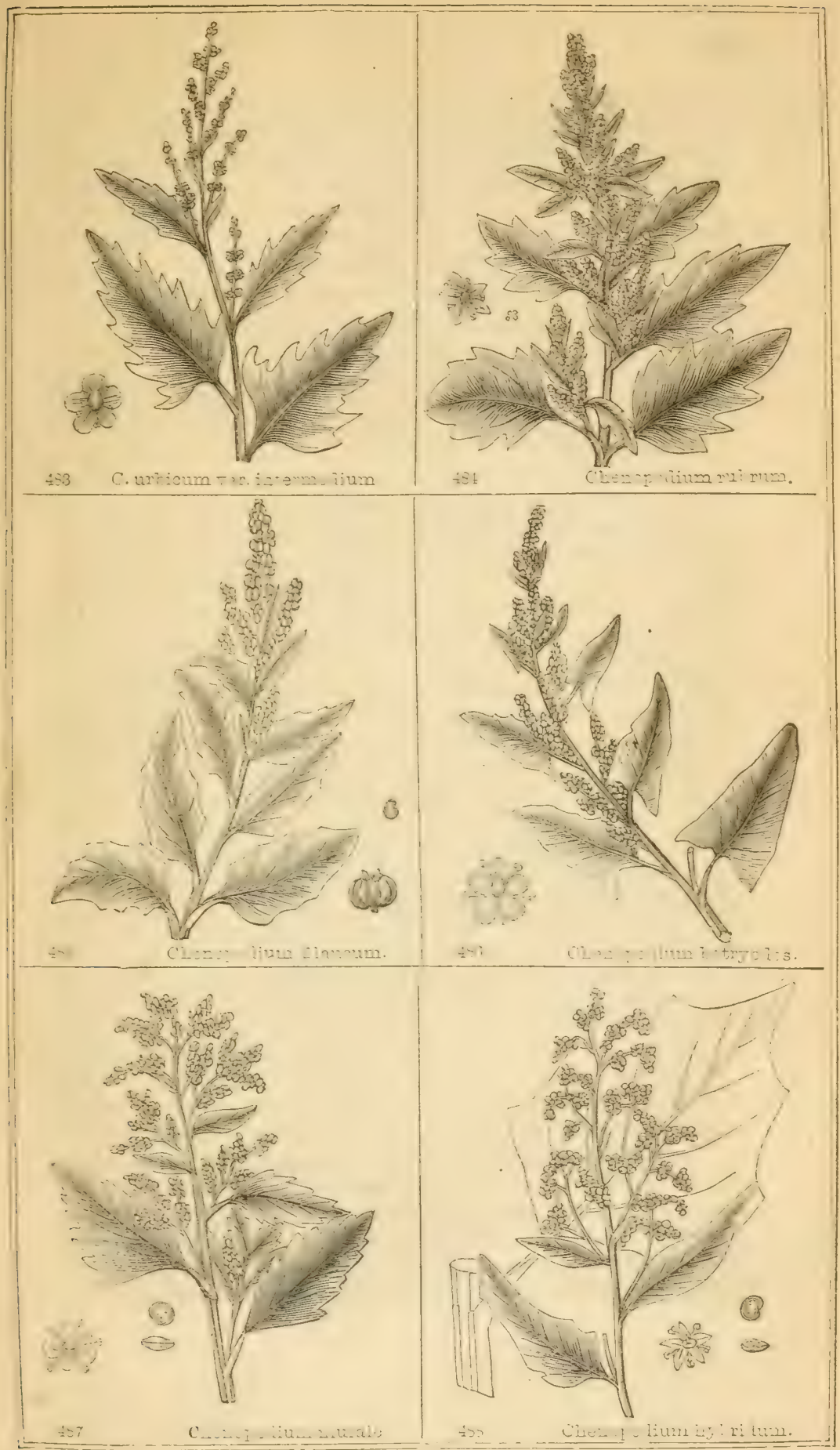



lateral spikes, intermixed with small lanceolate toothed or simple leaves. Perianth very small, of five ovate scarcely acute segments, Stamons with slender filaments, longer than the perianth, with small two lobed anthers. Fruit very small, like grains of sand, surrounderl by the dried perianth. Seed smooth, slining, enveloped in a very thin pale membrane.

IIabitat.-D Dughills, under walls, and waste places; not uncommon. Annual; flowering in August and September.

In drying, the alkaline salt contained in the juices of the plant crystalizes with a white frosted appearance upon the stem and petioles. The flowers on the lateral parts of the spikes are frequently with segments only having three clivisions, and also with only threc stamens, while those on the top and upper parts have five segments and stamens.

8. C. glau'cum, Linn. (Fig. 485.) Oak-leaved Goosefoot. Leaves ovate-oblong, obtuse, or oblong, with the margin distantly toothed, somewhat hastate, glaucous and mealy bencath; spikes compound, leafless; seeds minutely dotted.

English Botany, t. 1454.-English Flora, vol. ii.p. 14.-Hooker, British Flora, vol. i. p. 143.-Lindley, Synopsis, p. 215.-Blitum glaucum, Koch.

Root tibrous. Stem from a few inches to two feet long, mostly prostrate, simple or branched, spreading, stout, furrowed, leafy. Leares alternate, on short stout cbanneled fuotstalls, oblung, with an acute point, or oblong-orate, obtuse, the margin distantly toothed, with two teeth larger than the others near the base, a glaucous green above, sometimes purplish, white and mealy beneath. Flowers small, in dense cluse clustered branched spikes, both terminal and lateral, leafless, or with two or three leaves at the base. Perianth of five small smooth obtuse segments. Stamens with sliort filaments and yellow two lobed anthers. Styles very short. Fruit roundish, flatened, covered with a thin membrane, and crowned by the persistent styles. Sceds smooth, shining, purplish black, rery minutely dotted.

Habitat.-Waste grouml, cspecially on a sandy soil; about London, and apparently not very common elsewhere.

Annual; flowering in August.

9. C. Botry'odes, Sm. (Fig. 486.) Many spiked Goosefoot. Leaves triangular, somewhat tootherl, slightly lengthened at the base on the petiole; spikes erect, compound, and leafy; seed small, shining.

English Botany, t. 2247.-English Flora, rol. ii. p. 11.-Hooker, British Flora, vol. i. p. 142.-Lindley, Synopsis, p. 215.

Root fibrous. Stem spreading, or prostrate, mostly branched from the base, slightly angular, fursured, smooth, leafy, of a greenish purple colour. Leaves on short footstalks, rather small, triangular, with an 
almost entire margin, more or less tapering at the base on the petiole, the upper ones smaller, more blunt, at the angles becoming almost lanceolate, paler on the under side, with a mid-rib, mostly of a purplish colour, and slender branched veins. Flowers small, in crowded oblong clusters, more or less disiant on the terminal and axillary somewhat leafy spikes, of a green purplish colour. Perianth of five oblong slightly swelling segments. Stamens on slender filaments, longer than the perianth. Anthers small, yellow. Styles very short, two spreading. Fruit roundish, compressed. Seed small, black, and shining, enclosed in a thin pale membrane, crowned by the persistent styles, and enreloped with the dried perianth.

Habitat.-Moist sandy places near the sea. Yarmouth, Norfolk.Mr. Wigg. Cliffs by the sea, at Lowestoft.-Sir J. E. Smith. Shore at South Shuebury. $-M r$. E. Forster:

Annual; flowering in August and September.

This species is nearly allied to C. rubrum, but is much smaller, of a more fleshy texture, and the margins of the leaves less toothed. It is quite a different plant from the C. Botrys, of Linn., which is clothed with glandular hairs, the leaves oblong, deeply sinuated, and obtusely toothed, and is not a natire of this country.

10. C. mura'le, Linn. (Fig. 487.) Netlle-leaved Goosefoot. Leares ovate, approaching rhomboid, shining, acutely toothed; flowers in leafless much branched cymose spikes; seeds grey, finely dotted, surrounded with a cariuated margin.

English Botany, 1. 1722.-English Flora, rol. ii. p. 11.-Hooker, British Flora, vol. i. p. 142.-Lindley, Synopsis, p. 215.

Root fibrous. Stem erect, from one to three feet high, branched from the base upwards with short spreading alternate branches, roundish, smooth, striated, or somewhat furrowed, of a darkish slightly glaucous green, often with a purplish hue, as well as the branches. Leaves numerous, alternate, on rather long channeled footstalks, ovate, approaching a rhomboid figure, with sharp irregular hooked teeth, occasionally sinuated, the point generally long and attenuated, paler and more glaucous on the under side, with three ribs from the base, which are branched upwards. Flovers in close small clusters, of a palish green colour, arranged irregularly on slender much branched and spreading cymose spikes, which are numerous, terminal and axillary, leafless, each on a slender footstalk. Perianth of five ovate obtuse green segments, with a mid-rib and a pale narrow white membranous margin. Stamens on slender filaments, longer than the perianth, with yellow ovate anthers. Fruit roundish, much compressed, partly enreloped in the dried perianth, which closely embraces it. Seed greyish, finely dotted, roundish, much compressed, surrounded with a carinated margin litic a ring, and enclosed in a pale thin membrane. 
Habitat.--Under walls, in waste places, and road sides ; frequent.

Annual; flowering in August and September.

This is readily distinguished from the other species, especially by the colour and shape of its curious seeds. The whole plant when bruised has an unpleasant fœtid smell.

11. C.hybrid'um, Linn. (Fig. 488.) Maple-leared Goosefoot. Leares heart-shaped, with angular teeth and an acuminated point; flowers in much spreading branched leafless cymose spikes; seeds large, black, deeply dotted.

English Botany, t. 1919.-English Flora, vol. ii. p. 12.-Hooker, British Flora, vol. i. p. 142.-Lindley, Synopsis, p. 215.

Root fibrous. Stem erect, rather sleneler, mostly with spreading branches, from one to two feet high, round, or angular, smooth, green, with yellowish or purple lines. Leaves alternate, on short channeled footstalks, thickened at the lower part, large, bright green, spreading, heart-shaped, or broadly ovate, with a lengthened point, and about three angular teeth on each side towards the base, the upper ones almost or quite entire, orate-lanceolate, piller on the under side, with a stout mid-rib and lateral branched reins. Flowers green, scattered on the spreading numerous branches of the terminal and axillary cymose spikes, the flowers are sometimes solitary, but mostly there are two or three together along the branches. Perianth of fire spreading orate segments, palish green, mostly with a nurrow pale membranous margin. Stamens on slender filaments, longer than the perianth. Anthers yellow, small. Fruit roundish, much compressed, partly enveloped in the dried periauth. Seed large, shining black, much compressed, marked with irregular large deep pitted dots or furrows, and enclosed in a thin pale membrane.

Habitat.-Moist waste places; rare. About London, Ipswich, Colchester, Dedham, Ely, and Edinburgh.

Annual; flowering in August.

12. C. alb'um, Linn. (Fig. 489.) White Goosefoot. Leares ovate, approaching to rhomboid, erosed and toothed, entire at the base, the upper ones oblong, entire; spikes branched, somewhat leafy; seeds smooth and shining.

English Botany, t. 1723.-English Flora, rol. ii. p. 13.-Hooker, British Flora, rol. i. p. 143.-Lindley, Synopsis, p. 215.

a. spicatım. Leares erosed and toothed; flowers in crowded spikes.

B. cymigerum, (Fig. 490.) Leaves entire, or sparingly toothed; flowers in elongated branched spreading spikes.-C. viride, Linn.

Root branched and fibrous. Stem more or less erect, much branched mostly from the base, and spreading, from one and half to three feet high, round, or somewhat angular and furrowed, striated with palish yelluw lines, or reddish, corered like the rest of the plant with a white 
mealiness, haring a soft unctuous ftel. Leares numerous, three ribbed from the base, and branched, alternate, on rather long channeled footstalks, very rariable in size and width, mostly orate or orate-oblong, with an acute point, and tapering at the base down the footstalk, and one or two large angular teeth on each side, giving it a rtomboid shape, and above these the margic is more or less irregularly erosed and toothed, the upper ones are ovate-oblong, or ovate-lanceolate, entire, and in the variety $\beta$. cymigerum, they are almost all entire, or only slightly and irregularly toothed, smaller, narrower, and generally more green; the stem also is more branched from the base, and sprearling. Flowers rery numerous, terminal and axillary, green, in densely crowded oblong clusters, in long brancherl somewhat leafy spikes, in $\beta$. cymigerum they are much more branched and spreading, less leafy, and on longer stalks, in a somewhat cymose manner. Perianth in five orate acute segments, with a broad pale margin and green mid-rib. Stamens about the length of the perianth, with roundish ovate anthers. Styles short spreading. Fruit roundish, compressed, enclosed in the dried perianth. Seed roundish, kidney-shape, black, smooth, and shining, appear to be very finely dotted, enclosed in a pale thin inembrane.

Habitat. - Waste places, dunghills, \&c. ; very common.

Annual; flowering in August.

This is a very common and very variable species, especially in the size and shape of the leares. With attention, howerer, to the abore descriptions, we do not think much difficulty will be found in recognizing it. The whole plant is insipid and inodorous, and has been used as a substitute for the cultivated Spinach.

13. C. ficifo'lium, Smith. (Fig. 491.) Fig-leaved Goosefoot. Leares orate-oblong, with ovate-oblong lanceolate obtuse teeth, the lower ones sub-trilobate and toothed, the upper linear, lanceolate, entire; flowers in nearly leafless cymose spikes; seed smooth, shining, with pitted dots.

English Botany, t. 1724.-English Flora, vol. ii. p. 13.-Hooker, British Flora, vol. i. p. 143.-Lindley, Synopsis, p. 214.

Root branched, fibrous. Whole plant less glaucous and powdery than the abore. Stem erect, branched, and spreading, about two feet high, green, purplish at the base, roundish, or angular and furrowed, with pale yellowish lines, sometimes present. Leares numerous, alternate, on clianneled footstalks, purplish at the base, paler beneath, with a mid-rib and branched reins, the lower ones somewhat three lobed in a hastate manner, and with irregular teeth, tapering at the point, and elongated at the base down the footstalk, the upper ones linear lanceolate, quite entire, while the intermediate ones are oblong lanceolate, obtusely toothed, one or two at the base on each side larger than the others. Flowers green, in crowded oblong clusters, in terminal and axillary almost leafless branched spikes. Perianth in five oblong 



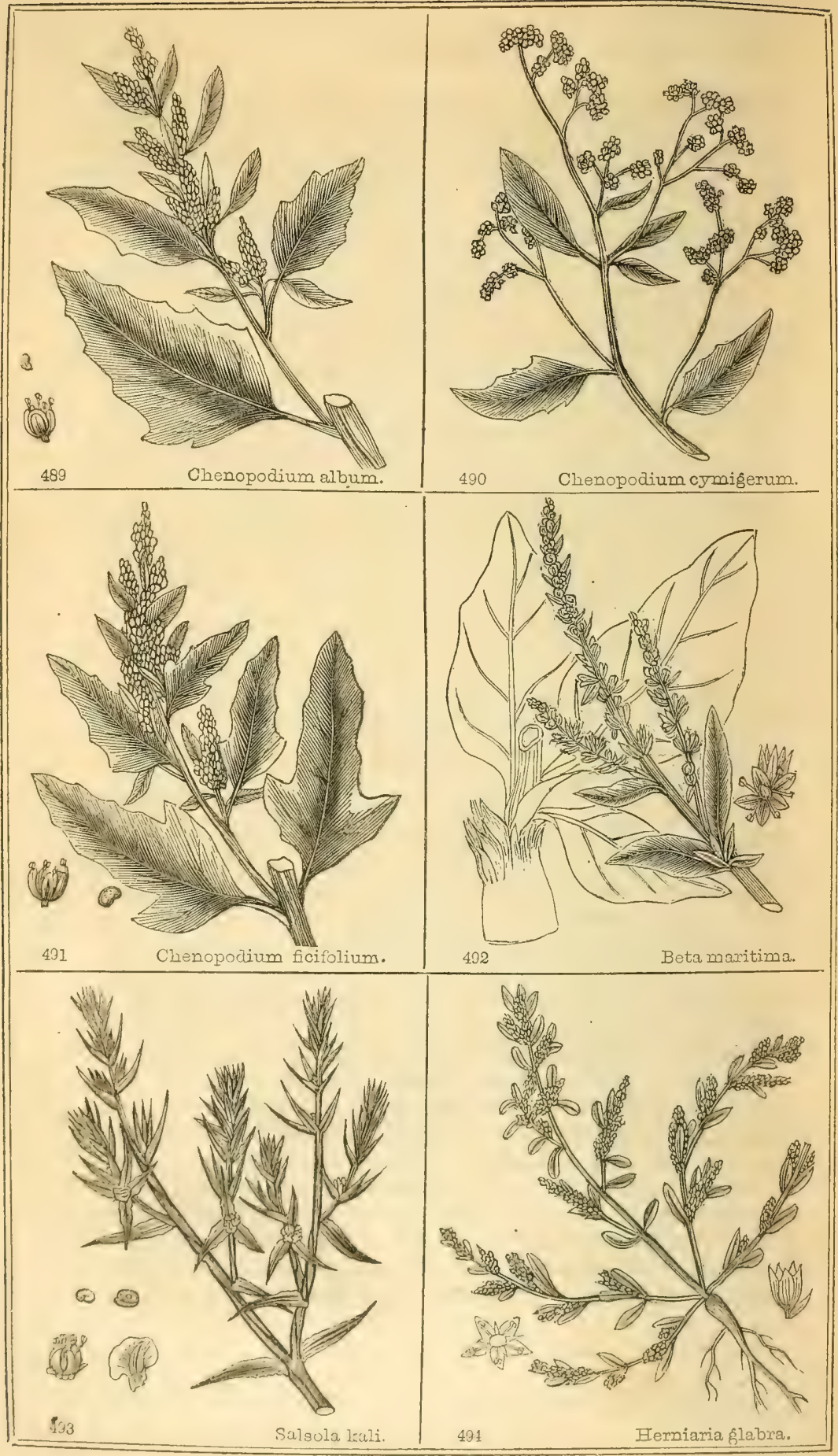


acute segments, green, with a pale thin membranous margin. Stamens shorter than the perianth, with small oblong yellow anthers. Fruit roundish, compressed, enclosed in the dried perianth. Seed roundish, kidney-shaped, black, shining, with numerous small irregular deep pitted duts.

Habitat.-Waste places, dunghills, \&c.; not common. About Loudon and Yarmouth.

Annual; flowering in August and September.

Readily distinguished from $C$. album, by its dotted seeds, to which it is nearly allied in the shape of its leaves, and the whole habit of the plant.

\section{GENUS XC. BE'TA.-Linn, Beet.}

Nat. Ord. Chenupódex. Vent.

Gen. Char. Perianth single, half inferior, five-cleft, persistent Stamens inserted into the fleshy top of the germen. Fruit kidneyshaped, enveloped in the capsular base of the calyx. Seed with a coriaceous covering. Flowers two or three, united at the base.Name from the Celtic worl bett, according to Theis, which means red; others suppose it to come from the Greek word $\varepsilon v \tau \lambda \circ$, bietola.

1. B. maritima, Linn. (Fig. 492.) Sea Beet. Stem procumbent at at the base; flowers sessile, solitary, or in pairs in the axis of the leaves of the spike; segments of the calyx entire; leaves ovate, obtuse.

English Botany, t. 285.-English Flora, vol. ii. p. 17.-Hooker, British Flora, vol. i. p. 143.-Lindley, Synopsis, p. 216.

Root large, thick, tapering, fleshy, black externally, white within. Stem procumbent at the base, from one to two feet high, angular, furrowed, green, with reddish longitudinal lines, branched and leafy. Leares of a dark green, succulent, entire, with a wared margin, stout mid-rib, and branched reins, those arising from the root and lower part of the stem large, ovate, obtuse, spreading, on channeled footstalks, dilated at the base, those of the stem nearly sessile, alternate, wared, and somewhat lanceolate. Flowers small, greenish, sessile, one or two together in the axis of the small leaves of the spikes, which are long, numerous, terminal and lateral. Perianth single, of five spreading obtuse segments, inserted about the middle of the germen. Stamens five, on short awl-shaped filaments, about as long as the perianth, inserted into the fleshy ring surrounding the germen. Anther's ovate, of two cells, yellow. Styles two, occasionally three, very short. Fruit kidney-shaped, imbedded in the fleshy capsular base of the calyx. Seed horizontal, corered with a leathery coat, two FOL. I. 
or three in the germen, which mostly becomes granulated, and reddish or purple.

Habitat.-Sea shore, especially in a muddy soil; not unfrequent.

Perennial ; flowering in August,

This species is regarded by some authors as a variety of $B$.vulgaris, from which it seems to differ only in having two or three flowers together instead of three or four; and Smith observed that according to Linnæus the keel of the calyx is entire, which is not so in B. vulgaris.

Several varietics of Beet are cultivated for various purposes. The common garden Beet is a well known vegetable; its leares are eaten in the Spring like Spinach, and the stems and mid-ribs of the leaves are blanched hy earthing them up, and make an excellent delicate dish used as chard; the roots are a fine dark colour, and are used in salads, soups, \&c., and with vinegar form a good and beautiful pickle, much used in urnamenting side dishes, \&e. Another kind is commonly known by the name of Mangel Wurzel, a root of scarcity. This plant is now cultivated in many parts of the country to a considerable extent, and is an excellent winter provender for sheep and cattle; its root, which is the part of the plant for which it is chiefly grown, yields an abundance of nutriment, from the great quantity of saccharine matter which it contains. It is surprising to what a large size the roots by being grown in a deep rich soil will attain, their weighing from twenty to thirty pounds is not an uncommon size, but sometimes they have been grown to near sixty pounds. These roots made into poultices are considered a better and a more useful application to irritable ulcers than those of carrots. The cultivation of the Beet is far more important in France than with us, for from its roots nearly the whole of the sugar which they consume is obtained; for this purpose the white Sicilian Beet is preferred, from its containing the greatest portion of saccharine matter. Although great improvements have been made in the preparation of the Beet sugar, it is not considered near so good as that oltained from the cane. The dried roots of Beet, after the juice has been for the most part extracted from them, used in the same way as malt, are said to make a good and wholesome kind of beer; and the dark red coloured roots are not unfrequently employed to heighten the colour of claret wine.

\section{GENUS XCI. SAL'SOLA.-Linn. Salt-wort.}

Nat. Ord. Crienopódex. Vent.

Gen. Cnar. Perianth single, inferior, five-partite, persistent, the segments after towering producing from the back a transverse 
appendage. Stamens inserted into the hase of the perianth. Fruit a depressed membranous utricle. Seed solitary, with a membranous covering. Embryo spiral.-Name from Sal, salt.

1. S. Kali, Linn. (Fig. 493.) Prickly Salt-ucort. Stem herbaceous, prostrate, with spreading branches; leaves rough, awl-shaped, with a spinous point; flowers axillary, solitary; perianth of the fruit cartilaginous.

English Botany, t. 634.-English Flora, vol, ii. 1. 18.-Hooker, British Flora, vol. i. p. 143.-Lindley, Synopsis, p. 214.

Root of numerous branched fibres. Stems numerous, prostrate, with spreading branches, from six to twelve inches long, roundish, furrowed or striated, with green and yellow longitudinal lines, rough, with short thick hairs, frequently almost smooth at the base, and sometimes almost entirely so, except the euds of the branches. Leaves alternate, numerous, aw l-shaped, fleshy, angular, channeled abore, with a mid-rib and obtuse margius, except at the base, where it is somewhat dilated, with pale narrow membranous entire or toothed margins; the point terminating in a sharp hard rigid cartilaginous spine, pale, smooth, and shining, especially when dry. Flowers solitary, sessile, in the axis of the leaves from the base upwards, of a pale pink or white, and with mostly three leaf-like bracteas as the base of each. Perianth of five deep ovate acuminate segments, converging over the centre of the flower, each three ribbed, and at the back about the middle a transverse prominence, which after flowering dilates into a thin roundish cartilaginous appendage, with a thin pale jagged membranous margin, and rein-like ramifications branching into it; this appendage spreads around, while the points of the segments above it closely converge orer the fruit. Stamens on slender filaments, longer than the perianth, with rather large ovate anthers, yellow. Styles two, sometimes three, short, united at the base. Stigmas spreading. Fruit a thin depressed pale brown membranous utricle, enveloped in the perianth, and crowned by the persistent styles. Seed solitary, roundish, compressed, almost flat, its pericarp membranous, pale brown, finely dotted, without albumen, the embryo of two spiral lobes.

Habitat.-Sandy sea shores; frequent.

Annual; flowering in July.

Saltwort is one of the plants grown on the sea coast and small islands in various parts of Europe, especially on the coast of Spain, and various other parts of the Mediterranean, and burned for the soda which it contains, which is known in the unwashed state, combined with the ashes of the plant, under the name of barilla; but within the last few years, the improrements made by the chemical manufacturers are such as to convert various hinds of their refuse, after being employed in the making of other articles, and especially the Muriate of Socti (common salt), after having being used in the process of making 
chlorine gas in the manufactoring of chloride of lime, is readily made into carbonate of soda, and at a much lower price than it can be afforded for by the former process of making it from Salsola and other like plants: consequently its growth is now much less attended to than formerly.

\section{GENUS XCII. HERNIA'RIA.-LinN. Rupture-wort.}

Nat. Ord. Panony'chiez, St. HiL.

Gen. Char. Calyx five-partite, slightly coloured within, persistent. Stamens five, alternating with five filiform entire petals, sometimes wanting. Styles very short, or wanting. Stigmas obtuse. Capsule membranous, indehescent, single sceded, covered by the calyx. -Named from the supposed use of the plants in the cure of Hernia.

1. H. gla'bra, Linn. (Fig. 494) smooth Rupture-uort. Leaves elliptic, oblong, attenuated at the base, smooth; flowers about ten, in crowded axillary clusters; calyx smooth.

English Botany, t. 206.-English Flora, vol. ii. p. 8.-Hooker, British Flora, vol. i. p. 144.-Lindley, Synopsis, p. 61.

B. hirsuta. Stem, leaves, and calys, more or less clothed with hairs.

H. hirsuta, Linn.-English Botany, t. 1379.-English Flora, vol. ii. p. 9.-Hooker, British Flora, vol. i. p. 144.-Lindley, Synopsis, p, 61 .

Root tapering, long, with decp branched fibres. Stems numerous, much branched, laying prostrate upon the ground, round or slightly angular, smooth, sometimes hairy, leafy, slender, occasionally putting out roots from the axis of the leaves. Leaves opposite, ovate-oblong, attenuated at the base into a very short footstalk, with a mid-rib and two obscure lateral ones, smouth, or more generally the margin is fringed with white transparent hairs, the floral leaves alternate, mostly narrower than the others. Stipules between the leaves, large, ovate, acute, with a ciliated margin, pale, thin, white, membranous. Flowers small, pale green or yellowish, sessile, about ten, in crowded clusters in the axil of the leaves, or opposite to them. Calyx of five ovate acute segments, green, somewhat striated, concave within, and slightly coloured at the base, the margin with a pale narrow border. Petals five, narrow, pale, thin, awl-shaped, alternating with the five stamens on filaments, shorter than the calyx, and with orate rather large yellow anthers. Both the petals and stamens are inserted into a fleshy disk at the base of the calyx. Styles very short, or wanting. Stigmas small, obtuse. Capsule enveloped in the persistent calyx, oblong, acute, formed of a membranous covering indehescent, singlc sceded. Seed small, roundish, shining black. 
Habitat.-Sandy or gravelly soil; rare. About the Lizard Point. Cornwall.-Rev. J. S. Tozer. Near Newmarket.-Rev. Mr. Hensted. Perennial; flowering from June to August.

We hare sought in *ain for some prominent characters between the plants distinguished as $H$. glabra and hirsuta; in every particular we find them the same, except in that of hairiness; but this is of so very variable a character as not to be constant in either one or the other. It is true we have plants, both natives, and from the Continent, some of which are quite smooth, and the others with the stem, leaves, and calyx hairy; but we have also numerous specimens in erery intermediate stage between the two states, so as to leare it doubtful to which species they belong; and after having watched with care the plants in different situations in Portugal, where they grow abundantly, we cannot longer think they are other than varieties of one species. It is a rery different plant from the $H$. incana, Lam., which is very hairy, with oblong lanceolate leares, and about three, not ten, flowers in a whorl, and it differs from $H$. alpina, Till, which has uvate-oblong leares, ciliated on the margin, and about one flower in the axis of the upper leares, and the calyx is hairy.

Fupture-wort was formerly supposed to possess the power of reducing hernia; but happily for us in our times so dangerous a malady is not left to the supposed efficacy of any plant. The whole herb is inodorous and insipid.

\section{GENUS XCIII. ULA'US.-LINN。 Elm。}

Nat, Ord. Uluí'Ce. Mirb.

Gen. Char. Perianth single, superior, bell-shaped, of four or five teeth, persistent. Stamens mostly five, but rarying from three to six. Stigmas sessile. Capsule membranous, compressed, winged all round, single seeded.-Named, according to Théis, from the Anglo-Saxon Elm.

1. U. campes'tris, Linn. (Fig. 495.) Common small leaved Elm. Narrou leared English Elm. Leaves rhomboid, orate, acuminate, wedge-shaped, and oblique at the base, always scabrous above, doubly and irregularly serrated, serratures incurred, downy beneath; branches wiry, slightly corky when young, bright brown and pubescent; fruit oblong, deeply cloven, naked.

English Botany, t. 1836.-English Flora, vol. ii. p. 20.-Hooker, British Flora, vol. i. p. 144.-Lindley, Synopsis, p. 226.

Trunk mostly crouked, seldom straight, with rough rugged bark, its branches widely sprearling, zigzag, brown, leafy, more or less winged, with corky excrescences, and when young more or less downy, slender 
and wiry. Leaves alteruate, rhomboid, ovate, from one to two inches long, with an acuminated point, unequal at the base, in a wedgeshaped manner, the margins irregularly and doubly serrated, the larger teeth curved upwards, dark green on the upper side, and rough, with short rigid points, paler beneath, and scattered over with bairs, the mid-rib and almost straight lateral veins pale, prominent, and mostly in the axis of the ribs the pubescence is most abundant. Flowers much earlier than the leaves, in dense tufts, bursting through the brown scaly buds, each elevated on a short footstalk, and having at its base a small oblong bractea, mostly fringed on the margin. Perianth of one piece, with a limb of four oblong pale pinkish lobes, with minutely fringed margins. Stamens four, on longish filaments, bearing dark purplish ovate two celled anthers. Stignas a downy line on the upper margin of the pointed curved short styles, which at length become much dilated into a thin palish green membrane, of an oblong wedge-shaped form, forming a winged border to the small oblong pale brown shining single seeded capsule, the point with a deep dilated sinus at the apex.

Habitat.-Woods and hedges; most frequent in the South of England, especially in Norfolk and Sussex.

Tree; flowering in March and April.

This is considered the most valuable of our Elms for the durability of its wood, being harder, tougher, and less liable to decay when exposed in damp situations, qualities rendering it more suitable for various purposes, especially the nave of wheels and instruments of husbandry. It is a large tree, with crooked trunk and branches, not producing flowers until it has attained its almost full size.

2. M. sub'erosa, Elcrh. (Fig. 496.) Common Cork-barked Elm. Leaves nearly orbicular, acute, obliquely cordate at the base, sharply, regularly, and doubly serrated, always scabrous above, downy beneath, especially in the axilla; branches spreading, bright brown, winged, with corky excrescences, when young very hairy; fruit nearly round, deeply cloven.

English Botany, t. 2161.-English Flora, vol. ii. p. 21 -Hooker, British Flora, vol. i. p. 144.-Lindley, Synopsis, p. 226.

Trunk mostly straight, with rigid spreading branches, mostly much clothed with thick corky excrescences, split into deep fissures, of a palish brown colour, the young shoots covered with a soft downiness. Leaves much larger than the last species, roundish, oblong, with an acute point, and oblique unequal somewhat heart-shaped base, the margins sharply, mostly regularly and doubly serrated, always rough above, with short rigid points, paler beneath, and hairy, with a strong mid-rib and straight lateral veins, the axis with dense tufts of pale hairs. Flowers much earlier than the leaves, in dense tufts, bursting through the brown scaly buds, rach flower elevated on a short stalk, 
with a small oblong smooth bractea at the base. Perianth of one piece, the limb of fuur or five roundish oblong reddish green lobes, smooth, or somewhat hairy. Stamens four or five, with long filaments, and ovate purplish two celled anthers. Stigmas downy. Capsule roundish oblong, yellowish green, deeply notched at the apex to the oblong, brown, shining, single seeded cells.

Habitat.-Hedges; frequent.

Tree; flowering in March and April.

This species, probably not indigenous, is readily distinguished by the shape of its leaves, the form of the tree, and the much winged branches, with corky excrescences, which crack into deep fissures, and fall off as the branches increases in thickness. Numerous rarieties are produced by cultiration, in the shape of the leares, and the more or less winged excrescences of its bark. The wood appears less durable in its quality than the last species. Both are more or less cultivated in almost all parts of Italy, planted on the borders of the fields, intermixed with poplar, maple, and other trees. The leading branch is cut off when the trees are young to force it to put out more numerous and stronger lateral branches. On the trunks of these trees the more slender stem of the vine is trained, and its pliant brauches festooned in every graceful form of its native elegance give a beautiful character to the landscape, and are a rich feature in the scene, especially in the Autumnal months, when laden with the generous fruit, deeply blushing in its purple hues.

3. U. ma'jor, Smith. (Fig. 497.) Dutch Cork-barked Elm. Leaves ovate, acuminate, very oblique, and subcordate at the base, sharply, doubly, and regularly serrated, always scabrous above, pubescent below, with dense tufts of white hairs in the axilla; branches spreading, bright brown, much winged, with corky excrescences, when young nearly smooth; fruit orate, slightly cloven.

English Botany, t. 2542.-English Flora, rol. ii. p. 22.-Hooker, British Flora, vol. i. p. 144.-Lindley, Synopsis, 1) 226.

Trunk straight, with rigid spreading or slightly drooping branches, mostly very rugged, and thickly clothed with corky excrescences, of a smooth brown colour, the young shoots scattered orer with soft pubescence. Leaves larger than the last species, orate, with an acuminated point, rather long and slender, very oblique at the base, in a somewhat heart-shaped manner, the margin deeply serrated, with sharp, regular, doubly serrated, somewhat curved teeth, always scabrous above, paler and downy on the under side, with dense tufts in the axis of the prominent mid-rib), and nearly straight lateral veins, the footstalk short and thick. Flouers numcrous, much earlier than the leares, in dense tufts, bursting through the brown obtuse scaly buds, each flower on a short footstalk, from the base of a small lanccolate bractea. Perianth of one piece, the limb of four or five short roundish oblong segments; 
mostly fringed on the margin with short hairs. Stamens three, four, or five, on slender purple filaments, with orate two celled purple anthers. Stigmas curved, downy. Capsules large, obovate, pale green, the cleft at the apex not reaching half way down to the single seeded smooth brown ovate cell.

Habitat.-Hedges in various parts of England.

Tree; flowering in March.

This, like the last species, appears a doubtful native. Smith quoting Miller says, "This Elm was brought from Holland in King William's reign, and being recommended fur its quick growth, was a fashionable tree for hedges in gardens, but afterwards fell into disuse." He adds, "the woud is good for nothing, so it is almost banished from this country." It is not unfrequent in Italy, but by the Italian Botanist not considered distinct from the last species.

4. U. gla'bra, Miller. (Fig. 498.) Smooth-leaved, or Witch Elm. Leaves ovate-lanceolate, acuminate, doubly and erenly serrated, wedgeshaped, and oblique at the base, becoming quite smooth above, smooth or glandular beneath, with a few hairs in the axilla; branches bright brown, smooth, slender, drooping; fruit obovate, deeply cloven.

English Botany, t. 2248.-English Flora, vol. ii. p. 23.-Hooker, British Flora, vol. i. p. 145.-Lindley, Synopsis, p. 226.

ß. glan'dulosa, Lindley. Leaves very glandular beneath.

$\gamma$.latifulia, Lindley. Leaves oblong, acute, rery broad.

A tall tree, with straight trunk, its branches smooth, drooping or spreading, slender, wiry, the young shoots only in their early growth covered over with a slight soft downiuess. Leares orate-lanceolate or ovate-oblong, with an acuminated point, obliquely wedge-shaped at the base, the margins doubly, evenly, somewhat coarsely serrated, of a firm texture, the upper side smooth, the under at first scattered nver with a few hairs, and somewhat glandular, hecoming smooth, except on the ribs and their axilla, paler than the upper, the mid-rib and almost straight lateral veins paler and prominent. Flowers in dense crowded tufts before the leaves appear, almost sessile from the bosom of an oblong downy bractea. Perianth of one piece, downy, the limb of five obtuse short segments. Stamens on long slender purple filaments, with small orate two celled purple anthers. Capsule obovate, pale green, deeply cloven to the apex of the ovate smooth brown single seeded cell.

Habitat.-Hedges, plantations, \&c.; not unfrequent in many parts of England.

Tree; flowering in March. $\beta$. near Ludlow.-Professor Lindley. $\gamma$. at West Hatch, in Essex.-Mr. Forster.

To this species Professor Lindley observes, the Dowton Elm and Sicampston Elm of the nurseries probably belong. 


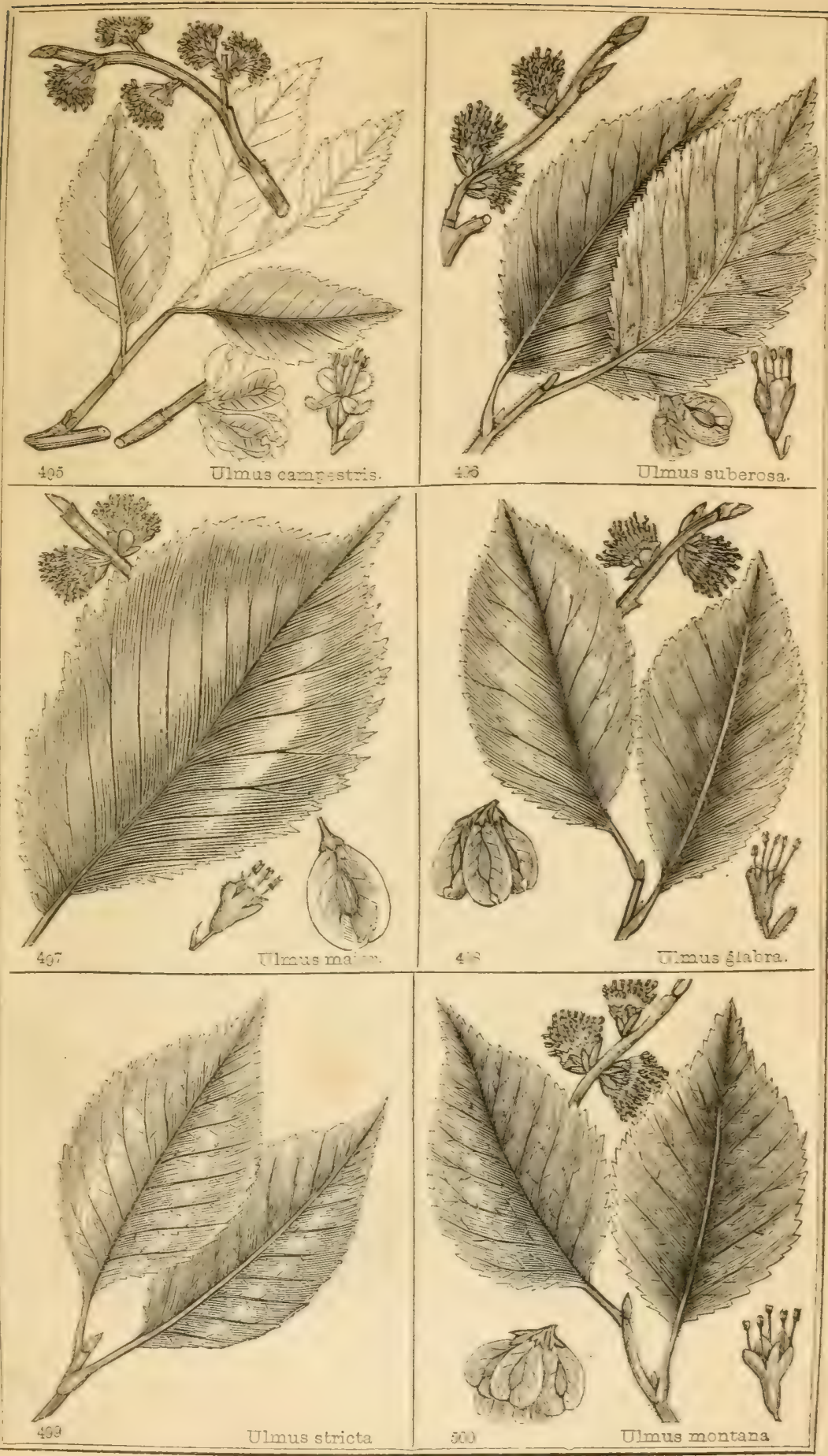



5. U. carpinifolia, Linn. Horn-beam leaved Elm. Leares ovate, acuminate, coriaceous, strongly veined, simply crenate, serrate, slightly ohlique and cordate at the base, shining, but rather scabrous above, smooth beneath; branches bright brown, nearly smooth, fruit-?

Lindley, Synopsis, p. 226.-Hooker, British Flora, vol. i. p. 145.

Habitat.-Four miles from Stratford Avon, on the road to Alcester.

Tree.

This species we are unacquainted with. The description is that of Professor Lindley, as given in his Syuopsis of the British Flora.

6. U. stric'ta, Lindley. (Fig. 499.) Cornish Elm. Leaves obovate, cuspidate, wedge-shaped at the base, evenly and nearly doubly crenate, serrate, strongly veined, coriaceous, rery smooth and slining above, smooth beneath, with hairy axillæ; branches bright brown, smooth, rigid, erect, very compact, fruit-?

$\beta$. parvifolia, Lindley. Leaves much smaller, less oblique at the base, finely and regularly crenate, acuminate rather than cuspidate.

Lindley, Synopsis, p. 227.-Hooker, British Flora, vol. i. p. 145.

Habitat.-Cornwall and North Devon; $\beta$. the less common.Lindley.

Tree.

Of this species we know nothing more than from dried specimens: the description is that of Lindley, who-appears to have given much attention to this genus, and truly observes, that " nothing can be more imperfect than the state of our knowledge of either our domestic or foreign elms. The whole genus requires to be carefully studied by some one who can observe the species in different states of growth, and also ascertain the quality of their timber ;" and he says, "I have no doubt that all here enumerated (referring to the above and following species) are distinct; and it is probable that the Wormsley Grange or Byford Elm of Hertfordshise, and the Black Elm of Ireland, are other species to add to our Flora." But, as he further very justly remarks, "let it always be remembered, however, that it is not from dried specimens that such a genus as this can be understood."

7. U. mon'tana, Bauh. (Fig. 500.) Broad-leaved Elm, Witchhasel Elm. Leaves obovate, cuspidate, doubly and coarsely semated, wedgeshaped, and nearly equal at the base, always very scabrous above, downy beneath; brancles smooth grey, drooping; fruit roundish ob. long, scarcely cloven.

English Botany, t. 1887.-English Flora, vol. ii. p. 22.-Hooker, British Flora, vol. i. p. 145.-Lindley, Synopsis, p. $22 \%$.

A large tall spreading tree of quick growth, with soft inferior wood, the branches spreading, and frequently weeping, slender, clothed with grey bark, smooth, except when in a young state they are downy. Leates broadly ovate, with a long point, and roundish, wedge-shaped at the base, the margins deeply, acutely, doubly, and coarsely serrated,

vor. $x$. 
the upper surface rough, with short rigid points, the under paler, and scattered orer with pale hairs, more abundant at the axilla of the midrib, and prominent almost straight lateral reins. Flouers in rather loose iufts before the leares appear, bursting through a numerous scaly bud, each flower on a rery short footstalk, smooth, or sometimes slightly hairs. Perianth of one piece, the limb mostly of fire orate segments, of a pinkish colour. Filaments long, with purple orate two celled anthers. Stigmas short. C'apsule roundish ohlong, of a pale yellowish green, scarcely notched at the apex, and in the centre is the orate pale brown smooth single seeded cell.

Habitat.-Groves and bedges; frequent.

Tree; flowering in March.

This species is readily distinguished by its large size, spreading or drooping branches and broad leares. It is, Professor Henslow remarks, perhaps the only true indigenous species. It is common in Scotland, and seems without doubt to be wild. Nany varieties of it are obtained by cultiration; and, according to Lindley, the Giant Elm and the Chichester Elm of the nurseries are varieties; and he says this species is often confounded by foreign botanists with $U$. pedunculata, a totally different species, not found in England. It is very nearly related to the $U$. rubra of Nurth Anerica, from which it can be scarcely distinguished by the leares.

This is perhaps the most ornamental and most generally userl of our species of elm; it is of more rapid growth, and obtains a more portly size than the others, rendering it better suited for ornamental scenery in parks, the formation of groves, shady walks, \&c.; and how many of our early associations are connected with the pleasures or the sorrows of scenes over-shadowed by the old elm tree; and what rolumes of ever bidden history do their pendant branches sometimes adumbrate; for

"Beneath those rugged elms, that yew tree's shade, Where heaves the turf in many a mouldering heap,

Each in his narrow cell for ever laid,

The rude forefathers of the hamlet sleep."

Gray.

But it is not only with griefs and sorrows that the noble elm combines; for

"How blithesome were we wont to rove

By rerdant hill or shady grope,

Where fervent bees, with bumming roice,

Around the houey'd oak rejoice,

And aged elms with awful bend,

In long cathedral walks extend !"

Blackstone.

These, howerer, are only its ornamental purposes; but perbaps there are not any other of our native trees, independent of its wood, that hase been applied to so many uses. The spongy cuticle of sorne of the species is similar to that of the Quersus suber, or corb oak, 
but the quantity produced is not sufficient, or its quality so good, as to be used for the purposes of cork. The inuer bark, as well as the leaves, are slightly astringent and mucilaginous, containing extractive matter, with gallic acid, and a small portion of supertartrate of potash. It is the inner bark which has obtained the greatest reputation as a medicine, and was admitted into the Pharmacopeias; and Klaproth, upon examination, found it to contain a peculiar substance, which he called' ulmine. It differs from erery other known body, and must, therefure, constitute a new and peculiar vegetable principle. It exudes spontaneously from the trunk and branches. The sap, too, which frequently exudes from wounds of the trunk and branches in great abundance, was formerly supposed to be useful in the cure of recent ruptures. It is the decoction of the inner bark which has obtained for it the greater reputation, especially in the cure of diseases of the skin; and from the time of Pliny we find it used with rinegar for the cure of scallia, infused in cold water, and taken copiously it purged the body and purified it from flemma ; but in all forms, either of the young buds, the leares, the bark, or root, it was supposed particularly useful in beautifying and cleansing the shin: hence it is that in latter days it has been extolled in the cure of icthyosis and other cutaneous diseases; but as to its curative properties, in some of the obstinate and untractable affections, there is but little opportunity of experience in this country, and the use of the elm bark seems almost confined to the fortn of decoction as a mucilaginous drink in affections of the bidney and bladder. In the northern parts of Europe, in times of scarcity, the inner bark of the elm, as well as that of other trees, has been dried and ground into a fine powder, and made into bread. The leares in many parts of Europe are collected and dried for winter provender for sheep and cattle; and for this purpose also, especially in some parts of Italy and the South of France, the leares of the mulberry, rine, plane, and chestnut, are collected and dried for the same use. What is called British herb, or spurious tea, is mostly the prepared leares of sume species of elm, generally, we believe, the $U$. campestris. This is seldom sold alone, but chiefly used for adulterating the China teas, 


\section{ORDER III.}

\section{TRIGYN'IA. 3 Pistils.}

\section{GENUS XCIV. VIBURN'UM.-Lriss. Guelder-rose.}

Nat. Ord. Caprifolia'ceze. Joss.

Gen. Char. Calyx five-cleft, superior. Corolla bell-shaped, five lobed. Stigmas sessile. Fruit a succulent berry, from one to three seeded.-Name of doubtful origin.

1. V. Lant'ana, Linn. (Fig. 501.) Mealy Guelder-rose, or Wayfaring tree. Leares ovate, acute, heart-shaped at the base, serratocrenate, veiny and rough, with starry down beneath.

English Botany, 1. 331.-English Flora, vol. ii. p. 10\%.-Hooker, British Flora, vol. i. p. 146.-Lindley, Synopsis, p. 132.

A large much branched shrub, or small tree, with numerous round smooth pliant opposite brauches, with reddish brown somewhat shining bark, the young shoots green, and thickly clothed with a mealy pubescence. Leares opposite, deciduous, ovate, with an obtuse or acute point, mostly keart-shaped at the base, sometimes obliquely so, one side longer on the channeled footstalk than the other, the margin crenated, or between crenated and serrated, with a strong mid-rib and numerous branched reins beneath, which, as well as the footstalk, are clothed with a thick mealy downiness, of beautiful star-like tissue, as well as the whole under side of the leaf, which is paler than the upper, where it is less downy, and the down not so much stellated. Inflo. rescence a terminal cyme, on short furrowed footstalks. Flowers numerous, white, crowded, regular. Bracleas several, small, linear, acute, downy. Calyx of five small ovate obtuse segments crowning the fruit. Corolla of one petal, bell or funnel-shaped, with a short tube, and the limb of five obtuse nearly equal spreading lobes. Stamens with slender flaments, as long as the corolla, and ovate yellow anthers. Stigmas obtuse, sessile.- Fruit a compressed berry, at first red, becoming black, with a little mealy pulp, and mostly one large flat furrowed seed.

Habitat.-Woods and hedges, especially in a chalky or lime-stone country, but very common. Dunglass glen, in Scotland.

Shrub; llowering in May.

The Wayfaring tree is not a shrub of either much beauty in its appearance, nor is it applied, that we are aware of, to any particular use. The leares change to a clark red in autumn. From the bark, lind lime may be made, but it is inferior to that of the Holly, (page 206;) and Pallas informs us, that in the Crimea the young shoots are 
used for the purpose of making tubes for tobacco pipes. This is supposed to be the plant mentioned in Virgil,

"Quantum leuta solent inter viburna cupressi."

The pubescence upon the leaves is a beautiful ohject for examination under the microscope, and a good example of stellated down.

2. V. O'pulus, Linn. (Fig. 502.) Common Guelder-rose, or Water Elder. Leaves three or five lobed, smooth, the lobes acuminated, toothed, petioles with glands, the outer flowers radiant, larger, neuter.

English Botany, t. 332.-English Flora, vol. ii. p. 107.-Hooker, British Flora, vol. i. p. 146.-Lindley, Synopsis, p. 132.

A small much branched tree or slirub, with pale smooth shining bark. Branches opposite, round, rather brittle. Leaves opposite, quite smooth above, large pale green, mostly of three, sometimes of five lobes, each lobe with an acuminated point, and a rather large mostly irregularly toothed margin, paler on the under side, with a stout midrib and numerous hranched veins, smooth, or more or less clothed with pale simple down, especially on the ribs and veins, footstalks channeled above, somewhat dilated at the base, and on the edge towards the top are several cup-shaped glands, and towards the base narrow leafy appendages. Inflorescence large terminal cymes, on short smooth furrowed footstalks, Flowers numerous, crowded, white, those of the centre rather small, bell-shaped, with a limb of five rounded scgments, those of the circumference radiating, much larger, irregular, plane, of five large unequal lobes, and without either stamens or pistils. Bracteas long, linear. Calyx of five very small teeth, crowning the fruit. Stamens with awl-shaped filaments, louger thau the corolla, the anthers yellow, ovate. Stigmas obtuse, sessile. Fruit drooping, fine scarlet, ovate, smooth shining berries, very succulent. Seed flat, ovate, minutely dotted.

Habitat.-IVoods, helges, and coppices; frequent, in damp places in England, Scotland, and Ireland.

Shrub; flowering in June and July.

The leaves in autumn, like the last species, become of a reddish colour. It is an ornamental plant in hedge rows when in flower, and not less so when laden with its drooping bunches of bright scarlet fruit. It is a well known plantation shrub, under the name of Snowball tree, when by cultivation the whole of the corollas of the flowers have expanded nearly as large as those of the radiant ones in the wild plant, and the cymes assume a globose figure, hence it has got the name of snow-ball tree, and makes a pretty variety with other shrubs; but its leaves fall away in winter, which renders it a much less favourite plantation shrub than the Laurestine, another species of this genus, the $V$. tinus, which is not uncommon in Italy and many other parts of the Continent, and is preferable to the others of this genus, as being evergreen, and in warm places continues in flower almost all the year round. 


\section{GENUS XCV. SAMBU'CUS-Linn, Elder.}

Nat. Ord. Caprifolia'cee, Juss,

Gen. Char. Calyx five-cleft, superior. Corolla wheel-shaped, of five at length reflexed lobes. Stigmas sessile. Fruit a succulent

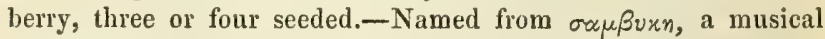
instrument, said formerly to have been made of this plant; and the Greek word is derived from the ITebrew sebeka, a kind of harp, or a triangular instrument, strung with cords; in the Book of Daniel, ch. iii., v. 5, 7, 10, 15, it is translated sackbut.

1. S. Ebu'lus, Linn. (Fig. 503.) Dwarf Elder, or Dane-vort. Stem herbaceous; cymes of three principal branches; stipules leafy, ovate, serrated.

English Botany, t. 475.-English Flora, vol. ii. p. 108.-Hooker, British Flora, vol. i. p. 146.-Lindley, Synopsis, p. 132.

Root fleshy, long, creeping. Stem herbaceous, from two to three feet high, simple, angular, furrowed unequally, roughish, leafy. Leaves opposite, pinnate, with a long striated common footstalk, roughish, slightly dilated at the base, with leafy ovate serrated stipules, and with three or four pairs of leaflets, and an odd one, narrow, lanceolate, from one to four inches long, smooth, dark green, paler beneath, and mostly somewhat hairy, with a prominent mid-rib and numerous branched veins, the margin finely serrated, and the base unequal. Inflorescence a terminal cyme, of three principal smooth or hairy branches, much divided above. Flowers numerous, crowded, purplish, equal. Calyx with five ovate acute persistent teeth. Corolla wheel-shaped, with five ovate acute spreading lobes, at length reflexed. Stamens with awl-shaped filaments, as long as the corolla and large ovate anthers, of a purple colour. Stigmas sessile. Fruit a small round purplish black berry, with from three to five angular seeds.

Habitat.-Road sides and waste places; not rery common in England and Scotland, or Ireland.

Perenuial ; flowering in June.

The root and whole plant has a disagreeable fotid smell, is violently purgative, and sometimes emetic. It is not unfrequently used by the country people, but is a violent medicine. It is said to drive away moles, and its leaves sprinkled in barns and other places will keep away mice, but this we have not found to be the case, nor will those of the following species, as is reported of it also.

2. S. nigra, Linn. (Fig. 504.) Common Elder. Stem woody; cymes of five principal branches; stipules obsolete.

English Botany, t. 476,-English Flora, vol. ii. p. 109,-Hooker, British Flora, vol. i. p. 147.-Lindley, Synopsis, p. 132.

B. leucocarpa. Fruit white. 
$\gamma$. laciniata. (Fig. 505.) Leaflets cut and lacinated.-S. laciniata Mill. Dict.

\$. virescens. Fruit green.-S. virescens, Desf.

A small bushy tree, with opposite branches, of quick growth, frequently putting out shoots a yard long during the year, which are full, of a soft spongy pith, and clothed with a smooth pale shining grey bark, mostly abundantly scattered over with small lenticular glands. Leares opposite, piunate, with striated channeled footstalks, smooth or hairy, with mostly two pairs of leaflets and an odd one, oratelanceolate, with a tapering point and generally oblique base, sessile, or on short partial footstalks, of a deep green, smooth, sometimes hairy, especially on the mid-rib and branched reins of the paler under side; the margin serrated in the variety $\delta$., cut and lacinated. Stipules two fleshy warts at the base of the leares. Inflorescence terminal, cymes of five principal branches, much dirided above. Flowers numerous, regular, cream coloured, with a sweetish faint unpleasant smell. Calyx limb of fire spreading teeth. Corolla wheel-shaped, limb of five roundish ovate segments. Stamens with awl-shaped stout filaments, scarcely as long as the corolla. Anthers oblong, notched, yellow. Stigmas obtuse, sessile. Fruit a dark purplish black small round berry, sometimes, as in the varieties, virescens green, and in leucocarpa white, with three or four seeds.

Habitat.-Woods, hedges, \&c.; frequent.

A Tree; flowering in June.

Perhaps there are nome of our nutive plants applied to so many useful purposes as the elder. The inner bark of the tree was formerly much used, and entered into the list of the Pharmacoprias; it has scarcely any smell, and but rery little taste, except that of slight sweetness, with a degree of acrimony; it was prepared by boiling three handsful in a quart of milk and water till reduced to a pint, one half to be taken at night, and the remainder in the morning, and this repeated for several days; it usually acts both as a purgatire and enietic. The expressed juice in doses of about half an ounce was also giren, medicinally, in many chrouic diseases; it is now, however, except in some country places, out of use. The wood is white, and close grained, and is esteemed as one of our most useful woods for the purpose of making knife handles, skewers, small toys, and ornamental articles. The leaves are strewed about barns to keep away mice, and in the subterranean passages of moles to drive them away, as it is said they have a great ohjection to them; boiling water, in which the leares have been infused, sprinkled orer delicate plants liable to the attack of small insects, protects them from injury, as few insects will feer upon elder: indeed it seems very objectionable, if not poisonous, to most of them. The undeveloped flower buds, when pickled with vinegar, form one of the best substitutes for capers; and the expanded flowers, which have an agreeablesmell, are, when fresh, used in the form 
of tea, which is gently aperient; the dried flowers are also used as tea, to make fomentations, and distilled with water, which has the fragrance of the flowers. It is considered a pleasant and good wash for inflamed eyes; made hot, and with the addition of a little sugar it is taken at bed time to produce perspiration, for the relief of colds, coughs, \&c. ; they are also made into ointment in the same way as the bark, and considered excellent in dispersing of tumors, the healing' of wounds, \&c. The dried flowers are also used to flavour vinegar, and the French scatter them amongst their heaps of apples, or pack them up with their fruits, to communicate to them an agreeable flarour. The ripe berries have a sweetish but rather sickly taste, and yield upon pressure a fine purple juice; when boiled with spices and sugar, and fermented, it forms an excellent kind of wine, much esteemed : taken hot before going to bed, with toasted bread, it is a very favourite remedy with the country people, both as a preventative and cure for colds, and is frequently of great use, as it produces perspiration, and mostly acts as an aperient; it is far from being to most persons an unpleasant remedy. The juice fermented with a small portion of sugar, and treated in the ordinary way of making wine, is by no means despisable; after it has been kept in bottles for some time it deposits part of its colouring matter, with a portion of salt, and bas much the appearance of port wine. The berries are also boiled with sugar into a kind of preserve, and thought to be very useful in sore throats, coughs, and colds; but they are said to be deleterious to poultry, especially to turkeys, if they are, we presume they very seldom eat them, for no trees are more common than the elder in farm yards and hedges in almost all parts of the country, and we know not of any circumstance that has led to the belief of their causing any injury to the poultry which are daily picking about them.

The elder is not much esteemed as an ornamental shrub; it is showy both in flower and fruit: and will grow in almost all situations in the close smoky recesses of towns, as well as in the country, but is heavy looking in its foliage. The variety with lacinated leaves, or the parsley leaved elder, as it is called, is far less objectionable, and there are some very pretty kinds occasionally met with having variegated leaves, which look very pleasing amongst other plants in plantations and shrubberies; but it is liable to lose its variegated appearance, if planted in too good soil, the whole leaves become green.

Paper stained with the purple juice of the berries, is a good test to ascertain the presence of acirls in making chemical experiments. 



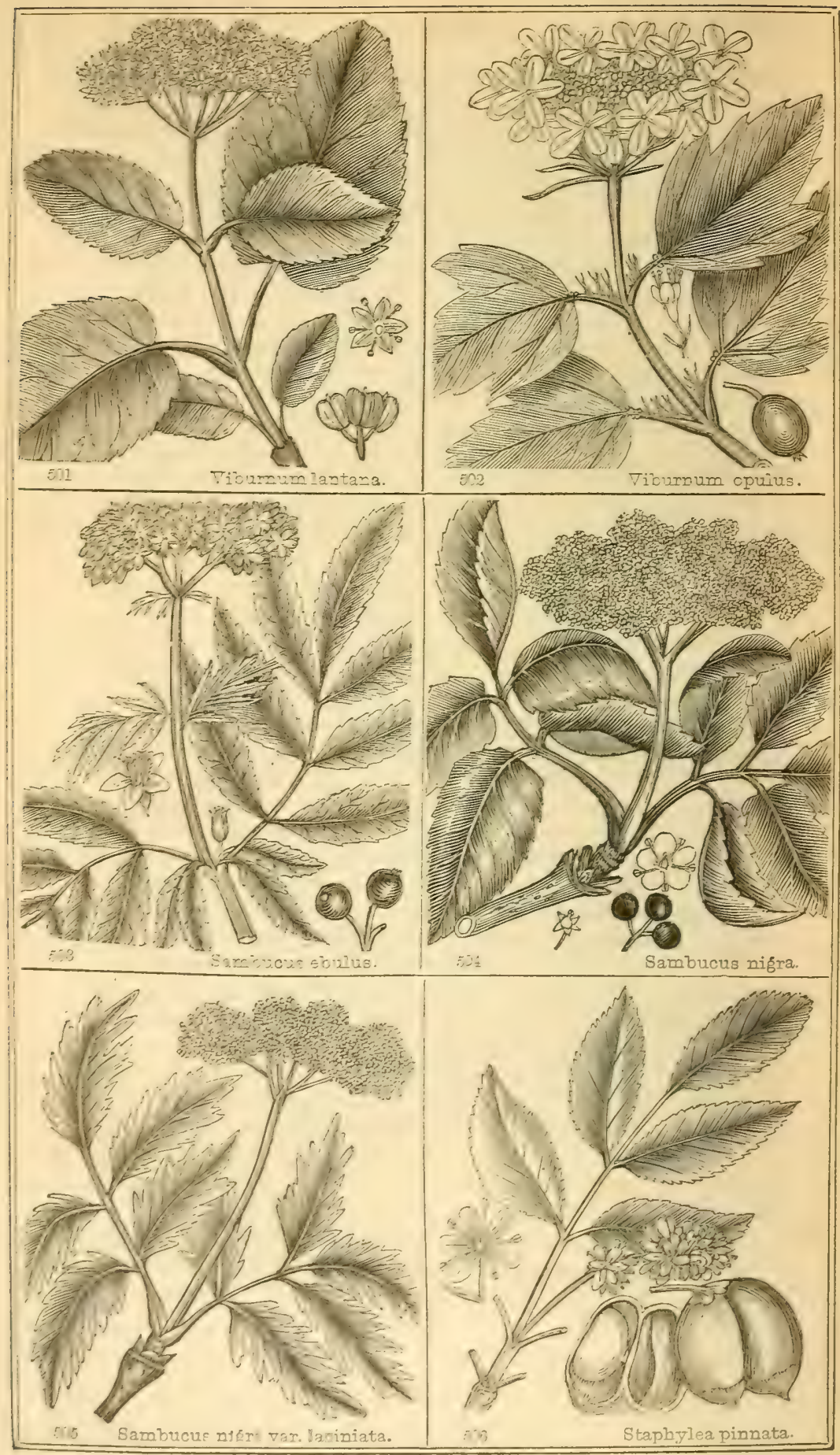




\title{
GENUS XCVI. STAPHYLE'A-DLINs. Bladder-nut.
}

\author{
Nat. Ord. Celastrin'ex, R, Brown.
}

Gen. Char. Calyx five-parted, inferior, coloured, with an urceolate disk at the base. Petals fire. Styles two or three, sometimes united. Fruit a membranous capsule, of two or three cells dehiscing internally. Seeds roundish.-Named from $\sigma r \alpha \varphi \nu \lambda, n$, a bunch of grapes; its flowers being in racemes.

1. S. pinna'ta, Linn. (Fig. 506.) Common Bladder-nut. Leares pinnate; leaflets ovate-lanceolate, five to seven, smooth, serrated; flowers racemose; capsule membranous inflated.

English Botany, t. 1560.-English Flora, vol. ii. p. 110.-Hooker, British Flora, rol. i. p. 147.-Lindley, Synopsis, p. 75.-(Ord. Staphyleacea.)

A branched spreading shrub, five or six feet high, with smooth greenish pale bark, with numerous leaves, similar in appearance to the ash, gracefully drooping on all sides. Leaves pinnate opposite, quite smooth, of a cheerful green, leaflets five to seren, opposite, with a terminal one urate-lanceolate, or orate, with a shortly acuminated point, the margin fine and sharply serrated, paler beneath, with a mid-rib and numerous slender branched reins, common footstalk long, channeled abore. Stipules pale, thin, membranous, soon falling aray hoth from the leares and leaflets. Inflorescence terminal drooping racemes, somew hat panicled. Bracteas small, linear at the base of the partial flower stalks, soon falling away. Flowers not very numerous, drooping, of a pale yellowish green. Calyx inferior, of one leaf, with a limb of five deep oblong obtuse coloured segments, as long as the corolla, haring at its base a culoured large urn.shaped disk. Petals five, alternating with the segments of the calyx, narrower, and of a thinner more delicate texture, inserted into the margin of the disk. Stamens as long as the corolla, with awl-shaped filaments, inserted into the disk, and with roundish yellow anthers. Styles rather long, two, erect, with obtuse stigmas. Fruit a large thin membranous inflated bladdery capsule, of two cells, pointed at the top and open, each containing one or two seeds, bursting internally, and seldom more than one or two capsules perfected on each raceme. Seed globose, hard, bony, light brown, polished, without albumen and thick cotyledons.

Habitat.-Hedges and thickets, but rare; Yorkshire, and about Ashford, in Kent. A very doubtful native, though said by Mr. Hailstone to be truly indigenous about Pontefract.

A shrub; flowering in June.

The Bladder-nut is a large ornamental shrub, frequently planted in shrubberies; its foliage is graceful, and the capsules are curious, remaining on the tree a long time. The seeds are highly polished,

$$
\text { VOL. I. }
$$


and used by the poor people on the Continent, where the plant is more frequent than with us, to make necklaces; they have a sweetish taste when masticated, succeeded by a somewhat nauseous bitterness, and if many of them are eaten produce sickness and romiting. The wood is white and brittle.

\section{GENUS XCVII. TA'MARIX.-Linn. Tamarisk.}

Nat. Ord. Tamariscíner. Des Vaex.

Gen. Char. Calyx four or five parted, persistent, inferior. Petals four or fire. Stamens four or five, or double the number. Stigmas three, long, spreading, glandular, and oblique at the apex. Capsule tapering to a point, of one cell, three valved, and many seeded. Seeds crowned with long simple hairs.-Named from the Tamarisci, a people who inhabit the banks of the Tamaris, now Tambra, in Spain, where the amarisk Tabounds.

1. T. Gal'lica, Linn. (Fig. 507.) French Tamarisk. Smooth glaucous leaves, ovate, acuminate, minute; spikes lateral, numerous; bracteas with a lung tapering point.

English Botany, t. 1318.-English Flora, vol. ii. p. 111.-Hooker, British Flora, vol. i. p. 147.-Lindley, Synopsis, p. 62.

Stem slender, nearly erect, with long drooping slender red shining branches. Leaves minute, glaucous green, ovate, with a long acuminated point, bluntly spined at the base, and embracing the stem. Inflorescence lateral and terminal, spikes becoming after flowering racemose, from the flowers being elevated on short footstalks. Flowers numerous, crowded, pale pink, inodorous, each with a small bractea at its base, somewhat ovate, with membranous margins and a long tapering point. Calyx of five ovate segments, with membranous margins united at the base. Corolla of five uvate oblong petals, three times as long as the calyx. Stamens on long slender filaments, alternating with the petals, dilated at the base, and either distinct or united at the hase, sometimes there are four, or eight, or ten. Anthers small, pink, ovate. Styles wanting. Stigmas three, long, spreading, somewhat feathery, the apex with a rather large oblique gland. Capsule ovate, with a long tapering triangular point, of one cell and three valves, with a central placenta at the base of the ralves. Seeds numerous, small, crowned with a stalked tuft, of a few long white sluining simple hairs (comose).

Habitat.-Rocks, cliffs, and sandy shores near the sea. In most of the coves from the Nore-head to the Land's-end, on St. Michael's Mount, and other places, Cormwall; near Hurst Castle, Hants; and near Hastings; but no where with suspicion of baving been planted.

Shrub; flowering in July. 
The tamarisk is frequent in shrubberies, but a very doubtul rative plant. In Cornwall, where it grows with the appearance of being wild, it is called by the common people Cypress, and forms in many places a beautiful ornamental feuce round gardens and fishermen's huts; and it is commonly beliered amongst the people that a Monk from the Continent, on landing on the Cornish coast, stuck his staff into the ground, and it grew into a tamarisk shrub. It is frequent in almost all parts of the Continent.

\section{GENUS XCVIII. CORRIGIOLA.-LINN. Strapwort.}

Nat. Ord. Parony'chiese. St. Hil.

Gen. Сина. Calyx five-parted, persistent, inferior. Petals five, inserted into the base of the calyx, and as long. Stigmas three, sessile. Capsule corered by the calyx, single seeded. Seed suspended by its cord, which arises from the bottom of the capsule. - Named from corrigia, a strap or thong, from its long pliant stems.

1. C. littora'lis, Linn. (Fig. 508.) Sand Strapwort. Stem leafy among the corymbose fluwers; leares of the stem linear, wedgeshaped.

English Botany, t. 1318.-English Flora, vol. ii. p. 112.-Hooker, British Flora, vol. i. p. 147.-Lindley, Synopsis, p. 60.-(Ord. Illecebrece.)

Root small, tapering, and branched. Stems numerous, much branched, and spreading on the ground in every direction, from six to eighteen inches long, slender, smooth, round, and leafy. Leaves alternate, sometimes opposite, a pale glaucous green, quite smooth, linear, with an acute point, and those of the stem tapering at the base in a werlge-shaped manuer iuto a short footstalk, each having at the base a pair of ovate acute very thin membranous stipulcs. Inflorescence in terminal and lateral corymbose leafy racemes at the end of the branches. Flowers very small, white, on short stalks. Bractea small, lanceolate, membranous. Caly $x$ of five deep obovate segments, nearly as long as the corolla, green. Corolla of five obovate white spreading petals. Stamens with awl-shaped filaments, shorter than the corolla, and small roundish anthers, of a dark purplish colour. Stigmas three, sessile, very small. Capsule eveloped in the calyx, broadly orate, of one cell, single seeded. Seed suspended from the top by its cord, which arises from the base of the capsule, black and shining.

Habitat.-South-west coast of England; rare. Slapham sands, and near the Star point, Deronshire; and at Helston and banks of the Loor, Cornwall.

Annual; flowering in July and August.

This rare little plant is rery common on almost every sand bank in Portugal, where it grows to a much larger size than with us. 


\section{ORDER IV.}

\section{TETRAgYNiA. 4 Pistils.}

\section{GENUS XCIX. PARNAS'SIA.-LinN. Grass of Parnassus.}

Gen. Char. Calyx five-parted, spreading. Petals five, veiny, and opposite the base of each is an heart-shaped fleshy scale, fringed with slender bristles, tipped with globular glands. Stigmas four, sessile. Capsule superior, of one cell, opening at the apex with four valves, each with a linear placenta bearing numerous seeds.Named from Mount Parnassus, though the plant is by no means peculiar to that situation.

1. P. palus'tris, Linn. (Fig. 509.) Common Grass of Parnassus. Scales with from nine to thirteen bristles; root leaves on footstalks, heart-shaped, the solitary one of the stem amplexicaul.

English Botany, t. 82-English Flora, vol. ii. p. 114.-Hooker, British Flora, vol. i. p. 147.-Lindley, Synopsis, p. 67.

Root of numerous long branched fibres. Stem erect, angular, striated, twisted, from " one inch" to eight or twelve high, quite smootl, as is the whole plant, with a solitary leaf below the middle, sessile, and embracing it. Leaves from the root numerous, on rather long channeled footstalks, heart.shaped, more or less acute at the point, not unfrequently rounded, with a mid-rib and several lateral ones from the base, paler beneath, and more or less profusely scattered over with small oblong glands, of a pinkish colour, sometimes wanting, but best seen in dried specimens, they are also numerous on the footstalks and lower part of the stem. Flower solitary at the top of the stem. Calyx five-partite, the segments ovate, acute, with numerous slender longitudiual veins, spreading. Corolla of five broadly ovate obtuse spread. ing concave petals of a beautiful white, with numerous pellucid veins, and sometimes, though rarely, the margin is fringed, the base with a short claw, and opposite to it is a fleshy heart-shaped scale, on a short stalk, having the margin fringed with from nine to thirteen awl-shaped slender bristles, each tipped with a small round yellow gland. Stamens alternating with them, and about the same length, with awl-shaped filaments and oval anthers, pale cream colour, of two cells, bursting longitudinally. Stigmas four, sessile, obtuse, spreading, crowning the capsule, which is broadly ovate, marked with four longitudinal furrows, nearly superior, of one cell, bursting about balf way down from the apex, each with a longitudinal lateral placenta, bearing numerous small brown seeds, curved upwards, with a narrow membranous border all round. 


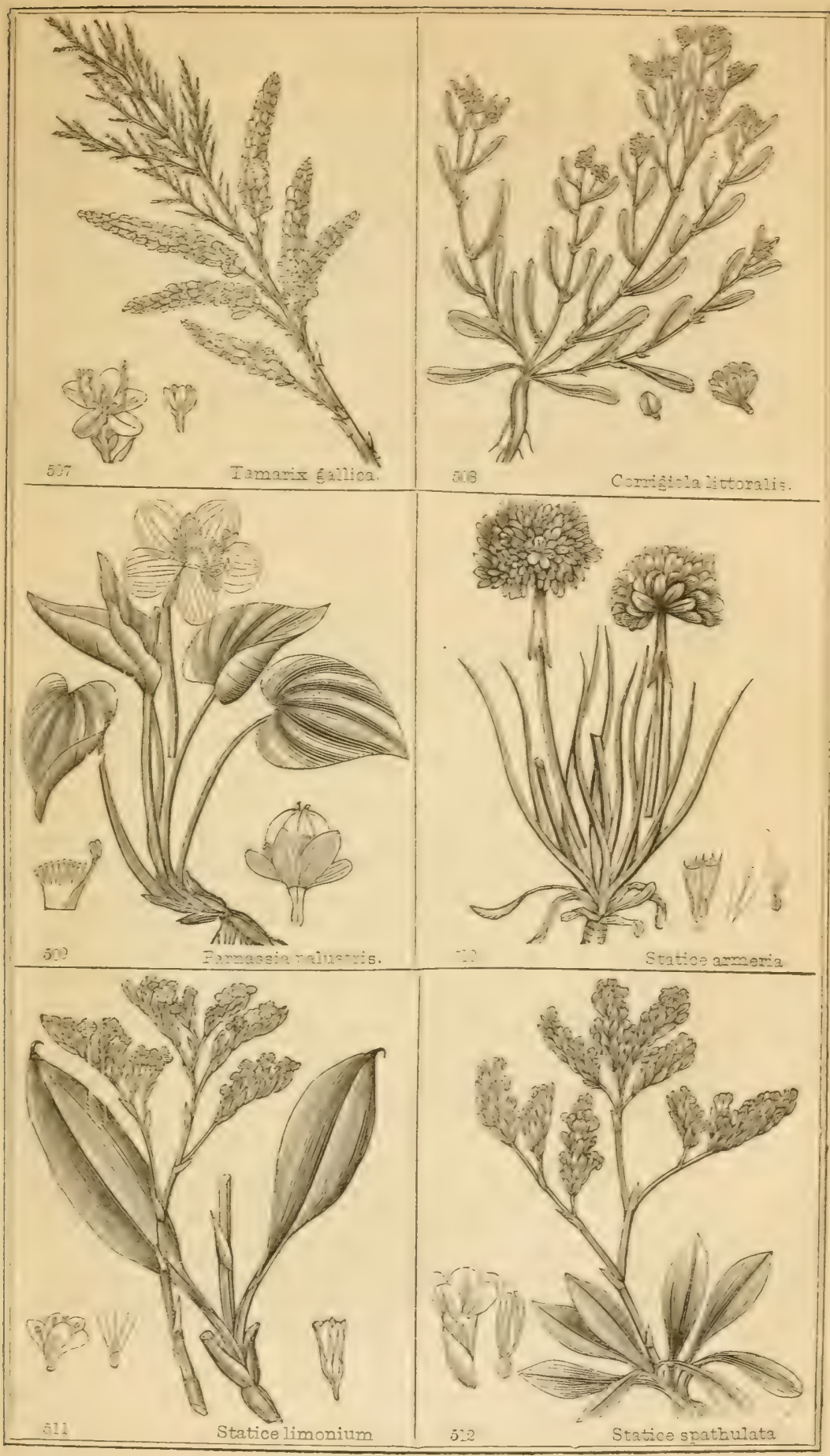



Habitat.-Bogs and wet places; common, especially in the North. Perennial; flowering from August to October.

The grass of Parnassus is one of our most interesting plants, remarkable for the very curious structure of the scales at the base of the corolla, and the stamens are remarkable, from their gradually one by one bending orer the stigmas, and discharging the pollen upon them; when one has performed this office it returns to its former position, and another succeeds it, each stamen going through the same process in like manner; sometimes, but very seldom, two of them may be obserred bending over at the same time. After the whole of the stamens have performed their office, the stigmas which were spreading now close up, the orules increase in size, the capsule enlarges, the numerous seeds are perfected, and then the capsule bursts its sutures at the top for the escape of its progeny to perpetuate and increase its species.

\section{ORDER V. \\ PENTAGYNIA. 5 PistiLs.}

\section{GENUS C. STA'TICE.-Linn. Thrift.}

Nat, Ord. Plumbaginez. Juss.

Gen. Char. Calyx of one piece, funnel-shaped, plaited, dry, membranous, persistent. Corolla of five petals, united at the base, and bearing the stamens. Stigmas five. Capsule enveloped in the calyx, with one seed.-Named from $\sigma \tau \alpha \tau \downarrow \jmath \omega$, to stop; from its supposed qualities in stopping dysentery.

* Flowers collected into a rounded head, inner scales of the involucre tubular at the base.-(Avmeria. De Cand.)

1. S. Armeria, Linn. (Fig. 510.) Common Thrift, or Sea Gilliflower. Leaves linear, single ribbed; scape simple, much longer than the leaves, bearing a round head of flowers; calyx with a striated hairy tube; the limb membranous, with five ribs, terminating in short bristles.

English Botany, t. 226.-English Flora, vol. ii. p. 115.-Hooker, British Flora, vol. i. p. 148.-Armeria maritima, Willd.-Lindley, Synopsis, p. 170.

Root long, woody, branched, dark brown, mostly very scaly and rough at the top, with the fibrous remains of old leaves. Leaves numerous, all radical, tufted, narrow, linear, lax, spreading, somewhat fleshy, dark green, slightly channeled above, with a narrow mid-rib, 
and sometimes, but rarely, two obscure lateral ones, quite smooth, or sometimes with a few pale slender bairs on the margin and mid-rib. Scape erect, round, smooth, or more or less clothed with a close soft downiness, three or four times longer than the leaves, sheathed at the top with a close brown membrane, with a torn edge. Flovers numerous, in a round head, inodorous, rose coloured. Involucre of numerous scales, the outer ones ovate-lanceolate, with a pale brown thin membranous margin, the inner ones broadly ovate, obtuse, almost entirely membranous, united at the base into short tubes, or in a tubular form. Calyx funnel-shaped, the tube striated, with ten ribs, rougb, with hairs pointed upwards, the limb longer than the tube, membranous, with five slender ribs, mostly hairy, continued from the tube, and elongated beyond the edge of the membrane in a short bristle, the pedicle of the calyx smooth, about as long as the tube, obliquely attached to the calyx. Corolla of five oblong obtuse petals, attenuated at the base, separate, or shortly united. Stamens attached to the base of the petals, with slender flaments, shorter than the petals. Anthers oblong, yellow. Styles ciliated, with long naked thread-like stigmas, as long as the stamens. Fruit a one celled ovate. oblong membranous capsule, enveloped in the persistent calyx. Seed solitary, pendulous from the apex of the umbilical cord, which arises from the bottom of the capsule. Albumen fleshy. Embryo straight.

Habitat.--Muddy sea shores, and amongst rocks by the sea side; frequent.

Perennial ; flowering in July and August.

Thrift is so called from its capability of growing in almost any situation, from the clear pure atmosphere of our mountain tops, and the saline breezes of the sea shore to the smoke-loaded air of our close cities and towns. It flowers freely for a considerable period of the summer months, and its bushy grass-like foliage, with its long hard penetrating roots, render it an admirable plant for making edgings to flower borders, \&c., and few gardens, especially in towns, have more suitable borders combining beauty and durability than when made with this plant.

S. plantaginea, a species not unfrequent on the Continent, was found on the west coast of the Island of Jersey, in August, 1833, and is admitted into our Flora by Sir IV. J. Hooker. We, however, much doubt its claim as a British plant. Its leaves are linear lanceolate, from three to five nerved, with a simple scape, bearing a round head of pale purple flowers, the outer scales of the involucre with a tapering point, the inner very obtuse, the calyx limb with five long bristly teeth, and the petals roundish or truncated.

** Flowers on one side on a paniculaled scape.-(Taxanthema, Neck.)

2 S. Limo'nium, Linn. (Fig. 511.) Spreading-spiked Thrift, or Sra Lavender.-Scape roundish, paniculated at the top; leares orate- 
lanceolate, stalked, smooth, with a mid-rih, terminating in a looked bristle.

English Botany, t. 102.-English Flora, vol. ii. p. 116-Hooker, British Flora, vol. i. p. 148.-Lindley, Synopsis, p. 170.

Root long, branched, tough, and woody. Scape erect, from five to ten inches high, round below, angular above, and much branched in a paniculated manner, and more or less rough, with furrows, and with several lanceolate taper pointed membranous scales, and one at the base of each branch of the panicle. Leaves all arising from the root, very variable in size and luxuriance, from two to four inches long or more, ovate-lanceolate, of a somewhat leathery texture, glaucous green, tapering at the base, obtuse at the apex, with a curved bristly point, formed by the continuation of the margin of the leaf and the mid-rib, channeled above, footstalks broad and short, or long, with a broad base continued along the leaf in a mid-rib, and with several small lateral branched veius. Inflorescence a corymbose panicle, alternately branched, spreading, sometimes recurved. Flowers numerous, imbricated, all turned to the upper side, each having at its base about four scales, ovate-lanceolate, with an acute or obtuse point, membranous, or with membranous margins. Calyx funnel-shaped, nearly sessile, the tube short, five ribbed, slightly hairy at the lower part, terminating in five angular teeth of the membranous $\operatorname{limb}$, the margin frequently with small intermediate teeth. Corolla a fine deep blue or purplish pale on the outside, ovate-oblong, obtuse, or slightly notched, tapering at the base into a claw. Stamens arising from the base of the claw, and nearly as long. Anthers small, ovate, yellow. "Pollen with three pellucid dots compressed." Pistils long as the stamens, slender, filiform, smooth. Stigmas rough, with minute papilla. "Germen granulated." Capsule oblong, single seeded, enveloped in the calyx.

Habitat.-Muddy sea shores, and salt marshes; frequent in England and Ireland, rare in Scotland.

Perennial; flowering in July and August.

The roots of the Sea Lavender are astringent and tonic, but in a very slight degree. The flowers are inodorous, of a beautiful colour, and resemble in appearance common Lavender (Lavandula spicata.)

3. S. spathula'ta, Desf. (Fig. 512.) 'Upright-spiked Thrift. Scape round, branched from below the middle; panicle elongated; spikes erect; calyx with blunt teeth; leares spatulate, three ribbed at the base, and a short obtuse point below the apex.

Sims, in Botanic Magaz. t. 1617.-Hooker, British Flora, vol. i. p. 149.-Lindley, Synopsis, Suppl. p. 327.-S. binervosa, Rev. G. E. Smith.-In English Botany Suppl. t. 2663.-S'. Limonium.- 3 . English Flora, vol. ii. p. 116.-Limonium minus.-Ray, Synopsis. p. 202.

Root woody, tapering, branched, crowned at the top with numerous 
remains of old withered leaves. Scape erect, somewhat zig-zag, round, branched from below the middle, its terminal branches angular, furrowed, scattered over with small prominent glands, especially above, and with several lanceolate membranous alternate scales below the middle, and one at the base of each division. Leaves all radical, somewhat leathery, of a glaucous green, small, reflexed, spatulate, with the footstalk of variable length, though never very long, with a mid-rib, slightly prominent on the under side, and terminating in a short obtuse point helow the apex, and besides this there are two lateral parallel ribs, which extend to the middle or below the middle of the leaf, and sometimes there are four of these short ribs, all of which are pellucid when held between the eye and the light. Inflorescence a branched corymbose panicle, of numerous crowded alternate erect flowers, all turned to the upper side. Flowers mostly two together, sessile, surrounded at the base with several orate scales, the outer ones green, leafy, with a pale membranous margin, the inner entire, membranous, sometimes jagged at the apex and sides. Corolla of five roundish ovate purplish blue petals, attenuated at the base into a narrow claw. Calyx funnel-shaped, with a long tube, of a reddish green colour, with five prominent ribs, tapering to about the middle of the pale membranous limb, and at the base are five others, intermediate shorter than the tube, smooth or fringed, with pale hairs pointed upwards, the limb about as long as the tube, pale, thin, membranous, with five roundish obtuse or emarginated segments. Stamens with slender awl-sbaped filaments, shorter than the petals, and ovate white anthers. "Pollen with four or five pellucid dots, compressed. Germen smooth." Styles long, slender, filiform. "Stigmas covered with a reticulation of vesicles, not prominent, much larger than the papillæ of S. Limonium." Capsule ovate, enveloped in the persistent calyx. Seed solitary.

Habitat.-Sea shores, and amongst rock near the sea. Coast of Kent in several places.-Gerard and Rev. G. E. Smith. Shakspeare Cliff, Dover.-Sir W. J. Hooker. Harwich.-Ray. Mull of Galloway, Scotland.-Mr. Goldie. Rocks near Holyhead, and St. Bee's Head, near Whitehaven.-Mr. W. Wilson. Several places in North Wales.-Dr. Howitt, who furnished me with beautiful specimens. Devon.-Mr. Banks. Somerset.-Mr. Christy. Near Baldoyle, Portmarnock, South side of the hill of Howth, Killiney-hill, and many other places on the Kerry coast, Ireland.-Mr. Mackey. North of Ireland.-Mr. Drummond.

Perennial; flowering in July and August.

The luwer branches, both in this species and $S$. Limonium, are sometimes barren. Small plants with the lower branches barren have generally been mistaken for the following species; they are, however, readily distinguished from each other upon careful examination.

4. S. reticula'ta, Linn. (Fig. 513.) Matted Thrift. Scape round, 



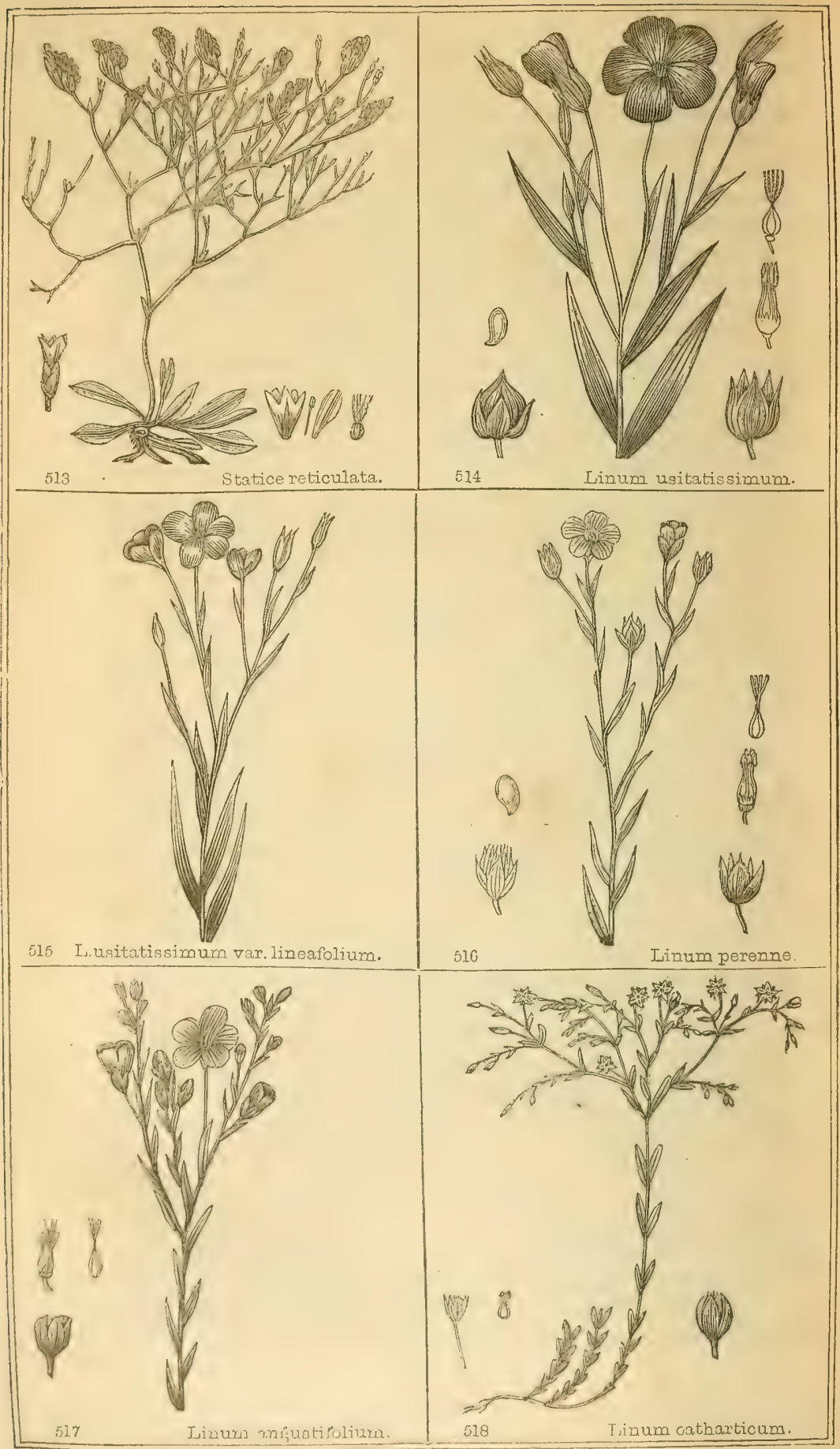


slender, much branched in a paniculated manner from near the base; the branches slender, much dirided, and matted together, the lower ones barren; flowers crowded; calyx with angular teeth; leares spatulate, small, without points.

English Botany, t. 328.-English Flora, vol. i. p. 117.-Hooker, British Flora, vol. i. p. 149.-Lindley, Synopsis, p. 171.

Root of several stout branches, tough and woody, crowned with the crowded withered remains of old leares, and mostly bearing several stems. Scape erect, roughish, with small prominent glands, round, branched from near the base, the branches slender, alternate, much divided, zig-zag, and above matted together, the low er branches always barren. Bracteas small, orate, acute, pale, thin, membranous, one at the division of each branch, and closely embracing it. Leaves all radical, small, spatulate, taperiug at the base into a footstalk of rariable length, chanueled above, the apex rounded or acute, without a point or bristle, single ribbed. Inforescence a much branched corymbose panicle, of slender zig-zag matted branches, the lower ones barren, and mostly reflexed. Flowers small, a pale blueish purple colour, much crowded, in small erect one sided tufts, each having at its base about four orate obtuse scales, green, with membranous margins, or entirely membranous. Calyx funnel-shaped, with a short tube, with five stout ribs, of a reddish colour, tapering into about the middle of the segments of the limb, smooth, or with a few pale erect hairs at the lower part, and sometimes there are small short intermediate ribs, the limb pale, membranous, with fire angular teeth. Corolla small, of five ovate petals, tapering into a claw. Stamens from the base of the petal, with a slender flament, shorter than the petal, and a small roundish anther, yellow. Style and stigmas filiform, as long as the stamens. Capsule small, orate, enclosed in the persistent calyx. Seed solitary.

Habitat.-Muddy salt marshes; rare. Chiefly on the coast of Norfolk; between St. Peter's Poiut and the Washway below Wrisbeach, and at Long Suttou Wash.

Perennial; flowering in July and August.

This is a smaller and more slender spreading plant than either of the ahove species. Its delicate much branched and entangled inflorescence is very remarkable; this, with numerous of the lower barren branches reflexed, readily distinguish it at first sight from the other species. It is seldom more than three inches high, sometimes, howerer, it is six. Small spreading branched specimens of $S$. spatulata have been mistaken for this plant, but they will be found rery different in many respects, especially in the leaf and calyx. 


\section{GENUS CI. LI'NUM.-Linn. Flax.}

Nat. Ord. Li'NEe. DE CAND.

Gen. Char. Calyx of live persistent pieces. Corolla of five petals. Stamens united at the base into a ring, with intermediate teeth opposite the petals, (abortive stamens). Capsule globose, pointed with the indurated base of the style, ten valved, and ten celled. Seeds ovate, compressed.-Named, according to Theis, from Lin, thread in Celtic.

\section{* Leaves alternate.}

1. L. usitatis'simum, Linn. (Fig. 514.) Common Flax. Stem erect, mostly solitary, branched upwards; leaves lanceolate, smooth; sepals ovate, acute, three ribbed; petals crenate.

English Botany, t. 1357.-English Flora, vol. ii. p. I18.--Hooker, British Flora, vol. i. p. 150.-Lindley, Synopsis, 1). 53.

B. lineafolium. (Fig. 515.). Leaves narrow, linear, and the whole plant small.

Root slender, tapering, branched. Stem erect, from two to three feet high, solitary, sometimes two from the same root, round, smooth, finely striated, leafy, slender, mostly much branched in the upper part, the branches erect, or slightly spreading. Leaves lanceolate, quite smooth, a bright cheerful green, sessile, alternate, with three parallel nearly equal ribs, uniting at the point with numerous slender reticulated branches, the lower leaves mostly shorter than the upper, obtuse at the point. Inflorescence a leafy panicle. Flowers solitary, on slender terminal and lateral peduncles, large, fine purplish blue. Calyx of five ovate acute sepals, green, with a pale membranous margin, somewhat ciliated, a mid-rib, and two lateral ones, about half as long as the sepal. Corolla of five broadly ovate petals, tapering at the base into a claw, the margin irregularly crenated, with numerous branched veins. Stamens shorter than the corolla, on slender awlshaped filaments, which are united round the germen in a narrow ring, and between each filament is a small tnoth, opposite the petals, which are abortive stamens. Anthers ohlong. Styles thread-shaped, erect, as long as the stamens, with blunt somewhat capitate stigmas. Capsule globose, smooth, pointed with the indurated base of the styles, formcd of ten valves, and divided with thin membranous partitions irto ten cells, each cell containing an ovate compressed seed, smooth, shining, brown. Embryo straight, and the cotyledons flat.

Habitat.-Corn fields and road sides; not unfrequent, but probably introduced, though now naturalized.

Annual; flowering in July.

Common Flax is one of the most useful of our plants; it is, in fact, called $L$. usitatissimum, from the great uses to which its various parts 
are applied. The stems of several species affurd tenacious fibres, but none are so valuable as those of this species. The stems are macerated for some time in water, until the bark and cellular substance becumo loosened; it is then dried and beaten until the fibrous part is free, and they are then known by the name of flax, which is applied to many useful purposes, being made into linen, \&c. The fibrous substance, which is very tenacious and durable, renders it capable of being spun into such extremely fine threads, and wove into the most delicate fabrics. The fibres are a most beautiful substance under the lens of a microscope of great power, when it will be seen that even the finest filaments are composed of a number of fine tubes; and interspersed amongst these will be seen, when it is in a fresh state, minute particles of greenish matter. This, which is called by vegetable anatomists woody fibre, is thought by some to be only a form of cellular substance, which by compression is formed into elongater tubes, having transverse partitions. There appears, however, some reason to suppose that it is a distinct form of tissue, and that it is tubular, without partitions. The anatomical investigation of regetable substances is one of extreme interest, and opens a wide field, in every step of which new objects of wonder and astonishment are presented requiring our further examination.

The seeds of this plant are known by the name of lineseed; they have an unctuous feel, a mucilaginous sweetish taste, without any remarkable smell. They yield by expression a large quantity of oil, which, when made without the application of heat, has not any particular flavour or taste; it is sometimes used instead of castor oil, but is not either so pleasant in its operation, or so powerful in its effects. It forms with lime water a thin linament, which is considered one of the best applications to scalds and burns; but of late years this seems to be superseded by the use of cotton, or the application of dried wheaten flour to the injured parts. The seeds of flax also give to boiling water a considerable quantity of bland mucilage, which has but little flavour, and is frequently of great use in coughs, hoarseness, and catarrhal affections, as well as in affections of the urinary passages. The flour of the seeds is much esteemed for making poultices for various external affections, and the pulp left after the expression of the oil is formed into cakes, commonly called oil-cake, is used as food for cattle, but if too great a quantity is given, it gives the meat a peculiar flavour, which by many persons is not considered pleasant. The oil, both raw and boiled with litharge, is extensively used in the arts and manufactures, painting, \&c.

2. L. pe'renne, Linn. (Fig. 516.) Perennial Blue Flax. Stems erect, numerous, branched upwards; leares linear, lanceolate, acute, smooth ; sepals obovate, obtuse, obscurely five ribbed, smootb.

English Botany, t. 40.-English Flora, vol. ii. p. 119.-Hooker, British Flora, vol, i. p. 150.-Lindley, Synopsis, p. 53. 
Root tapering, slender, branched. Stems sereral from the same root, slender, erect, or slightly bending in the lower part, branched towards the top, round, smooth, leafy, from one to one and a balf feet high. Leaves alternate, rather smaller than in the last species, linear, acute, single ribbed, somewhat glaucous green, especially beneath. Inflorezcence rather large panicles, the flowers racemose on the branches, large, rather pale purplish blue, with dark radiating veins. Calyx of fire, oborate, obtuse, each with a narrow membranous margin, and the outer ones mostly with a short obtuse point, five ribbed, the lateral ones sometimes obscure. Corolla of fire spreading heart-shaped petals, the notch more or less distinct, and the margin generally slightly crenated. Stamens on short slender awl-shaped filaments, with yellow oblong anthers. Styles slender, longer than the stamens, with obtuse somewhat capitate stigmas. Capsule globose, smooth, pointed, with the hardened base of the style ten ralved, ten celled, each cell single seeded.

Habitat.-Dry hilly situations. Cambridgeshire, Northamptonshire, Testmoreland, Norfolk, Suffolk; near Monkstown, Ireland.-MI. J. Drummind.

Perennial; flowering in June and July.

This plant is readily distinguished by its obtuse calyx, its smaller leares, and more numerous stems. It is frequently cultivated in gardens, and is a gay ornamental perennial border flower; its palish green foliage on its slender stem, and numerous rather large handsome flowers, have an elegant appearance, and successively expand for a considerable time.

3. L. angusti'folium, Huds. (Fig. 517.) Narrow-leaved Pale Flax. Stems numerous, erect, branched upwards; leares linear, lanceolate, acuminate ; sepals orate, acuminate, bristle pointed, three ribbed, the inner ones ciliated.

English Botany, 4. 40.-English Flora, vol. ii. p. 119.-Hooker, British Flora, vol. i. p. 150.-Lindley, Synopsis, p. 53.

Root somewhat tapering, branched and woody. Stems numerous from the same root, round, smooth, slender, erect, or somewhat bent at the base, slightly branched abore, leafy. Leares narrow, linear lanceolate, with an acuminated point, three ribbed, a somewhat glaucous green, paler beneath. Inflorescence slightly branched, few flowered, racemose panicles. Flowers smaller than either of the abore species, a pale purplish blue colour, with short darker radiating reins. Calyx of fire sepals, rather shorter than the capsules, orate, with an acuminated point, terminating in short bristle, the inner sepals more obtuse than the outer, with a shorter point, a broader membranous margin, and ciliated witls short hairs. I'ctuls broally oborate, tapering into a claw, sometimes notched, and has an lieart-shaped appearance, and frequently the margin is slightly crenated. Stamens like the last, of 
variable lengths, the filaments slender, awl-shaped, with ovate bluc anthers. Styles long, swollen upwards. Stigmas feathery. Capsule globose, smooth, pointed, the hardened base of the style bursting, with ten valves, ten celled, each cell single seeded.

Habitat.-Sandy and chalky pastures, especially near the sea. Kent, Sussex, Norfolk, Suffolk, near Liverpool; Truro, Falmouth, and other places in Cornwall; Plymouth.-MIr. Bunks. Near Valebrook Farm, Hastings.-Dr. Bromfield.

Perennial; flowering in July and August.

This species is nearly allied to the last, but is readily distinguished by its calyx, smaller flowers and leaves, and the less branched fewer flowered stems; and the whole plant is mostly smaller than either of the above species.

\section{** Leaves opposite.}

4. L. cathar'ticum, Linn, (Fig. 518.) Purging Flax. Stem forked above; leaves oblong, opposite, smooth; sepals oblong, acute, ciliated with glandular hairs; petals acute.

English Botany, t. 382.-English Flora, vol. ii. p. 119.-Hooker, British Flora, vol. i. p. 150.-Lindley, Synopsis, p. 54.

Root very small, tapering. Stem very slender, solitary, or numerous, erect, or bent at the base, round, smooth, from four to twelve inches high or more, simple below, branched above in a forked manner, with a solitary flower, on a sleuder footstalk from the angle of each division, and a pair of leaves. Leare's smooth, dark green, frequently just above the root they are numerous, crowaed, alternate, and opposite, short, obtuse, those of the stem opposite, oblong, obtuse, single ribbed, those of the branches oblong lanceolate, the margins slight, cartilaginous, and roughish. Flowers solitary, on a slender footstalk. Calyx of five oblong acutely pointed sepals, green, with a stout mid.rib, the margin with a narrow membranous border, ciliated with glandular hairs. Corolla of fire white ovate acute petals, twice as long as the calyx. Stamens on short filaments, with small yellow anthers. Styles short, with capitate stigmas. Capsule globose, smooth, as long as the calyx, tipped with the pointed base of the hardened style, opening with ten narrow lanceolate valves, ten celled, and each cell single seeded.

Habitat.-Road sides and pastures; abundant.

Annual ; flowering in June and July.

Purging Flax is a pretty little plant; its slender branches hang gracefully, drooping before its small star-like flowers have expanded, and then becomes erect. It has a bitter disagreeable taste, and acts as a cathartic; a handful infused in half a pint of boiling water is sufficient for a grown up person. It is frequently administered by the country people, and in suall doses it is said to give tone to the stomach and bowels. 


\section{GENUS CII. SIBBAL'DIA-Linn. Sibbuldia.}

Nat. Ord. ROSa'cere, JUSS.

Gen. Char. Calgx of ten segments, the alternate ones small. Corolla of five petals, inserted into the calyx. Fruit five small nuts, placed upon a dry receptacle. (Stamens and nuts vary from five to ten).- " Named in honour of Robert Sibbald, who wrote on the natural history of Scotland about the latter end of the $17 \mathrm{th}$ century, and who published a figure of our Scottish species of this genus."

1. S. procum'bens, Linn. (Fig. 519.) Procumbent Sibbaldia. Leaves ternate; leaflets wedge-shaped, three toothed; petals lanceolate.

English Botany, t. 897.-English Flora, vol. ii. p. 120.-Hooker, British Flora, vol. i.p. 151.-Lindley, Synopsis, p. 98.

Root stout, woody, with branched fibres, much branched and tufted at the top, and thickly clothed with the dry brown scaly remains of the old leaves. Stems herbaceous, mostly several, short, scarcely branched, leafy, round, procumbent, rough, with hairs pointed upwards. Leaves on long slender footstalks, hairy, with a pair of winged, pointed, membranous stipules at the base, leaflets three, on short footstalks, wedgeshaped, the apex with three teeth, the middle one the smallest, dark green, frequently tinged with a purplish hue, the mid-rib slender, with slender netted veins, hairy, especially on the under side. Inflorescence a leafy corymbose tuft, of a few yellow flowers. Calyx of ten segments, hairy, five lanceolate, acute, and the five intermediate ones linear, acute. Corolla of five petals, lanceolate, inserted into the calyx opposite the smaller segments, and about the same length, or shorter. Stamens five, short, inserted into the calyx between the petals. Anthers small, roundish, yellow. Germens five, or occasionally ten, each with a style arising from the side. Stigmas small, obtuse. Fruit five or ten small smooth ovate compressed nuts, placed upon a dry receptacle.

Habitat.-Near and upon the summit of the Highland Mountains of Scotland; abundant.

Perennial; flowering in July.

This hardy little perennial, growing upon the mountain top, is rery common on Ben Lomond and other Highland Mountains, and commemorates the name of one who loved to ramble over their rugged brows. It has much the habit and is nearly allied to Potentilla, and has the character of the natural order Rosacex; but has a definite number of stamens and pistils. It is as frequent in the alpine districts of Switzerland and Italy as with us, and sometimes it is found with leaves nearly smooth above, but very rough below. 


\section{ORDER VI. \\ HeXAGYNiA, 6 Pistils.}

\section{GENUS CIII. DROSE'RA.-Lins. Sun-dew.}

Nat. Ord. Drosera'cee. De Cand.

Gen. Char. Calyx deeply five-cleft. Corolla of five petals. Styles three or five, divided in two. Capsule one celled, three valved. Seeds numerous.-Name from Sporepo, dewy; which is from Spoos, dex; from the glands at the apex of the hairs appearing like dew.

1. D. rotundiffolia, Linn. (Fig. 520.) Round-leaved Sun-dew. Leaves orbicular, with hairy footstalks; scape erect; seeds chaffy.

English Botany, t. 807.-English Flora, rol. ii. p. 122.-Hooker, British Flora, rol. i. p. 151.-Lindley, Synopsis, p. 38.

$R$ oot fibrous. Scape erect, solitary, or sereral from the same root, round, smooth, from two to five inches high, leafless, round, smooth, red. Leaves numerous, orbicular, somewhat concare, green or purplish, the upper side clothed with red glandular hairs, those on and near the margin longer than those of the disk, and mostly recurved, the under side smooth, and mostly two or three ribbed, the footstalks of variable lengths, flattish, dilated upwards, and more or less clothed with simple soft hairs. Inflorescence a curved one sided raceme, of a few white flowers, each elevated on a short footstalk, from the bosom of a narrow lanceolate bractea, which soon falls away. Calyx of four or tire unequal ovate oblong smooth segments, with the margin more or less jagged. Corolla of five petals, white, oblong, expanding only in the bright sunshine. Stamens five, with small yellow two celled anthers. Styles generally six, sometimes five, rarely four. Capsule ovate, of onc cell, opening with three valves. Seeds small, chaffy, numerous.

Habitat.-Bogs and wet heathy ground; frequent.

Perennial; flowering in July and August.

2. D. longifolia, Linn. (Fig. 521.) Spathulate-leaved Sun-dew. Leaves obovate, wedge-shaped; scape curved or decumbent at the base, ascending, rather longer than the leares; seeds with a compact rough coat, not chaffy.

English Botany, t. 868.-English Flora, vol. ii. p. I23.-Hooker, British Flora, vol. i. p. 151.-Lindley, Synopsis, p. 38.-D. intermedia, Hayn. Schrad. Journ.

Root small, fibrous. Scape round, smooth, rather longer than the leaves, red, curred or decumbent at the base, becoming erect. Leaves 
numerous, all ridical, on slender footstalks, smooth, or scattered over with more or less numerous hairs, especially at the base, obovate, wedge-shaped or spathulate, greenish purple, thickly clothed on the upper somewhat concave side with glandular pink hairs, those on and near the margin much longer than the others, and generally curved. Inflorescence a curved one sided raceme, of a few white flowers, each on a short footstalk, fiom the base of an awl-shaped bractea, which in a short time falls away. Calyx of four or five unequal short obtuse or acute segments, smooth, pinkish green. Corolla white, of from five to eight ovate oblong petals, and with about the same number of stamens. Styles also variable, from six to eight. Stigmas cloven. Capsule ovate, obtuse, single celled. Seeds numerous, with a compact rough coat, not chaffy, as in the last species.

Habitat.-Bogs and wet heathy ground; frequent, but most common in the Southern Counties.

Perennial; flowering in July and August.

3. D. angli'ca, Huds. (Fig. 522.) Great Sun-dew. Leaves lineur, wedge-shaped; scape erect, much longer than the leares; seeds with a loose chaffy coat.

English Botany, t. 869.-English Flora, vol. ii. p. 123.-Hooker, British Flora, vol. i. p. 152.-Lindley, Synopsis, p. 38.-D. longifolia, Hayn. Schrad. Jour.

Root small, fibrous. Scape round, smooth, mostly as long again as the leaves, red, crect from the base. Leuves numerous, on long slender smooth or hairy footstalks, especially at the base, linear, wedge-shaped, pale purplish green, the upper surface thickly clothed with red glandular hairs, those of the margin much longer than the disk, straight, or curved, and of irregular lengths. Inflorescence a curred one sided raceme, of a few white flowers, each on a short footstalk, from the base of a narrow awl-shaped bractea, which shortly falls away. Caly $x$ smooth, of four or five ovate oblong acute segments, mostly of irregular lengths, and often with the margin jagged. Corolla of from four to eight oblong obtuse white petals. Stamens equal in number with the petals. Styles varying from five to eight, with clavate stigmas, not cleft, as in the last species. Capsule oblong, obtuse, of a single cell, with numerous seeds, having a loose chaffy coat.

Habilat.-Bogs and wet heathy ground; less frequent than the last. Both in Scotland and England, and occasionally found growing together.

Perennial; flowering in July and August.

This species was long thought only a variety of the former, but the shape of the stigmas and the different characters of the seed sufficiently point out the difference, independent of this being a much larger plant, with longer, narrower, more linear lcaves, and the scape of the former bcing curved at the base, while this is erect and never curved. 


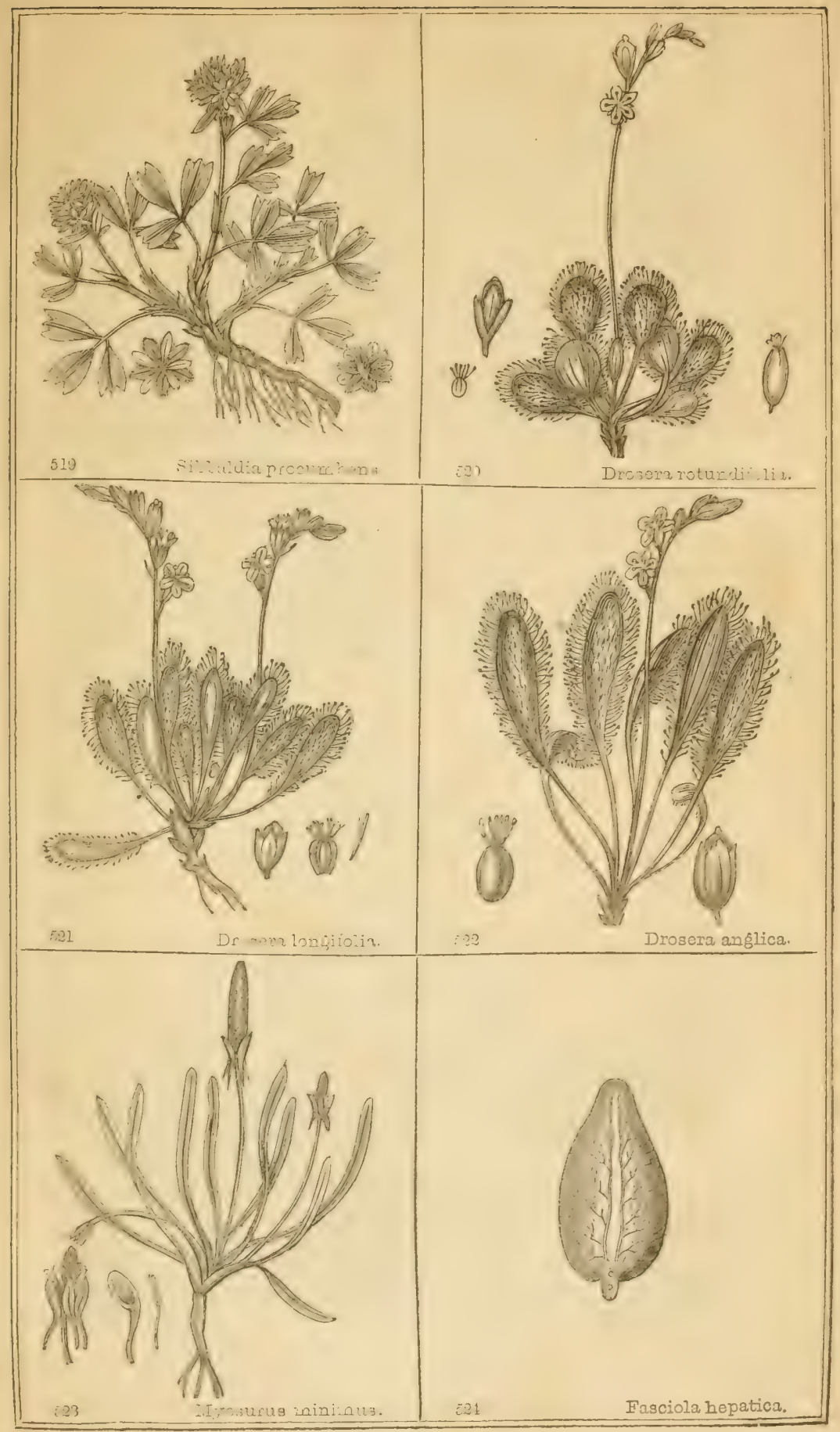



It was at one time thought that the leaves possessed the same irritable property that the America Fly-trap (Dimoa Muscipula) has, hence it is that they are sometimes called English Fly-trap; but the manner in which flies are entangled in the leaves of this plant appears quite different. Each hair is terminated with a small gland, which secretes a glutinous fluid, and when any insect settles upon any part of the leaf it sticks, and by its struggles to escape only entangles itself the more, and at leugth becomes so surrounded with the curved hairs, attaching themselves by the sticky fluid, as to entirely prevent the escape of the insect, and is held in that position, which consequently destroys it.

We have already adverted (in page 122) to the power of which these plants are accused, in causing the rot in sheep; and it was formerly thought that they were useful in promoting the cure of consumptive persons, from the idea which the old doctors had, that because they saw the glands on the hairs moist with these secretions, they would supply the moisture which they thought was necessary to prevent the drying up of the lungs, which seems to have been their notion of the disease known by the name of consumption; but the acridity of these plants appears from the account of Gerarde to have caused those who took this new restorative to die the sooner. All of them seem to contain a considerable proportion of colouring matter, as they stain the paper on which they are preserved for a considerable time after they are dried.

\section{ORDER VII.}

\section{POLYGYNiA. Many Pistils.}

\section{GENUS CIV. MYO'SURUS.-LINN。Mouse-tail.}

Nat, Ord. RanunCula'CE

Gen. Char. Calyx of five pieces, elongated at the base. Corolla of five petals, with filiform tubular claws. Capsules indehiscent, several, triquetrous, single seeded, inserted into a much elongated columnar receptacle, and terminated by the styles. - Name from $\mu \nu s, \mu v o s$, a mouse; and ovga, a tail; from the much elongated cylindrical receptacle.

1. M. mini'mus, Linn. (Fig. 523.) Common Mouse-tail.

English Botany, t. 435.-English Flora, vol. ii. p. 124.-Hooker, British Flora, vol. i. p. 152.-Lindley, Synopsis, p. 10.

Root small, fibrous. The whole plant herbaceous, from two to six inches high. Leaves numerous, all radical, mostly erect, liuear, spatu- 
late, pale green, somewhat fleshy, single ribbed, with an acute or bluntish point, and tapering at the base into a long footstalk. Scape erect, round, smooth, slender, green, longer than the leaves, bearing a single small pale green terminal flower. Calyx of five pieces, gibbous at the base, or elongated into a spur.like appendage, the upper part lanceolate, single ribbed, somewhat fleshy. Corolla of five white or reenish petals, with a dilated limb and long filiform tubular claw. Stamens various, mostly fire, with narrow yellow two celled anthers. Stigmas solitary, small, sessile. Receptacle at first included within the flower, crowded with numerous oblong germens, afterwards elongating to from one to three inches, much resembling in its round tapering form a mouse's tail. Germens somewhat triangular, very much crowded, each single seeded.

Habitat.-Corn fields and waste places, especially in a gravelly or sandy soil; in England not very common, doubtful if found in Scotland, and not known in Ireland.

Annual; flowering in May.

A curious little plant, well characterised by its generic name of Mouse-tail, which it much resembles in the columnar form of its receptacle, especially when the seeds are ripe, and the great number of seeds which each plant produces, these being not unfrequently from two to three hundred. 


\title{
I N D E X
}

\author{
OF THE
}

\section{GENERIC AND SPECIFIC NAMES, \&c.}

IN VOL. I.

\begin{tabular}{|c|c|c|c|c|c|}
\hline & & Page. & & & $\begin{array}{r}\mathrm{Pag} \\
. \quad 20\end{array}$ \\
\hline $\begin{array}{l}\text { Achnodon arenurius } \\
\text { EGoponIus }\end{array}$ & $\because$ & $\begin{array}{l}85 \\
\therefore \quad 363\end{array}$ & $\begin{array}{l}\text { arvensis } \\
\text { rulgaris }\end{array}$ & .. & \\
\hline Podagraria & $\because$. & $\begin{array}{l}. .500 \\
. .363\end{array}$ & A LOPECURUS & $\ddot{\ldots}$ & \\
\hline ZETHUSA & .. & .. 378 & agrest is & .. & 69 , \\
\hline Cynapium & .. & . 379 & alpinus & .. & .. \\
\hline Agropyrum caninum & .. & 158,154 & bulbosus & .. & .. \\
\hline cristatum. & .. & .. 156 & fulvus & .. & $\therefore$ \\
\hline juncium & .. & .. 156 & geniculatus & .. & 65 , \\
\hline repens & . & $\ldots 155$ & geniculatus bulbos & sus & .. \\
\hline Agrostis & .. & .. 91 & pratensis & .. & .. \\
\hline alba & .. & 94,95 & Amsophila & .. & .. \\
\hline aristata & .. & $\therefore 94$ & arenaria & & \\
\hline australis & .. & .. 81 & arundinacea & 65 & 9I, \\
\hline canina & .. & 91,94 & ANAGALLIS & .. & ..2 \\
\hline canina fasciculari & & .. 91 & arvensis & .. & .. \\
\hline canina capillaris & .. & .. 91 & carulea & .. & .. \\
\hline canina mutica & .. & .. 91 & tenella & .. & \\
\hline compressa & .. & .. 95 & ANCHUSA & .. & .. \\
\hline littoralis & .. & .. 88 & officinalis & .. & .. 2 \\
\hline minima & .. & .. 166 & sempervirens & .. & .. 2 \\
\hline is & .. & .. 94 & tinctoria & .. & .. \\
\hline panicea & .. & .. 88 & Andropogon nardus & .. & .. \\
\hline rila & .. & .. 94 & Anemugrostis & .. & \\
\hline repens & .. & .. 94 & oryza sativa & .. & 70 \\
\hline setacea & .. & .. 92 & spica venti & .. & .. \\
\hline spi & .. & .. 93 & Anethum forniculum & .. & .. 3 \\
\hline stolonifera & & .. 95 & ANGELICA ... & .. & .. 3 \\
\hline stoloniffera angust & tifolia & .. 94 & syl & & \\
\hline stolonifera aristat & & .. 94 & archangelica & .. & .. 3 \\
\hline stolonifera latifoli & & .. 94 & Aлthoxanthum & .. & 33, \\
\hline stricta & .. & .. 91 & odoratum & .. & 33,1 \\
\hline sylvatica & .. & .. 95 & ANTHRISCUS & .. & \\
\hline vulg & .. & .. 94 & Cerefolium & .. & .. \\
\hline vulgaris canina & .. & .. 94 & sylvestris & .. & \\
\hline Arra & & .. 96 & vulgaris & & \\
\hline alpina & .. & 65,93 & APIUMI & .. & .. 3 \\
\hline atic & .. & . 96 & graveolens & .. & \\
\hline escens & .. & .. 101 & Petroselinum & .. & .. \\
\hline ophyllea & .. & . 99 & Arach is hypogaa & .. & \\
\hline cæspitosa & .. & .. 97 & ARCHANGELICA & & \\
\hline crist & .. & .. 97 & alis & .. & .. 3 \\
\hline przecox & .. & .. 100 & Armeria maritima & .. & .. \\
\hline Airochloa cristata & .. & .. 97 & ARRHENATHERUMI & .. & \\
\hline $\mathrm{LCH}$ & .. & $\therefore 201$ & avenaceum & .. & \\
\hline alvina & .. & .. 201 & bulbosum & .. & .. \\
\hline
\end{tabular}


INDEX.

\begin{tabular}{|c|c|c|c|c|c|}
\hline Artocarpus incisus & $\ldots$ & $\begin{aligned} & \text { Page. } \\
& \ldots 72\end{aligned}$ & racemosus & $\ldots$ & $\begin{array}{r}\text { I'are. } \\
\ldots \quad 138\end{array}$ \\
\hline ARUNDO & . & .. 147 & secalinus & .. & .. 135 \\
\hline arenaria & .. & .. 80 & squarrosus & .. & .. 135 \\
\hline Calamagrostis & .. & .. 89 & sterilis & .. & .. 133 \\
\hline colorata & .. & .. 79 & sylvaticus & .. & .. 161 \\
\hline donax. & .. & .. 148 & triflorus & $\ldots$ & .. 131 \\
\hline Epigejos & . & .. 89 & relutinus & $\ldots$ & .. 136 \\
\hline phragmites & .. & $\ldots 147$ & BUFFOKIA & .. & .. 201 \\
\hline stricta & . & .. 90 & annua & .. & .. 204 \\
\hline Asarum euтopeum & .. & .. 61 & tenuifolia & $\ldots$ & .. 204 \\
\hline ASPERUGO & . & .. 239 & Buniuar & .. & .. 365 \\
\hline procumbens & .. & . 239 & Bulbocastanum & .. & .. 365 \\
\hline ASPERULA & .. & $\ldots 189$ & denudatum & $\cdots$ & . 365 \\
\hline arvensis & . & .. 190 & flexuosum & $\ldots$ & .. 365 \\
\hline Cynanchica & .. & .. 191 & Bupleuruat & $\ldots$ & .. 352 \\
\hline odorata. & .. & $\therefore 190$ & aristatum & $\ldots$ & . 352 \\
\hline Athumanta Meum & $\cdots$ & 381,384 & falcatum & $\cdots$ & .. 354 \\
\hline Libanotis & .. & .. 381 & Odontites & $\ldots$ & .. 352 \\
\hline Atropa $\quad$... & $\therefore$ & $\begin{array}{l}\ldots 278 \\
\ldots\end{array}$ & protractum & $\cdots$ & . 354 \\
\hline belladonna & . & . 278 & rotundifolium & .. & 353,354 \\
\hline AVENA & . & 70,139 & tenuissimum & . & . 353 \\
\hline alpina & . & . 141 & & & \\
\hline elatior & .. & $\ldots 104$ & Calystegia sepium & .. & .. 262 \\
\hline fatua & .. & .. I 34 & soldanella & .. & .. 263 \\
\hline flavescens & .. & .. 143 & CAMPANULA & .. & .. 293 \\
\hline planiculmis & $\cdots$ & $\ldots 141$ & aggregata & $\cdots$ & . 301 \\
\hline planiculmis & $\ldots$ & $\therefore 141$ & attenuata & $\ldots$ & .. 301 \\
\hline pratensis & $\cdots$ & $\therefore 140$ & elliptica & $\cdots$ & $\ldots 301$ \\
\hline pubescens & $\cdots$ & $\begin{array}{l}\ldots 142 \\
14\end{array}$ & farinosa & $\cdots$ & $\therefore 301$ \\
\hline strigosa & $\cdots$ & $\therefore 139$ & glomerata & $\therefore$ & $\therefore 300$ \\
\hline sativa & $\cdots$ & 139,140 & hederacea & $\because$ & $\therefore 302$ \\
\hline sterilis & .. & . 139 & hirta & $\ldots$ & .. 294 \\
\hline AZALEA & .. & $\therefore 264$ & hybrida & $\therefore$ & .. 304 \\
\hline procumbens & .. & .. 264 & lancifolia & . & $\cdots$ \\
\hline Berula & .. & .. 371 & $\begin{array}{l}\text { latilolia } \\
\text { major }\end{array}$ & . & $\begin{array}{l}\text {. } 29 \\
\ldots 29\end{array}$ \\
\hline angustifolium & . & .. 371 & patula & $\ldots$ & .. 295 \\
\hline Beta & . & .. 427 & persicifolia & .. & $\therefore 297$ \\
\hline maritima & . & .. 427 & petrert & $\ldots$ & .. 301 \\
\hline vulgaris & . & .. 428 & rapunculoides & .. & \\
\hline Betonica pauli & .. & .. 11 & Rapunculus & .. & .. \\
\hline Blitum glaucum & . & . 423 & rotundifolia & . & .. \\
\hline Bonus Henricus & . & .. 421 & sulviafolia & . & . \\
\hline rubrum & .. & . 422 & speciosa & .. & $\cdots$ \\
\hline Beysyus & .. & .. 55 & 'Trachelium & ... & .. 300 \\
\hline compressus & .. & .. 55 & Caprifolium perfoliatu & $u m$ & . 305 \\
\hline rufus & .. & . 56 & periclymenum & .. & .. 306 \\
\hline Borago & .. & .. 225 & CARUMI & .. & .. 364 \\
\hline officinalis & $\ldots$ & . 223 & Carui & . & .. 36 \\
\hline BrachroniuM & . & . Ifio & verticillatum & $\ldots$ & .. 36 \\
\hline pinn itum & .. & . 161 & Catabrosa & $\ldots$ & .. \\
\hline sylvaticum & .. & .. 161 & aquatica & .. & .. \\
\hline BrizA & . & . 123 & CaLAJAGRostis & .. & .. \\
\hline media & . & . $1: 23$ & Epegejos & . & .. \\
\hline minor & . & .. 121 & lanceolata & .. & .. 8 \\
\hline Bronsus & . & .. 131 & stricta & .. & .. 90 \\
\hline arvensis & .. & .. 134 & Catopodium loliaceum & & .. 157 \\
\hline asper & .. & . 132 & CATCALIS & .. & . 399 \\
\hline diandrus & . & . 133 & daucoides & $\ldots$ & .. 40 \\
\hline erectus & $\ldots$ & .. 134 & infesta & $\ldots$ & .. 40 \\
\hline giganteus & $\ldots$ & .. 1.31 & latifolia & $\ldots$ & .. 40 \\
\hline Madritensis & $\ldots$ & .. 133 & nodosa & $\ldots$ & . 40 \\
\hline minor & .. & $\ldots 136 j$ & Centranthus rubra & $\ldots$ & .. 3 \\
\hline mollis & . & .. 1.37 & Centunculus & .. & .. 196 \\
\hline multiflorus & .. & .. 136 & minimus & .. & . 190 \\
\hline pinnatus & . & .. 161 & Chanophy ala & . & .. 40 \\
\hline
\end{tabular}


INDEX.

\begin{tabular}{|c|c|c|c|c|c|}
\hline & & Page. & & & Page. \\
\hline aromaticum & . & . 409 & Crocus & .. & $\begin{array}{ll}\because \quad 39 \\
\therefore \quad 40\end{array}$ \\
\hline $\begin{array}{l}\text { aureum } \\
\text { sativum }\end{array}$ & $\because$ & .. 408 & aureus & - & $\begin{aligned} \because \quad 40 \\
\because \quad 39\end{aligned}$ \\
\hline $\begin{array}{l}\text { sativum } \\
\text { sylvestre }\end{array}$ & . & .. 406 & autumnalis & . & $\begin{array}{ll}\text {.. } 39 \\
40\end{array}$ \\
\hline $\begin{array}{l}\text { sylvestre } \\
\text { temulentum }\end{array}$ & . & .. 405 & lutens & . & . \\
\hline Chamagrostis minima & -. & .. 403 & minimus & .. & $\ddot{0}$ \\
\hline Chamadrys spuria & .. & $\begin{array}{ll}0166 \\
11\end{array}$ & nudiflorus & . & 42, \\
\hline IENOPODIUYS & .. & $\because 418$ & $\begin{array}{l}\text { pracox } \\
\text { тeticulatus }\end{array}$ & $\ddot{*}$ & $\begin{array}{l}\therefore 40 \\
\therefore 4\end{array}$ \\
\hline acutifolium & .. & $\therefore 420$ & sativus & 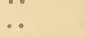 & 42,39 \\
\hline album & .. & 425,427 & speciosus & .. & 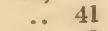 \\
\hline Bonus Henricus . & .. & .. 421 & vernus & .. 39, & 41 , \\
\hline Botryoides & .. & .. 423 & Cuscuta & .. & 340,34 \\
\hline Botrys & .. & .. 424 & Epithymum & .. & 340,34 \\
\hline cymoso-racemosum & & .. 420 & Europæa & .. & .. \\
\hline cymigerum & .. & .. 425 & Epilinum & .. & .. 34 \\
\hline ficifo & .. & .. 436 & Cycadea & .. & .. \\
\hline um & .. & .. 418 & CXCLAMEN & .. & .. 4 \\
\hline gla & .. & .. 423 & preum & .. & .. 24 \\
\hline hy & .. & .. 425 & hederæfolium & .. & .. 2 \\
\hline intermedium & .. & .. 422 & Crandon & .. & .. 16 \\
\hline ma & .. & .. 419 & ylon & .. & .. 1 \\
\hline spermum . & . & .. 422 & CrNoglossum & .. & .. 28 \\
\hline $\mathrm{mu}$ & .. & .. 424 & off & .. & .. 24 \\
\hline olis & .. & .. 419 & ticum & .. & .. 2 \\
\hline ermum & . & .. 420 & Cynost & .. & .. 14 \\
\hline & .. & $\therefore 72$ & cri: & .. & .. 1 \\
\hline rubrum & .. & 422,424 & echinatus & .. & .. \\
\hline spicato-racemosum & & $\therefore 420$ & CrPERUS & .. & .. \\
\hline spicatum & .. & $\because 425$ & esculentus & .. & . \\
\hline urbic & .. & 421,422 & fuscus & $\ldots$ & .. \\
\hline vir & .. & .. 425 & hydra & .. & .. \\
\hline Vulvaria & .. & .. 419 & longus & .. & .. \\
\hline Chironia Centaurium. & .. & .. 257 & papyrus & .. & .. \\
\hline litto & .. & .. 258 & rotundatus & .. & .. \\
\hline & .. & ․ 259 & & & \\
\hline $\begin{array}{l}\text { ICUTA } \\
\text { virosa }\end{array}$ & .. & .. 369 & Dactrlis & . & \\
\hline virosa & .. & .. 369 & aerata & .. 69, & 144,14 \\
\hline IRC. & .. & .. 25 & stricta & .. & .. 16 \\
\hline & .. & .. 26 & Datura & .. & $\therefore 27$ \\
\hline a & . & .. 25 & Stramonium & .. & 273,27 \\
\hline$m$ & .. & .. 26 & Daucus & .. &. .35 \\
\hline nedia & .. & .. 26 & Carota & .. & .. 39 \\
\hline Cladiu & .. & .. 32 & maritimus & .. & .. 39 \\
\hline$M$ & .. & .. 32 & Deschampsia coespitos & & .. \\
\hline Clematide prima & .. & .. 284 & Digitaria & .. & .. It \\
\hline Cnidiur & & .. 383 & he & .. & .. 17 \\
\hline Condylocarpus officinal & alis & .. 393 & sanguinalis & . & $\ldots 16$ \\
\hline Conius & .. & .. 415 & Digraphis arundinace & & \\
\hline $\mathrm{m}$ & .. & .. 415 & Dionaa Muscipula & .. & 216,45 \\
\hline denudatum & & .. 365 & Dioscorea alata & .. & .. \\
\hline Cosvor & .. & .. 261 & Dipsac & .. & $\ldots 17$ \\
\hline & .. & .. $26 !$ & fullonum & .. & 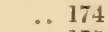 \\
\hline batc & .. & .. 72 & pilo & .. & \\
\hline & .. & .. 262 & sylvestris & .. & $\ldots 12 \mathrm{r}-\mathrm{a}-\mathrm{r}-\mathrm{a}$ \\
\hline Sold & .. & .. 263 & Dothidea ribesia & .. & .. 32 \\
\hline Corian & .. & .. 417 & Drosera & .. & \\
\hline sat & .. & .. 417 & Anglica & .. & .. 4 \\
\hline Corne & .. & .. Is $15-3-1$ & intermedia & .. & \\
\hline canadensis & .. & .. 199 & lungifolia & .. & 457,45 \\
\hline & .. & .. 198 & rotundifolia & .. & .. 4 \\
\hline Suec & .. & .. 199 & & & \\
\hline Corrig & .. & .. 445 & ECHINOPHORA & .. & \\
\hline & .. & .. 445 & spinosa & .. & \\
\hline Corynephorus canescen & & .. 101 & EсHüм & .. & .. $2=$ \\
\hline CRithaus & & .. 385 & pusiulatum & .. & \\
\hline maritimum & & .. 385 & violaceum & .. & \\
\hline
\end{tabular}


INDEE.

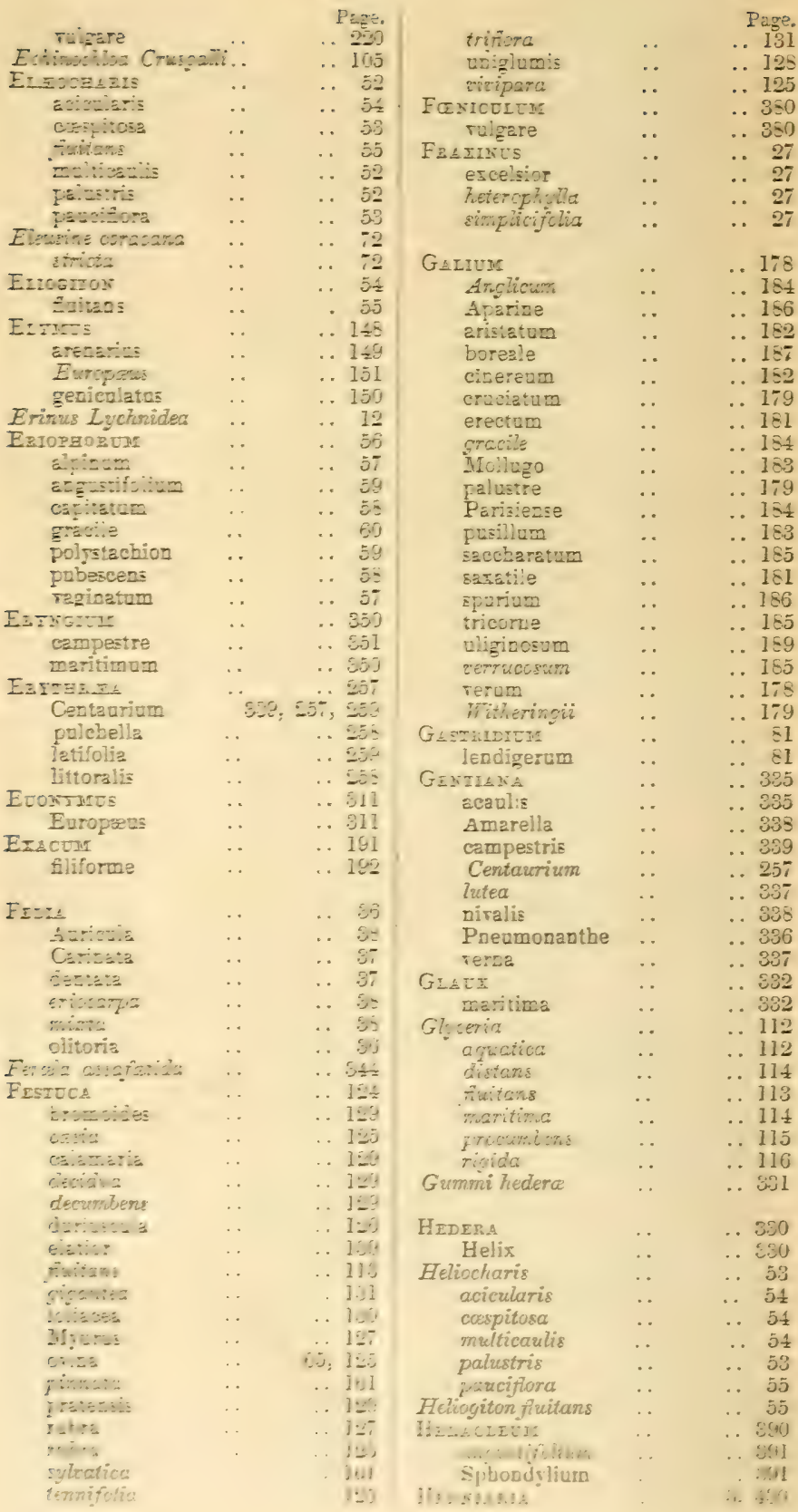


INDEX.

\begin{tabular}{|c|c|c|c|c|c|}
\hline glabra & & Page. & & & l'age. \\
\hline $\begin{array}{l}\text { glaura } \\
\text { hirsuta }\end{array}$ & $\because$ & $\begin{array}{l}. \quad 430 \\
. .430\end{array}$ & $\begin{array}{l}\text { minor } \\
\text { pollyrhiza }\end{array}$ & $\because$. & $\begin{array}{l}. .30 \\
. \quad 30\end{array}$ \\
\hline HIEROCHLOE & .. & .108 & irisulea & $\ddot{0}$ & $\begin{array}{l}30 \\
\ldots \quad 20\end{array}$ \\
\hline borealis & .. & .. 108 & Lemna & $\because$ & $\begin{array}{l}. . \\
\text {. } 29\end{array}$ \\
\hline Hipruris & .. & .. 3 & Lenticula & .. & $\therefore \quad 29$ \\
\hline vulgaris & .. & .. 3 & Lepis & .. & $\begin{array}{l}\therefore \quad 29 \\
\therefore \quad 2\end{array}$ \\
\hline Holcus & .. & .. 102 & Ligusticuse & .. & .. 382 \\
\hline avenaceus & .. & .. 104 & aquilegifolium & .. & .. 412 \\
\hline lanatus & .. & .. 103 & Cornubzense & .. & .. 412 \\
\hline mollis & .. & .. 102 & Meum & .. & .. 384 \\
\hline odoratus & .. & .. 108 & Scoticum & .. & .. 382 \\
\hline Holoseradium & .. & .. 359 & Ligustrum & .. & .. 4 \\
\hline nodiflorum & .. & . 359 & vulgare & .. & .. 4 \\
\hline repens & .. & .. 361 & Limonium minus & .. & \\
\hline inundatum & .. & .. 360 & LINUM & .. & .. 452 \\
\hline HoLosteun & .. & .. 172 & angustifolium & .. & .. 454 \\
\hline umbellatum & .. & .. 172 & catharticum & .. & .. 455 \\
\hline HORDEUM & .. & 70,150 & lineafolium & .. & .. 452 \\
\hline distichon & .. & .. 153 & perenne & .. & \\
\hline maritimum & .. & .. 153 & usitatissimum & .. & .. 452 \\
\hline murinum & .. & .. 151 & LITHOSPERMIUM & .. & .. 223 \\
\hline pratense & .. & .. 152 & arvense .. & .. & .. 224 \\
\hline sylvaticum & .. & .. 151 & maritimum & .. & .. 225 \\
\hline HotToNIA & .. & .. 247 & officinale & .. & .. 223 \\
\hline palustris & .. & .. 247 & purpuro-cærulet & & .. 224 \\
\hline Hydrangea hortensis & .. & .. 10 & LOBELIA .. & .. & . 287 \\
\hline Hydrochloa aquatica & .. & .. 112 & Dortmanna & .. & . . 289 \\
\hline HYDROCOTYLE & .. & .. 347 & urens , .. & .. & .. 288 \\
\hline inundatum & .. & .. 361 & caoutchouc & .. & .. 289 \\
\hline vulgaris & .. & .. 347 & inflata .. & .. & .. 289 \\
\hline asiatica & .. & .. 348 & lungiflora & .. & .. 288 \\
\hline HYoscyamus & .. & .. 275 & Tupa .. & .. & .. 288 \\
\hline niger & .. & .. 276 & Loltusi & .. & . 16: \\
\hline pallidus & .. & .. 273 & arvense & .. & 165,164 \\
\hline ILEX & & & perenne & .. & 163,162 \\
\hline $\begin{array}{l}\text { 1C.EX } \\
\text { aquifolium }\end{array}$ & . & $\therefore 205$ & temulentum & .. & 70,164 \\
\hline ILLECEBRUM & .. & .. 205 & LONICERA & .. & .. 305 \\
\hline verticillatum & .. & $\begin{array}{l}.3: 3: 2 \\
.3333\end{array}$ & Caprifolium & .. & .. 305 \\
\hline Impatiens & .. & $\begin{array}{l}. .3333 \\
. .31: 3\end{array}$ & Periclymenum & .. & .. 306 \\
\hline Noli-me-tangere & .. & $\begin{array}{l}. .31: 3 \\
. .31: 3\end{array}$ & Xylosteum & .. & .. 307 \\
\hline IMPERATORIA & .. & . . $31: 3$ & Lxcorsis & .. & .. 229 \\
\hline Ostruthium & 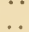 & $\begin{array}{l}. .396 \\
\ldots 396\end{array}$ & arvensis & .. & . 229 \\
\hline IRIS... & .. & $\begin{array}{l}. .396 i \\
. . \quad 4 ; 3\end{array}$ & LycopUs & .. & .. $\quad 23$ \\
\hline citrina & $\because$. & $\begin{array}{l}. .4 ; 3 \\
\ldots \quad 4 ; 3\end{array}$ & $\begin{array}{l}\text { Europæus } \\
\text { Eum }\end{array}$ & .. & . $\quad 23$ \\
\hline foetidissima & .. & $\begin{array}{l}.44 \\
. \quad 41\end{array}$ & $\begin{array}{l}\text { Lygeum spartum } \\
\text { LYSISACHIA }\end{array}$ & . & $\begin{array}{l}. .167 \\
\because \quad 250\end{array}$ \\
\hline florentina & .. & $\therefore \quad 4 ; 3$ & nemorum & 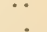 & $\begin{array}{l}\because 250 \\
\therefore 252\end{array}$ \\
\hline Pseudacorus & .. & .. $4: 3$ & nummularia & $\therefore$ & $\begin{array}{l}\because .252 \\
\therefore .253\end{array}$ \\
\hline ISNARDIA & .. & .. 20:2 & punctata & .. & .. 251 \\
\hline palustris & .. & .. 2022 & thyrsiflora & .. & .. 251 \\
\hline Ixia Bulbocodium & . & .. 43 & vulgaris & .. & .. 250 \\
\hline Jatropha manihot & .. & 72,158 & Melica & .. & .. 109 \\
\hline JASIONE & .. & . 290 & alpina .. & .. & .. 111 \\
\hline montana & .. & .. 240 & corrulea .. & .. & .. 111 \\
\hline KNAPPIA & .. & .. 166 & $\begin{array}{l}\text { nutan3 } \\
\text { uniflora }\end{array}$ & $\because$. & $\begin{array}{l}. .109 \\
. .110\end{array}$ \\
\hline agrostidea & .. & .. 166 & $\begin{array}{c}\text { unifiora } \\
\text { MENYANTiES }\end{array}$ & .. & .. 254 \\
\hline Knautia & .. & .. $\mathrm{J76}$ & nymplucoides & .. & .. 256 \\
\hline arvensis & .. & .. 176 & trifoliata & .. & .. 254 \\
\hline & & & MEUM & .. & .. 384 \\
\hline $\begin{array}{l}\text { LAGURUS } \\
\text { ovatus }\end{array}$ & . & $\begin{array}{l}\ldots \quad 86 \\
\ldots \quad 86\end{array}$ & $\begin{array}{l}\text { athamanticum } \\
\text { Foniculum }\end{array}$ & . & . 384 \\
\hline Lavandula spicata & .. & $6 i,+4 i$ & $\begin{array}{l}\text { Faniculum } \\
\text { Mrímin }\end{array}$ & $\because$ & $\begin{array}{l}.380 \\
\cdots \quad 81\end{array}$ \\
\hline LEMNA & & . $\quad 29$ & effusum & .. & .. 81 \\
\hline gibba & .. & .. 30 & lendigerum & .. & .. il \\
\hline
\end{tabular}


INDEX.

\begin{tabular}{|c|c|c|c|c|c|c|}
\hline MaENCHIA & .. & .. & $\begin{array}{l}\text { Page. } \\
\text {. } 218\end{array}$ & ostruthium & .. & $\begin{array}{r}\text { Page. } \\
\text {.. } 396\end{array}$ \\
\hline erecta & .. & .. & .. 218 & palustre & .. & .. 395 \\
\hline MIOLINIA & .. & .. & $\ldots 110$ & Silaus .. & .. & .. 383 \\
\hline \multirow{2}{*}{\multicolumn{2}{|c|}{$\begin{array}{l}\text { cœrulea } \\
\text { depauperata }\end{array}$}} & .. & $\ldots 111$ & Phalaris $\ldots$ & .. & .. 78 \\
\hline & & $\cdots$ & .. 111 & arenaria & $\ldots$ & .. 85 \\
\hline \multirow{2}{*}{\multicolumn{2}{|c|}{$\underset{\text { fontana }}{\text { Montia }}$}} & . & .. 171 & arundinacea & .. & .. 79 \\
\hline & & $\cdots$ & .. 171 & asper $\quad$.. & .. & .. 84 \\
\hline \multirow{2}{*}{\multicolumn{2}{|c|}{$\begin{array}{l}\text { Mrosotis } \\
\text { alpestris }\end{array} \cdots$}} & $\cdots$ & .. 231 & Canariensis & $\ldots$ & .. 78 \\
\hline & & $\cdots$ & . 235 & phleoides & .. & .. 84 \\
\hline & $\cdots$ & .. 236 & \multicolumn{2}{|c|}{ Phellandrium aquaticum } & .. 378 \\
\hline \multirow{2}{*}{\multicolumn{2}{|c|}{$\begin{array}{l}\text { arvensis } \\
\text { caspitosa }\end{array}$}} & . & . 237 & Phylanthropon & $\ldots$ & .. 187 \\
\hline \multirow{2}{*}{\multicolumn{2}{|c|}{$\begin{array}{l}\text { caspitosa } \\
\text { collina } . .\end{array}$}} & .. & .. 234 & Phleum & $\ldots$ & .. 182 \\
\hline & & .. & .. 237 & alpinum & .. & .. 83 \\
\hline \multicolumn{2}{|c|}{ palustris } & $\ldots$ & 12,232 & arenarium & .. & 65,85 \\
\hline \multirow{2}{*}{\multicolumn{2}{|c|}{$\begin{array}{l}\text { repens } \\
\text { rupicola }\end{array}$}} & .. & .. 233 & asperum .. & . & .. 84 \\
\hline & & .. & .. 235 & Boehmeri & .. & .. 84 \\
\hline \multicolumn{2}{|c|}{ scorpioides } & $\cdots$ & .. 236 & Michelii & .. & .. 85 \\
\hline & $\because$ & .. 235 & nodosum & 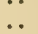 & $\begin{array}{l}\ldots 8 \\
\ldots 82\end{array}$ \\
\hline \multirow{2}{*}{\multicolumn{2}{|c|}{$\begin{array}{l}\text { versicolor } \\
\text { Myosurus }\end{array}$}} & .. & . 238 & paniculatum & $\ldots$ & .. 84 \\
\hline & & .. & .. 459 & pratense & .. & 69,82 \\
\hline \multirow{2}{*}{\multicolumn{2}{|c|}{$\begin{array}{c}\text { minimus } \\
\text { MYRRHIS }\end{array}$}} & . & . 459 & Physospenmum & $\ldots$ & $\ldots 411$ \\
\hline & & . & . 410 & aquilegifolium & $\ldots$ & $\ldots 412$ \\
\hline & & . & .. 409 & Cornubiense & .. & $\ldots 411$ \\
\hline aurea & .. & . & .. 408 & commutatum & $\ldots$ & .. 412 \\
\hline odorata & & . & .. 410 & Phyteuma & $\ldots$ & .. 291 \\
\hline temula & .. & $\cdots$ & .. 408 & orbiculare & .. & .. 291 \\
\hline & & & & spicatum & $\cdots$ & .. 292 \\
\hline NAEDUS & .. & .. & . 61 & Pinipinella & .. & .. 366 \\
\hline stricta & . & . & . 61 & dioica & $\cdots$ & .. 358 \\
\hline celtica & . & . & . 61 & dissectifolia & $\ldots$ & .. 367 \\
\hline italica & . & . & . 61 & hircina .. & $\ldots$ & .. 367 \\
\hline montana & & . & .. $6 \mathrm{I}$ & magna & .. & .. 368 \\
\hline Nymphea al & & .. & .. 215 & saxifraga & $\cdots$ & .. 367 \\
\hline & & & & Pinguicula & .. & .. 17 \\
\hline Ophiurus inc & curvatus & - & $\therefore 166$ & alpina .. & $\cdots$ & ir 19 \\
\hline Oryza sativa & & .. & 70,73 & grandiflora & $\ldots$ & 17,18 \\
\hline ENanthe & & & & Lusitanica & $\cdots$ & 19,20 \\
\hline $\begin{array}{l}\text { UENANTHE } \\
\text { apiifolia }\end{array}$ & & $\cdots$ & & & $\cdots$ & $\begin{array}{ll}\text {. } 13 \\
109\end{array}$ \\
\hline $\begin{array}{l}\text { aprefolia } \\
\text { crocata }\end{array}$ & . & $\cdots$ & $\begin{array}{l}\ldots 37 \\
\ldots 376\end{array}$ & $\begin{array}{l}\text { Plantago } \\
\text { coronopus }\end{array}$ & $\ddot{*}$ & $\begin{array}{l}\text {. } 192 \\
195\end{array}$ \\
\hline fistulosa & & $\ddot{m}$ & . 373 & $\begin{array}{l}\text { coronopus } \\
\text { lanceolata }\end{array}$ & $\begin{array}{l}\cdots \\
\cdots\end{array}$ & $\begin{array}{l}. \quad 194 \\
. .194\end{array}$ \\
\hline peuceda & nifolia & $\ddot{0}$ & .. 375 & major .. & $\ldots$ & .. 192 \\
\hline Phellanc & drium & .. & .. 374 & maritima & .. & .. 195 \\
\hline pimpine & lloides & .. & .. 377 & media $\quad$. & $\ldots$ & .. 193 \\
\hline Odontites lut & & . & .. 352 & major & . & $\ldots 195$ \\
\hline & & & & minor & $\cdots$ & .. 195 \\
\hline Panicum & .. & .. & .. 105 & PoA , . & .. & .. 111 \\
\hline arboresce & ens & .. & . 66 & abyssinica & .. & $\therefore 71$ \\
\hline Crus-gal & & .. & .. 105 & alpina & $\ldots$ & 65,117 \\
\hline Dactylo & & .. & .. 168 & angustifolia & . & .. 119 \\
\hline frumento & acium & .. & .. 72 & annua $\ldots$ & .. & 69,121 \\
\hline sanguine & & $\ldots$ & .. 169 & aquatica & .. & 65,112 \\
\hline verticilla & tum & .. & .. 106 & Dulbosa & .. & 65,118 \\
\hline viride & .. & . & $\ldots 107$ & compressa & .. & . 116 \\
\hline Papyrus ant & iquorum & . & . 46 & decumbens & $\ldots$ & .. 123 \\
\hline Pa rietaria & & $\ldots$ & . 199 & distans & .. & .. 114 \\
\hline officinali & & .. & . 200 & flexuosa & .. & .. 118 \\
\hline Parinassia & .. & .. & .. $44 b^{\circ}$ & fluitans & .. & .. 113 \\
\hline palustris & & .. & .. 446 & glauca .. & $\cdots$ & . 122 \\
\hline Pastinaca & .. & .. & . 359 & glomerata & .. & . 117 \\
\hline sativa & 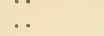 & .. & . 389 & laxa & $\cdots$ & . 118 \\
\hline PETROSELIN & UM & .. & . 356 & maritima & $\ldots$ & . 114 \\
\hline sativum & & . & . 356 & nemoralis & $\ldots$ & . 122 \\
\hline segitum & & . & . . 357 & procumbens & $\ldots$ & $\ldots 115$ \\
\hline PEUCEDANU & & . & . 3394 & pratensis & . & . 119 \\
\hline officinal & & $\therefore$ & . 3914 & rigida .. & $\ldots$ & $\ldots 116$ \\
\hline
\end{tabular}


INDEX.

\begin{tabular}{|c|c|c|c|c|c|}
\hline & & Page. & & & liats \\
\hline $\begin{array}{l}\text { sub-cerulea } \\
\text { trivialis .. }\end{array}$ & . & $\begin{array}{l}119 \\
120\end{array}$ & $\begin{array}{l}\text { petracum } \\
\text { pubescens }\end{array}$ & $\cdots$ & \\
\hline Polemoniusi & $\cdots$ & $\begin{array}{l}120 \\
260\end{array}$ & $\begin{array}{l}\text { pubescens } \\
\text { rubrum }\end{array}$ & $\cdots$ & . 328 \\
\hline caeruleum & $\begin{array}{l}\cdots \\
. .\end{array}$ & $\begin{array}{l}\cdots 2011 \\
\ldots 260\end{array}$ & $\begin{array}{l}\text { rubrum } \\
\text { reclinatum }\end{array}$ & $\cdots$ & $\begin{array}{ll}3.57 \\
302\end{array}$ \\
\hline Polycarpon & . & $\therefore 172$ & spicatum & $\cdots$ & .. 326 \\
\hline tetraphyllum & . & .. 173 & Uva crispa & . & . 323 \\
\hline PoLTPOGON .. & . & .. 87 & Rottbollia & .. & .. $16: 3$ \\
\hline littoralis & . & .. 88 & filiformis & .. & .. 166 \\
\hline Monspeliensis & .. & . 87 & incurvata. & . & .. 165 \\
\hline Pontederia crassipes & . & . 22 & RUBAA & . & .. $1 \leq 3$ \\
\hline Potamogeton & . & . 207 & pereyrina & . & .. 153 \\
\hline acutifolius & . & .. 209 & tinctoria & .. & .. 158 \\
\hline compressus & . & .. 203 & RuPPIA & . & .. 214 \\
\hline erispus .. & . & 210,214 & maritima & . & .. 214 \\
\hline cuspidatus & .. & .. 209 & rostellata & . & .. 215 \\
\hline densus .. & . & .. 207 & & & \\
\hline gramineus & .. & .. 209 & SAGINA & $\cdots$ & .. 217 \\
\hline heterophyllus & .. & . 211 & apetala .. & . & .. 217 \\
\hline lanceolatus & .. & . 212 & erectu $\quad$. & .. & .. $21 \mathrm{~s}$ \\
\hline lucens .. & .. & 210,212 & maritima & . & .. 217 \\
\hline major .. & .. & ․ 203 & procumbens & . & $\ldots 217$ \\
\hline natans .. & . & 213,214 & SALICORNIA & $\cdots$ & $\cdots$ \\
\hline oblonerus & . & . .213 & annua & . & . \\
\hline obtusifolius & . & .. 209 & fruticusa & . & . \\
\hline perfoliatus & . & .. 210 & herbacea & . & $\ldots$ \\
\hline pectinatus & $\cdots$ & .. 203 & procumbens & .. & .. \\
\hline prxelongus & $\cdots$ & .. 211 & radicans & . & .. \\
\hline proteus & . & . 211 & SALSOLA $\ldots$ & $\cdots$ & .. 423 \\
\hline pusillus & . & .. 203 & fruticosa & . & .. 415 \\
\hline rufescens & $\ldots$ & .. 212 & Kali $\quad \ldots$ & .. & .. 429 \\
\hline serratus & . & 120,214 & Saltia & $\cdots$ & .. 23 \\
\hline zosterzefolius & . & .. 209 & pratensi3 & $\cdots$ & .. 24 \\
\hline Primiula & $\cdots$ & . 242 & Verbenaca & . & . \\
\hline elatior ... & . & . 244 & glutinosa & $\cdots$ & . \\
\hline farinosa & . & . . 245 & formosa & .. & . \\
\hline Scotica & . & .. 246 & Indica ... & . & . \\
\hline veris $\quad \ldots$ & . & .. 244 & officinalis & . & . \\
\hline - acaulis & . & . 243 & splendens & . & .. \\
\hline - elatior & . & .. 244 & pomifera & . & .. 25 \\
\hline -officinalis & $\cdots$ & .. 244 & SAMEUUCUS & . & .. 440 \\
\hline vulgaris & . & . 242 & Ebulus .. & $\cdots$ & .. 440 \\
\hline Prismitocarpos & $\cdots$ & $\ldots 304$ & nigra $\quad \ldots$ & . & .. 440 \\
\hline bybridus & . & . 304 & leucocarpa & $\cdots$ & .. 440 \\
\hline speculum & . & . 304 & laciniata & . & .. 111 \\
\hline Puluionaria & .. & . 221 & virescens & $\cdots$ & ․ 441 \\
\hline angustifolia & $\cdots$ & . 222 & Samolus & . & .. 286 \\
\hline maculata & .. & . 222 & Valerandi & . & .. 286 \\
\hline maritima & $\cdots$ & .. 2:25 & SANGUISORBA & $\cdots$ & . . 203 \\
\hline officinalis & .. & . $2 \cdot 2 \cdot 2$ & $\begin{array}{l}\text { media } \\
\text { officinalis }\end{array}$ & $\begin{array}{l}\ldots \\
\ldots\end{array}$ & $\begin{array}{l}\text {. } 204 \\
\ldots 203\end{array}$ \\
\hline Quercus suber & $\cdots$ & .. 436 & $\begin{array}{l}\text { Sanicula } \\
\text { Europæa }\end{array}$ & . & $\begin{array}{l}\text {. } 349 \\
\ldots 349\end{array}$ \\
\hline RADIOLA & .. & . 219 & Scabiosa .. & ․ & $\begin{array}{l}.073 \\
\ldots .177\end{array}$ \\
\hline millegrana & .. & .. 219 & arvensis & . & .. 176 \\
\hline linoides & .. & . 219 & columbaria & . & .. 177 \\
\hline Rhamens & .. & . 305 & succisa .. & .. & . 177 \\
\hline catbarticus & . & . 309 & SCANDIX & . & .. $\$ 04$ \\
\hline Frangula & $\cdots$ & .. 310 & Anthriscus & . & .. 407 \\
\hline RHYNCHOSPORA & $\cdots$ & - & Cerefolium & . & .. 406 \\
\hline alba & .. & . 47 & infesta .. & . & .. 402 \\
\hline fusca & .. & .. 45 & odorata .. & . & .. 410 \\
\hline Ribes & . & . 324 & Pecten .. & . & .. 404 \\
\hline alpinum & .. & . 326 & SCHENUS & . & .. 46 \\
\hline glabrum & . & .. $3 \pm 3$ & albus & . & .. \\
\hline Grossularia & . & . 323 & compressus & . & .. 55 \\
\hline nigrum & . & . 327 & fuscus $\quad \ldots$ & . & $\ldots \quad 47$ \\
\hline
\end{tabular}


INDEX.

\begin{tabular}{|c|c|c|c|c|c|}
\hline & & Pagre. & & & Page. \\
\hline $\begin{array}{l}\text { nigricans } \\
\text { rufus }\end{array}$ & .. & $\therefore \quad 46$ & humile & .. & .283 \\
\hline $\begin{array}{l}\text { rufus } \\
\text { scliedonorus sylvaticus }\end{array}$ & $\ddot{s}$ & $\begin{array}{lr}. & 56 \\
. & 129\end{array}$ & $\begin{array}{l}\text { lateo-virens } \\
\text { Sorghum }\end{array}$ & .. & \\
\hline pratensis & .. & $\therefore 129$ & Spermodia clavatus & $\therefore$ & $\begin{array}{r}70 \\
\cdots \quad 163\end{array}$ \\
\hline elatior .. & .. & .130 & StafhyLea & $\because$ & $\begin{array}{l}\ldots 103 \\
\ldots 443\end{array}$ \\
\hline Loliacea .. & .. & .. 130 & pinnata .. & . & $\therefore 443$ \\
\hline Scrapes & .. & .. 48 & Statice ... & .. & $\therefore 447$ \\
\hline acicularis & .. & .. 54 & Armeria & .. & .. 447 \\
\hline cospitosus & .. & .. 53 & binervosa & .. & .. 449 \\
\hline caricinus & .. & .. 55 & Limonium & .. & . 448 \\
\hline carinatus & .. & .. 51 & plaztaginea & .. & .. 448 \\
\hline fluitans & .. & .. 55 & reticulata & .. & .. 450 \\
\hline glaucus & .. & .. 48 & spathulata & .. & \\
\hline Holo=ehænus & .. & .. 49 & STIPA & .. & .. \\
\hline lacustris & .. & .. 48 & pennata & .. & \\
\hline maritimus & .. & .. 50 & tenacissima & .. & \\
\hline monostcichys & .. & .. 50 & Suertia perennis & .. & .. 335 \\
\hline multicaulis & .. & .. 53 & SYMPHYTUM & .. & .. 226 \\
\hline palustris & .. & .. 52 & officinale & .. & .. 22 \\
\hline pauciflorus & .. & .. 53 & tuberosum & .. & \\
\hline rufus .. & .. & .. 56 & bohemicum & .. & .. 227 \\
\hline Savii $\quad$. & .. & .. 49 & patens .. & .. & .. 22 \\
\hline setaceus & .. & . 45 & & & \\
\hline sylraticus & .. & $\because 51$ & Tacca pinnatifida & .. & \\
\hline triqueter & . & 50,51 & TAMARIX & .. & .. 444 \\
\hline Schoberia maritima & .. & .. 419 & gallica & .. & .. 444 \\
\hline Sclerochloa muritima. & .. & .. 111 & Thea germanica & .. & .. \\
\hline procumbens & .. & .. 115 & THESIUMA & .. & .. 334 \\
\hline rigida & .. & .. 116 & linophyllum & .. & .. 334 \\
\hline Secale cornutum & .. & .. 163 & pratense & .. & .. 334 \\
\hline Selinum palustre & .. & .. 395 & TILLEA & .. & .. 218 \\
\hline Seseli & .. & .. 381 & muscosa.. & .. & .. 218 \\
\hline Libanotis & .. & .. 331 & TORDYLIUAR .. & .. & \\
\hline creticum & .. & .. 393 & maximam & .. & .. 392 \\
\hline SESLERIA $\ldots$ & .. & .. 107 & nodosum & .. & \\
\hline cærulea & . & .. 107 & officinale & .. & .. 398 \\
\hline Setaria & .. & .. 106 & Toriles & . & \\
\hline Perticillata & .. & .. 106 & Anthriscus & .. & .. 401 \\
\hline viridis $\quad$. & .. & .. 105 & infesta ... & .. & .. 402 \\
\hline SHERARELA & .. & .. $1 \notin 9$ & nodosa ... & .. & .. 403 \\
\hline arrensis & .. & .. 189 & Helvetica & .. & .. 402 \\
\hline Sibealdia .. & .. & .. 456 & Trichorïum caninum & .. & \\
\hline procumbens & .. & .. 456 & setaceum & .. & .. \\
\hline SiLALS & .. & .. $3 \equiv 3$ & TRICHONEMIA & .. & .. \\
\hline pratensis & .. & .. 353 & Bulbocodium & . & \\
\hline Sison $\quad$. & . & .. 362 & Columnæ & $\cdots$ & .. 43 \\
\hline Amomum & . & .. 362 & Trinia $\ldots$ & $\cdots$ & .. 358 \\
\hline $\begin{array}{l}\text { inundalum } \\
\text { segetum }\end{array}$ & $\because$ & $\begin{array}{l}\text {.. } 361 \\
\therefore 355\end{array}$ & glaberrima & .. & .. 358 \\
\hline $\begin{array}{l}\text { segetum } \\
\text { verticillatum }\end{array}$ & $\because$ & $\begin{array}{l}. .355 \\
\therefore 365\end{array}$ & TRIODIA.. & .. & .. 122 \\
\hline $\begin{array}{l}\text { verticillatum } \\
\text { Sruss }\end{array}$ & & .. 365 & decumbens & $\cdots$ & .. 122 \\
\hline $\begin{array}{l}\text { Siusr } \\
\text { angu }\end{array}$ & $\because$ & $\begin{array}{l}. .372 \\
\because 371\end{array}$ & Trisetum pubescens & .. & .. 142 \\
\hline $\begin{array}{l}\text { angustifolium } \\
\text { inundatum }\end{array}$ & $\because$. & $\begin{array}{l}. .371 \\
. \quad 361\end{array}$ & flavescens & .. & $\because 143$ \\
\hline $\begin{array}{l}\text { inundatum } \\
\text { latifolium }\end{array}$ & .. & $\begin{array}{l}. .361 \\
\therefore \quad 372\end{array}$ & Trimicusi & .. & 70,154 \\
\hline $\begin{array}{l}\text { latifolium } \\
\text { nodiflorum }\end{array}$ & 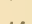 & . 372 & caninum & .. & .. 154 \\
\hline nodiflorum & & .. 553 & cristatum & .. & .. 156 \\
\hline repens .. & .. & . . 36,0 & junceum & .. & .. 156 \\
\hline verticillatum & .. & .. 395 & Loliaceum & .. & .. 157 \\
\hline UMI .. & .. & .. 413 & repens $\because$ & .. & .. 155 \\
\hline Olusatrum & .. & .. 413 & Turgenia latifolia & .. & .. 400 \\
\hline SOLANUMz $\quad$. & .. & .. $2=1$ & & & \\
\hline Dulcamara & .. & $2 \leq 1$ & UlJIUS & .. & .. 431 \\
\hline nigrum & . & $2 \div 2$ & campestris & .. & .. 431 \\
\hline Solanum lethale & . & $\begin{array}{l}279 \\
27\end{array}$ & campestris & .. & .. 437 \\
\hline furiosum & . & 275 & carpinifolia & .. & \\
\hline maniacum & & $\begin{array}{ll}2-i c \\
2=1\end{array}$ & glabra .. & .. & .. 434 \\
\hline tomentosum & . & $2=1$ & glandulose & .. & \\
\hline
\end{tabular}




\section{INDEX.}

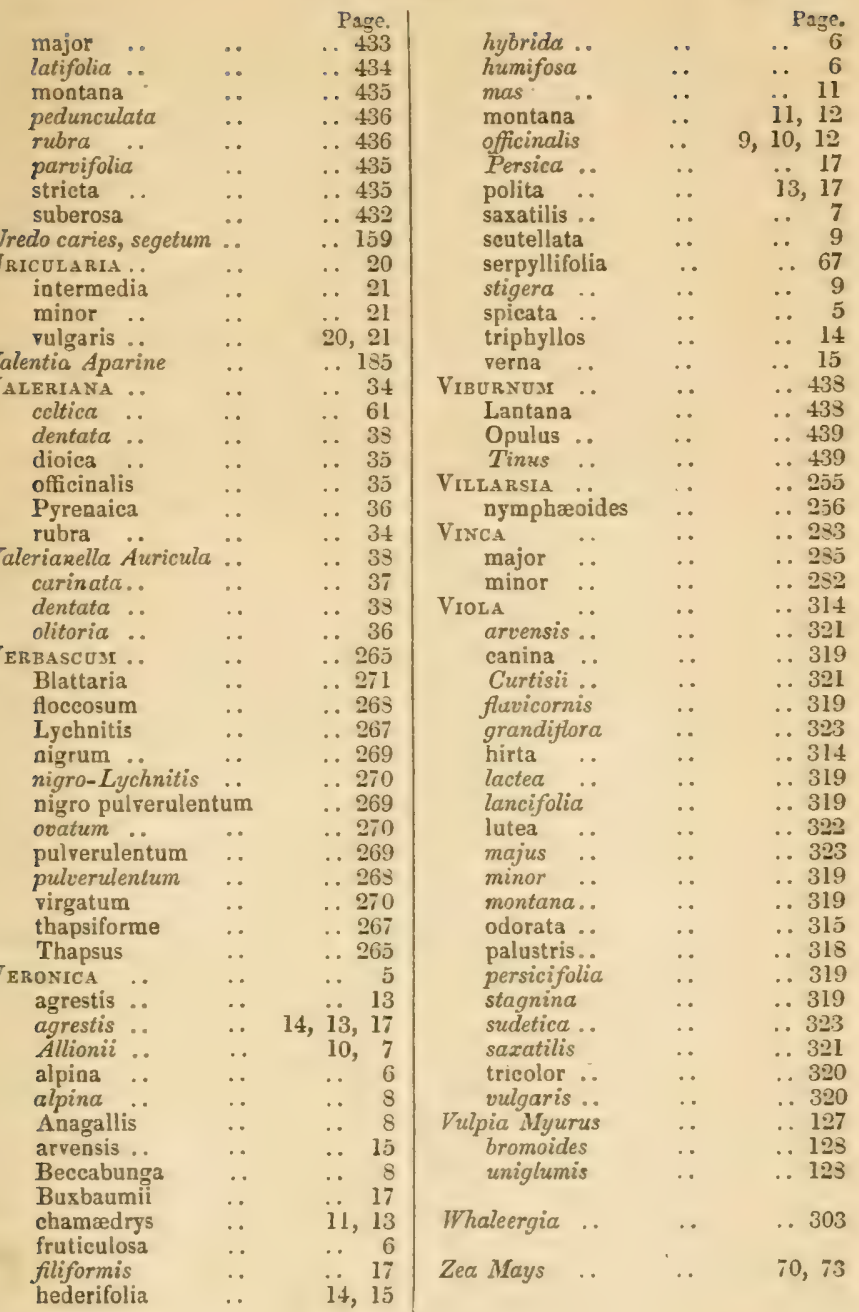




\begin{tabular}{|c|c|c|c|c|c|c|c|}
\hline & & & Page. & & & & Page. \\
\hline Coriander & .. & . & .. 417 & Gladwyn & & . & .. 44 \\
\hline Cork tree & .. & . & .. 436 & Glands Lentic & icular & .. & .. 4 \\
\hline Cornel & .. & .. & .. 198 & Glasswort & .. & .. & .. 1 \\
\hline Cotton grass & .. & .. & .. 56 & Gluten & & .. & \\
\hline Couch grass & .. & .. & .. 155 & Good King $\mathrm{H}$ & Henry & .. & .. 421 \\
\hline Cowbane & .. & .. & .. 369 & Gooseberry & .. & .. & .. 324 \\
\hline Cowslip & $\therefore$ & .. & .. 244 & Goosefoot & .. & .. & .. 418 \\
\hline Cowslip wine & & .. & .. 245 & Goutweed & & & .. 363 \\
\hline Crocus & .. & .. & .. 36 & Grain, horned & d or spurr & rred & .. 163 \\
\hline Currant & .. & .. & .. 324 & Greek valeria & & .. & .. $26 \mathrm{t}$ \\
\hline Cyclamen & .. & .. & .. 241 & Greymill & .. & .. & .. 223 \\
\hline Cyperus & .. & .. & .. 44 & $\begin{array}{l}\text { Grey millet } \\
\text { Gromwell }\end{array}$ & & $\begin{array}{l}. . \\
. .\end{array}$ & $\begin{array}{l}. \quad 223 \\
. \quad 223\end{array}$ \\
\hline Danewort & . & -. & .. 440 & Guelder rose & & .. & $\begin{array}{l}. .438 \\
\end{array}$ \\
\hline $\begin{array}{l}\text { Darn } \\
\text { Darnel }\end{array}$ & 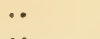 & .. & ‥ 255 & & & & \\
\hline $\begin{array}{l}\text { Darnel } \\
\text { Deadly night }\end{array}$ & shade & .. & . 162 & Hard grass & & .. & .. 165 \\
\hline Deadly night & shade & .. & .. 259 & Hare-bell & .. & .. & .. 293 \\
\hline Devil's apple & & .. & .. 274 & Hare's-ear & & .. & .. 352 \\
\hline Dodder & 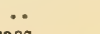 & .. & .. 340 & Hare's-tail gro & rass & .. & .. 86 \\
\hline Dog's-tail gr & & .. & .. 142 & Hair grass & & & .. 96 \\
\hline Dog's-tooth g & grass & .. & .. 168 & Hairs, lympha & atic and $s$ & secreting. & . 16 \\
\hline Dog wood & $\cdots$ & .. & .. 198 & Hartwort & $\therefore$ & .. & .. 392 \\
\hline Doob grass & .. & $\cdots$ & .. 169 & Heath grass & & .. & .. 122 \\
\hline Doura & $\because$ & .. & .. 72 & Hedge parsley & & .. & .. 401 \\
\hline Drop wort, w & vater & . & .. 373 & Hemlock & & .. & .. 415 \\
\hline Dry gangrene & e.. & .. & .. 163 & Hemlock, less & ser & .. & .. 379 \\
\hline Duckweed & .. & .. & .. $\quad 29$ & Hemlock, wat & & .. & .. 369 \\
\hline Dwale & .. & .. & .. 278 & $\begin{array}{l}\text { Henbane } \\
\text { Henbit, small }\end{array}$ & & $\ddot{*}$ & .. 275 \\
\hline Earth nut & .. & .. & .. 365 & Herb twopen & & $\ddot{0}$ & $\begin{array}{l}.14 \\
\therefore 253\end{array}$ \\
\hline Elder & ... & .. & .. 440 & Hog-weed & .. & .. & .. 276 \\
\hline - wine & .. & .. & .. 442 & Holy grass & .. & .. & .. 108 \\
\hline Elm & & .. & .. 431 & Holly & .. & .. & .. 205 \\
\hline Englishman's & $s$ foot & .. & $\therefore 193$ & Holly, sea & .. & .. & .. 350 \\
\hline Ergot. & .. & .. & .. 163 & Honewort & & .. & .. 358 \\
\hline Eryngo & . & $\cdots$ & . 350 & Honeysuckle & & .. & .. 305 \\
\hline & .. & & .. 247 & $\begin{array}{l}\text { Horehound, } \\
\text { Horse poison }\end{array}$ & $\begin{array}{l}\text { water } \\
\text {... }\end{array}$ & $\ddot{.}$ & $\begin{array}{l}25 \\
\because \quad 288\end{array}$ \\
\hline Feather gras & & $\ddot{.}$ & $\begin{array}{ll}. . & 87\end{array}$ & Hlound's tong & & $\begin{array}{l}. . \\
. .\end{array}$ & $\begin{array}{l}\text {. } 288 \\
239\end{array}$ \\
\hline Fedia & .. & .. & $\therefore \quad 37$ & & & $\cdots$ & \\
\hline Felon-wood & .. & .. & .. 282 & Indian rubber & & .. & .. 289 \\
\hline Felwort & .. & .. & .. 335 & Iris & .. & .. & $\begin{array}{l}. . \\
.43\end{array}$ \\
\hline Fennel & .. & .. & .. 380 & Isuardia & .. & .. & .. 202 \\
\hline - hogs & $\cdots$ & .. & ․ 394 & & . & .. & \\
\hline Fescue grass & $\cdots$ & .. & 163,124 & & & & \\
\hline Finger grass & $\cdots$ & .. & . 169 & $\begin{array}{l}\text { Jacob's ladde } \\
\text { James town }\end{array}$ & weed & $\begin{array}{l}. . \\
. .\end{array}$ & $\begin{array}{l}\because 260 \\
\therefore 2274\end{array}$ \\
\hline Flax & .. & $\cdots$ & .. 452 & $\begin{array}{l}\text { James town } \\
\text { Jerusalem }\end{array}$ & wslip & $\ddot{.}$ & .. 274 \\
\hline Flax seed & $\ddot{0}$ & $\therefore$ & .. 219 & $\begin{array}{l}\text { Jerusalem co } \\
\text { Jerusalem sag }\end{array}$ & & $\begin{array}{l}\cdots \\
\therefore\end{array}$ & $\begin{array}{l}\because 222 \\
2222\end{array}$ \\
\hline Flower-de-L & uce & $\because$. & $\begin{array}{l}. .43 \\
-\quad 347\end{array}$ & Jerusalem sag & & & \\
\hline $\begin{array}{l}\text { Flowk wort } \\
\text { Fluke, or flo }\end{array}$ & önder & sect & $\begin{array}{l}. .347 \\
\ldots 348\end{array}$ & & .. & .. & \\
\hline $\begin{array}{l}\text { Fluke, or flo } \\
\text { Flukes in sk }\end{array}$ & $\begin{array}{l}\text { under in } \\
\text { heep }(f a\end{array}$ & scicda & hepa- 348 & $\begin{array}{l}\text { Knappia } \\
\text { Knautia }\end{array}$ & .. & $\ddot{.}$ & $\begin{array}{l}.106 \\
\therefore 176\end{array}$ \\
\hline tica) & .. & .. & . 19 & Knot-grass & .. & .. & .. 332 \\
\hline Fly trap & ... & .. & .. 216 & & & & \\
\hline Fool's parsle & & .. & .. 378 & Lady's mantle & & .. & .. 201 \\
\hline Forget-me-n & & .. & $\because \quad 12$ & Lambs' lettuc & & .. & .. 36 \\
\hline Foxtail-grass & $8 .$. & .. & 163,74 & Lavender, sea & & .. & .. 448 \\
\hline French-berri & & .. & .. 310 & Lawrestine & $\because$. & $\ddot{.}$ & $\begin{array}{r}439 \\
27\end{array}$ \\
\hline Gali & .. & .. & .. 44 & Lobelia & .. & .. & .. 287 \\
\hline & & .. & .. 335 & Loosestrifo & .. & .. & .. 250 \\
\hline Gentianella, & least & .. & .. 192 & Lovage & .. & .. & .. 382 \\
\hline Gerarde herk & b.. & .. & .. 363 & Lungwort & .. & .. & .. 221 \\
\hline Germander, & wild & $\cdots$ & .. 11 & Lyme grass & .. & .. & .. 148 \\
\hline $\begin{array}{l}\text { Gilliflower, s } \\
\text { Gipsy-wort }\end{array}$ & sea & $\ddot{.}$ & $\begin{array}{lr}. \quad 447 \\
\ldots \quad 23\end{array}$ & Madder & .. & .. & \\
\hline & & & & & & & \\
\hline
\end{tabular}


INDEX.

\begin{tabular}{|c|c|c|c|c|c|c|c|}
\hline \multirow{2}{*}{\multicolumn{2}{|c|}{$\begin{array}{l}\text { Madder, field } \\
\text { Madwort, German }\end{array}$}} & \multirow{2}{*}{\multicolumn{2}{|c|}{$\begin{array}{l}\text { Page. } \\
\text {. } 189 \\
\text {.. } 239\end{array}$}} & & \multirow[b]{2}{*}{ i } & \multirow{2}{*}{\multicolumn{2}{|c|}{$\begin{array}{r}\text { Page. } \\
\ldots 243\end{array}$}} \\
\hline & & & & Pimpernel & & & \\
\hline Maize & .. & .. & $163,70,71$ & Pinks & .. & 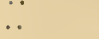 & \\
\hline Manna & .. & .. & .. 25 & Pisang & . & .. & .. \\
\hline Manna seeds & $\because$ & . & . 113 & Plane tree & .. & .. & .. 43 \\
\hline Mangel wurz & & $\cdots$ & . 423 & Plantain & .. & .. & .. 19 \\
\hline Manihot & . & .. & . 72 & Plantain, bes & som & .. & .. 19 \\
\hline Mare's tail & .. & . & . 3 & Plantain rose & e.. & .. & .. 19 \\
\hline Marsh penny & wort & $\ldots$ & .. 347 & Polyanthus & .. & .. & .. 24 \\
\hline Marsh mallow & & $\ldots$ & . 227 & Pond weed & .. & .. & .. 20 \\
\hline Iarsh trefoil & & .. & . . 254 & Potatoes & . & .. & .. \\
\hline larsh violet & .. & .. & . 19 & Prickwood & .. & .. & . \\
\hline Iarsh-wort & :. & .. & . 359 & Primrose & . & .. & .. \\
\hline Iaster-wort & $\therefore$ & .. & . 396 & Privet & .. & .. & . \\
\hline lat-grass & . & .. & . 61 & & & & \\
\hline Mat-weed, ba & astard & .. & .. 167 & Quaking gra & & $\ldots$ & $\ldots$ \\
\hline Meadow gras & & . & .. 111 & & & & \\
\hline Ielic-grass & . & . & . 109 & Rampion & .. & . & .. \\
\hline ew & . & . & . 159 & Reed & .. & .. & .. \\
\hline et & . & . & . 70 & Reed, small & .. & . & . \\
\hline Millet-grass & . & $\cdots$ & . 81 & Rib grass & .. & .. & .. 19 \\
\hline Milk-wort, se & & . & . 332 & Rib wort & .. & .. & $\because 1$ \\
\hline chia & . & . & . . 218 & Rice & & .. & 70 \\
\hline nia & . & . & .. 111 & Roast beef $p$ & lant & . & .. 4 \\
\hline e tail & . & . & . 459 & without & t a thorn & -. & ․ 29 \\
\hline oneywort & . & . & . 253 & Rup & $\cdots$ & $\cdots$ & .. 21 \\
\hline grass & .. & . & .. 107 & Rupture wor & & . & \\
\hline perry & . & . & . . 437 & Rye & .. & .. 163, & 70,7 \\
\hline Mullein & . & . & .. 265 & Rye grass & $\cdots$ & $\cdots$ & $\ldots 16$ \\
\hline Needle Cherv & vil & . & .. 404 & Saffron croce & & .. & \\
\hline Night shade & Enchan & & . $\quad 25$ & Sago & .. & . & 158, \\
\hline Night shade & 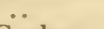 & .. & . . 281 & Sage & . & .. & .. \\
\hline & Garden & .. & . . 282 & Salad corn & .. & . & . \\
\hline$\pi$ & . & .. & .. 81 & Salep & . & . & .. 15 \\
\hline $\mathrm{Ni}$ & . & .. & 2 & $\begin{array}{l}\text { Salt wort } \\
\text { Salt-wort, bl }\end{array}$ & & $\begin{array}{l}. \\
\ldots\end{array}$ & $\begin{array}{l}\ldots 42 \\
\ldots 33\end{array}$ \\
\hline & & .. & $163,70,71$ & Sar & & . & .. 38 \\
\hline Oat, animal & .. & .. & .. 138 & ire, pr & rickly & . & .. 4 \\
\hline Oat grass & .. & . & . 139 & Sar & & .. & .. 3 \\
\hline Oat-like gras & & . & .. 103 & e, Yor & kshire & . & . \\
\hline Olive & & .. & ․ 27 & een pa & int & .. & .. 310 \\
\hline Oslip, primr & ose & . & .. 244 & $\begin{array}{l}\text { Saxifrage, bu } \\
\end{array}$ & $\begin{array}{l}\text { urnet } \\
\text { adow }\end{array}$ & $\begin{array}{l}\cdots \\
\ldots\end{array}$ & $\begin{array}{l}\ldots 36 \\
\ldots 38\end{array}$ \\
\hline le & $\cdots$ & $\cdots$ & $\therefore 214$ & - pel & per & 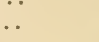 & $\therefore 38$ \\
\hline alms & $\cdots$ & $\cdots$ & 153,72 & Scal & $\cdots$ & .. & .. 17 \\
\hline Panick-grass & & .. & . 105 & ion gra & & . & .. 2 \\
\hline nassus, gr & ass of & . & . . 416 & ed & $\cdots$ & . & .. \\
\hline y & & . & . . 350 & Se & .. & .. & .. 7 \\
\hline$y$, fool' & & .. & . 378 & 's bit & 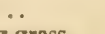 & .. & . 290 \\
\hline Parsley, milk & & .. & . 395 & killing & grass & . & . 347 \\
\hline - bur & & $\cdots$ & . 399 & s scabi & ous & . & .. 290 \\
\hline $\begin{array}{l}-h \\
-b\end{array}$ & & $\cdots$ & . 401 & erd's n & eedle & . & . 404 \\
\hline sley p & & $\cdots$ & ․ 405 & dia & . & . & .. 18 \\
\hline Parsley, st & $\ddot{\theta} b$ & $\cdots$ & . . 202 & Sib & . & . & . . 450 \\
\hline ip & 10 & .. & $\begin{array}{l}\text {. } 362 \\
\ldots 359\end{array}$ & lage & - & .. & . 35 \\
\hline snip, wat & & .. & $\begin{array}{l}\text {. } 389 \\
\ldots 372\end{array}$ & Smut & $\because$ & $\because$ & . 15 \\
\hline Wine & & .. & $\begin{array}{l}\ldots 312 \\
\ldots 390\end{array}$ & $\begin{array}{l}\text { dragon, } \\
\text { ball tree }\end{array}$ & $e^{i v y}$ & & . 303 \\
\hline - cow & & $\ldots$ & . 390 & $\begin{array}{l}\text { Snowt } \\
\text { Soda }\end{array}$ & & & \\
\hline ral or $\mathrm{fc}$ & odder gra & Isses & $\ldots 65$ & $\begin{array}{l}\text { Soda } \\
\text { Sodium }\end{array}$ & $\begin{array}{l}\cdots \\
\cdots\end{array}$ & $\begin{array}{l}\cdots \\
\cdots\end{array}$ & \\
\hline wort & & . & .. 217 & rass & . & .. & $\begin{array}{ll}\cdots & 10\end{array}$ \\
\hline ory, wa & & .. & . 199 & So & .. & .. & \\
\hline wort, $n$ & narsh & .. & . 347 & ead & .. & . & \\
\hline kle & . & . & . 283 & ell & . & . & .. \\
\hline & . & $\cdots$ & $\begin{array}{ll}. & 10\end{array}$ & Spi & . & . & . \\
\hline
\end{tabular}




\section{INDEX.}

\begin{tabular}{|c|c|c|c|c|c|c|c|}
\hline \multirow{2}{*}{\multicolumn{2}{|c|}{ Snikensh }} & \multirow{2}{*}{\multicolumn{2}{|c|}{$\begin{array}{r}\text { Page. } \\
\ldots \quad 52\end{array}$}} & \multirow[b]{2}{*}{ Valerian } & & & \multirow{2}{*}{$\begin{array}{l}\text { Page: } \\
\ldots \quad 34\end{array}$} \\
\hline & & & & & .. & .. & \\
\hline Spindle tree & & .. & & Venus' comb & & .. & \\
\hline Star of the ea & arth & .. & .. 194 & Venus's cup & & .. & .. 174 \\
\hline Stomata & & & .. 16 & Venus' looki & ng-glass. & .. & .. 304 \\
\hline Stone parsley, & 8 , bastard & I.. & .. 362 & Vernal grass & $\therefore$ & & .. 33 \\
\hline Stramonium &.. & .. & .. 274 & Villarsia, nyt & mphœa-lik & & .. 255 \\
\hline Strap wort & & .. & .. 445 & Vine leaves & . & .. & $\ldots 437$ \\
\hline Squirrel's tail & ll grass & .. & .. 153 & Violet & & .. & .. 314 \\
\hline Sulphur weed & & .. & .. 375 & Violet, wate & & .. & .. 247 \\
\hline Sundew & .. & .. & 122,457 & Viper's bugl & & .. & .. 220 \\
\hline weet flag & $\therefore$ & .. & .. 108 & & & & \\
\hline wertia & .. & . & .. 335 & & .. & . & .. 347 \\
\hline Tamarisk & .. & .. & .. 444 & Water lily & $\ddot{.}$ & $\because$ & $\begin{array}{l}\ldots 439 \\
\ldots 215\end{array}$ \\
\hline Taper, high & .. & .. & .. 265 & Water rush & $\because$ & .. & $\therefore 54$ \\
\hline Tapioca & .. & .. & .. 158 & Way bred & .. & .. & .. 193 \\
\hline Tares & .. & .. & .. 165 & Wayfaring $\mathrm{tr}$ & & & .. 438 \\
\hline Teasel & .. & .. & .. 173 & Weatherglas & $\mathrm{s}$, poor ma & an's & .. 248 \\
\hline Thorn apple & .. & .. & .. 273 & Wheat & $\ldots$ & & \\
\hline Thorow wax & .. & .. & .. 353 & Wheat grass & .. & .. & .. 154 \\
\hline Thrift & .. & .. & .. 447 & Whorl grass & .. & . & .. 96 \\
\hline Tillea & .. & .. & $\ldots 218$ & White rot & .. & .. & .. 347 \\
\hline Timothy gras & & .. & 163,82 & Woodbine & .. & .. & .. 306 \\
\hline Toad flax, ba & astard & .. & .. 334 & Wood ruff & $\therefore$ & .. & .. 189 \\
\hline Touch & & .. & .. 313 & & & & \\
\hline Trichonema & .. & .. & .. 42 & Yams & .. & $\cdots$ & \\
\hline ulip & & - & .. 10 & & & & \\
\hline wig-rusb, pr & rickly & .. & .. 32 & & & & \\
\hline
\end{tabular}

END OF YOL. I. 
Now publishing, to be continued Monthly, price 6d., with coloured Plate and other Illustrations,

\title{
MARNOCK'S FLORICULTURAL MAGAZINE,
}

\author{
AND MISCELLANY OF GARDENING,
}

\section{EDITED BY ROBERT MARNOCK,}

Curator of the Botanic Garden, Inner Circle, Regent's Park.

"This is exactly the publication which all those who bave pretty gardens will rejoice to possess; and the reading of which renews the regrets of those who do not possess such gardens."-Monthly Repository.

In foolscap 8ro, , price 2s, cloth,

\section{THE BOTANIST'S MANUAL;}

Comprising a complete

LIST OF THE BRITISE FLOWERING PLANTS AND FERNS,

Divided into the Linnæan Classes and Orders, according to the arrangement of Sir W. H. Hooker ; designed principally for the Out-door Convenience of Botanical Students and Amateurs, as a Book of Entry for the Discovery of Plants or Habitats; and also a convenient Pocket Companion for persons engaged in collecting materials for LOCAL FLORAS.

In demy 8vo.,

FLORIGRAPHIA BRITANNICA;

OR, ENGRAVINGS AND DESCRIPTIONS OF THE FLOWERING

PLANTS AND FERNS OF BRITAIN.

BY RICHARD DEAKIN, M. D.

Vol. I. is now complete, comprising Classes I. to V., illustrated by upwards of 500 figures of Plants, price $£ \mathrm{I} 10$ s. Od. Plain, and $£_{2} 17 \mathrm{~s}$. 6d. Coloured; the succeeding Classes are in course of publication, and may be had in Nos, price 6d. Plain, and 1s. Coloured.

In $12 \mathrm{mo} .$, price One Shilling, sewed,

\section{A MEMIOIR OF THE HISTORY AND CULTIVATION OF}

\section{THE G O O S B E R R Y.}

Great attention having of late years been paid to the cultivation of this old English fruit, a sketch of its history becomes interesting, not only to the grower, but to the user of the Gooseberry; while a compendious description of the various methods of treatment resorted to by those engaged in raising the different sorts for the market, for private use, or for prize exhibition, must needs be ac. ceptable to the public. Among other matters concisely treated of in this manual, will be found the raising of new sorts from seed-planting and training of the trees-remarks on the manuring and pruning - and notices of that especial care of the fruit required from those amateurs and others who aspire to produce the Gooseberry in its highest degree of perfection. 


\section{PEAK SCENERY:}

$\mathrm{OR}$,

\section{EXCURSIONS IN DERBYSHIRE,}

MADE CHIEFLY FOR THE PURPOSE OF

\section{PICTURESQUE OBSERVATIONS.}

BY EBENEZER RHODES.

With Twenty-Eight beautiful Plates, by Cooke, from Drawings by the celebrated Chantrey.

GEORGE RIDGE, PUBLISHER, SHEFFIELD,

Having become the Proprietor of the small remaining Stock of this beautiful and interesting Work, begs respectfully to inform the Nobility, Gentry, Clergy, \&c. of Derbyshire, and the Public in general, that he is determined to offer it to Purchasers at the following greatly reduced prices:-

ROYAL QUARTO, 2 Vols., handsomely half-bound, £I 18s., Published at $£ 616 \mathrm{~s}$.

DEMY QUARTO, 2 VoLs, handsomely half-bound, £l 8s., Published at $£ 416 \mathrm{~s}$.

Of the general design and attractive character of a Book so well known as the "PEAK SCENERT," it is almost as unnecessary to repeat the public approbation, as it would be to praise the beauties of that picturesque district to which the Descriptions and Illustrations refer. 
II||||||||||||||||||||||||||||||||||||||||||||||||||| 



\section{New vork Botanical Garden Library
QK306.D4 v.1 gen
Deakin.Richard/Florigraphia Britannica; | || || || || || || || || || || || || || || || || || || || || || \\ || ||||||||||||||||||||||||||||||||||||||||||||||| \\ 35185001204773}


(4)
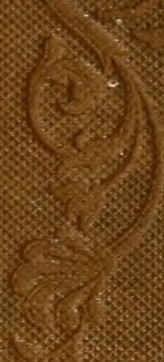

然

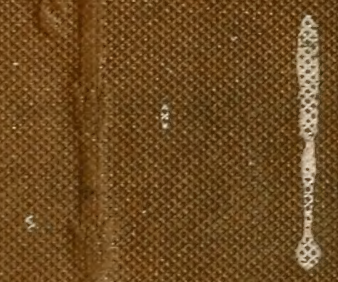

a. 5

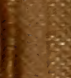

2

\%

40

1.

6.

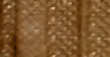

. $\left\{\begin{array}{l}\mid \\ 0\end{array}\right.$

(5)

$y_{3}(5)$

1
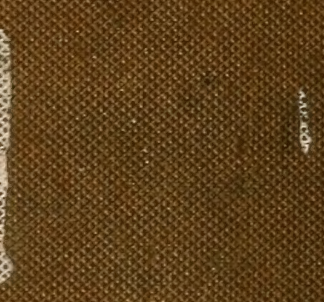

(c) (10
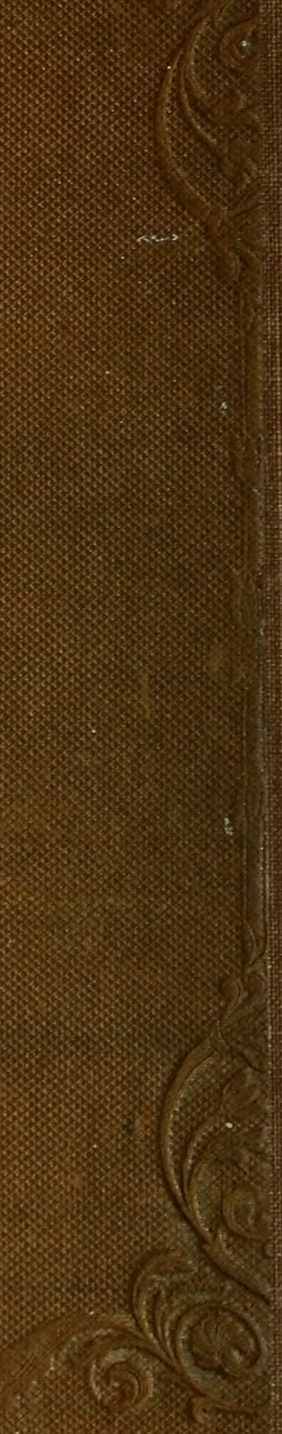